

\section{Class}

Shelf

No.

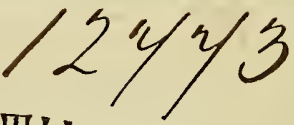
R OVA ARTILLER.

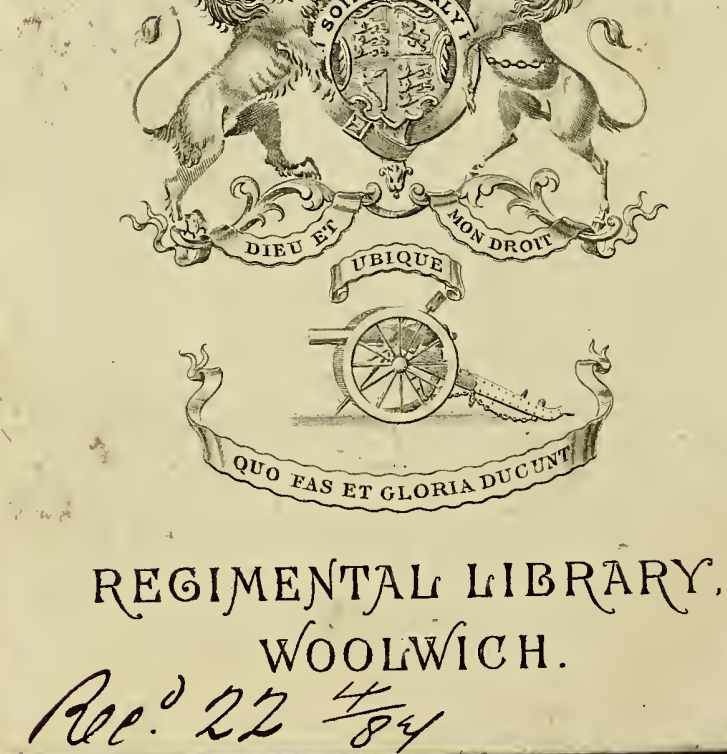



Digitized by the Internet Archive in 2010 with funding from

Boston Library Consortium Member Libraries

http://www.archive.org/details/geographicaldist02wall2 
. W18

\section{THE GEOGRAPHICAL}

\section{DISTRIBUTION OF ANIMALS.}

VOL. II. 


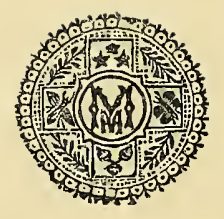




\title{
THE GEOGRAPHICAL
}

\section{DISTRIBUTION OF ANIMALS}

\author{
WITH A STUDY OF \\ THE RELATIONS OF LIVING AND EXTINCT FAUNAS \\ AS ELUCIDATING THE \\ PAST CHA NGES OF THE EARTH'S SURFACE.
}

BI

ALFRED RUSSEL WALLACE, /

AUTHOR OF "THE. MALAT ARCHIPELACO," ETC.

WITH MAPS AND ILLUSTRATIONS.

IN TWO VOLUMES.-VOLUHE II.

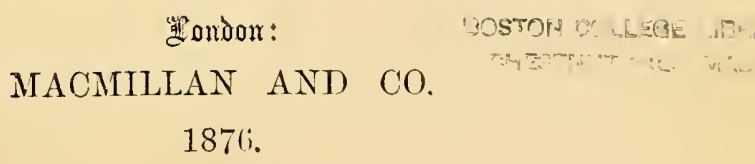

[The Right of Translation and Reproduction is Reservert.] 
LONDOY :

R. CLAY, gONS, AND TAYLOR, PRINTERS, BREAD BTREET HISL. 


\section{CONTENTS OF THE SECOND VOLUME.}

PART III. (continued).

ZOOLOGICAI GEOGRAPHY: A REVIEW OF THE CHIEF FORMS OF ANIMAL LIFE IN THE SEVERAL REGIONS AND SUB-REGIONS, WITH THE INDICATIONS THEY AFFORD OF GEOGRAPHICAL MUTATIONS.

CHAP'TER XIV.

THE NEOTPOPICAL REGION.

General Zoological Features of the Neotropical Region (p. 5)-Distinctive Charae: ters of Neotropical Hammalia (p. 6)-Of Neotropical Birds (p. 7)-Neotropical Reptiles (p. 9)-Fresh-water Fishes (p. 12)-Insects (p. 13)-Coleoptera (p. 15) -Land Shells (p. 19)-Marine Shells (p. 20)-Brazilian Sub-region (p. 21)Its Mammalia (p. 23)-Its Birds (p. 24)-Islands of Tropical South America, Galapagos (p. 29)-Chilian Sub-region (p. 36)-Birds (p. 38)-Reptiles and Amphibia (p. 40)-Fresh-water Fishes (p. 42)-Lepidoptera (p. 42)-Coleoptera (p. 44)-Islands of South Temperate Anerica (p. 49)-Mexican Sub-region (p. 51)-Mammalia and Birds (p. 52)-Reptiles and Fishes (p. 54)-Insects (p. 55)-Relations of the Mexican Sub-region to the North and South American Continents (p. 57)-Islands of the Mexican Sub-region (p. 59)-The Antillean Sub-region (p. 60)-Its Mammalia (p. 62)-Its Birds (p. 61)-Table of the Resident Land Birds of the Autilles (p. 68)-Reptiles (p. 72)-Insects (p. 73) -Land Shells (p. 75)-Past History of the Antilles (p. 78)-Summary of the Past History of the Neotropical Region (p. 80)-Table I. Families of Animals inhabiting the Neotropical Region (p. 85)-Table II. Genera of Terrestrial Mammalia and Birds of the Neotropical Region (p. 91) . . . . 1-113 


\section{CHAP'TER XV.}

THE NEARCTIC REGION.

Zoological Characteristics of the Nearctic Region (p. 115)-List of Typical Nearetic Genera of Land Birds (p. 118)-Summary of Nearctic Vertebrata (p. 120) -lusects (p. 122)-Terrestrial and Fluviatile Mollusea (p. 124)-The Californian Sub-region (p. 127)-The Rocky Mountain Sub-region (p. 129)-The Alleghany Sub-region (p. 131) -The Bermudas (p. 134)-The Canadiau Subregion (p. 135) - Greenland (p. 138)-Table I. Families of Animals inhabiting the Nearctic Region (p. 140)-Table II. Genera of Terrestrial Mammalia and Birds of the Nearctic Region (p. 145) . . . . . . 114-153

\section{CHAPTER XVI.}

SUMMARY OF THE PAST CIIANGS AND GENERAL RELATIONS OF THE SEYERAL REGIONS . . . . . . . . . . . 154-164

\section{PART IV.}

GEOGRAPHICAL ZOOLOGY : A SYSTEMATIC SKETCH OF THE CHIEF FAMILIES OF LAND ANIMALS IN THEIR GEOGRAPHICAL RELATIONS.

INTRODUCTION . . . . . . . . . . . . . . 167-169

\section{CHAPTER XVII.}

THE DISTRIBUTION OF THE FAMILIES AND GENERA OF MAMMALIA.

Primates (p. 170)-General Remarks on the Distribution of Primates (p. 179)Chiroptera (p. 181)-Remarks on the Distribution of Chiroptera (p. 185)Insectivora (p. 186)-General Remarks on the Distribution of Insectivora (p. 191)-Carnivora (p. 192)-General Remarks on the Distribution of the Carnivora (p. 204)-Cetacea (p. 207)-Sirenia (p. 210)-Ungulata (p. 211)General Remarks on the Distribution of the Ungulata (p. 226)-Proboscidea (p. 227)-Hyracoidea (p. 228)-Rodentia (p. 229)-General Remarks on the Distribution of the Rodentia (p. 243)-Edentata (p. 244)-General Reinarks on the Distribution of the Edentata (p. 247)-Marsupialia (p. 248)-General Remarks on the Distribution of Marstpialia (p. 253)-Monotremata (p. 253) 


\section{CHAPTER XVIII.}

THE DISTRIBUTION OF THE FAMLLIES AND GENERA OF BIRDS.

Passeres (p. 255)--General Remarks on the Distribution of the Passeres (p. 299)Picariæ (p. 302)-General Remarks on the Distribution of the Picariæ (p. 322) -Psittaci (p. 324)-General Remarks on the Distribution of the Psittaci (p. 329)-Columbe (p. 331)-General Remarks on the Distribution of the Columbæ (p. 335)-Gallinæ (p. 337)-General Remarks on the Distribution of Gallinæ (p. 344)-Opisthocomi (p. 345)-Accipitres (p. 345)-General Re. marks on the Distribution of the Accipitres (p. 351)-Grallæ (p. 351)-General Remarks on the Distribution of the Grallæ (p. 362)-Anseres (p. 363)-General Remarks on the Distribution of the Anseres (p. 367)-Struthiones (p. 368)Struthions Birds recently Extinct (p. 369)-General Rewarks on the Distribution of the Struthiones (p. 370)

$255-371$

\section{CHAPTER XIX.}

THE DISTRIBUTION OF TIE FAMILIES AND GENEIA OF REPTILES AND AMPHIBIA.

Ophidia (p. 372)-General Remarks on the Distribution of Oplidia (p. 386)Lacertilia (p. 388)-General Remarks on the Distribution of Lacertilia (p. 403) -Rhyncocephalina (p. 405)-Crocodilia (p. 405)-General Remarks on the Distribution of Crocodilia (p. 406)-Chelonia (p. 407)-Remarks on the Distribution of Chelonia (p. 410)-Amphibia, Pseudophidia (p. 411)-Urodela (p. 411)-Anura (p. 414)-General Remarks on the Distribution of Amphibia (p. 422)

$372-423$

\section{CHAPTER XX.}

THE DISTRIBUTION OF THE FAMILIES OF FISHEs, With THE RANGE OF SUCH GENERA AS INHABTT FRESH WATER.

Acanthopterygii (p. 424)-Acanthopterygii Pharyngngnathi (p. 437)-Anacanthini (p. 439)-Physostomi (p. 441)-Lophobranchii (p. 456)-Plectognathi (p. 457) Sirenoidei (p. 458)-Ganoidei (p. 458)-Chondropterygii (p. 460)Cyclostomata (p. 463)-Leptocardii (p. 464)-Remarks on the Distribution of Fishes (p. 464) 
CHAPTER XXI.

THE DISTRIBUTION OF SOME OF THE MORE IMPORTANT FAMILIES AND GENERA OF INSECTS.

Lepidoptera (p. 470)-General Remarks on the Distribution of the Diurnal Lepidoptera and Sphingidea (p. 483)-Coleoptera (p. 486)-Cicindelidæ (p. 486)Carabidæ (p. 488)-Lucanidæ (p. 492)-Cetoniidæ (p. 494)-Buprestidæ (p. 495)-Longicornia (p. 498)-General Observations on the Distribution of Coleoptera (p.502) . . . . . . . . 468-503

\section{CHAPTER XXII.}

AN OUTLINE OF THE GEOGRAPHICAL DISTRIBUTION OF MOLLUSOA.

Ceplatopoda (p. 505)--Gasteropoda (p. 507)-Pulmonifera (p. 512)-General Observations on the Distribution of Land Mollusca (p. 522)-Pteropoda (p. 531)-Brachiopoda (p. 532)-Conchifera (p. 533)-General Remarks on the Distribution of Marine Mollusea (p. 537) . . . . . 504-539

\section{CHAPTER XXIII.}

SUMMATY OF THE DISTRIBUTION AND LINES OF MIIGRATION OF THE SEVERAL CLASSES OF ANIMALS.

Mammalia (p. 540)-Lines of Migration of the Mammalia (p. 544)-Birds (p. 545)

Reptiles (p. 547)-Amphibia (p. 548)-Fresh-water Fishes (p. 549)-Insects (p. 550)-Terrestrial Mollusea (p. 551)-Conclusion (p. 552) , 540-553 


\section{MAPS AND ILLUSTRA'TIONS IN VOL. II.}

1. Map of the Neotropical Region . . . . . . . . 3

2. Plate XIV. A Brazilian Forest with Characteristic Mammalia . . 24

3. Plate XV. A Scene on the Upper Amazon, with some Characteristic Birds . . . . . . . . 28

4. Plate XVI. The Chilian Andes, with Characteristic Animals . . 40

5. Plate XVII. A Scene in Cnba, with Characteristic Animals . . 67

6. Map of the Nearctic Region . . . . . . 115

7. Plate XVIII. Scene in California with some Characteristic Birds . $\quad 128$

8. Plate XIX. The North American Prairies with Characteristic Mammalia 130

9. Plate XX. A Canadian Forest with Characteristic Mammalia . . 136 



\section{ERRATA IN VOL. II.}

As in Vol. I. mis-spellings are not given here, being mostly corrected in the Index.

Page 111, No. 642, for 1 read 2.

, 111, No. 643, for 15 read 9 .

,2 267, line 7 , add Borneo.

,, 276 , line 10, for 16 Genera read 11 Genera.

, , , 8 lines from foot, for Drepanomis read Neodrepenis.

,291, 5 lines from foot, for Sayornis read Empidius. 



\title{
THE \\ GEOGRAPHICAL DISTRIBUTION OF ANIMALS.
}

\author{
PART IIT. (continued.)
}

ZOOLOGICAL GEOGRAPHY:

A REVIEW OF THE CHIEF FORMS OF ANINAL LIFE IN THE SEVERAL REGIONS AND SUB-REGIONS, WITH THE INDICATIONS THEY AFFORD OF GEOGRAPHICAL MUTATIONS. 




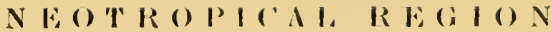

Sealo I inch-1, (1)(9) miles

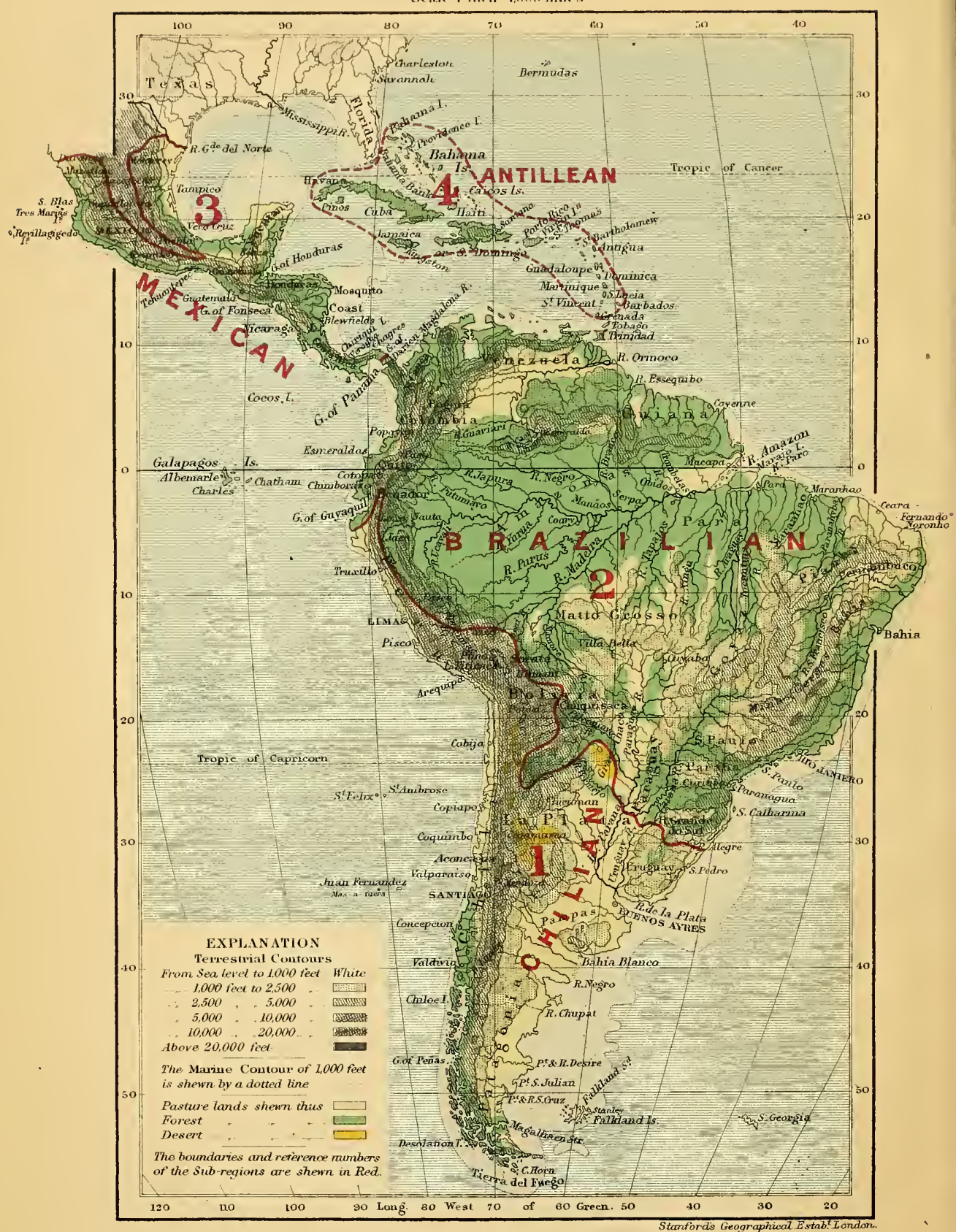

London; Macmillan \& Co. 


\section{CHÁPTER XIV.}

THE NEOTROPICAL REGION.

THIS region, comprehending not only South America but 'Tropical North America and the Antilles, may be compared as to extent with the Ethiopian region; but it is distinguished from all the other great zoological divisions of the globe, by the small proportion of its surface occupied by deserts, by the large proportion of its lowlands, and by the altogether unequalled extent and luxuriance of its tropical forests. It further possesses a grand mountain range, rivalling the Himalayas in altitude and far surpassing them in extent, and which, being wholly situated within the region and running through eighty degrees of latitude, offers a variety of conditions and an extent of mountain slopes, of lofty plateaus and of deep valleys, which no other tropical region can approach. It has a further advantage in a southward prolongation far into the temperate zone, equivalent to a still greater extension of its lofty plateaus; and this has, no doubt, aided the development of the peculiar alpine forms of life which abound in the southern Andes. Tue climate of this region is exceptionally favourable. Owing to the lofty mountain range situated along its western margin, the moisture-laden trade winds from the Atlantic have free access to the interior. A sufficient proportion of this moisture reaches the higher slopes of the Andes, where its condensation gives rise to innumerable streams, which cut deep ravines and carry down such an amount of sediment, that they have formed the vast plains of the Amazon, of Para- 
grtay, and of the Orinooko out of what were once, no doubt, arms of the sea, separating the large islands of Guiana, Brazil, and the Andes. From these concurrent favourable conditions, there has resulted that inexhaustible variety of generic and specific forms with a somewhat limited range of family and ordinal types, which charncterise neotropical zoology to a degree nowhere else to be met with.

Together with this variety and richness, there is a remarkable ıniformity of animal life over all the tropical continental portions of the region, so that its division into sub-regions is a matter of some difficulty. There is, however, no doubt about separating the West Indian islands as forming a well-marked subdivision; characterised, not only by that poverty of forms which is a general feature of ancient insular groups, but also by a number of peculiar generic types, some of which are quite foreign to the remainder of the region. We must exclude, however, the islands of Trinidad, Tobago, and a few other small islands near the coast, which znologically form a part of the main land. Again, the South Temperate portion of the continent, together with the high plateaus of the Andes to near the equator, form a well-marked subdivision, characterised by a peculiar fauna, very distinct both positively and negatively from that of the tropical lowland districts. The rest of Tropical South America is so homogeneous in its forms of life that it cannot be conveniently subdivided for the purposes of a work like the present. There are, no doubt, considerable differences in various parts of its vast area, due partly to its having been once separated into three or more islands, in part to existing diversities of physical conditions; and more exact knowledge may enable us to form several provinces or perhaps additional sub-regions. A large proportion of the genera, however, when sufficiently numerous in species, range over almost the whole extent of this sub-region wherever the conditions are favourable. Even the Andes do not seem to form such a barrier as has been supposed. North of the equator, where its western slopes are moist and forest-clad, most of the genera are found on both sides. To the south of this line its western valleys are arid and its lower plains almost deserts; and thus the absence of a 
number of groups to which verdant forests are essential, can be traced to the unsuitable conditions rather than to the existence of the mountain barrier. All Tropical South America, therefore, is here considered to form but one sub-region.

The portion of North America that lies within the tropics, closely resembles the last sub-region in general zoological features. It possesses hardly any positive distinctions; but there are several of a negative character, many important groups being wholly confined to South America. On the other hand many genera range into Mexico and Guatemala from the north, which never reach South America; so that it is convenient to separate this district as a sub-region, which forms, to some extent, a transition to the Nearctic region.

General Zoological Features of the Neotropical Region.-Richness combined with isolation is the predominant feature of Neotropical zoology, and no other region can approach it in the number of its peculiar family and generic types. It has eight families of Mammalia absolutely confined to it, besides several others which are rare elsewhere. These consist of two families of monkeys, Cebidæ and Hapalidæ, both abounding in genera and species; the Phyllostomidæ, or blood-sucking bats; Chinchillidæ and Caviidæ among rodents; besides the greater part of the Octodontidæ, Echimyidæ and Cercolabidæ. Among edentata, it has Bradypodidæ, or sloths, Dasypodidæ, or armadillos, and Myrmecophagidæ, or anteaters, constituting nearly the entire order; while Procyonidæ, belonging to the carnivora, and Didelphyidæ, a family of marsupials, only extend into the Nearctic region. It has also many peculiar groups of carnivora and of Muridæ, making a total of full a hundred genera confined to the region. Hardly less remarkable is the absence of many widespread groups. With the exception of one genus in the West Indian islands and a Sorex which reaches Guatemala and Costa Rica, the Insectivora are wholly wanting ; as is also the extensive and wide-spread family of the Viverridæ. It has no oxen or sheep, and indeed no form of ruminant except deer and llamas; neither do its vast forests and grassy plains support a single form of non-ruminant ungulate, except the tapir and the peccary. 
Birds.-In birds, the Neotropical region is even richer and more isolated. It possesses no less than 23 families wholly confined within its limits, with 7 others which only extend into the Nearctic region. The names of the peculiar families are: Cærebidæ, or sugar-birds; Phytotomidæ, or plant-cutters; Pipridæ, or manakins; Cotingidæ, or chatterers; Formicariidæ, or ant-thrushes ; Dendrocolaptidæ, or tree-creepers ; Pteroptochidæ; Rhamphastidæ, or toucans ; Bucconidæ, or puff-birds ; Galbulidæ, or jacamas; Todidæ, or todies; Momotidæ, or motmots; Steatornithidæ. the guacharo, or oil-bird; Cracidæ, or curassows; Tinamidæ, or tinamous ; Opisthocomidæ, the hoazin ; Thinocoridæ ; Cariamidæ : Aramidæ; Psophiidæ, or trumpeters ; Eurypygidæ, or sun-bitterns ; and Palamedeidæ, or horned-screamers. The seven which it possesses in common with North America are: Vireonidæe, or greenlets; Mniotiltidæ, or wood-warblers; Tanagridæ, or tanagers; Icteridæ, or hang-nests; Tyrannidæ, or tyrant-shrikes; Trochilidæ, or humming-birds ; and Conuridæ, or macaws. Most of these families abound in genera and species, and many are of immense extent ; such as Trochilidæ, with 1.15 genera, and nearly 400 species; Tyrannidæ, with more than 60 genera and nearly 300 species ; Tanagridæ, with 43 genera and 300 species; Dendrocolaptidæ with 43 genera and more than 200 species; and many other very large groups. There are nearly 600 genera peculiar to the Neotropical region; but in using this number as a basis of comparison with other regions we must remember, that owing to several ornithologists having made the birds of South America a special study, they have perhaps been more minutely subdivided than in the case of other entire tropical regions.

Distinctive Characters of Neotropical Mammalia.-It is important also to consider the kind and amount of difference between the various animal forms of this region and of the old World. To begin with the Quadrumana, all the larger American monkeys (Cebidæ) differ from every Old World group in the possession of an additional molar tooth in each jaw ; and it is in this group alone that the tail is developed into a prehensile organ of wonderful power, adapting the animals to a purely arboreal life. Four of the genera, comprising more than half the 
species, have the prehensile tail, the remainder having this organ either short, or lax as in the Old World monkeys. Other differences from Old World apes, are the possession of a broad nasal septum, and a less opposable thumb; and the absence of cheekpouches, ischial callosities, and a bony ear-tube. The Hapalidæ, or marmozets, agree with the Cebidx in all these characters, but have others in addition which still more widely separate them from the Simiidæ; such as an additional premolar tooth, acute claws, and thumb not at all opposable; so that the whole group of American monkeys are radically different from the remainder of the order.

The Procyonidæ are a distinct family of Carnivora, which make up for the scarcity of Mustelidæ in South America. The Suidæ are represented by the very distinct genus Dicotyles (Peccary) forming a separate sub-family, and differing from all other genera in their dentition, the absence of tail and of one of the toes of the hind feet, the possession of a dorsal gland, and only two mammæ. The rodents are represented by the Chinchillidæ and Caviidæ, the latter comprising the largest animals in the order. The Edentata are almost wholly confined to this region; and the three families of the sloths (Bradypodidæ), armadillos (Dasypodidæ), and ant-eaters (Myrmecophagidæ), are widely separated in structure from any Old World animals. Lastly, we lave the opossums (Didelphyidæ), a family of marsupials, but having no close affinity to any of the numerous Australian forms of that order. We have already arrived at the conclusion that the presence of marsupials in South America is not due to any direct transference from Australia, but that their introduction is comparatively recent, and that they came from the Old World by way of North America (vol. i., p. 155). But the numerous and deep-seated peculiarities of many other of its mammalia, would indicate a very remote origin; and a long-continued isolation of South America from the rest of the world is required, in order to account for the preservation and development of so many distinct groups of comparatively low-type quadrupeds.

Distinctive Characters of Ncotropical Birds.-The birds which are especially characteristic of this region, present similar distinctive features. In the enormous group of Passerine 
birds which, though comprising nearly three-fourths of the entire class, yet presents hardly any well-marked. differences of structure by which it can be subdivided-the families confined to America are, for the most part, more closely related to each other than to the Old World groups. The ten families forming the group of "Formicaroid Passeres," in our arrangement (vol. i., p. 94), are characterised by the absence of singing muscles in the larynx, and also by an unusual development of the first primary quill; and seven of this series of families (which are considered to be less perfectly developed than the great mass of old World passeres) are exclusively American, the three belonging to the Eastern hemisphere being of small extent. Another group of ten families-our "Tanagroid Passeres," are characterised by the abortion or very rudimentary condition of the first quill; and of these, five are exclusively American, and have numerous genera and species, while only two are non-American, and these are of small extent. On the other hand the "Turdoid Passeres," consisting of 23 families and comprising all the true "singing-birds," is poorly represented in America; no family being exclusively Neotropical, and only three being at all fully represented in South America, though they comprise the great mass of the Old World passeres. These peculiarities, which group together whole series of families of American birds, point to early separation and long isolation, no less surely than the more remarkable structural divergences presented by the Neotropical mammalia.

In the Picariæ, we have first, the toucans (Rhamphastidæ); an extraordinary and beautiful family, whose enormous gailycoloured bills and long feathered tongues, separate them widely from all other birds. The Galbulidæ or jacamars, the motmots (Momotidœ), and the curious little todies (Todidx) of the Antilles, are also isolated groups. But most remarkable of all is the wonderful family of the humming-birds, which ranges over all America from Tierra del Fuego to Sitka, and from the level plains of the Amazon to above the snow-line on the Andes; which abounds both in genera, species, and individuals, and is yet strictly confined to this continent alone! How vast must have been the time required to develop those beautiful and 
highly specialized forms out of some ancestral swift-like type; how complete and long continued the isolation of their birthplace to have allowed of their modification and adaptation to such divergent climates and conditions, yet never to have permitted them to establish themselves in the other continents. No naturalist can study in detail this single family of birds, without being profoundly impressed with the vast antiquity of the South American continent, its long isolation from the rest of the land surface of the globe, and the persistence through countless ages of all the conditions requisite for the development and increase of varied forms of animal life.

Passing on to the parrot tribe, we find the peculiar family of the Conuridæ, of which the macaws are the highest development, very largely represented. It is in the gallinaceous birds however that we again meet with wholly isolated groups. The Cracidæ, including the curassows and guans, have no immediate relations with any of the Old World families. Professor Huxley considers them to approach nearest to (though still very remote from) the Australian megapodes; and here, as in the case of the marsupials, we probably have divergent modifications of an ancient type once widely distributed, not a direct communication between the sonthern continents. The Tinamidæ or tinamous, point to a still more remote antiquity, since their nearest allies are believed to be the Struthiones or ostrich tribe, of which a few representatives are scattered widely over the globe. The hoazin of Guiana (Opisthocomus) is another isolated form, not only the type of a family, but perhaps of an extinct order of birds. Passing on to the waders, we have a number of peculiar family types, all indicative of antiquity and isolation. The Cariame of the plains of Brazil, a bird somewhat intermediate between a bustard and a hawk, is one of these; the elegant Psophic or trumpeter of the Amazonian forests; the beautiful little sun-bittern of the river banks (Eurypyga); and the horned screamers (Palamedea), all form distinct and isolated families of birds, to which the Old World offers nothing directly comparable.

Reptiles.-The Neotropical region is very rich in varied forms of reptile life, and the species are very abundant. It has six 
altogether peculiar families, and several others which only range into the Nearetic region, as well as a very large number of peculiar or characteristic genera. As the orders of reptiles differ considerably in their distributional features, they must be considered separately.

The snakes (Ophidia) differ from all other reptiles, and from most other orders of vertebrates, in the wide average distribution of the families; so that such an isolated region as the Neotropical possesses no peculiar family, nor even one confined to the American continent. The families of most restricted range arethe Scytalidæ, only found elsewhere in the Philippine islands; the Amblycephalidæ, common to the Oriental and Neotropical regions; and the Tortricidæ, most abundant in the Oriental region, but found also in the Austro-Malay islands and Tropical South America. Sixteen of the families of snakes occur in the region, the Colubridæ, Amblycephalidæ, and Pythonidæ, being those which are best represented by peculiar forms. There are 25 peculiar or characteristic genera, the most important being Dromicus (Colubridæ) ; Boa, Epicrates, and Ungalia (Pythonidæ); Elaps (Elapidæ); and Craspedocephalus (Crotalidæ).

The lizards (Lacertilia) are generally more restricted in their range; hence we find that out of 15 families which inhabit the region, 5 are altogether peculiar, and 4 more extend only to $\mathrm{N}$. America. The peculiar families are Helodermidæ, Anadiadæ, Chirocolidæ, Iphisiadæ, and Cercosauridæ ; but it must be noted that these all possess but a single genus each, and only two of them (Chirocolidæ and Cercosauridæ) have more than a single species. The families which range over both South and North America are Chirotidæ, Chalcidæ, Teidæ, and Iguanidæ; the first and second are of small extent, but the other two are very large groups, the Teidæ possessing 12 genera and near 80 species; the Iguanidæ 40 genera and near 150 species; the greater part of which are Neotropical. There are more than 50 peculiar or highly characteristic genera of lizards, about 40 of which belong to the Teidæ and Iguaniclæ, which thus especially characterize the region. The most important and characteristic genera are the following: Amciva (Teidæ); Gymnopthalmus (Gymmopthalmidæ); 
Celestus and Diploglossus (Scincidæ); Sphacrodactylus (Geckotidæ); Liocephalus, Liolocmus, Proctotretus, and many smaller genera (Iguanidæ). The three extensive Old World families Varanidæ, Lacertidæ, and Agamidæ, are absent from the entire American continent.

In the order Crocodilia, America has the peculiar family of the alligators (Alligatoridæ), as well as several species of true erocodiles (Crocodilidæ). The Chelonia (tortoises) are represented by the families Testudinidæ and Chelydidæ, both of wide range; but there are six peculiar genera,-Dermatemys and Staurotypus belonging to the former family,-Peltocephalus, Podocnemis, Hydromedusa, and Chelys, to the latter. Some of the Amazon river-turtles of the genus Podocnemys rival in size the largest species of true marine turtles (Cheloniidæ), and are equally good for food.

Amphibia.-The Neotropical region possesses representatives of sixteen families of Amphibia of which four are peculiar; all belonging to Anoura or tail-less Batrachians. The Cæciliadæ or snake-like amphibia, are represented by two peculiar genera, Siphonopsis and Rhinatrcma. Tailed Batrachians are almost unknown, only a few species of Spclerpes (Salamandridx) entering Central America, and one extending as far south as the Andes of Bogota in South America. Tail-less Batrachians on the other hand, are abundant ; there being 14 families represented, of which 4,-Rhinophryndæ, Hylaplesidæ, Plectromantidæ, and Pipidæ are peculiar. None of these families contain more than a single genus, and only the second more than a single species; so that it is not these which give a character to the South American Amphibia-fauna. The most important and best represented families are, Ranidæ (true frogs), with eleven genera and more than 50 species; Polypedatidæ (tree-frogs) with seven genera and about 40 species; Hylidæ (tree-frogs) with eight genera and nearly 30 species; Engystomidæ (toads) (5 genera), Bombinatoridæ (frogs), (4 genera), Phryniscidæ and Bufonidæ (toads), (each with 2 genera), are also fairly represented. All these families are widely distributed, but the Neotropical genera are, in almost every case, peculiar. 
Fresh-vater fishes.-The great rivers of Tropical America abound in fish of many strange forms and peculiar types. Three families, and three sub-family groups are peculiar, while the number of peculiar genera is about 120 . The peculiar families are Polycentridæ, with two genera; Gymnotidæ, a family which includes the electric eels, (5 genera); and Trygonidæ, the rays, which are everywhere marine except in the great rivers of South America, where many species are found, belonging to two genera. Of the extensive family Siluridæ, three sub-families Siluridæ anomalopteræ, S. olisthopteræ, and S. branchiolæ, are confined to this region. The larger and more important of the peculiar genera are the following: Percilia, inhabiting Chilian and Percichthys South Temperate rivers, belong to the Perch family (Percidæ); Acharnes, found only in Guiana, belongs to the Nandidæ, a family of wide range in the tropics; the Chromidx, a family of exclusively fresh-water fishes found in the tropics of the Ethiopian, Oriental and Neotropical regions, are here represented by 15 genera, the more important being Acara (17 sp.), Heros (26 sp.), Crenicichla (9 sp.), Satanoperca (7 sp.). Many of these fishes are beautifully marked and coloured. The Siluridæ proteropteræ are represented by 14 genera, of which Pimelodus (42 sp.), and Platystoma (11 sp.), are the most important; the Siluridæ stenobranchiæ by 11 genera, the chief being Doras (13 sp.), Auchenipterus (9 sp.), and Oxydoras ( $7 \mathrm{sp}$.). The Siluridæ proteropodes are represented by 16 genera, many of them being among the most singular of fresh-water fishes, clothed in coats of mail, and armed with hooks and serrated spines. The following are the most important,-Choctostomus (25 sp.), Loricaria (17 sp.), Plecostonus (15 sp.) and Callichthys (11 sp.). The Characinidæ are divided between Tropical America and Tropical Africa, the former possessing about 40 genera and 200 species. The Haplochitonidæ are confined to South America and Australia; the American genus being Haplochiton. The Cyprinodontidæ are represented by 18 genera, the most important being, Pccilia (16 sp.), Gircrdinus (10 sp.), and Gambusia (8 sp.) The Osteoglossidæ, found in Australian and African rivers, are represented in South America by the peculiar Arapaima, the "pirarucu" of the 
Amazon. The ancient Sirenoidei, also found in Australia and Africa, have the Lepidosiren as their American representative. Lastly, Ellipisurus is a genus of rays peculiar to the fresh waters of South America. We may expect these numbers to be largely increased and many new genera to be added, when the extensive collections made by Agassiz in Brazil are described.

Summary of Neotropical Vertebrates.-Summarizing the preceding facts, we find that the Neotropical region possesses no less than 45 families and more than 900 genera of Vertebrata which are altogether peculiar to it; while it has representatives of 168 families out of a total of 330 , showing that 162 families are altogether absent. It has also representatives of 131 genera of Mammalia of which 103 are peculiar to it, a proportion of $\frac{4}{5}$; while of 683 genera of land-birds no less than 576 are peculiar, being almost exactly $\frac{5}{6}$ of the whole. These numbers and proportions are far higher than in the case of any other region.

\section{Insects.}

The Neotropical region is so excessively rich in insect life, it so abounds in peculiar groups, in forms of exquisite beauty, and in an endless profusion of species, that no adequate idea of this branch of its fauna can be conveyed by the mere enumeration of peculiar and characteristic groups, to which we are here compelled to limit ourselves. Our facts and figures will, however, furnish data for comparison; and will thus enable those who have some knowledge of the entomology of any other country, to form a better notion of the vast wealth of insect'life in this region, than a more general and picturesque description could afford them.

Lepidoptera. - The Butterflies of South America surpass those of all other regions in numbers, variety and beauty; and we find here, not only more peculiar genera and families than elsewhere, but, what is very remarkable, a fuller representation of the whole series of fanilies. Out of the 16 families of butterflies in all parts of the world, 13 are found here, and 3 of these are wholly peculiar-Brassolidæ, Heliconidæ, and Eurygonidæ, with a fourth, Erycinidæ, which only extends into the Nearctic 
region; so that there are 4 families peculiar to America. These, four families comprise 68 genera and more than 800 species; alone constituting a very important feature in the entomology of the region. But in almost all the other families there are numbers of peculiar genera, amounting in all to about 200 , or not far short of half the total number of genera in the world(431). We must briefly notice some of the peculiarities of the several families, as represented in this region. The Danaidre consist of 15 genera, all peculiar, and differing widely from the generally sombre-tinted forms of the rest of the world. The delicate transparent-winged Ithomias of which 160 species are described, are the most remarkable. Melincea, Napeogenes, Ceratina and Dircennc are more gaily coloured, and are among the chief ornaments of the forests. The Satyridæ are represented loy 25 peculiar genera, many of great beauty; the most remarkable and elegant being the genus Hotera and its allies, whose transparent wings are delicately marked with patches of orange, pink, or violet. The genus Morpho is perhaps the grandest development of the butterfly type, being of immense size and adorned with the most brilliant azure tints, which in some species attain a splendour of metallic lustre unsurpassed in nature. The Brassolidæ are even larger, but are crepuscular insects, with rich though sober colouring. The true Heliconii are magnificent insects, most elegantly marked with brilliant and strongly contrasted tints. The Nymphalidæ are represented by such a variety of gorgeous insects that it is difficult to select examples. Prominent are the genera Catagramma and Callithea, whose exquisite colours and symmetrical markings are unique and indescribable; and these are in some cases rivalled by Agrias and Prepona, which reproduce their style of coloration. although not clusely allied to them. The Erycinidæ, consisting of 59 genera and 560 species, comprise the most varied and beautiful of small butterflies; and it would be useless to attempt to indicate the unimaginable combinations of form and colour they present. It must be sufficient to say that nothing elsewhere on the globe at all resembles them. In Lycænidæ the worldwide genus Thecla is wonderfully developed, and the South 
American species not only surpass all others in size and beauty, but some of them are so gorgeous on the under surface of their wings, as to exceed almost all the combinations of metallic tints we meet with in nature. The last family, Hesperidæ, is also wonderfully developed here, the species being excessively numerous, while some of them redeem the character of this generally sober family, by their rich and elegant coloration.

In the only other group of Lepidoptera we can here notice, the Sphingina, the Neotropical region possesses some peculiar forms. The magnificent diurnal butterfly-like moths, Urania, are the most remarkable; and they are rendered more interesting by the occurrence of a species closely resembling them in Madagascar. Another family of day-flying moths, the Castniidæ, is almost equally divided between the Neotropical and Australian regions, although the genera are more numerous in the latter. The American Castnias are large, thick-bodied insects, with a coarse scaly surface and rich dull colours; differing widely from the glossy and gaily coloured Agaristas, which are typical of the family in the East.

Coleopterc.-This is so vast a subject that, as in the case of the regions already treated, we must confine our attention to a few of the more important and best known families as representatives of the entire order.

Cicindelidæ.-We find here examples of 15 out of the 35 genera of these insects; and 10 of these genera are peculiar. The most important are Oxychila (11 sp.), Hiresia (14 sp.), and Ctenostome (26 sp.). Odontochila (57 sp.) is the most abundant and characteristic of all, but is not wholly peculiar, there being a species in the Malay archipelago. Tetrucha, another large genus, has species in Australia and a few in North America and Europe. The small genus Peridexic is divided between Brazil and Madagascar,- - a somewhat similar distribution to that of Urania noticed above. One genus, Agrius, is confined to the southern extremity of the continent.

Carabidæ.-Besides a considerable number of cosmopolitan or wide-spread genera, this family is represented by more than 100 genera which are peculiar to the Neotropical region. The 
most important of these are Agra (150 sp.), Ardistonus (44 sp.), Schizogenius (25 sp.), Pelecium (24 sp.), Calophena (22 sp.), As. pidoglossa (21 sp.), and Lia, Camptodonotus, Stenocrepis, and Lachnophorus, with each more than 12 species. These are all tropical; but there are also a number of genera (26) peculiar to Chili and South Temperate America. The most important of these are Antarctia (29 sp.), all except two or three confined to South Temperate America; Scelodontis (10 sp.), mostly Chilian; Feronomorpha (6 sp.) all Chilian; and Tropidopterus (4 sp.), all Chilian. Helluomorpha (18 sp.), is confined to North and South America; Galerita, Callida, and Tetragonoderus, are large genera which are chiefly South American but with a few species scattered over the other tropical regions. Casnonia and Lebia are cosmopolite, but most abundant in South America. Pachyteles is mostly South American but with a few species in West Africa; while Lobodonotus has one species in South America and two in Africa.

Lucanidæ.-The Neotropical species of this family almost all belong to peculiar genera. Those common to other regions are Syndesus, confined to Tropical South America and Australia, and Platycerus which is Palæarctic and Nearctic, with one species in Brazil. The most remarkable genus is undoubtedly Chiasognathus, confined to Chili. These are large insects of metallic green colours, and armed with enormous serrated mandibles. The allied genera, Pholidotus and Sphenognathus, inhabit Tropical South America. Streptocerus confined to Chili, is interesting, as being allied to the Australian Lamprima. The other genera present no remarkable features; but Sclerognathus and Lepiinoptera are the most extensive.

Cetoniidæ.-These magnificent insects are but poorly represented in America; the species being mostly of sombre colours. There are 14 genera, 12 of which are peculiar. The most extensive genus is Gymnetis, which, with its allies Cotinis and Allorhina, form a group which comprehends two-thirds of the Neotropical species of the family. The only other genera of importance are, Inca (7 sp.), remarkable for their large size, and being the only American group in which horns are developed on the head; 
and Trigonopcltastes (6 sp.), allied to the European Trichius. The non-peculiar genera are, Stethodesma, of which half the species are African and half tropical American; and Euphoria, confined to America both North and South.

Buprestidæ.-In this fine group the Neotropical region is tolerably rich, having examples of 39 genera, 18 of which are peculiar to it. Of these, the most extensive are Conognatha and Halecia, which have a wide range over most parts of the region; and Dactylozodes, confined to the south temperate zone. Of important genera which range beyond the region, Dicerca is mainly Nearctic and Palæarctic; Cinyra has a species in North America and one in Australia; Curis is divided between Chili and Australia; the Australian genus Stigmodera has a species in Chili; Polycesta has a species in Madagascar, two in the Mediterranean region, and a few in North America; Acherusia is divided between Australia and Brazil; Ptosima has one species in south temperate America, the rest widely scattered from North America to the Philippines; Actenodes has a single species in North America and another in West Africa; Coloboguster has two in West Africa, one in Java and one in the Moluccas. The relations of South America and Australia as indicated by these insects has already been sufficiently noticed under the latter region.

Longicornia.-The Neotropical Longicorn Coleoptera are overwhelming in their numbers and variety, their singularity and their beauty. In the recent Catalogue of Gemminger and Harold, it is credited with 516 genera, 489 of which are peculiar to it; while it has only 5 genera in common (exclusively) with the Nearctic, and 4 (in the same way) with the Australian region. Only the more important genera can be here referred to, under the three great families into which these insects are divided.

The Prionidæ are excessively numerous, being grouped in 64 genera, more than double the number possessed by any other region; and 61 of these are peculiar. The three, common to other regions, are, Parandra and Mallodon, which are widely distributed; and Ergates, found also in California and Europe. The most remarkable genera are, the magnificently-coloured Psalidognathus and Pyrodes; the large and strangely marked

VOL. II. 
Macrodontia; and Titanus, the largest insect of the entire family.

Of the Cerambycidæ there are 233 genera, exceeding by onehalf, the number in any other region; and 225 of these are peculiar. Only 2 are common to the Neotropical and Nearctic regions exclusively, and 3 to the Neotropical and Australian. The most extensive genera are the elegant Ibidion (80 sp.); the richly-coloured Chrysoprasis (47 sp.); the prettily-marked Trachyderes (53 sp.); with Odontocera (25 sp.); Criodon (22 sp.); and a host of others of less extent, but often of surpassing interest and beauty. The noteworthy genera of wide range are, Oeme and Cyrtomerus, which have each a species in West Africa, and Hammatocerus, which has one in Australia.

The Lamiidæ have 219 genera, and this is the only tropical region in which they do not exceed the Cerambycidæ. This number is almost exactly the same as that of the Oriental genera, but here there are more peculiar groups, 203 against 160 in the other region. The most extensive genera are Hemilophus (80 sp.), Colobothea (70 sp.), Acanthoderes (56 sp.), Oncoderes (48 sp.), Lepturgus (40 sp.), Hypsioma (32 sp.), and Teniotes (20 sp.). Macropus longimanus, commonly called the harlequin beetle, is one of the largest and most singularly-marked insects in the whole family. Leptostylus has a single species in New Zealand; Acanthoderes has one species in Europe, W. Africa, and Australia, respectively; Spalacopsis has a species in W. Africa; Pachypeza is common to S. America and the Philippines; Mesosa is Oriental and Palæarctic, but has one species on the Amazon; Apomecyna ranges through the tropics of the Eastern Hemisphere, but has two species in S. America; Acanthocinus has one species in Tasmania, and the rest in South America, North America, and Europe; Phoce is wholly Neotropical, except two species in the Philippine Islands.

General Conclusions as to the Ncotropical Inscet-fauna.Looking at the insects of the Neotropical region as a whole, we are struck with the vast amount of specialty they present; and, considering how many causes there are which must lead to the dispersal of insects, the number of its groups which are scattered 
over the globe is not nearly so great as we might expect. This points to a long period of isolation, during which the various forms of life have acted and reacted on each other, leading to such a complex yet harmoniously-balanced result as to defy the competition of the chance immigrants that from time to time must have arrived. This is quite in accordance with the very high antiquity we have shown most insect-forms to possess; and it is no doubt owing to this antiquity, that such a complete diversity of generic forms has been here brought about, without any important deviation from the great family types which prevail over the rest of the globe.

Land Shells.-The Neotropical region is probably the richest on the globe in Terrestrial Mollusca, but this is owing, not to any extreme productiveness of the equatorial parts of the continent, where almost all other forms of life are so largely developed, but to the altogether exceptional riches of the West India Islands. The most recent estimates show that the Antilles contain more species of land shells than all the rest of the region, and almost exactly as many as all continental America, north and south.

Mr. Thomas Bland, who has long studied American land shells, points out a remarkable difference in the distribution of the Operculated and Inoperculated groups, the former being predominant on the islands, the latter on the continent. The Antilles possess over 600 species of Operculata, to about 150 on the whole American continent, the genera being as 22 to 14 . Of Inoperculata the Antilles have 740, the Continent 1,250, the genera being 18 and 22 . The proportions of the two groups in each country are, therefore:

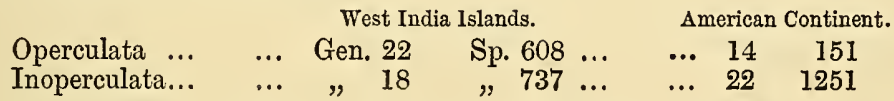

The extensive family of the Helicidæ is represented by 22 genera, of which 6 are peculiar. Spiraxis is confined to Central America and the Antilles; Stenopus and Sagda are Antillean only; Orthalicus, Macroceramus, and Bulimulus have a wider range, the last two extending into the southern. United 
States. Important and characteristie genera are, Glandina, in all the tropical parts of the region; Cylindrella, in Central America and the Antilles; Bulimus, containing many large and handsome speeies in South America; Stenogyra, widely spread in the tropics; and Streptaxis, in Tropical South America.

Among the Operculata, the Aciculidæ are mostly Antillean, two genera being peculiar there, and one, Truncatella, of wide distribution, but most abundant in the West Indian Islands. The Cyclostomidæ are represented by 15 genera, 9 being peculiar to the region, and 5 of these (belonging to the subfamily Licinidx) to the Antilles only. Of these peculiar genera Cistula and Chondropoma are the most important, ranging over all the tropical parts of the region. Other important genera are Cyclotus and Megalomastoma; while Cyclophorus also oecurs all over the region. The Helicinidæ are mostly Neotropical, six out of the seven genera being found here, and four are peculiar. Stoastoma, is one of the largest genera; and, with Trochatclla and Alcadia, is eonfined to the Antilles, while the wide-spread Helicina is most abundant there.

The Limacidæ, or Old World slugs, are absent from the region, their place being taken by the allied family, Oncidiadæ.

Marine Shells.-We go out of our usual comse to say a few words about the marine shells of this region, because their distribution on the two sides of the continent is important, as an indieation of the former separation of North and South America, and the connection of the Atlantic and Pacifie Oceans. It was once thought that no species of shells were common to the two sides of the Central American Isthmus, and Dr. Mörch still holds that opinion; but Dr. Philip Carpenter, who has paid special attention to the subject, eonsiders that there are at least 35 species absolutely identical, while as many others are so elose that they may be only varieties. Nearly 70 others are distinet but representative species. The genera of marine mollusca are very largely common to the east and west coasts, more than 40 being so named in the lists published by Mr. Woodward. The West Indian Islands being a rich shell district, produce a number of peculiar forms, and the west coast of 
South America is, to some extent, peopled by Oriental and Pacific genera of shells. On the west coast there is hardly any coral, while on the east it is abundant, showing a difference of physical conditions that must have greatly influenced the development of mollusca. When these various counteracting influences are taken into consideration, the identity or close affinity of about 140 species and 40 genera on the two sides of the Isthmus of Panama becomes very important; and, combined with the fact of 48 species of fish (or 30 per cent. of those known) being identical on the adjacent coasts of the two oceans (as determined by Dr. Giinther), render it probable that Central America has been partially submerged up to comparatively recent geological times. Yet another proof of this former union of two oceans is to be found in the fossil corals of the Antilles of the Miocene age, which Dr. Duncan finds to be more allied to existing Pacific forms, than to those of the Atlantic or even of the Caribbean Sea.

\section{Néotropical Sub-REgions.}

In the concluding part of this work devoted to geographical zoology, the sub-regions are arranged in the order best adapted to exhibit them in a tabular form, and to show the affinities of the several regions; but for our present purpose it will be best to take first in order that which is the most important and most extensive, and which exhibits all the peculiar characteristics of the region in their fullest development. We begin therefore with our second division.

\section{Tropical South-America, or the Brazilian Sub-region.}

This extensive district may be defined as consisting of all the tropical forest-region of South America, including all the open plains and pasture lands, surrounded by, or intimately associated with, the forests. Its central mass consists of the great forestplain of the Amazons, extending from Paranaiba on the north coast of Brazil (long. $42^{\circ} \mathrm{W}$.) to Zamora, in the province of Loja (lat. $4^{\circ} \mathrm{S}$., long. $79^{\circ} \mathrm{W}$.), high up in the Andes, on the west; a distance in a straight line of more than 2,500 English miles, 
along the whole of which there is (almost certainly) one continuous virgin forest. Its greatest extent from north to south, is from the mouths of the Orinooko to the eastern slopes of the Andes near La Paz in Bolivia and a little north of Sta. Cruz de la Sierra (lat. $18^{\circ} \mathrm{S}$.), a distance of about 1,900 miles. Within this area of continuous forests, are included some open "campos," or patches of pasture lands, the most important being,- - the Campos of the Upper Rio Branco on the northern boundary of Brazil; a tract in the interior of British Guiana; and another on the northern bank of the Amazon near its mouth, and extending some little distance on its south bank at Santarem. On the northern bank of the Orinooko are the Llanos, or flat open plains, partly flooded in the rainy season; but much of the interior of Venezuela appears to be forest country. The forest again prevails from Panama to Maracaybo, and southwards in the Magdalena valley; and on all the western side of the Andes to about 100 miles south of Guayaquil. On the N.E. coast of Brazil is a tract of open country, in some parts of which (as near Ceara) rain does not fall for years together; but south of Cape St. Roque the coast-forests of Brazil commence, extending to lat. $30^{\circ} \mathrm{S}$., clothing all the valleys and hill sides as far inland as the higher mountain ranges, and even penetrating up the great valleys far into the interior. To the south-west the forest country reappears in Paraguay, and extends in patches and partially wooded country, till it almost reaches the southern extension of the Amazonian forests. The interior of Brazil is thus in the position of a great island-platean, rising out of, and surrounded by, a lowland region of ever-verdant forest. The Brazilian subregion comprises all this forest-country and its included open tracts, and so far beyond it as there exists sufficient woody vegetation to support its peculiar forms of life. It thus extends considerably beyond the tropic in Paraguay and south Brazil; while the great desert of Chaco, extending from $25^{\circ}$ to $30^{\circ} \mathrm{S}$., lat. between the Parana and the Andes, as well as the high plateaus of the Andean range, with the strip of sandy desert on the Pacific coast as far as to about $5^{\circ}$ of south latitude, belong to south temperate America, or the sub-region of the Andes. 
Having already given a sketch of the zoological features of the Neotropical region as a whole, the greater part of which will apply to this sub-region, we must here confine ourselves to an indication of the more important groups which, on the one hand, are confined to it, and on the other are absent; together with a notice of its special relations to other regions.

Mammalia.-Many of the most remarkable of the American monkeys are limited to this sub-region; as Lagothrix, Pithecia, and Brachyurus, limited to the great Amazonian forests; Eriodes to south-east Brazil; and Callithrix to tropical South America. All the marmosets (Hapalidæ) are also confined to this sub-region, one only being found at Panama, and perhaps extending a little beyond it. Among other peculiar forms, are 8 genera of bats; 3 peculiar forms of wild dog; Pteronura, a genus of otters; Inia, a peculiar form of dolphin inhabiting the upper waters of the Amazon ; tapirs of the genus Tapirus (a distinct genus being found north of Panama) ; 4 genera of Muridæ ; Ctenomys, a genus of Octodontidæ; the whole family of Echimyidæ, or spiny rats, (as far as the American continent is concerned) consisting of 8 genera and 28 species; Chcetomys, a genus of Cercolabidæ; the capybara (Hydrochcerus) the largest known rodent, belonging to the Caviidæ; the larger ant-eaters (Myrmecophaga); sloths of the genus Bradypus ; 2 genera of armadillos (Dasypodidx); and two peculiar forms of the opossum family (Didelphyidæ). No group that is typically Neotropical is absent from this sub-region, except such as are peculiar to other single sub-regions and which will be noticed accordingly. The occurrence of a solitary species of hare (Lepus braziliensis) in central Brazil and the Andes, is remarkable, as it is cut off from all its allies, the genus not being known to occur elsewhere on the continent further south than Costa Rica. The only important external relation indicated by the Mammalia of this sub-region is towards the Ethiopian region, 2 genera of Echimyidæ, Aulacodes and Petromys, occurring in South and South-east Africa.

Plate IV. Characteristic Neotropical Mammalia.-Our illustration represents a morntainous forest in Brazil, the part of South America where the Neotropical Mammalia are perhaps best 
developed. The central and most conspicuous figure is the collared ant-eater, (Tamandua tetradactyla), one of the handsomest of the family, in its conspicuous livery of black and white. To the left are a pair of sloths (Arctopithecus flaccidus) showing the curious black spot on the back with which many of the species are marked, and which looks like a hole in the trunk of a tree; but this mark seems to be only found on the male animal. The fur of many of the sloths has a greenish tinge, and Dr. Seemann remarked its resemblance to the Tillandsia usneoides, or "vegetable horsehair," which clothes many of the trees in Central America; and this probably conceals them from their enemies, the harpy-eagles. On the right are a pair of opossums (Didelphys azarce), one of them swinging by its prehensile tail. Overhead in the foreground are a group of howling monkeys (Mycetes ursinus) the largest of the American Quadrumana, and the noisiest of monkeys. The large hollow vessel into which the hyoid bone is transformed, and which assists in producing their tremendous howling, is altogether unique in the animal kingdom. Below them, in the distance, are a group of Sapajou monkeys (Cebus sp.); while gaudy screaming macaws complete the picture of Brazilian forest life.

Birds.-A very large number of genera of birds, and some entire families, are confined to this sub-region, as will be seen by looking over the list of genera at the end of this chapter. We can here only notice the more important, and summarize the results. More than 120 genera of Passeres are thus limited, belonging to the follorving 12 families: Sylviidæ (1), Troglodytidæ (2), Cœrebidæ (4), Tanagridæ (26), Fringillidæ (8), Icteridæ (5), Pteroptochidæ (3), Dendrocolaptidæ (12), Formicariidæ (16), Tyrannidæ (22), Cotingidæ (16), Pipridæ (10). Of the Picariæ there are 76 peculiar genera belonging to 9 families, viz., Picidæ (2), Rhamphastidæ (1), Cuculidæ (1), Bucconidæ (2), Galbulidæ (5), Momotidæ (2), Podargidæ (1), Caprimalgidæ (4) Trochilidæ (58). There are 3 peculiar genera of Psittaci, 8 of Gallinæ, the only genus of Opisthocomidæ, 3 of Accipitres, 1 of Rallidæ, Psophia and Eurypyga types of distinct families, and 1 genus of Ardeidæ, Palamedeidæ, and Anatidæ respectively. The preceding enumeration shows how very rich this sub-region 


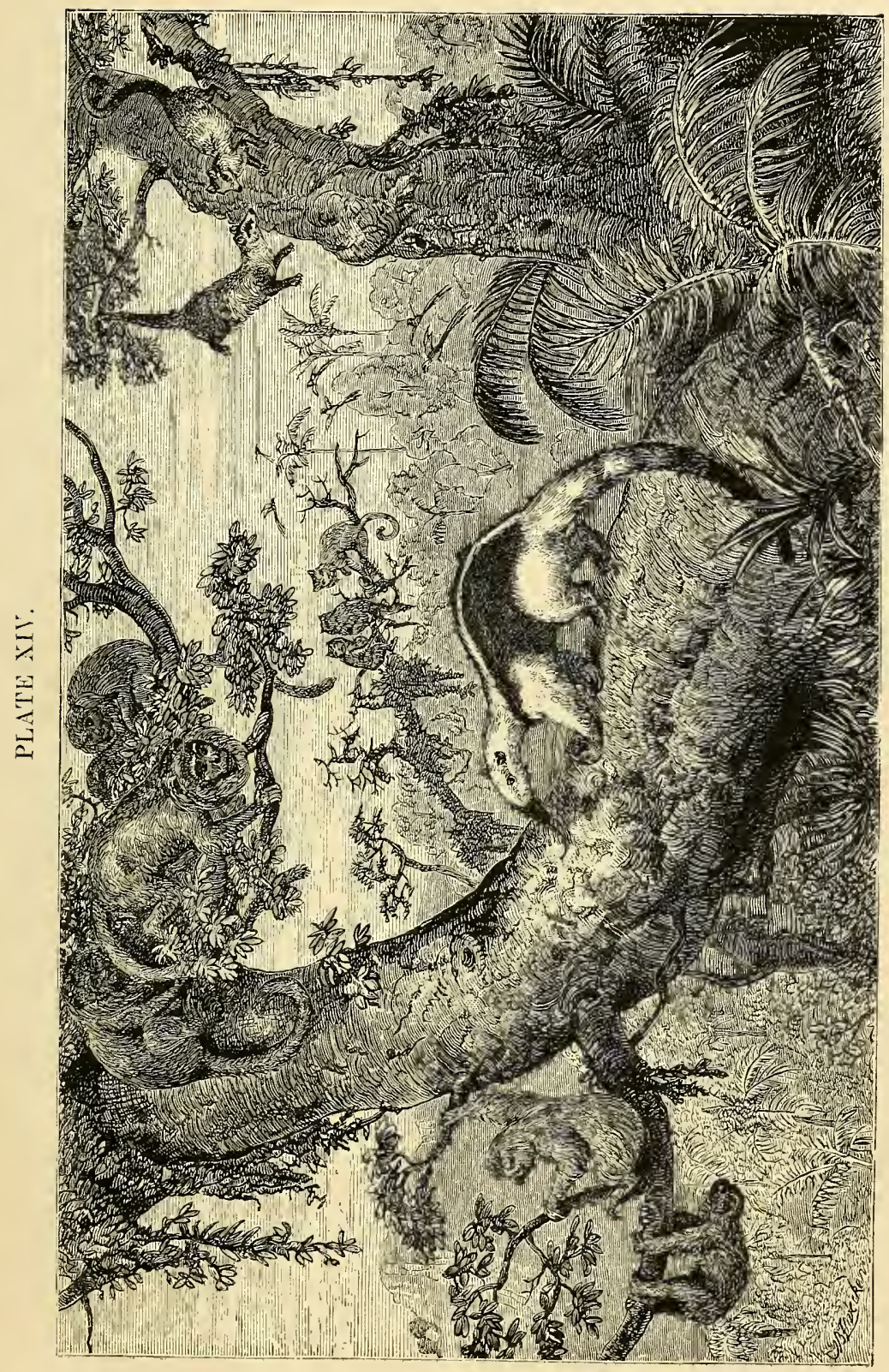

焉 

is in peculiar types of all the most characteristic American families, such as the Tanagridæ, Tyrannidæ, Cotingidæ, Formicariidæ, Trochilidæ, and Galbulidæ. A considerable proportion of the genera of the Chilian and Mexican sub-regions also occur here, so that out of about 680 genera of Neotropical landbirds more than 500 are represented in this sub-region.

Without entering minutely into the distribution of species it is difficult to sub-divide this extensive territory with any satisfactory result. ${ }^{1}$ The upland tract between the Amazon and Orinooko, which may be termed Guiana, was evidently once an island, yet it possesses few marked distinctive features. Brazil, which must have formed another great island, has more speciality, but the intermediate Amazonian forests form a perfect transition between them. The northern portion of the continent west of the Orinooko has more character; and there are indications that this has received many forms from Central and North America, and thus blended two faunas once more distinct than they are now. The family of wood-warblers (Mniotiltidæ) seems to have belonged to this more northern fauna; for out of 18 genera only 5 extend sonth of the equator, while 6 range from Mexico or the Antilles into Columbia, some of these being only winter immigrants and no genus being exclusively South American. The eastern slopes of the Andes constitute, however, the richest and best marked province of this sub-region. At least 12 genera of tanagers (Tanagridæ) are found here only, with an immense number of Fringillidæ, - the former confined to the forests; the latter ranging to the upland plains. The ant-thrushes (Formicariidæ) on the other hand seem more abundant in the lowlands, many genera being peculiar to the Amazonian forests. The superb chatterers (Cotingidæ) also seem to have their head-quarters in the forests of Brazil and Guiana, and to have thence spread

1 Messrs. Sclater and Salvin, and Professor Newton, divide the Neotropical Region into six sub-regions, of which our "Brazilian sub-region" comprises three-the "Brazilian," the "Amazonian," and the "Columbian ;" but, after due consideration, it does not seem advisable to adopt this subdivision in a general work which treats of all the classes of terrestrial animals. (See p. 27.) 
into the Amazonian valley. Guiana still boasts such remarkable forms as the cardinal chatterer (Phcenicocercus), the military chatterer (Homatoderus), as well as Querula, Gymnoderus, and Gymnocephalus; but the first three pass to the south side of the Lower Amazon. Here also belong the cock of the rock (Rupicola), which ranges from Guiana to the Andes, and the marvellous umbrella-birds of the Rio Nigro and Upper Amazon (Cephalopterus), which extends across the Ecuadorean Andes and into Costa Rica. Brazil has Ptilochloris, Casiornis, Tijuca, Phibalura, and Calyptura; while not a single genus of this family, except perhaps Heliochcera, is confined to the extensive range of the Andes. Almost the same phenomena are presented by the allied Pipridæ or manakins, the greater part of the genera and species occurring in Eastern South America, that is in Brazil, Guiana, and the surrounding lowlands rather than in the Andean valleys. The same may be said of the jacamars (Galbulidæ) and puff-birds (Bucconidæ); but the humming-birds (Trochilidæ) have their greatest development in the Andean district. Brazil and Guiana have each a peculiar genus of parrots; Guiana has three peculiar genera of Cracidæ, while the Andes north of the equator have two. The Tinamida on the other hand have their metropolis in Brazil, which has two or three peculiar genera, while two others seem confined to the Andes south of the equator. The elegant trumpeters (Psophiidæ) are almost restricted to the Amazonian valley.

Somewhat similar facts occur among the Mammalia. At least 3 genera of monkeys are confined to the great lowland equatorial forests and 1 to Brazil ; Icticyon (Canidæ) and Pteronurce (Mustelidæ) belong to Guiana and Brazil; and most of the Echimyidæ are found in the same districts. The sloths, anteaters, and armadillos all seem more characteristic of the eastern districts than of the Andean; while the opossums are perhaps equally plentiful in the Andes.

The preceding facts of distribution lead us to conclude that the highlands of Brazil and of Guiana represent very ancient lands, dating back to a period long anterior to the elevation of the Andean range (which is by no means of great geological anti- 
quity) and perhaps even to the elevation of the continuous land which forms the base of the mountains. It was, no doubt, during their slow elevation and the consequent loosening of the surface, that the vast masses of debris were carried down which filled up the sea separating the Andean chain from the great islands of Brazil and Guiana, and formed that enormous extent of fertile lowland forest, which has created a great continent; given space for the free interaction of the distinct famas which here met together, and thus greatly assisted in the marvellous development of animal and vegetable life, which no other continent can match. But this development, and the fusion of the various faunas into one homogeneous assemblage must have been a work of time; and it is probable that most of the existing continent was dry land before the Andes had acquired their present altitude. The blending of the originally distinct sub-faunas has been no doubt assisted by elevations and depressions of the land or of the ocean, which have alternately diminished and increased the land-area. This would lead to a crowding together at one time, and a dispersion at others, which would evidently afford opportunity for many previously restricted forms to enter fresh areas and become adapted to new modes of life.

From the preceding sketch it will appear, that the great subregion of Tropical South America as here defined, is really formed of three originally distinct lands, fused together by the vast lowland Amazonian forests. In the class of birds sufficient materials exist for separating these districts; and that of the Andes contains a larger series of peculiar genera than either of the other sub-regions here adopted. But there are many objections to making such a sub-division here. It is absolutely impossible to define even approximate limits to these divisions-to say for example where the "Andes" ends and where "Brazil" or "Amazonia" or "Guiana" begins; and the unknown border lands separating these are so vast, that many groups, now apparently limited in their distribution, may prove to have a very much wider range. In mammalia, reptiles, and insects, it is even more difficult to maintain such divisions, so that on the whole it seems better to treat the entire area as one sub-region, 
although recognizing the fact of its zoological and geographical diversity, as well as its vast superiority over every other subregion in the number and variety of its animal forms.

The reptiles, fishes, mollusca, and insects of this sub-region have been sufficiently discussed in treating of the entire region, as by far the larger proportion of them, except in the case of land-shells, are found here.

Plate XV. Characteristic Neotropical Birds. - To illustrate the ornithology of South America we place our scene on one of the tributaries of the Upper Amazon, a district where this class of animals is the most prominent zoological feature, and where a number of the most remarkable and interesting birds are to be found. On the left we have the umbrella-bird (Cephalopteris ornatus), so called from its wonderful crest, which, when expanded, completely overshadows its head like an umbrella. It is also adorned with a long tassel of plumes hanging from its breast, which is formed by a slender fleshy tube clothed with broad feathers. The bird is as large as a crow, of a glossy blue-black colour, and belongs to the same family as the exquisitely tinted blue-and-purple chatterers. Flying towards us are a pair of curlcrested toucans (Pteroglossus beauharnaisii), distinguished among all other toucaus by a crest composed of small black and shining barbless plumes, resembling curled whalebone. The general plumage is green above, yellow and red beneath, like many of its allies. To the right are two of the exquisite little whiskered hummers, or "frill-necked coquettes," as they are called by Mr. Gould, (Lophornis gouldi). These diminutive birds are adorned with green-tipped plumes springing from each side of the throat, as well as with beautiful crests, and are among the most elegant of the great American family of humming-birds, now numbering about 400 known species. Overhead are perched a pair of curassows (Crax globulosa), which represent in America the pheasants of the Old World. There are about a dozen species of these fine birds, most of which are adorned with handsome curled crests. That figured, is distinguished by the yellow caruncular swellings at the base of the bill. The tall crane-like bird near the water is one of the trumpeters, (Psophia lencoptera), elegant 


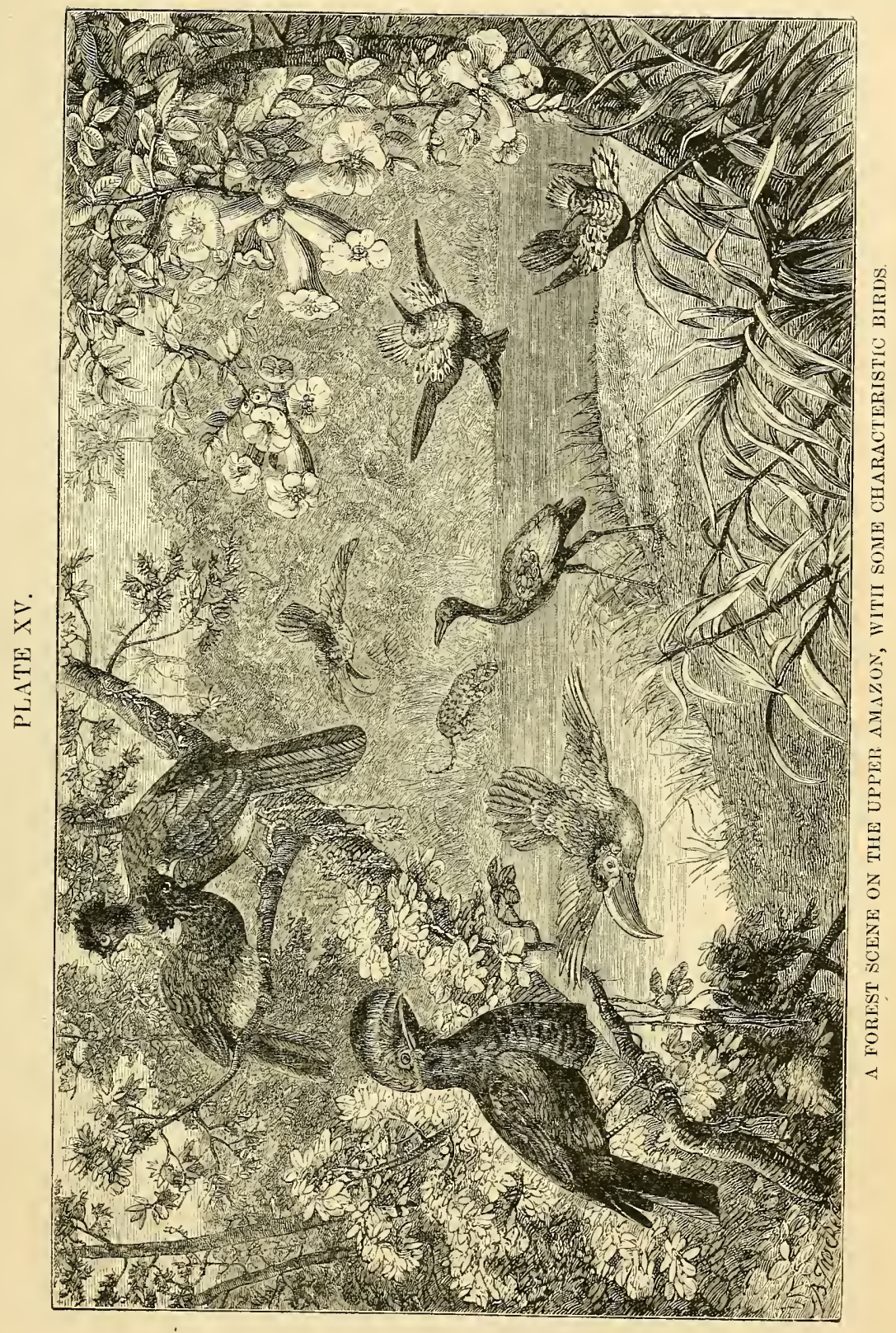



birds with silky plumage peculiar to the Amazon valley. They are often kept in houses, where they get very tame and affectionate; and they are useful in catching flies and other honse insects, which they do with great perseverance and dexterity.

\section{Islands of Tropical South America.}

These are few in number, and, with one exception, not of much interest. Such islands as Trinidad and Sta. Catherina form parts of South America, and have no peculiar groups of animals. The small islands of Fernando Noronha, Trinidad, and Martin Vaz, off the coast of Brazil, are the only Atlantic islands somewhat remote from land ; while the Galapagos Archipelago in the Pacific is the only group whose productions have been carefully examined, or which present features of special interest.

Galapagos Islands.-These are situated on the equator, abont 500 miles from the coast of Ecuador. They consist of the large Albemarle island, 70 miles long; four much smaller (18 to 25 miles long), named Narborough, James, Indefatigable, and Chatham Islands; four smaller still (9 to 12 miles long), named Abingdon, Bindloes, Hood's, and Charles Islands. All are volcanic, and consist of fields of black basaltic lava, with great numbers of extinct craters, a few which are still active. The islands vary in height from 1,700 to 5,000 feet, and they all rise sufficiently high to enter the region of moist eurrents of air, so that while the lower parts are parched and excessively sterile, above 800 or 1,000 feet there is a belt of comparatively green and fertile country.

These islands are known to support 58 species of Vertebrates, -1 quadruped, 52 birds and 5 reptiles, the greater part of which are found nowhere else, while a considerable number belong to peculiar and very remarkable genera. We must therefore notice them in some detail.

Mammalia.-This class is represented by a mouse belonging to the American genus Hespcromys, but slightly different from any found on the continent. A true rat (Mus), slightly differing from any Furopean species, also occurs; and as there can be little doubt that this is an escape from a ship, somewhat 
changed under its new conditions of life (the genus Mus not being indigenous to the American continent), it is not improbable, as Mr. Darwin remarks, that the American mouse may also have been imported by man, and have become similarly changed.

Birds. 1 - Recent researches in the islands have increased the number of land-birds to thirty-two, and of wading and aquatic birds to twenty-three. All the land birds but two or three are peculiar to the islands, and eighteen, or considerably more than half, belong to peculiar genera. Of the waders 4 are peculiar, and of the swimmers 2. These are a rail (Porzana spilonota); two herons (Butorides plumbea and Nycticorax pauper); a flamingo (Phcenicopterus glyphorhynchus); while the new aquatics are a gull (Larus fuliginosus), and a penguin (Spheniscus mendiculus).

The land-birds are much more interesting. All except the birds of prey belong to American genera which abound on the opposite coast or on that of Chili a little further south, or to peculiar genera allied to South American forms. The only species not peculiar are, Dolichonyx oryzivorus, a bird of very wide range in America and of migratory habits, which often visits the Bermudas 600 miles from North America,-and Asio accipitrinus, an owl which is found almost all over the world. The only genera not exclusively American are Buteo and Strix, of each of which a peculiar species occurs in the Galapagos, although very closely allied to South American species. There remain 10 genera, all either American or peculiar to the Galapagos ; and on these we will remark in systematic order.

1. Mimus, the group of American mocking-thrushes, is represented by three distinct and well-marked species. 2. Den$d r c e c a$, an extensive and wide-spread genus of the wood-warblers (Mniotiltidæ), is represented by one...species, which ranges over the greater part of the archipelago. The genus is especially abundant in Mexico, the Antilles, and the northern parts of

1 Mr. Salvin, who has critically examined the ornithological fauna of these islands, has kindly corrected my MS. List of the Birds, his valuable paper in the Transactions of the Zoological Society not having been published in time for me to make use of it. 
tropical America, only one species extending south as far as Chili. 3. Certhidea, a peculiar genus originally classed among the finches, but which Mr. Sclater, who has made Soutl American birds his special study, considers to belong to the Coerebidce, or sugar-birds, a family which is wholly tropical. Two species of this genus inhabit separate islands. 4. Progne, the American martins (Hirundinidæ), is represented by a peculiar species. 5. Geospiza, a peculiar genus of finches, of which no less than eight species occur in the archipelago, but not more than four in any one island. 6. Camarhynchus (6 sp.) and 7. Cactornis (4 sp.) are two other peculiar genera of finches; some of the species of which are confined to single islands, while others inhabit several. 8. Pyrocephalus, a genus of the American family of tyrant-flycatchers (Tyrannidæ), has one peculiar species closely allied to T. rubineus, which has a wide range in South America. 9. Myiarchus, another genus of the same family which does not range further south than western Ecuador, has also a representative species found in several of the islands. 10. Zenaida, an American genus of pigeons, has a species in James Island and probably in some of the others, closely allied to a species from the west coast of America.

It has been already stated that some of the islands possess peculiar species of birds distinct from the allied forms in other islands, but unfortunately our knowledge of the different islands is so unequal and of some so imperfect, that we can form no useful generalizations as to the distribution of birds among the islands themselves. The largest island is the least known; only one bird being recorded from it, one of the mocking-thrushes found nowhere else. Combining the observations of Mr. Darwin with those of Dr. Habel and Prof. Sundevall, we have species recorded as occurring in seven of the islands. Albemarle island has but one definitely known species; Chatham and Bindloe islands have 11 each; Abingdon and Charles islands 12 each; Indefatigable island and James island have each 18 species. This shows that birds are very fairly distributed over all the islands, one of the smallest and most remote (Abingdon) furnishing as many as the much larger Chatham Island, which is also the nearest 
to the mainland. Taking the six islands which seem tolerably explored, we find that two of the species (Dendroeca aurcola and Geospiza fortis) occur in all of them; two others (Geospiza strenua and Myiarchus magnirostris) in five; four (Mimus mclanotis, Gcospiza fuliginosa, G. parvula, and Camarhynchus prosthemelas) in four islands; five (Certhidea olivacca, Cactornis scandens, Pyrocephalus nanus), and two of the birds of prey, in three islands; nine (Certhided fusca, Progne concolor, Geospiza ncbulosa, G. magnirostris, Camarhynchus psittaculus, C. variegatus, C. habeli and Asio accipitrinus) in two islands; while the remaining ten species are confined to one island each. These peculiar species are distributed among the islands as follows. James, Charles and Abingdon islands, have 2 each ; Bindloes, Chatham, and Indefatigable, 1 each. The amount of speciality of James Island is perhaps only apparent, owing to our ignorance of the fauna of the adjacent large Albemarle island; the most remote islands north and south, $A$ bingdon and Charles, have no donbt in reality most peculiar species, as they appear to have. The scarcity of peculiar species in Chatham Island is remarkable, it being large, very isolated, and the nearest to the mainland. Thate is still room for exploration in these islands, especially in Albemarle, Narborough, and Hood's islands of which we know nothing.

Reptiles.-The few reptiles found in these islands are very interesting. There are two snakes, a species of the American genus Herpetodryas, and another which was at first thought to be a Chilian species (Psammophis Temminckir), but which is now considered to be distinct. Of lizards there are four at least, belonging to as many genera. One is a species of Phyllodactylus, a wide-spread genus of Geckotidæ; the rest belong to the American family of the Iguanas, one being a species of the Neotropical genus Leiocephalus, the other two very remarkable forms, Trachycephalus and Oreocephalus (formerly united in the genus A mblyrthynchus). The first is a land, the second a marine, lizard; both are of large size and very abundant on all the islands; and they are quite distinct from any of the very numerous genera of Iguanidæ, spread all over the American continent. The last 
reptile is a land tortoise (Testudo nigra) of immense size, and also abundant in all the islands. Its nearest ally is the equally large species of the Mascarene Islands; an unusual development due, in both cases, to the absence of enemies permitting these slow but continually growing animals to attain an immense age. It is believed that each island has a distinct variety or species of tortoise.

Insects.-Almost the only insects known from these islands are some Coleoptera, chiefly collected by Mr. Darwin. They consist of a few peculiar species of American or wide-ranging genera, the most important being, a Calosoma, Pocilus, Solenophorics, and Notuphus, among the Carabidæ; an Oryctes among the Lamellicornes; two new genera of obscure Heteromera; two Curculionidæ of wide-spread genera; a Longicorn of the South American genus Eburia; and two small Phytophaga,-a set of species highly suggestive of accidental immigrations at rare and distant intervals.

Land-Shells.-These consist of small and obscure species, forming two peculiar sub-genera of Bulimulus, a genus greatly developed on the whole West coast of America; and a single species of Buliminus, a genus which ranges over all the world except America. As in the case of the birds, most of the islands have two or three peculiar species.

General Conclusions.-These islands are wholly volcanic and surrounded by very deep sea; and Mr. Darwin is of opinion, not only that the islands have never been more nearly connected with the mainland than at present, but that they have never been connected among themselves. They are situated on the Equator, in a sea where gales and storms are almost unknown. The main currents are from the south-west, an extension of the Peruvian drift along the west coast of South America. From their great extent, and their volcanoes being now almost extinct, we may assume that they are of considerable antiquity. These facts exactly harmonize with the theory, that they have been peopled by rare accidental immigrations at very remote intervals. The only peculiar generc consist of birds and lizards, which must therefore have been the earliest 
immigrants. We know that small Passerine birds annually reach the Bermudas from America, and the Azores from Europe, the former travelling over 600 , the latter over 1000 miles of ocean. These groups of islands are both situated in stormy seas, and the immigrants are so numerous that hardly any specific change in the resident birds has taken place. The Galapagos receive no such annual visitants ; hence, when by some rare accident a few individuals of a species did arrive, they remained isolated, probably for thousands of generations, and became gradually modified through natural selection under completely new conditions of existence. Less rare and violent storms would suffice to carry some of these to other islands, and thus the archipelago would in time become stocked. It would appear probable, that those which have undergone most change were the earliest to arrive; so that we might look upon the three peculiar genera of finches, and Certhidea, the peculiar form of Coerebidæ, as among the most ancient inhabitants of the islands, since they have become so modified as to have apparently no near allies on the mainland. But other birds may have arrived nearly at the same time, and yet not have been much changed. A species of very wide range, already adapted to live under very varied conditions and to compete with varied forms of life, might not need to become modified so much as a bird of more restricted range, and more specialized constitution. And if, before any considerable change had been effected, a second immigration of the same species occurred, crossing the breed would tend to bring back the original type of form. While, therefore, we may be sure that birds like the finches, which are profoundly modified and adapted to the special conditions of the climate and vegetation, are among the most ancient of the colonists; we cannot be sure that the less modified form of tyrant-flycatcher or mocking-thrush, or even the unchanged but cosmopolitan owl, were not of coeval date; since even if the parent form on the continent has been changed, successive immigrations may have communicated the same change to the colonists.

The reptiles are somewhat more difficult to account for. We know, however, that lizards have some means of dispersal over 
the sea, because we find existing species with an enormous range. The ancestors of the Amblyrhynchi must have come as early, probably, as the earliest birds; and the same powers of dispersal have spread them over every island. The two American genera of lizards, and the tortoises, are perhaps later immigrants. Latest of all were the snakes, which hardly differ from continental forms; but it is not at all improbable that these latter, as well as the peculiar American mouse, have been early human importations. Snakes are continually found on board native canoes whose cabins are thatched with palm leaves; and a few centuries would probably suffice to produce some modification of a species completely isolated, under conditions widely different from those of its native country. Land-shells, being so few and small, and almost all modifications of one type, are a clear indication of how rare are the conditions which lead to their dispersal over a wide extent of ocean; since two or three individuals, arriving on two or three occasions only during the whole period of the existence of the islands, would suffice to account for the present fauna. Insects have arrived much more frequently; and this is in accordance with their habits, their lower specific gravity, their power of flight, and their capacity for resisting for some time the effects of salt water.

We learn, then, from the fauna of these islands, some very important facts. We are taught that tropical land-birds, unless blown out of their usual course by storms, rarely or never venture out to sea, or if they do so, can seldom pass safely over a distance of 500 miles. The immigrants to the Galapagos can hardly have averaged a bird in a thousand years. We learn, that of all reptiles lizards alone have some tolerably effective mode of transmission across the sea; and this is probably by means of currents, and in connection with floating vegetation. Yet their transmission is a far rarer event than that of land-birds; for, whereas three female immigrants will account for the lizard population, at least eight or ten ancestors are required for the birds. Land serpents can pass over still more rarely, as two such transmissions would have sufficed to stock the islands with their snakes; and it is not certain that either of these occurred without the aid of man. 
It is doubtful whether mammals or batrachians have any means of passing, independently of man's assistance; the former having but one doubtfully indigenous representative, the latter none at all. The remarkable absence of all gay or conspicuous flowers in these tropical islands, though possessing a zone of fairly luxuriant shrubby vegetation, and the dependence of this phenomenon on the extreme scarcity of insects, has been already noticed at Vol. I. p. 461, when treating of a somewhat similar peculiarity of the New Zealand fauna and flora.

\section{South Temperate America, or the Chilian Sub-region.}

This sub-region may be generally defined as the temperate portion of South America. On the south, it commences with the cold damp forests of Tierra del Fuego, and their continuation up the west coast to Chiloe and northward to near Santiago. To the east we have the barren plains of Patagonia, gradually changing towards the north into the more fertile, but still treeless, pampas of La Plata. Whether this sub-region should be continued across the Rio de la Plata into Uruguay and Entre-rios, is somewhat doubtful. To the west of the Parana it extends northward over the Chaco desert, till we approach the border of the great forests near St. Cruz de la Sierra. On the plateau of the Andes, however, it must be continued still further north, along the "paramos" or alpine pastures, till we reach $5^{\circ}$ of South latitude. Beyond this the Andes are very narrow, having no double range with an intervening platean; and although some of the peculiar forms of the temperate zone pass on to the equator or even beyond it, these are not sufficiently numerous to warrant our extending the sub-region to include them. Along with the high Andes it seems necessary to include the western strip of arid country, which is mostly peopled by forms derived from Chili and the south temperate regions.

Mammalia.-This sub-region is well characterised by the possession of an entire family of mammalia having Neotropical affinities-the Chinchillidæ. It consists of 3 genera-Chinchilla (2 sp.), inhabiting the Andes of Chili and Peru as far as $9^{\circ}$ south latitude, and at from 8,000 to 12,000 feet altitude; Lagidium (3 sp.), ranging over the Andes of Chili, Peru; and South Esuador, 
from 11,000 to 16,000 feet altitude; and Lagostomus (1 sp.), the "viscacha," contined to the pampas between the Uruguay and Rio Negro. Many important genera are also confined to this subregion. Auchenia (4 sp.), inchuding the domesticated llamas and alpacas, the vicugna which inhabits the Andes of Peru and Chili, and the guanaco which ranges over the plains of Patagonia and Tierra del Fuego. Although this genus is allied to the Old World camels, it is a very distinct form, and its introduction from North America, where the family appear to have originated, may date back to a remote epoch. Ursus ornatus, the "spectacled bear" of the Chilian Andes, is a remarkable form, supposed to be most allied to the Malay bear, and probably forming a distinct genus, which has been named Tremaretos. Four genera of Octodontidie are also peculiar to this sub-region, or almost so; Habrocomus (1 sp.) is Chilian ; Spalacopus (2 sp.) is found in Chili and on the east side of the southern Andes; Octodon (3 sp.) ranges from Chili into Peru and Bolivia; Ctenomys (6 sp.) from the Straits of Magellan to Bolivia, with one species in South Brazil. Dolichotis, one of the Cavies, ranges from Patagonia to Mendoza, and on the east coast to $37 \frac{1}{2}^{\circ} \mathrm{S}$. latitude. Myopotamus (1 sp.), the coypu (Echimyidæ), ranges from $33^{\circ}$ to $48^{\circ} \mathrm{S}$. latitude on the west side of the Andes, and from the frontiers of Peru to $42^{\circ} \mathrm{S}$. on the east side. Reithrodon and Acodon, genera of Muridæ, are also confined to Temperate South America; Tolypeutes and Chlamydophorus, two genera of armadillos, the latter very peculiar in its organization and sometimes placed in a distinct family, are found only in La Plata and the highlands of Bolivia, and so belong to this sub-region. Otaria, one of the "eared seals" (Otariidæ), is confined to the coasts of this subregion and the antarctic islands. Deer of American groups extend as far as Chiloe on the west, and the Straits of Magellan on the east coast. Mice of the South American genera'Hesperomys and Reithrodon, are abundant down to the Straits of Magellan and into Tierra del Fuego, Mr. Darwin having collected more than 20 distinct species. The following are the genera of Mammalia which have been observed on the shores of the Straits of Magellan, those marked * extending into Tierra del Fuego : 
*Pseudalopex (two wolf-like foxes), Felis (the puma), Mephitis (skunks), Cervus (deer), *Auchenia (guanaco), *Ctenomys (tucutueu), ${ }^{*}$ Reithrodon and *Hesperomys (American mice).

Birds.-Three families of Birds are confined to this sub-region, -Phytotomidæ (1 genus, 3 sp.), inhabiting Chili, La Plata, and Bolivia; Chionididæ (1 genus, 2 sp.) the "sheath-bills," found only at the southern extremity of the continent and in Kerguelen's Island, which with the other antarctic lands perhaps comes best here; Thinocoridæ (2 genera, 6 species) an isolated family of waders, ranging over the whole sub-region and extending northward to the equatorial Andes. Many genera are also peculiar: 3 of Fringillidæ, and 1 of Icteridæ; 9 of Dendrocolaptidæ, 6 of Tyrannidæ, 3 of Trochilidæ, and 4 of Pteroptochidæ,- the last four South American families. There is also a peculiar genus of parrots (Henicognathus) in Chili; two of pigeons (Metriopelia and Gymnopelia) confined to the Andes and west coast from Peru to Chili; two of Tinamous, Tinamotes in the Andes, and Calodromus in La Plata; three of Charadriidæ, Phogornis, Pluvianellus, and Oreophilus; and Rhea, the American ostriches, inhabiting all Patagonia and the pampas. Perhaps the Cariamidæ have almost as much right here as in the last sub-region, inhabiting as they do, the "pampas" of La Plata and the upland "campos" of Brazil; and even among the wide-ranging aquatic birds, we have a peculiar genus, Merganettd, one of the duck family, which is confined to the temperate plateau of the Andes.

Against this extensive series of characteristic groups, all either of American type or very distinct forms of old World families, and therefore implying great antiquity, we find, in mammalia and birds, very scanty evidence of that direct affinity with the north temperate zone, on which some naturalists lay so much stress. We cannot point to a single terrestrial genus, which is characteristic of the north and reappears in this south temperate region without also occurring over much of the intervening land. Mustela seems only to have reached Peru; Lepus is isolated in Brazil; true Ursus does not pass south of Mexico. In birds, the northern groups rarely go further south than Mexico or the Columbian Andes; and the only case of discontinuous 
distribution we can find recorded is that of the genus of ducks, Camptolcemus, which has a species on the east side of North America and another in Chili and the Falkland Islands, but these, Professor Newton assures me, do not properly belong to the same genus. Out of 30 genera of land-birds collected on the Rio Negro in Patagonia, by Mr. Hudson, only four extend beyond the American continent, and the same exclusively American character applies equally to its southern extremity. No list appears to have been yet published of the land-birds of the Straits of Magellan and Tierra del Fuego. The following is compiled from the observations of Mr. Darwin, the recent voyage of Professor Cunningham, and other sources; and will be useful for comparison.

TURDIDE.

1. Turdus falklandicus.

TROGLODYTIDE.

2. Troglodytes magellanicus.

Fringillide.

3. Chrysomitris barbata.

*4. Phrygilus gayi.

*5. $"$ aldunatii.

6. " $"$ fruticeti.

*7. " xanthogrammus.

8. Zonotrichia pileata.

ICTERIDA.

9. Sturnella militaris.

10. Curæus aterrimus.

HiRUNDINIDE.

11. Hirundo meyeni.

TrRANNIDE.

12. Tænioptera pyrope.

13. Myiotheretes rufiventris.

14. Muscisaxicola mentalis.

15. Centrites niger.

16. Anæretes parulus.

17. Elainea griseogularis.

Dendrocola PTIDE.

18. Upucerthia dumetoria.

* 19. Cinclodes patagonicus.

*20. " fuscus.

*21. Oxyurus spinicauda.

Pteroptochide.

*22. Scytalopus magellanicus.
PICID.E.

*23. Campephilus magellanicus.

24. Picus lignarius.

ALCEDINIDA.

25. Ceryle stellata.

Trochilide.

26. Eustephanus galeritus.

Conuride:

27. Conurus patagonus.

VULTURIDA.

28. Cathartes aura.

29. Sarcorliamphus gryphus.

FALCONIDA.

30. Circis macropterus.

31. Buteo erythronotus.

32. Geranoaëtus melanolencus.

33. Accipiter chilensis.

34. Cerchneis sparverius.

35. Milvago albogularis.

36. Polyborus tharus.

STRIGID在.

37. Asio accipitriuus.

38. Bubo magellanicus.

39. Pholeoptynx cunicularia.

40. Glaucidium nana.

41. Syrnium rufipes.

Struthionide.

42. Rhea darwinii, 
In the above list the species marked * extend to Tierra del Fuego. It is a remarkable fact that so many of the species belong to genera which are wholly Neotropical, and that the specially South American families of Icteridæ, Tyrannidæ, Dendrocolaptidæ, Pteroptochidæ, Trochilidæ, and Conuridæ, should supply more than one-third of the species; while the purely South American genus Phrygilus, should be represented by four species, three of which abound in Tierra del Fuego.

Plate XVI. A Scene in the Andes of Chili, with characteristic Animals.-The fauna of South Temperate America being most fully developed in Chili, we place the scene of our illustration in that country. In the foreground we have a pair of the beautiful little chinchillas (Chinchilla lanigerc), belonging to a family of animals peculiar to the sub-region. There are only two species of this group, both confined to the higher Andes, at about 8000 feet elevation. Coming round a projecting ridge of the mountain, are a herd of vicunas (Auchenia vicugna), one of that peculiar form of the camel tribe found in South America and confined to its temperate and alpine regions. The upper bird is a plant-cutter (Phytotoma rara), of sober plumage but allied to the beautiful chatterers, though forming a separate family. Below, standing on a rock, is a plover-like bird, the Thinocorns orbignianus, which is considered to belong to a separate family, though allied to the plovers and sheath-bills. Its habits are, however, more those of the quails or partridges, living inland in dry and desert places, and feeding on plants, roots, and insects. Above is a condor, the most characteristic bird of the high Andes.

Reptiles and Amphibia.-These groups show, for the most part, similar modifications of American and Neotropical forms, as those we have seen to prevail among the birds. Snakes do not seem to go very far south, but several South American genera of Colubridæ and Dendrophidæ occur in Chili ; while Enophrys is peculiar to La Plata, and Callorrinus to Patagonia, both belonging to the Colubridæ. The Elapidæ do not extend into the temperate zone; but Craspedocephalus, one of the Crotalidæ, occurs at Bahia Blanca in Patagonia (Lat. $40^{\circ} \mathrm{S}$.) 


\section{PLATE XYL.}

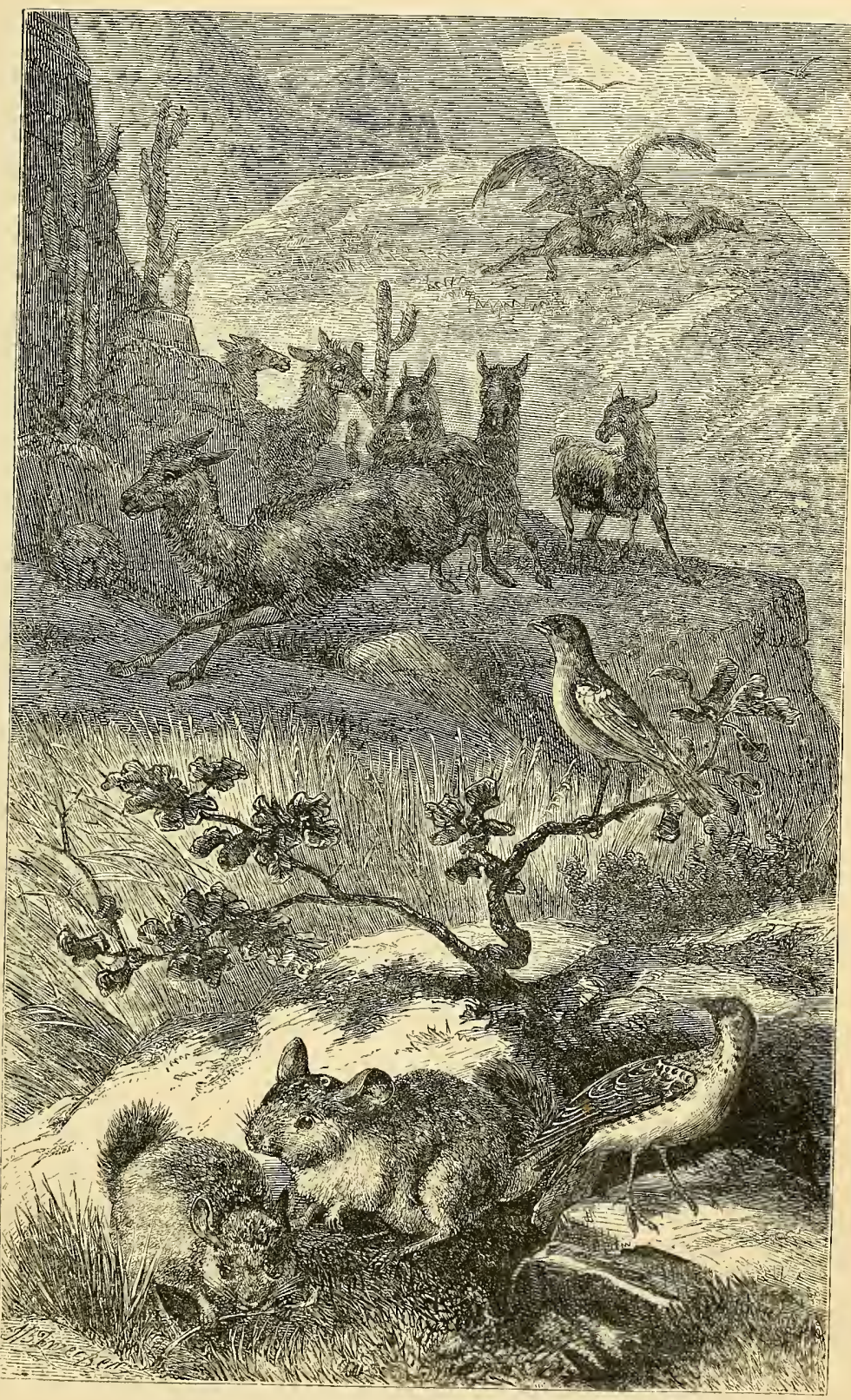

IHE CHILIAN ANDES, WITH CHARACTERISTIC ANIILIS 

Lizards are much more numerous, and there are several peculiar and interesting forms. Three families are represented; Teidæ by two genera-Callopistes peculiar to Chili, and Ameiva which ranges over almost the whole American continent and is found in Patagonia; Geckotidæ by four genera, two of which,Caudiverbera and Homonota-are peculiar to Chili, while Spherodactylus and Cubina are Neotropical, the former ranging to Patagonia, the latter to Chili; and lastly the American family Ignanidæ represented by eight genera, no less than six being peculiar, (or almost so,) to the South temperate region. These are Leioderc, Diplolcemus and Proctrotretus, ranging from Chili to Patagonia; Leiolcemus, from Peru to Patagonia; Phrymaturus, confined to Chili, and Ptygoderus peculiar, to Patagonia and Tierra del Fuego. The other two genera, Oplumus and Leiosaurus, are common to Chili and tropical South America.

Tortoises appear to be scarce, a species of Hydromedusa only being recorded. Of the Amphibia, batrachia (frogs and toads) alone are represented, and appear to be tolerably abundant, seventeen species having been collected by Mr. Darwin in this sub-region. Species of the South American genera Phryniscus, Hylaplesia, Telmatobius, Cacotus, Hylodes, Cyclorhamphus, Pleurodema, Cystignathus, and Leiuperus, are found in various localities, some extending even to the Straits of Magellan,-the extreme southern limit of both Reptilia and Amphibia, except one lizard (Ptygoderus) found by Professor Cunningham in Tierra del Fuego. There are also four peculiar genera, Rhinoderma belonging to the Engystomidx; Alsodes and Nannophryne to the Bombinatoridæ; Opisthodelphys to the Hylidæ; and Calyptocephalus to the Discoglossidæ.

It thus appears, that in the Reptiles all the groups are typically American, and that most of the peculiar genera belong to families which are exclusively American. The Amphibia, on the other hand, present some interesting external relations, but these are as much with Australia as with the North temperate regions. The Bombinatoridæe are indeed Palæurctic, but a larger proportion are Neotropical, and one genus inbabits New Zealand. The Chilian genus Calyptocephalus is allied to Australian tropical genera. 
The Neotropical genera of Ranidæ, five of which extend to Chili and Patagonia, belong to a division which is Australian and Neotropical, and which has species in the Oriental and Ethiopian regions.

Fresh-water Fishes.-These present some peculiar formis, and some very interesting phenomena of distribution. The genus Percilia has been found only in the Rio de Maypu in Chili; and Percichthys, also belonging to the perch family, has five species confined-to the fresh waters of South Temperate America, and one far away in Java. Nematogenys (1 sp.) is peculiar to Chili ; Trichomycterus reaches 15,000 feet elevation in the Andes,-both belonging to the Siluridæ; Chirodon (2 sp.), belonging to the Characinidæ, is peculiar to Chili; and several other genera of the same family extend into this sub-region from Brazil. The family Haplochitonidæ has a remarkable distribution; one of its genera, Haplochiton (2 sp.), inhabiting Tierra del Fuego and the Falkland Islands, while the other, Prototroctes, is found only in South Australia and New Zealand. Still more remarkable is Galaxias (forming the family Galaxidæ), the species of which are divided between Temperate South America, and Australia, Tasmania, and New Zealand; and there is even one species (Galaxias attenuatus) which is found in the Chathain Islands, New Zealand, and Tasmania, as well as in the Falkland Islands and Patagonia. Fitzroya (1 sp.) is found only at Montevideo; Orestias ( $6 \mathrm{sp}$.) is peculiar to Lake Titicaca in the high Andes of Bolivia; Jenynsid (1 sp.) in the Rio de la Plata -all belonging to the characteristic South American family of the Cyprinodontidæ.

Insects.-It is in insects more than in any other class of animals, that we find clear indications of a not very remote migration of northern forms, along the great mountain range to South Temperate America, where they have established themselves as a prominent feature in the entomology of the country. The several orders and families, however, differ greatly in this respect; and there are some groups which are only represented by modifications of tropical forms, as we have seen to be almost entirely the case in birds and reptiles. 
Lepidopterc.-The butterflies of the South Temperate Subregion are not numerous, only about 29 genera and 80 species being recorded. Most of these are from Chili, which is sufficiently accounted for by the general absence of wood on the east side of the Andes from Buenos Ayres to South Patagonia. The families represented are as follows: Satyridæ, with 11 genera and 27 species, are the most abundant; Nymphalidæ, 2 genera and 8 species; Lemoniidæ, 1 genus, 1 species; Lycænidæ, 3 genera, 8 species; Pieridæ, 6 genera, 14 species; Papilionidæ, 2 genera, 8 species; Hesperidæ, 4 genera, 13 species. One genus of Satyridæ (Elina) and 2 of Pieridæ (Eroessa and Phulia) are peculiar to Chili. The following are the genera whose derivation must be traced to the north temperate zone:Tetraphlybia, Neosatyrus, and 3 allied genera of 1 species each, were formerly included under Ercbia, a northern and arctic form, yet having a few species in South Africa; Argyrophorus, allied to Aineis, a northern genus; Hipparchia, a northern genus yet having a species in Brazil ;-all Satyridæ. The Nymphalidæ are represented by the typical north temperate genus Argynnis, with 7 species in Chili; Colias, among the Pieridæ, is ustally considered to be a northern genus, but it possesses representatives in South Africa, the Sandwich Islands, Malabar, New Grenada, and Peru, as well as Chili, and nust rather be classed as cosmopolitan. These form a sufficiently remarkable group of northern forms, but they are accompanied by others of a wholly Neotropical origin. Such are Stibomorpha with 6 species, ranging through South America to Guatemala, and Eteona, common to Chili and Brazil (Satyridæ); Apodemia (Lemoniidæ) confined to Tropical America and Chili. Hesperocharis and Callidryas (Pieridæ), both tropical; and Thracides (Hesperidæ) confined to Tropical America and Chili. Other genera are widely scattered; as, Epinephile found also in Mexico and Australia; Cupido, widely spread in the tropics; Euryades, found only in La Plata and Paraguay, allied to South American forms of Papilio, to the Australian Eurycus, and the northern Parnassius; and Heterop. terus, scattered in Chili, North America, and Tropical Africa. We find then, among butterflies, a large north-temperate element, 
intermingled in nearly equal proportions with forms derived from Tropical America; and the varying degrees of resemblances of the Chilian to the northern species, seems to indicate successive immigrations at remote intervals.

Colenptera.-It is among the beetles of South Temperate America that we find some of the most curious examples of remote affinities, and traces of ancient migrations. The Carabidæ are very well represented, and having been more extensively collected than most other families, offer us perhaps the most complete materials. Including the Cicindelidie, about 50 genera are known from the South Temperate Sub-region, the greater part from Chili, but a good number also from Patagonia and the Straits of Magellan. Of these more than 30 are peculiar, and most of them are so isolated that it is impossible to determine with precision their nearest allies.

The only remarkable form of Cicindelidæ is Agrius, a genus allied to the Amblycheila and Omus of N.W. America. Two genera of Carabidæ, Cascellius and Baripus, are closely allied to Promecoderus, an Australian genus; and another, Lecanomerus, has one species in Chili and the other in Australia. Five or six of the peculiar genera are undoubtedly allied to characteristic Palrarctic forms; and such northern genera as Carabus, Pristonychus, Anchomenus, Ptcrostichus, Percus, Bradycellus, Trechus, and Bembidium, all absent from Tropical America, give great support to the view that there is a close relation between the insects of the northern regions and South 'Temperate America. A decided tropical element is, however, present. Tropopterus is near Colpodes, a Tropical and South American genus; Mimodromius and Plagiotelium are near Calleida, a South American genus; while Pachyteles, Pericompsus, Variopalpus, and Calleida are widely spread American groups. The preponderance of northern forms seems, however, to be undoubted.

Six Carabidæ are known from Juan Fernandez, 3 being identical with Chilian species and 3 peculiar. As the island is 350 miles from the mainland, we have here a proof of how readily insects may be transported great distances. 
The Palæarctic affinity of the South Temperate Carabidæ may be readily understood, if we bear in mind the great antiquity of the group, and the known long persistence of generic and specific forms of Coleoptera ; the facility with which they may be transported to great distances by gales and hurricanes, either on land or over the sea; and, therefore, the probability that suitable stations would be rapidly occupied by species already adapted to them, to the exclusion of those of the adjacent tracts which had been specialised under different conditions. If, for example, we carry ourselves back to the time when the Andes had only risen to half their present altitude, and Patagonia had not emerged from the ocean (an epoch not very remote geologically), we should find nearly all the Carabidx of South America, adapted to a warm, and probably forest-covered country. If, then, a further considerable elevation of the land took place, a large temperate and cold area would be formed, without any suitable insect inhabitants. During the necessarily slow process of elevation, many of the tropical Carabidæ would spread upwards, and some would become adapted to the new conditions; while the majority would probably only maintain themselves by continued fresh immigrations. But, as the mountains rose, another set of organisms would make their way along the highest ridges. The abundance and variety of the North Temperate Carabidæ, and their complete adaptation to a life on barren plains and rock-strewn mountains, would enable them rapialy to extend into any newly-raised land suitable to them; and thus the whole range of the Rocky Mountains and Andes would obtain a population of northern forms, which would overflow into Patagonia, and there, finding no competitors, would develope into a variety of modified groups. This migration was no doubt effected mainly, during successive glacial epochs, when the mountain-range of the Isthmus of Panama, if moderately increased in height, might become adapted for the passage of northern forms, while storms would often carry insects from -peak to peak over intervening forest lowlands or narrow straits of sea. If this is the true explanation, we ought to find no such preponderant northern element in groups which 
are proportionally less developed in cold and temperate climates. Our further examination will show how far this is the case.

Lucanidæ.-Only four genera are known in the sub-region. Two are peculiar, Chiasognathus and Streptocerus, the former allied to Tropical American, the latter to Australian genera; the other two genera are exclusively South American.

Cetoniidæ.-These seem very scarce, only a few species of the Neotropical genus Gymnetis reaching Patagonia.

Buprestidæ.-These are rather numerous, many very beautiful species being found in Chili. Nineteen genera are represented in South Temperate America, and 5 of these are peculiar to it; 3 others are South American genera; 2 are Australian, and the remainder are wide-spread, but all are found also in Tropical America. The only north-temperate genus is Dicerca, and even this occurs also in the Antilles, Brazil, and Peru. Of the peculiar genera, the largest, Dactylozodes (26 sp.), has one species in South Brazil, and is closely allied to Hyperantha, a genus of Tropical America; Epistomcntis is allied to Nascis, an Australian genus; Tyndaris is close to Acmcodera, a genus of wide range and preferring desert or dry countries. The other two are single species of cosmopolitan affinities. On the whole, therefore, the Buprestidæ are unmistakeably Neotropical in character.

Longicorns.-Almost the whole of the South Temperate Longicorns inhabit Chili, which is very rich in this beautiful tribe. About 75 genera and 160 species are known, and nearly half of the genera are peculiar. Many of the species are large and handsome, rivalling in beauty those of the most favoured tropical lands. Of the 8 genera of Prionidæ 6 are peculiar, but all are allied to Tropical American forms except Microplophorus, which belongs to a group of genera spread over Australia, Europe, and Mexico. The Cerambycidæ are much more abundant, and their affinities more interesting. Two (Syllitus and Pseudocephalus) are common to Australia and Chili. Twenty-three are Neotropical; and among these Ibidion, Compsocerus, Callideriphus, Trachyderes, and Xylocharis, are best represented. Twenty are 
altogether peculiar, but most of them are more or less closely allied to genera inhabiting Tropical America. Some, as the handsome Chcloderus and Oxypeltus, have no close allies in any part of the world. Holopterus, though very peculiar, shows most resemblance to a New Zealand insect. Sibylla, Adalbus, and Phantagoderus, have Australian affinities; while Calydon alone shows an affinity for north-temperate forms. One species of the northern genus, Leptura, is said to have been found at Buenos Ayres.

The Lamiidæ are less abundant. Nine of the genera are Neotropical. Two (Apomecyna and Exocentrus) are spread over all tropical regions. Ten genera are peculiar; and most of these are related to Neotropical groups or are of doubtful affinities. Only one, Aconopterus, is decidedly allied to a northern genus, Pogonochcerus. It thus appears, that none of the Lamiidæ exhibit Australian affinities, although these are a prominent feature in the relations of the Cerambycidæ.

It is evident, from the foregoing outline, that the insects of South Temperate America, more than any other class of animals, exhibit a connection with the north temperate regions, yet this connection is only seen in certain groups. In Diurnal Lepidoptera and in Carabidæ, the northern element is fully equal to the tropical, or even preponderates over it. We have already suggested an explanation of this fact in the case of the Carabidr, and with the butterflies it is not more difficult. The great mass of Neotropical butterflies are forest species, and have been developed for countless ages in a forest-clad tropical country. The north temperate butterflies, on the other hand, are very largely open-country species, frequenting pastures, mountains, and open plains, and often wandering over an extensive area. These would find, on the higher slopes of mountains, a vegetation and conditions suited to them, and would occupy such stations in less time than would be required to adapt and modify the foresthaunting groups of the American lowlands. In those groups of insects, however, in which the conditions of life are nearly the same as regards both temperate and tropical species, the superior 
number and variety of the tropical forms has given them the advantage. Thus we find that among the Lucanidæ, Buprestidæ, and Longicorns, the northern element is hardly perceptible. Most of these are either purely Neotropical, or allied to Neotropical genera, with the admixture, however, of a decided Australian element. As in the case of the Amphibia and fresh-water fishes, the Australian affinity, as shown by insects, is of two kinds, near and remote. We have a few genera common to the two countries; but more commonly the genera are very distinct, and the affinity is shown by the genera of both countries belonging to a group peculiar to them, but which may be of very great age. In the former case, we must impute some of the resemblance of the two faumas to an actual interchange of forms within the epoch of existing genera-a period of vast and unknown duration in the class of insects; while in the latter case, and perhaps also in many of the former, it seems more in accordance with the whole of the phenomena, to look upon most of the instances as survivals, in the two southern temperate areas, of the relics of groups which had once a much wider distribution. That this is the true explanation, is suggested by the numerous cases of discontinuous and scattered distribution we have had to notice, in which every part of the globe, without exception, is implicated; and there is a reason why these survivals should be rather more frequent in Australia and temperate South America, inasmuch as these two areas agree in the absence of a considerable number of otherwise cosmopolitan vertebrate types, and are also in many respects very similar in climatic and other physical conditions. The preponderating influence of the organic over the physical environment, as taught by $\mathrm{Mr}$. Darwin, leads us to give most weight to the first of the above-mentioned causes; to which we may also impute such undoubted cases of survival of ancient types as the Centetide of the Antilles and Madagascar-both areas strikingly deficient in the higher vertebrate forms. The probable mode and time of the cross migration between Australia and South America, has been sufficiently discussed in our chapter on the Australian region, when treating of the origin and affinities of the New Zealand fauna. 
Islands of the South Temperate Sub-rcgion.

These are few, and of not much zoological interest. Tierra del Fuego, although really an island, is divided from the mainland by so narrow a channel that it may be considered as forming part of the continent. The guanaco (Auchenia huanaco) ranges over it, and even to small islands further south.

The Falkland Islands.-These are more important, being situated about 350 miles to the east of Southern Patagonia; but the intervening sea is shallow, the 100 fathom line of soundings passing outside the islands. We have therefore reason to believe that they have been connected with South America at a not distant epoch; and in agreement with this view we find most of their productions identical, while the few that are peculiar are closely allied to the forms of the mainland.

The only indigenous Mammals are a wolf-like fox (Pseudalopex antarcticus) said to be found nowhere else, but allied to two other species inhabiting Southern Patagonia; and a species of mouse, probably one of the American genera Hesperomys or Reithrodon.

Sixty-seven species of Birds have been obtained in these islands, but only 18 are land-birds; and even of these 7 are birds of prey, leaving only 11 Passeres. The former are all common South American forms, but one species, Milvago australis, seems peculiar. The 11 Passeres belong to 9 genera, all found on the adjacent mainland. Three, or perhaps four, of the species are however peculiar. These are Phrygilus melanoderus, $P$. xanthogrammus, Cinclodes antareticus, and Muscisaxicola macloviana. The wading and swimming birds are of little interest, except the penguins, which are greatly developed; no less than eight species being found, five as residents and three as accidental visitors.

No reptiles are known to inhabit these islands.

Juan Fernandez.-This island is situated in the Pacific Ocean, about 400 miles west of Valparaiso in Chili. It is only a few miles in extent, yet it possesses four land-birds, excluding the powerful Accipitres. These are Turdus falklandicus; Anceretes 
fernandensis, one of the Tyrannidæ; and two humming-birds, Eustephanus fernandensis and $E$. galeritus. The first is a widespread South Temperate species, the two next are peculiar to the island, while the last is a Chilian species which ranges south to Tierra del Fuego. But ninety miles beyond this island lies another, called "Mas-a-fuero," very much smaller; yet this, too, contains four species of similar birds; one, Oxyurus mas- $\alpha$-fuerce, allied to the wide-spread South Temperate O. spinicauda, and Cinclodes fusus, a South Temperate speciesboth Dendrocolaptidæ; with a humming-bird, Eustephanus leyboldi, allied to the species in the larger island. The preceding facts are taken from papers by Mr. Sclater in the Ibis for 1871, and a later one in the same journal by Mr. Salvin (1875). The former author has some interesting remarks on the three species of humming-birds of the genus Eustephanus, above referred to. The Chilian species, $E$. galeritus, is green in both sexes. $E$. fernandensis has the male of a fine red colour and the female green, though differently marked from the female of $E$. galeritus. $E$. leyboldi (of Mas-a-fuera) has the male also red and the female green, but the female is more like that of $E$. galeritus, than it is like the female of its nearer ally in Juan Fernandez. Mr. Sclater supposes, that the ancient parent form of these three birds had the sexes alike, as in the present Chilian bird; that a pair (or a female having fertilised ova) reached Juan Fernandez and colonised it. Under the action of sexual selection (unchecked by some conditions which had impaired its efficacy on the continent) the male gradually assumed a brilliant plumage, and the female also slightly changed its markings. Before this change was completed the bird had established an isolated colony on Mas-a-fuera; and here the process of change was continued in the male, but from some unknown cause checked in the female, which thus remains nearer the parent form. Lastly the slightly modified Chilian bird again reached Juan Fernandez and exists there side by side with its strangely altered cousin.

All the phenomena can thus be accounted for by known laws, on the theory of very rare accidental immigrations from the 
mainland. The species are here so very few, that the greatest advocate for continental extensions would hardly call such vast causes into action, to account for the presence of these three birds on so small and so remote an island, especially as the union must have continued down to the time of existing species. But if accidental immigration has sufficed here, it will also assuredly have sufficed where the islands are larger, and the chances of reaching them proportionately greater; and it is because an important principle is here illustrated on so small a scale, and in so simple a manner as to be almost undeniable. that we have devoted a paragraph to its elucidation.

A few Coleoptera from Juan Fernandez present analogous phenomena. All belong to Chilian genera, while a portion of them constitute peculiar species.

Land-shells are rather plentiful, there being about twenty species belonging to seven genera, all found in the adjacent parts of South America; but all the species are peculiar, as well as four others found on the island of Mas-a-fuera.

\section{Tropical North America, or the Mexican Sub-region.}

This sub-region is of comparatively. small extent, consisting of the irregular neck of land, about 1,800 miles long, which connects the North and South American continents. Almost the whole of its area is mountainous, being in fact a continuation of the great range of the Rocky Mountains. In Mexico it forms an extensive table-land, from 6,000 to 9,000 feet above the sea, with numerous volcanic peaks from 12,000 to 18,000 feet high; but in Yucatan and Honduras, the country is less elevated, though still mountainous. On the shores of the Caribbean Sea and Gulf of Mexico, there is a margin of low land from 50 to 100 miles wide, beyond which the mountains rise abruptly; but on the Pacific side this is almost entirely wanting, the mountains rising almost immediately from the sea shore. With the exception of the elevated plateaus of Mexico and Guatemala, and the extremity of the peninsula of Yucatan, the whole of Central America is clothed with forests; and as its surface is much broken up into hill and valley, and the volcanic 
soil of a large portion of it is very fertile, it is altogether well adapted to support a varied fauna, as it does a most luxuriant vegetation. Although many peculiar Neotropical types are absent, it yet possesses an ample supply of generic and specific forms ; and, as far as concerus birds and insects, is not perhaps inferior to the richest portions of South America in the number of species to be found in equal areas.

Owing to the fact that the former Republic of Mexico comprised much territory that belongs to the Nearctic region, and that many Nearctic groups extend along the high-lands to the capital city of Mexico itself, and even considerably further south, there is much difficulty in determining what animals really belong to this sub-region. On the low-lands, tropical forms predominate as far as $28^{\circ} \mathrm{N}$. latitude; while on the cordilleras, temperate forms prevail down to $20^{\circ}$, and are found even much farther within the tropics.

Mammalia.-Very few peculiar forms of Mammalia are restricted to tropical North America; which is not to be wondered at when we consider the small extent of the country, and the facility of communication with adjacent sub-regions. A peculiar form of tapir (Elasmognathus bairdi) inhabits Central America, from Panama to Guatemala, and, with Myxomys, a genus of Muridæ, are all at present discovered. Bassxris, a remarkable form of Procyonidæ, has been included in the Nearctic region, but it extends to the high-lands of Guatemala. Heteromys, a peculiar genus of Saccomyidæ or pouched rats, inhabits Mexico, Honduras, Costa Rica, and Trinidad. Five genera of monkeys extend here,-Ateles, Mycetes, Cebus, Nyctipithecus, and Saimiris; the two former alone reaching Mexico, the last only going as far as Costa Rica. Other typical Neotropical forms are Galerc, the tayra, belonging to the weasel family; $N$ asua, the coatimundi; Dicotyles, the peccary ; Cercolabes, the tree porcupine; Dasyprocta, the agouti; Coelogenys, the paca; Choloepus, and Arctopithecus, sloths; Cyclothurus, an ant-eater; Tatusia, an armadillo; and Didelphys, oppossum. Of Northern forms, Sorex, Vulpes, Lepus, and Pteromys reach Guatemala.

Birds. - The productiveness of this district in bird life, may 
be estimated from the fact, that Messrs. Salvin and Sclater have catalogued more than 600 species from the comparatively small territory of Guatemala, or the portion of Central America between Mexico and Honduras. The great mass of the birds of this sub-region are of Neotropical families and genera, but these are intermingled with a number of migrants from temperate North America, which pass the winter here; with some northern forms on the high-lands; and with a considerable number of peculiar genera, mostly of Neotropical affinities.

The genera of birds peculiar to this sub-region belong to the following families :-Turdidæ (2 genera) ; Troglodytidæ (1 gen.); Vireonidæ (1 gen.); Corvidæ (2 gen.); Ampelidæ (1 gen.); Tanagridæ (1 gen.); Fringillidæ (2 gen.); Icteridæ (1 gen.); Formicariidæ (2 gen.) ; Tyrannidæ (2 gen.) ; Cotingidæ (1 gen.); Momotidæ (1 gen.); Trogonidæ (1 gen.); Trochilidæ (14 gen.); Conuridæ (1 gen.); Cracidæ (2 gen.); Strigidæ (1 gen.); in all 37 genera of land-birds. The Neotropical families that do not extend into this sub-region are, Pteroptochidæ; the sub-family Furnariince of the Dendrocolaptidæ; the sub-family Conophagince of the Tyrannidæ; the sub-family Rupicolina of the Cotingidæ; Phytotomidæ; Todidæ; Opisthocomidæ; Chionididæ; Thinocoridæ; Cariamidæ; Psophiidæ; Eurypygidæ; Palamedeidæ; and Struthionidæ. On the other hand Paridæ, Certhiidæ, Ampelidæ, and Phasianidæ, are northern families represented here, but which do not reach South America; and there are also several northern genera and species, of Turdidæ, Troglodytidæ, Mniotiltidæ, Vireonidæ, Fringillidæ, Corvidæ, Tetraonidæ, and Strigidæ, which are similarly restricted. Some of the most remarkable of the Neotropical genera only extend as far as Custa Rica and Veragua,-countries which possess a rich and remarkable fauna. Here only are found an umbrella bird, (Cephalopterus glabricollis); a bell bird (Chasmorhynchus tricarunculatus); and species of Dacnis (Cerœbidæ), Buthraupis, Eucometis, Tachyphonus (Tanagridæ), Xiphorhynchus (Dendrocolaptidæ) ; Hypocnemis (Formicariidæ); Euscarthmus (Tyrannidæ); Attila (Cotingidæ); Piprites (Pipridæ); Capito, Tetragonops (Megalæmidæ); Selenidera (Rhamphastidæ); Neomorphus 
(Cuculidæ); Monasa (Bucconidæ); many genera of Trochilidæ; and Nothocercus (Tinamidx); none of which extend further north. A considerable number of the peculiar genera noted above, are also found in this restricted area, which is probably one of the richest ornithological districts on the globe.

Reptiles.-These are much less known than the preceding classes, but they afford several peculiar and interesting forms. Snakes are perhaps the least remarkable; yet there are recorded 4 peculiar genera of Calamariidæ, 1 of Colubridæ, 1 of Homalopsidæ, 3 of Dipsadidæ; while Boa and Elaps are in common with South America. Lizards are much more specially developed. Chirotes, one of the Amphisbænians, is confined to Mexico and the southern part of the Nearctic region ; Heloderma forming a peculiar family, Helodermidæ, is Mexican only ; Abronic and Barissia (Zonuridæ) are also Mexican, as is Siderolampus belonging to the Scincida, while Blepharactitis (same family) inhabits Nicaragua; Brachydactylus, one of the geckoes, is from Costa Rica; while Phymatolcpis, Lananctus, Corytheolus, Cachrix, Corythophanes and Chamceleopsis, all belonging to the Iguanidæ, are confined to various parts of the sub-region. In the same family we have also the Antillean, Cychira, and the Nearetic Plirynosoma and Tropidolepis, as well as the wide-spread American genns Anotius.

Among the tortoises, Stcurrotypus, allied to Chelydra, is found in Mexico and Guatemala; and another genus, Clciudius, has been lately described from Mexico.

Amphibia.-These are chiefly Batrachians; Rhinophryna (forming a peculiar family) being confined to Mexico ; Triprion, a genus of Hylidæ, inhabiting Yucatan, with Leyla and Strabomantis (Polypedatidx) found only in Costa Rica and Veragua, are peculiar genera. The Salamandridæ, so abundant in the Nearctic region, are represented by a few species of Amblystoma and Spelerpes.

Fresh-water fish.- Since the British Museum catalogne was published, a valuable paper by Dr. Giinther, in the Transactions of the Zoological Society for 1868, furnishes much additional information on the fishes of Central America. In that part of the region south of Mexico, 106 species of fresh-water fishes are 
enumerated; and 17 of these are found in streams flowing into both the Atlantic and Pacific Oceans. On the whole, 11 families are represented among the fresh-water fish, and about 38 genera. Of these, 14 are specially Nearctic,-Amiurus'(Siluridæ); Fundulus (Cyprinodontidæ); Sclerognathus (Cyprinidæ); and Lepidosteus (Ganoidei). A much larger number are Neotropical; and several Neotropical genera, as Heros and Pcecilia, are. more largely developed here than in any other part of the region. There are also a considerable number of peculiar genera;-Petenia, Theraps, and Neotrophus (Chromides); Alurichthys (Siluridæ); Chalcinopsis (Characniidæ); Characodon, Belonesox, Pseudoxiphophorus, Platypocilus, Mollienesia, and Xiphophorus (Cyprinodontidæ). A few peculiar Antillean forms are also present; as Agonostoma (Mugilidæ); Gambusia and Girardinuus (Cyprinodontidæ). The other families represented are Pẹcidæ (1 genus); Pristopomatidæ (2 gen.); Gobiidæ (1 gen.); Clupeidæ (2 gen.) ; and Gymnotidæ (1 genus).

On the whole the fish-fauna is typically Neotropical, but with a small infusion of Nearctic forms. There are a considerable proportion of peculiar genera, and almost all the species are distinct from those of other countries. The predominant family is that of the Cyprinodontidæ, represented by 12 genera; and the genus Heros (Chromidæ) has here its maximum development, containing between thirty and forty species. Dr. Günther considers that a number of sub-faunas can be distinguished, corresponding to some extent, with the islands into which the country would be divided by a subsidence of about 2,000 feet. The most important of these divisions is that separating Honduras from Costa Rica, and as it also divides a very marked ornithological fauna we have every reason to believe that such a division must have existed during the latter portion of the tertiary epoch. We shall find some farther evidence of this division in the next class.

Insects. - The butterflies of various parts of Central America and Mexico, having been largely collected, offer us some valuable evidence as to the relations of this sub-region. Their general character is wholly Neotropical, about one half of the 
South American genern being found here. There are also a few peculiar genera, as, Dimeina (Satyridæ); Microtia (Nymphalidæ); Lumoeus (Lycienide); and Eucheira (Pieridæ). Clothilda (Nymphalidx) is confined to this sub-region and the Antilles. The majority of the genera range over the whole sub-region from Panama to Mexico, but there are a considerable number, comprising many of the suost characteristic South American forms, which do not pass north of Costa Rica or Nicaragua. Such are Lycorea, Ituna, Thyridia, Callithomia, Oleria and Ceratina, -all characteristic South American groups of Danaidæ; Pronophila and Dynastor (Satyridæ); Protogonius, Pycina, Prepona, Nica, Ectima and Coloenis (Nymphalidæ); Eurybia and Methonella (Nemeobiidæ); Hades, and Panthemos (Erycinidæ).

Colcopter $a$.-These present some interesting features, but owing to their vast number only a few of the more important families can be noticed.

Cicindelidæ.-The only specially Neotropical genera recorded as occurring in this sub-region, are Ctenostoma and Hiresia, both reaching Mexico.

Carabidæ.-Several genera are peculiar. Molobrus is found in all parts of the sub-region, while Onychopterygia, Phymatocephalus, and Anisotarsus are Mexican only. There are about 20 South American genera, most of which extend to Mexico, and include such characteristic Neotropical forms as Agra, Callida, Coptodera, Pachyteles, Ardisiomus, Aspidoglossa, Stenocrepis, and Pelecium.

Lucanidæ.-Of this important family there is, strange to say, not a single species recorded in Gemminger and Harold's catalogue up to 1868 ! It is almost impossible that they can be really absent; yet their place seems to be, to some extent, supplied by an unusual development of the allied Passalidæ, of which there are five South American and six peculiar genera,

Cetoniidæ.-All the larger South American genera extend to Mexico, which country possesses 3 peculiar forms, Ischnoscelis, Psilocnemis, and Dialithus; while Trigonopeltastes is characteristic, having 4 Mexican, 1 Brazilian, and 1 North American species. 
Buprestidæ.-In this family there are no peculiar genera. All the large South American groups are absent, the ouly important and characteristic genus being Stenogaster.

Longicorns.-'This important group is largely developed, the country being well adapted to them; and their distribution presents some features of interest.

In the Prionidæe there are 6 peculiar genera, the largest being Holonotus with 3 species; two others, Derotrachus and Mallaspis, are characteristic; 3 more are common to South America, and 1 to Cuba. The Cerambycidæ are much more numerous, and there are 24 peculiar genera, the most important being Sphenothecus, Entomosterna, and Cyphosterna ; while Crioprosopus and Metaleptus are characteristic of the sub-region, although extending into South America; about 12 Neotropical genera extend to Mexico or Guatemala, while 12 more stop short, as far as yet known, at Nicaragua. Lamiidæ have a very similar distribution ; 13 genera are peculiar, the most important being Monilema, Hamatoderus, and Carneades, while Phoca and Lagochirus are characteristic. About sixteen typical Neotropical genera extend to Mexico, and 15 more only reach Nicaragua, among which are such important genera as Anisopus, Lepturgus, and Callia.

The land-shells are not sufficiently known to furnish any corresponding results. They are however mostly of South American genera, and have comparatively little affinity for those of the Antilles.

Relations of the Mexican sub-region to the North and South American Continents.-The sudden appearance of numerous South American forms of Edentata in temperate North America, in Post-Tertiary times, as narrated in Chapter VII., together with such facts as the occurrence of a considerable number of identical species of sea fish on the two sides of the Central American isthmus, render it almost certain that the union of North and South America is comparatively a recent occurrance, and that during the Miocene and Pliocene periods, they were separated by a wide arm of the sea. The low country of Nicaragua was probably the part submerged, leaving the highlands of Mexico and Guatemala still united with the North 
American continent, and forming part of the Tertiary "Nearctic region." This is clearly indicated both by the many Nearctic forms which do not pass south of Nicaragua, of which the turkeys (Meleagris) are a striking example, and by the comparative poverty of this area in typical Neotropical groups. During the Miocene period there was not that marked diversity of climate between North and South America that now prevails; for when a luxuriant vegetation covered what are now the shores of the Arctic Ocean, the country south of the great lakes must have been almost or quite tropical. At an early Tertiary period, the zoological differences of the Nearctic and Neotropical regions were probably more radical than they are now, South America being a huge island, or group of islands-a kind of Australia of the New World, chiefly inhabited by the imperfectly organized Edentata; while North America abounded in Ungulata and Carnivora, and perhaps formed a part of the great old World continent. There were also one or more very ancient unions (in Eocene or Miocene times) of the two continents, admitting of the entrance of the ancestral types of Quadrumana into South America, and, somewhat later, of the Camelidæ; while the isthmus south of Nicaragua was at one time united to the southern continent, at another made insular by subsidence near Panama, and thus obtained that rich variety of Neotropical types that still characterises it. When the final union of the two continents took place, the tropical climate of the lower portions of Guatemala and Mexico would invite rapid immigration from the south; while some northern forms would extend their range into and beyond the newly elevated territory. The Mexican sub-region has therefore a composite character, and we must not endeavour too rigidly to determine its northern limits, nor claim as exclusively Neotropical, forms which are perhaps comparatively recent imnigrants; and it would perhaps be a more accurate representation of the facts, if we were to consider all the highlands of Mexico and Guatemala above the limits of the tropical forests, as still belonging to the Nearctic region, of which the whole country so recently formed a part.

The long-continued separation of North and South America 
by one or more arms of the sea, as above indicated, is further rendered necessary by the character of the molluscan fauna of the Pacific shores of tropical America, which is much more closely allied to that of the Caribbean sea, and even of West Africa, than to that of the Pacific islands. The families and many of the genera are the same, and a certain proportion of very closely allied or identical species, shows that the union of the two oceans continued into late Tertiary times. When the evidence of both land and sea animals support each other as they do here, the conclusions arrived at are almost as certain as if we had (as we no doubt some day shall have) geological proof of these successive subsidences.

Islands of the Mexican Sub-region.-The only islands of interest belonging to this sub-region, are Tres Marias and Socorro, recently investigated by Col. Grayson for some of the American Natural History societies.

Tres Marias consist of four small islands lying off the coast of north-western Mexico, about 70 miles from San Blas. The largest is about 15 miles long by 10 wide. They are of horizontally stratified deposits, of moderate height and flat-topped, and everywhere covered with luxuriant virgin forests. They appear to lie within the 100 fathom line of soundings. Fifty-two species of birds, of which 45 were land-birds, were collected on these islands. They consisted of 19 Passeres; 11 Picariæ (7 being humming-birds); 10 Accipitres ; 2 parrots, and 3 pigeons. All were Mexican species except 4, which were new, and presumably peculiar to the islands, and one tolerably marked variety. The new species belong to the following genera;-Parula and Granatellus (Mniotiltidæ); Icterus (Icteridæ); and Amazilia (Trochilidæ). A small Psittacula differs somewhat from the same species on the mainland.

There are a few mammalia on the islands; a rabbit (Lepus) supposed to be new ; a very small opossum (Didclphys), and a racoon (Procyon). There are also several tree-snakes, a Boa, and many lizards. The occurrence of so many mammalia and snakes is a proof that these islands have been once joined to the mainland; but the fact that some of the species of both birds and 
mammals are peculiar, indicates that the separation is not a very receut one. At the same time, as all the species are very closely allied to those of the opposite coasts when not identical, we may be sure that the subsidence which isolated them is not geologically remote.

Socorro, the largest of the Revillagigedo Islands, is altogether different from the Tres Marias. It is situated a little further south (19 S. Latitude), and about 300 miles from the coast, in deep water. It is about 2,000 feet high, very rugged and bare, and wholly volcanic. No mammalia were observed, and no reptiles but a small lizard, a new species of a genus (Uta) characteristic of the deserts of N.-Western Mexico. The only observed land-shell (Orthalicus undatus) also inhabits N.-W. Mexico. Only 14 species of birds were obtained, of which 9 were land-birds; but of these 4 were new species, one a peculiar variety, and another (Pamula insularis) a species first found in the Tres Marias. With the exception of this bird and a Buteo, all the land-birds belonged to different genera from any found on the Tres Marias, though all were Mexican forms. The peculiar species belonged to the genera Harporhynchus (Turdidæ); Troglodytes (Troglodytidæ) ; Pipilo (Fringillidæ) ; Zenaidura (Columbidæ) ; and a variety of Conurus holochrous (Psittacidæ).

The absence of mammals and snakes, the large proportion of peculiar species, the wholly volcanic nature of these islands, and their situation in deep water 300 miles from land,-all indicate that they have not formed part of the continent, but have been raised in the ocean; and the close relation of their peculiar species to those living in N.-Western Mexico, renders it probable that their antiquity is not geologically great.

The Cocos Islands, about 300 miles S.-W. of the Isthmus of Panama, are known to possess one peculiar bird, a cuckoo of the Coccyzus type, which is considered by some ornithologists to constitute a peculiar genus, Nesococcyx.

\section{The West Indian Islands, or Antillean Sub-region.}

The West Indian islands are, in many respects, one of the most interesting of zoological sub-regions. In position they 
form an unbroken chain uniting North and South America, in a line parallel to the great Central American isthmus; yet instead of exhibiting an intermixture of the productions of Florida and Venezuela, they differ widely from both these countries, possessing in some groups a degree of speciality only to be found elsewhere in islands far removed from any continent. They consist of two very large islands, Cuba and Hayti $;^{1}$ two of moderate size, Jamaica and Portorico; and a chain of much smaller islands, St. Croix, Anguilla, Barbuda, Antigua, Guadeloupe, Dominica, Martinique, St. Lucia, St. Vincent, Barbadoes, and Grenada, with a host of intervening islets. Tobago, Trinidad, Margarita, and Curaçao, are situated in shallow water near the coast of South America, of which they form part zoologically. To the north of Cuba and Hayti are the Bahamas, an extensive group of coral reefs and islands, 700 miles long, and although very poor in animal life, belonging zoologically to the Antilles. All the larger islands, and most of the smaller ones (except those of coral formation) are very mountainous and rocky, the chains rising to about 8,000 feet in Hayti and Jamaica, and to nearly the same height in Cuba. All, except where they have been cleared by man, are covered with a luxuriant forest vegetation; the temperature is high and uniform; the rains ample; the soil, derived from granitic and limestone rocks, exceedingly fertile ; and as the four larger islands together are larger than Great Britain, we might expect an ample and luxuriant fauna. The reverse is however the case; and there are probably no land areas on the globe, so highly favoured by nature in all the essentials for supporting animal life, and at the same time so poor in all the more highly organised groups of animals. Before entering upon our sketch of the main features of this peculiar but limited fauna, it will be well to note a few peculiarities in the physical structure of the islands, which have an important bearing on their past

1 This name will be used for the whole island of St. Domingo, as being both shorter and more euphonious, and avoiding all confusion with Dominica, one of the Lesser Antilles. It is also better known than "Hispaniola," which is perhaps the most correct name. 
history, and will enable us to account for much that is peculiar in the general character of their natural productions.

If we draw a line immediately south of St. Croix and St. Bartholomew, we shall divide the Archipelago into two very different groups. The southern range of islands, or the Lesser Antilles, are, almost without exception, volcanic ; beginning with the small detached volcanoes of Saba and St. Eustatius, and ending with the old volcano of Grenada. Barbuda and Antigua are low islands of Tertiary or recent formation, connected with the volcanic islands by a submerged bank at no great depth. The islands to the north and west are none of them volcanic; many are very large, and these have all a central nucleus of ancient or granitic rocks. We must also note, that the channels between these islands are not of excessive depth, and that their ontlines, as well as the direction of their mountain ranges, point to a former union. Thus, the northern range of Hayti is continued westward in Cuba, and eastward in Portorico; while the south-western peninsula extends in a direct line towards Jamaica, the depth between them being 600 fathoms. Between Portorico and Hayti there is only 250 fathoms; while close to the sonth of all these islands the sea is enormously deep, from more than 1,000 fathoms south of Cuba and Jamaica, to 2,000 south of Hayti, and 2,600 fathoms near the south-east extremity of Portorico. The importance of the division here pointed out will be seen, when we state, that indigenous mammalia of peculiar genera are found on the western group of islands only; and it is on these that all the chief peculiarities of Antillian zoology are developed.

Mammalia.-The mammals of the West Indian Islands are exceedingly few, but very interesting. Almost all the orders most characteristic of South America are absent. There are no nonkeys, no carnivora, no edentata. Besides bats, which are abundant, only two orders are represented; rodents, by peculiar forms of a South American family; and insectivora (an order entirely wanting in South America) by a genus belonging to a family largely developed in Madagascar and found nowhere else. The early voyagers mention "Coatis" and "Agoutis" as being 
found in Hayti and the other large islands, and it is not improbable that species allied to Nasua and Dasyprocta did exist, and have been destroyed by the dogs of the invaders; though, on the other hand, these names may have been applied to the existing species, which do bear some general resemblance to these two forms.

The Chiroptera, or bats, are represented by a large number of species and by several peculiar genera. The American family of Phyllostomidæ or vampires, has six genera in the Antilles, of which three, Lonchorina, Brachyphylla, and Phyllonycteris, are peculiar, the latter being found only in Cuba. The Vespertilionidæ have four genera, of which one, Nycticellus, is confined to Cuba. There are six genera of Noctilionidæ, of which one, Phyllodia, is confined to Jamaica.

The Insectivora are represented by the genus Solenodon, of which two species are known, one inhabiting Cuba the other: Hayti. These are small animals about the size of a cat, with long shrew-like snout, bare rat-like tail, and long claws. Their peculiar dentition and other points of their anatomy shows that they belong to the family Centetidæ, of which five different genera inhabit Madagascar; while there is nothing closely allied to them in any other part of the world but in these two islands.

Seals are said to be found on the shores of some of the islands, but they are very imperfectly known.

The rodents belong to the family Octodontidæ, or, according to some authors, to the Echimyidæ, both characteristic South American groups. They consist of two genera, Capromys, containing three or four species inhabiting Cuba and Jamaica; while Plagiodontia (very closely allied) is confined to Hayti. A peculiar mouse, a species of the American genus Hesperomys, is said to inhabit Hayti and Martinique, and probably other islands. A Dasyprocta or agouti, closely allied to, if not identical with, a South American species, inhabits St. Vincent, St. Lucia, and Grenada, and perhaps St. Thomas, and is the only mammal of any size indigenous to the Lesser Antilles. All the islands in which sugar is cultivated are, however, overrun with European rats and mice, and it is not improbable that these may have 
starved out and exterminated some of the smaller native rodents.

Birds.-The birds of the Antilles, although very inferior in number and variety to those of the mainland, are yet sufficiently abundant and remarkable, to offer us good materials for elucidating the past history of the comntry, when aided by such indications as geology and physical geography can afford.

The total number of land-birds which are permanent residents in the West India islands is, as nearly as can be ascertained from existing materials, 203. There are, in addition to this number, according to Prof. Baird, 88 migrants from North America, which either spend the winter in some of the islands or pass on to Central or South America. These migrants belong to 55 genera, and it is an interesting fact that so many as 40 of these genera have no resident representatives in the islands. This is important, as showing that this northern migration is probably a recent and superficial phenomenon, and has not produced any (or a very slight) permanent effect on the famna. The migratory genera which have permanent residents, and almost always representative species, in the islands, are in most cases characteristic rather of the Neotropical than of the Nearctic fauna, as the following list will show; Turdus, Dendreeca, Vireo, Polioptila, Ageloeus, Icterus, Contopus, Myiarchus, Tyrannus, Antrostomus, Chordeiles, Coccyzus, Columba. By far the larger part of these birds visit Cuba only; 81 species being recorded as occurring in that island, while only 31 have been found in Jamacia, 12 in Porto Rico and St. Croix, and 2 in Tobago and Trinidad. Setting aside these migratory birds, as having no bearing on the origin of the true Antillean fauna, we will discuss the residents somewhat in detail.

The resident land-birds (203 in number) belong to 95 genera and 26 families. Of these families 15 are cosmopolitan or nearly so-Turdidæ, Sylviidæ, Corvidæ, Hirundinidæ, Fringillidæ, Picidæ, Cuculidæ, Caprimulgidæ, Cypselidæ, Trogonidæ, Psittacidæ, Columbidæ, Tetraonidæ, Falconidæ, and Strigidæ; 5 are American only-Vireonidæ, Mniotiltidæ, Icteridæ, Tyrannidæ, Trochilidæ ; 4 are Netropical only or almost exclusively - : 
Cœrebidæ, Tanagridæ, Cotingidæ, Conuridæ; 1 is Antillean only-Todidæ; while 1-Ampelidæ-is confined (in the western hemisphere) to North America, and almost to the Nearctic region. Of the 95 genera, no less than 31, or almost exactly one-third, are peculiar; while of the 203 resident species, 177 are peculiar, the other 26 being all inhabitants of South or Central America. Considering how closely the islands approach the continent in several places-Florida, Yucatan, and Venezuela-this amou $1 \hat{t}$ of speciality in such locomotive creatures as birds, is probably unexampled in any other part of the globe. The most interesting of these peculiar genera are the following: 4 of Turdidx, or thrushes -1 confined to the large islands, 1 to the whole archipelago, while 2 are limited to the Lesser Antilles; 2 genera of Tanagridæ, confined to the larger islands; 2 of Trogonidx, also confined to the larger islands; 5 of hummingbirds, 3 confined to the Greater, 1 to the Lesser Antilles; 2 of cuckoos, one represented in all the large islands, the other in Jamaica only; 2 of owls, one peculiar to Jamaica, the other represented in St. Croix, St. Thomas, Portorico, and Cuba; and lastly, Todus, constituting a peculiar family, and having representative species in each of the larger islands, is especially interesting because it belongs to a group of families which are wholly Neotropical-the Momotidæ, Galbulidæ, and Todidæ. The presence of this peculiar form, with 2 trogons; 10 species of parrots, all but one peculiar; 16 peculiar humming-birds lelonging to 8 genera; a genus of Cotingidæe; 10 peculiar tanagers belonging to 3 genera; 9 Cœrebidæ of 3 genera; together with species of such exclusively Netropical grenera as Coreba, Certhiola, Sycalis, Phonipara, Elainea, Pitangus, Campephilus, Chloronerpes, Nyctibius, Stenopsis, Lampornis, Calypte, Ara, Chrysotis, Zenaida, Leptoptila, and Geotrygon, sufficiently demonstrate the predominant affinities of this fauna; although there are many cases in which it is difficult to say, whether the ancestors of the peculiar genera or species may not have been derived from the Nearctic rather than from the Neotropical region.

The several islands differ considerably in their apparent proVOL. II. 
ductiveness, but this is, no doubt, partly due to our knowledge of Cuba and Jamaica being much more complete than of Hayti. The species of resident land-birds at present known are as follows:-

\begin{tabular}{|c|c|c|c|c|c|c|}
\hline Cuba & $68 \mathrm{~s}$ & & hio & 40 & cll & 0 it. \\
\hline Hayti & 40 & " & ": & 17 & $"$ & \\
\hline Jamaica & 67 & 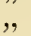 &, & 41 &, & " \\
\hline Portorico & 40 & , &, & 15 & , & ", \\
\hline Lesser Antilles & 45 & ", & , & 24 & , & " \\
\hline
\end{tabular}

If we count the peculiar genera of each island, and reckon as $\left(\frac{1}{2}\right)$ when a genus is common to two islands only, the numbers are as follows:-Cuba $7 \frac{1}{2}$, Hayti $3 \frac{1}{2}$, Jamaica $8 \frac{1}{2}$, Portorico 1, Lesser Antilles $3 \frac{1}{2}$. These figures show us, that although Jamaica is one of the smaller and the most isolated of the four chief islands, it yet stands in the first rank, both for the number of its species and of its peculiar forms of birds,- - and although this superiority may be in part due to its having been more investigated, it is probably not wholly so, since Cuba has also heen well explored. This fact indicates, that the West Indian islands have undergone great changes, and that they were not peopled by immigration from surrounding countries while in the condition we now see them; for in that case the smaller and more remote islands would be very much poorer, while Cuba, which is not only the largest, but nearest to the mainland in two directions, would be immensely richer, just as it really is in migratory birds.

The number of birds common to the four larger islands is very small-probably not more than half a dozen; between 20 and 30 are common to some two of the islands (counting the Lesser Antilles as one island) and a few to three; but the great mass of the species (at least 140) are confined each to some one of the five islands or groups we have indicated. This is an amount of isolation and speciality, probably not to be equalled elsewhere, and which must have required a remarkable series of physical changes to bring about. What those changes probably were, we shall be in a better position to consider when we have completerl our survey of the various classes of land animals. 

PLATE XVII.

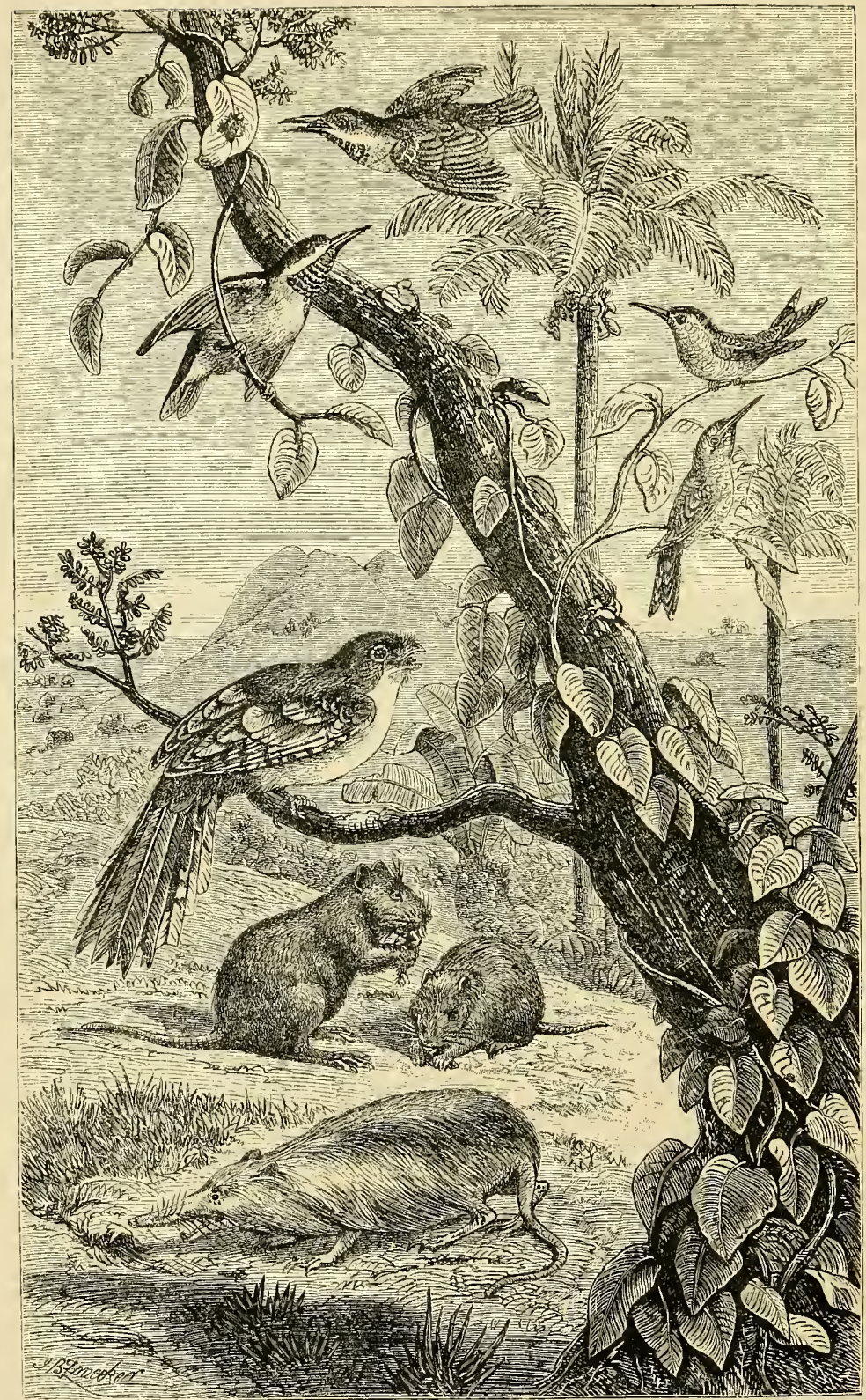

A SCENE IN CUBA, WITH CHARACTERISTIC ANIMALS 
In the preceding enumeration the Bahamas have been included with Cuba, as regards the birds they have in common; but they possess some half dozen species not found elsewhere, and even one central American genus of humming.birds (Doricha) not found in any other part of the Antilles. We have thus given Cuba rather more peculiar species than it really possesses, 'so that the proportionate richness of Jamaica is rather greater than shown by our figures.

The destruction of the forests and the increase of population, with, perhaps, the use of firearms, seem to have led to the extermination of some species of birds in the smaller islands. Professor Newton has called attention to the work of M. Ledru, who, in 1796, described the birds of St. Thomas. He mentions a parrot and a parroquet in the island, the latter only being now known, and very scarce; also a green pigeon and a tody, both now unknown. No less than six species of parrots are said to have been formerly found in Guadeloupe and Martinique, which are now extinct.

Plate XVII. Illustrating the peculiar Mammalia and Birds of the Antilles.-The scene of this illustration is Cuba, the largest of the West Indian islands, and one in which all its peculiar zoological features are well developed. In the foreground is the agouta (Solenodon cubanus), a remarkable insectivorous animal which, with another species inhabiting Hayti, has no allies on the American continent; nor anywhere in the world but in Madagascar, where a group of animals are found constituting the family Centetidæ, to which Solenodon is said undoubtedly to belong. Above it are a pair of hutias (Capromys fournieri), rat-like animals belonging to the South American family Octodontidæ. They live in the forests, and climb trees readily, eating all kinds of vegetable food. Three species of the genus are known, which are found only in Cuba and Jamaica. Just above these animals is a white-breasted trogon (Prionoteles temnurus), confined to Cuba, and the only species of the genus. Near the top of the picture are a pair of todies (Todus multicolor), singular little insectivorous birds allied to the motmots, but forming a very distinct family which is confined to the islands of the 
Greater Antilles. They are beantifully-coloured birds,-green above, red and white berieath, and are exceedingly active in their movements. To the right are a pair of small humming-birds (Sporadinus ricordi), not very remarkable in this beautiful family, but introduced here because they belong to a genus which is confined to the Greater Antilles.

I'ablc of distribution of West-Indian Birds.-As the birds of the West-Indian islands are particularly interesting and their peculiarities comparatively little known, we give here a table of the genera of land-birds. compiled from all available sources of information. Owing to the numerous independent observations on which it is founded, the discrepancies of nomenclature, and uncertainty in some cases as to the locality of species, it can only be looked upon as an approximative summary of the existing materials on Antillean ornithology.

\section{TABLE OF THE RESIDENT LAND-BIRDS OF THE ANTILLES.}

Note.-Genera confined to the West Indies are in Italics. An $(a)$ after (1) indicates a species common to two islands : but where there are two or more species in an island, or the localities are doubtful, this indication cannot be given. All species not otherwise noted arc peculiar to the Antilles.

\begin{tabular}{|c|c|c|c|c|c|c|c|c|c|}
\hline \multirow[b]{2}{*}{ Family and Genus. } & & \multicolumn{6}{|c|}{ Number of Species in each Islard. } & \multirow{2}{*}{ 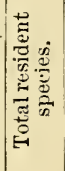 } & \multirow[b]{2}{*}{ Remarks. } \\
\hline & & 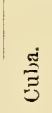 & 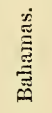 & 焉 & & 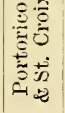 & 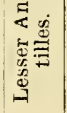 & & \\
\hline \multicolumn{10}{|l|}{ TURDIDE. } \\
\hline Turdus .. $\quad \ldots$ & $\ldots$ & - & - & - & 1 & - & - & 1 & Five species migrate to Cuba \\
\hline Mimocichla $\ldots$ &. & 2 & 1 & 1 & 1 & $\overline{1}$ & - & 5 & Martiniane St Jupis Gula \\
\hline $\begin{array}{l}\text { Margarops ... } \\
\text { Rhamphocinclus }\end{array}$ & $\begin{array}{l}\cdots \\
\cdots\end{array}$ & - & - & $\underline{1 a}$ & - & $1 a$. & $\begin{array}{l}3 \\
1\end{array}$ & $\begin{array}{l}4 \\
1\end{array}$ & $\begin{array}{l}\text { Martinique, St. Lucia, Guada. } \\
\text { Martinique and St. Lucia }\end{array}$ \\
\hline Cinclocerthica... & $\ldots$ & - & - & - & - & - & 3 & 3 & Nevis to St. Lucia \\
\hline Mimus ... $\quad .$. & .. & 1 & 1 & - & 1 & (?) & - & 3 & $\begin{array}{l}\text { Another species migrates to } \\
\text { the Antilles }\end{array}$ \\
\hline SYLVIID无. & & & & & & & & & \\
\hline $\begin{array}{l}\text { Myiadestes } \\
\text { Poliontila }\end{array}$ & $\ldots$ & $\begin{array}{l}1 \\
1\end{array}$ & - & - & 1 & - & 1 & $\begin{array}{l}3 \\
1\end{array}$ & St. Lucia \\
\hline & ( & & & & & & & & \\
\hline
\end{tabular}




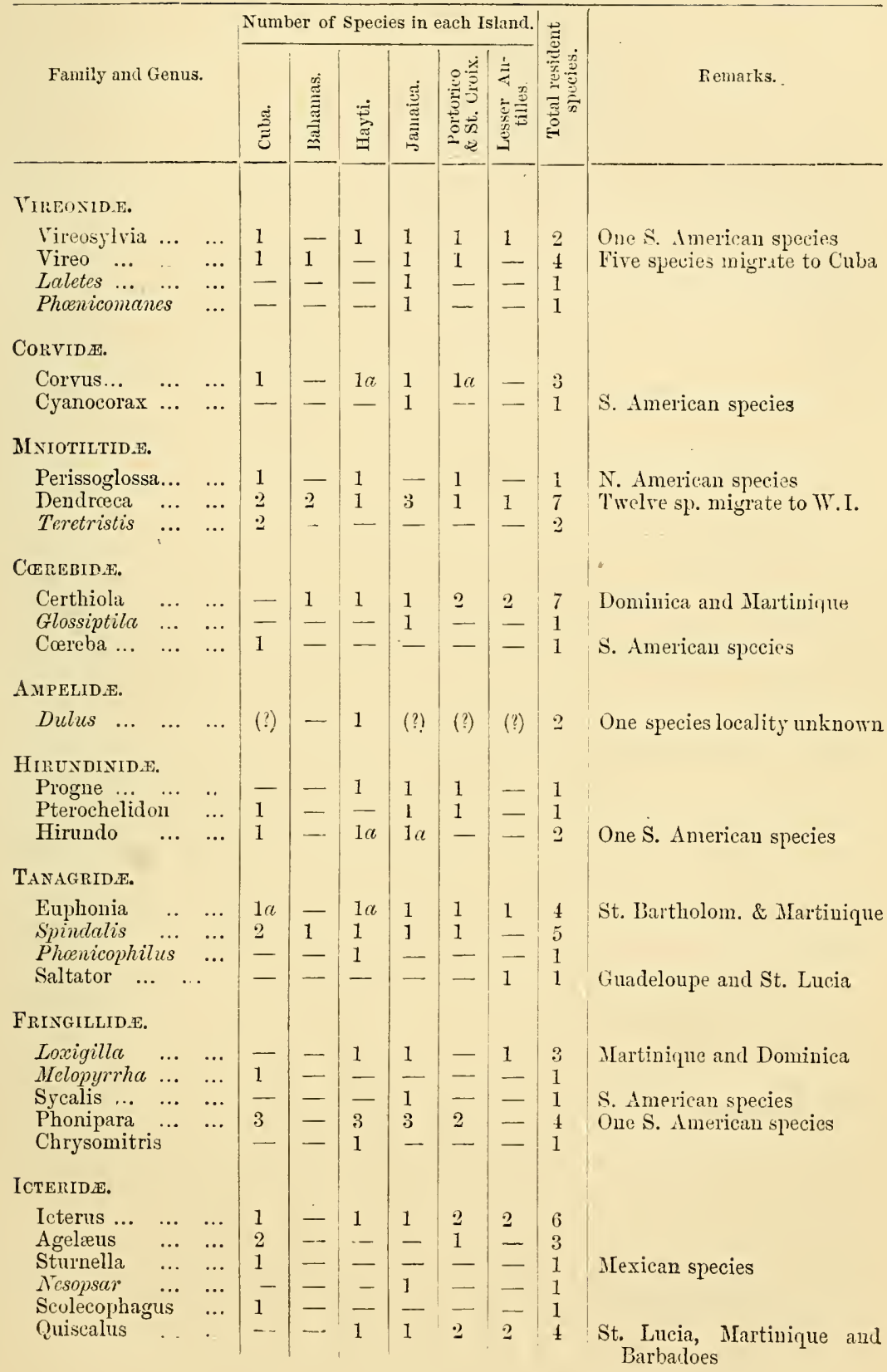




\begin{tabular}{|c|c|c|c|c|c|c|c|c|c|c|}
\hline \multirow{2}{*}{\multicolumn{3}{|c|}{ Family and Genus. }} & \multicolumn{6}{|c|}{ Number of species in each 1sland } & \multirow{2}{*}{ 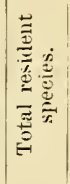 } & \multirow[b]{2}{*}{ Remarks. } \\
\hline & & & 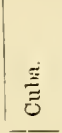 & 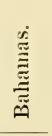 & . & 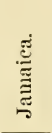 & 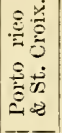 & 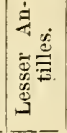 & & \\
\hline \multicolumn{11}{|l|}{ TYRANNIDA. } \\
\hline Elainea . & $\cdots$ & $\ldots$ & - & - & - & 2 & - & 1 & 3 & \\
\hline Pitangns & ... & $\cdots$ & $1 a$ & - & - & $\begin{array}{l}1 a \\
1\end{array}$ & 1 & $\overline{1}$ & $\begin{array}{l}2 \\
2\end{array}$ & St. Lucia \\
\hline $\begin{array}{l}\text { Contopus } \\
\text { Myiarchus }\end{array}$ & $\begin{array}{l}\cdots \\
\cdots\end{array}$ & $\begin{array}{l}\cdots \\
\cdots\end{array}$ & $\overline{2}$ & - & 1 & 3 & 1 & 16 & 7 & One S. Arnerican species $(b)$ \\
\hline Biacicus & $\cdots$ & $\cdots$ & la & - & $1 a$ & 1 & $\overline{-1}$ & - & 2 & \\
\hline Tyrannus & $\cdots$ & $\cdots$ & 2 & - & - & $1 b$ & $1 b$ & $2 b$ & 3 & One sp. in Cen. America (b) \\
\hline \multicolumn{11}{|l|}{ COTIXGIDE. } \\
\hline Hadrostomu & & $\ldots$ & - & - & - & 1 & - & - & 1 & \\
\hline \multicolumn{11}{|l|}{ PiCIDA. } \\
\hline Campephilus & & $\cdots$ & 1 & - & - & - & - & - & $\begin{array}{l}1 \\
1\end{array}$ & \\
\hline $\begin{array}{l}\text { Xiphidiopict } \\
\text { Melaneryes }\end{array}$ & & $\ldots$ & 1 & - & - & - & 1 & 二 & $\begin{array}{l}1 \\
1\end{array}$ & \\
\hline Chloronerpes & & $\cdots$ & - & - & 1 & - & - & - & 1 & \\
\hline Centurus & .. & $\ldots$ & 1 & - & 1 & 1 & - & - & 3 & \\
\hline Colaptes & $\ldots$ & $\ldots$ & 2 & - & - & - & - & - & 2 & \\
\hline Nesoceleus & .. & $\ldots$ & 1 & - & - & - & - & - & 1 & \\
\hline Picumnus & $\cdots$ & $\cdots$ & - & - & $? 1$ & - & - & - & 1 & \\
\hline \multicolumn{11}{|l|}{ Cuculide. } \\
\hline Saurothera & $\cdots$ & $\ldots$ & 1 & - & 1 & 1 & 1 & - & 4 & \\
\hline Hyetornis & ... & $\ldots$ & - & - & 1 & 1 & - & - & 2 & \\
\hline Coccygus & $\cdots$ & $\cdots$ & 1 & - & 2 & 1 & 1 & 1 & 3 & $\begin{array}{l}\text { Dominica, St. Lncia, all Neo- } \\
\text { tropical species }\end{array}$ \\
\hline Crotophaga & $\cdots$ & $\cdots$ & 1 & - & - & 1 & 1 & 1 & 2 & N. \& Cen. American species \\
\hline \multicolumn{11}{|l|}{ TODIDE. } \\
\hline Torlus $\ldots$ & $\cdots$ & $\ldots$ & 1 & - & 1 & 2 & 1 & - & 5 & \\
\hline \multicolumn{11}{|l|}{ Trogonily. } \\
\hline $\begin{array}{l}\text { Prionotcles } \\
\text { Temnotrogon }\end{array}$ & & $\begin{array}{l}\cdots \\
\cdots\end{array}$ & 1 & - & $\overline{1}$ & - & $\overline{-}$ & - & $\begin{array}{l}1 \\
1\end{array}$ & \\
\hline \multicolumn{11}{|c|}{ CapRinulgide. } \\
\hline $\begin{array}{l}\text { Nyctibins } \\
\text { Chordeiles }\end{array}$ & $\ldots$ & $\cdots$ & - & - & - & $\begin{array}{l}1 \\
1\end{array}$ & - & - & $\begin{array}{l}1 \\
1\end{array}$ & Neotropical species \\
\hline Antrostomus & & $\cdots$ & 2 & - & - & 1 & - & 1 & 2 & One Neotropical speeies \\
\hline Siphomorhis & & $\ldots$ & - & - & - & 1 & - & - & 1 & \\
\hline Stenopsis & $\cdots$ & $\cdots$ & - & - & - & - & 一 & 1 & 1 & Martinique (S. America sp.) \\
\hline \multicolumn{11}{|l|}{ Crpselide. } \\
\hline $\begin{array}{l}\text { Cypselus } \\
\text { Panyptila }\end{array}$ & $\begin{array}{l}\ldots \\
\ldots\end{array}$ & $\begin{array}{l}\ldots \\
\ldots\end{array}$ & 1 & - & $\overline{1}$ & 1 & - & - & $\begin{array}{l}1 \\
1\end{array}$ & S. American species \\
\hline Hemiprocue & $\ldots$ & $\cdots$ & - & - & 1 & 1 & - & - & 1 & Mexican species \\
\hline Cypseloides & & $\ldots$ & - & - & - & 1 & - & - & 1 & \\
\hline
\end{tabular}




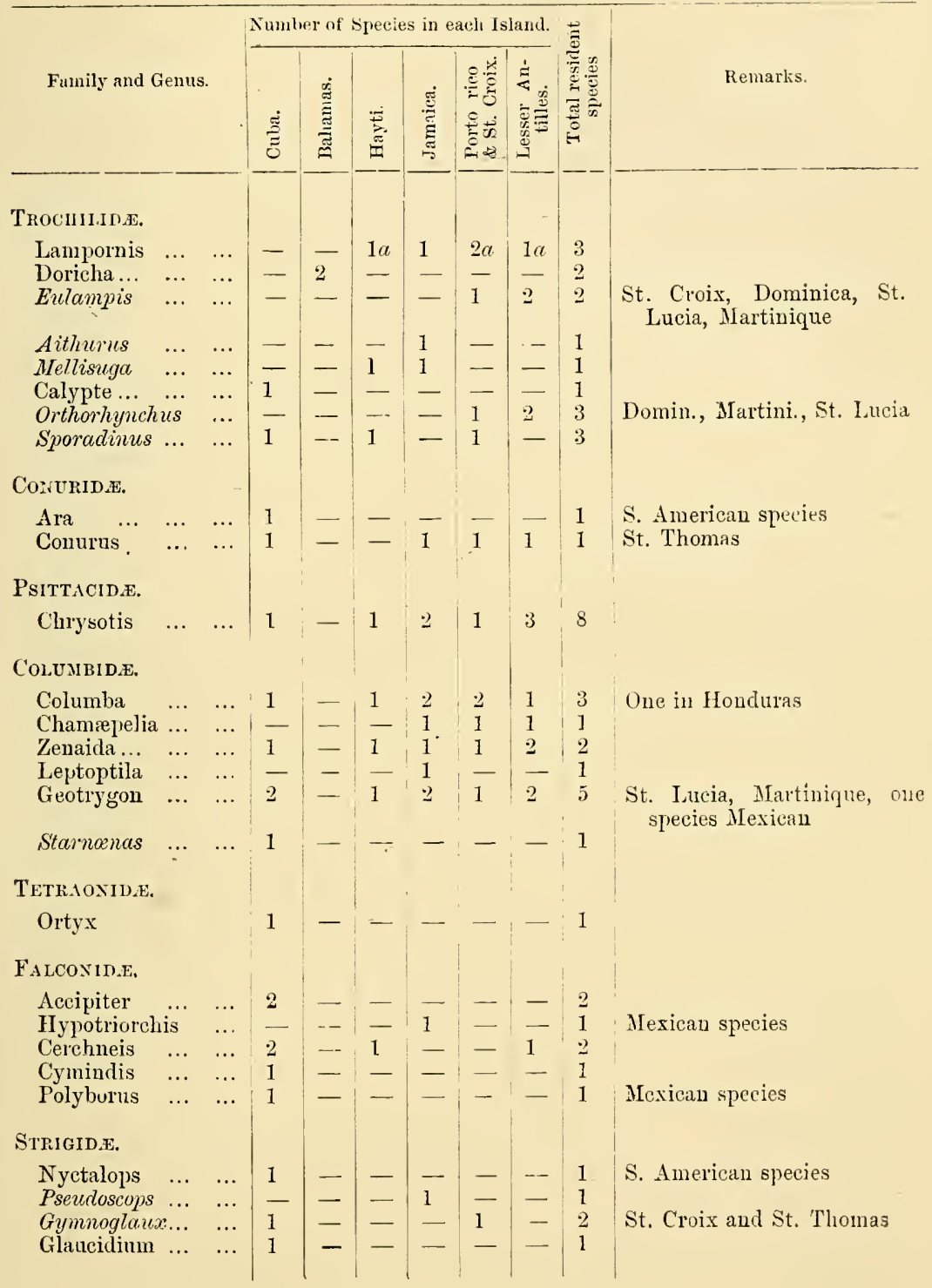

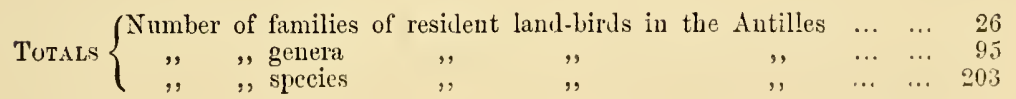


Reptiles and Amphibia.-These classes not having been systematically collected, aud the numerous described genera not having undergone careful revision, little trustworthy information can be derived from them. The following enumeration of the chief groups hitherto noticed or described, will, however, show very similar features to those presenter by the birds-a general relation to Neotropical forms, a more special relation to those of Central America and Mexico, and a considerable number of peculiar types.

Snakes.-Arrhyton (Calamariidæ) from Cuba, Hypsirhynchus from Barbadoes, Cryptodacus from Cuba, Ialtris from Hayti, and Coloragia from Cuba (all Colubridæ), have been described as genera peculiar to the Antilles. Phylodryas and Dromicus (Colubridæ) are Antillean and Neotropical; Ahcetulla (Dendrophidæ) has the same distribution but extends to tropical Africa; Epicratcs and Corallus (Pythonidæ) are Neotropical and Antillean; while Chilabothrus from Jamaica and Ungalia from Cuba and Jamaica (both Pythonidæ) are found elsewhere only in Central America and Mexico. There appear to be no Crotalidæ except an introduced species of Craspedocephalus in St. Lucia.

Lizards are more numerous. Ameiva (Teidæ) is found all over America. Gerrhonotus (Zonuridæ) is Neotropical and'occurs in Cuba; Gymnopthalmus is South American and Antillean. Of Scincidæ seven genera are noted. Cclestus (with 9 species) is peculiar to the Antilles; Camilia (1 species) to Jamaica, Panoplus (1 species) and Embryopus (1 species) to Hayti; Diplogossus is Antillean and South American; while Plestiodon and Mabouya are cosmopolite. Of Geckotidæ there are four genera; Phyllodactylus and Hemidactylus which are cosmopolite; Sphocrodactylus which is wholly American ; and Cubina found only in Martinique and Brazil. Of Iguanidæ there are six genera; Anolis, which ranges all over America; Polychrus, which is Neotropical; Iguana and Liocephalus which are South American; Tropedurus found in Cuba and Brazil; and Cyclura only known from Jamaica, Cuba, and Central America.

Amphitia.-'The genus Trachycephalus, belonging to the 
Hylida or tropical tree-frogs, is almost peculiar to the Antilles; Cuba, Hayti, and Jamaica possessing seven species, while only one is recorded from South America. Other genera are, Peltctphryne (Bufonidæ) from Portorico; Phyllobates (Polypedatidæ) from Cuba ; Leiuperus (Ranidæ) from Hayti,-all Neotropical. Of the Urodela, or tailed batrachians, no representative occurs, although they are so characteristic a feature of the Nearctic region.

Fresh-water fish.-The same general remarks apply to these as to the reptiles. Only one peculiar genus is noted-Lebistes, a form of Cyprinodontidæ from Barbadloes; other genera of the same family being, Haplochilus, Rivulus, and Girardinus, widely spread in the Neotropical region; while Gambusia is confined to Central America, Mexico, and the Antilles. Four other families are represented; Siluridæ by Chotostomus, found in Portorico and South America; Chromidæ by the South American Acara; Mugillidæ by the Central American Agonostoma; and Percidæ by the North American Centrarchus, of which a species is recorded from Cuba.

Insects. - The various West Indian islands have not been well explored entomologically; one reason no doubt being, that their comparative poverty renders them little attractive to the professional collector, while the abounding riches of Central and South America lie so near at hand. We can, therefore, hardly tell whether the comparative poverty, or even total absence of some families while others seem fairly represented, is a real phenomenon of distribution, or only dependent on imperfect knowledge. Bearing this in mind, we proceed to give a sketch of what is known of the chief groups of Lepidoptera and Coleoptera.

Lepidoptera.-The Neotropical butterfly-fauna is but poorly represented, the majority of the most remarkable types being entirely wanting; yet there are a few peculiar and very characteristic forms which show great isolation, while the majority of the species are peculiar. Four genera are exclusively or characteristically Antillean,-Calisto belonging to the Satyridæ, with four species, of which one ranges to Sonth Carolina; Clothilda 
(Nymphalidæe) a fine genus which has 4 Antillean species and 2 in Central America; Lucinia (Nymphalidæ) 2 species, confined to Jamaica and Hayti ; and Kricogonia belonging to the Pieridæ, which has 2 West Indian species, while 1 inhabits Mexico and Florida. Genera which show a special relation to Central America are Euptoictu, Eumous, and Nathalis. Almost all the other genera are South American, the total number recorded in each family as occurring in the West Indian islands, being, 3 of Danaidæ; 1 of Heliconiidæ; 2 of Satyridæ ; 18 of Nymphalidæ ; 1 of Erycinidæ; 4 of Lycænidæ; 6 of Pieridæ; 1 of Papilionidæ, and 10 of Hesperidæ. The genus Papilio is represented by about 20 species, 2 of which are North American, 4 South American, while the rest form little characteristic groups allied to those of Central America. The most marked feature seems to be the scarcity of Satyridæ and the almost total absence of Erycinidæ, with a great deficiency in characteristic Neotropical forms of Danaidæ and Nymphalidæ.

Colcoptera.-Cicindelidæ and Carabidæ are very poorly represented, by a few species of wide-spread groups, and hardly any peculiar genera. No Lucanidæ are recorded. Of Cetoniidæ, Gymnetis only appears to be represented. Buprestidæ seem to be more numerous; 15 genera being recorded, but almost all of wide distribution. One only is peculiar-Tetragonoschoma, found in Hayti ; Halecia is the only exclusively South American genus; Chalcophora is widely scattered over the tropical regions but is absent from South America, yet it occurs in the Nearctic region and extends to Jamaica and Guadeloupe. We now come to the Longicorns, the only group of Coleoptera which seems to be well represented, or which has been carefully collected. No less than 40 genera are known from the West Indian islands, and 15 of these are peculiar. Prionidæ are proportionately very numerous, there being 10 genera, 2 of which are widely distributed in both South and North America, 1 is North American, and 1 South American, while the following are peculiar,Stenodontes (Hayti and Cuba); Dendroblaptus (Cuba); Monodesmus (Cuba and Jamaica); Prosternodes (Cuba); Solenoptera and Elatcropsis, the two largest genera found in most of the 
islands. Of Cerambycidxe there are 16 genera, 2 of which range all over America, 4 are Neotropical, 1 South American only, while the following are confined to the islands,-Mcrostenus, Pentomacrus, and Eburiola (Jamaica); Bromiades (Cuba); Trichrous, Heterops, and Pociloderma (Antilles). One genus, Smodicum, is widely spread, having a species in Carolina, 1 in South America, 1 in Hayti, and 1 in West Africa. Of Lamiidæ there are 14 genera, 8 of which are Neotropical, 1 common to Central America and Mexico, 1 to the United States and Cuba, while 2, Proech $\alpha$ and Phidola, are confined to Cuba. Several of the genera are curiously distributed;-Spalacopsis is South American, with 4 species in Cuba and Tropical Africa; Lagocheirus is Neotropical, with a species in Australia; while Leptostilus is characteristic of the Antilles and North America, with a few species in South America, and one in New Zealand. These cases of erratic distribution, so opposed to the general series of phenomena among which they occur, must be held to be sufficiently explained by the great antiquity of these groups and their former wide distribution. They may be supposed to be the remnants of types, now dying out, which were once, like Callichroma, Clytus, and many others, almost universally distributed.

All the peculiar Antillean genera of Cerambycidæ and Lamiidæ are allied to Neotropical forms. The peculiar Prionidæ, however, are mostly allied to Mexican and North American groups, and one, Monodesmus, belongs to a group all the other genera of which inhabit the East Indies and South Africa.

Land-shells. - This subject has already been generally treated under the Region, of which, in this class of animals, the Antilles form so important a part. We must therefore now confine ourselves mainly to the internal distribution of the genera, and to a few remarks on the general bearing of the facts.

The excessive and altogether unexampled productiveness of the West Indian islands in land-shells, may be traced to two main sets of causes. The first and least known, consist of the peculiar influences and conditions which render islands always more productive than continents. Whatever these conditions 
are, they will be more effective where the islands have been long separated from the mainland, as is here undoubtedly the case. It seems most probable that the great development of landshells in islands, is due to the absence or deficiency of the vertebrata, which on continents supply a variety of species adapted to prey upon these molluscs. This view is supported by the fact, that in such islands as have been united to a continent at no very distant epoch, and still maintain a continental variety of vertebrata, no such special development of land-shells has taken place. If we compare the Philippine islands with the Sunda group, we find the development of vertebrata and land-molluscs in inverse ratio to each other. The same thing occurs if we compare New Zealand and Tasmania; and we have a still more striking example in the Antillean group itself, continental Trinidad having only 20 genera and 38 species, while the highly insular Jamaica has about 30 genera and more than 500 species.

The other causes favourable to the increase and development of land-shells are of a physical nature. A great extent of limestone-rock is one; and in the larger West Indian islands we have a considerable proportion of the surface consisting of this rock. But perhaps equally or more important, is the character of the land surface, and the texture of the exposed rock itself. A much broken surface, with numerous deep ravines, cutting up the whole country into isolated valleys and ridges, seems very favourable to the specialization of forms in this very sedentary class of animals. Equally favourable is a honeycombed and highly-fissured rock-surface, affording everywhere cracks and crannies for concealment. Now, taking Jamaica as an example of the archipelago, we find all these conditions in a wonderful degree. Over a large part of this island, a yard of level ground can hardly be found; but ridges, precipices, ravines, and rockbound valleys, succeed each other over the whole country. At least five-sixths of the entire surface is limestone, and under the influence of tropical rains this rock is worn, fissured, and honeycombed, so as to afford ample shelter and concealment for landshells. 
It is probable that the three chief islands, Cuba, Jamaica and Hayti, are nearly equally rich in land-shells; but the last is very much less known, and therefore, perhaps, appears to be much poorer. Cuba has rather more species than Jamaica; but while the former has only 1 peculiar genus (Diplopoma), the latter has 3 (Geomelania, Chittya, and Jamaicea), as well as two others only represented in the other jslands by single species. From Hayti, only about one-third as many species are known as from the two former islands. It has no peculiar genera, but it has some forms in common with Cuba and others with Jamaica, which show that those islands have more connection with it, than with each other; just as we found to be the case in birds. Portorico and the Virgin islands have still fewer species than Hayti; and, as many of the genera common to the other three islands are wanting, there is, no doubt, here a real deficiency. In the islands farther south (Barbuda to Martinique) more Antillean genera disappear or become very rare, while some continental forms take their place. The islands from St. Lucia to Trinidad have a still more continental character; the genus Bulimus, so largely developed on the continent, only reaching St. Lucia. The Bahamas contain about 80 species of land-shells, of which 25 are Antillean, the rest peculiar; all the genera being Antillean. The affinity is chiefly with Hayti and Cuba, but closest with the latter island.

In the West Indian islands as a whole, there are 11 peculiar genera; 9 operculate (Geomelania, Chittya, Jamaicea, Licina, Choanopoma, Ctenopoma, Diplopoma, Stoastoma, Lucidclla); and 2 inoperculate (Sagda and Stenopus), besides Cyclostomus, which belongs to the old World and is not found on the American continent. Mr. Bland considers, that many of the Antillean land-shells exhibit decided African and Asiatic, rather than South American affinities. A species of the Asiatic genus Diplommatince has been found in Trinidad, and an Indian species of Ennca occurs in Grenada and St. Thomas; a clear indication that land-shells are liable to be accidentally imported, and to become established in the less productive islands.

Although these islands are so wonderfully rich even now, 
there is good reason to believe that many species have become extinct since the European occupation of them. When small islands are much cultivated, many of these molluses which can only live under the shade of forests, are soon extirpated. In St. Croix many species have become extinct at a comparatively recent period, from the burning of forests; and as we know that in all the islands many of the species are excessively local, being often confined to single valleys or ridges, we may be sure that wherever the native forests have disappeared before the hand of man, numbers of land shells have disappeared with them. As some of the smaller islands have been almost denuded of their wood, and in the larger ones extensive tracts have been cleared for sugar cultivation, a very considerable number of species have almost certainly been exterminated.

General Conclusions as to the Past History of the West Indian Islands.-The preceding sketch of the peculiarities of the animal life of these islands, enables us to state, that it represents the remains of an ancient fauna of decided Neotropical type, having on the whole most resemblance to that which now inhabits the Mexican sub-region. The number of peculiar genera in all classes of animals is so great in proportion to those in common with the adjacent mainland, as to lead us to conclude that, subsequent to the original separation from the Mexican area, a very large tract of land existed, calculated to support a rich and varied fauna, and, by the interaction of competing types, give rise to peculiar and specially modified organisms. We have already shown that the ontline of the present islands and the depths of the surrounding seas, give indications of the position and extent of this ancient land; which not improbably occupied the space enclused by uniting Western Cuba with Yucatan, and Jamaica with the Mosquito Coast. This land must have stretched eastward to include Anguilla, and probably northward to include the whole of the Bahamas. At one time it perhaps extended southward so as to unite Hayti with northern Venezuela, while Panama and Costa Rica were sunk beneath the Pacific. At this time the Lesser Antilles had no existence.

The only large island of whose geology we have any detailed 
account, is Jamaica; and taking this as a type of what will probably be found in Cuba, and Hayti, we must place the continental period as having occurred after the close of the Miocene, or during some part of the Pliocene epoch, since a large portion of the surface of the former island consists of beds of marine limestone from 2,000 to 3,000 thick, believed to be of Pliocene age. After some time, the land between Hayti and South America subsided, and still later that between Central America and Cuba with Jamaica; but a large tract of land remained insulated, and no doubt supported a very much richer and more varied fauna than now. We have evidence of this in extinct Mammalia of large size, belonging to the peculiar South American family of the chinchillas, which have been found in caves in the small islands of Anguilla, and which, from the character of the land-shells associated with them, are believed to be of Pliocene or Post-pliocene age. This discovery is most interesting, and gives promise of very valuable results from the exploration of the numerous caverns that undoubtedly exist in the abundant limestone strata of the larger islands. This extensive Antillean land, after long continuing undivided, was at length broken up by subsidence into several islands; but as this alone would not account for the almost complete annihilation of the mammalian fauna, it seems probable that the subsidence was continued much farther, so as greatly to reduce the size and increase the number of the islands. This is indicated, by the extensive alluvial plains in Cuba and Hayti, and to a less extent in Jamaica; and by elevated berds of Post-pliocene marls in the latter island.

The series of changes now suggested, will account for all the main features of the Antillean fauna in its relations to that of the American continent. There remains the affinity with Madagascar, indicated by Solenodon, and a few cases of African and Asiatic affinity in insects and land-shells; but these are far too scanty to call for any attempt at special explanation. Sucl cases of remote affinity and discontinuous distribution, occur in all the regions, and in almost every group of animals; and we look upon them almost all, as cases of survival, under favourable 
conditions, of once wide-spread groups. If no wild species of the genus Equus were now to be found, except in South Africa (where they are still most abundant), and in South Temperate America, where their fossil remains show us they did exist not very long ago, what a strong fact it would have appeared for the advocates of continental extensions! Yet it would have been due to no former union of the great southern continents, but to the former extensive range of the family or the genus to which the two isolated remnants belonged. And if such an explanation will apply to the higher vertebrata, it is still more likely to be applicable to similar cases occurring among insects or mollusca, the genera of which we have every reason to believe to be usually much older than those of vertebrates. It is in these classes that examples of widely scattered allied species most frequently occur; and the facility with which they are diffused under favourable conditions, renders any other explanation than that here given altogether superfluous.

The Solenodon is a member of an order of Mammalia of low type (Insectivora) once very extensive and wide-spread, but which has begun to die out, and which has left a number of curious and isolated forms thinly scattered over three-fourths of the globe. The occurrence, therefore, of an isolated remnant of this order in the Antilles is not in itself remarkable; and the fact that the remainder of the family to which the Antillean species belong has found a refuge in Madagascar, where it has developed into several distinct types, does not afford the least shred of argument on which to found a supposed independent land connection between these two sets of islands.

\section{Summary of the Past History of the Neotropical Region.}

We have already discussed this subject, both in our account of extinct animals, and in various parts of the present chapter. It is therefore only necessary here, briefly to review and summarise the conclusions we have arrived at.

The whole character of Neotropical zoology, whether as regards its deficiencies or its specialities, points to a long continuance of isolation from the rest of the world, with a few very distant. 
periods of union with the northern continent. The latest important separation took place by the submergence of parts of Nicaragua and Honduras, and this separation probably continued thronghout much of the Mincene and Pliocene periods; but some time previous to the coming on of the glacial epoch, the union between the two continents took place which has continued to our day. Earlier submergences of the isthmus of Panama probably occurred, isolating Costa Rica and Veragua, which then may have had a greater extension, and have thus been able to develope their rich and peculiar fauna.

The isthmus of Tehuantepec, at the south of Mexico, may, probably, also have been submerged; thus isolating Guatemala and Yucatan, and leading to the specialization of some of the peculiar forms that now characterise those countries and Mexico.

The West Indian Islands have been long isolated and have varied much in extent. Originally, they probably formed part of Central America, and may have been united with Yucatan and Honduras in one extensive tropical land. But their separation from the continent took place at a remote period, and they have since been broken up into numerous islands, which have probably undergone much submergence in recent times. This has led to that poverty of the higher forms of life, combined with the remarkable speciality, which now characterises them; while their fauna still preserves a sufficient resemblance to that of Central America to indicate its origin.

The great continent of South America, as far as we can jndge from the remarkable characteristics of its fauna and the vast depths of the oceans east and west of it, has not during Tertiary, and probably not even during Secondary times, been united with any other continent, except through the intervention of North America. During some part of the Secondary epoch it probably received the ancestral forms of its Edentates and Rodents, at a time when these were among the highest types of Mammalia on the globe. It appears to have remained long isolated, and to have already greatly developed these gronps of animals, before it received, in early Tertiary times, the ancestors of its marmosets and monkeys, and, perhaps also, some of its peculiar forms of

VOL. II. 
Carnivora. Later, it received its Camelidæ, peccaries, mastodons, and large Carnivora; and later still, just before the Glacial epoch, its deer, tapir, opossums, antelopes, and horses, the two latter having since become extinct. All this time its surface was undergoing important physical changes. What its earlier condition was we cannot conjecture, but there are clear indications that it has been broken up into at least three large masses, and probably a number of smaller ones; and these have no. doubt undergone successive elevations and subsidences, so as at one time to reduce their area and separate them still more widely from each other, and at another period to unite them into continental masses. The richness and varied development of the old fauna of South America, as still existing, proves, however, that the country has always maintained an extensive area; and there is reason to believe that the last great change has been a long continued and steady increase of its surface, resulting in the formation of the vast alluvial plains of the Amazon, Orinoko, and La Plata, and thus greatly favouring the production of that wealth of specific forms, which distinguishes South America above all other parts of our globe.

The southern temperate portion of the continent, has probably had a considerable southward extension in late Tertiary times; and this, as well as the comparatively recent elevation of the Andes, has given rise to some degree of intermixture of two distinct faunas, with that proper to Sonth Temperate America itself. The most important of these, is the considerable Australian element that appears in the insects, and even in the reptiles and fresh-water fishes, of South Temperate America. These may be traced to several causes. Icebergs and icefloes, and even solid fields of ice, may, during the Glacial epoch, have afforded many opportunities for the passage of the more cold-enduring groups; while the greater extension of southern lands and islands during the warm periods-which there is reason to believe prevailed in the southern as well as in the northern regions in Miocene times - would afford facilities for the passage of the reptiles and insects of more temperate zones. That no actual land-connection occurred, is proved by the total absence 
of interchange of the mammals or land-birds of the two countries, no less than by the very fragmentary nature of the resemblances that do exist. The northern element consists almost wholly of insects ; and is evidently due to the migration of arctic and north temperate forms along the ridges and plateaus of the Andes; and most likely occurred when these organisms were driven southward at successive cold or Glacial periods.

A curious parallel exists between the past history and actual zoological condition of South America and Africa. In both we see a very ancient land-area extending into the South Temperate zone, isolated at a very early period, and developing only a low grade of Mammalian life; chiefly Edentates and Rodents on the one, Lemurs and Insectivora in the other. Later we find an irruption into both of higher forms, including Qnadrumana, which soon acquired a large and special development in the tropical portions of each country. Still later we have an irruption into both of northern forms, which spread widely over the two regions, and having become extinct in the land from whence they came, have been long held to be the original denizens of their adopted country. Such are the various forms of antelopes, the giraffe, the elephant, rhinoceros, and lion in Africa; while in America we have deer and peccaries, the tapir, opossums, and the puma.

On the whole, we cannot lut consider that the broad outlines of the zoological history of the Neotropical region can be traced with some degree of certainty; but, owing to the absence of information as to the most important of the geological periods - the Miocene and Eocene-we have no clue to the character of its early fauna, or to the land comnections with other countries, which may possibly have occurred in early Tertiary times. 


\section{TABLES OF DISTRIBUTION.}

In drawing up these tables, showing the distribution of the various classes of animals in the Neotropical region, the following sources of information have been relied on, in addition to the general treatises, monographs, and catalogues used in the compilation of the Fourth Part of this work.

Mammalia.-D'Orbigny, and Burmeister, for Brazil and La Plata; Darwin, and Cunningham, for Temperate S. America; Tschudi, for Peru ; Frazer, for Ecuador; Salvin, for Guatemala ; Frantzius, for Costa Rica; Sclater, for Quadrumana N. of Panama; Gundlach, for Cuba; and papers by Dr. J. E. Gray, and Mr. Tomes.

Birds.-Sclater and Salvin's Nomenclator; Notes by Darwin, and Cunningham; Gundlach, March, Bryant, Baird, Elliot, Newton, Semper, and Sundevall, for various islands of the Antilles; and papers by Hudson, Lawrence, Grayson, Abbott, Sclater, and Salvin. 


\section{TABLE I.}

\section{FAMILIES OF ANIMALS INHABITING THE NEOTROPICAL REGION.}

\section{Explanation.}

Names in italics show the families which are peculiar to the region.

Names enclosed thus (......) indicate families which barely enter the region, and are not considered properly to belong to it.

Numbers correspond with those of the series of families in Part IV.

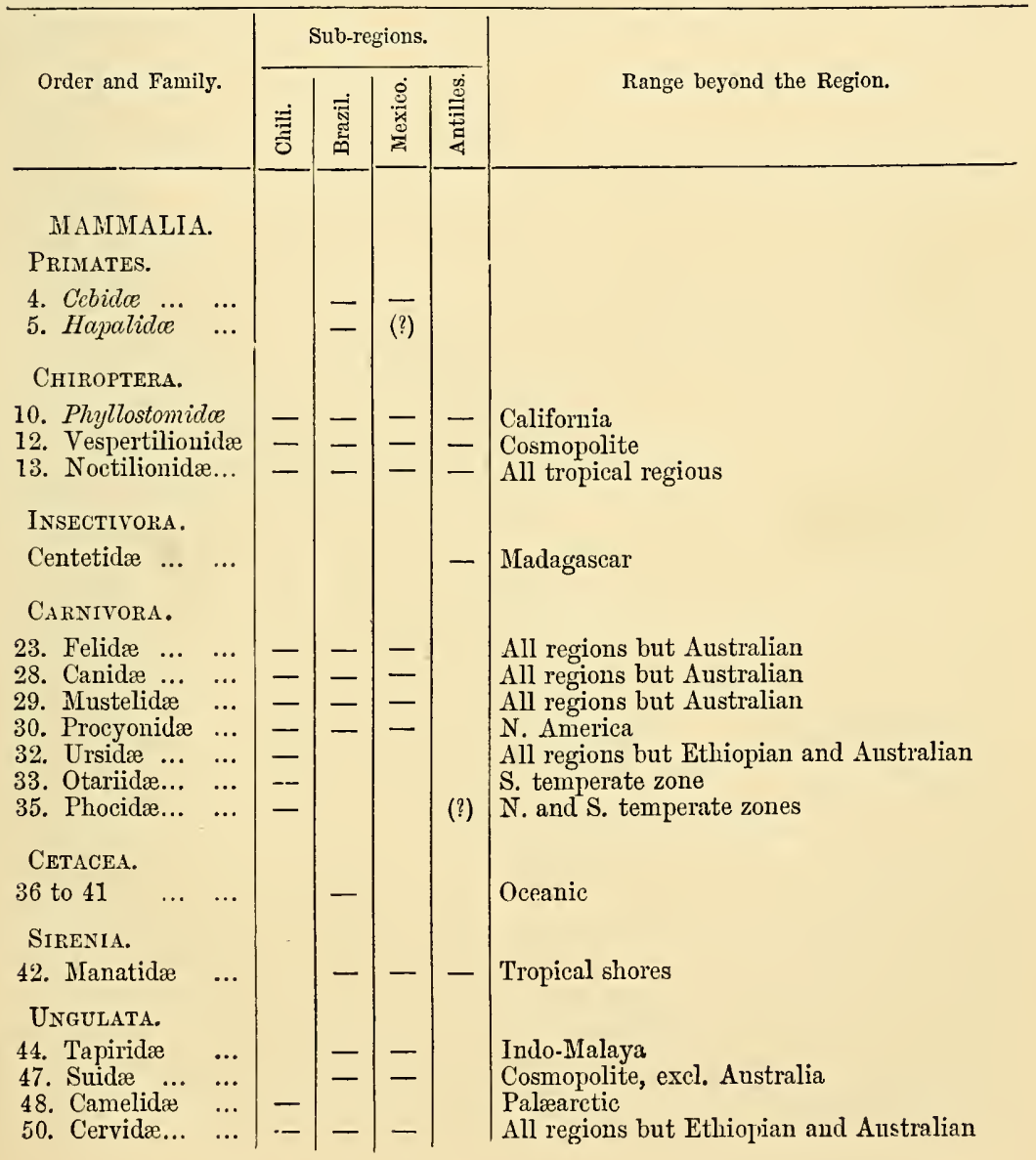




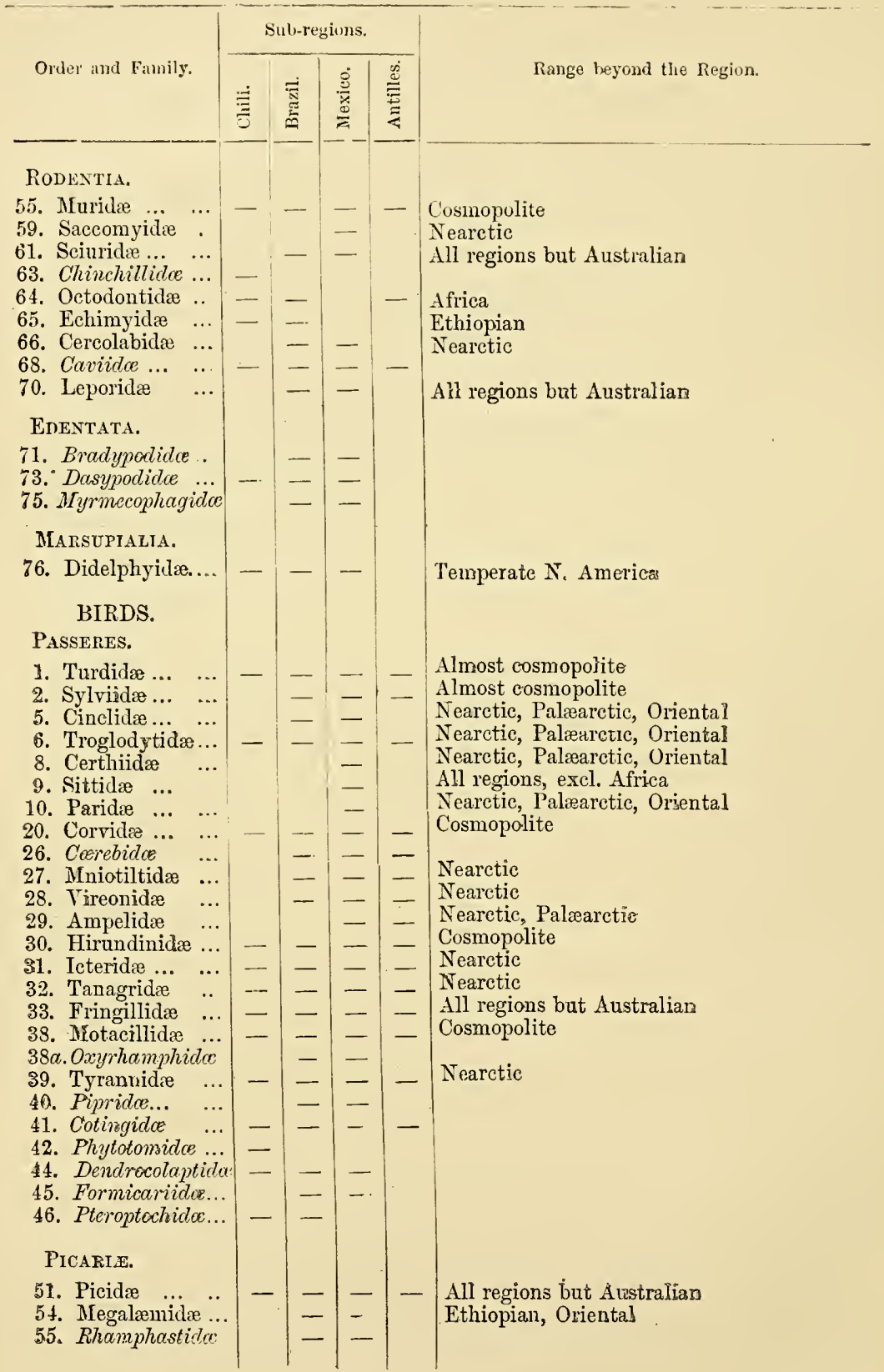




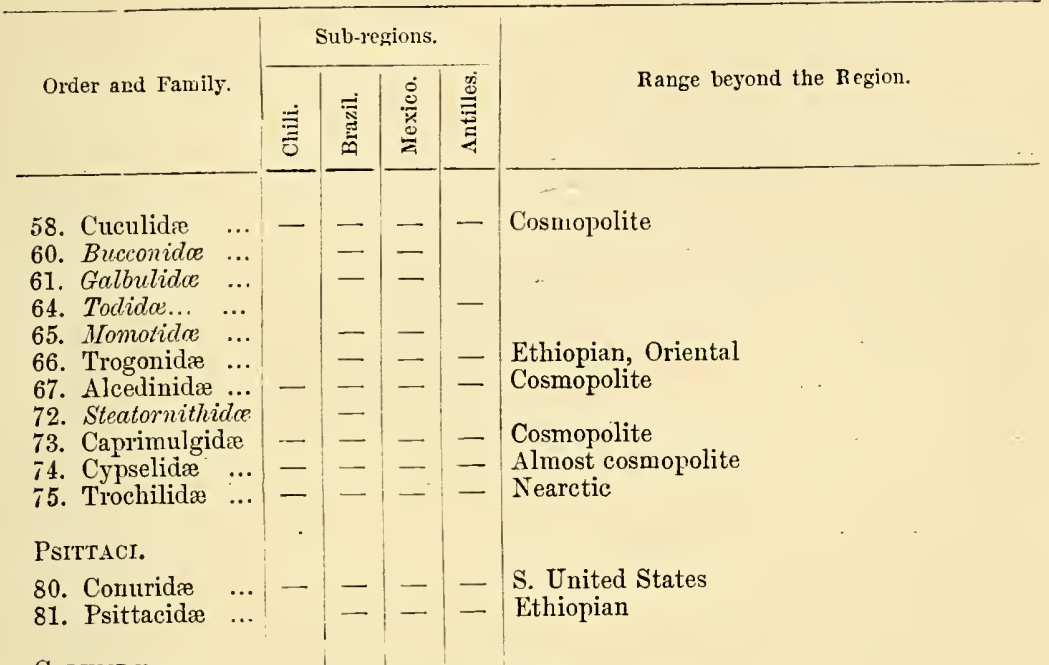

Colimax.

84. Columbidæ .. $-\rightarrow-6-$ Cosmopolite

Gallinæe.

87. Tetraonidæ .

88. Phasianidæ

91. Cracidae

92. Tinamidae $\ldots-. .-1-$

OPISTHOCOMI.

93. Opisthocomidce

Accipitres.
94. Vulturidæ ..

96. Falconidæ ... - - - - Cosmopolite

97. Pandionidæ ... $\quad-\quad-\quad$ Cosmopolite

98. Strigidæ... ... $-\longrightarrow--$ Cosmopolite

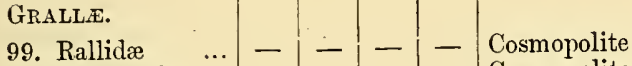

99. Rallidæ
100. Scolopacidæ...
101. Chionididce

102. Thinocorides... -

102. Thinocorida ...

108. Cariamida ... -

110. Psophiidas ...

111. Eurypygida ...

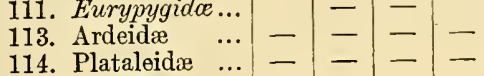

- Almost cosmopolite

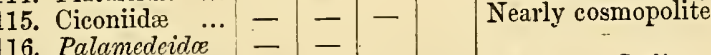

117. Phœnicopteridæ - $|-|-\mid$ Ethiopian, Indian 


\begin{tabular}{|c|c|c|c|c|c|}
\hline \multirow[b]{2}{*}{ Order and Family. } & \multicolumn{4}{|c|}{ Sub-rergions. } & \multirow[b]{2}{*}{ Range beyond the Region. } \\
\hline & $\dot{\Xi}$ & 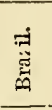 & 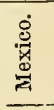 & 兽 & \\
\hline \multicolumn{6}{|l|}{ Axseres. } \\
\hline 118. Anatide .. & 一 & 一 & - & - & Cosmopolite \\
\hline 119. Laridæ ... ... & - & - & - & - & Cosmopolite \\
\hline 120. Procellariidæ & - & - & - & - & Cosmopolite \\
\hline 121. Pelecanidæe ... & - & - & - & - & Cosmopolite \\
\hline 122. Spheniscidæ... & - & & & & S. temperate zone \\
\hline 124. Porlicipidie ... & - & - & - & - & Cosmopolite \\
\hline \multicolumn{6}{|l|}{ STRUTHIONEE. } \\
\hline 126. Struthionidx & - & & & & Ethiopian \\
\hline \multirow{2}{*}{\multicolumn{6}{|c|}{$\begin{array}{l}\text { REPTILIA. } \\
\text { OPHIDLA. }\end{array}$}} \\
\hline & & & & & \\
\hline $\begin{array}{l}\text { 1. Typhlopidæ ... } \\
\text { 2. Tortricidæ..... }\end{array}$ & & - & - & - & $\begin{array}{l}\text { Tropical regions and S. Palæarctic } \\
\text { Orientai, N.-W. America }\end{array}$ \\
\hline 5. Calamariidæ... & 一 & - & - & - & All warm countries \\
\hline 6. Oligodontida & & - & & & Oriental, Japan \\
\hline 7. Colubridæ ... & - & - & - & - & Almost cosmopolite \\
\hline 8. Homalopsidæ & - & & & - & All the regions \\
\hline 11. Dendrophidæ & - & - & - & - & All tropical regions \\
\hline 12. Dryiophidæ .. & & - & - & & Oriental, Ethiopian \\
\hline 13. Dipsadidæ $\quad .$. & & - & 一 & & All tropical regions \\
\hline 14. Scytalidæ ... & & - & 一 & & Philippine Islands \\
\hline 16.Amblycephalid: & & - & - & & Oriental \\
\hline 17. Pythonidx $\ldots$ & - & - & - & - & All tropical regions, California \\
\hline 20. Ělapidæ $\quad \cdots$ & - & - & - & & $\begin{array}{l}\text { Tropical regions, Japan, S. Carolina } \\
\text { Oriental, Anstralian, Madagascar }\end{array}$ \\
\hline 23. Hydrophidæ... & & & - & & $\begin{array}{l}\text { Oriental, Australian, Madagascar } \\
\text { Nearctic, Palæarctic, Oriental }\end{array}$ \\
\hline 24. Crotalidæ $\ldots$ & - & - & - & - & Nearctic, Palæarctic, Oriental \\
\hline \multicolumn{6}{|l|}{ LACERTILIA. } \\
\hline 27. Chirotidæ ... & & & - & & Missouri \\
\hline $\begin{array}{l}\text { 23. Amphisbænid:e } \\
\text { 29. Lepidosternidæ }\end{array}$ & - & - & & 一 & $\begin{array}{l}\text { Ethiopian, S. Palæarctic } \\
\text { Ethiopian }\end{array}$ \\
\hline $\begin{array}{l}\text { 29. Lepidosternidæ } \\
\text { 31. Hclodermidce }\end{array}$ & - & - & - & & Ethiopian \\
\hline 32. Teidæ $\ldots$... & - & - & - & - & Nearetic \\
\hline 34. Zonuridæ $\quad \ldots$ & & - & 一 & - & Nearctic, Ethiopian, S. Europe, and N. India \\
\hline 35. Chalcidee $\ldots$ & - & - & - & & Nearctic \\
\hline 36. Anadiadee ... & & - & & & \\
\hline 37. Chirocolida ... & & - & & & \\
\hline 38. Iphisadee ... & & 二 & & & \\
\hline 41. Gymnopthal- & & - & & - & Australian, Ethiopian, Palæarctic \\
\hline 45. Scincidæ $\quad \cdots$ & - & - & - & - & Almost cosmopolite \\
\hline 49. Geckotidæ & - & - & - & - & Almost cosmopolite \\
\hline 50. Iguanidæ $\quad \ldots$ & 一 & - & - & - & Nearctic \\
\hline Croconilia. & & & & & \\
\hline $\begin{array}{l}\text { 55. Crocodilidæ ... } \\
\text { 56. Alligatoridæ... }\end{array}$ & & - & - & - & $\begin{array}{l}\text { Ethiopian, Oriental, N. Australian } \\
\text { Nearctic }\end{array}$ \\
\hline
\end{tabular}




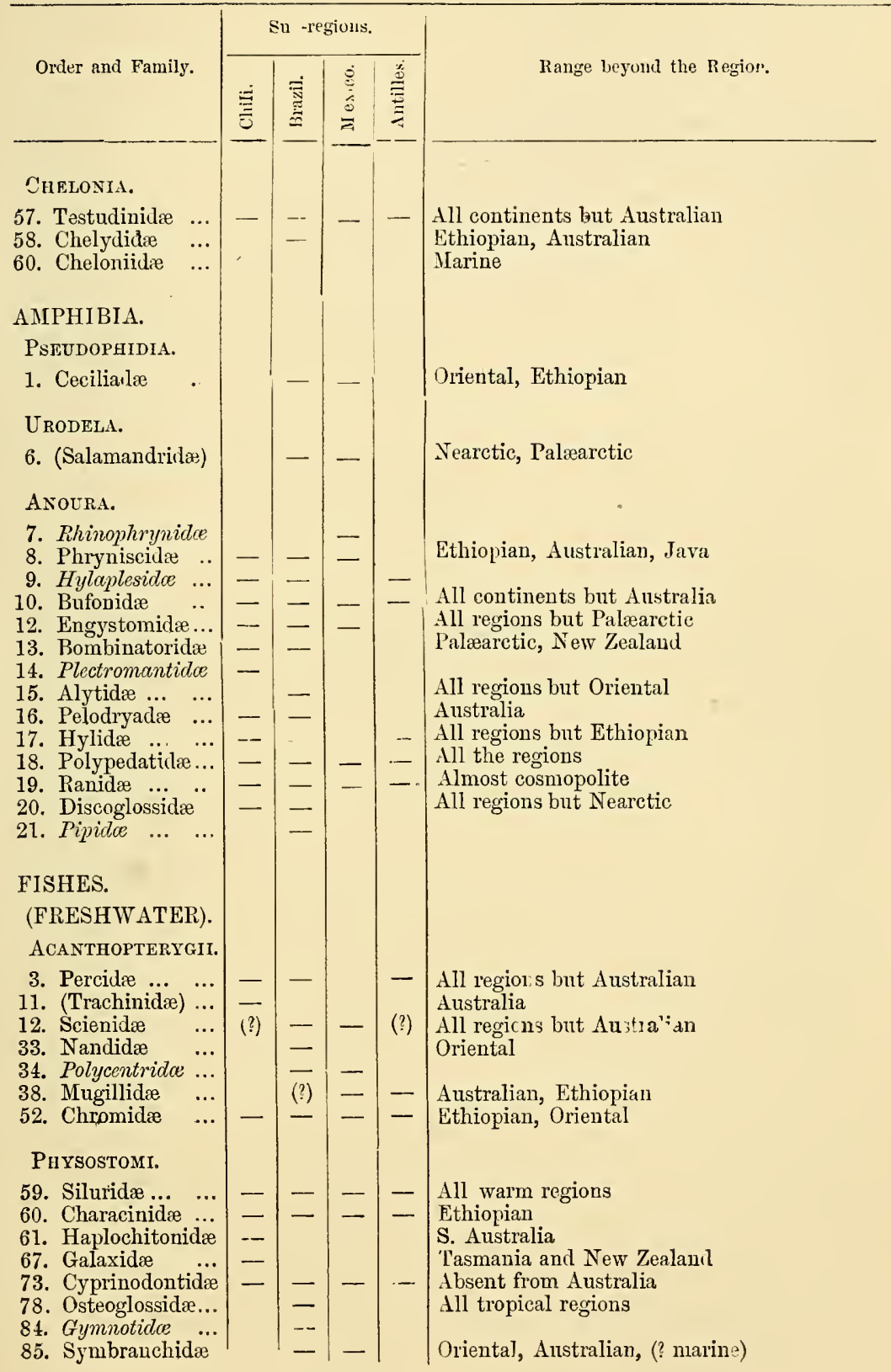




\begin{tabular}{ll|l|l|l|l} 
& \\
Order and Family. & & & \\
\end{tabular}


TABLE 11 .

\section{GENERA OF TERRESTRIAL MAMILALA AND BIRDS INHABITING THE NEOTROPICAL REGION.}

\section{Explanation.}

Names in italics show the genera peculiar to the region.

Names enclosed thus (......) indicate genera which barely enter the region, and are not considered properly to belong to it.

Genera undoubtedly belonging to the region are numbered consecutively.

IIA.MIILIA.

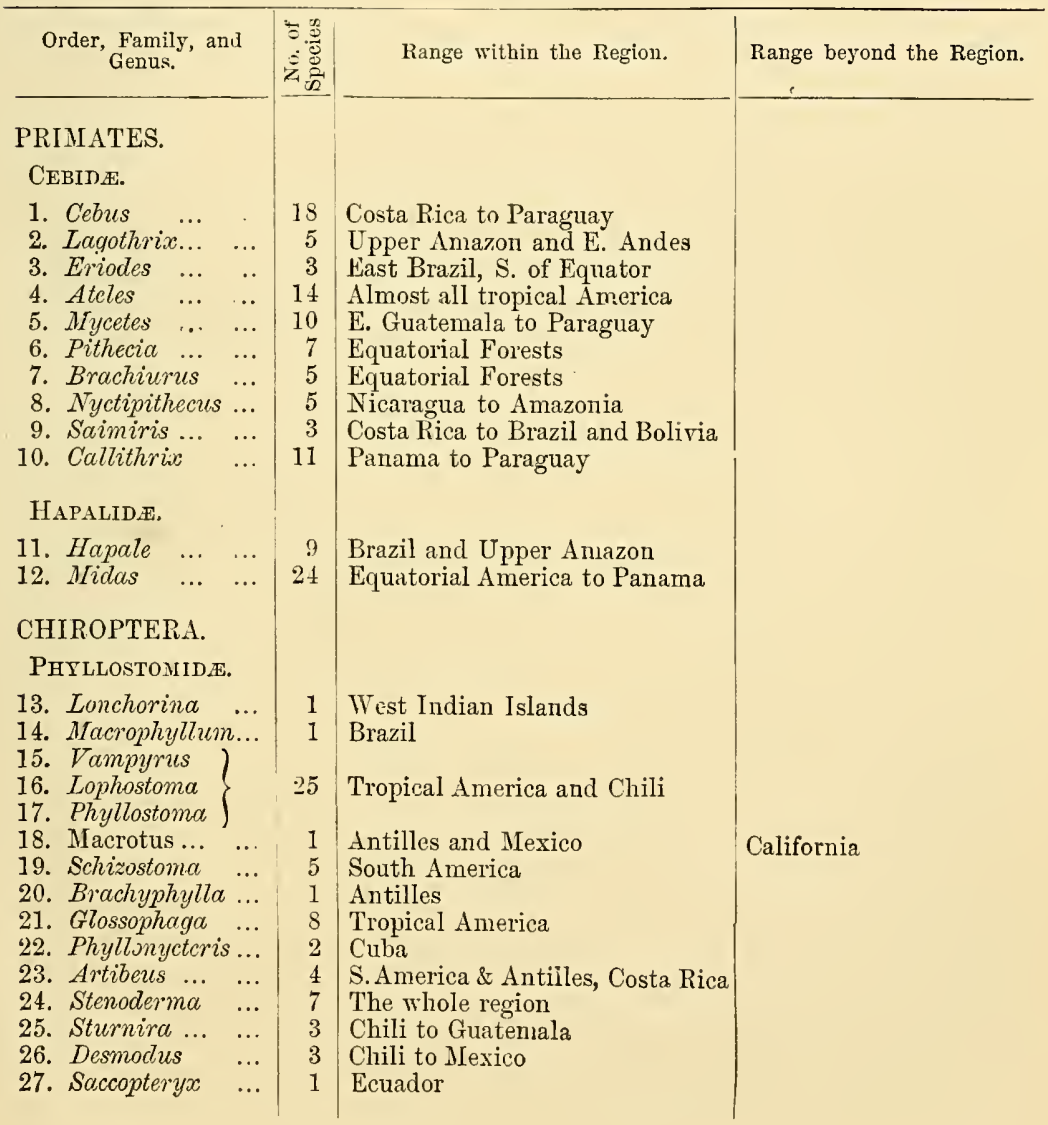




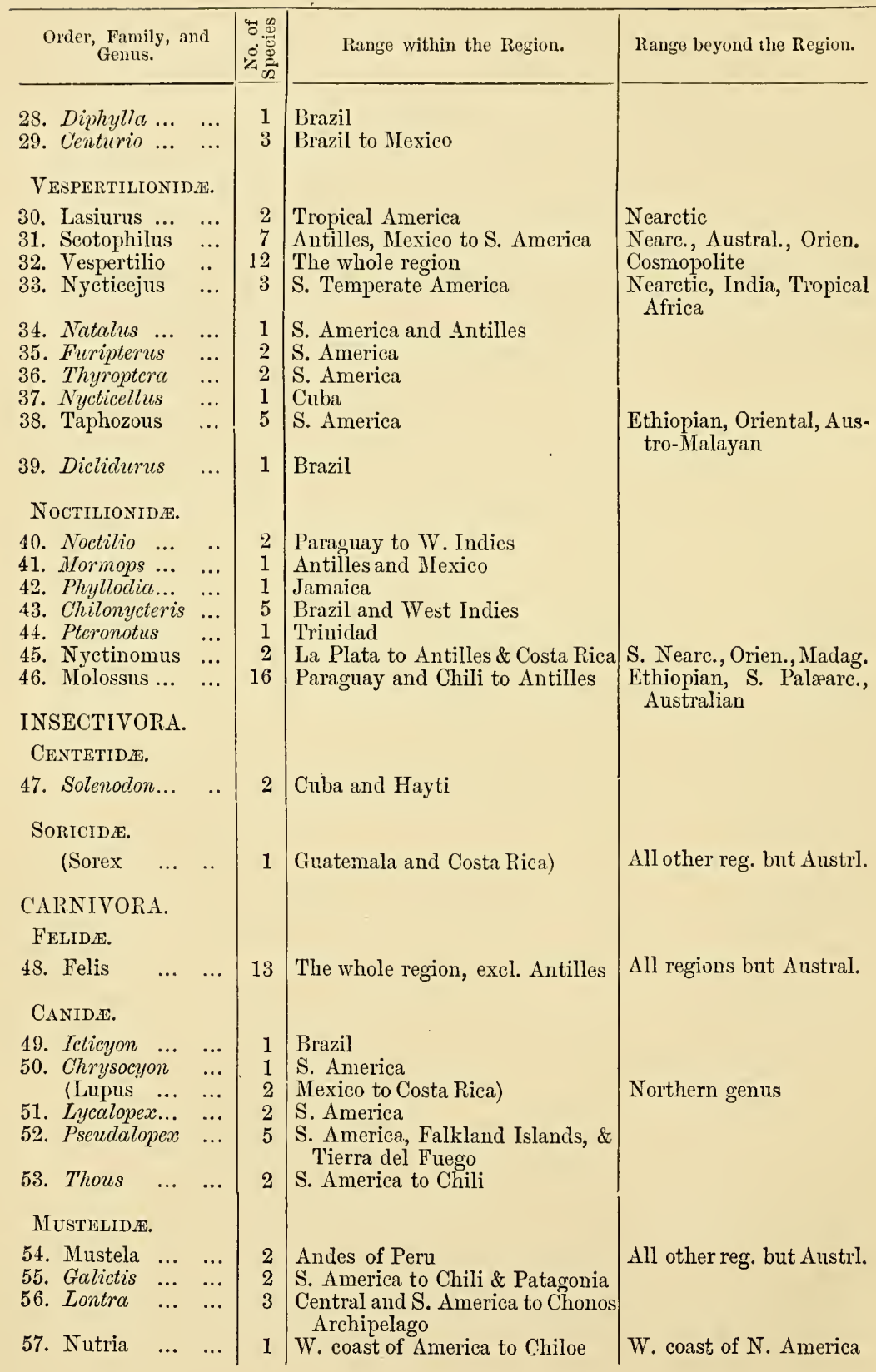




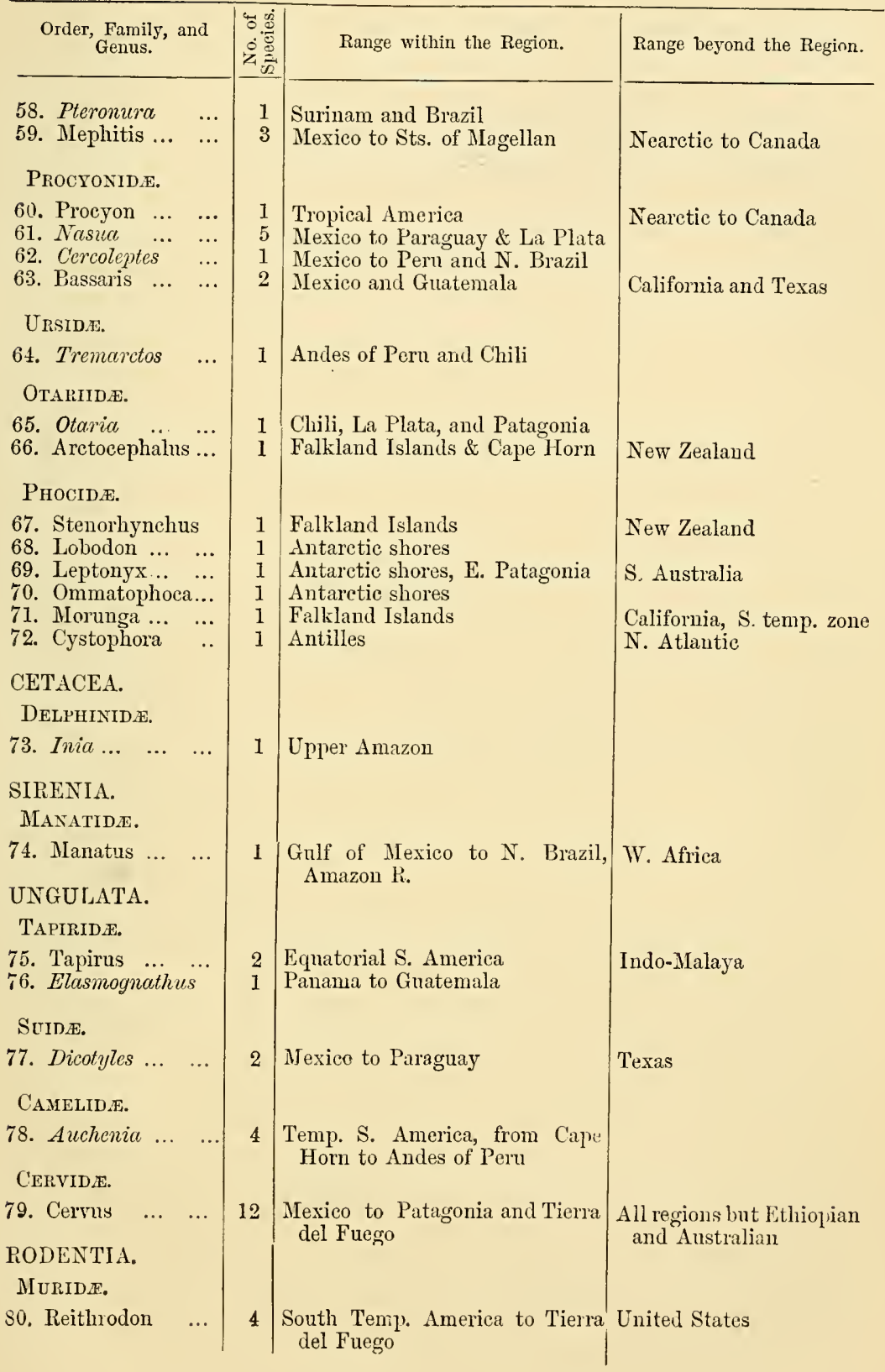




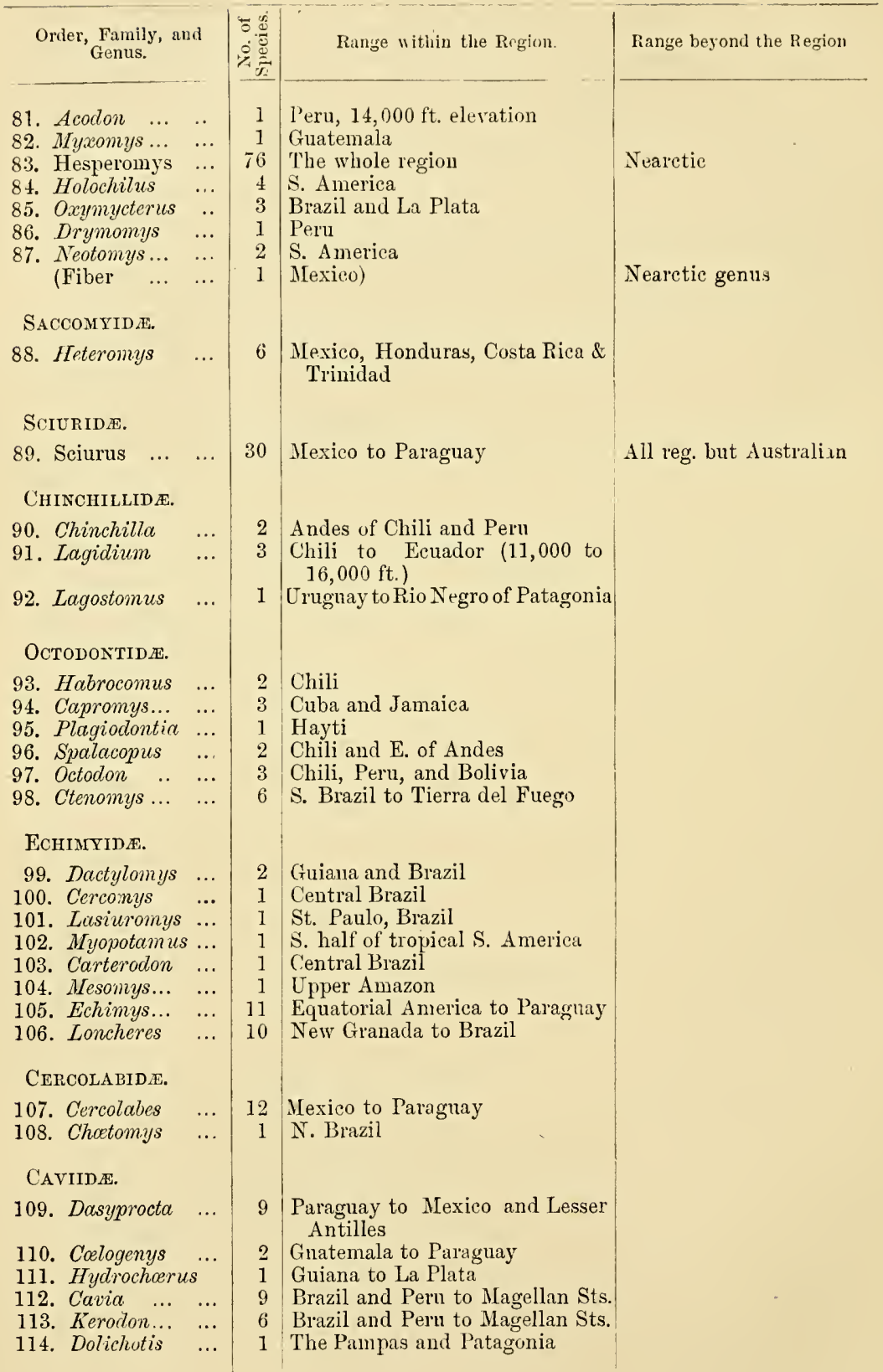




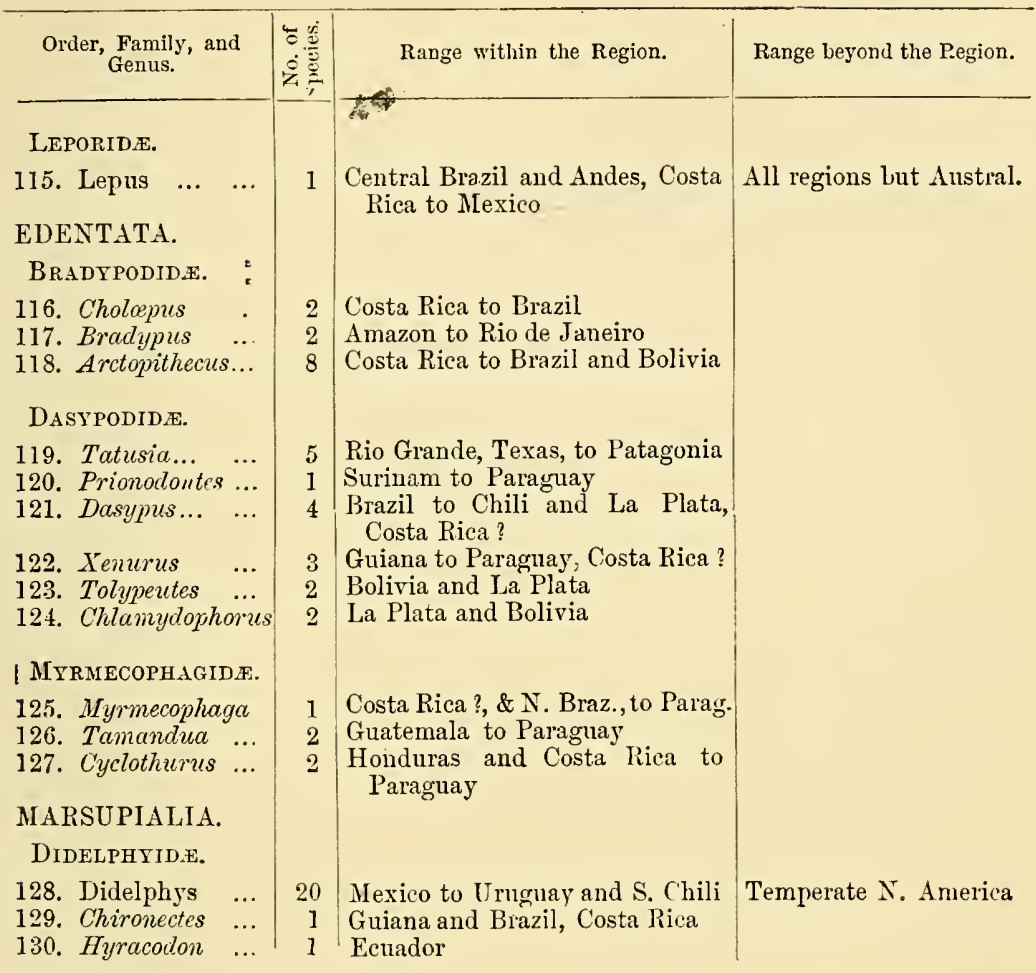

BIRDS.

\section{PASSERES.}

TURDIDE.

\begin{tabular}{lll|l|l|} 
1. Turdus & $\ldots$ & $\ldots$ & 32 & The whole reg. to Tierra del Fuego
\end{tabular}

Almost cosmopolite

2. Rhorlinocichla... 1 Mexico to Venezuela

3. Melanoptila $\ldots .11$ Honduras

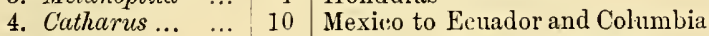

5. Margarops … 4 Hayti and Lesser Antilles

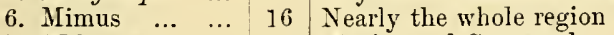

7. Melanotis...

8. Galeoscoptes ... 1 Mexico to Panama

9. Mimocichla ... 4 Cnba to Porto Rico (Harporhynchus 3 Mexico)

10. Cinclocerthia ... $\quad 3$ Lesser Antilles

11. Rimphocinclus

1 Martinique and St. Lucia

SYLYIIDE

12. Myiadestes

8. Nexico and Antilles to Peru and Bolivia 


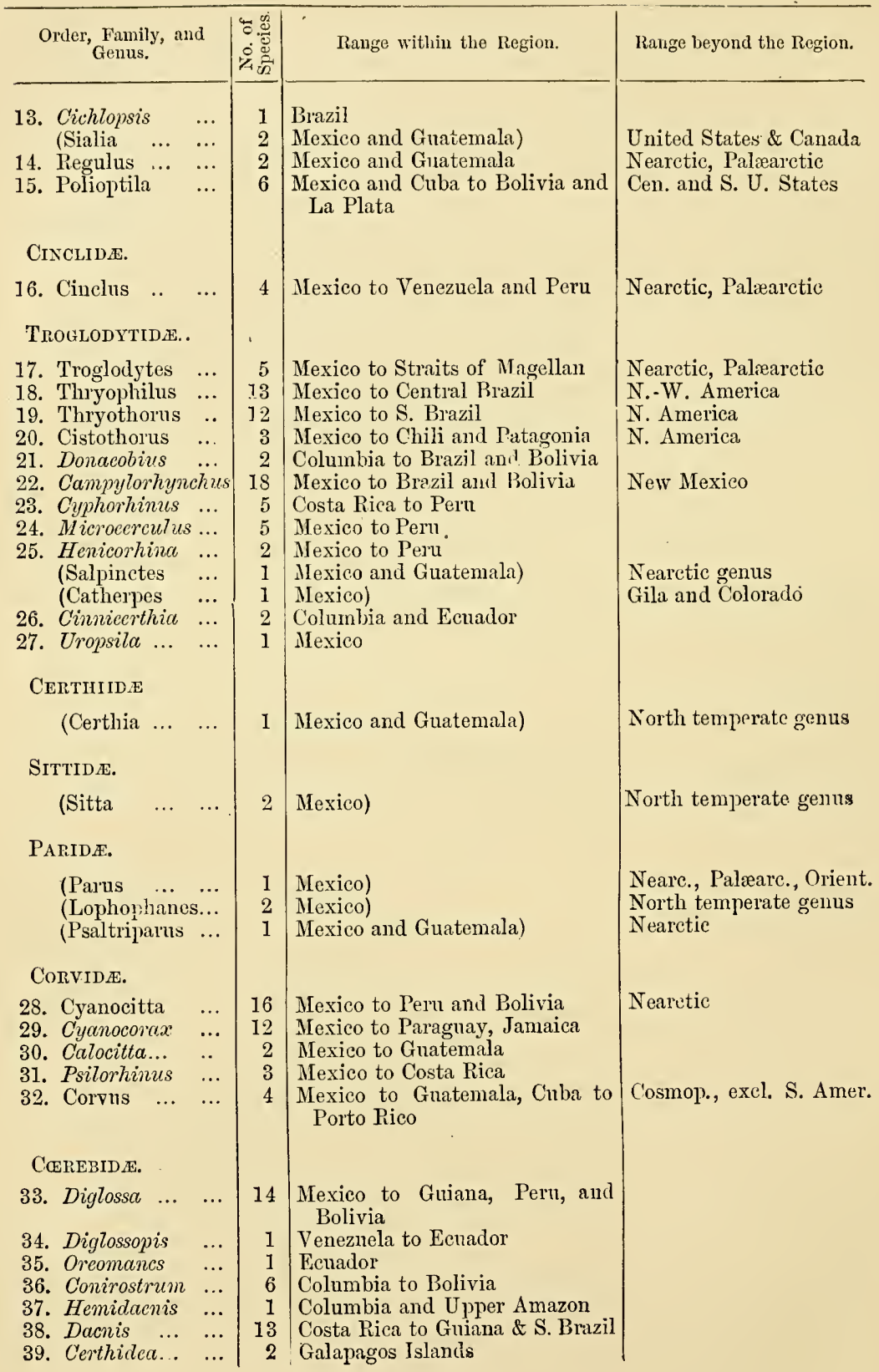




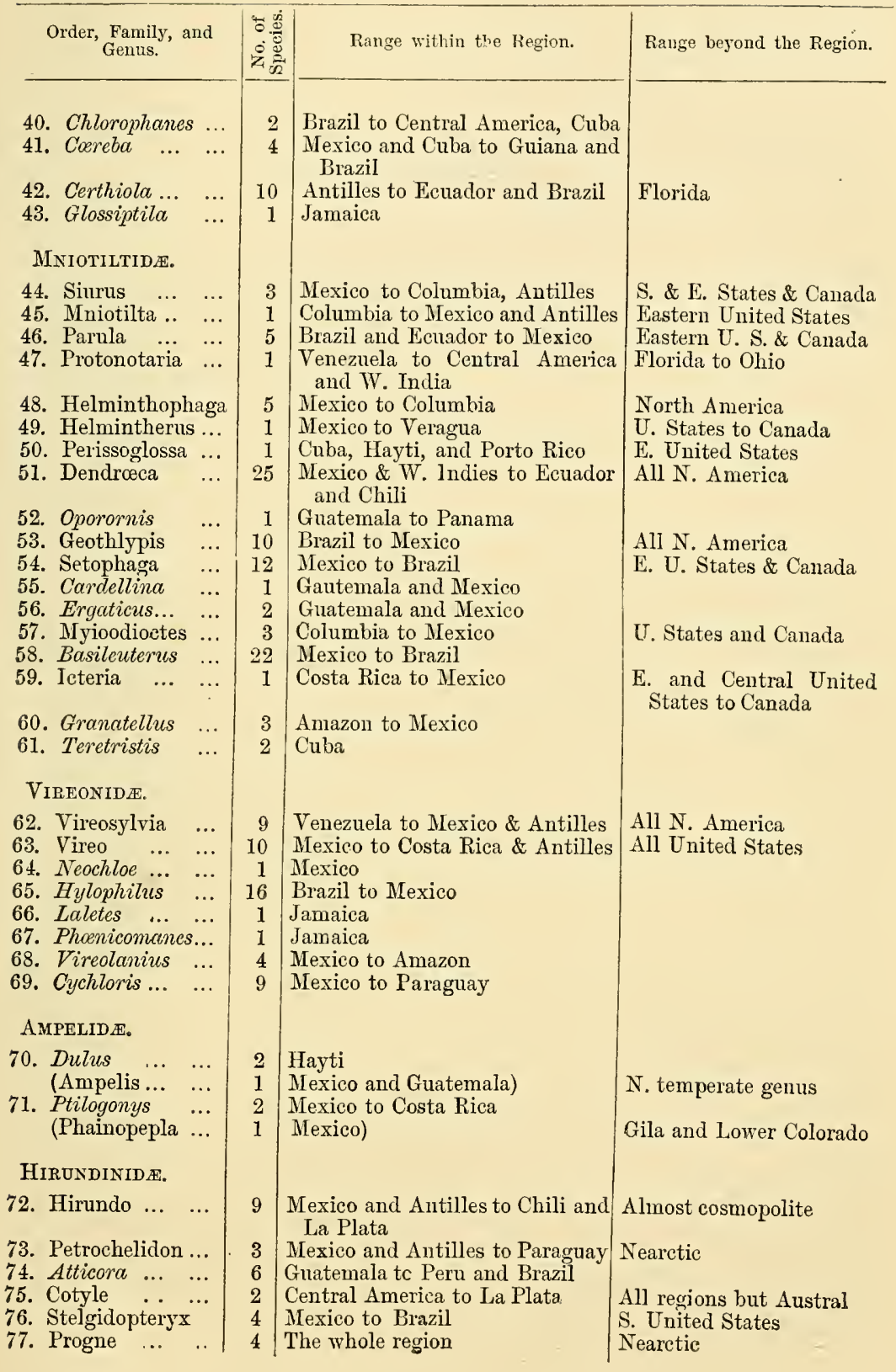

VOL. II. 


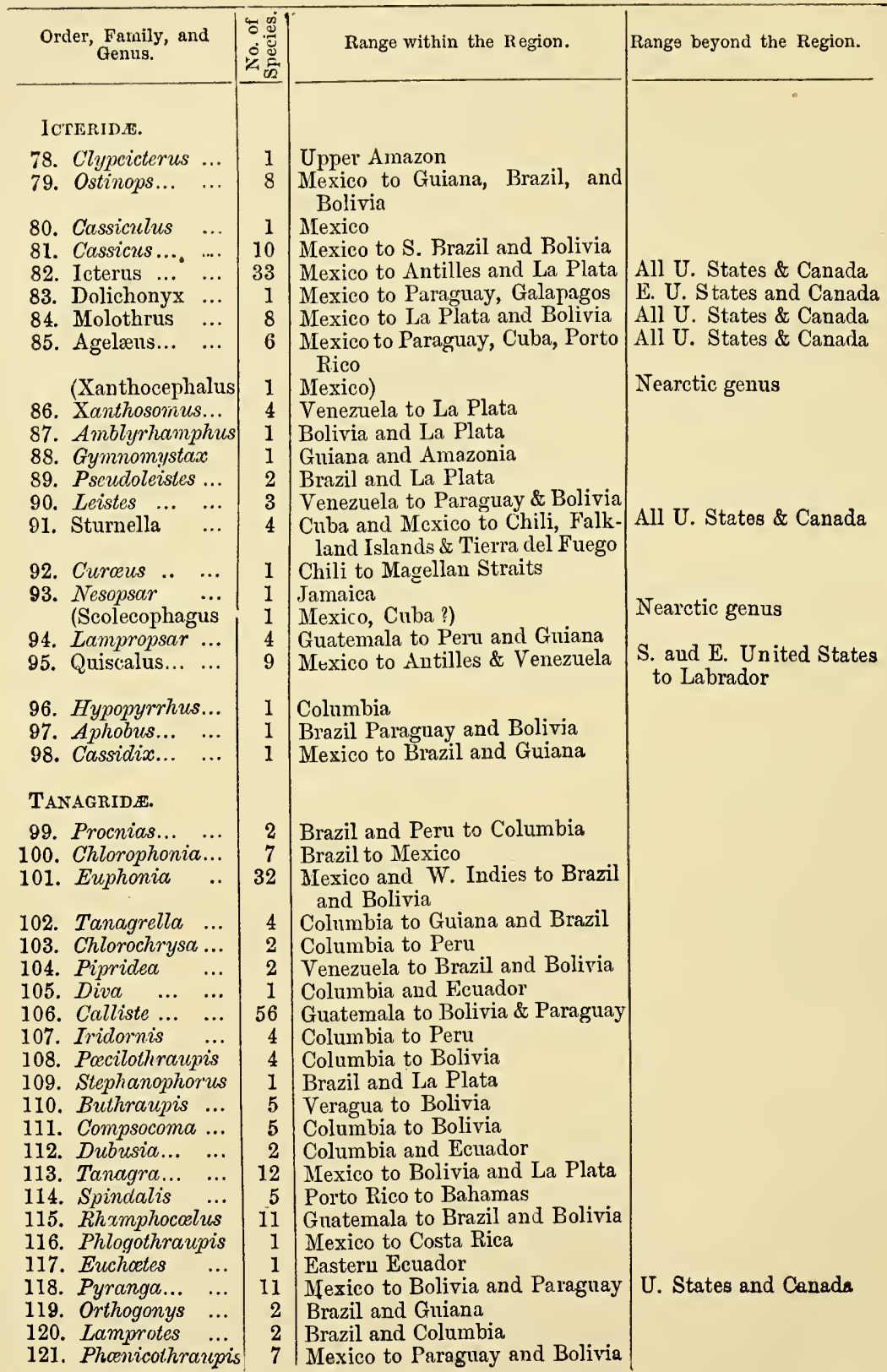




\begin{tabular}{|c|c|c|c|}
\hline $\begin{array}{l}\text { Order, Family, and } \\
\text { Genus. }\end{array}$ & 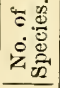 & Range within the Region. & Range beyond the Region. \\
\hline 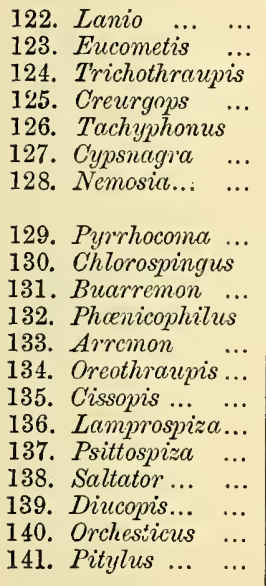 & $\begin{array}{r}1 \\
18 \\
20 \\
1 \\
12 \\
1 \\
3 \\
1 \\
2 \\
17 \\
2 \\
3 \\
8\end{array}$ & $\begin{array}{l}\text { Mexico to Boliria } \\
\text { Costa Rica to Bolivia } \\
\text { S. Brazil aua Paraguay } \\
\text { West Ecuador } \\
\text { Nicaragua to Paragnay } \\
\text { S. Brazil and Bolivia } \\
\text { Venezuela, W. Ecuador, to Bra- } \\
\text { zil and Bolivia } \\
\text { S. Brazil and Paraguay } \\
\text { Mexico to Peru and Bolivia } \\
\text { Mexico to S. Brazil and Bolivia } \\
\text { Hayti } \\
\text { Mexico to S. Brazil } \\
\text { East Ecuador } \\
\text { Columbia to Peru and Bolivia } \\
\text { Guiana } \\
\text { Columbia to Peru } \\
\text { Mexico to La Plata and Bolivia } \\
\text { Upper Amazon and S. Brazil } \\
\text { Tropical S. America } \\
\text { Mexico to Brazil and Ecuador }\end{array}$ & \\
\hline $\begin{array}{l}\text { FringILlid } \\
\text { 142. Chrysomitris... } \\
\text { 143. Sycalis .. }\end{array}$ & 12 & $\begin{array}{l}\text { Mexico to Brazil, Chili and } \\
\text { Patagonia } \\
\text { Mexico to Chili and La Plata, } \\
\text { Jamaica }\end{array}$ & Nearctic, Palæarctic \\
\hline $\begin{array}{l}\text { 144. Coccothraustes } \\
\text { 145. Geospiza... } \\
\text { 146. Camarhynchus } \\
\text { 147. Cactornis } \quad \ldots \\
\text { 148. Phrygilus _... }\end{array}$ & $\begin{array}{r}2 \\
7 \\
5 \\
4 \\
10\end{array}$ & $\begin{array}{l}\text { Mexico and Guatemala } \\
\text { Galapagos Islands } \\
\text { Galapagos Islands } \\
\text { Galapagos Islands } \\
\text { Columbia to Fuegia and Falk- }\end{array}$ & Nearctic, Palæarctio \\
\hline 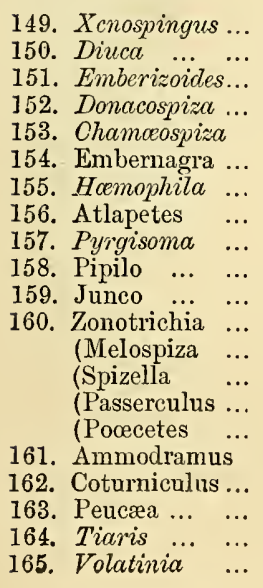 & $\begin{array}{l}1 \\
3 \\
3 \\
1 \\
1 \\
9 \\
6 \\
1 \\
5 \\
4 \\
2 \\
5 \\
2 \\
3 \\
1 \\
1 \\
1 \\
4 \\
4 \\
1 \\
1\end{array}$ & $\begin{array}{l}\text { Peru } \\
\text { Peru, Chili, and Patagonia } \\
\text { Venezuela to Paraguay } \\
\text { S. Brazil and La Plata } \\
\text { Mexico } \\
\text { Mexico to La Plata } \\
\text { Mexico to Costa Rica } \\
\text { Mexico } \\
\text { Mexico to Costa Rica } \\
\text { Mexico to Guatemala } \\
\text { Mexico and Guatemala } \\
\text { Mexico to Straits of Magellan } \\
\text { Mexico and Guatemala) } \\
\text { Mexico and Guatemala) } \\
\text { Mexico and Guatemala) } \\
\text { Mexico) } \\
\text { Guatemala } \\
\text { Mexico to Bolivia, Jumaica } \\
\text { Mexico } \\
\text { Brazil } \\
\text { Mexico to Brazil }\end{array}$ & $\begin{array}{l}\text { Rocky Mountains } \\
\text { Nearctic? } \\
\text { All Nearctic region } \\
\text { United States } \\
\text { Nearctic } \\
\text { Nearctic genus } \\
\text { Nearctic genus } \\
\text { Nearctic genus } \\
\text { Nearctic genus } \\
\text { Nearctic } \\
\text { E. \& N. of N. America } \\
\text { S. E. States \& California }\end{array}$ \\
\hline
\end{tabular}




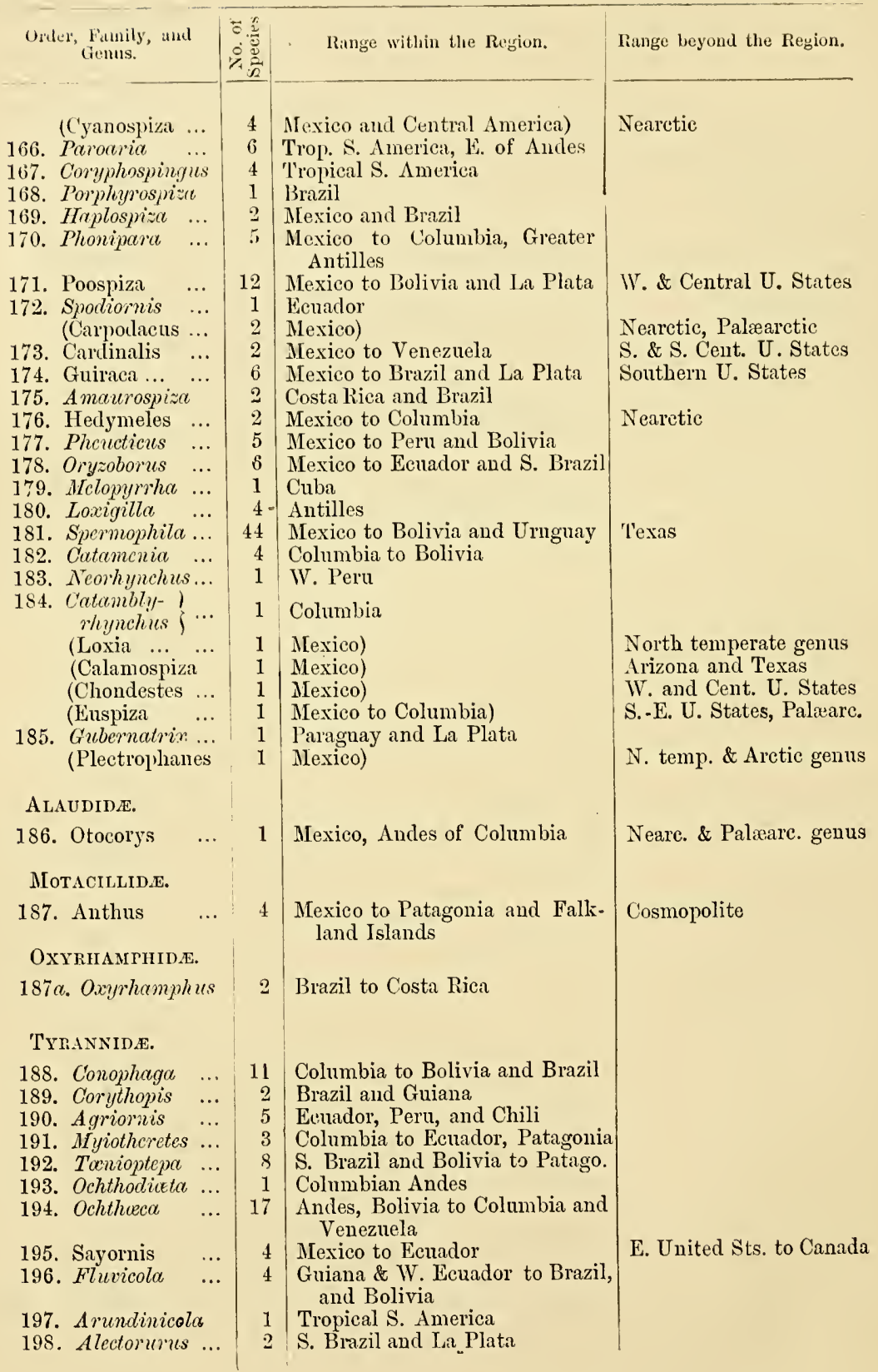




\begin{tabular}{|c|c|c|c|}
\hline $\begin{array}{l}\text { Order, Family, and } \\
\text { Genus. }\end{array}$ & 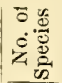 & Range within the Region. & Range beyond the Region. \\
\hline 199. Cybernctes & 1 & Brazil & \\
\hline 200. Sysopygis & 1 & S. Brazil and La Plata & \\
\hline 201. Cnipolegus ... & 9 & Amazonia to Patagonia & \\
\hline 202. Lichenops ... & 1 & Brazil and La Plata & \\
\hline 203. Nisscipipra ... & 1 & S. Brazil & \\
\hline 204. Copurus... ... & 3 & Costa Rica to S. Brazil & \\
\hline 205. Machetomis ... & 1 & Venezuela to Brazil & \\
\hline 206. Muscisaxicola & 11 & $\begin{array}{l}\text { Andes of Ecuador to Chili and } \\
\text { Patagonia }\end{array}$ & \\
\hline 207. Centrites & 2 & Bolivia to Patagonia & \\
\hline 208. Museigralla ... & 1 & W. Eeuador & \\
\hline 209. Platyrhynchuss & 7 & Mexico to Brazil & \\
\hline 210. Todirostrum ... & 11 & Tropical N. and S. America & \\
\hline 211. Oncosotma ... & 2 & Tropical N. America & \\
\hline 212. Euscarthmus... & 12 & $\begin{array}{l}\text { Costa Pica to W. Ecuador, Brazil, } \\
\text { and Bolivia }\end{array}$ & \\
\hline 213. Orchitus... ... & 2 & Costa Rica to Brazil and Bolivia & \\
\hline 214. Colopterus $\ldots$ & 2 & Veragua to Columbia and Guiana & \\
\hline 215. Henitriceus ... & 1 & Brazil & \\
\hline 216. Phylloscartcs ... & 1 & Columbia to Brazil & \\
\hline 217. Hapalocercus... & 3 & Brazil to Chili and La Plata & \\
\hline 218. Habrura $\ldots$ & 1 & Uriguay & \\
\hline 219. Pogonotrieeus... & 2 & Brazil and Colnmbia & . \\
\hline 220. Leptotriccus ... & 2 & Brazil and Veragua & 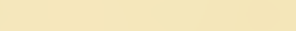 \\
\hline 221. Stigmatzra ... & 2 & Upper Amazon to La Plata & \\
\hline 222. Serphophaga ... & 7 & Columbia to Chili and La Plata & \\
\hline 223. Anceretes ... & 4 & $\begin{array}{l}\text { Columbia to Chili and La Plata, } \\
\text { Magell. Sts. \& Inan Fernand. }\end{array}$ & \\
\hline 224. Cyanotis & 1 & W. Peru to La Plata & \\
\hline 225. Mioneetes & 4 & Mexico to Brazil and Bolivia & \\
\hline 226. Leptopogon ... & 6 & Mexico to Peru and Brazil & \\
\hline 227. Capsicmpis ... & 1 & Chiriqui to Brazil & \\
\hline 228. Phyllomyias ... & 5 & Columbia to Brazil & \\
\hline 229. Ornithion ... & 4 & Míexico to Brazil & \\
\hline 230. Tysansulus ... & 3 & Giratemala to Amazonia & \\
\hline 231. Tyrannisers ... & 9 & Guatemala to E. Perı & \\
\hline 232. Elainea ... .. & 18 & $\begin{array}{l}\text { Mexico to Tierra del Fuego, An- } \\
\text { tilles }\end{array}$ & \\
\hline 233. Empidagra ... & 1 & Bolivia and La Plata & \\
\hline 234. Legatus ... & 2 & Mexico to Brazil & \\
\hline 235. Sublegatus & 2 & Venezuela and Lower Amazon & \\
\hline 236. Myiozetctes ... & 8 & Mexico to W. Peru and Brazil & \\
\hline 237. Rhymchocyclus & 10 & Mexico to W. Ecuador \& Brazil & \\
\hline 238. Conopias & 3 & Venezuela to Peru and Brazil & \\
\hline 239. Pitangus & 7 & Mexico to La Plata, Antilles & \\
\hline 240. Sirystes ... $\ldots$ & 2 & Panama to Brazil & \\
\hline 241. Myiodynastes .. & 6 & Mexico to Bolivia and Paraguay & \\
\hline 242. Megarluynchus & 1 & Mexico to Brazil & \\
\hline 243. Muscivora & 5 & Mexico to W. Ecuador \& Brazil & \\
\hline 244. Hirundinea ... & 3 & Columbia \& Guiana to Paragnay & \\
\hline 245. Cnipodectes & 1 & Panama to W. Ecuador \& Amiazon & \\
\hline 246. Myiobius & 13 & $\begin{array}{l}\text { Mexico to W. Peru, Bolivia, } \\
\text { and La Plata }\end{array}$ & \\
\hline 247. Pyrocephalus... & 3 & $\begin{array}{l}\text { Tropical N. and S. America and } \\
\text { Gralapragos Istinds }\end{array}$ & Gila anıl Tiio Granıle \\
\hline
\end{tabular}




\begin{tabular}{|c|c|c|c|c|}
\hline \multicolumn{2}{|l|}{$\begin{array}{l}\text { Order, Family, and } \\
\text { Genus. }\end{array}$} & 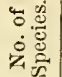 & Range within the Region. & Range beyond the Region. \\
\hline \multicolumn{2}{|l|}{ 248. Empidochancs } & 4 & Venezuela to S. Brazil. & \\
\hline \multicolumn{2}{|l|}{$\begin{array}{l}\text { 248. Emprobenancs } \\
\text { 249. Mitrephorus ... }\end{array}$} & 2 & Mexico to Costa Rica & \\
\hline \multirow{2}{*}{\multicolumn{2}{|c|}{$\begin{array}{l}\text { 250. Empidonax } \ldots \\
\text { 251. Contopus }\end{array}$}} & 12 & Mexico to Columbia \& Eenador & All N. America \\
\hline & & 10 & Mexico to Amazonia, Antilles & N. \& E. of Rocky Mtns. \\
\hline \multicolumn{2}{|c|}{ 252. Nyiochanes $\ldots$} & 1 & Amazonia and Brazil & \\
\hline \multicolumn{2}{|l|}{ 253. Мyiarehus $\ldots$} & 12 & $\begin{array}{l}\text { Mexico to W. Eeuador \& Brazil, } \\
\text { Galapagos and Antilles }\end{array}$ & $\begin{array}{l}\text { East and West Coasts to } \\
\text { Canada }\end{array}$ \\
\hline 254. Blacicus... . & .. & 2 & Cuba, Hayti, Jamaica & \\
\hline (Empidias & $\cdots$ & 1 & Mexico) & Eastern United States \\
\hline \multicolumn{2}{|l|}{ 255. Empidonomus } & 1 & Guiana and Brazil & \\
\hline \multirow{2}{*}{\multicolumn{2}{|c|}{$\begin{array}{l}\text { 256. Tyrannus } \\
\text { 257. Milvulus }\end{array}$}} & 11 & All tropical sub-regions & All U. States to Canada \\
\hline & & 2 & Tropical N. and S. America & Texas \\
\hline \multicolumn{5}{|l|}{ PiPRID死. } \\
\hline 258. Pipritcs... . & $\ldots$ & 4 & Costa Rica to Brazil & \\
\hline 259. Masius ... . & $\ldots$ & 2 & Columbia and Ecuador & \\
\hline 260. Chloropipo & $\ldots$ & 1 & Columbia & \\
\hline 261. Xenopipo & $\ldots$ & 1 & Guiana and Columbia & \\
\hline 262. Pipra ... & $\ldots$ & 19 & Trop. $\mathrm{N}$. and S. America & \\
\hline 263. Neopipo... & $\ldots$ & 1 & Upper Amazon & \\
\hline 264. Machceropteru & & 4 & Columbia to Brazil & \\
\hline 265. Ilicura ... . & $\ldots$ & 1 & Brazil & \\
\hline 266. Chiroxiphia. & $\ldots$ & 5 & Guatemala to Brazil & \\
\hline 267. Metopia ... & ... & 1 & Brazil & \\
\hline 268. Metopothrix . & $\ldots$ & 1 & Upper Amazon & \\
\hline 269. Chiromachoeri & is & 6 & Mexico to Ecuador and Brazil & \\
\hline 270. Hetoropelma. & $\ldots$ & 10 & Mexico to Guiana and Brazil & \\
\hline 271. Heterocercus. & $\ldots$ & 2 & Guiana and Upper Amazon & \\
\hline 272. Schiffornis. & $\cdots$ & 2 & Upper Amazon and BraziI & \\
\hline \multicolumn{5}{|l|}{ CotiNGID正. } \\
\hline \multirow{2}{*}{\multicolumn{2}{|c|}{$\begin{array}{l}\text { 273. Tityra ... ... } \\
\text { 274. Hadrostomus... }\end{array}$}} & 6 & Tropical N. and S. America & \\
\hline & & 5 & $\begin{array}{l}\text { Mexico to W. Ecuador \& Brazil, } \\
\text { Jamaica }\end{array}$ & \\
\hline \multirow{2}{*}{\multicolumn{2}{|c|}{ 275. Pachyhamphus }} & 11 & Mexico to W. Ecuador \& Brazil & \\
\hline & & 5 & Mexico to Brazil & \\
\hline 277. Aulia ... & $\ldots$ & 3 & Veragua to Brazil & \\
\hline 278. Lipaugus & $\ldots$ & 3 & Guatemala to Brazil and Guiana & \\
\hline 279. Ptilochloris. & $\ldots$ & 2 & Brazil & \\
\hline 280. Attila $\ldots$. & $\ldots$ & 8 & Costa Rica to Brazil and Guiana & \\
\hline 281. Casionis & $\ldots$ & 2 & S. Brazil to Paraguay & \\
\hline 282. Rupicola & $\ldots$ & 3 & Guiana to W. Eeuador \& Bolivia & \\
\hline 283. Phenicocercus & & 2 & Griana aud Amazonia & \\
\hline 284. Тіјиса ... & $\ldots$ & 1 & Brazil & \\
\hline 285. Phibalura . & $\ldots$ & 1 & Brazil & \\
\hline 286. Pipreola... & $\ldots$ & 7 & Venezuela to Eevador and Pert & \\
\hline 287. Ampelio... & $\ldots$ & 4 & Colnumbia to Peru and Brazil & \\
\hline 288. Carpodectes . & $\ldots$ & 1 & Nicaragua and Costa Rica & \\
\hline 289. Heliochoera . & $\ldots$ & 2 & Columbia to Peru and Bolivia & \\
\hline 290. Cotinga ... & $\ldots$ & 6 & Guatemala to Peru and Brazil & \\
\hline 291. Xipholena & $\ldots$ & 3 & Guiana to Brazil & \\
\hline 292. Iodopleura & $\ldots$ & 3 & Guiana to Brazil & \\
\hline 293. Calyptura & ...- & 1 & Brazil & \\
\hline 294. Querula... . & ... & 1 & Panama to Amazonia & \\
\hline
\end{tabular}




\begin{tabular}{|c|c|c|c|}
\hline $\begin{array}{l}\text { Order, Family, and } \\
\text { Genus. }\end{array}$ & 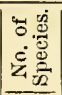 & Range within the Region. & Range beyond the Region. \\
\hline 295. Hoematoderus & 1 & Guiana and Lower Amazon & \\
\hline 296. Chasmorhynchus & 4 & Costa Rica to Guiana and Brazil & \\
\hline 297. Gymnocephalus & 1 & Guiana and Rio Negro & \\
\hline 298. Gymnoderus ... & 1 & Guiana and Upper Amazon & \\
\hline 299. Pyroderus ... & 3 & Venezuela to Brazil & \\
\hline 300. Cephalopterus & 3 & $\begin{array}{l}\text { Costa Rica to W. Ecuador \& Upr. } \\
\text { Amazon }\end{array}$ & \\
\hline PHYTOTOMIDE. & & (1). & \\
\hline 301. Phytotoma ... & 3 & Bolivia, Chili, and La Plata & \\
\hline DENDROCOLAPTIDE. & & & \\
\hline 302. Geobates ... & 1 & South Brazil & \\
\hline 303. Geositta ... & 6 & Peru to Chili and Patagonia & \\
\hline 304. Furnarius ... & 9 & Guiana \& W. Ecuador to La Plata & \\
\hline 305. Clibanomis ... & 1 & S. Brazil & \\
\hline 306. Upucerthia ... & 4 & $\begin{array}{l}\text { Andes of Ecuador to Chili and } \\
\text { Patagonia }\end{array}$ & \\
\hline 807. Cinclodes & 5 & $\begin{array}{l}\text { Ecuador to Chili, Patagonia and } \\
\text { Tierra del Fuego }\end{array}$ & \\
\hline 308. Henicornis ... & 2 & Patagonia & \\
\hline 309. Lochmias & 2 & Venezuela and Brazil & \\
\hline 310. Sclerurus & 6 & Mexico to Brazil & \\
\hline 311. Oxyurus... ... & 2 & $\begin{array}{l}\text { Chili to Tierra del Fuego, and } \\
\text { Masafuera Islands }\end{array}$ & \\
\hline $\begin{array}{l}\text { 312. Sylviorthor- } \\
\text { hynehus }\end{array}$ & 1 & Chili & \\
\hline 313. Phloocryptes... & 1 & W. Peru to La Plata & \\
\hline 314. Leptasthenura & 5 & $\begin{array}{l}\text { Andes of Ecuador to Brazil and } \\
\text { Patagonia }\end{array}$ & \\
\hline 315. Synallaxis ... & 55 & The whole region (excl. Antilles) & \\
\hline 316. Coryphistera ... & 1 & La Plata & \\
\hline 317. Anumbius ... & 1 & Paraguay and La Plata & \\
\hline 318. Limnornis ... & 1 & Uruguay and La Plata & \\
\hline 319. Placellodomus & 4 & Venezuela to Peru and La Plata & \\
\hline 320. Thripophaga... & 3 & Brazil and Columbia & \\
\hline 321. Pseudocolaptes & 1 & Columbia to Peru & \\
\hline 322. Homorus & 3 & Brazil, Bolivia, and La Plata & \\
\hline 323. Thripadectes... & 1 & Columbia & \\
\hline 32t. Ancistrops $\quad .$. & 1 & Upper Amazon & \\
\hline 325. Automolus & 9 & Mexico to Amazonia & \\
\hline 326. Philydor & 14 & Tropical South America & \\
\hline 327. Helioblctus & 1 & Brazil & \\
\hline 328. Anabatoides ... & 1 & Brazil & \\
\hline 329. Anabazenops ... & 5 & Mexico to Brazil & \\
\hline 330. Xenops ... ... & 3 & Trop. North and South America & \\
\hline 331. Sittasomus ... & 3 & Mexico to Ecuador and Brazil & \\
\hline 332. Margarornis ... & 4 & Costa Rica to Peru and Bolivia & \\
\hline 333. Glyphorhynchus & 1 & Trop. North and South America & \\
\hline 334. Pygarrhicus ... & 1 & Chili & \\
\hline 335. Dendrocincla... & 10 & Mexico to Venezuela and Brazil & \\
\hline 336. Dendrocolaptes & 7 & Guatemala to Peru and Brazil & \\
\hline 337. Nasica ... ... & 1 & Guiana & \\
\hline 338. Drymornis ... & 1 & La Plata & \\
\hline 339. Xiphocolaptcs, & 5 & IIexico to Bolivia and Paraguay & \\
\hline
\end{tabular}




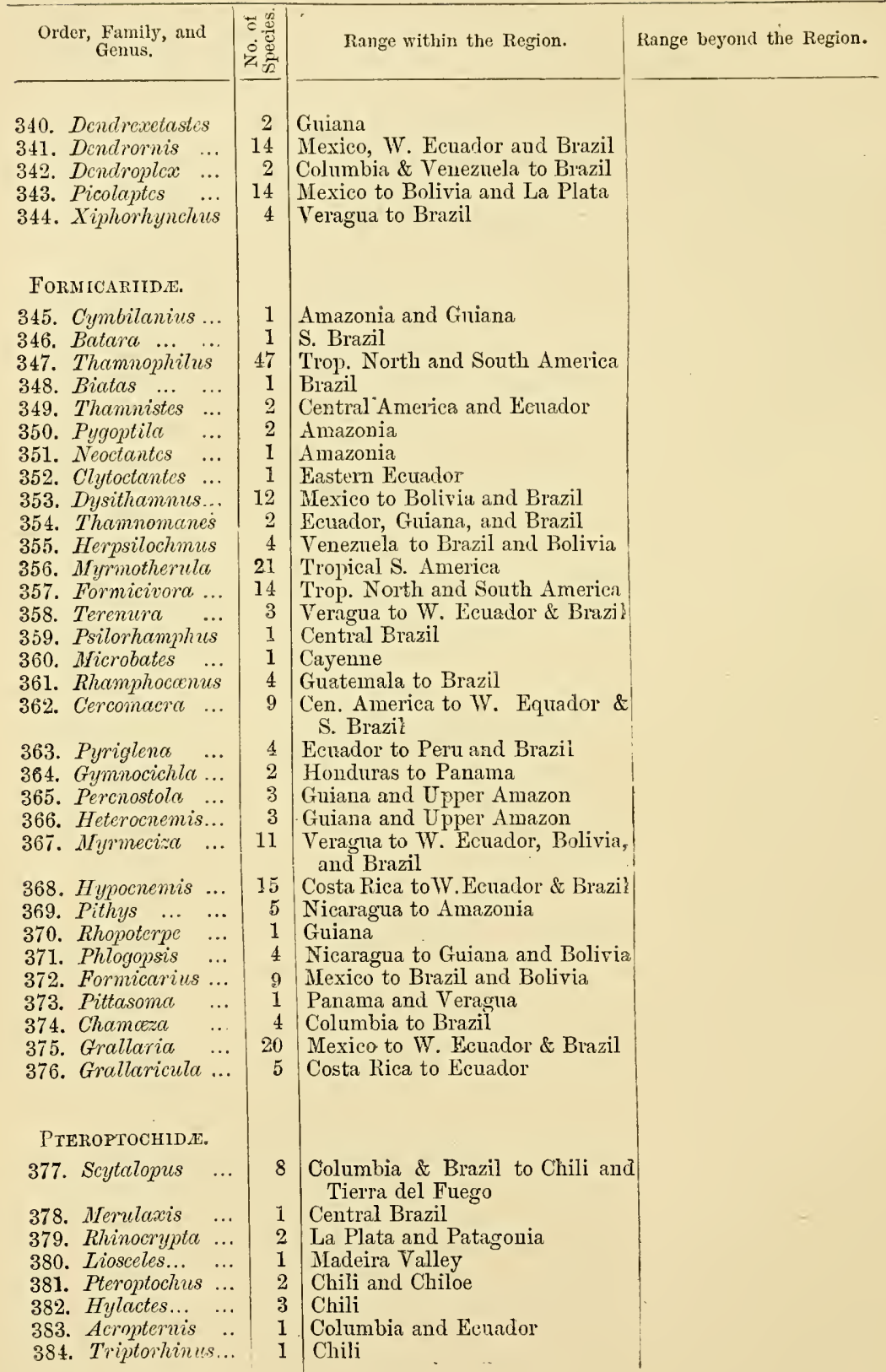




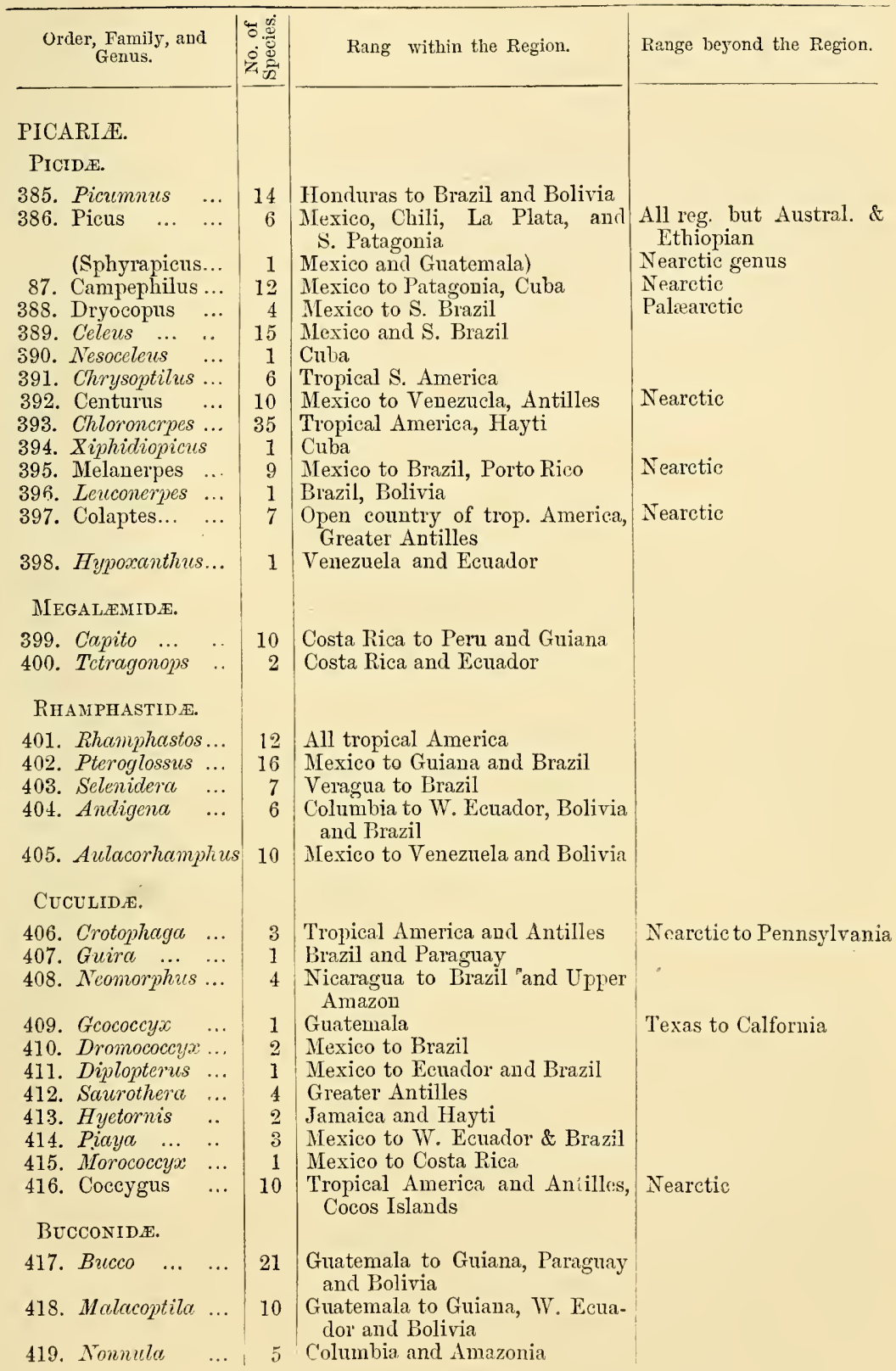




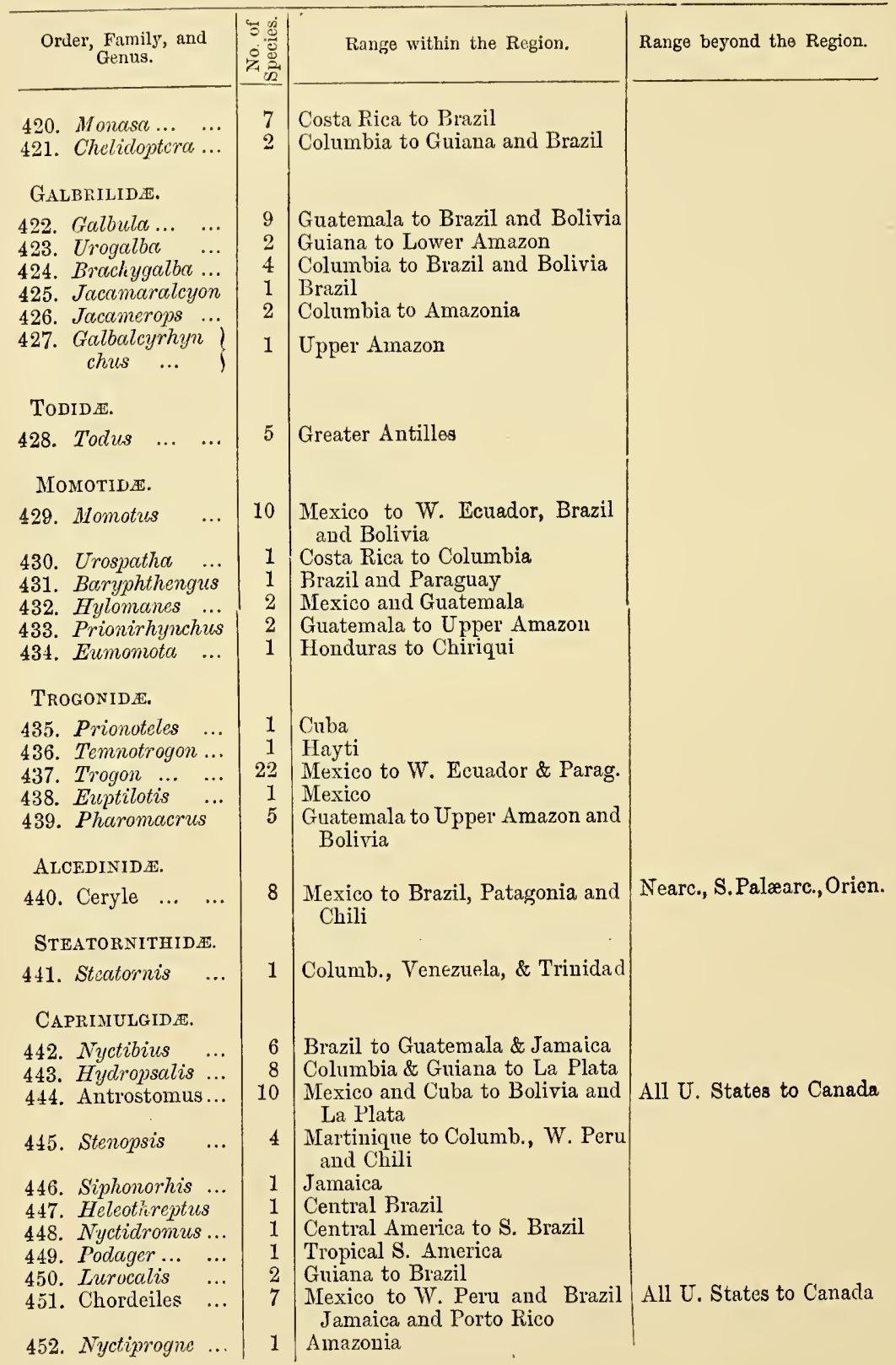




\begin{tabular}{|c|c|c|c|c|}
\hline \multicolumn{2}{|l|}{$\begin{array}{l}\text { Order, Family, and } \\
\text { Genus. }\end{array}$} & \multirow[t]{2}{*}{ 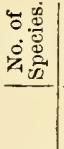 } & Range within the Region. & \multirow{6}{*}{$\begin{array}{l}\text { Range beyond the Region. } \\
\text { The Eastern Hemisphere } \\
\text { Almost cosmopolite }\end{array}$} \\
\hline Cypselide. & & & & \\
\hline 453. Cypselus & $\ldots$ & 3 & Antilles to Guiana and Bolivia & \\
\hline 454. Panyptila & $\ldots$ & 3 & Guatemala and Guiana & \\
\hline 455. Chætura... & $\ldots$ & 9 & Mexico to Ecuador and Brazil & \\
\hline 456. Hemiprocne & ... & 3 & $\begin{array}{l}\text { Mexico to La Plata, Jamaica } \\
\text { and Hayti }\end{array}$ & \\
\hline 457. Cypseloides & $\ldots$ & 2 & Brazil and Peru & \\
\hline 458. Nephocetes & $\cdots$ & 1 & Jamaica & \\
\hline TrochiLIDE. & & & & \\
\hline 459. Grypus ... & $\ldots$ & 1 & Brazil & \\
\hline 460. Androdon & $\ldots$ & 1 & Ecuador & \\
\hline 461. Eutoxeres & $\ldots$ & 2 & Costa Rica to Ecuador & \\
\hline 462. Glaucis ... & $\ldots$ & 2 & Panama to Brazil & \\
\hline 463. Phaethornis & $\ldots$ & 14 & Tropical N. and S. America & \\
\hline 464. Pygmornis & $\ldots$ & 8 & Mexico to Guiana and Brazil & \\
\hline 465. Threnetes & $\ldots$ & 4 & $\begin{array}{l}\text { Costa Rica to Amazonia and } W \text {. } \\
\text { Ecuador }\end{array}$ & \\
\hline 466. Dolerisca & ... & 1 & Venezuela & \\
\hline 467. Eupetomena & $\ldots$ & 1 & Guiana to Brazil & \\
\hline 468. Sphenoproctus & & 2 & Mexico to Guatemala & \\
\hline 469. Campylopteru & & 9 & Mexico to Amazonia & \\
\hline 470. Phooochroa & & 2 & Guatemala to Columbis & \\
\hline 471. Aphantochroa & & 3 & Ecuador and Brazil & \\
\hline 472. Urochroa & .. & 1 & Ecuador & \\
\hline 473. Sternoclyta & $\ldots$ & 1 & Venezuela & \\
\hline 474. Eugenes... & $\ldots$ & 2 & Mexico to Costa Rica & \\
\hline 475. Coeligena & $\ldots$ & 1 & Mexico & \\
\hline 476. Lamprolcema & & 1 & Mexico and Guatemala & \\
\hline 477. Delattria & $\ldots$ & 2 & Guatemala & \\
\hline 478. Oreopyra & $\ldots$ & 4 & Costa Rica to Chiriqui & \\
\hline 479. Heliopoedica & $\ldots$ & 2 & Mexico and Guatemala & \\
\hline 480. Тораzа ... & & 2 & Guiana & \\
\hline 481. Oreotrochilus & & 6 & Ecuador to Peru and Chili & \\
\hline 482. Lampornis & $\ldots$ & 7 & Mexico \& W. India to Amazonia & \\
\hline 483. Eulampis & $\ldots$ & 2 & Lesser Antilles & \\
\hline 484. Avocettula & ... & 1 & Guiana & \\
\hline 485. Lafresnaya & $\ldots$ & 2 & Venezuela and Columbia & \\
\hline 486. Doryphora & $\ldots$ & 5 & Costa Riea to Ecuador & \\
\hline 487. Chalybura & $\ldots$ & 5 & Costa Rica to Columbia & \\
\hline 488. Heliodoxa & $\ldots$ & 5 & Costa Rica to Venezne. \& Boliv. & \\
\hline 489. Iolama ... & $\ldots$ & 2 & Ecuador to Peru & \\
\hline 490. Phceolama & $\ldots$ & 2 & Columbia and Ecuador & \\
\hline 491. Eugenia... & $\cdots$ & 1 & Ecuador & \\
\hline 492. Aithurus & $\ldots$ & 1 & Jamaica & \\
\hline 493. Thalurania & $\ldots$ & 10 & $\begin{array}{l}\text { Costa Rica to Guiana, Ecuador } \\
\text { and Brazil }\end{array}$ & \\
\hline 494. Panoplites & $\ldots$ & 3 & Columbia and Ecuador & \\
\hline 495. Florisuga & $\cdots$ & 2 & Guatemala to Brazil & \\
\hline 496. Microchera & $\ldots$ & 2 & Nicaragua to Veragua & \\
\hline 497. Lophorius & $\ldots$ & $\overline{7}$ & Mexico to Brazil, Peru, \& Bolivia & \\
\hline 498. Polemistria & $\ldots$ & 2 & Columbia to S. Brazil & \\
\hline 499. Discura... & $\ldots$ & 2 & Brazil & \\
\hline 500. Gouldia ... & & 4 & Costa Rica to Brazil \& Bolivia & \\
\hline
\end{tabular}




\begin{tabular}{|c|c|c|c|c|}
\hline $\begin{array}{l}\text { Order, Family, anc } \\
\text { Genus. }\end{array}$ & & 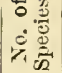 & Range within the Region. & Range beyoud the Region. \\
\hline 501. Trochïls & $\ldots$ & 2 & Mexico to Veragua & To Canada and Sitka \\
\hline 502. Mellisuga & $\cdots$ & 1 & Iamaica to Hayti & \\
\hline 503. Calypte... & $\ldots$ & 3 & Mexico and Cnba & \\
\hline 504. Selasphorus & $\ldots$ & 7 & Mexico to Veragua & W. \& Cen. United States \\
\hline 505. Atthis $\ldots$ & $\ldots$ & 1 & Mexico and Guatemala & California and Colorado \\
\hline 506. Stellula ... & $\ldots$ & 1 & Mexico & \\
\hline 507. Calothorax & $\ldots$ & 2 & Mexico & \\
\hline 508. Accstrura & $\cdots$ & 3 & Venezuela to Ecuador \& Bolivia & \\
\hline 509. Chcetocercus & $\ldots$ & 3 & Venezuela and Ecuarlor & \\
\hline 510. Myrtis ... & $\ldots$ & 2 & Ecuador to Bolivia, W. of Andes & \\
\hline 511. Thaumasture & & 1 & W. Peru & \\
\hline 512. Rhodopis... & $\ldots$ & 2 & W. Pern and Chili & \\
\hline 513. Doricha ... & - & 5 & Mexico to Veragua, Bahamas & \\
\hline 514. Tilmatura & $\cdots$ & 1 & Guatemala & \\
\hline 515. Calliphlox & $\ldots$ & 2 & Leuador and Brazil & \\
\hline 516. Loddigesia & $\ldots$ & 1 & Pernvian Andes & \\
\hline 517. Steganura & $\cdots$ & 6 & Venezuela to Ecuador \& Bolivia & \\
\hline 518. Lesbia...... & $\ldots$ & 6 & Columbia to Peru & \\
\hline 519. Cymanthus & $\cdots$ & 2 & Venezuela to Ecuador & \\
\hline 520. Sparganura & $\begin{array}{l}\cdots \\
\ldots\end{array}$ & 4 & Columbia to Bolivia \& La Plata & \\
\hline 521. Pterophanes & $\ldots$ & 1 & Columbia to Peru & \\
\hline 522. Agloeactis & $\cdots$ & 4 & Columbia to Bolivia & \\
\hline 523. Oxypogon & $\begin{array}{l}\cdots \\
\cdots\end{array}$ & 2 & Venezuela and Columbia & \\
\hline 524. Oreonympha & $\ldots$ & 1 & Peru & \\
\hline 525. Rhamphonic & ron & 6 & Columbia to Bolivia & \\
\hline 526. Urosticte.. & $\ldots$ & 2 & Ecuador & \\
\hline 527. Metallura & $\ldots$ & 6 & Columbia to Bolivia & \\
\hline 528. Adelomia & $\ldots$ & 4 & Venezuela to Peru \& Bolivia & \\
\hline 529. Avocettinus & $\begin{array}{l}\cdots \\
\cdots\end{array}$ & 1 & Columbia & \\
\hline 530. Anthocephala & & 1 & Columbia & \\
\hline 531. Chrysolamwis & & 1 & Venezuela to Brazil & \\
\hline 532. Orthorhynch? & & 2 & Lesser Antilles & \\
\hline 533. Cephalolepis & $\ldots$ & 3 & Brazil & \\
\hline 534. Clais $\quad \ldots$ & $\ldots$ & 1 & Venezuela and Columbia & \\
\hline 535. Baucis ... & $\cdots$ & 1 & Mexico to Veragna & \\
\hline 536. Heliactin & $\ldots$ & 1. & Brazil & \\
\hline 537. Heliothrix & $\ldots$ & 3 & Guatemala to Ecuador \& Brazil & \\
\hline 538. Schistes ... & $\cdots$ & 2 & Columbia and Ecnador & \\
\hline 539. Phlogophitus & & 1 & Ecuador & \\
\hline 540. Augastes... & $\ldots$ & 2 & Brazil & \\
\hline 541. Petasophora & & 5 & Mexico to Peru and Brazil & \\
\hline 542. Chrysobronch & & 3 & Venezuela to Brazil & \\
\hline 543. Patagona & .. & 1 & Eeuador to Bolivia and Chili & \\
\hline 544. Docimastes & $\ldots$ & 1 & Columbia and Ecuador & \\
\hline 545. Helianthea & $\ldots$ & 7 & Culmmbia to Bolivia & \\
\hline 546. Heliotrypha & $\ldots$ & 2 & Colnmbia and Ecuador & \\
\hline 547. Hcliangelus & $\ldots$ & 6 & Venezuela to Perı & \\
\hline 548. Diphlogiena & $\begin{array}{l}\cdots \\
\ldots\end{array}$ & 3 & Bolivia & \\
\hline 549. Clytoloema & $\ldots$ & 2 & E. Ecuador and Brazil & \\
\hline 550. Bourcieria & & 5 & Venezuela to Peru & \\
\hline 551. Lampropygia & & 4 & Venezuela to Bolivia & \\
\hline 552. Heliomastes & & 5 & Mexico to Ecuador \& Venezuela & \\
\hline 553. Lepidolarynx & & 1 & Brazil & \\
\hline 554. Calliperidia & & 1 & Central Brazil and Paraguay & \\
\hline 555. Eustephanus & & 3 & $\begin{array}{l}\text { Chili, S. Patagonia, and Juan } \\
\text { Fernandez lslands, }\end{array}$ & \\
\hline
\end{tabular}




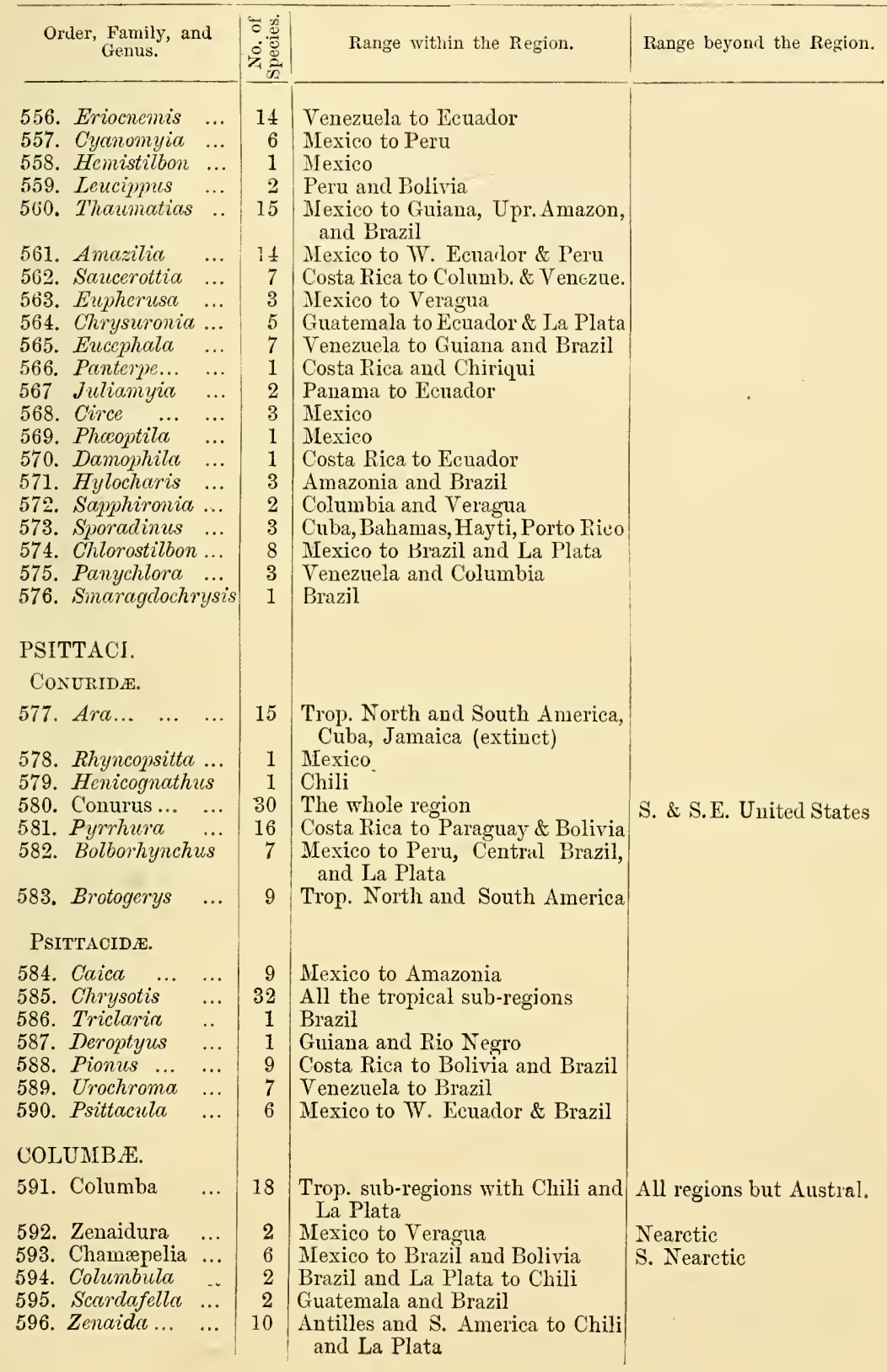




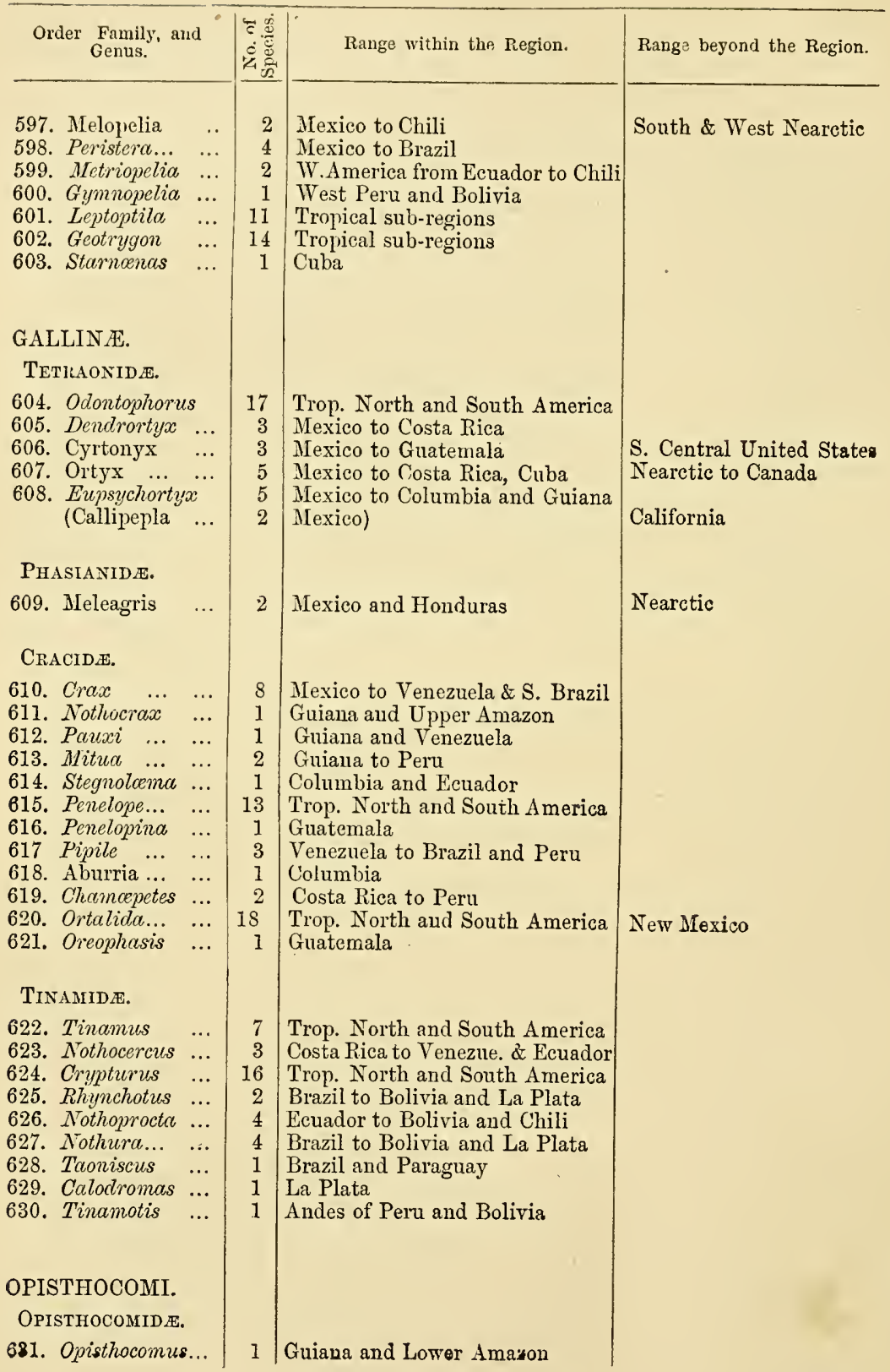




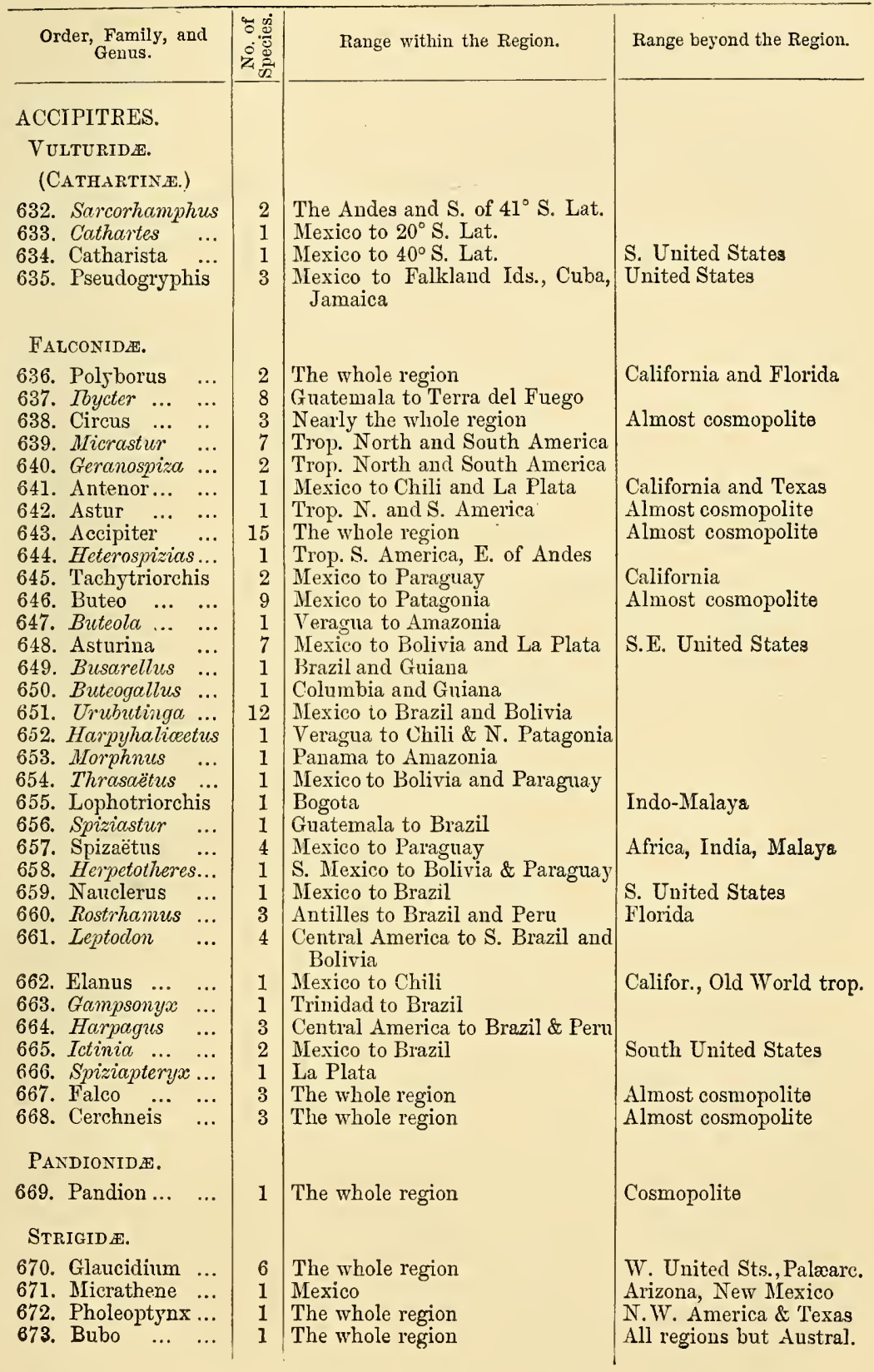




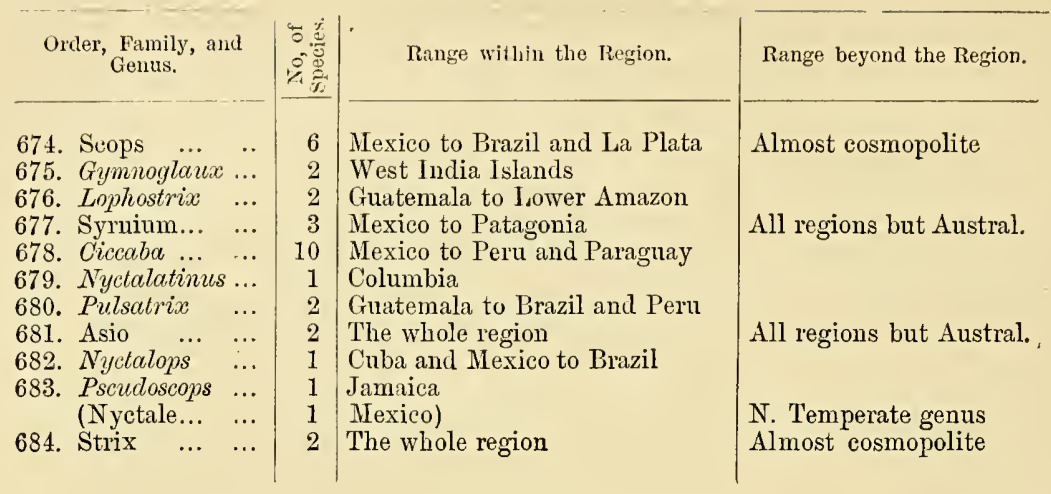

Peculiar or very Characteristic Genera of Wading and Swimming Birds.

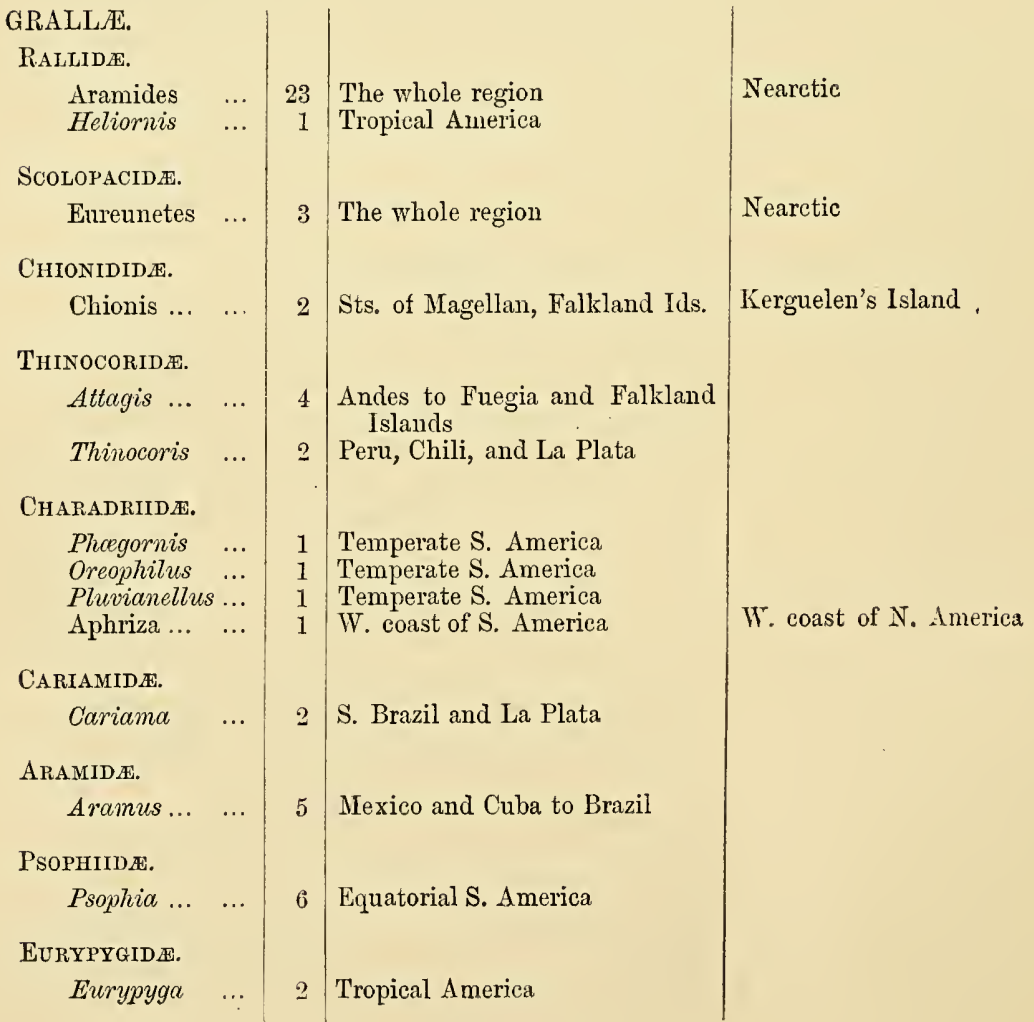




\begin{tabular}{|c|c|c|c|c|}
\hline $\begin{array}{l}\text { Order, Family, an } \\
\text { Genus. }\end{array}$ & & 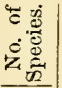 & Range within the Region. & Range beyond the Region. \\
\hline $\begin{array}{l}\text { ARDEIDA. } \\
\text { Tigrisoma } \\
\text { Cancroma }\end{array}$ & $\begin{array}{l}\ldots \\
\ldots\end{array}$ & $\begin{array}{l}3 \\
1\end{array}$ & $\begin{array}{l}\text { The whole region } \\
\text { Tropical S. America }\end{array}$ & \\
\hline $\begin{array}{c}\text { PALAMEDEID } \text {. } \\
\text { Palamedea } \\
\text { Chauna... }\end{array}$ & $\begin{array}{l}\cdots \\
\cdots\end{array}$ & $\begin{array}{l}1 \\
2\end{array}$ & $\begin{array}{l}\text { Equatorial America } \\
\text { Columbia, Brazil, and La Plata }\end{array}$ & \\
\hline $\begin{array}{l}\text { ANSERES. } \\
\text { ANATIDÆ. } \\
\text { Cairina... } \\
\text { Merganetta } \\
\text { Micropterus }\end{array}$ & $\begin{array}{l}\cdots \\
\cdots \\
\cdots\end{array}$ & $\begin{array}{l}1 \\
3 \\
1\end{array}$ & $\begin{array}{l}\text { Tropical S. America } \\
\text { Andes } \\
\text { Temperate S. America }\end{array}$ & \\
\hline $\begin{array}{l}\text { SPHENISCID } \approx . \\
\text { Eudyptes } \\
\text { Aptenodytes }\end{array}$ & $\cdots$ & $\begin{array}{l}6 \\
2\end{array}$ & $\begin{array}{l}\text { Temperate S. America } \\
\text { Falkland Islands }\end{array}$ & $\begin{array}{l}\text { Antarctic shores } \\
\text { Antaretic shores }\end{array}$ \\
\hline $\begin{array}{l}\text { STRUTHIONES. } \\
\text { STRUTHIONIDE. } \\
685 \text {. Phed ... }\end{array}$ & & 3 & S. Temperate America & \\
\hline
\end{tabular}

VOL. II. 


\section{CHAPTER XY.}

\section{TIIF NEARCTIC REGION.}

THis region consists almost wholly of Temperate North America as defined by physical geographers. In area it is about equal to the Neotropical region. It possesses a vast mountain range traversing its entire length from north to south, comparable with, and in fact a continuation of, the Andes,-and a smaller range near the east coast, equally comparable with the mountains of Brazil and Guiana. These mountains supply its great riversystem of the Mississippi, second only to that of the Amazon; and in its vast group of fresh-water lakes or inland seas, it possesses a feature unmatched by any other region, except perhaps by the Ethiopian. It possesses every variety of climate between aretic and tropical; extensive forests and vast prairies; a greatly varied surface and a rich and beautiful flora. But these great advantages are somewhat neutralized by other physical features. It extends far towards the north, and there it reaches its greatest width; while in its southern and warmest portion it suddenly narrows. The northern mass of land causes its isothermal lines to bend southwards; and its winter temperature especially, is far lower than at corresponding latitudes in Europe. This diminishes the available area for supporting animal life; the amount and character of which must be, to a great extent, determined by the nature of the least favourable part of the year. Again, owing to the position of its mountain ranses and the direction of prevalent winds, a large extent of its interior, east of the Rocky Mountains, is bare and arid, and often almost desert; while the most favoured districts,-those east of 

NEARCTIC REGION

Scale 1 inch-1,000 miles

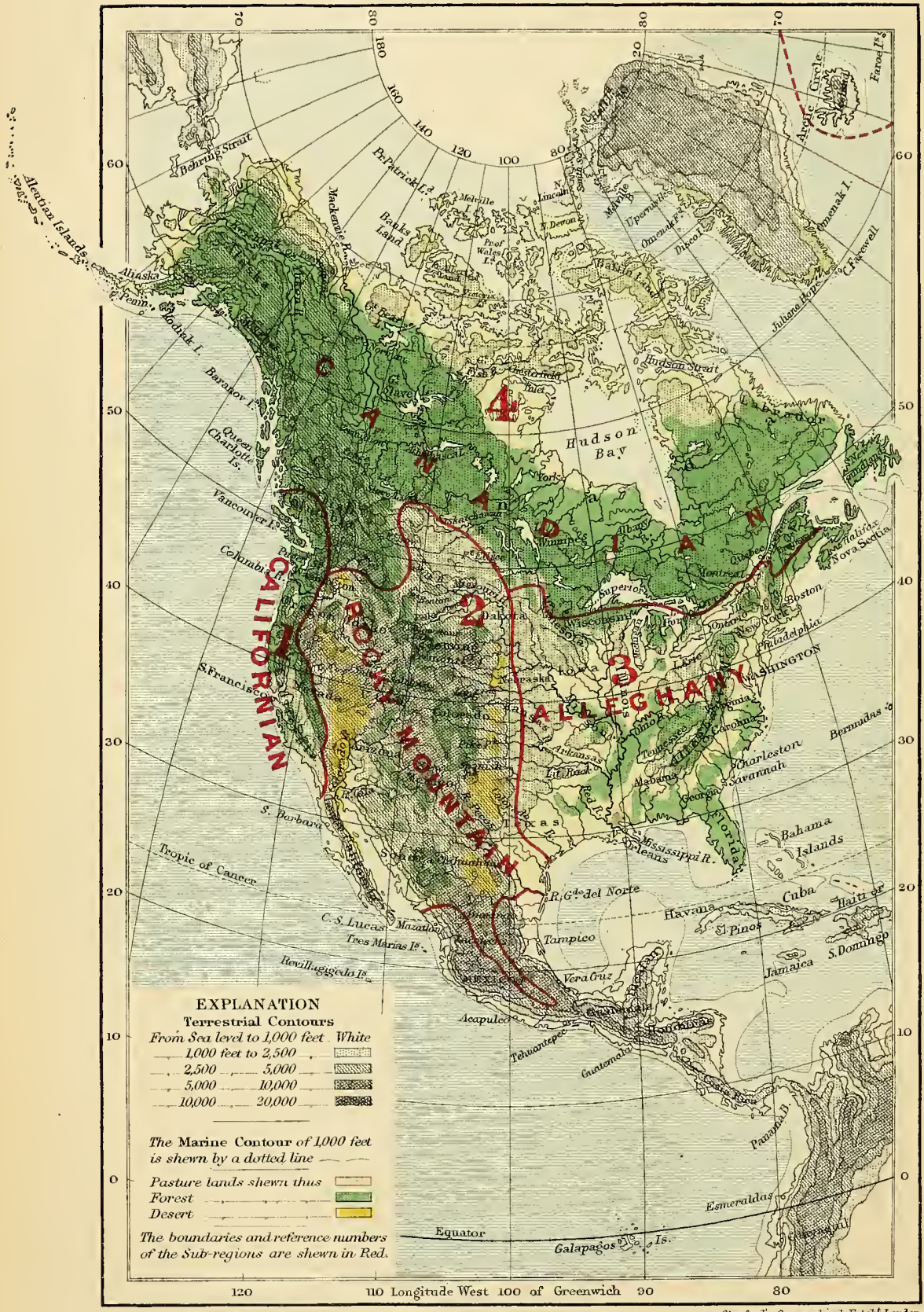

Loxdon; Macmillan \& Co

Stanford's Geographical Estab! Loution. 
the Mississippi and west of the Sierra Nevada, bear but a small proportion to its whole area. Again, we know that at a very recent period geologically, it was subjected to a very severe Glacial epoch, which wrapped a full half of it in a mantle of ice, and exterminated a large number of animals which previously inhabited it. Taking all this into account, we need not be surprised to find the Nearctic region somewhat less rich and varied in its forms of life than the Palæarctic or the Australian regions, with which alone it can fairly be compared. The wonder rather is that it should be so little inferior to them in this respect, and that it should possess such a variety of groups, and such a multitude of forms, in every class of animals.

Zoological charactcristics of the Nearctic Region.-Temperate North America possesses representatives of 26 families of Mammalia, 48 of Birds, 18 of Reptiles, 11 of Amphibia, and 18 of Fresh-water Fish. The first three numbers are considerably less than the corresponding numbers for the Palæarctic region, while the last two are greater-in the case of fishes materially so, a circumstance readily explained by the wonderful group of freshwater lakes and the noble southward-flowing river system of the Mississippi, to which the Palæaretic region has nothing comparable. But although somerhat deficient in the total number of its families, this region possesses its full proportion of peculiar and characteristic family and generic forms. No less than 13 families or sub-families of Vertebrata are confined to it, or just enter the adjacent Neotropical region. These are,-three of mammalia, Antilocaprinæ, Saccomyidæ and Haploodontidæ; one of birds, Chamæidæ; one of reptiles, Chirotidæ; two of amphibia, Sirenidæ and Amphiumidæ; and the remaining six of fresh-water fishes. The number of peculiar or characteristic genera is perhaps more inportant for our purpose ; and these are very cousiderable, as the following enumeration will show.

Mammalia.-Of the family of moles (Talpidi) we have 3 peculiar genera: Condylura, Scapanus, and Scalops, as well as the remarkable Urotrichus, found only in California and Japan. In the weasel family (Mustelidie) we have Latax, a peculiar kind of otter; Taxidea, allied to the badgers; and one of the 
remarkable and characteristic sliunks is separated by Dr. J. E. Gray as a genus-Spilogale. In the American family Procyonidæe, a peculiar genus (Bassaris) is found in California and Texas, extending south along the mountains of Mexico and Guatemala. Eumetopias, and Halicyon, are seals confined to the west coast of Nortl America. The Bovidx, or hollow-horned ruminants, contain three peculiar forms; Antilocapra, the remarkable prong-buck of the Rocky Mountains ; Aplocerus, a goatlike antelope; and Ovibos, the musk-sheep, confined to Arctic America and Greenland. Among the Rodents are many peculiar genera: Neotoma, Sigmodon, and Fiber, belong to the Muridæ, or rats; Juculus to the Dipodidæ, or jerboas. The very distinct family Saccomyidce, or pouched rats, which have peculiar cheek pouches, or a kind of outer hairy mouth, consists of five genera all confined to this region, with one of doubtful affinities in Trinidad and Central America. In the squirrel family (Sciuridæ), Cynonys, the prairie-dogs, are peculiar; and Tamias, the ground squirrel, is very characteristic, though found also in North Asia. Haploodon, or sewellels, consisting of two species, forms a distinct family; and Ercthizon is a peculiar form of tree porcupine (Cercolabidæ). True mice and rats of the genus Mus are not indigenous to North America, their place being supplied by a distinct genus (Hesperomys), confined to the American continent.

Birds.-The genera of birds absolutely peculiar to the Nearctic region are not very numerous, because, there being no boundary but one of climate between it and the Neotropical region, most of its characteristic forms enter a short distance within the limits we are obliged to concede to the latter. Owing also to the severe winter-climate of a large part of the region (which we know is a comparatively recent phenomenon), a large proportion of its birds migrate southwards, to pass the winter in the West-Indian islands or Mexico, some going as far as Guateinala, and a few even to Venezuela.

In our chapter on extinct animals, we have shown, that there is good reason for believing that the existing union of North and South America is a quite recent occurrence; and that the 
separation was effected by an arm of the sea across what is now Nicaragua, with perhaps another at Panama. This would leave Mexico and Guatemala joined to North America, and forming part of the Nearctic region, although no doubt containing many Neotropical forms, which they had received during earlier continental periods; and these countries might at other times have been made insular by a strait at the isthmus of Tehuantepec, and have then developed some peculiar species. The latest climatal changes have tended to restrict these Neotropical forms to those parts where the climate is really tropical; and thus Mexico has attained its present strongly marked Neotropical character, although deficient in many of the most important groups of that region.

In view of these recent changes, it seems proper not to draw any decided line between the Nearctic and Neotropical regions, but rather to apply, in the case of each genus, a test which will show whether it was probably derived at a comparatively recent date from one region or the other. The test referred to, is the existence of peculiar species of the genus, in what are undoubtedly portions of ancient North or South America. If, for example, all the species of a genus occur in North America, some, or even all, of them, migrating into the Neotropical region in winter, while there are no peculiar Neotropical species, then we must class that genus as strictly Nearctic; for if it were Neotropical it would certainly have developed some peculiar resident forms. Again, even if there should be one or two resident species peculiar to that part of Central America north of the ancient dividing strait, with an equal or greater number of species ranging over a large part of Temperate North America, the genus must still be considered Nearctic. Examples of the former case, are Helminthophaga and Myiodioctes, belonging to the Mniotiltidæ, or wood-warblers, which range over all Temperate North America to Canada, where all the species are found, but in each case one of the species is found in South America, probably as a winter migrant. Of the latter, are Ammodramus and Junco (genera of finches), which range over the whole United States, but each have one peculiar species in Guatemala. These 
may be claimed as exchusively Nearctic genera, on the ground that Guatemala was recently Nearetic; and is now really a transition territory, of which the lowlands have been invaded and taken exclusive possession of by a Neotropical fama, while the highlands are still (in part at least) occupied by Nearctic forms.

In his article on "Birds," in the new edition of the "Encyclopædia Britannica" (now publishing), Professor Newton points out, that the number of peculiar genera of Nearctic birds is much less than in each of the various sub-divisions of the Neotropical region; and that the total number of genera is also less, while the bulk of them are common either to the Neotropical or Palæarctic regions. This is undoubtedly the case if any fixed geographical boundary is taken; and it would thus seem that the "Nearetic" should, in birds, form a sub-region only. But, if we define "Nearctic genera" as above inclicated, we find a considerable amount of speciality, as the following list will show. The names not italicised are those which are represented in Mexico or Guatemala by peculiar species:-

\section{List of Typical Nearctic Genera of Land Birds.}
1. Oreoscoptes
2. Harporhynchus
3. Sicelia
4. Chamea
5. Catherpes
6. Salpinctus
7. Pzaltriparus
8. Auriparus
9. Gymnolitta
10. Picicorvus
11. Mniotilta.
12. Oporornis
13. Icteria
14. Helmintherus
15. Helminthophaga
16. Myiodioctes
17. Phanopepla
18. Xanthocephalus
19. Scolecophagus
20. Pipilo
21. Junco
22. Melospiza
23. Spizella
24. Passerculus
25. Pocecetes
26. Ammodiomus
27. Cyanospiza
28. Pyrrhuloxia
29. Calamospi:a
30. Chondestes
31. Centronyx
32. Neocoryss
33. Empidias
34. Sphyrapicus
35. Hylatomus
36. Trochilus
37. Atthis
38. Ectopistes
39. Centroccrers
40. Pedincertes
41. Cupidonia
? Ortyx
42. Orcortyx
43. Lophortyx
44. Callipepla
45. Cyrtonyx
46. Meleagris
47. Micrathene

The above are all groups which are either wholly Nearctic or typically so, but entering more or less into the debatable ground of the Neotropical region; though none possess any peculiar species in the ancient Neotropical land south of Nicaragua. But we hare, besides these, a number of genera which we are accus- 
tomed to consider as typically European, or Palrarctic, having representatives in North America; although in many cases it would be more correct to say that they are Nearctic genera, represented in Europe, since America possesses more species than Europe or North Asia. T'he following is a list of genera which have as much right to be considered typically Nearctic as Palæarctic:-
1. Regulus
2. Certhia
3. Sitta
4. Parus
5. Lophophanes
6. Lanius
7. Perisoreus
8. Pica

\author{
9. Corvus \\ 10. Ampelis \\ 11. Loxia \\ 12. Pinicola \\ 13. Linota \\ 14. Passerelia \\ 15. Leucostictc.
}

16. Euspiza

17. Plectrophanes

18. Tetrao

19. Lagopus

20. Nyctala

21. Archibuteo

22. Haliæetus

The seven genera italicized have a decided preponderance of Nearctic species, and have every right to be considered typically Nearctic; while the remainder are so well represented by peculiar species, that it is quite possible many of them may have originated here, rather than in the Palæarctic region, all alike being quite foreign to the Neotropical.

On the whole, then, we have 47 in the first and 7 in the second table, making 54 genera which we may fairly class as typically Nearctic, ont of a total of 168 genera of land birds, or nearly one-third of the whole. This is an amount of peculiarity which is comparable with that of either of the less isolated regions; and, combined with the more marked and more exclusively peculiar forms in the other orders of vertebrates, fully establishes Temperate North America as a region, distinct alike from the Neotropical and the Palæarctic.

Reptiles.-Although temperate climates are always comparatively poor in reptiles, a considerable number of genera are peculiar to the Nearctic region. Of suakes, there are, Conophis, Chilomeniscus, Pituophis, and Ischnognathus, belonging to the Colubridæ; Farancia, and Dimodes, Homalopsidæ; Lichanotus, one of the Pythonidæ; Cenchris, Crotalophorus, Uropsophorus, and Crotalus, belonging to the Crotalidæ or rattlesnakes.

Of Lizards, Chirotes, forming a peculiar family ; Ophisaumes, 
the curious glass-snake, belonging to the Zonuridæ; with Phrynosoma (commonly called horned toads), Callisaurus, Uta, Euphryne, Uma, and Holbrookia, genera of Iguanidæ.

Testudinidie, or Tortoises, show a great development of the gentus Emys; with Aromochelys and Chclydra as peculiar genera.

Amphibia.-In this class the Nearctic region is very rich, possessing representatives of nine of the families, of which two are peculiar to the region, and there are no less than fifteen peculiar genera. Siren forms the family Sirenidæ; Menobranchus belongs to the Proteidx; Ampliuma is the only representative of the Amphiumidæ; there are nine peculiar genera of Salamandrida. Among the tail-less batrachians (frogs and toads) we have Scaphiopus, belonging to the Alytida; Pseudacris to the Hylidæ; and Acris to the Polypedatidæ.

Fresh-uvater Fishcs.-The Nearctic region possesses no less than five peculiar family types, and twenty-four peculiar genera of this class. The families are Aphredoderidæ, consisting of a single species found in the Eastern States; Percopsidæ, founded on a species peculiar to Lake Superior; Heteropygii, containing two genera peculiar to the Eastern States; Hyodontida and Amiidæ, each consisting of a single species. The genera are as follows: Parulabrax, found in California; Huro, peculiar to Lake Huron; Pileoma, Boleosoma, Bryttus and Pomotis in the Eastern States-all belonging to the perch family. Hypodelus and Noturus, belonging to the Siluridx. Thaleichthys, one of the Salmonidie peculiar to the Columbia river. Moxostoma, Pimephales, Hyborhynchus, Rhinichthys, in the Eastern States; Ericymba, Exoglossum, Lcucosomus, and Carpiodcs, more widely distributed; Cochlognathus, in Texas; Mylaphorodon and Orthodon, in California; Meda, in the river Gila; and Acrochilus, in the Columbia river-all belonging to the Cyprinidæ. Scaphirhynchus, found only in the Mississippi and its tributaries, belongs to the sturgeon family (Accipenseridæ).

Summary of Nearctic Vertebrata. - The Nearctic region possesses 24 peculiar genera of mammalia, 49 of birds, 21 of reptiles, and 29 of fresh-water fishes, making 123 in all. Of these 70 are mannmals and land-birds, out of a total of 242 
genera of these groups, a proportion of about two-sevenths. This is the smallest proportion of peculiar genera we have found in any of the regions; but many of the genera are of such isolated and exceptional forms that they constitute separate families, so that we have no less than 12 families of vertebrata confined to the region. The Palæarctic region has only 3 peculiar families, and even the Oriental region only 12; so that, judged by this test, the Nearctic region is remarkably well characterized. We must also remember that, owing to the migration of many of its peculiar forms during the Glacial period, it has recently lost some of its speciality; and we should therefore give some weight to the many characteristic groups it possesses, which, though not quite peculiar to it, form important features in its fauna, and help to separate it from the other regions with which it has been thought to be closely allied. It is thus well distinguished from the Palæaretic region by its Procyonidæ, or racoons, Hesperomys, or vesper mice, and Didelphys, or opossums, among Mammalia; by its Vireonidæ, or greenlets, Nniotiltidæe, or wood-warblers, Icteridæ, or hang-nests, Tyrannidæ, or tyrant shrikes, and Trochilidæ, or humming-birds, among birds, families which, extending to its extreme northern limits must be held to be as truly characteristic of it as of the Neotropical region; by its Teidæ, Iguanidæ, and Cinosternum, among reptiles; and by its Siluridæ, and Lepidosteidæ, among fishes. From the Neotropical region it is still more clearly separated, by its numerous insectivora; by its bears; its Old World forms of ruminants ; its beaver ; its numerous Arvicolce, or voles; its Sciuropterus, or flying squirrels; Tamias, or groundsquirrels; and-Lagomys, or marmots, among mammals; its numerous Paridæ, or tits, and Tetraonidæ, or grouse, among birds; its Trionychidæ among reptiles; its Proteidæ, and Salamandridæ, among Amphibia ; and its Gasterosteidre, Atherinidæ, Esocidæ, Umbridæ, Accipenseridæ, and Polydontidæ, among fishes.

These characteristic features, taken in conjunction with the absolutely peculiar groups before enumerated, demonstrate that the Nearctic region cannot with propriety be combined with 
any other. Though not very rich, and having many disadvantages of climate and of physical condition, it is yet sufficiently well characterized in its zoological features to rank as one of the well-marked primary divisions of the earth's surface.

There is one other consideration bearing on this question which should not be lost sight of. In establishing our regions we have depended wholly upon their now possessing a sufficient number and variety of animal forms, and a fair proportion of peculiar types; but when the validity of our conclusion on these grounds is disputed, we may supplement the evidence by an appeal to the past history of the region in question. In this case we find a remarkable support to our views. During the whole Tertiary period, North America was, zoologically, far more strongly contrasted with South America than it is now; while, during the same long series of ages, it was always clearly separated from the Eastern hemisphere or the Paliearctic region by the exclusive possession of important families and numerous genera of Mammalia, as shown by our summary of its extinct fauna in Chapter VII. Not only may we claim North America as now forming one of the great zoological regions, but as having continued to be one ever since the Eocene period.

\section{Insects.}

In describing the Palæarctic and Neotropical regions, many of the peculiarities of the insect-fauna of this region have been incidentally referred to; and as a tolerably full account of the distribution of the several families is given in the Fourth Part of our work (Chapter XXI.), we shall treat the subject very briefly here.

Lepidoptera.-The butterflies of the Nearctic region have lately been studied with much assiduity, and we are now able to form some idea of their nature and extent. Nearly 500 species belonging to about 100 genera have been described; showing that the region, which a few years ago was thought to be very poor in species of butterflies, is really much richer than Europe, and probably about as rich as the more extensive Palæaretic region. There is, however, very little speciality in the 
forms. A considerable number of Neotropical types enter the southern States; but there are hardly any peculiar genera, except one of the Lycrnidre and perhaps a few among the Hesperidæe. The most conspicuous feature of the region is its fine group of Papilios, belonging to types ( $P$. tumus and $P$. troilus) which are characteristically Nearctic. It is also as rich as the Palrearctic region in some genera which we are accustomed to consider as pre-eminently European; such as Argynnis, Mclitcea, Grapta, Chionabas, and a few others. Still, we must acknowledge, that if we formed our conclusions from the butterflies alone, we could hardly separate the Nearctic from the Palæarctic region. This identity probably dates from the Miocene period; for when our existing arctic regions supported a luxuriant vegetation, butterflies would have been plentiful; and as the cold came on, these would move southwards both in America and Europe, and, owing to the long continuance of the generic types of insects, would remain little modified till now.

Coleopter a.-Only a few indications ean be given of the peculiarities of the Nearctic coleoptera. In Cicindelidæ the region possesses, besides the cosmopolite Cicindela, four other genera, two of which-Amblychile and Omus-are peculiar to the West Coast and the Rocky Mountains. Of Carabidre it possesses Dicalus, Pasimachus, Eurytrichus, Sphcroderus, Pinacodera, and a number of smaller genera, altogether peculiar to it; Helluomorpha, Galerita, Callida, and Tetragonoderus, in common with South America; and a large number of characteristic European forms.

The Lucanidie are all of European types. The region is poor in Cetoniidre, but has representatives of the South American Euphoria, as well as of four European genera. Of Buprestidie it has the South American Actenodes; a single species of the Ethiopian and Eastern Belionotc, in California; and about a dozen other genera of European and wide distribution.

Among Longicorns it possesses fifty-nine peculiar genera, representatives of five Neotropical, and thirteen Palearctic genera; as well as many of wider distribution. Prionus is the chief representative of the Prionidr; Lepture and Crossidius of the 
Cerambycidæ; Leptostylus, Liopus, Graphidurus, and Tetrcopes, of the Lamiidre, the latter genus being confined to the region.

\section{Terrestrial and Fluviatile Mollusce.}

The land-shells of temperate North America almost all belong to the Inoperculate or Pulmoniferous division; the Operculata being represented only by a few species of Helicina and Truncatella, chiefly in the Southern States. According to Mr. Binney's recent "Catalogue of the Terrestrial Air-breathing Mollusks of North America," the fauna consists of the following genera:-Glandina (6 sp.); Macrocyclis (5 sp.) ; Zonites (37 sp.); Vitrina (4 sp.); Limax (5 sp.); Arion (3 sp.); Ariolimax (3 sp.); Prophysaon (1 sp.) ; Binneia (1 sp.) ; Hemiphillia (1 sp.) ; Patula (16 sp.); Helix (80); Holospira (2 sp.); Cylindrella (2 sp.); Macroceramus (2 sp.); Bulimulus (8 sp.); Cionella (2 sp.); Stenogyra (4 sp.); Pupa (19 sp.); Strophia (1 sp.); Vertigo (6 sp.); Liguus (1 sp.); Orthalicus (2 sp.); Punctum (1 sp.); Succinca (26 sp.); Tebennophorus (1 sp.); Pallifera (1 sp.); Veronicella (2 sp.).

All the larger genera range over the whole region, but the following have a more restricted distribution; Macrocyclis has only one species in the East, the rest being Californian or Central; Ariolimax, Prophysaon, Binneia, and Hemiphillia, are confined to the Western sub-region. Lower California has affinities with Mexico, 18 species being peculiar to it, of which two are true Bulimi, a genus unknown in other parts of the region. The Central or Rocky Mountain sub-region is chiefly characterised by six peculiar species of Patula. The Eastern sub-region is by far the richest, nine-tenths of the whole number of species being found in it. The Alleghany Mountains form the richest portion of this sub-region, possessing nearly half the total number of species, and at least 24 species found nowhere else. The southern States have also several peculiar species, but they are not so productive as the Alleghanies. The Canadian sub-region possesses 32 species, of which nearly half are northern forms more or less common to the whole Arctic regions, and several of this character have spread southwards all 
over the United States. Species of Vitrina, Zonites, Pupa, and Suecined, are found in Greenland; and Eastern Palæarctic species of Vitrina, Patula, and Pupa occur in Alaska. Nore than 30 species of shells living in the Easteru States, are found fossil in the Post-Pliocene deposits of the Ohio and Mississippi.

Fresh-water Shells.-North America surpasses every other part of the globe in the number and variety of its fresh-water mollusca, both univalve and bivalve. The numbers up to 1866 were as follows:-Melanialæ, 380 species; Paludinidæ, 58 species; Cycladidæ, 44 species; and Unionidæ, 552 species. The last family had, however, increased to 832 species in 1874, according to Dr. Isaac Lea, who has made them his special study; but it is probable that many of these are such as would be considered varieties by most conchologists. Many of the species of Unio are very large, of varied forms, and rich internal colouring, and the group forms a prominent feature of the Nearctic fauna. By far the larger proportion of the fresh-water shells inhabit the Eastern or Alleghany sub-region; and their great development is a powerful argument against any recent extensive submergence beneath the ocean of the lowlands of North America.

\section{The Nearetie Sub-regions.}

The sub-divisions of the Nearctic region, although pretty clearly indicated by physical features and peculiarities of climate and vegetation, are by no means so strongly marked out in their zoology as we might expect. The same genera, as a rule, extend over the whole region; while the species of the several sub-regions are in most cases different. Even the vast range of the Rocky Mountains has not been an effectual barrier against this wide dispersal of the same forms of life; and although some important groups are limited by it, these are exceptions to the rule. Even now, we find fertile valleys and plateaus of moderate elevation, penetrating the range on either side; and both to the north and south there are passes which can be freely traversed by most animals during the summer. Previous to the glacial epoch there was probably a warm period, when every part of the range supported an abundant and varied 
fauna, which, when the cold period arrived, would descend to the lowlands, and people the country to the east, west, and south, with similar forms of life.

The first, and most important sub-division we can make, consists of the Eastern United States, extending across the Mississippi and the more fertile prairies, to about the $100^{\circ}$ th. meridian of west longitude, where the arid and almost desert country commences. Southwards, the boundary bends towards the coast, near the line of the Brazos or Colorado rivers. To the north the limits are undefined; but as a considerable number of species and genera occur in the United States but not in Canada, it will be convenient to draw the line somewhere near the boundary of the two countries, except that the district between lakes Huron and Ontario, and probably Nova Scotia, may be included in the present sub-region. As far west as the Mississippi, this was originally a vast forest country; and it is still well wooded, and clothed with a varied and luxuriant vegetation.

The next, or Central sub-region, consists of the dry, elevated, and often arid district of the Rocky Mountains, with its great plateaus, and the barren plains of its eastern slope; extending northwards to near the commencement of the great forests north of the Saskatchewan, and southward to the Rio Grande del Norte, the Gulf of California, and to Cape St. Lucas, as shown on our maps. This sub-region is of an essentially desert character, although the higher valleys of the Rocky Mountains are often well wooded, and in these are found some northern and some western types.

The third, or Californian sub-region, is small, but very luxuriant, occupying the comparatively narrow strip of country between the Sierra Nevada and the Pacific. To the north it may include Vancouver's Island and the southern part of British Columbia, while to the south it extends to the head of the Gulf of California.

The fourth division, comprises the remainder of North America; and is a country of pine forests, and of barren wastes towards the Arctic Ocean. It has fewer peculiar species to characterise it than any other, but it possesses several characteristic arctic 
forms, while many of those peculiar to the south are absent; so that it is a very convenient, if it should not be considered an altogether natural, sub-region.

We will now give an outline of the most important zoological features of each of these divisions, taking them in the order in which they are arranged in the Fourth Part of this work. California comes first, as it has some tropical forms not found elsewhere, and thus forms a transition from the Neotropical region.

\section{The Western or Califomian Sub-region.}

This small district possesses a fruitful soil and a highly favourable climate, and is, in proportion to its extent, perhaps the richest portion of the continent, both zoologically and botanically. Its winters are far milder than those of the Eastern States in corresponding latitudes; and this, perhaps, has enabled it to support several tropical forms which give a special character to its fauma. It is here only, in the whole region, that bats of the families Phyllostomidre and Noctilionidæ, and a serpent of the tropical family, Pythonidæ, are found, as well as several Neotropical forms of birds and reptiles.

Mammalia.-The following genera are not found in any other part of the Nearctic region. Mlacrotus (Phyllostomidæ), one species in California; Antrozous (Vespertilionidæ), one species on the West Coast; Urotrichus (Talpidæ) one species in British Columbia ; sub-genus Nesorex (Soricidx), one species in Oregon; Bassaris (Procyonidæ), California ; Enhydra (Mustelidæ), Pacific Coast; Morunga (Phocidx), California ; Haploodon (Haploodontidæ) a rat-like animal, allied to the beavers and marmots, and constituting a peculiar family found only in California and British Columbia. The following characteristic Nearctic forms also extend into this sub-region :-Taxidea, Procyon, Didelphys, Sciuropterus, Tamias, Spermophilus, Dipodomys, Perognathus, Jaculus.

Birds.-Few genera of birds are quite peculiar to this subregion, since most of the Western forms extend into the central district, yet it has a few. Glaucidium, a genus of Owls, is confined 
(in the Nearctic region) to California; Chamce, a singular form allied to the wrens, and forming a distinct family, is quite peculiar; Geococcyx, a Neotropical form of cuckoo, extends to California and Southern Texas. The following genera are very characteristic of the sub-region, and some of them almost confined to it: Myiadestes (Sylviidæ); Psaltriparus (Paridæ); Cyanocitta, Picicorvus (Corvidæ); Hesperiphona, Peuccea, Chondestes (Fringillidæ); Selasphorus, Atthis (Trochilidæ); Columba, Melopelic (Columbidx); Oreortyx (Tetraonidæ).

Reptiles.-The following genera are not found in any other part of the Nearctic region: Charina (Tortricidæ); Lichanotus (Pythonidæ); Gerrhonotus (Zonuridæ); Phyllodactylus (Geckotidæ); Anolius and Tropidolepis (Iguanidæ). Sceloporus (Iguanidæ) is only found elsewhere in Florida. All the larger North American groups of lizards and snakes are also represented here; but in tortoises it is deficient, owing to the absence of lakes and large river's.

Amphibia.-California possesses two genera of Salamandridæ, Aneides and Heredia, which do not extend to the other subregions.

Fresh-water Fish.-There are two or three peculiar genera of Cyprinidæ, but the sub-region is comparatively poor in this group.

Plate XVIII. Illustrative of the Zoology of California and the Rocky Mountains. - We have chosen for the subject of this illustration, the peculiar Birds of the Western mountains. The two birds in the foreground are a species of grouse (Pediocates Columbianus), entirely confined to this sub-region; while the only other species of the genus is found in the prairies north and west of Wisconsin, so that the group is peculiar to northern and western America. The crested birds in the middle of the picture (Oreortyx picta), are partridges, belonging to the American subfamily Odontophorinæ. This is the only species of the genus which is confined to California and Oregon. The bird at the top is the blue crow (Gymnokitta cyanocephala), confined to the Rocky Mountains and Sierra Nevada from New Mexico and Arizona northwards, and more properly belonging to the Central 
PLATE XVIII.

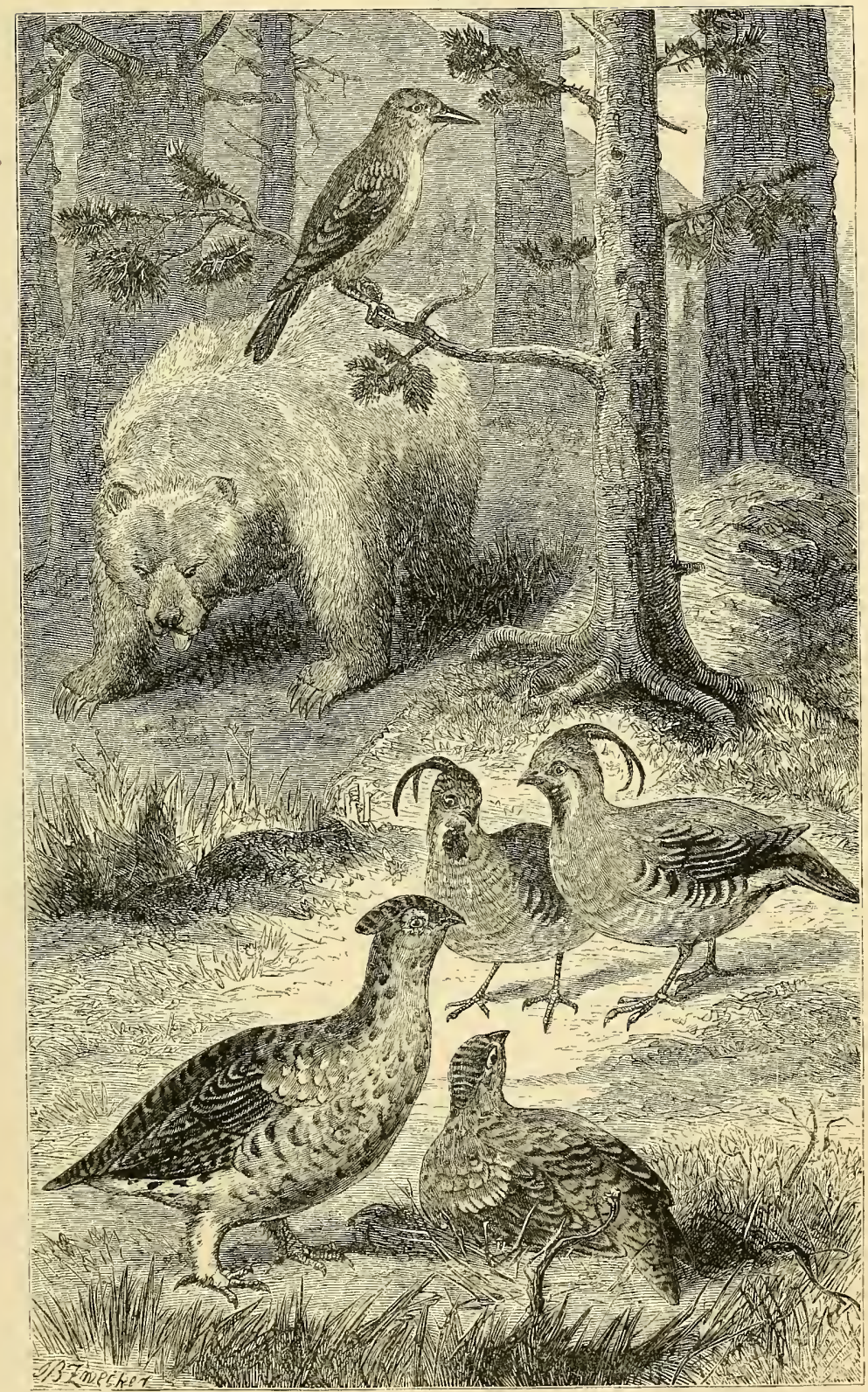

SCENE IN CALIFORNIA, WITH SOHE CHARACTERISTIC BIRDS. 

sub-region. It is allied to the European nutcracker; but according to the American ornithologist, Dr. Cones, has also resemblances to the jays, and certainly forms a distinct genus. The grizzly bear (Ursus ferox) in the background, is one of the characteristic animals of the Californian highlands.

\section{The Gentral, or Rocky Mountain Sub-region.}

This extensive district is, for the greater part of its extent, from 2,000 to 5,000 feet above the sea, and is excessively arid; and, except in the immediate vicinity of streams and on some of the higher slopes of the mountains, is almost wholly treeless. Its zoology is therefore peculiar. Many of the most characteristic genera and families of the Eastern States are absent; while a number of curious desert and alpine forms give it a character of its own, and render it very interesting to the naturalist.

Mammalia.-The remarkable prong-horned antelope (Antilocapra), the mountain goat (Aplocerus), the mountain sheep or bighorn (Ovis montana), and the prairie-dog (Cynomys), one of the Rodentia, are peculiar to this sub-region; while the farnily of the Saccomyidæ, or pouched rats, is represented by many forms and is very characteristic. Here is also the chief home of the bison. The glutton (Gulo) and marmot (Lagomys) enter it from the north; while it has the racoon (Procyon), flying squirrel (Sciuropterus), ground squirrel (Tamias), pouched marmot (Spermophilus) and jumping mouse (Jaculus) in common with the countries east or west of it.

Plate XIX. Illustrative of the Zoology of the Central Plains or Prairies.-We here introduce four of the most characteristic mammalia of the great American plains or prairies, three of them being types confined to North America. The graceful animals on the left are the prong-horned antelopes (Antilocapra americanc), whose small horus, though hollow like those of the antelopes, are shed annually like those of the deer. To the right we have the prairie-dogs of the trappers (Cynomys ludovicianus) which, as will be easily seen, are rodents, and allied to the marmots of the European Alps. Their burrows are numerous on the prairies, and the manner in which they percl

VOL. II. 
themselves on little mounds and gaze on intruders, is noticed by all travellers. On the left, in the foreground, is one of the extraordinary pouched rats of America (Geomys bursarius). These are burrowing animals, feeding on roots; and the mouth is, as it were, double, the outer portion very wide and hairy, behind which is the small inner mouth. Its use may be to keep out the earth from the mouth while the animal is gnawing roots. A mouth so constructed is found in no other animals but in these North American rats. In the distance is a herd of bisons (Bison americanus), the typical beast of the prairies.

Birds.-This sub-region has many peculiar forms of birds, both residents, and migrants from the south or north. Among the peculiar resident species we may probably reckon a dipper, (Cinclus); Salpinctes, one of the wrens; Poospiza, Calamospiza, genera of finches; Picicortus, Gymnokitta, genera of the crow family; Centrocercus and Pediocetes, genera of grouse. As winter migrants from the north it has Lcucosticte and Plectrophanes, genera of finches; Perisoreus, a genus of the crow family; Picoides, the Arctic woodpecker; and Lagopus, ptarmigan. Its summer migrants, many of which may be resident in the warmer districts, are more numerous. Such are, Oreoscoptes, a genus of thrushes; Campylorhynchus and Catherpes, wrens; Paroides, one of the tits; Phcenopepla, allied to the waxwing; Embernagra and Spermophila, genera of finches; Pyrocephalus, one of the tyrant shrikes; Callipepla and Cyrtonyx, American partridges. Besides these, the more widely spread genera, Harporhynchus, Lophophanes, Carpodacus, Spizella, and Cyanocitta, are characteristic of the central district, and two genera of humming-birds-Atthis and Selasphorus-only occur here and in California. Prof. Baird notes 40 genera of birds which are represented by distinct allied species in the western, central, and eastern divisions of the United States, corresponding to our sub-regions.

It is a curious fact that the birds of this sub-region should extend across the Gulf of California, and that Cape St. Lucas, at the southern extrenity of the peninsula, should be decidedly more "Central" than "Californian" in its ornithology. Prof. 


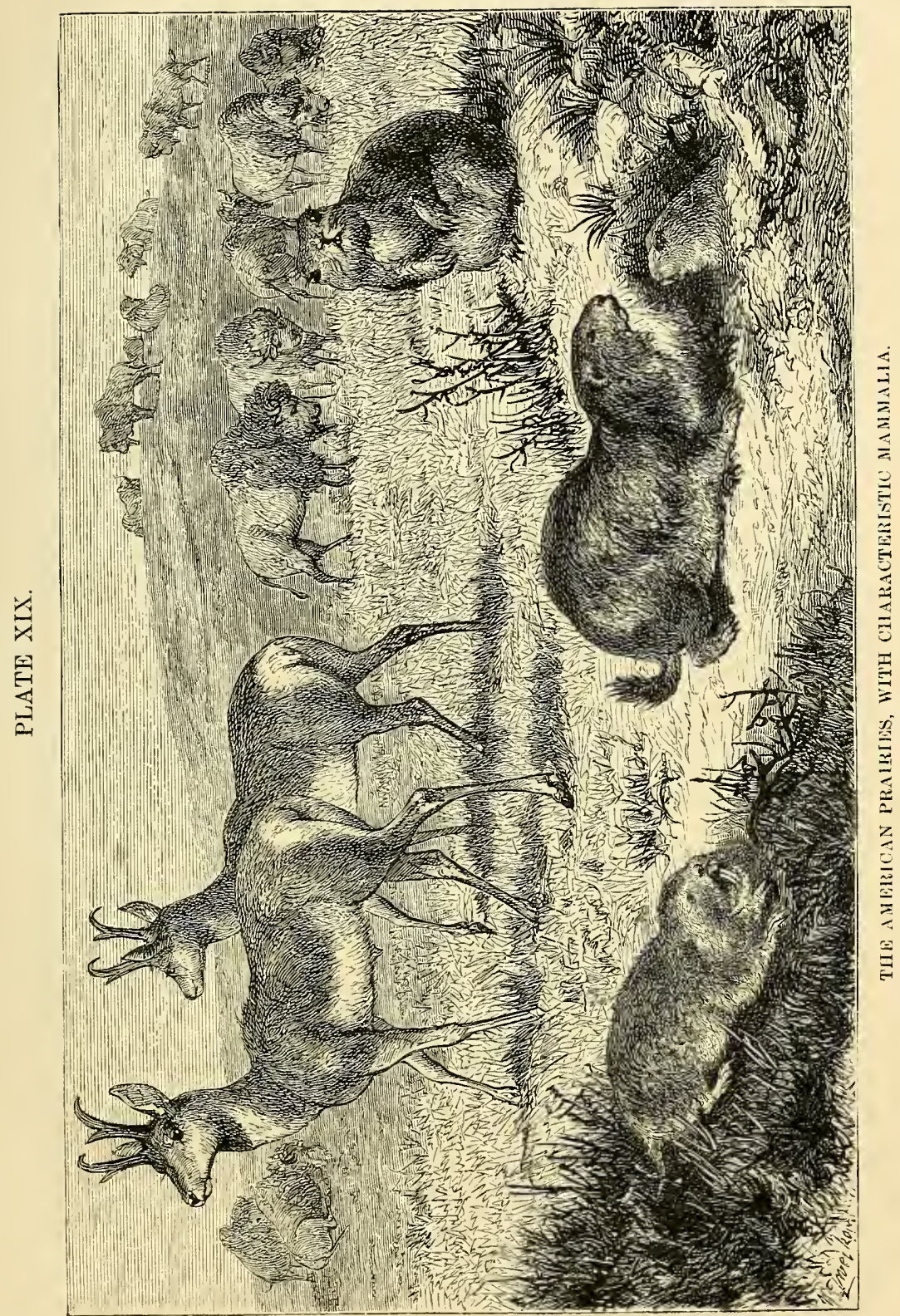



Baird says, that its fauna is almost identical with that of the Gila River, and has hardly any relation to that of Upper California. It possesses a considerable number (about twenty) of peculiar species of birds, but all belong to genera characteristic of the present sub-region; and there is no resemblance to the birds of Mazatlan, just across the gulf in the Neotropical region.

Reptiles, Amphibia, and Fishes.-A large number of snakes and lizards inhabit this sub-region, but they have not yet been classified with sufficient precision to enable us to make much use of them. Among lizards, Iguanidæ, Geckotidæ, . Scincidæ, and Zonuridæ, appear to be numerous; and many new genera of doubtful value have been described. Among snakes, Calamariidæ, Colubridæ, and Crotalidæ are represented. Among Amphibia, Siredon, one of the Proteidæ, is peculiar. The rivers and lakes of the Great Central Basin, and the Colorado River, contain many peculiar forms of Cyprinidæ.

\section{The Eastern or Alleghany Sub-region.}

This sub-region contains examples of all that is most characteristic of Nearctic zoology. It is for the most part an undulating or mountainous forest-clad country, with a warm or temperate climate, but somewhat extreme in character, and everywhere abounding in animal and vegetable life. To the west, across the Mississippi, the country becomes more open, gradually rises, becomes much drier, and at length merges into the arid plains of the central sub-region. To the south, in Georgia, Florida, and Louisiana, a sub-tropical climate prevails, and winter is almost unknown. To the north, in Michigan and New England, the winters are very severe, and streams and lakes are frozen for months together. These different climates, however, produce little effect on the forms of animal life; the species to some extent change as we go from north to south, but the same types everywhere prevail. This portion of the United States, having been longest inhabited by Europeans, has been more thoroughly explored than other parts of North America; and to this more complete knowledge its superior zoological richness 
may be to some extent dne; but there can be little doubt that it is also positively, and not merely relatively, more productive in varied forms of animal life than either of the other sub-regions.

Mammalia.-There seems to be only one genus absolutely peculiar to this sub-region-the very remarkable Condylura, or star-nosed mole, only found from Pennsylvania to Nova Scotia, and as far as about $94^{\circ}$ west longitude. It also has opossums (Didelphys) in common with California, and three out of four species of Scalops, a genus of moles; as well as the skunk (Mephitis), Ameriean badger (Taxidea), racoon (Procyon), pouehed - rat (Geomys), beaver rat (Fiber), jumping mouse (Jaculus), tree porcupine (Erethizon), and other eharaeteristie Nearetie forms.

Birds.-The birds of this sub-region have been earefully studied by American naturalists, and many interesting facts aseertained as to their distribution and migrations. About 120 species of birds are peculiar to the east çoast of the United States, but only about 30 of these are residents all the year round in any part of it; the bird population being essentially a migratory one, coming from the north in winter and the sonth in summer. The largest number of speeies seems to be congregated in the district of the Alleghany mountains. A considerable proportion of the passerine birds winter in Central Ameriea and the West Indian Islands, and go to the Middle States or Canada to breed; so that even the luxuriant Southern States do not possess many birds which may be ealled permanent residents. Thus, in East Pennsylvania there are only 52, and in the district of Columbia 54 species, found all the year round, out of about 130 which breed in these localities; very much below the number which permanently reside in Great Britain.

This sub-region is well characterised by its almost exclusive possession of Ectopistes, the celebrated passenger pigeon, whose enormous flocks and breeding places have been so often described; and Cupidonia, a remarkable genus of grouse. The only Nearctic parrot, Conurus carolinensis, is found in the Southeru States; as well as Crotophaga, a South American genus usually associated with the euckoos. Helmintherus and 
Oporornis, genera of wood-warblers, may be considered to be peculiar to this sub-region, since in each case only one of the two species migrates as far as Central America; while two other genera of the same family, Siurus and Setophaga, as well as the finch genus, Euspizc, do not extend to either of the western sub-regions. Parus, a genus of tits, comes into the district from the north; Otocorys, an alpine lark, and Coturniculus, an American finch, from the west; and such characteristic Nearctic genera as Antrostomus (the whip-poor-will goatsuckers); Helminthophaga, Dendrece, and Myiodioctes (wood-warblers); Vireo (greenlets); Dolichonyx (rice-bird); Quiscalus (troupial); Meleagris (turkey); and Ortyx (Americall partridge), are wide-spread and abundant. In Mr. J. A. Allen's elaborate and interesting paper on the birds of eastern North America, he enumerates 32 species which breed only in the more temperate portions of this province, and may therefore be considered to be especially characteristic of it. These belong to the following genera:-Turdus, Galeoscoptes, Harporhynchus, Sialia, Dendreca, Wilsonia, Pyranga, Vireo, Lanivireo, Lophophanes, Coturniculus, Ammodromus, Spizella, Euspiza, Hedymeles, Cyanospiza, Pipilo, Cardinalis, Icterus, Corvus, Centurus, Melanerpes, Antrostomus, Coccyzus, Ortyx, and Cupidonia.

Reptiles.-In this class the Eastern States are rich, possessing many peculiar forms not found in other parts of the region. Among snakes it has the genera Farancia and Dimodes belonging to the fresh-water snakes (Homalopsidæ); the South American genus Elaps; and 3 genera of rattlesnakes, Cenchris, Crotalophorus, and Crotalus. The following genera of snakes are said to occur in the State of New York:-Coluber, Tropidonotus, Leptophis, Calamaria, Heterodon, Trigonocephalus, Crotalus, Psammophis, Helicops, Rhinostoma, Pituophis, and Elaps.

Among lizards, Chirotes, forming a peculiar fanily of Amphisbenians, inhabits Missouri and Mexico; while the remarkable glass-snake, Ophisaurus, belonging to the family Zonuridæe, is peculiar to the Southern States; and the South American Sphcerodactylus, one of the gecko family, reaches Florida. Other genera which extend as far north as the State of New 
York are, Scincus, Tropidolepis, Plestiodon, Lygosoma, Ameiva, and Phrynosoma.

Tortoises, especially the fresh-water kind, are very abundant; and the genera Aromochclys, Chelydra, Terrapene, and Trionyx, are nearly, if not quite, confined to this division of the region.

Amphibia.-Almost all the remarkable forms of Urodela, or tailed batrachians, peculiar to the region are found here only; such as Siren and Pseudobranchus, constituting the family Sirenidæ; Menobranchus, allied to the Proteus of Europe; Amphiuma, an eel-like creature with four rudimentary feet, constituting the family Amphiumidæ; Notopthalmus, Desmognathus, and Menopoma, belonging to the Salamandridæ; together with several other genera of wider range. Of Anura, or tail-less batrachians, there are no peculiar genera, but the Neotropical genus of toads, Engystoma, extends as far as South Carolina.

Fishes.-Owing to its possession of the Mississippi and the great lakes, almost all the peculiar forms of North American fishes are confined to this sub-region. Such are Perca, Pileoma, Huro, Bryttus, and Pomotis (Percidæ); the families Aphredoderidæ and Percopsidæ; several genera of Cyprinodontidæ and Cyprinidæ; and the family Polydontidæ.

\section{Islands of the Alleghany Sub-reyion.}

The Bermudas.-These islands, situated in the Atlantic, about 700 miles from the coast of Carolina, are chiefly interesting for the proof they afford of the power of a great variety of birds to cross so wide an extent of ocean. There are only 6 or 8 species of birds which are permanent residents on the islands, all common North American species; while no less than 140 species have been recorded as visiting them. Most of these are stragglers, many only noticed once; others appear frequently and in great numbers, but very few, perhaps not a dozen, come every year, and can be considered regular migrants. The permanent residents are, a greenlet (Vireo noveboracensis), the catbird (Galeoscoptes carolinensis), the blue bird (Sialia sialis), the cardinal (Cardinalis virginianus), the American crow (Corvus 
americanus), and the ground dove (Chamoepelia passerina). The most regular visitants are a kingfisher (Ceryle alcyon), the woodwagtail (Siurus noveboracensis), the rice-bird (Dolichonyx oryzivorus), and a moorhen (Gallinula galeata). Besides the American species, four European birds have been taken at the Bermudas: Saxicola cenanthe, Alauda arvensis (perhaps introduced), Crex pratensis, and Scolopax gallinago.

A common American lizard, Plestiodon longirostris, is the only land reptile found on the islands.

\section{The Sub-Arctic or Canadian Sub-region.}

This sub-region serves to connect together the other three, since they all merge gradually into it; while to the north it passes into the circumpolar zone which is common to the Palæarctic and Nearctic regions. The greater portion of it is an extensive forest-district, mostly of coniferæ; and where these cease towards the north, barren wastes extend to the polar ocean. It possesses several northern or arctic forms of Mammalia, such as the glutton, lemming, reindeer, and elk, which barely enter the more southern sub-regions; as well as the polar bear and arctic fox; but it also has some peculiar forms, and many of the most characteristic Nearctic types. The remarkable musk-sheep (Ovibos) is confined to this sub-region, ranging over a considerable extent of country north of the forests, as well as Greenland. It has been extinct in Europe and Asia since the Post-pliocene epoch. Such purely Nearctic genera as Procyon, Latax, Erethizon, Jaculus, Fiber, Thomomys, and Hesperomys, abound, many of them ranging to the shores of Hudson's Bay and the barren wastes of northern Labrador. Others, such as Blarina, Condylura, and Mephitis, are found only in Nova Scotia and various parts of Canada. About 20 species of Mammalia seem to be peculiar to this sub-region.

Plate XX. Illustrating the Zoology of Canada.-We have here a group of Mammalia characteristic of Canada and the colder parts of the United States. Conspicuous in the foreground is the skunk (Mephitis mephitica), belonging to a genus of the weasel family found only in America. This animal is 
celebrated for its power of ejecting a terribly offensive liquid, the odour of which is almost intolerable. The skunks are nocturnal animals, and are generally marked, as in the species represented, with conspicuous bands and patches of white. This enables them to be easily seen at night, and thus serves to warn larger animals not to attack them. To the left is the curious little jumping mouse (Jaculus hudsonins), the American representative of the Palæarctic jerboa. Climbing up a tree on the left is the tree porcupine (Erethizon dorsatus), belonging to the family Cercolabidæ, which represents, on the American continent, the porcupines of the old World. In the background is the elk or moose (Alces americanus), perhaps identical with the European elk, and the most striking inhabitant of the northern forests of America, as the bison is of the prairies.

Birds.-Although the Canadian sub-region possesses very few resident birds, the numbers which breed in it are perhaps greater than in the other sub-regions, because a large number of circumpolar species are found here exclusively. From a comparison of Mr. Allen's tables it appears, that more than 200 species are regular migrants to Canada in the breeding season, and nearly half of these are land-birds. Among them are to be found a considerable number of genera of the American families Tyrannidæ and Mniotiltidæ, as well as the American genera Sialia, Progne, Vireo, Cistothorus, Junco, Pipilo, Zonotrichia, Spizella, Melospiza, Molothrus, Agelous, Cyanura, Sphyrapicus, and many others; so that the ornithology of these northern regions is still mainly Nearctic in character. Besides these, it has such specially northern forms as Sumia (Strigidæ); Picoides (Picidæ); Pinicola (Fringillidæ); as well as Leucosticte, Plectrophanes, Perisoreus, and Lagopus, which extend further south, especially in the middle sub-region. No less than 212 species of birds have been collected in the new United States territory of Alaska (formerly Russian America), where a humming-bird (Selasphorus rufus) breeds. The great majority of these are typically American, including such forms as Colaptcs, Helminthophara, Siurus, Dendrceca, Myiodioctes, Passcrculus, Zonotrichia, Junco, Spizella, Melospizpa, Passcrella, Scoleopleregas, Pediocctes, and Bonasa; 
PLATE XX.

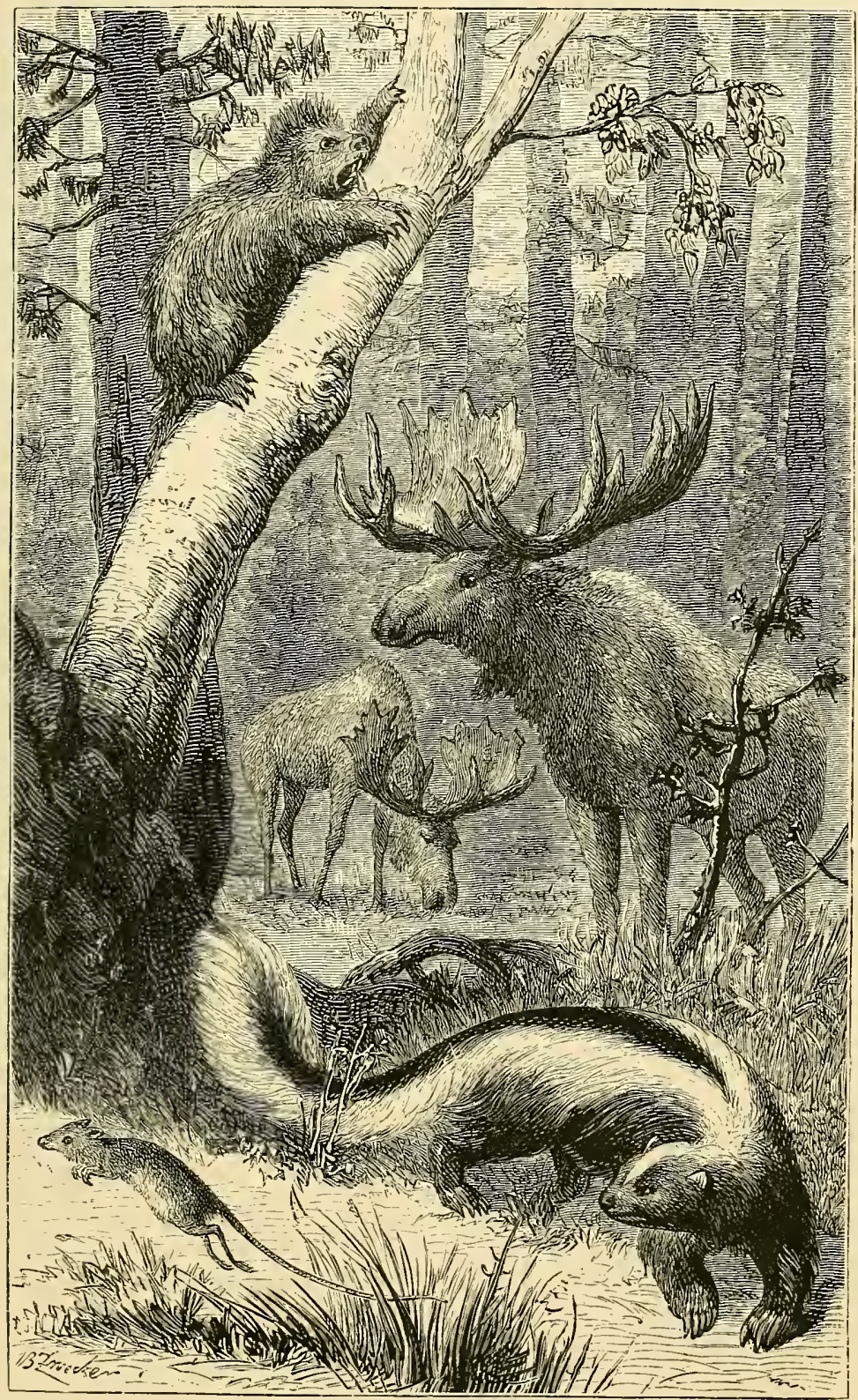

A CANADIAN FOREST, WITH CHARACTERISTIC MAMMALIA. 

together with many northern birds common to both continents. Yet a few Palæarctic forms, not known in other parts of the sub-region, appear here. These are Budytes flava, Phylloscopus kennicottii, and Pyrrhula coccinea, all belonging to genera not occurring elsewhere in North Ameriea. Considering the proximity of the district to North-east Asia, and the high probability that there was an actual land connection at, and south of, Behring's Straits, in late Tertiary times, it is somewhat remarkable that the admixture of Palæarctic and Nearctic groups is not greater than it is. The Palrearctic element, however, forms so small a portion of the whole fauna, that it may be satisfactorily accounted for by the establishment of immigrants since the Glacial period. The great interest felt by ornithologists in the discovery of the three genera above-named, with a wren allied to a European species, is an indication that the faunas even of the northern parts of the Nearctic and Palæarctic regions are, as regards birds, radically distinct. It may be mentioned that the birds of the Aleutian Isles are also, so far as known, almost wholly Nearctic. The number of land-birds known from Alaska is 77 ; and from the Aleutian Isles 16 species, all of which, except one, are North American.

Reptiles.-These are comparatively few and unimportant. There are however five snakes and three tortoises which are limited to Canada proper; while further north there are only Amphibia, represented by frogs and toads, and a salamander of the genus Plethodon.

Fishes.-Most of the groups of fresh-water fish of the Nearctic region are represented here, especially those of the perch, salmon, and pike families ; but there seem to be few or no peculiar genera.

Insects.-These are far less numerous than in the more temperate districts, but are still tolerably abundant. In Canada there are 53 species of butterflies, viz., Papilionidæ, 4 ; Pieridæ, 2; Nymphalidæ, 21 ; Satyridæ, 3; Lycænidæ 16, and Hesperidæ 7. Most of these are, no doubt, found chiefly in the southern parts of Canada. That Coleoptera are pretty numerous is shown, by more than 800 species having been collected on the 
shores of Lake Superior; 177 being Geodephaga and 39 Longicorns.

Grcenland.-This great arctic island must be considered as belonging to the Nearctic region, since of its six land mammals, three are exclusively American (Myodes torquatus, Lepus glacialis, and Ovibos moschatus), while the other three (Vulpes lagopus, Ursus maritimus, and Rangifer tarundus) are circumpolar. Only fourteen land-birds are either resident in, or regular migrants to the country; and of these two are European (Haliceetus albicilla, and Falco peregrinus), while three are American (Anthus ludovicianus, Zonotrichia lcucophrys, and Lagopus rupestris), the rest being arctic species common to both continents. The waders and aquatics (49 in number) are nearly equally divided between both continents; but the land-birds which visit Greenland as stragglers are mostly American. Yet although the Nearctie element somewhat preponderates, Greenland really belongs to that circumpolar debateable land, which is common to the two North Temperate regions.

Concluding remarks.-We have already discussed pretty fully, though somewhat incidentally, the status and relations of the Nearctic region; first in our chapter on Zoological regions, then in our review of extinct faunas, and lastly in the earlier part of this chapter. It will not therefore be necessary to go further into the question here; but we shall, in our next chapter, give a brief summary of the general conclusions we have reached as to the past history and mutual zoological relations of all the great divisions of the earth. 


\section{TABLES OF DISTRIBUTION.}

In drawing up these tables, showing the distribution of various classes of animals in the Nearctic region, the following sources of information have been chiefly relied on, in addition to the general treatises, monographs, and catalogues used in the compilation of the 4th Part of this work.

Mammalia.-Professor Baird's Catalogue; Allen's List of the Bats; Mr. Lord's List for British Columbia ; Brown, for Greenland; Packard for Labrador.

Birds.-Baird, Cassin, and Allen's Lists for United States; Richardson's Fauna Boreali Americana; Jones, for Bermudas; and papers by Brown, Coues, Lord, Packard, Dall, and Professor Newton. 
TABLE I.

FAMILIES OF ANIMALS INHABITING THE NEARCTIC REGION.

\section{Explanation.}

Names in italics show the families which are peculiar to the region.

Names inclosed thus (......) show families which barely enter the region, and are not considered properly to belong to it.

Numbers correspond to the series of numbers to the families in Part IV.

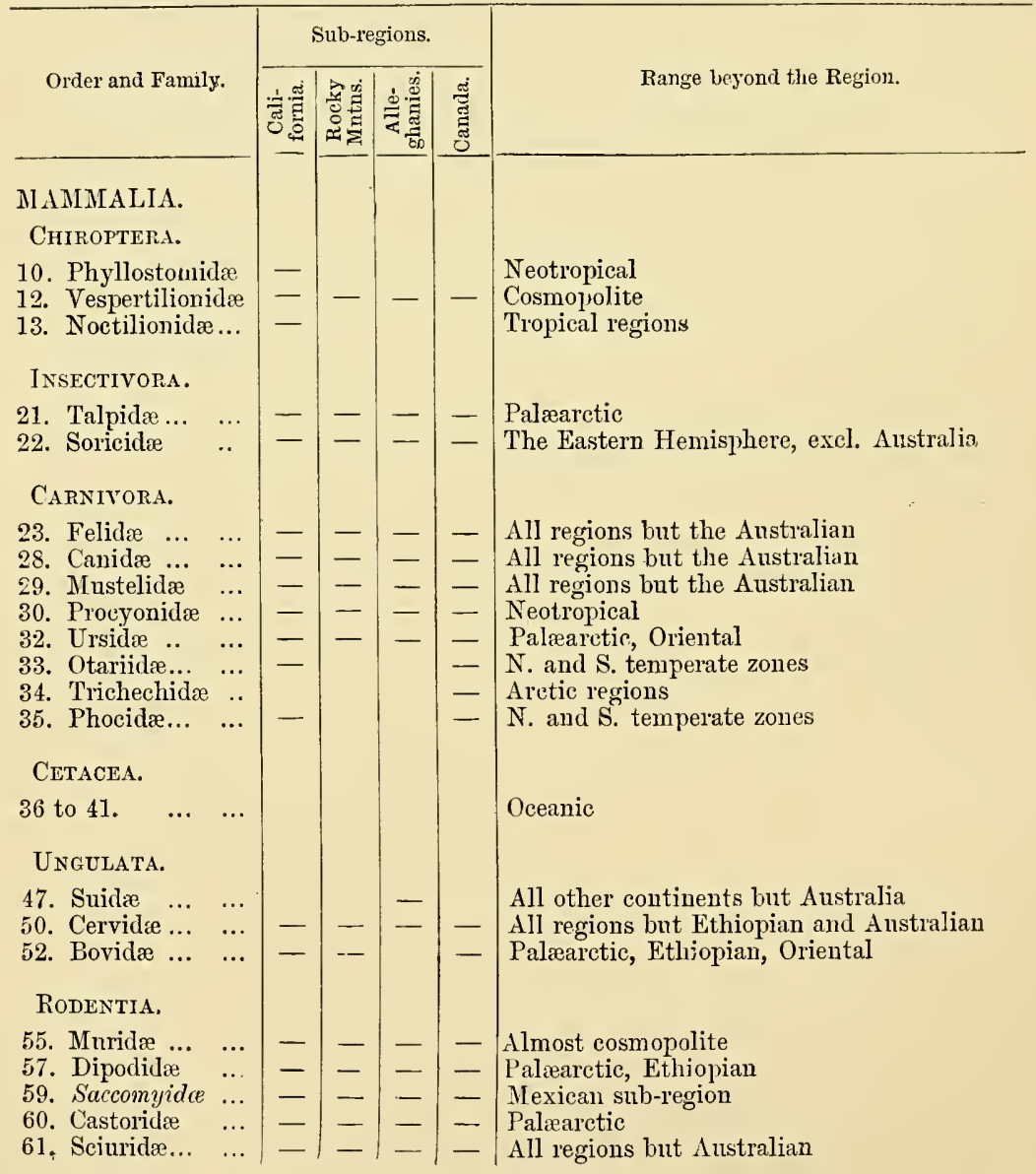




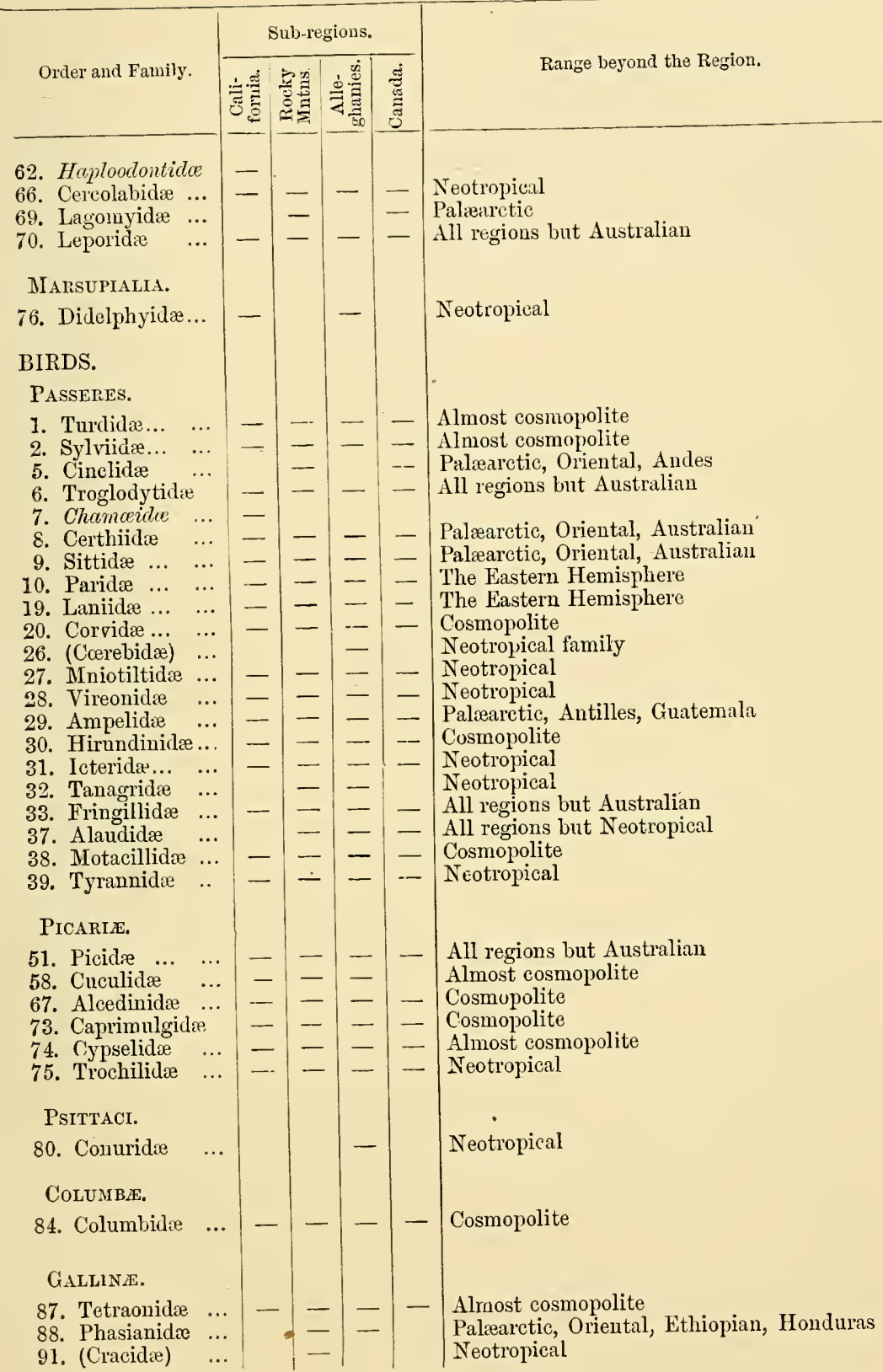




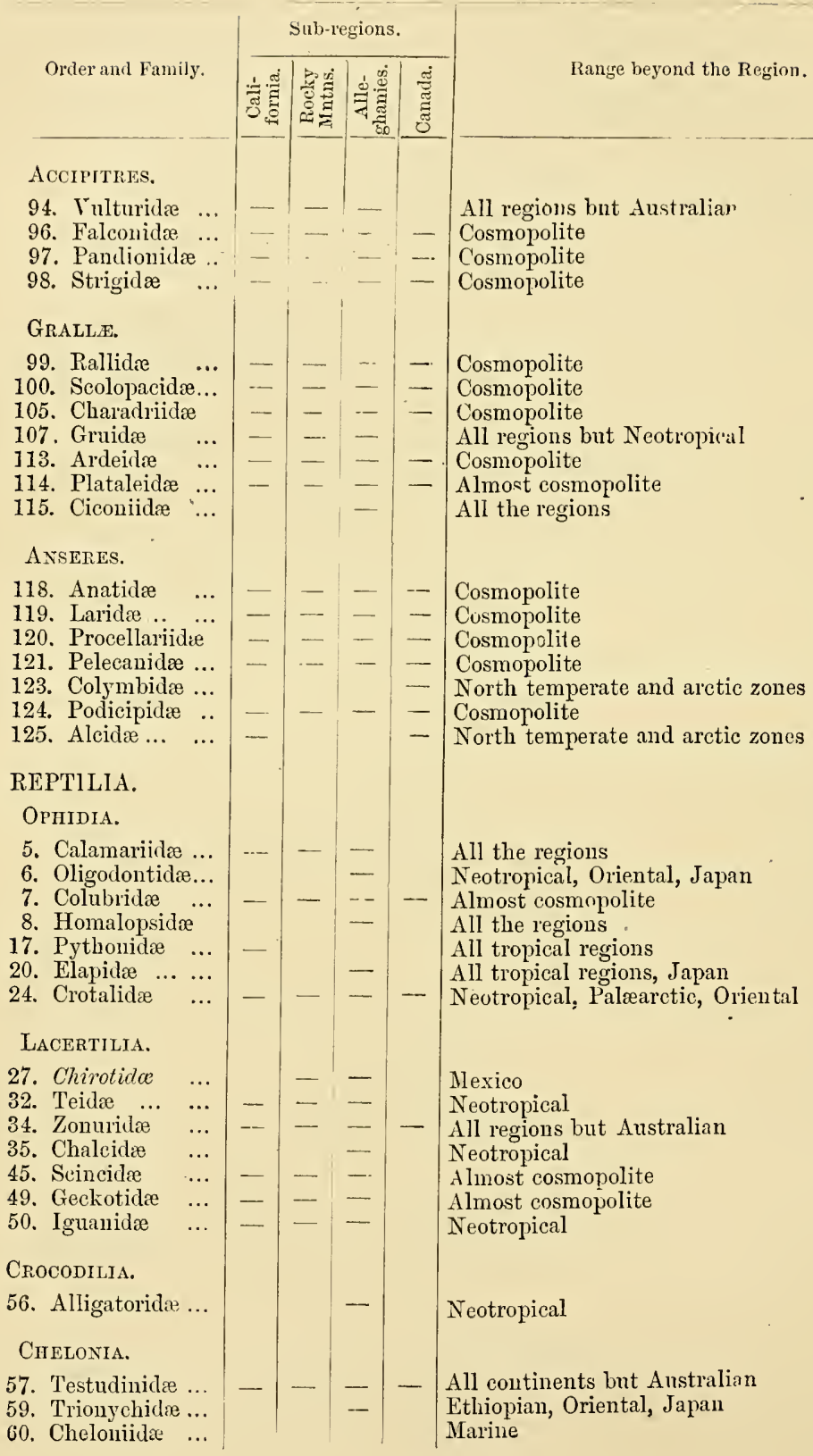




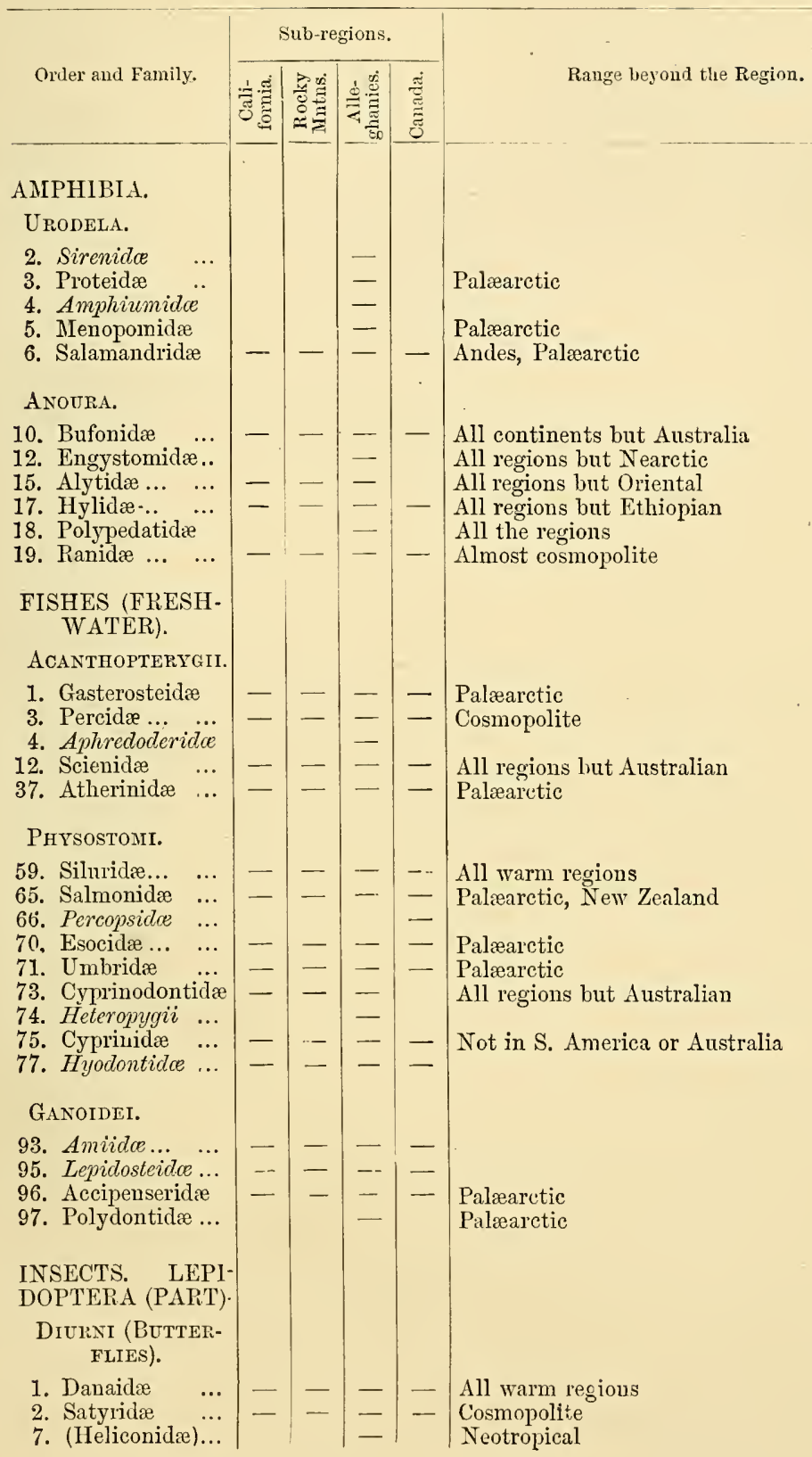




\begin{tabular}{|c|c|c|c|c|c|}
\hline \multirow[b]{2}{*}{ Order and Family. } & \multicolumn{4}{|c|}{ Sub-regions. } & \multirow[b]{2}{*}{ Range beyond the Reginn. } \\
\hline & 吾苛 & 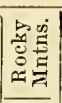 & 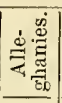 & $\begin{array}{l}\text { శ్ } \\
\text { శ్ } \\
\text { లే }\end{array}$ & \\
\hline 8. Nymphalidie... & - & - & - & - & Cosmopolite \\
\hline 9. Libytheidæ ... & & - & - & & Not in Australia \\
\hline 12. Erycinidre $\ldots$ & - & - & - & & Neotropical \\
\hline 13. Lycrenidx $\ldots$ & - & - & - & - & Cosmopolite \\
\hline 14. Pierida ... ... & - & - & - & - & Cosmopolite \\
\hline 15. Papilionidæ ... & - & - & - & - & Cosmopolite \\
\hline 16. Hesperidæ $\ldots$ & - & - & - & - & Cosmopolite \\
\hline SPHINGIDEA. & & & & & \\
\hline 17. Zygænidæ & 一 & - & - & - & Cosmopolite \\
\hline 18. Castniidæ & & & - & & Neotropical, Australian \\
\hline 22. Aigeriidæ $\ldots$ & - & - & -1 & - & Not in Australia \\
\hline 23. Sphingidx $\ldots$ & - & - & - & - & Cosmopolite \\
\hline
\end{tabular}


TABLE II.

\section{IIST OF GENERA OF TERRESTRIAL MAMMALIA AND BIRDS INHABITING THE NEARCTIC REGION.}

\section{Explanation.}

Names in italics show genera peculiar to the region.

Names enclosed thus (...) indicate genera which barely enter the region, and are not considered properly to belong to it.

Genera properly belonging to the region are numbered consecutively.

MAMMALIA.

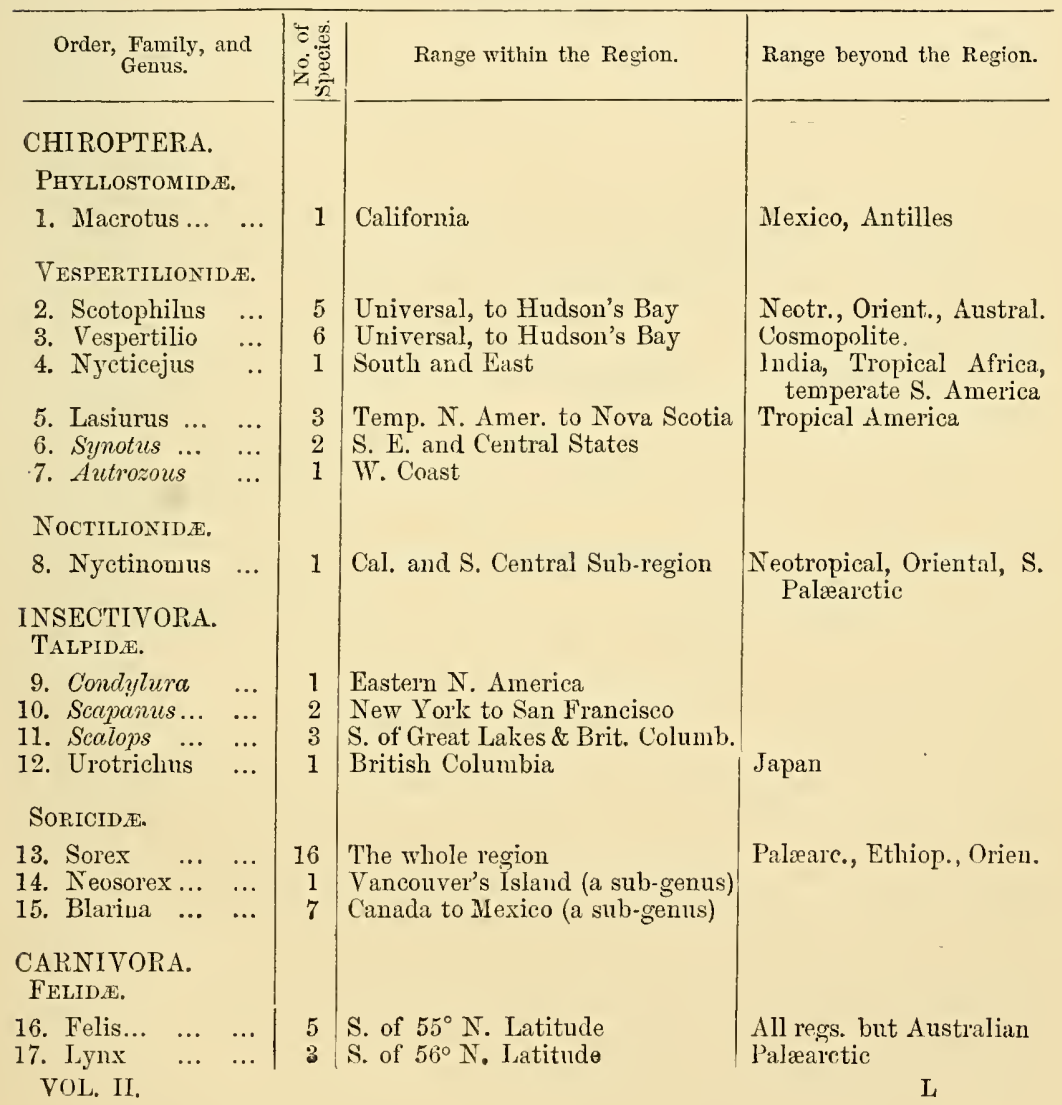




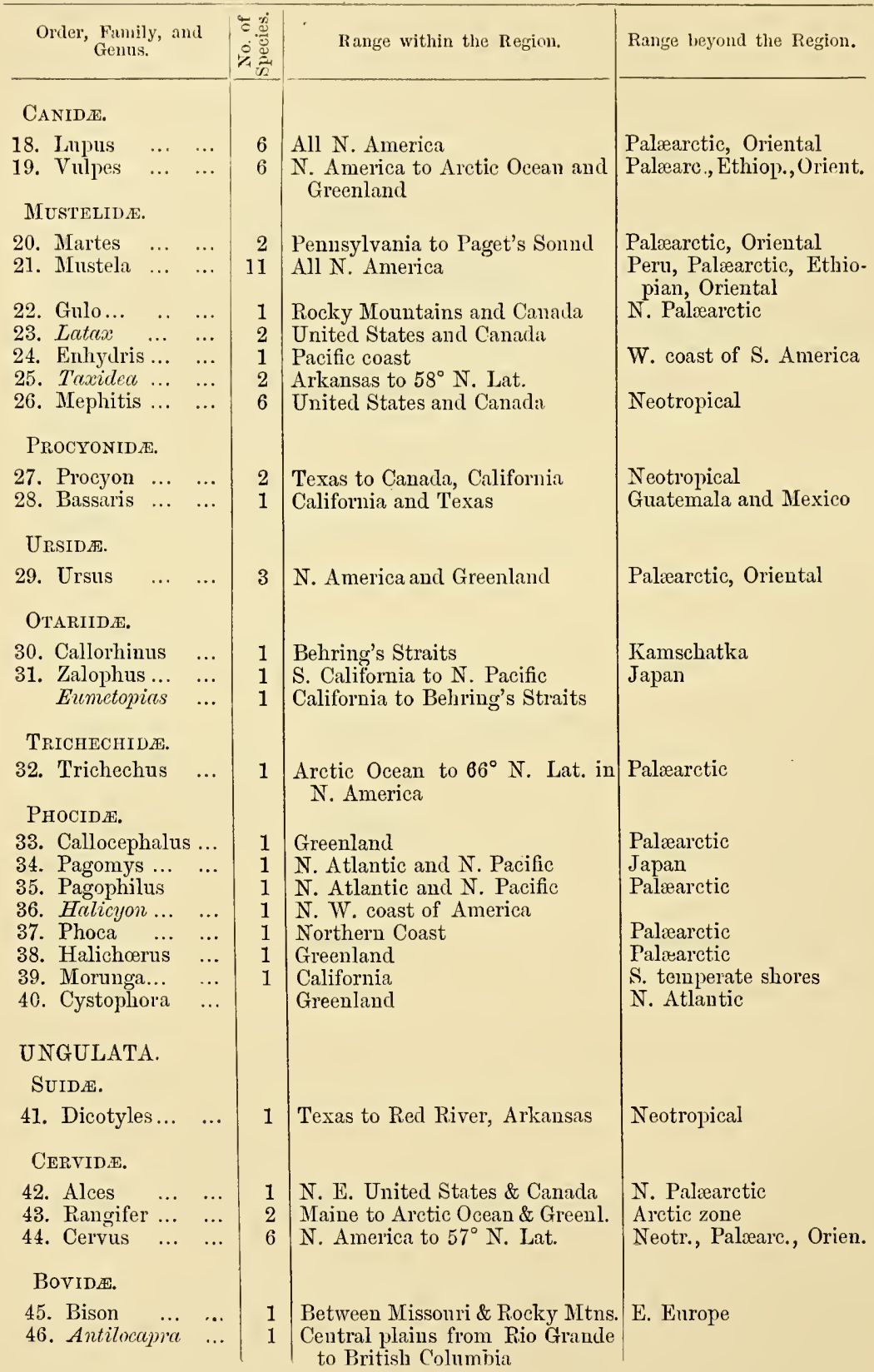




\begin{tabular}{|c|c|c|c|c|}
\hline $\begin{array}{l}\text { Order, Family, and } \\
\text { Genus. }\end{array}$ & & 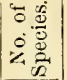 & Range within the Region. & Range beyond the Region. \\
\hline $\begin{array}{l}\text { 47. Aplocerus... } \\
\text { 48. Capra } \quad \text {.. }\end{array}$ & $\cdots$ & $\begin{array}{l}1 \\
1\end{array}$ & $\begin{array}{l}\text { Northern Rocky Mountains } \\
\text { Upper Missouri and Rocky } \\
\text { Mountains northwards }\end{array}$ & Palæaretic \\
\hline $\begin{array}{l}\text { 49. Ovibos .. } \\
\text { RODENTIA. } \\
\text { MURIDE. }\end{array}$ & $\cdots$ & 1 & Arctic America and Greenland & - \\
\hline $\begin{array}{l}\text { 50. Reithrodon } \\
\text { 51. Hesperomys } \\
\text { 52. Neotoma .... } \\
\text { 53. Sigmodon... } \\
\text { 54. Arvicola .... }\end{array}$ & $\begin{array}{c}\cdots \\
\cdots \\
\cdots \\
\cdot \\
\cdots\end{array}$ & $\begin{array}{r}5 \\
16 \\
7 \\
2 \\
27\end{array}$ & $\begin{array}{l}\text { N. America to Lat. } 39^{\circ} \mathrm{N} \text {. } \\
\text { Temperate N. America } \\
\text { Temperate N. America } \\
\text { S. and S. E. States } \\
\text { Texas and California to Hndson's } \\
\text { Bay }\end{array}$ & $\begin{array}{l}\text { Neotropical } \\
\text { Neotropical } \\
\text { Palæarctic }\end{array}$ \\
\hline 55. Myodes $\ldots$. & $\cdots$ & 3 & $\begin{array}{l}\text { N. United States to Arctic Reg. } \\
\text { and Greenland }\end{array}$ & N. Palrarctie \\
\hline $\begin{array}{l}\text { 56. Fiber } \quad \cdots \\
\text { DIPODIDE. }\end{array}$ & $\cdots$ & 1 & All N. America & Mexico \\
\hline $\begin{array}{l}\text { 57. Jaculus } \ldots . \\
\text { SACCONYIDE. }\end{array}$ & $\ldots$ & 1 & $\begin{array}{l}\text { Pennsylvania to Canada and Cali- } \\
\text { foruia }\end{array}$ & \\
\hline 58. Dipodomys & $\ldots$ & 5 & $\begin{array}{l}\text { New Mexico to Columbia River } \\
\text { and Carolina }\end{array}$ & \\
\hline $\begin{array}{l}\text { 59. Perognathus } \\
\text { 60. Thomomys }\end{array}$ & \begin{tabular}{l|}
$\cdots$ \\
$\cdots$
\end{tabular} & $\begin{array}{l}6 \\
2\end{array}$ & $\begin{array}{l}\text { New Mexico to British Columbia } \\
\text { Upper Missouri to Hudson's Bay }\end{array}$ & \\
\hline 61. Geomys $\ldots$. & $\ldots$ & 5 & $\begin{array}{l}\text { New Mexico to Alabama and Ne- } \\
\text { braska }\end{array}$ & \\
\hline $\begin{array}{l}\text { 62. Saccomys... } \\
\text { CASTORIDE. }\end{array}$ & $\cdots$ & 1 & N. America & \\
\hline $\begin{array}{ll}\text { 63. Castor } & \ldots \\
\text { ScrURIDA } & \end{array}$ & $\cdots$ & 1 & N. Mexico to Labrador & Pillearctic \\
\hline $\begin{array}{l}\text { 64. Sciurus ... } \\
\text { 65. Sciuropterus . } \\
\text { 66. Tamias ... } \\
\text { 67. Spermophilus. } \\
\text { 68. Cynomys ... } \\
\text { 69. Arctomys . }\end{array}$ & $\begin{array}{l}\cdots \\
\cdots \\
\cdots \\
\cdots \\
\cdots\end{array}$ & \begin{tabular}{r|}
18 \\
4 \\
4 \\
15 \\
2 \\
4
\end{tabular} & $\begin{array}{l}\text { N. America to Labrador } \\
\text { California \& E. States northwds. } \\
\text { Mexico and Virginia to Canada } \\
\text { N., W., \& Central N. America } \\
\text { Rio Grande to Missouri (Central) } \\
\text { Virginia and Nebraska, northws. }\end{array}$ & $\begin{array}{l}\text { All regs. but Australian } \\
\text { Palæaretic, Oriental } \\
\text { Mexico, N. Asia } \\
\text { Palæaretic } \\
\text { N. Palæaretic }\end{array}$ \\
\hline $\begin{array}{l}\text { HAPLOODONTIDE. } \\
\text { 70. Haploodon }\end{array}$ & E. & 2 & California and British Columbia & \\
\hline CERCOLABIDEt & & & & \\
\hline $\begin{array}{l}\text { 71. Erethizon... } \\
\text { LAGOMYIDE. }\end{array}$ & $\ldots$ & 2 & $\begin{array}{l}\text { Pennsylvania to Canada, \& Paci- } \\
\text { fic coast }\end{array}$ & \\
\hline $\begin{array}{l}\text { 72. Lagomys ... } \\
\text { LRPORIDE. }\end{array}$ & $\ldots$ & 1 & $\begin{array}{l}\text { Rocky Mountains, } 42^{\circ} \text { to } 60^{\circ} \mathrm{N} \text {. } \\
\text { Lat. }\end{array}$ & laliearctic \\
\hline 73. Lepus & $\ldots$ & 15 & All N. America to Greenland & $\begin{array}{c}\text { All regs. but Australian } \\
\text { L } 2\end{array}$ \\
\hline
\end{tabular}




\begin{tabular}{|c|c|c|c|}
\hline $\begin{array}{l}\text { Order, Family, and } \\
\text { Genus. }\end{array}$ & 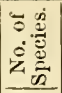 & Range within the Region. & Range beyond the Region. \\
\hline $\begin{array}{l}\text { MARSUPIALIA. } \\
\text { DIDELPHYIDE. }\end{array}$ & & & \\
\hline 74. Didelphys & 2 & $\begin{array}{l}\text { From Hudson's River \& Lower } \\
\text { California, southward }\end{array}$ & Neotropical \\
\hline
\end{tabular}

BIRDS.

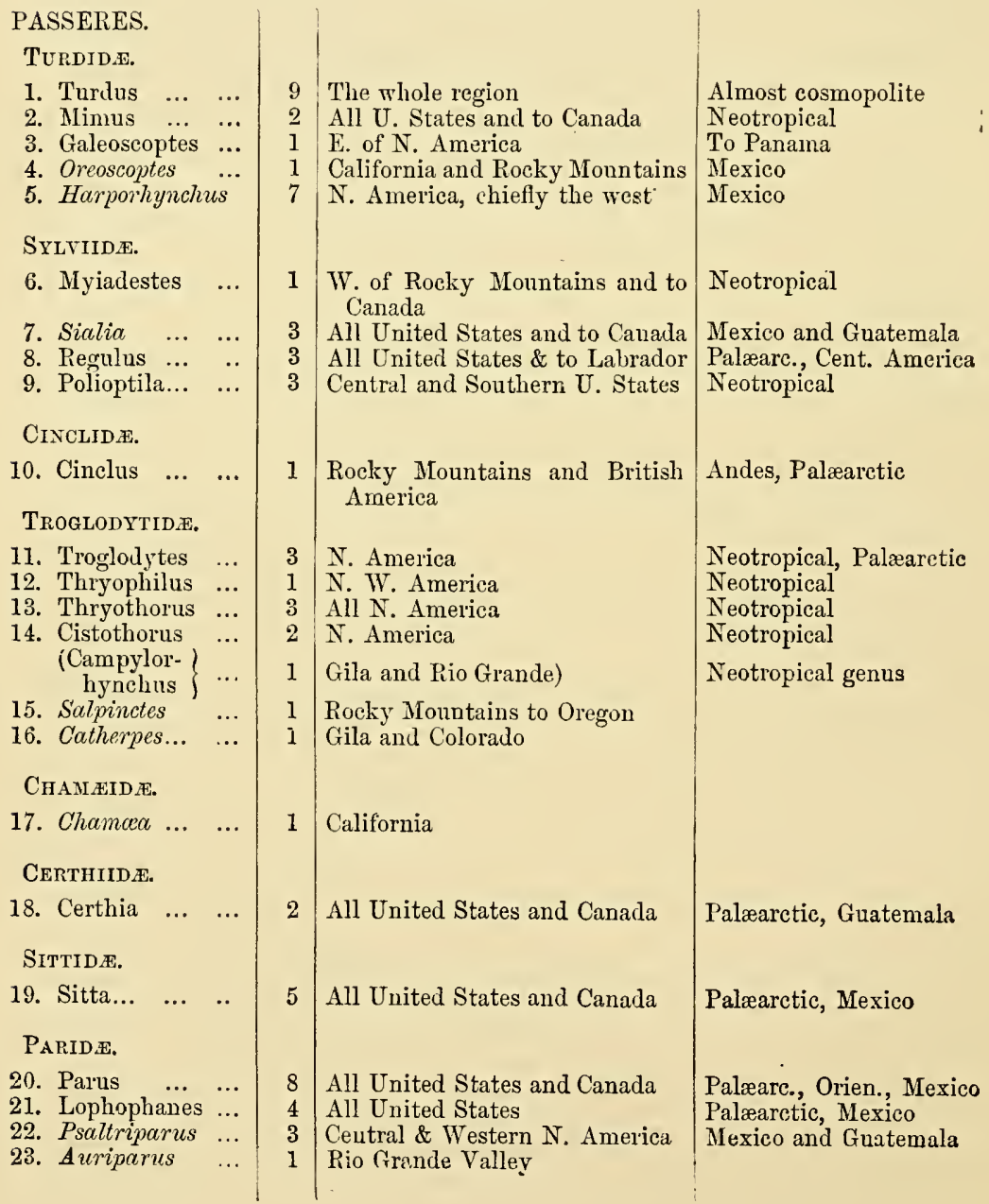




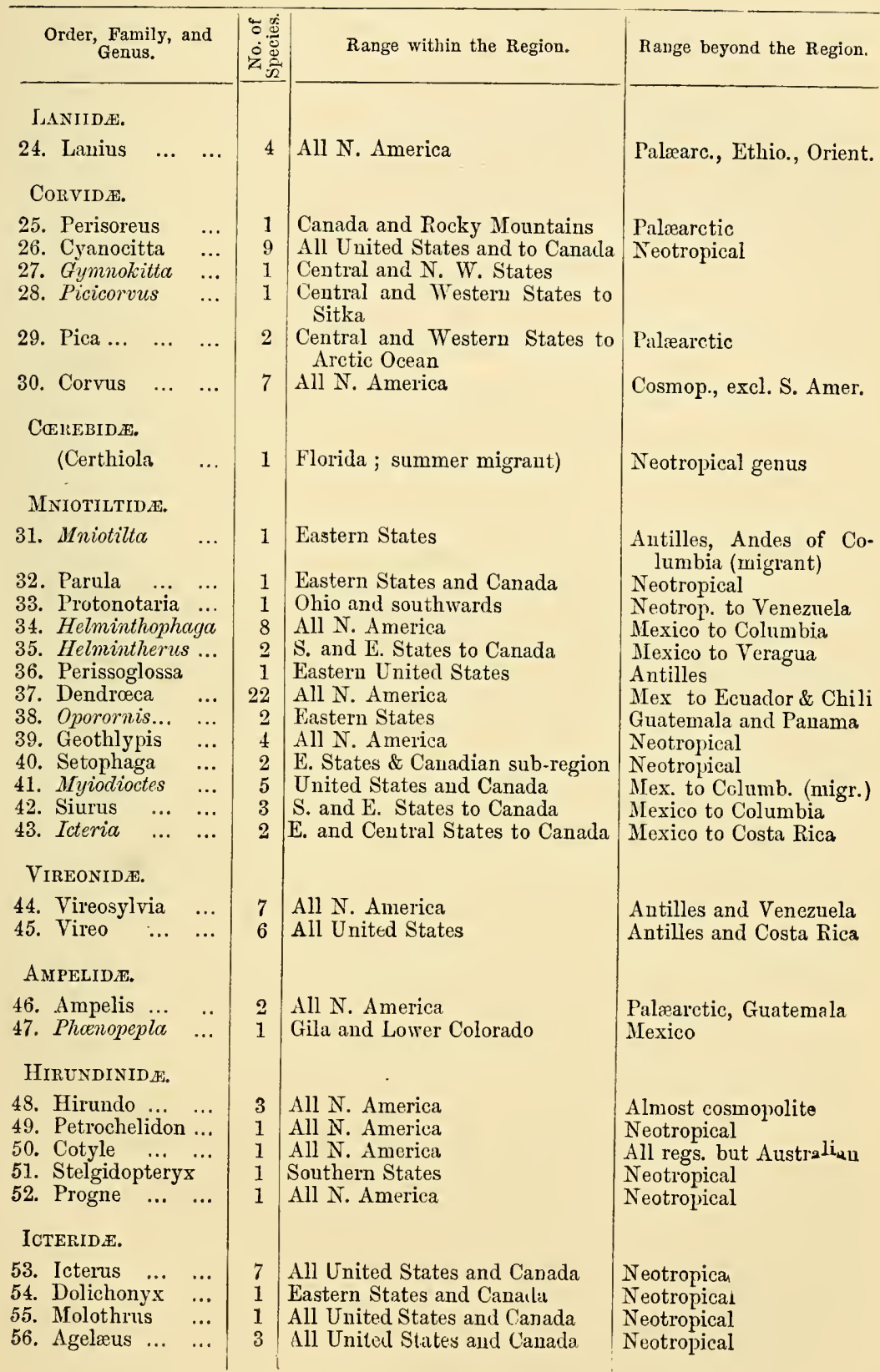




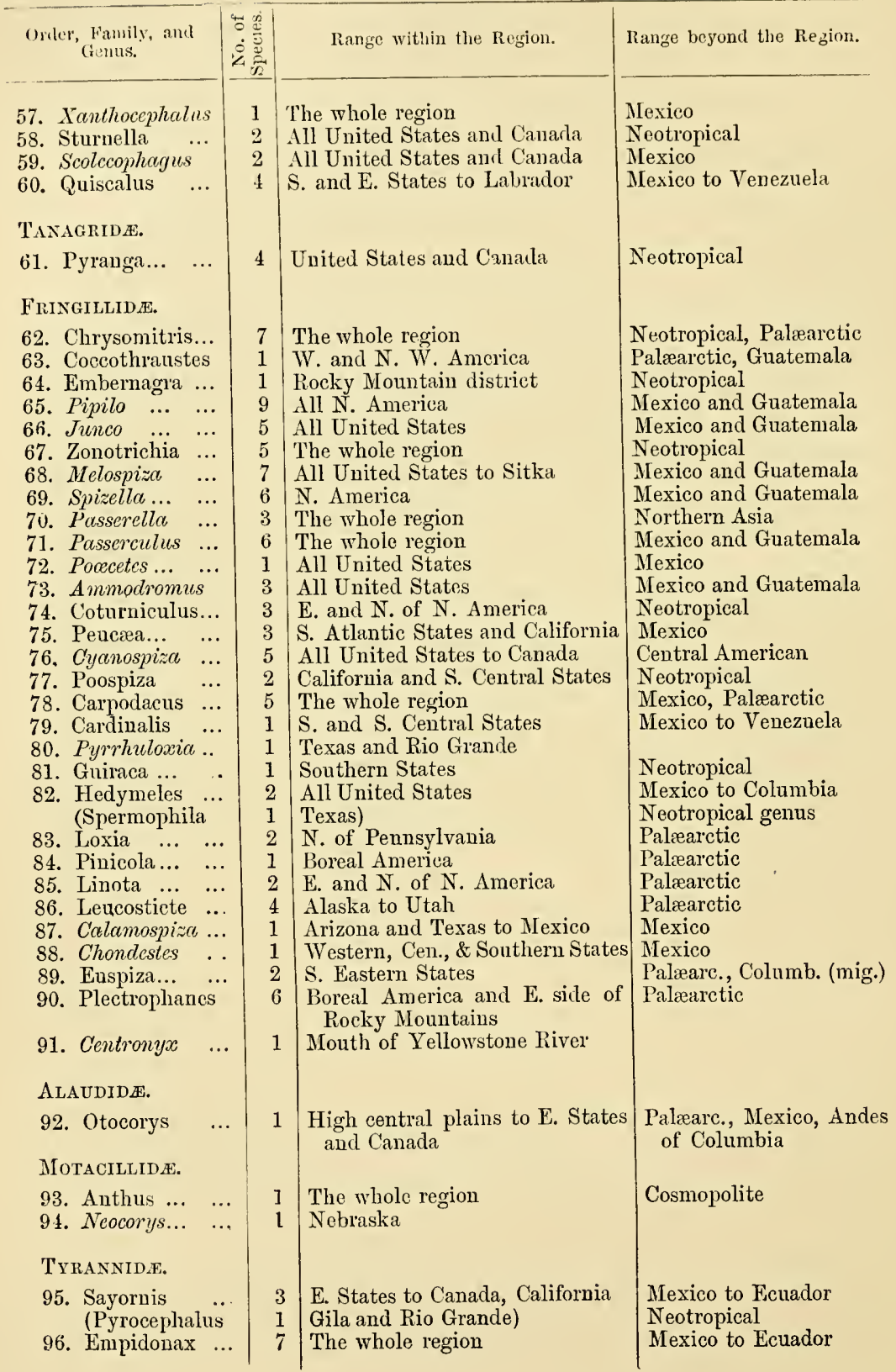




\begin{tabular}{|c|c|c|c|c|}
\hline \multicolumn{2}{|l|}{$\begin{array}{l}\text { Order, Family, and } \\
\text { Genus. }\end{array}$} & 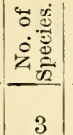 & Range within the Region. & $\begin{array}{l}\text { Range beyond the Region. } \\
\text { Mexico to Amazonia }\end{array}$ \\
\hline $\begin{array}{l}\text { 97. Contopus } \\
\text { 98. Myiarchus } \\
\text { 99. Empidias } \\
\text { 100. Tyramms } \\
\text { (Milvulus }\end{array}$ & $\begin{array}{l}\cdots \\
\cdots \\
\cdots \\
\cdots \\
\cdots\end{array}$ & $\begin{array}{l}3 \\
2 \\
1 \\
4 \\
1\end{array}$ & $\begin{array}{l}\text { N. and E. of Rocky Mountains } \\
\text { E. and W. coasts and Canacla } \\
\text { Eastern States } \\
\text { All United States to Canarla } \\
\text { Texas) }\end{array}$ & $\begin{array}{l}\text { Mexico to Amazonia } \\
\text { Neotropical } \\
\text { Mexico } \\
\text { Neotropical } \\
\text { Neotropical genus }\end{array}$ \\
\hline $\begin{array}{l}\text { PICARIÆ. } \\
\text { PICIDA. }\end{array}$ & & & & \\
\hline $\begin{array}{l}\text { 101. Picoides } \\
\text { 102. Picus } \\
\text { 103. Sphyrapicus }\end{array}$ & \begin{tabular}{l|l}
$\cdots$ \\
$\cdots$ \\
$\cdots$
\end{tabular} & $\begin{array}{l}3 \\
6 \\
6\end{array}$ & $\begin{array}{l}\text { Arctic zone and Rocky Monnts. } \\
\text { AIl United States and Canada } \\
\text { Brit. Colnmbia and Pennsylvania } \\
\text { southwards }\end{array}$ & $\begin{array}{l}\text { Palæarctic } \\
\text { All regs. but Eth. \& Aus. } \\
\text { Mexico and Guatemala }\end{array}$ \\
\hline $\begin{array}{l}\text { 104. Campephilus } \\
\text { 105. Hylatomus } \\
\text { 106. Centurus } \\
\text { 107. Melanerpes } \\
\text { 108. Colaptes }\end{array}$ & \begin{tabular}{l|}
$\mathrm{s} \ldots$ \\
$\cdots$ \\
$\cdots$ \\
$\cdots$ \\
$\cdots$
\end{tabular} & $\begin{array}{l}2 \\
1 \\
3 \\
3 \\
3\end{array}$ & $\begin{array}{l}\text { United States and Canada } \\
\text { E. and W. States and Canada } \\
\text { The whole region } \\
\text { United States and S. Canada } \\
\text { United States and Canada }\end{array}$ & $\begin{array}{l}\text { Neotropical } \\
\text { Mexico to Veneznela } \\
\text { Neotropical } \\
\text { Neotropical }\end{array}$ \\
\hline CUCULID & & & & \\
\hline $\begin{array}{l}\text { 109. Crotophaga } \\
\text { 110. Coccyzus } \\
\text { 111. Geococcyx }\end{array}$ & $\begin{array}{l}\cdots \\
\cdots \\
\cdots\end{array}$ & $\begin{array}{l}2 \\
3 \\
1\end{array}$ & $\begin{array}{l}\text { E. States from Pemsylvania S. } \\
\text { S. E. and Cen. States to Canada } \\
\text { California to New Mex. \& Texas }\end{array}$ & $\begin{array}{l}\text { Neotropical } \\
\text { Neotropical } \\
\text { Gnatemala }\end{array}$ \\
\hline $\begin{array}{l}\text { ALCEDINIDA. } \\
\text { 112. Ceryle ... } \\
\text { CAPRIMULGID.. }\end{array}$ & $\cdots$ & 2 & The whole region & S. Palæare- \\
\hline $\begin{array}{l}\text { 113. Chordeiles } \\
\text { 114. Antrostonus } \\
\text { CyPSELIDE. }\end{array}$ & $\begin{array}{l}\ldots \\
\text { s... }\end{array}$ & $\begin{array}{l}3 \\
3\end{array}$ & $\begin{array}{l}\text { All United States to Can } \\
\text { All United States to Can }\end{array}$ & $\begin{array}{l}\text { Neotro } \\
\text { Neotro }\end{array}$ \\
\hline $\begin{array}{l}\text { 115. Nephoecetes } \\
\text { 116. Chætura } \\
\text { TrocHIL1DÆ. }\end{array}$ & $\begin{array}{l}\cdots \\
\cdots\end{array}$ & $\begin{array}{l}1 \\
2\end{array}$ & $\begin{array}{l}\text { N. W. Anerica } \\
\text { Ail U. States \& British Columbia }\end{array}$ & $\begin{array}{l}\text { Jamaica } \\
\text { AImost cosmopolite }\end{array}$ \\
\hline $\begin{array}{l}\text { 117. Trochilus } \\
\text { 118. Selasphorus } \\
\text { 119. Atthis ... }\end{array}$ & $\begin{array}{l}\cdots \\
\cdots \\
\cdots\end{array}$ & $\begin{array}{l}2 \\
2 \\
2\end{array}$ & $\begin{array}{l}\text { The whole region } \\
\text { W. coast and Centre } \\
\text { California and Colorado Valley }\end{array}$ & $\begin{array}{l}\text { Mexico to Veragua (? mi.) } \\
\text { Mexico to Veragua } \\
\text { Mexico to Guatemala }\end{array}$ \\
\hline $\begin{array}{l}\text { PSITTACI. } \\
\text { CONURIDE. }\end{array}$ & & & & \\
\hline $\begin{array}{l}\text { 120. Conurus... } \\
\text { COLUMB } E . \\
\text { COLUMBIDE. }\end{array}$ & .. & 1 & S. and S. E. States & Neotropical \\
\hline $\begin{array}{l}\text { 121. Columba } \\
\text { 122. Ectopistcs }\end{array}$ & $\begin{array}{l}\cdots \\
\cdots\end{array}$ & $\begin{array}{l}3 \\
1\end{array}$ & $\begin{array}{l}\text { W. and Central States to Canada } \\
\text { E. coast to Cen. plains, Canada } \\
\text { and British Columbia }\end{array}$ & All regs. but Australian \\
\hline $\begin{array}{l}\text { 123. Melopelia } \\
\text { 124. Zenaidura } \\
\text { 125. Chæmepelia }\end{array}$ & $\begin{array}{l}\cdots \\
\cdots \\
. .\end{array}$ & $\begin{array}{l}1 \\
1 \\
1\end{array}$ & $\begin{array}{l}\text { W. and S. Central States } \\
\text { All United States to Canada } \\
\text { California and S. E. States }\end{array}$ & $\begin{array}{l}\text { Neotropical } \\
\text { Mexico to Veragua } \\
\text { Neotropical }\end{array}$ \\
\hline
\end{tabular}




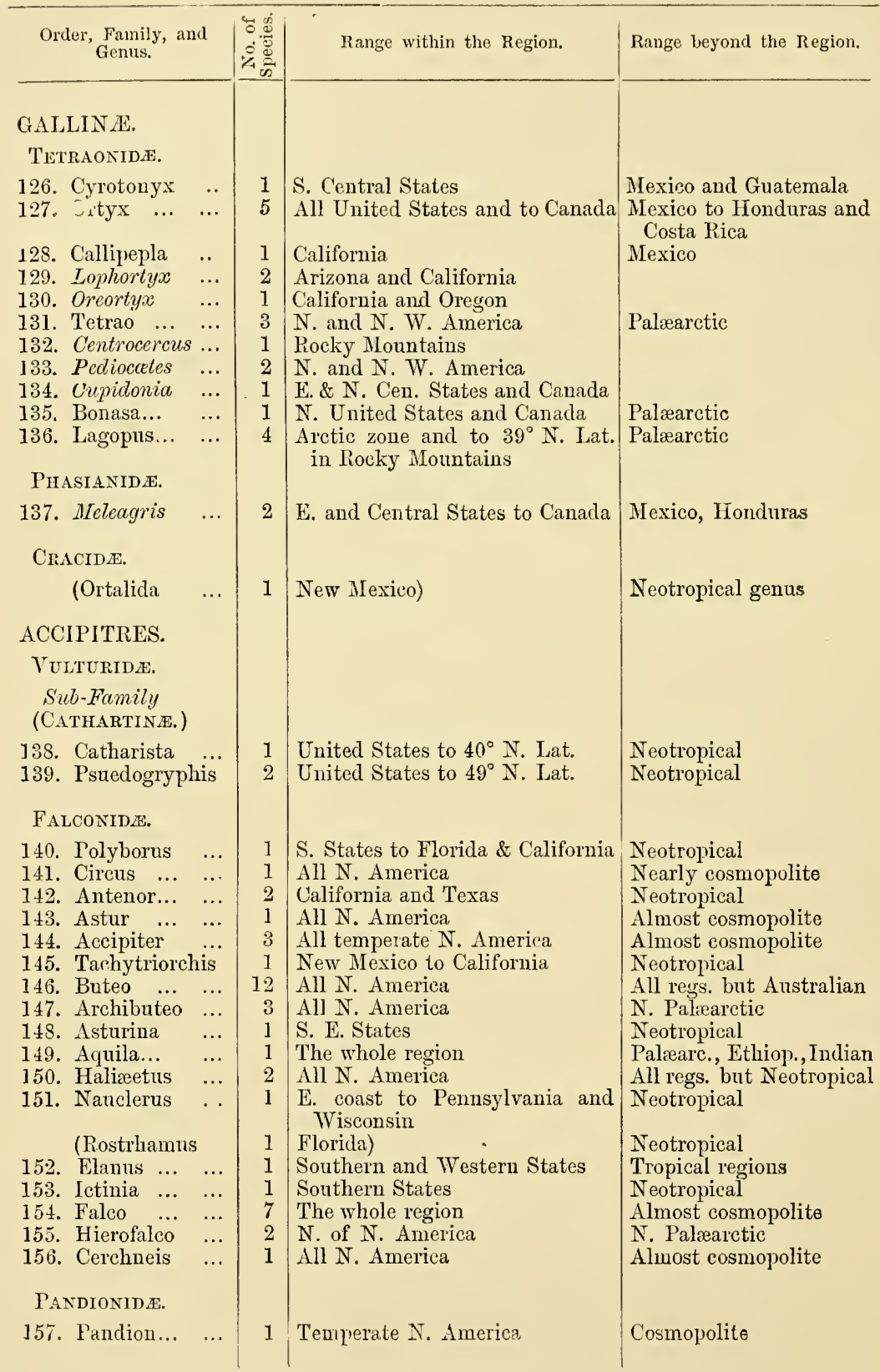




\begin{tabular}{|c|c|c|c|}
\hline $\begin{array}{l}\text { Order, Family, and } \\
\text { Genus. }\end{array}$ & 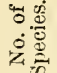 & Range within the Region. & Range beyond the Region. \\
\hline STRIGIDE. & & & \\
\hline 158. Surnia & 1 & Arctic \& N. Temperate America & N. Palæarctic \\
\hline 159. Nyctea ... & 1 & S. Carolina to Greenland & N. Palæaretic \\
\hline 160. Glaucidium ... & 1 & Oregon and California & Neotropical, Palæaretic \\
\hline 161. Micrathene ... & 1 & Arizona and New Mexico & Mexico \\
\hline 162. Pholeoptyux... & 1 & N. W. America, Texas & Neotropical \\
\hline 163. Bubo … & 1 & All N. America & All regs. but Australian \\
\hline 164. Scops $\ldots$... & 2 & The whole region & Almost cosmopolite \\
\hline 165. Syrnium & 2 & E. States, California, Canada & All regs. but Australian \\
\hline 166. Asio & 2 & The whole region & All regs. but Australian \\
\hline 167. Nyctale... ... & 3 & All N. America & Palæaretic \\
\hline 168. Strix $\quad \ldots \quad \ldots$ & 1 & Temperate N. America & Almost cosmopolite \\
\hline
\end{tabular}

Peculiar or very Characteristic Genera of Wading and Swimming Birds.

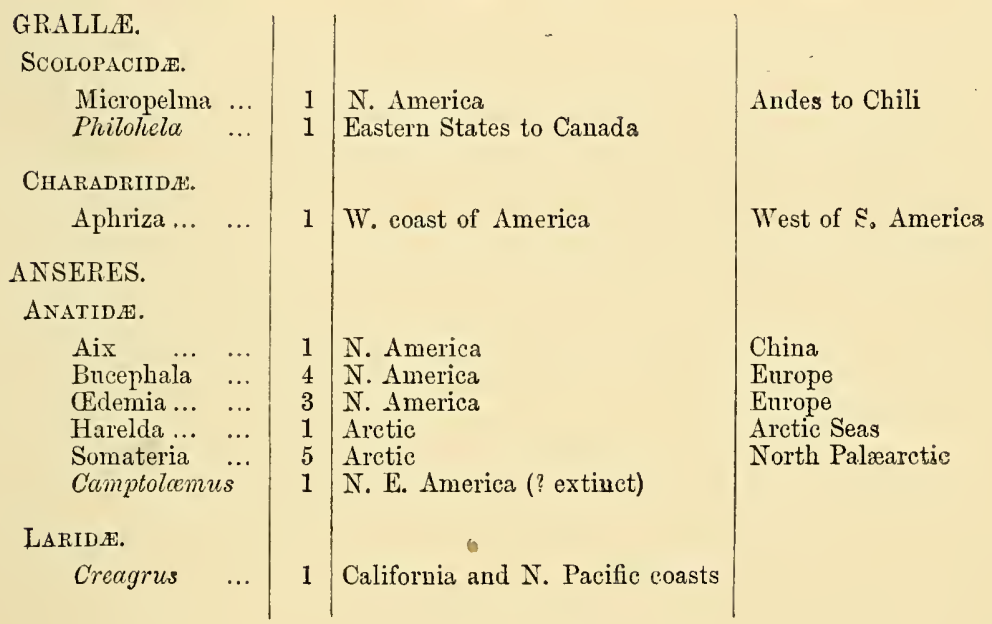




\section{CHAPTER XVI.}

SUMMARY OF THE PAST CHANGES AND GENERAL RELATIONS OF THE SEVERAL REGIONS.

HAVing now closed our survey of the animal life of the whole earth-a survey which has necessarily been encumbered with a multiplicity of detail-we proceed to summarize the general conclusions at which we have arrived, with regard to the past history and mutual relations of the great regions into which we have divided the land surface of the globe.

All the palæontological, no less than the geological and physical evidence, at present available, points to the great land masses of the Northern Hemisphere as being of immense antiquity, and as the area in which the higher forms of life were developed. In going back through the long series of the Tertiary formations, in Europe, Asia, and North America, we find a continuous succession of vertebrate forms, including all the highest types now existing or that have existed on the earth. These extinct animals comprise ancestors or forerunners of all the chief forms now living in the Northern Hemisphere; and as we go back farther and farther into the past, we meet with ancestral forms of those types also, which are now either confined to, or specially characteristic of, the land masses of the Southern Hemisphere. Not only do we find that elephants, and rhinoceroses, and hippopotami, were once far more abundant in Europe than they are now in the tropics, but we also find that the apes of West Africa and Malaya, the lemurs of Madagascar, the Edentata of Africa and South America, and the 
Marsupials of America and Australia, were all represented in Europe (and probably also in North America) during the earlier part of the Tertiary epoch. These facts, taken in their entirety, lead us to conclude that, during the whole of the Tertiary and perhaps during much of the Secondary periods, the great land masses of the earth were, as now, situated in the Northern Hemisphere; and that here alone were developed the successive types of vertebrata from the lowest to the highest. In the Southern Hemisphere there appear to have been three considerable and very ancient land masses, varying in extent from time to time, but always keeping distinct from each other, and represented, more or less completely, by Australia, South Africa, and South America of our time. Into these flowed successive waves of life, as they each in turn became temporarily united with some part of the northern land. Australia appears to have had but one such union, perhaps during the middle or latter part of the Secondary epoch, when it received the ancestors of its Monotremata and Marsupials, which it has since developed into a great variety of forms. The South African and South American lands, on the other hand, appear each to have had several successive unions and separations, allowing first of the influx of low forms only (Edentata, Insectivora and Lemurs); subsequently of Rodents and small Carnivora, and, latest of all, of the higher types of Primates, Carnivora and Ungulata.

During the whole of the Tertiary period, at least, the Northern Hemisphere appears to have been divided, as now, into an Eastern and a Western continent; always approximating and sometimes united towards the north, and then admitting of much interchange of their respective faunas; but on the whole keeping distinct, and each developing its own special family and generic types, of equally high grade, and generally belonging to the same Orders. During the Eocene and Miocene periods, the distinction of the Palæarctic and Nearctic regions was better marked than it is now; as is shown by the floras no less than by the faunas of those epochs. Dr. Newberry, in his Report on the Cretaceous and Tertiary floras of the Yellowstone and Missouri Rivers, states, that although the Miocene flora of Central North 
America corresponds generally with that of the European Miocene, yet many of the tropical, and especially the Australian types, such as Hakea and Dryandra, are absent. Owing to the recent discovery of a rich Cretaceous flora in North America, probably of the same age as that of Aix-la-Chapelle in Europe, we are able to continue the comparison; and it appears, that at this early period the difference was still more marked. The predominant feature of the European Cretaceous flora seems to have been the abundance of Proteaceæ, of which seven genera now living in Australia or the Cape of Good Hope have been recognised, besides others which are extinct. There are also several species of Pandanus, or screw-pine, now confined to the tropics of the Eastern Hemisphere, and along with these, oaks, pines, and other more temperate forms. The North American Cretaceous flora, although far richer than that of Europe, contains no Proteaceæ or Pandani, but immense numbers of forest trees of living and extinct genera. Among the former we have oaks, beeches, willows, planes, alders, dog-wood, and cypress ; together with such American forms as magnolias, sassafras, and liriodendrons. There are also a few not now found in America, as Araucaria and Cinnamomum, the latter still living in Japan. This remarkable flora has been found over a wide extent of country-New Jersey, Alabama, Kansas, and near the sources of the Missouri in the latitude of Quebec-so that we can hardly impute its peculiarly temperate character to the great elevation of so large an area. The intervening Eocene flora approximates closely, in North America, to that of the Miocene period; while in Europe it seems to have been fully as tropical in character as that of the preceding Cretaceous period; fruits of Nipa, Pandanus, Anona, Acacia, and many Proteaceæ, occurring in the London clay at the mouth of the Thames.

These facts appear, at first sight, to be inconsistent, unless we suppose the climates of Europe and North America to have been widely different in these early times; but they may perhaps be harmonised, on the supposition of a more uniform and a somewhat milder climate then prevailing over the whole Northern Hemisphere; the contrast in the regetation of these countries 
being due to a radical difference of type, and therefore not indicative of climate. The early European flora seems to have been a portion of that which now exists only in the tropical and sub-tropical lands of the Eastern Hemisphere; and, as much of this flora still survives in Australia, Tasmania, Japan, and the Cape of Good Hope, it does not necessarily imply more than a warm and equable temperate climate. The early North American flora, on the other hand, seems to have been essentially the same in type as that which now exists there, and which, in the Miocene period, was well represented in Europe; and it is such as now flourishes best in the warmer parts of the United States. But whatever conclusion we may arrive at on the question of climate, there can be no doubt as to the distinctness of the floras of the ancient Nearctic and Palæarctic regions; and the view derived from our study of their existing and extinct famnasthat these two regions have, in past times, been more clearly separated than they are now-receives strong support from the unexpected evidence now obtained as to the character and mutations of their vegetable forms, during so vast an epoch as is comprised in the whole duration of the Tertiary period.

The general phenomena of the distribution of living animals, combined with the evidence of extinct forms, lead us to conclude that the Palæarctic region of early Tertiary times was, for the most part, situated beyond the tropics, although it probably had a greater southward extension than at the present time. It certainly included much of North Africa, and perhaps reached far into what is now the Sahara; while a southward extension of its central mass may have included the Abyssinian highlands, where some truly Palæarctic forms are still found. This is rendered probable by the fossils of Perim Island a little further east, which show that the characteristic Miocene fauna of South Europe and North India prevailed so far within the tropics. There existed, however, at the extreme eastern and western limits of the region, two extensive equatorial land-areas, our Indo-Malayan and West African sub-regions--both of which must have been united for more or less considerable periods with the northern continent. They would then have received 
from it such of the higher vertebrates as were best adapted for the peculiar climatal and organic conditions which everywhere prevail near the equator; and these would be preserved, under variously modified forms, when they had ceased to exist in the less favourable and constantly deteriorating climate of the north. At later epochs, both these equatorial lands became united to some part of the great South African continent (then including Madagascar), and we thus have explained many of the similarities presented by the faunas of these distant, and generally very different countries.

During the Miocene period, when a subtropical climate prevailed over much of Europe and Central Asia, there would be no such marked contrast as now prevails between temperate and tropical zones; and at this time much of our Oriental region, perhaps, formed a hardly separable portion of the great Palæarctic land. But when, from unknown causes, the climate of Europe became less genial, and when the elevation of the Himalayan chain and the Mongolian plateau caused an abrupt difference of climate on the northern and southern sides of that great mountain barrier, a tropical and a temperate region were necessarily formed; and many of the animals which once roamed over the greater part of the older and more extensive region, now became restricted to its southern or northern divisions respectively. Then came the great change we have already described (vol. i. p. 288), opening the newly-formed plains of Central Africa to the incursions of the higher forms of Europe; and following on this, a still further deterioration of climate, resulting in that marked contrast between temperate and tropical faunas, which is now one of the most prominent features in the distribution of animal as well as of vegetable forms.

It is not necessary to go into any further details here, as we have already, in our discussion of the origin of the fauna of the several regions, pointed out what changes most probably occurred in each case. These details are, however, to a great extent speculative; and they must remain so till we obtain as much knowledge of the extinct faunas and past geological history of the southern lands, as we have of those of Europe and North 
America. But the broad conclusions at which we have now arrived seem to rest on a sufficiently extensive basis of facts; and they lead us to a clearer conception of the mutual relations and comparative importance of the several regions than could be obtained at an earlier stage of our inquiries.

If our views of the origin of the several regions are correct, it is clear that no mere binary division-into north and south, or into east and west-can be altogether satisfactory, since at the dawn of the Tertiary period we still find our six regions, or what may be termed the rudiments of them, already established. The north and south division truly represents the fact, that the great northern continents are the seat and birth-place of all the higher forms of life, while the southern continents have derived the greater part, if not the whole, of their vertebrate fauna from the north; but it implies the erroneous conclusion, that the chief southern lands-Australia and South America-are more closely related to each other than to the northern continent. The fact, however, is that the fauna of each has been derived, independently, and perhaps at very different times, from the north, with which they therefore have a true genetic relation; while any intercommunion between themselves has been comparatively recent and superficial, and has in no way modified the great features of animal life in each. The east and west division, represents-according to our views - a more fundamental diversity; since we find the northern continent itself so divided in the earliest Eocene, and even in Cretaceous times; while we have the strongest proof that South America was peopled from the Nearctic, and Australia and Africa from the Palxarctic region: hence, the Eastern and Western Hemispheres are the two great branches of the tree of life of our globe. But this division, taken by itself, would obscure the facts-firstly, of the close relation and parallelism of the Nearctic and Palæarctic regions, not only now but as far back as we can clearly trace them in the past; and, secondly, of the existing radical diversity of the Australian region from the rest of the Eastern Hemisphere.

Owing to the much greater extent of the old Palæarctic region (including our Oriental), and the greater diversity of 
Mammalia it appears to have produced, we can have little doubt that here was the earliest seat of the development of the vertebrate type; and probably of the higher forms of insects and land-molluscs. Whether the Nearctic region ever formed one mass with it, or only received successive immigrations from it by northern land-connections both in an easterly and westerly direction, we cannot decide; but the latter seems the most probable supposition. In any case, we must concede the first rank to the Palæarctic and Oriental regions, as representing the most important part of what seems always to have been the Great Continent of the earth, and the source from which all the other regions were supplied with the higher forms of life. These once formed a single great region, which has been since divided into a temperate and a tropical portion, now sufficiently distinct; while the Nearctic region has, by deterioration of climate, suffered a considerable diminution of productive area, and has in consequence lost a number of its more remarkable forms. The two temperate regions have thus come to resemble each other more than they once did, while the Oriental retains more of the zoological aspect of the great northern regions of Miocene times. The Ethiopian, from having been once an insular region, where lower types of vertebrates alone prevailed, has been so overrun with higher types from the old Palæarctic and Oriental lands that it now rivals, or even surpasses, the Oriental region in its representation of the ancient fauna of the great northern continent. Both of our tropical regions of the Eastern Hemisphere possess faunas which are, to some extent, composite, being made up in different proportions of the productions of the northern and southern continents,- the former prevailing largely in the Oriental, while the lat." constitutes an important feature in the Ethiopian fauna. The Neotropical region has probably undergone great fluctuations in early times; but it was, undoubtedly, for long periods completely isolated, and then developed the Edentate type of Mammals and the Formicaroid type of Passerine birds into a variety of forms, comparable with the diversified Marsupials of Australia, and typical Passeres of the Eastern Hemisphere. 
It has, however, received successive infusions of higher types from the north, which now mingle in various degrees with its lower forms. At an early period it must have received a low form of Primates, which has been developed into the two peculiar families of American monkeys; while its llamas, tapirs, deer, and peccaries, came in at a later date, and its opossums and extinct horses probably among the latest. The Australian region alone, after having been united with the great northern continent at a very early date (probably during the Secondary period) has ever since remained more or less completely isolated; and thus exhibits the development of a primeval type of mammal, almost wholly uninfluenced by any incursions of a later and higher type. In this respect it is unique among all the great regions of the earth.

We see, then, that each of our six regions has had a history of its own, the main outlines of which we have been able to trace with tolerable certainty. Each of them is now characterised-as it seems to have been in all past time of which we have any tolerably full record-by well-marked zoological features; while all are connected and related in the complex modes we have endeavoured to unravel. To combine any two or more of these regions, on account of existing similarities which are, for the most part, of recent origin, would obscure some of the most important and interesting features of their past history and present condition. And it seems no less impracticable to combine the whole into groups of higher rank; since it has been shown that there are two opposing modes of doing this, and that each of them represents but one aspect of a problem, which can only be solved by giving equal attention to all its aspects.

For reasons which have been already stated, and which are sufficiently obvious, we have relied almost exclusively on the distribution of living and extinct manmalia, in arriving at these conclusions. But we believe they will apply equally to elucidate the phenomena presented by the distribution of all terrestrial organisms, when combined - with a careful consideration of the

VOL. II. 
various means of dispersal of the different groups, and the comparative longevity of their species and genera. Even insects, which are perhaps of all animals the farthest removed from mammalia in this respect, agree, in the great outlines of their distribution, with the vertebrate orders. The Regions are admittedly the same, or nearly the same for both; and the discrepancies that occur are of a nature which can be explained by two undoubted facts-the greater antiquity, and the greater facilities for dispersal, of insects.

But tliis principle, if sound, must be carried farther, and be applied to plants also. There are not wanting indications that this may be successfully done; and it seems not improbable, that the reason why botanists have hitherto failed to determine, with any unanimity, which are the most natural phytological regions, and to work out any connected theory of the migrations of plants, is, becanse they have not been furnished with the clue to the past changes of the great land masses, which could only be arrived at by such an examination of the past and present distribution of the higher animals as has been liere attempted. The difficulties in the way of the study of the distribution of plants, from this point of view, will be undoubtedly very great; owing to the unusual facilities for distribution many of them possess, and the absence of any group which might take the place of the mammalia arnong animals, and serve as a guide and standard for the rest. We caninot expect the regions to be so well defined in the case of plants as in that of animals; and there are sure to be many anomalies and discrepancies, which will require long study to unravel. The Six Great Regions here adopted, are however, as a whole, very well characterised by their vegetable forms. The floras of tropical America, of Australia, of South Africa, and of Indo-Malaya, stand out with as much individuality as do the famus; while the plants of the Palanrctic and Nearctic regions, exhibit resemblances and diversities, of a character not unlike those found among the animals.

This is not a mere question of applying to the vegetable kingdom a series of arbitrary divisions of the earth which have been 
found useful to zoologists; for it really involves a fundamental problem in the theory of evolution. The question we have to answer, is, firstly - whether the distribution of plants is, like that of animals, mainly and primarily dependent on the past revolutions of the earth's surface; or, whether other, and altogether distinct causes, have had a preponderating influence in determining the range and limits of vegetable forms ; and, secondly-whether those revolutions have been, in their general outlines, correctly interpreted by means of a study of the distribution and affinities of the higher animals. The first question is one for botanists alone to answer; but, on the second point, the author ventures to hope for an affirmative reply, from such of his readers as will weigh carefully the facts and arguments he has adduced.

The remaining part of this volume, will consist, of a systematic review of the distribution of each family of animals, and an application of the principles already established to elucidate the chief phenomena they present. The present chapter must, therefore, be considered as the conclusion of the argumentative and theoretical part of the present work; but it must be read in connection with the various discussions in Parts II. and III., in which the conclusions to be drawn from the several groups of facts have been successively given;-and especially in connection with the general observations at the end of each of the six chapters on the Zoological Regions.

The hypothetical view, as to the more recent of the great Geographical changes of the Earth's surface, here set forth, is not the result of any preconceived theory, but has grown out of a careful study of the facts accumulated, and has led to a considerable modification of the author's previous views. It may be described, as an application of the general theory of Evolution, to solve the problem of the distribution of animals; but it also furnishes some independent support to that theory, both by showing what a great variety of curious facts are explained by its means, and by answering some of the objections, 
which have been founded on supposed difficulties in the distribution of animals in space and time.

It also illustrates and supports the geological doctrine, of the general permanence of our great continents and oceans, by showing how many facts in the distribution of animals can only be explained and understood on such a supposition; and it exhibits, in a striking manner, the enormous influence of the Glacial epoch, in determining the existing zoological features of the various continents.

And, lastly, it furnishes a more consistent and intelligible idea than has yet been reached by any other mode of investigation, of all the more important changes of the earth's surface that have probably occurred during the entire Tertiary period; and of the influence of these changes, in bringing about the general features, as well as many of the more interesting details and puzzling anomalies, of the Geographical Distribution of Animals. 


\section{PART IV.}

\section{GEOGRAPHICAL ZOOLOGY:}

A SYSTEMATIC SKETCH OF THE CHIEF FAMILIES OF LAND ANIMALS IN THEIR GEOGRAPHICAL RELATIONS. 



\section{INTRODUCTION.}

Is the preceding part of our work, we have liseussed the geographical distribution of animals from the point of view of the geographer; taking the different regions of the earth in succession, and giving as full an account as cur space would permit of their chief forms of animal life. Now, we proceed from the standpoint of the systematic zoologist; taking in succession each of the families with which we deal, and giving an account of the distribution, both of the entire family and, as far as practicable, of each of the genera of which it is composed. As in the former part, our mode of treatment led us to speculate on the past changes of the earth's surface; so here we shall endeavour to elucidate the past migrations of animals, and thus, to some extent, account for their actual distribution.

The tabular headings, showing the range of the family in each region, will enable the reader to determine at a glance the general distribution of the group, as soon as he has familiarised himself, by a study of our general and regional maps, with the limits of the regions and sub-regions, and the figures ( 1 to 4 ) by which the latter are indicated. Much pains have been taken, to give the number of the known genera and species in each family, correctly; but these numbers must, in most cases, only be looked upon as approximations; because, owing to constant accessions of fresh material on the one hand, and the discovery that many supposed species are only varieties, on the other, such statistics are in a continual state of fluctuation. In the number of genera there is the greatest uncertainty; as will be seen by the two sets of numbers sometimes given, which denote the genera according to different modern authorities. 
There is also a considerable difference in the dependence to be placed on the details given in the different classes of animals. In Mammalia and Birds some degree of accuracy has, it is hoped, been attained; the classification of these groups being much advanced, and the materials for their study ample. In Reptiles this is not the case, as there is no recently published work dealing with the whole subject, or with either of the larger orders. An immense number of new species and new genera of snakes and lizards, have been described in the last $t$ wenty years; and Dr. Günther-our greatest authority on reptiles in this country - has kindly assisted me in incorporating such of these as are most trustworthy, in a general system; but until entire Orders have been described or catalogued on a uniform plan, nothing more than a general approximation to the truth can be arrived at. Still, so many of the groups are well defined, and have a clearly limited distribution, that some interesting and valnable comparisons may be made.

For Fishes, the valuable "Catalogue" of Dr. Günther was available, and it has rarely been attempted to go beyond it. A large number of new species have since been described, in all parts of the world; but it is impossible to say how many of these are really new, or what genera they actually belong to. The part devoted to this Class is, therefore, practically a summary of Dr. Günther's Catalogue ; and it is believed that the discoveries since made will not materially invalidate the conclusions to be drawn from such a large number of species, which have been critically examined and classified on a uniform system by one of our most able naturalists. When a supplement to this catalogue is issued, it will be easier to make the necessary alterations in distribution, than if a mass of untrustworthy materials had been mixed up with it.

For Insects, excellent materials are furnished, in the Catalogue of Mr. Kirby for Butterflies and in that of Drs. Gemminger and Harold for Coleoptera. I have also made use of some recently published memoirs on the Insects of Japan and St. Helena, and a few other recent works; and have, I believe, elaborated a more extensive series of facts to illustrate the distribution of insects, 
than has been made use of by any previous writer. Several discussions on the bearing of the facts of insect distribution, will also be found under the several Regions, in the preceding part of this work.

Terrestrial Mollusca form a group, as to the treatment of which I have most misgivings ; owing to my almost entire ignorance of Malacology, and the great changes recently made in the classification of shells. There is also much uncertainty as to genera and sub-genera, which is very puzzling to one who merely wishes to get at general results. Finding it impossible to incorporate the new matter with the old, or to harmonise the different classifications of modern conchologists, I thought it better to confine myself to the standard works of Martens and Pfeiffer, with such additions of new species as I could make without fear of going far wrong. In some cases I have made use of recent monographs-especially on the shells of Europe, North America, the West Indian Islands, and the Sandwich Islands; and have, I venture to hope, not fallen into much error in the general conclusions at which $I$ have arrived. 


\section{CHAPTER XVII.}

THE DISTRIBUTION OF TIIE FAMILIES AND GENERA OF MAMMALIA.

$$
\text { Order I.-PRIMATES. }
$$

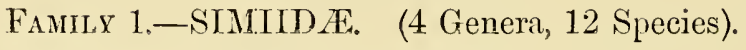

\begin{tabular}{|c|c|c|c|c|c|}
\hline \multicolumn{6}{|c|}{ General Distribution. } \\
\hline $\begin{array}{l}\text { NEOTROPICAL } \\
\text { SUB-REGIONS. }\end{array}$ & $\begin{array}{l}\text { NEARCTIC } \\
\text { SuB-REGIONS. }\end{array}$ & $\begin{array}{l}\text { PALFARCTIC } \\
\text { SUU-HEGIONS. }\end{array}$ & $\begin{array}{c}\text { ETHIOPIAN } \\
\text { SuB-REGIONS. }\end{array}$ & $\begin{array}{c}\text { ORIENTAL } \\
\text { SuB-HEGIONS. }\end{array}$ & $\begin{array}{l}\text { AUSTralian } \\
\text { SUB-REdions. }\end{array}$ \\
\hline---- & $-\cdots-$ & ---- & $-2--$ & --3.4 & -- \\
\hline
\end{tabular}

THE Simiidæ, or Anthropoid Apes, comprehend those forms of the monkey-tribe which, in general organization, approach nearest to man. They inhabit the tropics of the old World, and are most abundant near the equator; but they are limited to certain districts, being quite unknown in eastern and southern Africa, and the whole peninsula of Hindostan.

The genus Troglodytes (or Mimetes, as it is sornetimes named) comprehends the chimpanzee and gorilla. It is confined to the West African sub-region, being found on the coast about $12^{\circ}$ North and South of the equator, from the Gambia to Benguela, and as far inland as the great equatorial forests extend. There are perhaps other species of chimpanzee; since Livingstone met with what he supposed to be a new species in the forest region west of Lake Tanganyika, while Dr. Schweinfurth found one in the country beyond the western watershed of the Nile. The gorilla is confined within narrower limits on and near the equator. 
We have to pass over more than $70^{\circ}$ of longitude before we again meet with Anthropoid Apes, in the northern part of Sumatrawhere a specimen of the orang-utan (Simia satyrus) now in the Calcutta Museum, was obtained by Dr. Abel, and described by him in the Asiatic Researches, vol. xv.-and in Borneo, from which latter island almost all the specimens in European museums have been derived. There are supposed to be two species of Simia in Bornco, a larger and a smaller ; but their distinctness is not admitted by all naturalists. Both appear to be confined to the swampy forests near the north, west, and south coasts.

The Gibbons, or long-armed apes, forming the genus Hylobates, (7 species) are found in all the large islands of the Indo-Malayan sub-region, except the Philippines; and also in Sylhet and Assam south of the Brahmaputra river, eastward to Cambodja and South China to the west of Canton, and in the island of Hainan.

The Siamang (Siamanga syndactyla) presents some anatomical peculiarities, and has the second and third toes united to the last joint, but in general form and structure it does not differ from Hylobates. It is the largest of the long-armed apes, and inhabits Sumatra and the Malay peninsula.

\section{FaMrly 2.-SEMNOPITHECID A. (2 Genera, 30 Species.)}

\begin{tabular}{|c|c|c|c|c|c|}
\hline $\begin{array}{l}\text { NeOTROPICAL } \\
\text { Sub-REgIONS. }\end{array}$ & $\begin{array}{c}\text { NEARCTIC } \\
\text { SUB-REGIONS. }\end{array}$ & $\begin{array}{l}\text { PAL.EARCTIC } \\
\text { SUB-HEGIONS. }\end{array}$ & $\begin{array}{c}\text { ETHIOPIAN } \\
\text { SUB-REGIONS. }\end{array}$ & $\begin{array}{c}\text { Orirntal } \\
\text { Sub-kEgIons. }\end{array}$ & $\begin{array}{l}\text { Australian } \\
\text { Sub-REgions. }\end{array}$ \\
\hline--- & ---- & $--\ldots 4$ & $1.2--$ & $1.2 \cdot 3 \cdot 4$ & $-\ldots$ \\
\hline
\end{tabular}

The Semnopithecidæ, are long-tailed monkeys without cheekpouches, and with rather rounded faces, the muzzle not being prominent. They have nearly the same distribution as the last family, but are more widely dispersed in both Africa and Asia, one species just entering the Palæarctic region.

The Eastern genus Presbytes or Semnopithecus (29 species), is spread over almost the whole of the Oriental region wherever the forests are extensive. They cxtend along the Himalayas to beyond Simla, where a species has been observed at an altitude of 11,000 
feet, playing among fir-trees laden with snow wreatlis. On the west sicle of India they are not found to the north of $14^{\circ} \mathrm{N}$. latitude. On the east they extend into Arakan, and to Borneo and Java, but not apparently into Siam or Cambodja. Along the eastern extension of the Himalayas they again occur in East Thibet; a remarkable species with a large upturned nose ( $S$. roxellana) having been discovered by Père David at Moupin (about Lat. $32^{\circ} \mathrm{N}$.) in the highest forests, where the winter's are severe and last for several months, and where the vegetation, and the other forms of animal life, are wholly those of the Palæarctic region. It is very curious that this species should somewhat resemble the young state of the proboscis monkey (S. nasalis), which inhabits one of the most uniform, damp, and hot climates on the globe-the river-swamps of Borneo.

Colobus, the African genus (11 species), is very closely allied to the preceding, differing chiefly in the thumb being absent or rudimentary. They are confined to the tropical regions-Abyssinia on the east, and from the Gambia to Angola and the island of Fernando Po, on the west.

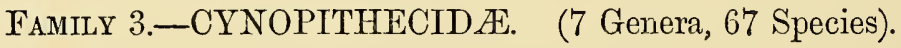

\begin{tabular}{|c|c|c|c|c|c|}
\hline \multicolumn{6}{|c|}{ General Distribution. } \\
\hline $\begin{array}{l}\text { NEOTROPICAL } \\
\text { SUB-REGIONS. }\end{array}$ & $\begin{array}{c}\text { Nearctic } \\
\text { Sub-REgIONS. }\end{array}$ & $\begin{array}{l}\text { Palaiarctic } \\
\text { Sub-hegions. }\end{array}$ & $\begin{array}{c}\text { ETHIOPIAN } \\
\text { SUR-REGIONS. }\end{array}$ & $\begin{array}{c}\text { ORIENTAL } \\
\text { SUB-EEGIONS. }\end{array}$ & $\begin{array}{l}\text { AUSTRALIAN } \\
\text { SUB-REGIONS. }\end{array}$ \\
\hline--- & ---- & $-2-4$ & $1 \cdot 2 \cdot 3-$ & $1 \cdot 2 \cdot 3 \cdot 4$ & $1--$ \\
\hline
\end{tabular}

This family comprehends all the monkeys with cheek pouches, and the baboons. Some of these have very long tails, some none; some are dog-faced, others tolerably round-faced; but there are so many transitions from one to the other, and such a general agreement in structure, that they are now considered to form a very natural family. Their range is more extensive than any other family of Quadrumana, since they not only occur in every part of the Ethiopian and Oriental regions, but enter the Palaarctic region in the east and west, and the Australian region as far as the islands of Timor and Batchian. The African genera 
are Myiopithecus, Cercopithecus, Cercocebus, Theropithecus, and Cynocephalus; the Oriental genera, Macacus, and Cynopithecus.

Myiopithecus (1 species), consisting of the talapoin monkey of West Africa, differs from the other African monkeys in the structure of the last molar tooth ; in the large ears, short face, and wide internasal septum; in this respect, as well as in its grace and genileness, resembling some of the American monkeys.

Cercopithecus (24 species), contains all the more graceful and prettily coloured monkeys of tropical Africa, and comprises the guenons, the white-nosed, and the green monkeys. They range from the Gambia to the Congo, and from Abyssinia to the Zambesi.

Cercocebus (5 species), the mangabeys, of West Africa, are very closely allied to the eastern genus Macacus.

Theropithecus (2 species), including the gelada of Abyssinia and an allied species, resemble in form the baboons, but have the nostrils placed as in the last genus.

Cynocephalus (10 species), the baboons, are found in all parts of Africa. They consist of animals which vary much in appearance, but which agree in having an elongated dog-like muzzle with terminal nostrils, and being of terrestrial habits. Some of the baboons are of very large size, the mandrill $(C$. maimon) being only inferior to the orang and gorilla.

Macacus (2 2 species), is the commonest form of eastern monkey, and is found in every part of the Oriental region, as well as in North Africa, Gibraltar, Thibet, North China, and Japan ; and one of the commonest species, $M$. cynomolgus, has extended its range from Java eastward to the extremity of Timor. The tail varies greatly in length, and in the Gibraltar monkey (II. innus) is quite absent. A remarkable species clothed with very thick fur, has lately been discovered in the snowy mountains of eastern Thibet.

Cynopithecus (? 2 sp.).-This genus consists of a black baboonlike Ape, inhabiting Celebes, Batchian, and the Philippine Islands; but perhaps introduced by man into the latter islands and into Batchian. It is doubtful if there is more than one species. The tail of this animal is a fleshy tubercle, the nostrils as in Macacus, but the muzzle is very prominent; and the 
development of the maxillary bones into strong lateral ridges corresponds to the structure of the most typical baboons. This species extends further east than any other quadrumanous animal.

Fanily 4-CEBID $2 . \quad$ (10 Genera, 78 Species.)

\begin{tabular}{|c|c|c|c|c|c|}
\hline $\begin{array}{l}\text { NEOTROPICAL } \\
\text { SUB-REGIONS. }\end{array}$ & $\begin{array}{c}\text { NeARctic } \\
\text { Sub-REGions. }\end{array}$ & $\begin{array}{l}\text { Paldearctic } \\
\text { Sub-hEgions. }\end{array}$ & $\begin{array}{c}\text { Ethiopian } \\
\text { Sub-REgloNs. }\end{array}$ & $\begin{array}{c}\text { Oriental } \\
\text { SUB-REgIONS. }\end{array}$ & $\begin{array}{l}\text { AUSTRalian } \\
\text { SUb-REgions. }\end{array}$ \\
\hline$-2.3-$ & --- & --- & ---- & ---- & -- \\
\hline
\end{tabular}

The Cebidxe, which comprehend all the larger American Monkeys, differ from those of the old World by having an additional molar tooth in each jaw, and a broad nasal septum; while they have neither cheek-pouches nor ischial callosities, and the thumb is never completely opposable. Some have prehensile tails, especially adapting them for an arboreal life. They are divided into four sub-families,-Cebinæ, Mycetinæ, Pitheciinæ, and Nyctipithecinæ. The Cebidæ are strictly confined to the forest regions of tropical America, from the southern part of Mexico to about the parallel of $30^{\circ}$ South Latitude. The distribution of the genera is as follows:-

Sub-family, Cebinæ.-Cebus (18 sp.), is the largest genus of American monkeys, and ranges from Costa Rica to Paraguay. They are commonly called sapajons. Lagothrix (5 sp.), the woolly monkeys, are rather larger and less active than the preceding; they are confined to the forests of the Upper Amazon Valley, and along the slopes of the Andes to Venezuela and Bolivia. Ateles (14 sp.), the spider monkeys, have very long limbs and tail. They range over the whole area of the family, and occur on the west side of the Equatorial Andes and on the Pacific coast of Guatemala. Eriodes (3 sp.), are somewhat intermediate between the last two genera, and are confined to the eastern parts of Brazil south of the equator. The three last mentioned genera have very powerful prehensile tails, the end being bare beneath; whereas the species of Cebus have the tail 
completely covered with hair, although prehensile, and therefore not so perfect a grasping organ.

Sub-family, Mycetinæ, consists of but a single genus, Mycctes (10 sp.), the howling monkeys, characterized by having a hollow bony vessel in the throat formed by an enlargement of the hyoid bone, which enables them to produce a wonderful howling noise. They are large, heavy animals, with a powerful and perfect prehensile tail. They range from East Guatemala to Paraguay. (Plate XIV., vol, ii., p. 24.)

Sub-family, Pitheciinæ, the sakis, have a non-prehensile bushy tail. Pithecia (7 sp.), has the tail of moderate length; while Brachiurus (5 sp.) has it very short. Both appear to be restricted to the great equatorial forests of South America.

Sub-family, Nyctipithecinæ, are small and elegant monkeys, with long, hairy, non-prehensile tails. Nyctipithecus ( $5 \mathrm{sp}$.), the night-monkeys or douroucoulis, have large eyes, nocturnal habits, and are somewhat lemurine in their appearance. They range from Nicaragua to the Amazon and eastern Peru. Saimiris or Chrysothrix (3 sp.), the squirrel-inonkeys, are beautiful and active little creatures, found in most of the tropical forests from Costa Rica to Brazil and Bolivia. Callithrix (11 sp.), are somewhat intermediate between the last two genera, and are found all over Sonth America from Panama to the sonthern limits of the great forests.

Fayily 5.-HAPALIDA. (2 Genera, 32 Species.)

\begin{tabular}{|c|c|c|c|c|c|}
\hline \multicolumn{6}{|c|}{ General Distribution. } \\
\hline $\begin{array}{l}\text { NiOTROPICAL } \\
\text { StiB-REGIONS. }\end{array}$ & $\begin{array}{c}\text { NEARCTIC } \\
\text { SUUB-REGIONS. }\end{array}$ & $\begin{array}{l}\text { PaLEARCTIC } \\
\text { Sub-EEGIONS. }\end{array}$ & $\begin{array}{c}\text { ETHIOPIAN } \\
\text { SUB-REGIONS. }\end{array}$ & $\begin{array}{c}\text { ORIENTAL } \\
\text { SUB-REGIONS. }\end{array}$ & $\begin{array}{l}\text { Australian } \\
\text { Sub-regions. }\end{array}$ \\
\hline$-2-\cdots$ & $--\cdots$ & $-\cdots-$ & ---- & $---\cdots$ & $--\cdots$ \\
\hline
\end{tabular}

The Hapalidie, or marmosets, are very snall monkeys, which differ from the true Cebide in the absence of one premolar tooth, while they possess the additional molar tooth; so that while they have the same number of teeth (thirty-two) as the old World monkeys, they differ from them even more than do the 
Cebidæ. The thumb is not at all opposable, and all the fingers are armed with sharp claws. The hallux, or thumb-like great toe, is very small; the tail is long and not prehensile. The two genera Hapale (9 sp.), and Midas (24 sp.), are of doubtful value, though some naturalists have still further sub-divided them. They are confined to the tropical forests of South America, and are most abundant in the districts near the equator.

\section{Sub-order-LEMUROIDEA.}

Family 6.-LEMURID $\approx$. (11 Genera, 53 Species.)

\begin{tabular}{|c|c|c|c|c|c|}
\hline \multicolumn{6}{|c|}{ General Distribution. } \\
\hline $\begin{array}{l}\text { NeOTROPICAL } \\
\text { SUB-REGIONS. }\end{array}$ & $\begin{array}{c}\text { NEAHCTIO } \\
\text { SUB-REGIONS. }\end{array}$ & $\begin{array}{l}\text { PALAarctic } \\
\text { SUB-K EGIONS. }\end{array}$ & $\begin{array}{c}\text { EtHiopian } \\
\text { SUB-REgIONS. }\end{array}$ & $\begin{array}{c}\text { ORIENTAL } \\
\text { SUB-EEgIONS. }\end{array}$ & $\begin{array}{l}\text { AUSTRALIAN } \\
\text { SUB-REgIONS. }\end{array}$ \\
\hline--- & $-\ldots$ & $1.2 \cdot 3 \cdot 4$ & $-2 \cdot 3 \cdot 4$ & ---- & $--\cdots$ \\
\hline
\end{tabular}

The Lemuridæ, comprehending all the animals usually termed Lemurs and many of their allies, are divided by Professor Mivart -who has carefully studied the group-into four sub-families and eleven genera, as follows :-

Sub-family Indrisinæ, consisting of the genus Indris (5 sp.), is confined to Madagascar.

Sub-family Lemurinæ, contains five genera, viz.:-Lemur, (15 sp.); Hapalemur (2 sp.); Microcebus (4 sp.); Chirogaleus (5 sp.); and Lepilemur (2 sp.);-all confined to Madagascar.

Sub-family Nycticebinæ, contains four genera, viz. :-Nycticcbus (3 sp.) - small, short-tailed, nocturnal animals, called slow-lemurs, -range from East Bengal to South China, and to Borneo and Java; Loris (1 sp.) - a very small, tail-less, nocturnal lemur, which inhabits Madras, Malabar, and Ceylon; Perodicticus (1 sp.) - the potto-a small lemur with almost rudimentary forefinger, found at Sierra Leone (Plate V., vol. i., p. 264); Arctocebus (1 sp.) - the angwantibo,-another extraordinary form in which the forefinger is quite absent and the first toe armed with a long claw,-inhabits Old Calabar. 
Sub-family Galaginæ, contains only the genus Galago (14 sp.), which is confined to the African continent, ranging from Senegal and Fernando Po to Zanzibar and Natal.

FAnitu 7.-TARSIID A. $\quad$ (1 Genus, 1 Species.)

\begin{tabular}{|c|c|c|c|c|c|}
\hline \multicolumn{6}{|c|}{ Gexeral Distribution. } \\
\hline $\begin{array}{l}\text { NEOTROPICAL } \\
\text { SUB-REGIONS. }\end{array}$ & $\begin{array}{c}\text { NEARCTIC } \\
\text { SUB-REGIONS. }\end{array}$ & $\begin{array}{l}\text { Pal-Eakctic } \\
\text { SUB-REGTONS. }\end{array}$ & $\begin{array}{c}\text { ETHIOPIAN } \\
\text { SUB-REGIONS. }\end{array}$ & $\begin{array}{c}\text { ORIENTAI, } \\
\text { Sưb-REGIONS. }\end{array}$ & $\begin{array}{l}\text { AUSTRALIAN } \\
\text { SUB-REGIONS, }\end{array}$ \\
\hline--- & $\ldots-$ & ---- & ---- & ---4 & ---- \\
\hline
\end{tabular}

The curious Tarsins spectmum, which constitutes this family, inhabits Sumatra, Banca, and Borneo, and is also found in some parts of Celebes, which would bring it into the Australian region; but this island is altogether so anomalous that we can only consider its productions to have somewhat more affinity with the Australian than the Oriental region, but hardly to belong to either. The Tarsier is a small, long-tailed, nocturnal animal, of curious structure and appearance; and it forms the only link of connection with the next family, which it resembles in the extraordinary development of the toes, one of which is much larger and more slender than the rest. (Plate VIII., vol. i. p. 337.)

Family 8.-CHIRomyid A. (1 Genus, 1 species.)

Gexeral Distribution.

\begin{tabular}{|c|c|c|c|c|c|}
\hline $\begin{array}{l}\text { NeOTROPICAL } \\
\text { SUB-REgIONS. }\end{array}$ & $\begin{array}{c}\text { NEARCTIC } \\
\text { SUB-REGIONS. }\end{array}$ & $\begin{array}{l}\text { Paldearctic } \\
\text { Sub-REgIONS. }\end{array}$ & $\begin{array}{c}\text { ETHIOPIIN } \\
\text { SUB-REGIONS. }\end{array}$ & $\begin{array}{c}\text { ORIENTAL } \\
\text { SUB-REGIONS. }\end{array}$ & $\begin{array}{c}\text { AUSTRALIAN } \\
\text { SUB-REGIONS. }\end{array}$ \\
\hline$-\cdots-$ & --- & ---- & -- & --- & -- \\
\hline
\end{tabular}

The Aye-aye, (Chiromys), the sole representative of this family, is confined to the island of Madagascar. It was for a long time very imperfectly known, and was supposed to belong to the Rodentia; but it has now been ascertained to be an exceedingly specialized form of the Lemuroid type, and must be considered to be one of the most extraordinary of the mammalia now inhabiting the globe. (Plate VI., vol. i., p. 278.)

VOL, II. 


\section{Fossil Quadrumana.}

Not much progress has yet been made in tracing back the various forms of Apes and Monkeys to their earliest appearance on the globe; but there have been some interesting recent discoveries, which lead us to hope that the field is not yet exhausted. The following is a summary of what is known as to the early forms of each family :-

Simiidoc.-Two or three species of this family have been found in the Upper Miocene deposits of France and Switzerland. Pliopithecus, of which a species has been found at each locality, was allied to the gibbons (Hylobates), and perhaps to Semnopithecus. A more remarkable form, named Dryopithccus, as large as a man, and having peculiarities of structure which are thought by Gervais and Lartet to indicate a nearer approach to the human form than any existing Ape, has been found in strata of the same age in France.

Semnopithecidae._Species of Semnopithecus have been found in the Upper Mrocene of Greece, and others in the Siwalik Hills of N. W. India, also of Upper Miocene age. An allied form also occurs in the Miocene of Wurtemburg. Mesopithecus from Greece is somewhat intermediate between Semnopithecus and Macacus.

Remains supposed to be of Semnopithceus, have also occurred in the Pliocene of Montpellier.

Cynopithecidce.-Macacus has occurred in Pliocene deposits at Grays, Essex; and also in the South of France along with Cercopithecus.

Cebidce.-In the caves of Brazil remains of the genera Cebus, Mycetes, Callithrix, and Hapale, have been found; as well as an extinct form of larger size-Protopithecus.

Lemuroidea.-A true lemur has recently been discovered in the Eocene of France; and it is supposed to be most nearly allied to the peculiar West African genera, Perodicticus and Arctorebus. Ccenopithecus, from the Swiss Jura, is supposed to have affinities both for the Lemuridæ and the American Cebidæ.

In the lower Eocene of North America remains have been 
discovered, which are believed to belong to this sub-order: but they form two distinct families,--Lemuravidæe and Limnotheridæ. Other remains from the Miocene are believed to be intermediate between these and the Cebidæ, - a most interesting and suggestive affinity, if well founded. For the genera of these American Lemuroidea, see vol. i., p. 133.

\section{General Remarks on the Distribution of Primates.}

The most striking fact presented by this order, from our present point of view, is the strict limitation of well-marked families to definite areas. The Cebiclæ and Hapalidæ would alone serve to mark out tropical America as the nucleus of one of the great zoological divisions of the earth. In the Eastern Hemisphere, the corresponding fact is the entire absence of the order from the Australian region, with the exception of one or two outlying forms, which have evidently transgressed the normal limits of their group. The separation of the Ethiopian and Oriental regions is, in this order, mainly indicated by the distribution of the genera, no one of which is common to the two regions. The two highest families, the Simiidæ and the Semnopithecidæ, are pretty equally distributed about two equatorial foci, one situated in West Africa, the other in the Malay archipelago,--in Borneo or the Peninsula of Malacea;-while the third family, Cynopithecidæ, ranges over the whole of both regions, and somewhat overpasses their limits. The Lemuroid group, on the other hand, offers us one of the most singular phenomena in geographical distribution. It consists of three families, the species of which are grouped into six sub-families and 13 genera. One of these families and two of the sub-families, comprising 7 genera, and no less than 30 out of the total of 50 species, are confined to the one island of Madagascar. Of the remainder, 3 genera, comprising 15 species, are spread over tropical Africa; while three other genera with 5 species, inhabit certain restricted portions of India and the Malay islands. These curious facts point unmistakably to the former existence of a large tract of land in what is now the Indian Ocean, connecting Madagascar on the one hand with Ceylon, and with the Malay countries on the 
other. About this same time (but perhaps not contemporaneously) Madagascar must have been connected with some portion of Southern Africa, and the whole of the country would possess no other Primates but Lemuroidea. After the Madagascar territory (very much larger than the existing island) had been separated, a connection appears to have been long maintained (probably by a northerly route) between the more equatorial portions of Asia and Africa; till those higher forms had become developed, which were afterwards differentiated into Simia, Presbytes, and Cynopithecus, on the one hand, and into Troglodytes, Colobus, and Cynocephalus, on the other. In accordance with the principle of competition so well expounded by Mr. Darwin, we can understand how, in the vast Asiatic and African area north of the Equator, with a great variety of physical conditions and the influence of a host of competing forms of life, higher types "were developed than in the less extensive and long-isolated countries sonth of the Equator. In Madagascar, where these less complex conditions prevailed in a considerable land-area, the lowly organized Lemuroids have diverged into many specialized forms of their own peculiar type; while on the continents they have, to a great extent, become exterminated, or have maintained their existence in a few cases, in islands or in mountain ranges. In Africa the nocturnal and arboreal Galagos are adapted to a special mode of life, in which they probably have few competitors.

How and when the ancestors of the Cebidæ and Hapalidæ entered the South American continent, it is less easy to conceive. The only rays of light we yet have on the subject are, the supposed affinities of the fossil Ccenopithecus of the Swiss, and the Lemuravidæ of the North American Eocene, with both Cebidæ and Lemuroids, and the fact that in Miocene or Eocene times a mild slimate prevailed up to the Arctic circle. The discovery of an undoubted Lemuroid in the Eocene of Europe, indicates that the great Northern Continent was probably the birthplace of this low type of mammal, and the source whence Africa and Southern Asia were peopled with them, as it was, at a later period, with the higher forms of monkeys and apes. 
Order II.-CHIROPTERA.

Family 9.-PTEROPID Æ. (9 Genera, 65 Species.)

\begin{tabular}{|c|c|c|c|c|c|}
\hline \multicolumn{6}{|c|}{ General Distribution. } \\
\hline $\begin{array}{l}\text { NFOTROPICAL } \\
\text { StiB-REGIONS. }\end{array}$ & $\begin{array}{c}\text { NEARCTIC } \\
\text { SUB-REGIONS. }\end{array}$ & $\begin{array}{l}\text { PAL.EARCTIC } \\
\text { SU B-REGIONS. }\end{array}$ & $\begin{array}{c}\text { ETHIOPIAN } \\
\text { SUB-REGIONS. }\end{array}$ & $\begin{array}{l}\text { ORIFNTIL } \\
\text { SUB-RI GIJASS. }\end{array}$ & $\begin{array}{l}\text { Australian } \\
\text { Sub-REgions. }\end{array}$ \\
\hline---- & --- & ---4 & 1.2 .3 .4 & 1.2 .3 .4 & $1.2 .3-$ \\
\hline
\end{tabular}

The Pteropidæ, or fruit-eating Bats, sometimes called flyingfoxes, are pretty evenly distributed over the tropical regions of the Old World and Australia. They range over all Africa and the whole of the Oriental Region, and northward, to Amoy in China and to the South of Japan. They are also found in the more fertile parts of Australia and Tasmania, and in the Pacific Islands as far east as the Marianne and Samoa Islands; but not in the Sandwich Islands or New Zealand.

The genera of bats are exceedingly numerous, but they are in a very unsettled state, and the synonymy is exceedingly confused. The details of their distribution cannot therefore be usefully entered into here. The Pteropidæe differ so much from all other bats, that they are considered to form a distinct suborder of Chiroptera, and by some naturalists even a distinct order of Mammalia.

No fossil Pteropidæ have been discovered.

Fanily 10.-PHYLLOSTOMID E. (31 Genera, 60 Species.)

Gexeral Distribution.

\begin{tabular}{|c|c|c|c|c|c|}
\hline $\begin{array}{l}\text { NeOTROPICAL } \\
\text { SUB-REGIONS }\end{array}$ & NeARCTIC & PaLfeARCTIC & ETHIOPI.IN & Onizantal & Australian \\
\hline $1.2 .3-$ & $1---$ & ---- & $---\cdots$ & $-\cdots--$ & -- \\
\hline
\end{tabular}

The Phyllostomidæ, or simple leaf-siosed Bats, are confined to the Neotropical region, from Mexico and the Antilles to the 
sonthern limits of the forest region east of the Andes, and to about lat. $33^{\circ} \mathrm{S}$. in Chili. None are found in the Nearetic region, with the exception of one species in California (Macrotus Californicus), closely allied to Mexican and West Indian forms. The celebrated blood-sucking vampyre bats of Sonth America belong to this group. Two genera, Desmodus and Diphylla, form Dr. Peters' family Desmodidæ. Mr. Dobson, in his recently published arrangement, divides the family into five groups:Mormopes, Vampyri, Glossophagre, Stenodermata, and Desmodontes.

Numerous remains of extinct species of this family have been found in the bone-caves of Brazil.

Family 11.-Rhinolophide. (7 Genera, 70 Species.)

\begin{tabular}{|c|c|c|c|c|c|}
\hline \multirow[b]{2}{*}{$\begin{array}{l}\text { NEUTROPICAL } \\
\text { SUB-REG!ONS. }\end{array}$} & \multicolumn{4}{|c|}{ General Distribution. } & \multirow[b]{2}{*}{$\begin{array}{l}\text { ALstralian } \\
\text { St:B-REitions. }\end{array}$} \\
\hline & $\begin{array}{c}\text { NEARGIIC } \\
\text { SUB-REGIONS. }\end{array}$ & $\begin{array}{l}\text { PAL_Earctic } \\
\text { SUb-HEGIONS. }\end{array}$ & $\begin{array}{c}\text { ETHIOPIAN } \\
\text { SUB-REgIONS. }\end{array}$ & $\begin{array}{c}\text { ORIENTAL } \\
\text { SUB-EEGIONS. }\end{array}$ & \\
\hline--- & $\ldots \ldots$ & 1.2 .3 .4 & 1.2 .3 .4 & 1.2 .3 .4 & $1.2--$ \\
\hline
\end{tabular}

The Rhinolophidæ, or Horse-shoe. Bats (so-called from a curiously-shaped membranous appendance to the nose), range over all the Ethiopian and Oriental regions, the southern part of the Palæarctic region, Anstralia and Tasmania. They are most abundant and varied in the Oriental region, where twelve genera are found; while only five inhabit the Australian and Ethiopian regions respectively. Europe has only one genus and four species, mostly found in the southern parts, and none going further north than the latitude of England, where two species occur. Two others are found in Japan, at the opposite extremity of the Palæarctic region.

The genera Nycteris and Mcgaderma, which range over the Ethiopian and Oriental regions to the Moluccas, are considered by Dr. Peters to form a distinct family, Megadermidæ; and Mr. Dobson in his recent arrangement (published after our first 
volume was printed) adopts the same family under the name of Nycteridx. The eurious Indian genus Rhinopoma, which, following Dr. J. E. Gray, we have classed in this family, is considered by Mr. Dobson to belong to the Noctilionidæ.

Fossil Rhinolophidce--Remains of a species of Rhinolophus still living in England, have been found in Kent's Cavern, near Torquay.

Family 12.-VESPEPTILIONID AE. (18 Genera, 200 Species.)

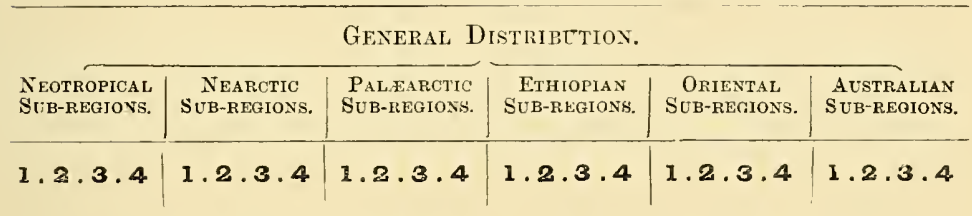

The small bats constituting the family Vespertilionidæ, have no nose-membrane, but an internal earlet or tragus, and often very large ears. They range over almost the whole globe, being apparently only limited by the necessity of procuring insect food. In America they are found as far north as Hudson's Bay and the Columbia river; and in Europe they approach, if they do not pass the Arctic circle. Such remote islands as the Azores, Bermudas, Fiji Islands, Sandwich Islands, and New Zealand, all possess species of this group of bats, some of which probably inhabit every island in warm or temperate parts of the globe.

The genus Taphozous, which, in our Tables of Distribution in vol. i. we have included in this family, is placed by Mr. Dobson in his family Emballonuridæ, which is equivalent to our next family, Noctilionidæ.

Fossil Vespertilionida.-Several living European bats of this family-Scotophilus murinus, Plecotus auritus, Vespertilio noctula, and $V$. pipestrellus-have been found fossil in bone-caves in various parts of Europe.

Extinct species of Vespertitio have occurred in the Lower Miocene at Mayence, in the Upper Miocene of the South of France, and in the Upper Eocene of the Paris basin. 
Family 13.-NOCTILIONIDA. (14 Genera, 50 Species.)

\begin{tabular}{|c|c|c|c|c|c|}
\hline \multicolumn{6}{|c|}{ General Distribution. } \\
\hline $\begin{array}{l}\text { NrotropiCAL } \\
\text { StiB-REGIONS. }\end{array}$ & $\begin{array}{c}\text { Nearctic } \\
\text { SuE-REGIONS. }\end{array}$ & $\begin{array}{l}\text { Palanarctic } \\
\text { Sub-Itegions. }\end{array}$ & $\begin{array}{c}\text { ETHIOPIAN } \\
\text { SUB-REGIONS. }\end{array}$ & $\begin{array}{c}\text { ORIENTAL } \\
\text { SUB-REGIONS. }\end{array}$ & $\begin{array}{l}\text { AUsTRALIAN } \\
\text { SUB-REGIONS. }\end{array}$ \\
\hline $1.2 .3 \cdot 4$ & $1---$ & $-2--$ & 1.2 .3 .4 & 1.2 .3 .4 & ---4 \\
\hline
\end{tabular}

The Noctilionidæ, or short-headed Bats, are found in every region, but are very unequally distributed. Their head-quarters is the Neotropical region, where most of the genera occur, and where they range from Mexico to Buenos Ayres and Chili, while in North America there is only one species in California. They are unknown in Australia; but one species occurs in New Zealand, and another in Norfolk Island. Several species of Dysopes (or Molossus) inhabit the Oriental region; one or two species being widely distributed over the continent, while two others inhabit the Indo-Malayan Islands. A species of this same genus occurs in South Africa, and another in Madagascar and in the Island of Bourbon; while one inhabits Southern Europe and North Africa, and another is found at Amoy in China. It will be seen therefore, that these are really South American bats, which have a few allies widely scattered over the various regions of the globe. Their affinities are, according to Mr. Tomes, with the Phyllostomidæ, a purely South American family. The species which forms the connecting link is the Mystacina tuberculata, a New Zealand bat, which may, with almost equal propriety be placed in either family, and which affords an interesting illustration of the many points of resemblance between the Australian and Neotropical regions.

Dr. Peters has separated this family into three,-Mormopidæ, which is wholly Neotropical, and is especially abundant in the West Indian Islands; Molossidæ, chiefly consisting of the genus Molossus; and Noctilionidæ, comprising the remainder of the family, and wholly Neotropical. Mr. Dobson, however, classes the Mormopes with the Phyllostomida, and reduces the 
Molossi to the rank of a sub-family. In our first volume we have classed Rhinopoma with the Rhinolophidæ, and Taphozous with the Vespertilionidæ; but according to Mr. Dobson both these genera belong to the present family.

\section{Remarks on the Distribution of the Order Chiroptera.}

Although the bats, from their great powers of flight, are not amenable to the limitations which determine the distribution of other terrestrial mammals, yet certain great facts of distribution come out in a very striking manner. The speciality of the Neotropical region is well shown, not only by its exclusive possession of one large family (Phyllostomidæ), but almost equally so by the total absence of two others (Pteropidæ and Phinolophidæ). The Nearctic region is also unusually well marked, by the total absence of a family (Rhinolophidæ) which is tolerably well represented in the Palæarctic. The Pteropidæ well characterize the tropical regions of the Old World and Australia; while the Vespertilionidæ are more characteristic of the Palæarctic and Nearctic regions, which together possess about 60 species of this family.

The bats are a very difficult study, and it is quite uncertain how many distinct species are really known. Schinz, in his Synopsis Mammalium (1844) describes 330, while the list given by Mr. Andrew Murray in his Geographical Distribution of Mammalia (1866), contains 400 species. A small number of new species have been since described, but others have been sunk as synonyms, so that we can perhaps hardly obtain a nearer approximation to the truth than the last number. In Europe there are 35 species, and only 17 in North America.

Fossil Chiroptera.-The fossil remains of bats that have yet been discovered, reing chiefly allied to forms still existing in the same countries, throw no light on the origin or affinities of this remarkable and isolated order of Mammalia; but as species very similar to those now living were in existence so far back as Miocene or even Eocene times, we may be sure the group is one of immense antiquity, and that there has been ample time for the amount of variation and extinction required to bring about 
the limitation of types, and the peculiarities of distribution we now find to exist.

Order III.-INSECTIVORA.

Family 14.-GALEOPITHECID E. (1 Genus, 2 Species.)

\begin{tabular}{|c|c|c|c|c|c|}
\hline \multicolumn{6}{|c|}{ General Distribution. } \\
\hline $\begin{array}{l}\text { NEOTROPIFAL } \\
\text { SUB-RFOIONS. }\end{array}$ & $\begin{array}{c}\text { NEARCTIC } \\
\text { SUB-REOIONS. }\end{array}$ & $\begin{array}{l}\text { P'al-AaRCTiC } \\
\text { SUB-kEGIOASS. }\end{array}$ & $\begin{array}{c}\text { ETHIOPIAN } \\
\text { SUB-REGIONS. }\end{array}$ & $\begin{array}{l}\text { ORIENTAL } \\
\text { SUB-FEGIONS. }\end{array}$ & $\begin{array}{l}\text { A Uutralian } \\
\text { Sue-rbiions. }\end{array}$ \\
\hline$--\cdots$ & --- & $---\cdots$ & ---- & --4 & --- \\
\hline
\end{tabular}

The singular and isolated genus Galeopitheeus, or flying lemur, has been usually placed among the Lemuroidea, but it is now considered to come best at the head of the Insectivora. Its food however, seems to be purely vegetable, and the very small, blind, and naked young, closely attached to the wrinkled skin of the mother's breast, perhaps indicates some affinity with the Marsupials. This animal seems, in fact, to be a lateral offshoot of some low form, which has survived during the process of development of the Insectivora, the Lemuroidea, and the Marsupials, from an ancestral type. Only two species are known, one found in Malacca, Sumatra, and Borneo, but not in Java; the other in the Philippine islands (Plate VIII. vol. i. p. 337).

FAMILY 15.-MACROSCELIDID E. (3 Genera, 10 Species.)

\begin{tabular}{|c|c|c|c|c|c|}
\hline \multicolumn{6}{|c|}{ General Distribution. } \\
\hline $\begin{array}{l}\text { NEOTROPICAL } \\
\text { SUB-REGIONS. }\end{array}$ & $\begin{array}{c}\text { NEARCTIC } \\
\text { SUB-REGIONS. }\end{array}$ & $\begin{array}{l}\text { PaLAarcti } \\
\text { FUB-kFGIONS. }\end{array}$ & $\begin{array}{l}\text { ETHIOPIIN } \\
\text { SUB-REGIONS. }\end{array}$ & $\begin{array}{l}\text { ORIENTAL } \\
\text { Sub-REgions. }\end{array}$ & $\begin{array}{l}\text { AUSTRALIAN } \\
\text { SUB-REGIONS. }\end{array}$ \\
\hline--- & --- & $-2--$ & $1-3-$ & $-\cdots-$ & ---- \\
\hline
\end{tabular}

The Macroscelides, or elephant shrews, are extraordinary little animals, with trunk-Jike snout and kangaroo-like hind-legs. They are almost confined to South Africa, whence they extend up the east coast as far as the Zambezi and Mozambique. A 
single outlying species of Macroscelides inhabits Barbary and Algeria; while the two genera Petrodromus, and Rhyncocyon, each represented by a single species, have only been found at Mozambique.

FAmily 16.-TUPAIID Æ. (3 Genera, 10 species.)

\begin{tabular}{|c|c|c|c|c|c|}
\hline \multicolumn{6}{|c|}{ General Distribution. } \\
\hline $\begin{array}{l}\text { NEOTROPICAL } \\
\text { SUB-REGIONS. }\end{array}$ & $\begin{array}{c}\text { Nearctic } \\
\text { Sub-REGions. }\end{array}$ & $\begin{array}{l}\text { PaLAarctic } \\
\text { SuB-hEGIONS. }\end{array}$ & $\begin{array}{c}\text { EtHIOPIAN } \\
\text { SUB-REGIONS. }\end{array}$ & $\begin{array}{c}\text { ORIENTAL } \\
\text { SUB-kEGIONS. }\end{array}$ & $\begin{array}{c}\text { AUSTRALIAN } \\
\text { SUB-REgIONS. }\end{array}$ \\
\hline$\ldots-\ldots$ & $---\cdots$ & $-\ldots$ & $\cdots-\cdots$ & $-2 \cdot 3 \cdot 4$ & - \\
\hline
\end{tabular}

The Tupaiidre are squirrel-like shrews, having bushy tails, and often climbing up trees, but also feeding on the ground and among low bushes. The typical Tupaia (7 species), are called ground squirrels by the Malays. They are most abundant in the Malay islands and Indo-Chinese countries, but one species is found in the Khasia Mountains, and one in the Eastern Ghauts near Madras. The small shorter-tailed Hylomys (2 species) is found from Tenasserim to Java and Borneo; while the elegant little Ptilocerus (1 species) with its long pencilled tail, is confined to Borneo; (Plate VIlI. vol. i. p. 337). The family is therefore especially Malayan, with outlying species in northern and continental India.

Extinct Species.-Oxygomphus, found in the Tertiary deposits of Germany, is believed to belong to this family; as is Omomys, from the Pliocene of the United States.

Fanily 17.-ERINACEID E. (2 Genera, 15 Species.)

\begin{tabular}{|c|c|c|c|c|c|}
\hline \multicolumn{6}{|c|}{ Gexeral Distribution. } \\
\hline $\begin{array}{l}\text { NEOTROPICAL } \\
\text { SUB-REGIONS. }\end{array}$ & $\begin{array}{l}\text { NEARCTIC } \\
\text { SUB-REGYONS. }\end{array}$ & $\begin{array}{l}\text { PAI.AEARCTIC } \\
\text { SUB-REGIONS. }\end{array}$ & $\begin{array}{c}\text { ETHIOPIIN } \\
\text { SUB-PEgIONS. }\end{array}$ & $\begin{array}{l}\text { ORIENTAL } \\
\text { SUB-REGIONS. }\end{array}$ & $\begin{array}{l}\text { Australian } \\
\text { SUb-REgIONS. }\end{array}$ \\
\hline$---\cdots$ & $---\cdots$ & 1.2 .3 .4 & $--3-$ & $1.2-4$ & $--\cdots$ \\
\hline
\end{tabular}

The Hedgehogs, comprised in the genus Erinaceus (14 species), are widely distributed over the Palæarctic, and a part of the 
Oriental regions; but they only occur in the Ethiopian region in South Africa and in the Deserts of the north, which more properly belong to the Palæarctic region. They are absent from the Malayan, and also from the Indo-Chinese sub-regions; except that they extend from the north of China to Amoy and Formosa and into the temperate lighlands of the Western Himalayas. The curious Gymnura ( 1 species) is found in Borneo, Sumatra, and the Malay peninsula.

Extinct Species.-The common hedgehng has been found fossil in several Post-tertiary deposits, while extinct species occur in the lower Miocene of Auvergne and in some other parts of Europe. Many of these remains are classed in different genera from the living species;--(Amphechinus, Tetracus, Galerix.)

FAnILY 18.-CENTETID Æ. (6 Genera, 10 Species.)

\begin{tabular}{|c|c|c|c|c|c|}
\hline \multicolumn{6}{|c|}{ Gexeral Distribution. } \\
\hline $\begin{array}{l}\text { NEOTROPICAL } \\
\text { SUB-REGJONS. }\end{array}$ & $\begin{array}{c}\text { NEARCTIC } \\
\text { SUUB-REGIONS. }\end{array}$ & $\begin{array}{c}\text { Pat.aARCTIC } \\
\text { SUB-REGIONS. }\end{array}$ & $\begin{array}{l}\text { ETHIOPIIN } \\
\text { SUB-REGIONS. }\end{array}$ & $\begin{array}{l}\text { ORIENTAL } \\
\text { SUB-HEGIONS. }\end{array}$ & $\begin{array}{l}\text { Australian } \\
\text { Sub-REgions. }\end{array}$ \\
\hline--4 & ---- & ---- & ---4 & ---- & $--\cdots$ \\
\hline
\end{tabular}

The Centetidæ are small animals, many of them having a spiny covering, whence the species of Centetes have been called Madagascar hedgehogs. The genera Centetes (2 species), Hemicentetes (1 species), Ericulus (1 species), Echinops (3 species), and the recently described Oryzorictes ( 1 species), are all exclusively inhabitants of Madagascar, and are almost or quite tail-less. The remaining genus, Solenodon, is a more slender and active animal, with a long, rat-like tail, shrew-like head, and coarse fur; and the two known species are among the very few indigenous mammals of the West Indian islands, one being found in Cuba (Plate XVII., vol. ii., p. 67), the other in Hayti. Although presenting many points of difference in detail, the essential characters of this curious animal are, according to Professors Peters and Mivart, identical with the rest of the Centetidæ. We have thus a most remarkable and well-established case of discontinuous distribution, two portions of the same family 
being now separated from each other by an extensive continent, as well as by a deep ocean.

Extinct Species.-Remains found in the Lower Miocene of the South of France are believed to belong to the genus Echinops, or one closely allied to it.

\section{Family 19.-POTamogalid $\mathrm{A} . \quad$ (1 Genus, 1 Species,)}

\begin{tabular}{|c|c|c|c|c|c|}
\hline \multicolumn{6}{|c|}{ Gexeral Distribution. } \\
\hline $\begin{array}{l}\text { NEOTROPICAL } \\
\text { SUB-REGIONS. }\end{array}$ & $\begin{array}{c}\text { NEARCIIC } \\
\text { SUB-REGHONS. }\end{array}$ & $\begin{array}{l}\text { PALAEARCTIC } \\
\text { SUB-REGIONS. }\end{array}$ & $\begin{array}{c}\text { ErHIOPIIN } \\
\text { SUB-REGIONS. }\end{array}$ & $\begin{array}{l}\text { ORIENTAL } \\
\text { SUB-KEGIONS. }\end{array}$ & $\begin{array}{l}\text { Australian } \\
\text { SUb-REgions. }\end{array}$ \\
\hline--- & ---- & ---- & $-2--$ & ---- & ---- \\
\hline
\end{tabular}

The genus Potamogale was founded on a curions, small, otterlike animal from West Africa, first found by M. Du Chaillu at the Gaboon, and afterwards by the Portuguese at Angola. Its affinities are with several groups of Insectivora, but it is sufficiently peculiar to require the establishment of a distinct family for its reception. (Plate V., vol. i., p. 264.)

\section{Family 20.-CHRYSOCHLORID A. (2 Genera, 3 Species.)}

\begin{tabular}{|c|c|c|c|c|c|}
\hline \multicolumn{6}{|c|}{ General Distribution. } \\
\hline $\begin{array}{l}\text { NEOTROPICAL } \\
\text { SUB-REGIONS. }\end{array}$ & $\begin{array}{l}\text { NEARCTIC } \\
\text { SUB-REOIONS. }\end{array}$ & $\begin{array}{l}\text { PALAEARCTIC } \\
\text { SUB-KEGIONS. }\end{array}$ & $\begin{array}{c}\text { ETHIOPIAN } \\
\text { SUB-REGIONS. }\end{array}$ & $\begin{array}{c}\text { ORIENTAL } \\
\text { SUB-KEGIONS. }\end{array}$ & $\begin{array}{l}\text { AUSTRALIAN } \\
\text { SUB-REGIONS. }\end{array}$ \\
\hline---- & ---- & --- & $--3-$ & ---- & --- \\
\hline
\end{tabular}

The Chrysochloridx, or golden moles, of the Cape of Good Hope have been separated by Professor Mivart into two genera, Chrysochloris and Chalcochloris. They are remarkable mole-like animals, having beautiful silky fur, with a metallic lustre and changeable golden tints. They are peculiar to the Cape district, but one species extends as far north as the Mozambique territory. Their dentition is altogether peculiar, so as to completely separate them from the true moles. 
FAMILY 21.-TALPIDA. (8 Genera, 19 Species.

\begin{tabular}{|c|c|c|c|c|c|}
\hline \multicolumn{6}{|c|}{ General Distribution. } \\
\hline $\begin{array}{l}\text { NEOTROPICAL } \\
\text { SUB-REGIONS. }\end{array}$ & $\begin{array}{c}\text { NEARCTIC } \\
\text { SUB-REGIONS. }\end{array}$ & $\begin{array}{l}\text { PAL-EARCTIC } \\
\text { SUB-IEGIONS. }\end{array}$ & $\begin{array}{c}\text { ETHIOPIAN } \\
\text { SUB-REGIONS. }\end{array}$ & $\begin{array}{l}\text { ORIF NTAL } \\
\text { SUB-III GIONS. }\end{array}$ & $\begin{array}{l}\text { AUSTRAlian } \\
\text { SUB-REGIONS. }\end{array}$ \\
\hline--- & 1.2 .3 .4 & 1.2 .3 .4 & ---- & $--3-$ & --- \\
\hline
\end{tabular}

The Moles comprise many extraordinary forms of small mammalia especially characteristic of the temperate regions of the northern hemisphere, only sending out a few species of Talpa along the Himalayas as far as Assam, and even to Tenasserim, if there is no mistake about this locality; while one species is found in Formosa, the northern part of which is almost as much Palæarctic as Oriental. The genus Talpa (7 species), spreads over the whole Palæarctic region from Great Britain to Japan; Scaptochirus (1 species) is a recent discovery in North China; Condylura (1 species), the star-nosed mole, inhabits Eastern North America from Nova Scotia to Pennsylvania; Scapanus (2 species) ranges across from New York to St. Francisco; Scalops (3 species), the shrew-moles, range from Mexico to the great lakes on the east side of America, but on the west only to the north of Oregon. An allied genus, Myogale (2 species), has a curious discontinuous distribution in Europe, one species being found in South-East Russia, the other in the Pyrenees (Plate II., vol. i., p. 218). Another allied genus, Nectogale (1 species), has recently been described by Professor Milne-Edwards from Thibet. Urotrichus is a shrew-like mole which inhabits Japan, and a second species has been discovered in the mountains of British Columbia; an allied form, Uropsilus, inhabits East Thibet. Anurosorex and Scaptonyx, are new genera from North China.

Extinct Species.-The common mole has been found fossil in bone-caves and diluvial deposits, and several extinct species of mole-like animals occur in the Miocene deposits of the South of France and of Germany. These have been described under the generic names Dimylus Geotrypus, Hyporissus, Galeospalax ; while Palocospalax has been found in the Pliocene forest-beds of Norfolk 
and Ostend. Species of Myogale also occur from the Miocene downwards.

Family 22.-SORICID Æ. (1 Genus, 11 Sub-genera, 65 Species.)

\begin{tabular}{|c|c|c|c|c|c|}
\hline \multicolumn{6}{|c|}{ Geareal Distribulios. } \\
\hline $\begin{array}{l}\text { NeOTROPICAL } \\
\text { SUD-REG:ON. }\end{array}$ & $\begin{array}{l}\text { NEARCTIC } \\
\text { SUB-REGIOAS. }\end{array}$ & $\begin{array}{l}\text { PALATRUT:C } \\
\text { SUB-nEGIONS. }\end{array}$ & 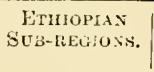 & $\begin{array}{l}\text { ORIGNTAL, } \\
\text { SUB-hEGioNs. }\end{array}$ & 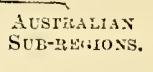 \\
\hline$--3-$ & $1 \cdot 2 \cdot 3 \cdot 4$ & 1.2 .3 .4 & 1.2 .3 .4 & $1.2 \cdot 3 \cdot 4$ & ---- \\
\hline
\end{tabular}

The Shrews have a wide distribution, being found throughout every region except the Australian and Neotropical ; although, as a species is found in Timor and in some of the Moluccas, they just enter this part of the former region, while one found in Guatemala brings them into the latter. A number of species have recently been described from India and the Malay Islands, so that the Oriental region is now the richest in shrews, having 28 species; the Nearctic comes next with 24; while the Ethiopian has 11, and the Palæarctic 10 species. The sub-genera are Crossopus, Amphisorex, Neosorex, Crocidura, Diplomesodon, Pinulia, Pachyura, Blarina, Feroculus, Anausorex.

Extinct Specics. - Several species of Sorex have been found fossil in the Miocene of the Sonth of France, as well as the extinct genera Mysarachne and Plesiosorex; and some existing species have occurred in Bone Caves and Diluvial deposits.

General Remarks on the Distribution of the Insectivora.

The most prominent features in the distribution of the Insectivora are,-their complete absence from South America and Australia; the presence of Solenodon in two of the West Indian islands while the five allied genera are found only in Madagascar ; and the absence of hedgehogs from North America. If we consider that there are only 135 known species of the order, 65 of which belong to the one genus Sorex; while the remaining 26 genera contain only 70 species, which have to be classed in 8 distinct families, and present such divergent and highly specialized forms as Galcopithecus, Erinaceus, Solenodon, and Condylura, it becomes evident that we have here the detached fragments of a much more 
extensive group of animals, now almost extinct. Many of the forms continue to exist only in islands, removed from the severe competition of a varied mammalian population, as in Madagascar and the Antilles; while others appear to have escaped extermination either by their peculiar habits-as the various forms of Moles; by special protection - as in the Hedgehogs; or by a resemblance in form, coloration, and habits to dominant groups in their own district-as the Tupaias of Malay which resemble squirrels, and the Elephant-shrews of Africa which resemble the jerboas. The numerous cases of isolated and discontinuous distribution among the Insectivora, offer no difficulty from this point of view; since they are the necessary results of an extensive and widelyspread group of animals slowly becoming extinct, and continuing to exist only where special conditions have enabled them to maintain themselves in the struggle with more highly organized forms.

The fossil Insectivora do not throw much light on the early history of the order, since even as far back as the Miocene period they consist almost wholly of forms which can be referred to existing families. In North America they go back to the Eocene period, if certain doubtful remains have been rightly placed. The occurrence of fossil Centetidæ in Europe, supports the view we have maintained in preceding chapters, that the existing distribution of this family between Madagascar and the Antilles, proves no direct connection between those islands, but only shows us that the family once had an extensive range.

Order IV.-CARNIVORA.

Family 23.-FELID A. (3 Genera, 14 Sub-genera, 66 Species.)

\begin{tabular}{|c|c|c|c|c|c|}
\hline \multicolumn{6}{|c|}{ General Distribution. } \\
\hline $\begin{array}{l}\text { NEOTROPICAL } \\
\text { SUB-REGIONS. }\end{array}$ & $\begin{array}{c}\text { AEARCTIC } \\
\text { SUB-REGIONS. }\end{array}$ & $\begin{array}{c}\text { PaLfirarctic } \\
\text { Sub-REGIONS. }\end{array}$ & $\begin{array}{c}\text { ETHIOPIAN } \\
\text { SUB-REGIONS. }\end{array}$ & $\begin{array}{c}\text { ORIENTAL } \\
\text { SUB-REGIONS. }\end{array}$ & $\begin{array}{l}\text { AUSTRALIAN } \\
\text { SUB-REGIONS. }\end{array}$ \\
\hline $1.2 .3-$ & 1.2 .3 .4 & 1.2 .3 .4 & $1.2 .3-$ & $1.2 .3 \cdot 4$ & --- \\
\hline
\end{tabular}

The Cats are very widely distributed over the earth-with the exception of the Australian region and the island sub-region 
of Madagascar and the Antilles-universally ; ranging from the torrid zone to the Arctic regions and the Straits of Magellan. They are so uniform in their organization that many naturalists group them all under one genus, Felis; but it is now more usual to class at least the lynxes as a separate genus, while the hunting leopard, or cheetah, forms another. Dr. J. E. Gray divides these again, and makes 17 generic groups; but as this subdivision is not generally adopted, and does not bring out any special features of geographical distribution, I shall not further notice it.

The genus Felis (56 species) has the same general range as the whole family, except that it does not go so far north; the Amoor river in Eastern Asia, and $55^{\circ} \mathrm{N}$. Lat. in America, marking its limits. Lyncus (10 species) is a more northern group, ranging to the polar regions in Europe and Asia, and to Lat. $66^{\circ} \mathrm{N}$. in America, but not going further south than Northern Mexico and the European shores of the Mediterranean, except the caracal, which may be another genus, and which extends to Central India, Persia, North Africa and even the Cape of Good Hope. The lynxes are thus almost wholly peculiar to the Nearctic and Palæarctic regions. Cyncelurus (1 species) the hunting leopard, ranges from Southern and Western India through Persia, Syria, Northern and Central Africa, to the Cape of Good Hope.

Extinct Felido.-More than twenty extinct species of true Felidæ have been described, ranging in time from the epoch of prehistoric man back to the Miocene or even the Eocene period. They occur in the south of England, in Central and South Europe, in North-West India, in Nebraska in North America, and in the caves of Brazil. Most of them are referred to the genus Felis, and closely resemble the existing lions, tigers, and other large cats. Another group however forms the genus Machairodus, a highly specialized form with serrated teeth. Five species have been described from Europe, Northern India, and both North and South America; and it is remarkable that they exhibit at least as wide a range, both in space and time, as the more numerous species referred to Felis. One of them undoubtedly coexisted VOL. II. 
with man in England, while another, as well as the allied Dinictis, has been found in the Mauvaises Terres of Nebraska, associated with Anchitherium and other extinct and equally remarkable forms, which are certainly Miocene if not, as some geologists think, belonging to the Eocene period. These facts clearly indicate that we have as yet made little approach to discovering the epoch when Felidxe originated, since the oldest forms yet discovered are typical and highly specialized representatives of a group which is itself the most specialized of the Carnivora. Another genus, Pseudcelurus, is common to the Miocene deposits of Europe and North America.

FAMILY 24.-CRYPTOPROCTIDA. (1 Genus, 1 Species.)

\begin{tabular}{|c|c|c|c|c|c|}
\hline \multicolumn{6}{|c|}{ General Distribution. } \\
\hline $\begin{array}{l}\text { NFOTROPICAL } \\
\text { SVB-REGYONS. }\end{array}$ & $\begin{array}{c}\text { NEARCTIC } \\
\text { SUB-REGIOAS. }\end{array}$ & $\begin{array}{c}\text { PaLfaARCTIC } \\
\text { SUB-ILGIONS. }\end{array}$ & $\begin{array}{c}\text { ETHIOPIAN } \\
\text { SUB-REGIONS. }\end{array}$ & $\begin{array}{l}\text { ORYENTAL } \\
\text { SUB-REGIONS. }\end{array}$ & $\begin{array}{l}\text { AUSTRALIAN } \\
\text { SUB-REGIONS. }\end{array}$ \\
\hline---- & ---- & $-\cdots--$ & ---4 & $-\div--$ & ---- \\
\hline
\end{tabular}

The Cryptoprocta ferox, a small and graceful cat-like animal, peculiar to Madagascar, was formerly classed among the Viverridæ, but is now considered by Professor Flower to constitute a distinct family between the Cats and the Civets.

Family 25.-VIVERRID A. (8-33 Genera, 100 Species.)

\begin{tabular}{|c|c|c|c|c|c|}
\hline $\begin{array}{l}\text { NFOTROPICAL } \\
\text { StiB-REGIONS. }\end{array}$ & $\begin{array}{l}\text { NEARCTIC } \\
\text { SUB-BEGYONS. }\end{array}$ & $\begin{array}{l}\text { PalfarctrC } \\
\text { SUB-IEEGIONS. }\end{array}$ & $\begin{array}{l}\text { ETHIOPIAN } \\
\text { SUB-REGYONS. }\end{array}$ & $\begin{array}{c}\text { ORIENTAL } \\
\text { SUB-REGIONS. }\end{array}$ & $\begin{array}{l}\text { AUSTRALIAN } \\
\text { SUB-REgIONS. }\end{array}$ \\
\hline---- & --- & $-2--$ & 1.2 .3 .4 & 1.2 .3 .4 & $1---$ \\
\hline
\end{tabular}

The Viverridæ comprise a number of small and moderate-sized carnivorous animals, popularly known as civets, genets, and ichneumons, highly characteristic of the Ethiopian and Oriental regions, several of the genera being common to both. A species of Genetta, and one of Herpestes, inhabit South Europe; while Viverra extends to the Moluccas, but is doubtfully indigenous. The extreme geographical limits of the family are marked by 
Genetta in France and Spain, Viverre in Shanghae and Batchian Island, and Herpestes in Java and the Cape of Good Hope.

The following are the genera with their distribution as given by Dr. J. E. Gray in his latest British Museum Catalogue:

Sub-family ViverRin\&.-Viverra (3 species), North and tropical Africa, the whole Oriental region to the Moluccas; Viverricula (1 species) India to Java; Genetta (5 species), South Europe, Palestine, Arabia, and all Africa; Fossa (1 species), Madagascar; Linsang (2 species), Malacca to Java; Poiana (1 species), West Africa; Galidic (3 species), Madagascar; Hemigalea (1 species), Malacca and Borneo; Arctictis (1 species) Nepal to Sumatra and Java; Nandinia (1 species), West Africa; Paradoxurus (9 species), the whole Oriental region; Paguma (3 species), Nepal to China, Sumatra, and Borneo; Arctogale (1 species), Tenasserim to Java.

Sub-family Herpestin w.-Cynogale (1 species), Borneo ; Galidictis (2 species), Madagascar ; Herpestes (22 species), South Palæarctic, Ethiopian, and Oriental regions ; Athylax (3 species), Tropical and South Africa; Galogale (13 species), all Africa, North India, to Cambodja; Galerella (1 species), East Africa; Calictis (1 species),Ceylon (?); Ariella (1 species), South Africa; Ichneumia (4 species), Central, East, and South Africa; Bdeogale (3 species), West and East Africa; Urva (1 species), Himalayas to Aracan; Toniogale (1 species), Central India; Onychogale (1 species), Ceylon; Helogale (2 species) East and South Africa; Cynictis (3 species), South Africa.

Sub-family RuINogalid ж.-Rhinogale (1 species), East Africa ; Mungos (3 species), all Africa ; Crossarchus (1 species), Tropical Africa; Eupleres (1 species), Madagascar; Suricata (1 species), South Africa.

Fossil Viverridce.-Several species of Viverra and Genetta have been found in the Upper Miocene of France, and many extinct genera have also been discovered. The most remarkable of these was Ictitherium, from the Upper Miocene of Greece, which has also been found in Hungary, Bessarabia, and France. Some of the species were larger than any living forms of Viverridæ, and approached the hyænas. Other extinct genera are Thalassictis 
and Soricictis from the Upper Miocene, the former as large as a panther; Tylodon, of small size, from the Upper Eocene; and Palcenyctis from the Lower Eocene, also small and showing a very great antiquity for this family, if really belonging to it.

Family 26.-PROTELID $A . \quad$ (1 Genus, 1 Species.)

\begin{tabular}{|c|c|c|c|c|c|}
\hline \multicolumn{6}{|c|}{ General Distribution. } \\
\hline $\begin{array}{l}\text { NFotroptoAL } \\
\text { StiB-REGIONS. }\end{array}$ & $\begin{array}{c}\text { NeARCTIC } \\
\text { SuB-REGIONS. }\end{array}$ & $\begin{array}{l}\text { PaLAfarctic } \\
\text { Sub-ILEGIONS. }\end{array}$ & $\begin{array}{l}\text { ETHIOPIAN } \\
\text { SUB-REGIONS. }\end{array}$ & $\begin{array}{l}\text { ORIENTAL } \\
\text { SUB-REGIONS. }\end{array}$ & $\begin{array}{l}\text { AUSTRALIAN } \\
\text { SUB-REGIONS. }\end{array}$ \\
\hline--- & ---- & ---- & $--3-$ & ---- & --- \\
\hline
\end{tabular}

The curious Proteles or Aard-wolf, a highly-modified form of hyæna, approaching the ichneumons, and feeding on white ants and carrion, is peculiar to South Africa.

FAMILY 27.-HY ENID E. (1 Genus, 3 Species.)

\begin{tabular}{|c|c|c|c|c|c|}
\hline \multicolumn{6}{|c|}{ General Distribution. } \\
\hline $\begin{array}{l}\text { NEOTROPIOAL } \\
\text { SUB-REGIONS. }\end{array}$ & $\begin{array}{c}\text { NEARCTIC } \\
\text { SUB-REGIONS. }\end{array}$ & $\begin{array}{l}\text { PALAARCTIC } \\
\text { SAB-REGIONS. }\end{array}$ & $\begin{array}{l}\text { ETHIOPIIN } \\
\text { SUb-REGIONS. }\end{array}$ & $\begin{array}{l}\text { ORIENTAL } \\
\text { SUB-REGIONS. }\end{array}$ & $\begin{array}{l}\text { AUSTRALIAN } \\
\text { SUB-REGIONS. }\end{array}$ \\
\hline--- & ---- & $-2--$ & 1. $2.3-$ & $1---$ & --- \\
\hline
\end{tabular}

The Hyænas are characteristically Ethiopian, to which region two of the species are confined. The third, Hycena striata, ranges over all the open country of India to the foot of the Himalayas, and through Persia, Asia Minor, and North Africa. Its fossil remains have been found in France.

Extinct Species.-The cave hyæna (H. speloca) occurs abundantly in the caverns of this country and of Central Europe, and is supposed to be most nearly allied to the $H$. crocuta of South Africa. Another species is found in some parts of France. The earliest known true hyænas occur in the Pliocene formation in France, in the Red Crag (Older Pliocene) of England, and in the Upper Miocene of the Siwalik hills. In the Miocene period in Europe, quite distinct genera are found, such as Hyoenictis and Lycana from the Upper Miocene of Greece; 
Ictitherinm, supposed to be intermediate between Viverridæ and Hyænidæ; and Thalassictis, uniting the weasels and hyænas.

FAMILY 28.-CANID E. (3 Genera, 17 Sub-Genera, 54 Species.)

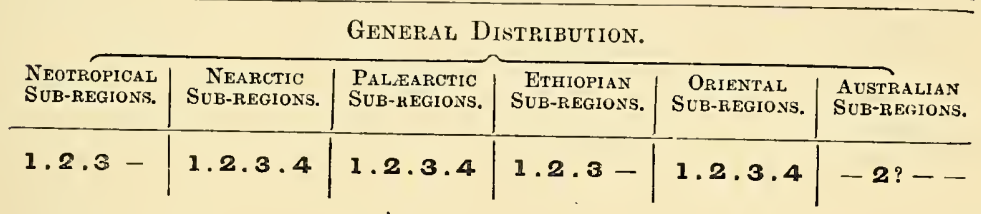

The Canidæ, comprising the animals commonly known as dogs, wolves, and foxes, have an almost universal range over the earth, being only absent from the island sub-regions of Madagascar, the Antilles, Austro-Malaya, New Zealand, and the Pacific Islands. With the exception of two remarkable formsthe hyæna $\operatorname{dog}$ (Lycaon picta), and the great-eared fox (Megalotis Lalandei), both from South Africa-all the species are usually placed in the genus Canis, the distribution of which will be the same as that of the family. Dr. J. E. Gray, in his arrangement of the family (Proc. Zool. Soc., 1868), subdivides it into fifteen genera, the names and general distribution of which are as follows:-

Icticyon (1 species), Brazil ; Cuon (4 species), Siberia to Java; Lupus (5 species), North America, Europe, India to Ceylon; Dieba (1 species), North and West Africa; Simenia (1 species), Abyssinia; Chrysocyon (2 species), North and South America; Canis (4 species), India, Australia (indigenous ?) Iycalopex (2 species), South America; Pseudalopex (5 species), South America and Falkland Islands; Thous (2 species), South America to Chili; Vulpes (17 species), all the great continents, except South America and Australia; Fennecus (4 species), all Africa; Leucocyon (1 species), Arctic regions; Urocyon (2 species), North America; Nyctereutes (1 species), Japan, Amoorland to Canton (Plate III., vol. i. p. 226). These are all sub-genera according to Professor Carus, except Icticyon. The same author makes Lycaon a sub-genus, while Dr. Gray makes it a sub-family!

Extinct Species.-The dog, wolf, and fox, are found fossil in 
caverns in many parts of Europe, and several extinct species have been found in Tertiary deposits in Europe, North India, and South America. Two species have been found so far back as the Eocene of France, but the fragments discovered are not sufficient to determine the characters with any certainty. In North America, several species of $C$ anis occur in the Pliocene of Nebraska and La Plata. The genus Galecynus, of the Pliocene of Eninghen, and Palcoocyon, of the Brazilian caves, are supposed to belong to the Canidæ. Amplicyon abounded in the Miocene period, both in Europe and North America; and some of the species were as large as a tiger. Other extinct genera are, Cynodictis, Cyotherium, and Galethylax, from the Eocene of France; Pseudocyon, Simocyon, and Hemicyon, from the Miocene; but all these show transition characters to Viverridæ or Ursidæ, and do not perhaps belong to the present family.

\section{Fanily 29.-MUSTELID $\mathbb{E}$. (21-28 Genera, 92 Species.)}

\begin{tabular}{|c|c|c|c|c|c|}
\hline $\begin{array}{l}\text { NFoTROPICAL } \\
\text { StIB-REGIONS. }\end{array}$ & $\begin{array}{c}\text { NEARCTIC } \\
\text { Sub-REGIONS. }\end{array}$ & $\begin{array}{c}\text { Palearctic } \\
\text { Sub-REQIONS. }\end{array}$ & $\begin{array}{c}\text { ETHIOPIAN } \\
\text { SUB-REOIONS. }\end{array}$ & $\begin{array}{c}\text { ORIENTAL } \\
\text { Sub-REGIONS. }\end{array}$ & $\begin{array}{l}\text { AUSTRALIAN } \\
\text { SUB-REGIONS. }\end{array}$ \\
\hline $1.2 .3-$ & 1.2 .3 .4 & 1.2 .3 .4 & $1.2 .3-$ & 1.2 .3 .4 & --- \\
\hline
\end{tabular}

The Mustelidæ constitute one of those groups which range over the whole of the great continental areas. They may be divided into three sub-families-one, the Mustelinæ, containing the weasels, gluttons, and allied forms; a second, the Lutrinæ, containing the otters; and a third, often considered a distinct family, the Melininæ, containing the badger's, ratels, skunks, and their allies.

In the first group (Mustelinæ) the genera Martes and Putorius (13 species), range over all the Palæarctic region, and a considerable part of the Oriental, extending through India to Ceylon, and to Java and Borneo. Two species of Martes (=Mustela of Baird) occur in the United States. The weasels, forming the genus Mustela (20 species), have a still wider range, extending into tropical Africa and the Cordilleras of Peru, but 
not going south of the Himalayas in India. The North American species are placed in the genus Putorius by Professor Baird. An allied genus, Gymnopus (4 species), is confined to the third and fourth Oriental sub-regions. Gulo (1 species), the glutton, is an arctic animal keeping to the cold regions of Europe and Asia, and coming as far south as the great lakes in North America. Galictis (2 species), the grisons, are confined to the Neotropical region.

The Otters (Lutrinæ) range over the whole area occupied by the family. They have been subdivided into a number of groups, such as Barangia (1 species), found only in Sumatra; Lontra, containing 3 South American species; Lutra (7 species), ranging over the whole of the Palæarctic and Oriental regions; Nutria (1 species), a sea-otter confined to the west coast of America from California to Chiloe; Lutronectes ( 1 species), from Japan only; Aonyx (5 species), found in West and South Africa, and the third and fourth Oriental sub-regions. Hydrogale (1 species), confined to South Africa; Latax (2 species), Florida and California to Canada and British Columbia; Pteronura (1 species), Brazil and Surinam ; and Enhydris (1 species), the peculiar sea-otter of California, Kamschatka and Japan. The last two are the only groups of otters, besides Lutra, admitted by Professor Carus as genera.

The Badgers and allies (MIelininæ) have also a wide range, but with one exception are absent from South America. They comprise the following genera : Arctonyx (1 species), Nepal to Aracan; Meles (4 species), North Europe to Japan, and China as far south as Hongkong (Plate I., vol. i., p. 195); Taxidea (2 species), Central and Western North America to $58^{\circ} \mathrm{N}$. Lat.; Mydaus (1 species), mountains of Java and Sumatra; Melivora (3 species), Tropical and South Africa and India to foot of Himalayas; Mephitis (12 species), America from Canada and British Columbia to the Straits of Magellan (Plate XX., vol. ii., p. 136). Ietonyx (2 species), Tropical Africa to the Cape; Helictis (4 species), Nepal to Java, Formosa and Shanghai (Plate VII., vol. i. p. 331).

Fossil Mrustelidce.-Species of otter, weasel, badger, and glutton, occur in European bone caves and other Post-tertiary deposits; and in North America Galictis, now found only in the Neotropical region, and, with Mephitis, occurring in Brazilian caves. 
Species of Mustcla have been found in the Pliocene of France and of South America; and Lutra in the Pliocene of North America.

In the Miocene deposits of Europe several species of Mustclu and Lutra have been found; with the extinct genera Taxodon, Potamotherium, and Pulcomephitis; as well as Promephitis in Greece.

In the Upper Miocene of the Siwalik Hills species of Lutra and Mellivora are found, as well as the extinct genera Enhydrion and Ursitaxus.

The family appears to have been unknown in North America during the Miocene period.

Family 30.-PROCYONIDA. (4 Genera, 8 Species.)

\begin{tabular}{|c|c|c|c|c|c|}
\hline \multirow[b]{2}{*}{$\begin{array}{l}\text { NEOTRopical } \\
\text { Sob-REgIONS. }\end{array}$} & \multicolumn{4}{|c|}{ General Distribution. } & \multirow[b]{2}{*}{$\begin{array}{l}\text { AUSTRaLian } \\
\text { Sub-REgIONS. }\end{array}$} \\
\hline & $\begin{array}{c}\text { NEARCTTC } \\
\text { SUEB-REGIONS. }\end{array}$ & $\begin{array}{l}\text { PALAEARCTIC } \\
\text { SUB-REGIONS. }\end{array}$ & $\begin{array}{c}\text { ETHIOPIAN } \\
\text { SUB-RFGIONS. }\end{array}$ & $\begin{array}{c}\text { ORIENTAL } \\
\text { SUB-HEGIONS. }\end{array}$ & \\
\hline$-2.3-$ & 1.2 .3 .4 & --- & $---\cdots$ & ---- & ---- \\
\hline
\end{tabular}

The Procyonidæe are a small, but very curious and interesting family of bear-like quadrupeds, ranging from British Columbia and Canada on the north, to Paraguay and the limits of the tropical forests on the soutl.

The Racoons, forming the genus Procyon, are common all over North America; a well-marked variety or distinct species inhabiting the west coast, and another, most parts of South America. The genus Nasua, or the coatis (5 species ?), extends from Mexico and Guatemala to Paraguay. The curious arboreal prehensiletailed kinkagou (Cercoleptes candivolvus) is also found in Mexico and Guatemala, and in all the great forests of Peru and North Brazil. Bassaris (2 species), a small weasel-like animal with a banded tail, has been usually classed with the Viverridæ or Mustelidæ, but is now found to agree closely in all important points of internal structure with this family. It is found in California, Texas, and the highlands of Mexico, and belongs therefore as much to the Nearctic as to the Neotropical region. A second species has recently been described by Professor Peters 
from Coban in Guatemala, in which country it has also been observed by Mr. Salvin.

Fossil Procyonida.-A species of Nasua has been found in the bone caves of Brazil, and a Procyon in the Pliocene or Postpliocene deposits of Illinois and Carolina.

Family 31.- ELURID Æ. (2 Genera, 2 Species.)

General Distribution.

\begin{tabular}{|c|c|c|c|c|c|}
\hline $\begin{array}{l}\text { NeOtropical } \\
\text { Sub-REgIoNs. }\end{array}$ & $\begin{array}{c}\text { NEARCTIC } \\
\text { SUB-REGIONS. }\end{array}$ & $\begin{array}{l}\text { PALFARCTIC } \\
\text { SUB } \rightarrow \text { REGIONS. }\end{array}$ & $\begin{array}{c}\text { ErhIOPIAN } \\
\text { SUb-REGIONS. }\end{array}$ & $\begin{array}{c}\text { ORIENTAL } \\
\text { SUB-REGIONS. }\end{array}$ & $\begin{array}{l}\text { AUSTRALIAN } \\
\text { SUb-REgIONS. }\end{array}$ \\
\hline$--\cdots$ & $---\cdots$ & ---4 & $-\cdots-$ & $--3-$ & --- \\
\hline
\end{tabular}

The Panda (Allurus fulgens), of the forest regions of the Eastern Himalayas and East Thibet, a small cat-like bear, has peculiarities of organization which render it necessary to place it in a family by itself. (I'late VII. vol. i. p. 331). An allied genus, Asluropus, a remarkable animal of larger size and in colour nearly all white, has recently been described by Professor Milne-Edwards, from the mountains of East Thibet; so that the family may be said to inhabit the border lands of the Oriental and Palæarctic regions. These animals have their nearest allies in the coatis and bears

Family 32.-URSID $\mathbb{E}$. (5 Genera, or Sub-genera, 15 Species.)

\begin{tabular}{|c|c|c|c|c|c|}
\hline \multicolumn{6}{|c|}{ General Distribution. } \\
\hline $\begin{array}{l}\text { NFOTROPICAL } \\
\text { StiB-REGIONS. }\end{array}$ & $\begin{array}{l}\text { NEARCTIC } \\
\text { SUB-RECIONS. }\end{array}$ & $\begin{array}{c}\text { Palmarctic } \\
\text { Sub-reglons. }\end{array}$ & $\begin{array}{l}\text { EThIOPIAN } \\
\text { SUB-REGIONS. }\end{array}$ & $\begin{array}{c}\text { ORIENTAL } \\
\text { SUB-REGIONS. }\end{array}$ & $\begin{array}{l}\text { AUstralian } \\
\text { Sub-REgrovs. }\end{array}$ \\
\hline $1-\cdots$ & 1.2 .3 .4 & 1.2 .3 .4 & $-\cdots-$ & 1.2 .3 .4 & -- \\
\hline
\end{tabular}

The Bears have a tolerably wide distribution, although they are entirely absent from the Australian and Ethiopiar, and almost so from the Neotropical region, one species only being found in the Andes of Peru and Chili. They comprise the following groups, some of which are doubtfully ranked as genera.

Thalassarctos, the polar bear ( 1 species) inhabiting the Arctic regions; Ursus, the true bears (12 species), which range over 
all the Nearctic and Palrarctic regions as far as the Atlas Mountains, the Indo-Chinese sub-region in the mountains, and to Hainan and Formosa; Helarctos, the Malay or sun-bear (1 species) confined to the Indo-Malayan sub-region; Melursus or Proctilus, the honey-bear (1 species), confined to the first and second Oriental sub-regions, over which it ranges from the Ganges to Ceylon; and Tremarctos, the spectacled bear-commonly known as Ursus ornatus - which is isolated in the Andes of Peru and Chili, and forms a distinct group.

Fossil Ursidce.-Two bears (Ursus spelceus and U. priscus) closely allied to living species, abound in the Post-tertiary deposits of Europe; and others of the same age are found in North America, as well as an extinct genus, Arctodus.

Ursus arvernensis is found in the Pliocene formation of France, and the extinct genus Leptarchus in that of North America.

Several species of Amplicyon, which appears to be an ancestral form of this family, are found in the Miocene deposits of Europe and N. India; while Ursus also occurs in the Siwalik Hills and Nerbudda deposits.

FAMILY 33.-OTARIIDÆ. (4 Genera, 8 Species.)

\begin{tabular}{|c|c|c|c|c|c|}
\hline \multicolumn{6}{|c|}{ Gexeral Distribution. } \\
\hline $\begin{array}{l}\text { NEOTROPICAL } \\
\text { SUB-REGIONS. }\end{array}$ & $\begin{array}{c}N_{\text {EARCTIC }} \\
\text { SUB-REGIONS. }\end{array}$ & $\begin{array}{l}\text { PALAaARCTIC } \\
\text { Sud-REGIONS. }\end{array}$ & $\begin{array}{l}\text { ETHIOPIIN } \\
\text { SUB-REGIONS. }\end{array}$ & $\begin{array}{l}\text { ORIENTAL } \\
\text { SUB-HEGIONS. }\end{array}$ & $\begin{array}{l}\text { AUSTRALIAN } \\
\text { Sub-REGION }\end{array}$ \\
\hline $1-\cdots-$ & $1--4$ & ---- & $--\mathbf{3}-$ & ---- & $-2.3-$ \\
\hline
\end{tabular}

The Otariidæ, or Eared Seals, comprehending the sea-bears and sea-lions, are confined to the temperate and cold shores of the North Pacific, and to similar climates in the Southern Hemisphere, where the larger proportion of the species are found. They are entirely absent from the North Atlantic shores. Mr. J. A. Allen, in his recent discussion of this family (Bull. Harvard Museum) divides them into the following genera:-

Otairic (1 species), Temperate South America, from Chili to La Plata; Callorhinus (1 species), Behring's Straits and Kamschatka; Arctocephalus (3 species), temperate regions of the 
Southern Hemisphere; Zalophus (2 species), North Pacific, from California to Japan, and the shores of Australia and New Zealand; Eumetopias (1 species), Behring's Straits and California.

Fossil Otariida.-Remains supposed to belong to this family have been found in the Miocene of France.

Family 34.-TRICHECHID A. (1 Genus, 1 Species.)

\begin{tabular}{|c|c|c|c|c|c|}
\hline \multicolumn{6}{|c|}{ General Distribution. } \\
\hline $\begin{array}{l}\text { NEOTROPICAL } \\
\text { SUB-REGIONS. }\end{array}$ & $\begin{array}{c}\text { NEARCTIC } \\
\text { SUB-REGIONS. }\end{array}$ & $\begin{array}{l}\text { PALAEARCTIC } \\
\text { SUB-kEGIONS. }\end{array}$ & $\begin{array}{c}\text { ETHIOPIAN } \\
\text { SUB-REGIONS. }\end{array}$ & $\begin{array}{c}\text { ORIENTAL } \\
\text { Sub-EEgIONS. }\end{array}$ & $\begin{array}{l}\text { AUSTRALIAN } \\
\text { SUb-REGiIONS. }\end{array}$ \\
\hline$-\cdots-$ & ---4 & $1-3-$ & ---- & ---- & -- \\
\hline
\end{tabular}

The Morse, or Walrus (Trichecus rosmarus), which alone constitutes this family, is a characteristic animal of the North Polar regions, hardly passing south of the Arctic circle except on the east and west coasts of North America, where it sometimes reaches Lat. $60^{\circ}$. It is most abundant on the shores of Spitzbergen, but is not found on the northern shores of Asia between Long. $80^{\circ}$ and $160^{\circ} \mathrm{E}$, or on the north shores of America from $100^{\circ}$ to $150^{\circ}$ west.

Its remains have been found fossil in Europe as far south as France, and in America as far as Virginia; but the small fragments discovered may render the identification uncertain.

FAnily 35.-PHOCID A. (13 Genera, 21 Species.)

\begin{tabular}{|c|c|c|c|c|c|}
\hline \multirow[b]{2}{*}{$\begin{array}{l}\text { NEOTROPICAL } \\
\text { SUB-REgIONS. }\end{array}$} & \multicolumn{4}{|c|}{ Gexeral Distribution. } & \multirow[b]{2}{*}{$\begin{array}{l}\text { AUSTRALIAN } \\
\text { SUB-REGIONS. }\end{array}$} \\
\hline & $\begin{array}{c}\text { NEARCTIC } \\
\text { SUB-REGIONS. }\end{array}$ & $\begin{array}{c}\text { PALAARCTIC } \\
\text { SUB-REGIONS. }\end{array}$ & $\begin{array}{c}\text { ETHIOPIIN } \\
\text { SUB-REGIONS. }\end{array}$ & $\begin{array}{c}\text { ORIENTAL } \\
\text { Sub-REGIONS. }\end{array}$ & \\
\hline $1--4 ?$ & $1--4$ & 1.2 .3 .4 & --- & --- & $-2.3-$ \\
\hline
\end{tabular}

The earless or true Seals are pretty equally divided between the Northern and Southern Hemispheres, frequenting almost exclusively the temperate and cold regions, except two species said to occur among the West Indian islands. The genus Phoca and its close allies, as well as Halichcerus and Pelagins, are 
northern; while Stenorhynchus and Morunga, with their allies, are mostly southern. The genera admitted by Dr. Gray in his catalogue are as follows:-

Callocepplatus (3 species), Greenland, North Sea, also the Caspian Sea, and Lakes Aral and Baikal; Pagomys (2 species), North Sea, North Pacific, and Japan; Pagophilus (2 species), North Pacific and North Atlantic; Halicyon (1 species), North West coast of America; Phoca (2 species), North Atlantic and North Pacific, Japan; Halichorus (1 species), Greenland, North Sea, and Baltic; Pelagius (2 species), Madeira, Mediterranean, Black Sea; Stenorhynchus (1 species), Antarctic Ocean, Falkland Islands, New Zealand; Lobodon (1 species), Antarctic Ocean; Leptonyx (1 species), Antarctic Ocean, South Australia, East Patagonia; Ommatophoca (1 species), Antarctic Ocean ; Morunga (2 species), California, Falkland Islands, Temperate regions of Southern Ocean ; Cystophora (2 species), North Atlantic, Antilles.

Fossil Seals.-Remains of living species of seals have been found in Post-tertiary deposits in many parts of Europe and in Algeria, as well as in New Zealand. Pristiphoca occitan $\alpha$ is a fossil seal from the Pliocene of Montpellier, while a species of Phoca is said to have been found in the Miocene deposits of the United States.

\section{General Remarks on the Distribution of the Carnivora.}

Terrestrial Carnivora.-For the purposes of geographical distribution, the terrestrial and aquatic Carnivora differ too widely to be considered in one view, their areas being limited by barriers of a very different nature. The terrestrial Carnivora form a very extensive and considerably varied group of animals, having, with the doubtful exception of Australia, a world-wide distribution. Yet the range of modification of form is not very great, and the occurrence of three families consisting of but one species each, is an indication of a great amount of recent extinction. One of the most marked features presented by this group is its comparative scarcity in the Neotropical region, only four families being represented there (not counting the Ursidæ, which has only one Andean species), and both genera and species are few in number. Even the Procyonidæ, which are especially South 
American, have but two genera and six species in that vast area. We might therefore, from these considerations alone, conclude that Carnivora are a development of the northern hemisphere, and have been introduced into the Neotropical region at a comparatively recent epoch. The claim of the Nearctic region to be kept distinct from the Palæarctic (with which some writers have wished to unite it) is well maintained by its possession of at least six species of Mephitis, or skunk, a group having no close allies in any other region,-and the genera Procyon and Bassaris, - for the latter, ranging from the high lands of Guatemala and Mexico to Texas and California, may be considered a Nearctic rather than a Neotropical form. In the other families, the most marked feature is the total absence of Ursidæ from the Ethiopian region. The great mass of the generic forms of Carnivora, however, are found in the Oriental and Ethiopian regions, which possess all the extensive group of Viverridæ (except a few species in the fourth Palæarctic subregion) and a large number of Felidæ and Mustelidæ.

Aquatic Carnivora.-The aquatic Carnivora present no very marked features of distribution, except their preference for cold and temperate rather than tropical seas. Their nearest approximation to the terrestrial group, is supposed to be that of the Otariidæ to the Ursidæ; but this must be very remote, and the occurrence of both seals and bears in the Miocene period, shows, that until we find some late Secondary or early Tertiary formation rich in Mammalian remains, we are not likely to get at the transition forms indicating the steps by which the aquatic Carnivora were developed. The most interesting special fact of distribution to be noticed, is the occurrence of seals, closely allied to those inhabiting the northern seas, in the Caspian, Lake Aral, and Lake Baikal. In the case of the two first-named localities there is little difficulty, as they are connected with the North Sea by extensive plains of low elevation, so that a depression of less than 500 feet would open a free communication with the ocean. At a comparatively recent epoch, a great gulf of the Arctic ocean must have occupied the valley of the Irtish, and extended to the Caspian Sea; till the elevation of the Kirghiz Steppes cut off the 
communication with the ocean, leaving an inland sea with its seals. Lake Baikal, however, offers much greater difficulties; since it is not only a fresh-water lake, but is situated in a mountain district nearly 2,000 feet above the sea level, and entirely separated from the plains by several hundred miles of high land. It is true that such an amount of submergence and elevation is known to have occurred in Europe so recently as during the Glacial period; but Lake Baikal is so surrounded by mountains, that it must at that time have been filled with ice, if at anything like its present elevation. Its emergence from the sea must therefore have taken place since the cold epoch, and this would imply that an enormous extent of Northern Asia has been very recently under water.

We are accustomed to look on Seals as animals which exclusively inhabit salt water; but it is probably from other causes than its saltness that they usually keep to the open sea, and there seems no reason why fresh-water should not suit them quite as well, provided they find in it a sufficiency of food, facilities for rearing their young, and freedom from the attacks of enemies. As already remarked in vol. i. p. 218, Mr. Belt's ingenious hypothesis (founded on personal examination of the Siberian Steppes), that during the Glacial period the northern ice-cap dammed up the waters of the northward flowing Asiatic rivers, and thus formed a vast fresh-water lake which might have risen as high as Lake Baikal, seems to offer the best solution of this curious problem of distribution.

Range of Carnivora in Time.-Carnivora have been found in all the Tertiary deposits, and comprise a number of extinct genera and even families. Several genera of Canidæ occur in the Upper Eocene of Europe; but the most remarkable fact is, that even in the Lower Eocene are found two well-marked forms, Palceonyctis, one of the Viverridæ, and Arctocyon, forming a distinct family type of very generalized characters, but unmistakably a carnivore. This last has been found at La Fère, in the north-east of France, in a deposit which, according to M. Gaudry, is the very lowest of the Lower Eocene formation in Europe. Arctocyon is therefore one of the oldest, if not the very oldest, of the higher forms of mammal yet discovered. 


\section{Order $V .-C E T A C E A$.}

\section{Family 36.-BALAENID E. (6 Genera, 14 Species.)}

General Distriburion.-Temperate and Cold Seas of both Northern and Sonthern Hemispheres.

This family comprises the whalebone or "right" whales, the best known species being the Greenland whale (Balcenc mysticetus). Allied species are found in all parts of the southern seas, as far north as the Cape of Good Hope; while some of the northern species are found off the coast of Spain, and even enter the Mediterranean. As most of the species indicated are imperfectly known, and their classification by no means well settled, no useful purpose will be served by enumerating the genera or sub-genera.

\section{FAMILY 37.-BALÆNOPTERID Æ. (9 Genera, 22 Species.)}

Generai. Distribution.-Cold and Temperate Seas of both Hemispheres.

This family comprises the fimner whales and rorquals, and are characterised by possessing a dorsal fin and having the baleen or whalebone less developed. They are abundant in all northern seas, less so in the southern hemisphere, but they seem occasionally to enter the tropical seas. The best known genera are Megaptera (7 species); Physalus (4 species); and Balcenoptera (2 species); all of which have species in the North Sea.

\section{Fanily 38.-CATODONTID $\approx$. (4 Genera, or Sub-Genera, 6 Species.)}

General Distribution.-All the Tropical Oceans, extending north and south into Temperate waters.

This family, comprising the cachalots or sperm whales, and black-fish, are separated from the true whales by having teeth in the lower jaw and no whalebone. They are pre-eminently a tropical, as distinguished from the two preceding which are 
arctic and antarctic families. The spermaceti whale (Catodon macrocephalus) abounds in the Pacific Ocean and in the deep Moluccan Sea, and also in the Indian Ocean and the Mozambique Channel. In the Atlantic it is scarce, although it occasionally comes north as far as our shores.

The genera of Catodontidæ as given by Dr. Gray are, Catodon (2 species ?), Warm Eastern Oceans; Physeter (1 species), "the black fish," North Sea; Cogia (2 species), South Temperate Oceans; Euphysetes (1 species), Coast of Australia.

FAMily 39.-HYPEROODONTID Æ. (9 Genera or Sub-Genera, 12 Species.)

General Distribution.-Atlantic, Mediterranean, Indian Ocean, and Southern Ocean.

This family consists of the beaked whales, which have no permanent teeth in the upper jaw. The genera, according to Dr. Gray, are, Hyperoodon (2 species) " bottle-nosed whales," North Sea; Lagenocetus (1 species), North Sea ; Epiodon (2 species), North and South Atlantic; Petrorhynchus (2 species), Mediterranean Sea and Southern Ocean; Berardius (1 species), New Zealand; Xiphius (1 species) North Atlantic; Dolichodon (1 species), Cape of Good Hope; Neoziphius (1 species) Mediterranean; Dioplodon (1 species), Indian Ocean.

Family 40.-MONODONTID AE. (1 Genus, 1 Species.)

The "Narwhal" (Monodon monoceros) which constitutes this family, is placed by Dr. Gray along with the "white whales," in his family Belugidæ. It inhabits the North Sea.

\section{FAnily 41.-DELPHINID Æ. (24 Genera or Sub-Genera, 100 Species.)}

General Distribution.-All Oceans, Seas, and Great Rivers of the globe.

This family, including the Porpoises, Dolphins, White Whales, \&c., may be described as small, fish-shaped whales, having teeth 
in both jaws. According to Dr. Gray they form seven families and 24 genera; according to Professor Carus, four sub-families and 8 genera, but as these groups appear to be established on quite different principles, and often differ widely from each other, I shall simply enumerate Dr. Gray's genera with their distribution as given in his British Museum Catalogue.

Platanista (2 species), long-snouted porpoises, inhabiting the Ganges and Indus ; Inia (1 species), a somewhat similar form, inhabiting the upper waters of the Amazonian rivers: Steno (8 species), Indian Ocean, Cape of Good Hope, and West Pacific ; Sotalia (1 species), Guiana; Delpkinus (10 species), all the oceans ; Clymenia (14 species), all the oceans ; Delphinapterus (1 species), South Atlantic; Tursio (7 species), Atlantic and Indian Oceans; Eutropia (2 species), Chili, and Cape of Good Hope; Electra (8 species), all the oceans; Leucopleurus (1 species), North Sea ; Lagenorhynchus (1 species), North Sea; Pseudorca (2 species), North Sea, Tasmania; Orccella (2 speeies), Ganges; Acanthodelphis (1 species), Brazil ; Phoccena (2 species), North Sea ; Noomeris (1 species), India; Grampus (3 species), North Sea, Mediterranean, Cape of Good Hope ; Globiocephalus (14 species), all the oceans; Sphccrocephalus (1 species), North Atlantic; Orca (9 species), Northern and Southern Oceans; Ophysia (1 species), North Pacific ; Beluga (6 species), Arctic Seas, Australia ; Pontoporia (1 species), Monte Video.

\section{Fossil Cetacca.}

Remains of Cetacea are tolerably abundant in Tertiary deposits, both in Europe and North America. In the Lower Pliocene of England, France, and Germany, extinct species of five or six living genera of whales and dolphins have been found ; and most of these occur also in the Upper Miocene, along with many others, referred to about a dozen extinct genera.

In the Post-pliocene deposits of Vermont and South Carolina, several extinct species have been found belonging to living genera; but in the Miocene deposits of the Eastern United States cetacean remains are much more abundant, more than 30 species of VOL. II. 
extinct whales and dolphins having been described, most of them belonging to extinct genera.

The Zeuglodontida, an extinct family of carnivorous whales, with double-fanged serrated molar teeth, whose affinities are somewhat doubtful, are found in the older Pliocene of Europe, and in the Miocene and Eocene of the Eastern United States. Zeuglodon abounds in the United States, and one species reached a length of seventy feet. A species of this genus is said to have been found in Malta. Squalodon occurs in Europe and North A merica ; and in the latter country four or five other genera have been described, of which one, Saurocetes, has been found also at Buenos Ayres.

$$
\text { Order VI,-SIRENIA. }
$$

\section{FAMILY 42.-MANATIDE. (3 Genera, 5 Species ?)}

\begin{tabular}{|c|c|c|c|c|c|}
\hline \multicolumn{6}{|c|}{ General Distribution. } \\
\hline $\begin{array}{l}\text { NEOTROPICAL } \\
\text { SLB-REGiONS. }\end{array}$ & $\begin{array}{c}\text { NeARCTIC } \\
\text { SUB-HEGIONS. }\end{array}$ & $\begin{array}{l}\text { PALFARCTIC } \\
\text { SUB-hEGIOES. }\end{array}$ & $\begin{array}{c}\text { ETHIOPIAN } \\
\text { SUB-REgIONS. }\end{array}$ & $\begin{array}{l}\text { ORIENTAL } \\
\text { SUB-kEGIONS. }\end{array}$ & $\begin{array}{l}\text { Australian } \\
\text { Sub-REitions. }\end{array}$ \\
\hline$-2-4$ & $-\cdots-$ & $1-3-$ & $1.2--$ & $1.2-4$ & $1--\cdots$ \\
\hline
\end{tabular}

The Sea-cows are herbivorous aquatic animals living on the coasts or in the great rivers of several parts of the globe. $M a-$ natus (2 species) inhabits both shores of the Atlantic, one species ranging from the Gulf of Mexico to North Brazil, and ascending the Amazon far into the interior of the continent; while the other is found on the west coast of Africa. Halicore (2 species?), the Dugong, is peculiar to the Indian Ocean, extending from Mozambique to the Red Sea, thence to Western India and Ceylon, the Malay Archipelago and the north coast of Australia. Rytina (1 species), supposed to be now extinet, inhabited recently the North Pacific, between Kamschatia and Behring's Straits.

Fossil Sircnia.-Extinct species of Manatus have been found in the Post-pliocene deposits of Eastern North America from 
Maryland to Florida; and an extinct genus, Prorastomus, in some Tertiary deposits in the Island of Jamaica.

In Post-pliocene deposits in Siberia, remains of Rytina have been found; while several species of the extinct genus Hali. therium, perhaps intermediate between Manatus and Halicore, have been found in the older Pliocene and Upper Miocene of France and Germany.

Order VII.-UNGULATA.

FAMILY 43.-EQUID AE. (1 Genus, 8 Species.)

\begin{tabular}{|c|c|c|c|c|c|}
\hline \multicolumn{6}{|c|}{ General Distribution. } \\
\hline $\begin{array}{l}\text { Nfotropical } \\
\text { Sib-REgions. }\end{array}$ & $\begin{array}{c}\text { NEARCTIC } \\
\text { SUB-REGIONS. }\end{array}$ & $\begin{array}{l}\text { Palmarctic } \\
\text { Sub-regions. }\end{array}$ & $\begin{array}{c}\text { ETHIOPIAN } \\
\text { SUB-REGIONS. }\end{array}$ & $\begin{array}{c}\text { ORIENTAL } \\
\text { SUB-REGIONS. }\end{array}$ & $\begin{array}{l}\text { Australian } \\
\text { Sub-REGIONg. }\end{array}$ \\
\hline
\end{tabular}

Lrving Species.

$$
----|----|-2.3-|1.2 .3-|---\mid---
$$

Extinct Specilis.

$$
1.2--|1.2 .3-| 1.2 .3 .4|----| 1-3-\mid----
$$

The Horses, Asses, and Zebras form a highly specialized group now confined to the Ethiopian and Palæarctic regions, but during the middle and later tertiaries having a very extensive range. The zebras ( 3 species) inhabit the greater part of the Ethiopian region, while the asses ( 4 species) are characteristic of the deserts of the Palæarctic region from North Africa and Syria to Western India, Mongolia, and Manchuria. The domestic horse is not known in a wild state, but its remains are found in recent deposits from Britain to the Altai Mountains, so that its clisappearance is probably due to human agency.

Extinct Equidce.-Extinct forms of this family are very numerous. The genus Equus occurs in Post-pliocene and Pliocene deposits in Europe, North America, and South America. In North America the species are most numerous. An allied genus Hipparion, having rudimentary lateral toes, is represented 
by several species in the Pliocene of North America, while in Europe it occurs both in the Older Pliocene and Upper Miocene. Various other allied forms, in which the lateral toes are more and more developed, and most of which are now classed in a distinct family, Anchitheridæ, range back through the Miocene to the Eocene period. A sufficient account of these has already been given in vol. i. chap. vi. p. 135, to which the reader is referred for the supposed origin and migrations of the horse.

FAMLI 44.-TAPIRIDÆ. (2 Genera ? 6 Species.)

\begin{tabular}{|c|c|c|c|c|c|}
\hline \multicolumn{6}{|c|}{ Gexeral Distinibution. } \\
\hline $\begin{array}{l}\text { NEOTROPICAL } \\
\text { SuB-REgLONS. }\end{array}$ & $\begin{array}{c}\text { NEARCTIC } \\
\text { SUB-REGIONS. }\end{array}$ & $\begin{array}{l}\text { Palaarctic } \\
\text { Sub-hegions. }\end{array}$ & $\begin{array}{l}\text { ETHIOPIAN } \\
\text { SUB-REGIONS. }\end{array}$ & $\begin{array}{c}\text { ORIENTAL } \\
\text { SUB-KEGIONS. }\end{array}$ & $\begin{array}{l}\text { AUSTRALIAN } \\
\text { SUB-REGIUNS. }\end{array}$ \\
\hline$-2.3-$ & --- & $-\cdots-$ & --- & ---4 & - \\
\hline
\end{tabular}

The Tapirs form a small group of animals whose discontinuous distribution plainly indicates their approaching extinction. For a long time only two species were known, the black American, and the white-banded Malay tapir, the former confined to the equatorial forests of South America, the latter to the Malay peninsula, Sumatra, and Borneo (Plate VIII. vol. i. p. 337). Lately however another, or perhaps two distinct species (or according to Dr. J. E. Gray, four!) have been discovered in the Andes of New Granada and Ecuador, at an elevation of from 8,000 to 12,000 feet; while one or perhaps two more, forming the allied genus Elasmognathus, have been found to inhabit Central America from Panama to Guatemala.

Extinct Tapirs.-True tapirs inhabited Western Europe, from the latest Pliocene back to the earliest Miocene times; while they only occur in either North or South America in the Postpliocene deposits and caves. The singular distribution of the living species is thus explained, since we see that they are an Old World group which only entered the American continent at a comparatively recent epoch. An ancestral form of this group-Lophiodon-is found in Miocene and Eocene deposits of 
Europe and North America; while a still more ancient form of large size is found in the Lower Eocene of France and England, indicating an immense antiquity for this group of Mammalia. There are many other extinct forms connecting these with the Palæotheridæ,"already noticed in chapter vi. (vol. i. pp. 119-125).

Family 45.-RHINOCEROTID $\approx$. (1 Genus, 9 Species.)

\begin{tabular}{|c|c|c|c|c|c|}
\hline \multicolumn{6}{|c|}{ General Distribution. } \\
\hline $\begin{array}{l}\text { NEOTROPICAL } \\
\text { SUB-REGIONS. }\end{array}$ & $\begin{array}{c}\text { NEARCTIC } \\
\text { SUB-REGIONS. }\end{array}$ & $\begin{array}{l}\text { PaLfearctic } \\
\text { Sub-REgIons. }\end{array}$ & $\begin{array}{c}\text { ETHIOPIAN } \\
\text { SUb-REGIONS. }\end{array}$ & $\begin{array}{c}\text { ORIENTAL } \\
\text { SUB-REGIONS. }\end{array}$ & $\begin{array}{l}\text { AUSTRALIAN } \\
\text { SUB-REGIONS. }\end{array}$ \\
\hline
\end{tabular}

Living Species.

$$
---.|---|---|1.2 .3-|--3.4 \mid-\ldots
$$

Exinct Species.

$----|1.2--| 1.2 .3 .4|\ldots--| 1-3-\mid \ldots--$

Living Rhinoceroses are especially characteristic of Africa, with Northern and Malayan India. Four or perhaps five species, all two-horned, are found in Africa, where they range over the whole country south of the desert to the Cape of Good Hope. In the Oriental region there are also four or five species, which range from the forests at the foot of the Himalayas eastwards through Assam, Chittagong, and Siam, to Sumatra, Borneo and Java. Three of these are one-horned, the others found in Sumatra, and northwards to Pegu and Chittagong, two-horned. The Asiatic differ from the African species in some dental characters, but they are in other respects so much alike that they are not generally considered to form distinct genera. In his latest catalogue however (1873), Dr. Gray has four genera, Rhinoceros (4 species), and Ceratorhinus (2 species), Asiatic; Rhinaster (2 species), and Ceratotherium (2 species), African.

E'xtinct Rhinocerotidce.-Numerous species of Rhinoceros ranged over Europe and Asia from the Post-pliocene back to the Upper Miocene period, and in North America during the Pliocene period 
only. The hornless Accrolherium is Miocene only, in both countries. Other genera are, Leptodon from Greece, and IIyraeodon from Nebraska, both of Miocene age. More than 20 species of extinct rhinoceroses are known, and one has even been found at an altitude of 16,000 feet in Thibet.

FAMILY 46.-HIPPOPOTAMID无. (1 Genus, 2 Species.)

\begin{tabular}{|c|c|c|c|c|c|}
\hline \multicolumn{6}{|c|}{ General Distribution. } \\
\hline $\begin{array}{l}\text { NEOTROPICAL } \\
\text { Si;B-REgIONS. }\end{array}$ & $\begin{array}{c}\text { NEARCTIC } \\
\text { SUB-REGIONS. }\end{array}$ & $\begin{array}{l}\text { Palaarctic } \\
\text { Sub-IEGIONS. }\end{array}$ & $\begin{array}{c}\text { ETHIOPIAN } \\
\text { SUB-REGIONS. }\end{array}$ & $\begin{array}{l}\text { ORIENTAL } \\
\text { SUB-REGIONE. }\end{array}$ & $\begin{array}{l}\text { AtstraLIAN } \\
\text { SUB-REGIONS. }\end{array}$ \\
\hline \multicolumn{6}{|c|}{ Living Species. } \\
\hline---- & $--\cdots$ & ---- & $1.2 .3-$ & ---- & --- \\
\hline \multicolumn{6}{|c|}{ Extinct Species. } \\
\hline---- & --- & $1.2--$ & ---- & $1-3-$ & $-\cdots$ \\
\hline
\end{tabular}

The Hippopotamus inhalits all the reat river: of Africa; a distinct species of a smaller size being found on the west coast, and on some of the rivers flowing into Lake Tchad.

Fossil Hippopotani.--Eight extinct species of Hippopotamus are known from Europe and India, the former Post-pliocene or Pliocene, the latter of Upper Miocene age. They ranged as far north as the Thames valley. An extinct genus from the Siwalik Hills, Meryeopotamus, according to Dr. Falconer connects Hippopotamus with Anthracotherium, an extinct form from the Miocene of Europe, allied to the swine.

Family 47.-SUID A. (5 Genera, 22 Species.)

\begin{tabular}{|c|c|c|c|c|c|}
\hline $\begin{array}{l}\text { NeOTROPICAL } \\
\text { SUB-REGIONS. }\end{array}$ & $\begin{array}{c}\text { NEARCTIC } \\
\text { SUB-REOIONS. }\end{array}$ & $\begin{array}{l}\text { PaLEarctic } \\
\text { Sub-hEGIoNS. }\end{array}$ & $\begin{array}{l}\text { ErHIOPIAN } \\
\text { SUB-REGIONS. }\end{array}$ & $\begin{array}{l}\text { ORIENTAL } \\
\text { SUB-REGIONS. }\end{array}$ & $\begin{array}{l}\text { Atstralian } \\
\text { SUB-REGIONS. }\end{array}$ \\
\hline$-2 \cdot 3-$ & $-2.3-$ & 1.2 .3 .4 & 1.2 .3 .4 & 1.2 .3 .4 & 1. - - \\
\hline
\end{tabular}

The Swine may be divided into three well-marked groups, from peculiarities in their dentition. 1. The Dicotyline, or 
peccaries ( 1 genus, Dicotyles). These offer so many structural differences that they are often classed as a separate family. 2 . The true swine (3 genera, Sus, Potamochoerus, and Babirusa); and, 3. The Phacochœrinæ, or wart hogs (1 genus, Phacachnrus). These last are also sometimes made into a separate family, but they are hardly so distinct as the Dicotylinæ.

The Peccaries ( 2 species), are pecnliar to the Neotropical region, extending from Mexico to Paraguay. They also spread northwards into Texas, and as far as the Red River of Arkansas, thus just entering the Nearetic region; but with this exception swine are wholly absent from this region, forming an excellent feature by which to differentiate it from the Palæaretic.

Sus (14 species), ranges over the Palæarctic and Oriental regions and into the first Australian sub-region as far as New Guinea; but it is absent from the Ethiopian region, or barely enters it on the north-east. Potamochœrus (3 species?), is wholly Ethiopian (Plate V. vol. i. p. 278). Babirusa (1 species), is confined to two islands, Celebes and Bouru, in the first Australian sub-region.

Phacochœrus (2 species), rauges over tropical Africa from Abyssinia to Caffraria.

Dr. J. E. Gray divides true swine (Sus) into 7 genera, but it seems far better to keep them as one.

Fossil Suidce.-These are very numerous. Many extinct species of wild hog (Sus), are found in Europe and North India, ranging back from the Post-pliocene to the Upper Miocene formations. In the Miocene of Europe are numerous extinct genera, Bothriodon, Anthracothcrinm, Palcochcerus, Hyotherium, and some others; while in the Upper Eocene occur Ccbochcerus, Choropotamus, and Acotherium,--these early forms having more resemblance to the peccaries.

None of these genera are found in America, where we have the living genus Dicotyles in the Post-pliocene and Pliocene deposits, both of North and South America; with a number of extinct genera in the Miocene. The chief of these are, Elotherium, Perchcerus, Leptochcerus, and Nunohyus, all from Dakota, and Thinohyus, from Oregon. One extinct genus, Platygonus, closely allied to Dicotyles, is found in the Post-pliocene of Nebraska. 
Oregon, and Arkansas. Elotherium is said to be allied to the peccary and hippopotamus. Hyopotamus, from the Miocene of Dakota, is allied to Anthracotherium, and forms with it (according to Dr. Leidy) a distinct family of ancestral swine.

It thus appears, that the swine were almost equally well represented in North America and Europe, during Miocene and Pliocene times, but by entirely distinct forms ; and it is a remarkable fact that these hardy omnivorous animals, should, like the horses, have entirely died out in North America, except a few preccaries which have preserved themselves in the sub-tropical parts and in the southern continent, to which they are comparatively recent emigrants. We can hardly have a more convincing proof of the vast physical changes that have occurred in the North American continent during the Pliocene and Post-pliocene epochs, than the complete extinction of these, along with so many other remarkable types of Mammalia.

According to M. Gaudry, the ancestors of all the swine, with the hippopotani and extinct Anthracotherium, Merycopotamus, and many allied forms,--are the Hyracotherium and Pliolophus, both found only in the London clay belonging to the Lower Eocene formation.

Family 48.-CAMELID $\mathbb{E}$. (2 Genera, 6 Species).

\begin{tabular}{l|c|c|c|c|c}
\hline General Distribution. \\
$\begin{array}{l}\text { Nentropical } \\
\text { Sub-R egions. }\end{array}$ & $\begin{array}{c}\text { Nearctic } \\
\text { Sub-Regions. }\end{array}$ & $\begin{array}{c}\text { Palearctic } \\
\text { Sub-hegions. }\end{array}$ & $\begin{array}{c}\text { Ethiopian } \\
\text { Sub-Regions. }\end{array}$ & $\begin{array}{c}\text { Oriental } \\
\text { Sub-Regions. }\end{array}$ & $\begin{array}{c}\text { Australian } \\
\text { Sub-regions. }\end{array}$ \\
\hline
\end{tabular}

Livisg Species.

$$
\begin{aligned}
& \text { 1. }-\ldots|-\ldots-|-2.3-|-\ldots-| \ldots--\mid \ldots-- \\
& 1---|-2.3 .4|--3-|----|--3 . \mid-\ldots--
\end{aligned}
$$

The Camels are an exceedingly restricted group, the majority of the species now existing only in a state of domestication. The geuus Camelus (2 species), is a highly characteristic desert form 
of the Palæarctic region, from the Sahara to Mongolia as far as Lake Baikal. Auchenia (4 species), comprehending the Llamas and Alpacas, is equally characteristic of the mountains and deserts of the southern part of South America. Two species entirely domesticated inhabit the Peruvian and Bolivian Andes; and two others are found in a wild state, the vicuna in the Andes of Peru and Chili (Plate XVI. vol. ii. p. 40), and the guanaco over the plains of Patagonia and Tierra del Fuego.

Extinct Camelida.-No fossil remains of camels have been found in Europe, but one occurs in the deposits of the Siwalik Hills, usually classed as Upper Miocene, but which some naturalists think are more likely of Older Pliocene age. Merycotherium, teeth of which have been found in the Siberian drift, is supposed to belong to this family.

In North America, where no representative of the family now exists, the camel-tribe were once abundant. In the Post-pliocene deposits of California an Auchenic has been found, and in those of Kansas one of the extinct genus Procamelus. In the Pliocene period, this genus, which was closely allied to the living camels, abounded, six or seven species having been described from Nebraska and Texas, together with an allied form Homocamelus. In the Miocene period different genera appear,-Pobrotherizm, and Protomeryx,-while a Procamelus has been found in deposits of this age in Virginia.

In South America a species of Auchenia has been found in the caves of Brazil, and others in the Pliocene deposits of the pampas, together with two extinct genera, Palceolama and Camelotherium.

We thus find the ancestors of the Camelidæ in a region where they do not now exist, but which is situated so that the now widely separated living forms could easily have been derived from it. This case offers a remarkable example of the light thrown by palæontology on the distribution of living animals; and it is a warning against the too common practice of assuming the direct land connection of remote continents, in order to explain similar instances of discontinnons distribution to that of the present family. 


\section{Fanily 49.-TRAGULID $2 . \quad$ (2 Genera, 6 Species.)}

\begin{tabular}{|c|c|c|c|c|c|}
\hline \multirow[b]{2}{*}{$\begin{array}{l}\text { NEU IROPICAL } \\
\text { SUB-RBGIONS. }\end{array}$} & \multicolumn{4}{|c|}{ General Distribution. } & \multirow[b]{2}{*}{$\begin{array}{l}\text { Australian } \\
\text { SuB-REGions. }\end{array}$} \\
\hline & $\begin{array}{c}\text { NEARCTIC } \\
\text { SUB-REGIONS. }\end{array}$ & $\begin{array}{l}\text { PALAARCTIC } \\
\text { SUB-HEGIONS. }\end{array}$ & $\begin{array}{c}\text { ETHOPIAN } \\
\text { SUb-REGIONS. }\end{array}$ & $\begin{array}{l}\text { ORIENTAL } \\
\text { SUB-EEGIONS. }\end{array}$ & \\
\hline--- & --- & $--\cdots$ & $-2--$ & 1.2 .3 .4 & -- \\
\hline
\end{tabular}

The Tragulidæ are a group of small, horuless, deer-like animals, with tusks in the upper jaw, and having some structural affinities with the camels. The musk-deer was formerly classed in this family, which it resembles externally; but a minute examination of its structure by M. Milne-Edwards, has shown it to be more nearly allied to the true deer. The Chevrotains, or mouse-deer, Tragulus (5 species), range over all India to the foot of the Himalayas and Ceylon, and through Assam, Malacca, and Cambodja, to Sumatra, Borneo, and Java (Plate VIII., vol. i. p. 337). Hyomoschus (1 species), is found in West Africa.

Extinct Tragulidee.-A species of Hyomoschus is said to have been found in the Miocene of the Soutl of France, as well as three extinct genera, Dremotherium (also found in Greece), with Lophiomeryx from the Upper Miocene, said to be allied to Tragulus; and Amphitragulus from the Lower Miocene, of more remote affinities, and sometimes placed among the Deer. There seems to be no doubt, however, that this family existed in Europe in Miocene times; and thus another case of discontinuous distribution is satisfactorily accounted for.

$$
\text { Family 50.-CERVID A:. (8 Genera, } 52 \text { Species.) }
$$

\begin{tabular}{|c|c|c|c|c|c|}
\hline \multicolumn{6}{|c|}{ General Distribution. } \\
\hline $\begin{array}{l}\text { N̦EOTROPICAL } \\
\text { SUB-REGIOXS. }\end{array}$ & $\begin{array}{c}\text { NEARCTIC } \\
\text { SUB-REGIONS. }\end{array}$ & $\begin{array}{l}\text { PAL_AARCTIC } \\
\text { SUB-HEGIONS. }\end{array}$ & $\begin{array}{c}\text { ETHIOPIAN } \\
\text { SUB-REGIO:S. }\end{array}$ & $\begin{array}{c}\text { ORIRNTAL } \\
\text { SUB-EEGIONS. }\end{array}$ & $\begin{array}{l}\text { AUSTRALIAN } \\
\text { SUB-REGions. }\end{array}$ \\
\hline $1.2 .3-$ & 1.2 .3 .4 & 1.2 .3 .4 & ---- & 1.2 .3 .4 & $1---$ \\
\hline
\end{tabular}

The Cervidæ, or deer tribe, are an extensive group of animals equally adapted for inhabiting forests or open plains, the Arctic 
regions or the Tropics. They range in fact over the whole of the great continents of the globe, with the one striking exception of Africa, where they are only found on the shores of the Mediterranean which form part of the Palæarctic region. The following is the distribution of the genera.

Alces (1 species), the elk or moose, ranges all over Northern Europe and Asia, as far south as East Prussia, the Caucasus, and North China ; and over Arctic America to Maine on the East, and British Columbia on the west. The American species may however be distinct, although very closely allied to that of Europe. Tarandus (1 species), the reindeer, has a similar range to the last, but keeps farther north in Europe, inhabiting Greenland and Spitzbergen; and in America extends farther south, to New Brunswick and the north shore of Lake Superior. There are several varieties or species of this animal confined to special districts, but they are not yet well determined. Cervus (40 species), the true deer, have been sub-divided into numerous subgenera characteristic of separate districts. They range over the whole area of the family, except that they do not go beyond $57^{\circ} \mathrm{N}$. in America and a little further in Europe and Asia. In South America they extend over Patagonia and even to Tierra del Fuego. They are found in the north of Africa, and over the whole of the Oriental region, and beyond it as far as the Moluccas and Timor, where however they have probably been introduced by man at an early period. Dama (1 species), the fallow deer, is a native of the shores of the Mediterranean, from Spain and Barbary to Syria. Capreolus (2 species), the roe-deer, inhabits all Temperate and South Europe to Syria, with a distinct species in N. China. Ccrvulus (4 species), the muntjacs, are found in all the forest districts of the Oriental region, from India and Ceylon to China as far north as Ningpo and Formosa, also southward to the Philippines, Borneo, and Java. Moschus (1 species) the musk-deer, inhabits Central Asia from the Amoor and Pekin, to the Himalayas and the Siamese mountains above $8000 \mathrm{ft}$. elevation. This is usually classed as a distinct family, but M. Milne-Edwards remarks, that it differs in no important points of organisation from the rest of the Cervidæ. Hydropotes 
(1 species) inhabits China from the Yang-tse Kiang northwarls. This new genus has recently been discovered by Mr. Swinhoe, who says its nearest affinities are with Moschus. Other new forms are Lophotragus, and Elaphodus, both inhabiting North China; the former is hornless, the latter has very small horns about an inch long.

Extinct Deer.-Numerous extinct species of the genus Cervus are found fossil in many parts of Europe, and in all formations between the Post-pliocene and the Upper Miocene. The Elk and Reindeer are also found in caves and Post-pliocene deposits, the latter as far south as the South of France. Extinct genera only, occur in the Upper Miocene in various parts of Europe :Micromcryx, Palocomeryx, and Dicrocercus have been described; with others referred doubtfully to Moschus, and an allied genus Amphimoschus.

In N. America, remains of this family are very scarce, a Cervus allied to the existing wapiti deer, being found in Post-pliocene deposits, and an extinct genus, Leptomeryx, in the Upper Miocene of Dakota and Oregon. Another extinct genus, Merycodus, from the Pliocene of Oregon, is said to be allied to camels and deer.

In South America, several species of Cervus have been found in the Brazilian caves, and in the Pliocene deposits of $\mathrm{La}$ Plata.

It thus appears, that there are not yet sufficient materials for determining the origin and migrations of the Cervidæ. There can be little doubt that they are an Old World group, and a comparatively recent development; and that some time during the Miocene period they passed to North America, and subsequently to the Southern continent. They do not however appear to have developed much in North America, owing perhaps to their finding the country already amply stocked with numerous forms of indigenous Ungulates. 
Family 51.-CAMELOPARDALID $Æ . \quad(1$ Genus, 1 Species.)

\begin{tabular}{|c|c|c|c|c|c|}
\hline \multicolumn{6}{|c|}{ General Distribution. } \\
\hline $\begin{array}{l}\text { NEOTROPICAL } \\
\text { SUB-REGIONS. }\end{array}$ & $\begin{array}{c}\text { NEARCTIC } \\
\text { SUB-REGIONS. }\end{array}$ & $\begin{array}{l}\text { PaLAaActic } \\
\text { SUE-MEGIONS. }\end{array}$ & $\begin{array}{c}\text { ETHIOPIAN } \\
\text { SUB-REGIONS. }\end{array}$ & $\begin{array}{l}\text { ORIENTAL } \\
\text { SUB-REGIONS. }\end{array}$ & $\begin{array}{l}\text { AUSTRALIAN } \\
\text { SUB-REGIONS. }\end{array}$ \\
\hline \multicolumn{6}{|c|}{ Luving Species. } \\
\hline---- & ---- & ---- & $1-3-$ & ---- & ---- \\
\hline \multicolumn{6}{|c|}{ Extinct Species. } \\
\hline--- & --- & $-2--$ & $1---$ & $--3-$ & ---- \\
\hline
\end{tabular}

The Camelopardalidæ, or giraffes, now consist of but a single species which ranges over all the open country of the Ethiopian region, and is therefore almost absent from West Africa, which is more especially a forest district. During the Middle Tertiary period, however, these animals had a wider range, over Southern Europe and Western India as far as the slopes of the Himalayas.

Extinct Species.-Species of Camelopardalis have been found in Greece, the Siwalik Hills, and Perim Island at the entrance to the Red Sea; and an extinct genus, Helladotherium, more bulky but not so tall as the giraffe, ranged from the south of France to Greece and North-west India.

FaMiLY 52.-BOVIDÆE. (34 Genera, 149 Species.)

\begin{tabular}{|c|c|c|c|c|c|}
\hline \multicolumn{6}{|c|}{ General Distribution. } \\
\hline $\begin{array}{l}\text { NFnTROPICAL } \\
\text { SUB-REGIONS. }\end{array}$ & $\begin{array}{l}\text { NEARCTIC } \\
\text { SUB-REOIONS. }\end{array}$ & $\begin{array}{l}\text { Palearrtic } \\
\text { Sub-kEgiuns. }\end{array}$ & $\begin{array}{c}\text { ErHIOPIAN } \\
\text { Sub-REGIONS. }\end{array}$ & $\begin{array}{c}\text { Oriental } \\
\text { Sub-kieglons. }\end{array}$ & $\begin{array}{l}\text { AUSralias } \\
\text { SuB-REGions. }\end{array}$ \\
\hline---- & $1.2-4$ & $1 \cdot 2 \cdot 3 \cdot 4$ & $1.2 .3-$ & 1.2 .3 .4 & $1---$ \\
\hline
\end{tabular}

This large and important family, includes all the animals commonly known as oxen, buffaloes, antelopes, sheep, and goats, which have been classed by many naturalists in at least three, and sometimes four or five, distinct families. Zoologically, they 
are briefly and accurately defined as, "hollow-horned ruminants;" and, although they present wide differences in external form, they grade so insensibly into each other, that no satisfactory definition of the smaller family groups can be found. As a whole they are almost confined to the great Old World continent, only a few forms extending along the highlands and prairies of the Nearctic region; while one peculiar type is found in Celebes, an island which is almost intermediate between the Oriental and Australian regions. In each of the Old World regions there are found a characteristic set of types. Antelopes prevail in the Ethiopian region; sheep and goats in the Palæarctic; while the oxen are perhaps best developed in the Oriental region.

Sir Victor Brooke, who has paid special attention to this family, divides them into 13 sub-families, and 1 here adopt the arrangement of the genera and species which he has been so good as to communicate to me in MSS.

Sub-family I. Bovine (6 genera, 13 species). This group is one of the best marked in the family. It comprises the Oxen and Buffaloes with their allies, and has a distribution very nearly the sume as that of the entire family. The genera are as follows: Bos (1 sp.), now represented by our domestic cattle, the descendants of the Bos primigenius, which ranged over a large part of Central Europe in the time of the Romans. The Chillingham wild cattle are supposed to be the nearest approach to the original species. Bison (2 sp.), one still wild in Poland and the Caucasus; the other in North America, ranging over the prairies west of the Mississippi, and on the eastern slopes of the Rocky Mountains (Plate XIX., vol. ii., p. 129). Bibos (3 sp.), the Indian wild cattle, ranging over a large part of the Oriental region, from Southern India to Assam, Burmah, the Malay Peninsula, Borneo, and Java. Poephagus (1 sp.), the yak, confined to the high plains of Western Thibet. Bubalus (5 sp.), the buffaloes, of which three species are African, ranging over all the continental parts of the Ethiopian region; one Northern and Central Indian; and the domesticated animal in South Europe and North Africa. Anoa (1 sp.), the small wild cow of Celebes, 
a very peculiar form more nearly allied to the buffaloes than to any other type of oxen.

Sub-family II. Tragelaphine (3 genera, 11 species). The Bovine Antelopes are large and handsome animals, mostly Ethiopian, but extending into the adjacent parts of the Palrearctic and Oriental regions. The genera are: Oreas (2 sp.), elands, inhabiting all Tropical and South Africa. T'ragelaphus (8 sp.), including the bosch-bok, kudu, and other large antelopes, ranges over all Tropical and South Africa (Plate IV., vol. ii., p. 261). Portax (1 sp.) India, but rare in Madras and north of the Ganges.

Sub-family III. Oryarne (2 genera, 5 species). Oryx (4 sp.) is a desert genus, ranging over all the African deserts to South Arabia and Syria; Addax (1 sp.) inhabits North Africa, North Arabia, and Syria.

Sub-family IV. Hippotragin a (1 genus, 3 species). The Sable Antelopes, Hippotragus, form an isolated group inhabiting the open country of Tropical Africa and south to the Cape.

Sub-family V. GazelurNe (6 genera, 23 species). This is a group of small or moderate-sized animals, most abundant in the deserts on the borders of the Palæarctic, Oriental, and Ethiopian regions. Gazella (17 sp.) is typically a Palæarctic desert group, ranging over the great desert plateaus of North Africa, from Seneyal and Abyssinia to Syria, Persia, Beloochistan, and the plains of India, with one outlying species in South Africa. Procapra (2 sp.), Western Thibet and Mongolia to about $110^{\circ}$.east longitude. Antilope (1 sp.) inhabits all the plains of India. Epyceros (1 sp.) the pallah, inhabits the open country of South and South-east Africa. Saiga (1 sp.) a singular sheep-faced antelope, which inhabits the steppes of Eastern Europe and Western Asia from Poland to the Irtish River, south of $55^{\circ}$ north latitude. (Plate II., vol. i., p. 218.) Panthalops (1 sp.) confined to the highlands of Western Thibet and perhaps Turkestan.

Sub-family VI. Antilocaprinas (1 genus, 1 species), Antilocapra, the prong-horned antelope, inhabit both sides of the Rocky Mountains, extending north to the Saskatchewan and 
Columbia liver, west to the coast range of California, and east to the Missouri. Its remarkable deciduous horns seem to indicate a transition to the Cervidx. (Plate XIX., vol. ii., p. 129.)

Sub-family VII. Cervicaprine (5 genera, 21 species). This group of Antelopes is wholly confined to the continental portion of the Ethiopian region. The genera are: Cervicapra (4 sp.), Africa, south of the equator and Abyssinia; Kobus (6 sp.), grassy plains and marshes of Tropical Africa; Pelea (1 sp.), South Africa; Nanotragnes (9 species), Africa, south of the Sahara; Neotragus (1 sp.) Abyssinia and East Africa.

Sub-family VIII. Cephalophine (2 genera, 24 species), Africa and India; Cephalophus (22 sp.), continental Ethiopian region; Tetraceros (2 sp.) hilly part of all India, but rare north of the Ganges.

Sub-family IX. Alcephaline (2 genera, 11 species), large African Antelopes, one species just entering the Palæarctic region. The genera are: Alcephalus (9 sp.) all Africa and north-east to Syria; Catoblepas (2 sp.), gnus, Africa, south of the Equator.

Sub-region X. Budorcin $\approx$ (1 genus, 2 species) Budoreas inhabits the high Himalayas from Nepal to East Thibet.

Sub-family XI. RupICaprine (1 genus, 2 species) the Chamois, Rupicapra, inhabit the high European Alps from the Pyrenees to the Caucasus. (Plate I., vol. i., p. 195.)

Sub-family XII. Nemoriredin ж (2 genera, 10 species). These goat-like Antelopes inhabit portions of the Palæarctic and Oriental regions, as well as the Rocky Mountains in the Nearctic region. Nemorhedus (9 sp.) ranges from the Eastern Himalayas to N. China and Japan, and south to Formosa, the Malay Peninsula and Sumatra. Aplocerus (1 sp.), the mountain goat of the trappers, inhabits the northern parts of California and the Rocky Mountains.

Sub-family XIII. CAPRIN $\&$ (2 genera, 23 species). The Goats and Sheep form an extensive series, highly characteristic of the Palæarctic region, but with an outlying species on the Neilgherries in Southern India, and one in the Rocky Mountains and California. The genera are Capra (22 sp.) and Ovibos (1 sp.). 
The genus Capra consists of several sub-groups which have been named as genera, but it is unnecessary here to do more than divide them into "Goats and Ibexes" on the one hand and "Sheep" on the other-each comprising 11 species. The former range over all the South European Alps from Spain to the Caulcasus ; to Abyssinia, Persia, and Scinde; over the high Himalayas to E. Thibet and N. China; with an outlying species in the Neilgherries. The latter are only found in the mountains of Corsica, Sardinia, and Crete, in Europe; in Asia Minor, Persia, and in Central and North-Eastern Asia, with one somewhat isolated species in the Atlas momntains; while in America a species is found in the Rocky Mountains and the coast range of California. Ovibos (1 sp.), the musk-sheep, inhabits Arctic America north of lat. 60 ; but it occurs fossil in Post-glacial gravels on the Yena and Obi in Siberia, in Germany and France along with the Mammoth and with flint implements, and in caves of the Reindeer period; also in the brick earth in the south of England, associated with Rhinoceros megartiinus and Elephas antiquus.

Extinct Bovida.-In the caverns and diluviums of Europe, of the Post-Pliocene period, the remains are found of extinct species of Bos, Bison, and Capra; and in the caverns of the south of France Rupicapra, and an antelope near Hippotragus. Bos and Bison also occur in Pliocene deposits. In the Miocene of Europe, the only remains are antelopes closely allied to existing species, and these are especially numerous in Greece, where remains referred to two living and four extinct genera have been discovered. In the Miocene of India numerous extinct species of Bos, and two extinct genera, Hemibos and Amplizbs, have been found, one of them at a great elevation in Thibet. Antelopes, allied to living Indian species, are chiefly found in the Nerbudda deposits.

In North America, the only bovine remains are those of a Bison, and a sheep or goat, in the Post-pliocene deposits; and of two species of musk-sheep, sometimes classed in a distinct yenus Bootherium, from bets of the same age in Arkansas and Ohio. Casoryx, from the Pliocene of Nebraska, is supposed to be allied to the antelopes and to deer.

VOT. II. 
In the caves of Brazil remains of two animals said to be antelopes, have been discovered. They are classed by Gervais in the genera Antilope and Leptotherium, but the presence of true antelopes in $\mathrm{S}$. America at this period is so improbable, that there is probably some error of identification.

The extinct family Sivatheridx, containing the extraordinary and gigantic four-horned Sivatherium and Eramatherium, of the Siwalik deposits, are most nearly allied to the antelopes.

From the preceding facts we may conclude, that the great existing derelopment of the Bovidæ is comparatively recent. The type may have originated early in the Miocene period, the oxen being at first most tropical, while the antelopes inhabited the desert zone a little further north. The sheep and goats seem to be the most recent development of the bovine type, which was probably long confined to the Eastern Hemisphere.

General Remarks on the Distribution of the Ungulata.

With the exception of the Australian region, from which this order of mammalia is almost entirely wanting, the Ungulata are almost universally distributed over the continental parts of all the other regions. Of the ten families, 7 are Ethiopian, 6 Oriental, 5 Palearctic, 4 Neotropical, and 3 Nearctic. The Ethiopian region owes its superiority to the exclusive possession of the hippopotamus and giraffe, both of which inhabited the Palæarctic and Oriental regions in Miocene times. The excessive poverty of the Nearctic region in this order is remarkable; the swine being represented only by Dicotyles in its extreme southern portion, while the Bovidre are restricted to four isolated species. Deer alone are fairly well represented. But, during the Eocene and Miocene periods, North America was wonderfully rich in varied forms of Ungulates, of which there were at least $\delta$ or 9 families; while we have reason to believe that during the same periods the Ethiopian region was excessively ponr, and that it probably received the ancestors of all its existing families from Europe or' Western Asia in later Miocene or Pliocene times. Many types that once abounded in both Furope and North America are now preserved only in South America and Central or Tropical Asia,-as 
the tapirs and camels; while others once confined to Europe and Asia have found a refuge in Africa,--as the hippopotamus and giraffe; so that in no other order do we find such striking examples of those radical changes in the distribution of the higher animals which were effected during the latter part of the Tertiary period. The present distribution of this order is, in fact, utterly unintelligible without reference to the numerous extinct forms of existing and allied families; but as this subject has been sufficiently discussed in the Second Part of this work (Chapters VI. and VII.) it is unnecessary to give further details here.

\section{Orier VIII.-PROBOSCIDEA.}

Fanily 53.-ELEPHANTID E. (1 Gemus, 2 species.)

\begin{tabular}{|c|c|c|c|c|c|}
\hline \multicolumn{4}{|c|}{ General Distribution. } & \multicolumn{2}{|l|}{ - } \\
\hline $\begin{array}{l}\text { Nrotropical } \\
\text { Sib-REgLoNs. }\end{array}$ & $\begin{array}{c}\text { Nearctic } \\
\text { SUb-REaioN3. }\end{array}$ & $\begin{array}{l}\text { Palanarctic } \\
\text { Sub-IiEg Ionis. }\end{array}$ & $\begin{array}{c}\text { ETHIOPIAN } \\
\text { SUB-REGIONS. }\end{array}$ & $\begin{array}{c}\text { OAIENTaL } \\
\text { Sug-hidgoss. }\end{array}$ & $\begin{array}{l}\text { ArstraltaN } \\
\text { SLE-FEGIONG. }\end{array}$ \\
\hline
\end{tabular}

LIVING SPECIES.

$-\ldots-|-\ldots-|-\ldots-|1.2 .3-| 1.2 .3 .4 \mid \ldots-\cdots$

Extinct Species.

$1.2--|1.2 .3 .4| 1.2 .3 .4|1---| 1-3-\mid \ldots \ldots-$

The elephants are now represented ly two species, the African, which ranges all over that continent south of the Sahara, and the Indian, which is found over all the wooded parts of the Oriental region, from the slopes of the Himalayas to Ceylon, and eastward, to the frontiers of China and to Sumatra and Borneo. These, however, are but the feeble remnants of a host of gigantic creatures, which roamed over all the great continents except Australia during the Tertiary period, and severil of which were contemporary with man.

Extinct Elephants.-At least 14 extinct species of Elephas, and a rather greater number of the allied genus Mastodon (distinguished by their less complex grinding teetly) have now been 
discovered. Elephants ranged over all the Paliearetic and Nearctic regions in Post-Pliocene times; in Europe and Central India they go back to the Pliocene; and only in India to the Upper Miocene period; the number of species increasing as we go back to the older formations.

In North America two or three species of Mastoclon are Postpliocene and Pliocene; and a species is found in the caves of Brazil, and in the Pliocene deposits of the pampas of La Plata, of the Bolivian Andes, and of Honduras and the Bahamas. In Europe the genus is Upper Miocene and Pliocene, but is especially abundant in the former period. In the East, it extends from Perim island to Burmah and over all India, and is mostly Miocene, but with perhaps one species Pliocene in Central India.

An account of the range of such animals as belong to extinct families of Proboscidea, will be found in Chapters VI. and VII.; from which it will be seen that, although the family Elephantidæe undoubtedly originated in the Eastern Hemisphere, it is not improbable that the first traces of the order Proboscidea are to be found in N. America.

Order IX.--HYRACOIDEA.

Fanily 54.-HYRACIDA. (1 Genus. 10-12 Species.)

\begin{tabular}{|c|c|c|c|c|c|}
\hline \multicolumn{6}{|c|}{ General Distribution. } \\
\hline $\begin{array}{l}\text { Nrotropical } \\
\text { StiB-REGIONS. }\end{array}$ & $\begin{array}{l}\text { NEARCTIC } \\
\text { SUB-REGIONS. }\end{array}$ & $\begin{array}{l}\text { PaLAaRCTIC } \\
\text { SUB-HEGIONS. }\end{array}$ & $\begin{array}{l}\text { ETHIOPIAN } \\
\text { SUB-REGIONS. }\end{array}$ & $\begin{array}{l}\text { ORIENTAL } \\
\text { SUB-REGIONS. }\end{array}$ & $\begin{array}{l}\text { AUSTRALIAN } \\
\text { SUB-REGIONS. }\end{array}$ \\
\hline---- & ---- & $-2 .--$ & $1.2 .3-$ & ---- & \\
\hline
\end{tabular}

The genus $H y r^{2}(a x$, which alone constitutes this family, consists of small animals having the appearance of hares or marmots, but which more resemble the genus Rhinoeeros in their teeth and skeleton. They range all over the Ethiopian region, except Madagascar; a peculiar species is found in Fernando Po, and they just enter the Palæarctic as far as Syria. They may therefore be considered as an exclusively Ethiopian group. In Dr. Gray's 
last Catalogue (1873) he divides the genus into three-Hyrax, Euhyrax and Dendrohyrax - the latter consisting of two species confined apparently to West and South Africa.

No extinct forms of this family have yet been discovered; the Hyracotherium of the London clay (Lower Eocene) which was supposed to resemble $H_{y r a x}$, is now believed to be an ancestral type of the Suidæ or swine.

\section{Order X.-RODENTIA.}

Family 55.-MURID E. (37 Genera, 330 Species.)

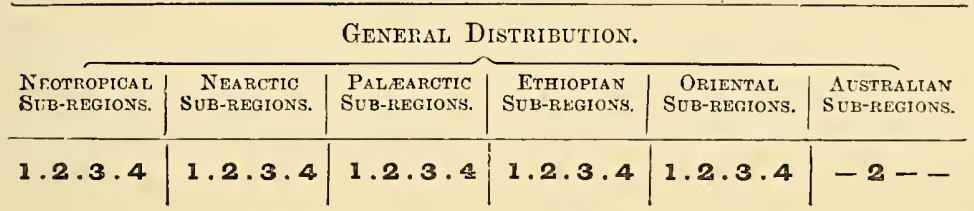

The Muridæ, comprising the rats and mice with their allies, are almost nniversally distributed over the globe (even not reckoning the domestic species which have been introduced almost everywhere by man), the exceptions being the three insular groups belonging to the Australian region, from none of which have any species yet been obtained. Before enumerating the genera it will be as well to say a few words on the peculiarities of distribution they present. The true mice, forming the genus Mrus, is distributed over the whole of the world except $\mathrm{N}$. and $\mathrm{S}$. America where not a single indigenous species occurs, being replaced by the genus Hesperomys; five other genera, comprehending all the remaining species found in South America are peculiar to the Neotropical region. Three genera are confined to the Palæarctic region, and three others to the Nearctic. No less than twelve genera are exclusively Ethiopian, while only three are exclusively Oriental and three Australian.

MIus (100-120 sp.) the Eastern Hemisphere, but absent from the Pacific and Austro-Malayan Islands, except Celebes and Papua; Lasiomys (1 sp.) Guinea; A canthomys ( $5-6$ sp.) Africa, India and 
N. Australia ; Cricetomys (1 sp.) Tropical Africa ; Saccostomus (2 sp.) Mozambique; Cricetus (9 sp.) Palæarctic region and Egypt; Cricetulus (1 sp., Milne-Edwards, 1870) Pekin ; Pseudomys (1 sp.) Australia ; Hapalotis (13 sp.) Australia ; Phlcomys (1 sp.) Philippines; Platacanthomys (1 sp., Blyth, 1865) Malabar ; Dendromys (2 sp.) S. Africa; Nesomys (1 sp. Peters, 1870) Madagascar; Steatomys (2 sp.) N. and S. Africa; Pelomys (1 sp.) Mozambique; Reithrodon (9 sp.) N. America, Lat. $29^{\circ}$ to Mexico, and south to Tierra del Fuego; Acodon (1 sp.) Peru; Myxomys (1 sp.) Guatemala; Hesperomys (y0 sp.) North and South America; Holochilus (4 sp.) South America; Oxymyctcrus (4sp.) Brazil and La Plata; Ncotoma (6 sp.) U.S., East coast to California; Sigmodon (2 sp.) Southern United States; Drymonys (I sp.) Peru; Ncotomys (2 sp.) S. America ; Otomys (6 sp.) S. and E. Africa; Meriones = Gerbillus (20-30 sp.) Egypt, Central Asia, India, Africa; Rhombomys (6 sp.) S. E. Europe, N. Afriza, Central Asia ; Malacothrix (2 sp.) South Africa; Mystromys (1 sp.) South Africa; Psammomys (1 sp.) Egypt ; Spalacomys (1 sp.) India ; Sminthus (1-3 sp.) East Europe, Tartary, Siberia; Hydromys.(5 sp.) Australia and Tas. mania ; Hypogeomys (1 sp., Grandidier, 1870) . Madagascar ; Brachytar'somys (1 sp., Günther, 1874) Madagascar ; Fiber (2 sp.) N. America to Mexico; Arvicola (50 sp.) Europe to Asia Minor, North Asia, Himalayas, Temp. N. America; Cuniculus (1 sp.) N. E. Europe, Siberia, Greenland, Arctic America; Myodes (4 sp.) Europe, Siberia, Arctic America, and Northern United States; Myospalax =Siphneus (2 sp.) Altai Mountains and N. China'; Lophiomys (1 sp.) S. Arabia, and N. E. Africa; Echiothrix (1 sp.) Australia.

Extinct Murida.-Species of Mus, Cricetus, Arvicola, and Myodcs, occur in the Post-Pliocene deposits of Europe; Arvicola, Meriones, and the extinct genus Cricctodon, with some others, ia the Miocene.

In North America, Fiber, Arvicola, and Neotoma, occur in caves;

1 Myospalax has hitherto formed part of the next family, Spalacidæ ; but a recent examination of its anatomy by M. Milne-Edwards shows that it belongs to the Muridæ, and comes near Arvicola. 
an extinct genus, Eumys, in the Upper Miocene of Dakota, and another, Mysops, in the Eocene of Wyoming.

In South America Mrus, or more probably Hcsperomys, is abundant in Brazilian caverns, and Oxymycterus in the Pliocene of La Plata; while Arvicola is said to lave occurred both in the Pliocene and Eocene deposits of the same country.

FAnuly 56.-SPALACIDE. (7 Genera, 17 species.)

\begin{tabular}{|c|c|c|c|c|c|}
\hline $\begin{array}{l}\text { NFOTROPICAL } \\
\text { Stib-REGIONS. }\end{array}$ & $\begin{array}{l}\text { NEARCTIC } \\
\text { SUB-REGIONS. }\end{array}$ & $\begin{array}{l}\text { Palakarctic } \\
\text { Sub-Iteg IONS. }\end{array}$ & $\begin{array}{l}\text { Etimopian } \\
\text { SUB-REGIONS. }\end{array}$ & $\begin{array}{l}\text { ORIENTAL } \\
\text { SCB-REGIONS. }\end{array}$ & $\begin{array}{l}\text { AUSTRALIAN } \\
\text { SUB-REGIONS. }\end{array}$ \\
\hline---1 & $-\cdots-$ & $1.2 .3 \ldots$ & 1.2.3- & $1-3.4$ & $\ldots$ \\
\hline
\end{tabular}

The Spalacide, or mole-rats, have a straggling distribution over the Old World continents. They are found over nearly the whole of Africa, but only in the South-east of Europe, and West of Temperate Asia, but appearing again in North India, Malacca, and South China. Ellobius (1 sp.), is found in South Russia and South-west Siberia; Spalax (1 sp.), Southern Russia, West Asia, Hungary, Moldavia, and Greece (Plate II., vol. i. p. 218); Rhizomys (6 sp.), Abyssinia, North India, Malacea, South China; Heterocephalus (1 sp.), Abyssinia ; Bathyerges (= Orycterus $1 \mathrm{sp}$.), South Africa; Georychus (6 sp.), South, Central, and East Africa; Ileliophobrss (1 sp.), Mozambique.

Family 57.-DIPOIDIE. (3 Genera, 22 Species.)

\begin{tabular}{|c|c|c|c|c|c|}
\hline \multicolumn{6}{|c|}{ General Distilibution. } \\
\hline $\begin{array}{l}\text { NEOTROPICAL } \\
\text { SUB-REGIOAS. }\end{array}$ & $\begin{array}{c}\text { NEARCTIC } \\
\text { SUB-REGIONS. }\end{array}$ & $\begin{array}{l}\text { PALAAARCTIC } \\
\text { SUD-REGIONS. }\end{array}$ & $\begin{array}{l}\text { ETHIOPIAN } \\
\text { SUB-REGIONS. }\end{array}$ & $\begin{array}{c}\text { ORIENTAL } \\
\text { SUB-FEGIONS. }\end{array}$ & $\begin{array}{l}\text { ACSTRALIAN } \\
\text { SUE-TEGiONS. }\end{array}$ \\
\hline---- & 1.2 .8 .4 & -2.3 .4 & $1.2 .3-$ & $--\cdots$ & ---- \\
\hline
\end{tabular}

The Jerboas, or jumping mice, are especially characteristic of the regions about the eastern extremity of the Mediterranean, being found in South Russia, the Caspiau clistrict, Arabia, Egypt, 
and Abyssinia; but they also extend over a large part of Africa, and eastward to India; while isolated forms occur in North America, and the Cape of Good Hope. Dipus = Gerbillus (20 sp.), inhabits North and Central Africa, South-East Europe, and across Temperate Asia to North China, also Affghanistan, India, and Ceylon; Pedetes (1 sp.), South Africa to Mozambique and Angola ; Jaculus = Mcrioncs (1 sp.), North America, from Nova Scotia and Canada, sonth to Pemsylvania and west to California and British Columbia (Plate XX., vol. ii. p. 135).

Extinct Dipodida.-Dipus occurs fossil in the Miocene of the Alps; and an extinct genus, Issiodromys, said to be allied to Pedctes of the Cape of Good Hope, is from the Pliocene formations of Auvergne in France.

Fanily 58.-MYOXIDA. (1 Genus, 12 Species.)

\begin{tabular}{|c|c|c|c|c|c|}
\hline \multicolumn{6}{|c|}{ General Distribution. } \\
\hline $\begin{array}{l}\text { NrotROPICAL } \\
\text { SIBB-REGIONS. }\end{array}$ & $\begin{array}{l}\text { NEARCTIC } \\
\text { SUB-REGIUNS. }\end{array}$ & $\begin{array}{l}\text { PaliearCtic } \\
\text { SUb-1iEhiozis. }\end{array}$ & $\begin{array}{c}\text { ETHIOPIAN } \\
\text { SUB-REGIONS. }\end{array}$ & $\begin{array}{l}\text { ORIENTAL } \\
\text { SuB-EEfitoNs. }\end{array}$ & $\begin{array}{l}\text { Atstraliay } \\
\text { Sub-REgION }\end{array}$ \\
\hline---- & ---- & 1.2 .3 .4 & $1.2 \cdot 3-$ & ---- & -- \\
\hline
\end{tabular}

The Dormice (IIyoxus), are small rodents found over all the temperate parts of the Palearctic region, from Britain to Japan; and also over most parts of Africa to the Cape, but wanting in India. Some of the African species have been separated under the name of Graphidurus, while those of Europe and Asia form the sub-genera Glis, MLuscardinus, and Eliomys.

Extinct Myoxida.-Myoxus ranges from the Post-pliocene of the Maltese caverns to the Miocene of Switzerland and the Upper Eocene of France; and an extinct genus Brachymys is found in the Miocene of Central Europe. 


\section{FAMILY 59._SACCOMYIDÆ. (6 Genera, 33 Species.)}

\begin{tabular}{|c|c|c|c|c|c|}
\hline \multicolumn{6}{|c|}{ Gexeral Distribution. } \\
\hline $\begin{array}{l}\text { NEOTROPICAL } \\
\text { SUB-REGIONS. }\end{array}$ & $\begin{array}{c}\lambda_{\text {EARCT!C }} \\
\text { SUB-REGIONS. }\end{array}$ & $\begin{array}{l}\text { PaLafarctic } \\
\text { SUB-REGIONS. }\end{array}$ & $\begin{array}{c}\text { ETHIOPI.IN } \\
\text { SUB-REGIONS. }\end{array}$ & $\begin{array}{c}\text { ORIENTAL } \\
\text { SUB-HEGIONS. }\end{array}$ & $\begin{array}{l}\text { AUSTRALIAN } \\
\text { SUB-rEglONS.- }\end{array}$ \\
\hline--- & 1.2 .3 .4 & --- & --- & ---- & ---- \\
\hline
\end{tabular}

The Saccomyidx, or pouched rats, are almost wholly confined to our second Nearctic sub-region, comprising the Rocky Mountains and the elevated plains of Central North America. A few species range from this district as far as Hudson's Bay on the north, to South Carolina on the east, and to California on the west, while one genus, doubtfully placed here, goes south as far as Honduras and Trinidad. The group must therefore be considered to be pre-eminently characteristic of the Nearctic region.

The genera are,-Dipodomys (5 sp.), North Mexico, California, the east slope of the Rocky Mountains to the Columbia River, and one species in South Carolina ; Perognathus (6 sp.), North Mexico, California, east slope of the Rocky Mountains to British Columbia; Thomomys (2 sp.), Upper Missouri, and Upper Columbia Rivers to Hudson's Bay ; Geomys (5 sp.), North Mexico, and east slope of Rocky Mountains to Nebraska (Plate XIX., vol. ii. p. 129); Saccomys (1 sp.), North America, locality unknown; Heteromys (6 sp.), Mexico, Honduras, and Trinidad. Gcomys and Thomomys constitute a separate family Geomyidæ, of Professor Carus; but I follow Professor Lilljeborg, who has made a special study of the Order, in keeping them with this family.

In the Post-Pliocene deposits of Illinois and Nebraska, remains of an existing species of Gcomys have been found. 
Family 60.-CASTORIDAe. (1 Genus, 2 Species.)

\begin{tabular}{|c|c|c|c|c|c|}
\hline \multicolumn{6}{|c|}{ Gexeral Distribution. } \\
\hline $\begin{array}{l}\text { NEOTROPICAL } \\
\text { SUD-REGIONS. }\end{array}$ & $\begin{array}{c}\text { N EARCTIC } \\
\text { SUB-REGiONS. }\end{array}$ & $\begin{array}{l}\text { PALEARCTIC } \\
\text { SUB-LEGIONS. }\end{array}$ & $\begin{array}{c}\text { ETHIOPIAN } \\
\text { SUB-REGIONS. }\end{array}$ & $\begin{array}{c}\text { ORIENTAL } \\
\text { SUD-KEGIONS. }\end{array}$ & $\begin{array}{l}\text { AUSTRALIAN } \\
\text { SUB-REGIONS. }\end{array}$ \\
\hline--- & 1.2 .3 .4 & $1-3-$ & $-\ldots$ & --- & $--\cdots$ \\
\hline
\end{tabular}

The Beavers, forming the grenus Castor, consist of two species, the American (Castor canadensis) ranging over the whole of North America from Labrador to North Mexico; while the European (Castor fiber) appears to be confined to the temperate regions of Europe and Asia, from France to the River Amoor, over which extensive region it doubtless roamed in prehistoric times, although now becoming rare in many districts.

Extinct Castoridce.-Extinct species of Castor range back from the Post-pliocene to the Upper Miocene in Europe, and to the Newer Pliocene in North America. Extinct genera in Europe are, Trogontherium, Post-Pliocene and Pliocene; Chalicomys, Older Pliocene; and Steneofibcr, Upper Miocene. In North America Castoroides is Post-Pliocene, and Palcocastor, Upper Miocene. The family thus first appears on the same geological horizon in both Europe and North America.

Family 61.-SCIURIDA.-(8 Genera, 180-200 Species.)

General Distribution.

\begin{tabular}{|c|c|c|c|c|c|}
\hline $\begin{array}{l}\text { NEOTROPICAL } \\
\text { SUB-REOIONS. }\end{array}$ & $\begin{array}{c}\text { NEARCTIC } \\
\text { SUB-REGIONG. }\end{array}$ & $\begin{array}{l}\text { Pal.aActic } \\
\text { SUb-heglons. }\end{array}$ & $\begin{array}{c}\text { ETHIOPIAN } \\
\text { SUB-REGIONB. }\end{array}$ & $\begin{array}{c}\text { ORIENTAL } \\
\text { SUB-REOIONS, }\end{array}$ & $\begin{array}{l}\text { AUSTRalian } \\
\text { Sub-REolons. }\end{array}$ \\
\hline$-2.3-$ & 1.2 .3 .4 & 1.2 .3 .4 & $1.2 .3-$ & 1.2 .3 .4 & -- \\
\hline
\end{tabular}

The Squirrel family, comprehending also the marmots and prairie-dogs, are very widely spread over the earth. They are especially abundant in the Nearctic, Palæarctic, and Oriental regions, and rather less frequent in the Ethiopian and Neotropical, in which last region they do not extend south of Paraguay. They are absent from the West Indian islands, Madagascar, and Australia, only occurring in Celebes which doubtfully belongs to the Australian region. The genera are as follows :- 
Sciurus (100-120 sp., inclurling the sub-genera Spermosciurus, Xerus, Macroxus, Rheithrosciurus, and Rhinosciurus), comprises the true squirrels, and occupies the area of the whole family wherever woods and forests occur. The approximate number of species in each region is as follows: Nearctic 18, Palaarctic 6, Ethiopian 18, Oriental 50, Australian (Celebes) 5, Neotropical 30. Sciuropterns (16-19 sp.), comprises the flat-tailed flying squirrels, which range from Lapland and Finland to North China and Japan, and southward through India and Ceylon, to Malacea and Java, with a species in Formosa; while in North America they occur from Labrador to British Columbia, and south to Minnesota and Southern California. Pteromys (12 sp.), comprising the roundtailed flying squirrels, is a more southern form, being confined to the wooded regions of India from the Western Himalayas to Java and Borneo, with species in Formosa and Japan. Tamias (5 sp.), the ground squirrels, are chiefly North American, ranging from Mexico to Puget's Sound on the west coast, and from Virginia to Montreal on the Atlantic coast; while one species is found over all northern Asia. Spermophilus (26 sp.), the pouched marmots, are confined to the Nearctic and Palæarctic regions ; in the former extending from the Arctic Ocean to Mexico and the west coast, but not passing east of Lake Michigan and the lower Mississippi; in the latter from Silesia through South Russia to the Amoor and Kamschatka, most abundant in the desert plains of Tartary and Mongolia. Arctomys ( $8 \mathrm{sp}$.), the marmots, are found in the northern parts of North America as far down as Virginia and Nebraska to the Rocky Mountains and British Columbia, but not in California; and from the Swiss Alps eastward to Lake Baikal and Kamschatka, and south as far as the Himalayas, above 8,000 feet elevation. Cynomys ( 2 sp.), the prairie-dogs, inbabit the plains east of the Rocky Mountains from the Upper Missouri to the Red River and Rio Grande (Plate XIX., vol.ii. p. 129). Anomalurus (5 sp.), consists of animals which resemble flying-squirrels, but differ from all other members of the family in some points of internal structure. They form a very aberrant portion of the Sciuridæ, and, according to some naturalists, a distinct family. They inhabit West Africa and the island of Fernando I'o. 
Extinct Sciurida,-These are tolerably abundant. The genus Sciurus appears to be a remarkably ancient form, extinct species being found in the Miocene, and even in the Upper Eocene formations of Europe. Spermophilus goes back to the Upper Miocene; Arctomys to the Newer Pliocene. Extinct genera are, Brachymys, Lithomys and Plesiarctomys, from the European Miocene, the latter said to be intermediate between marmots and squirrels.

In North America, Sciums, Tamias, and Arctomys occur in the Post-pliocene deposits only. The extinct genera are Ischyromys, from the Upper Miocene of Nebraska; Paramys, allied to the marmots, and Sciuravis, near the squirrels, from the Eocene of Wyoming.

Here we have unmistakable evidence that the true squirrels (Sciurus) are an Old World type, which has only recently entered North America; and this is in accordance with the comparative scarcity of this group in South America, a country so well adapted to them, and their great abundance in the Oriental region, which, with the Palæarctic, was probably the country of their origin and early development. The family, however, has been traced equally far back in Europe and North America, so that we have as yet no means of determining where it originated.

Family 62.-HAPLOODONTID $\approx .-(1$ Genus, 2 Species.)

\begin{tabular}{|c|c|c|c|c|c|}
\hline \multicolumn{6}{|c|}{ General Distribution. } \\
\hline $\begin{array}{l}\text { NEOTROPICAL } \\
\text { StB-REGIONS. }\end{array}$ & $\begin{array}{l}\text { NEARCTIC } \\
\text { SUB-REGIONS. }\end{array}$ & $\begin{array}{l}\text { PaLAaARCTIC } \\
\text { SUB-IEGIONS. }\end{array}$ & $\begin{array}{c}\text { ETHIOPIAN } \\
\text { SUB-REGIONS. }\end{array}$ & $\begin{array}{c}\text { ORIENTAL } \\
\text { SUB-REGions. }\end{array}$ & $\begin{array}{l}\text { AUSTRALIAN } \\
\text { SUB-REGIONS. }\end{array}$ \\
\hline--- & $1---$ & --- & --- & $---\cdots$ & \\
\hline
\end{tabular}

The genus Haploodon or Aplodontia, consists of two curious rat-like animals, inhabiting the west coast of America, from the southern part of British Columbia to the mountains of California. They seem to have affinities both with the beavers and - marmots, and Professor Lilljeborg constitutes a separate family to receive them. 
Family 63.-ChINCHILLID Æ. (3 Genera, 6 Species)

\begin{tabular}{|c|c|c|c|c|c|}
\hline \multicolumn{6}{|c|}{ General Distribution. } \\
\hline $\begin{array}{l}\text { NEOTROPICAL } \\
\text { SUB-REGIONS. }\end{array}$ & $\begin{array}{c}\text { NEARCTIC } \\
\text { SUB-REGIONS. }\end{array}$ & $\begin{array}{l}\text { Palmarctic } \\
\text { Sub-heGions. }\end{array}$ & $\begin{array}{c}\text { ETHIOPIAN } \\
\text { SUB-REGIONS. }\end{array}$ & $\begin{array}{c}\text { ORIENTAL } \\
\text { SUB-fEGIONS, }\end{array}$ & $\begin{array}{l}\text { AUSTRALIAN } \\
\text { SUB-REGIONS. }\end{array}$ \\
\hline $1---$ & ---- & ---- & $-\cdots-\cdots$ & ---- & ---- \\
\hline
\end{tabular}

The Chinchillidæ, including the chinchillas and viscachas, are confined to the alpine zones of the Andes, from the boundary of Ecuador and Peru to the southern parts of Chili; and over the Pampas, to the Rio Negro on the south, and the River Uruguay on the east. Chinchilla (2 sp.), the true chinchillas, are found in the Andes of Chili and Peru, south of $9^{\circ} \mathrm{S}$. lat., and from 8,000 to 12,000 feet elevation (Plate XVI. vol. ii. p. 40); Lagidium (3 sp.), the alpine viscachas, inhabit the loftiest plateaus and mountains from 11,000 to 16,000 feet, and extend furthest north of any of the family; while Lagostomus (1 sp.), the viscacha of the Pampas, has the range above indicated. The family is thus confined within the limits of a single sub-region.

Extinct Chinchillidce.-Lagostomus has been found fossil in the caves of Brazil, and in the Pliocene deposits of $\mathrm{La}$ Plata. The only known extinct forms of this family are Amblyrhizc and Loxomylus, found in cavern-deposits in the island of Anguilla, of Post-Pliocene age. These are very interesting, as showing the greater range of this family so recently; though its absence from North America and Europe indicates that it is a peculiar development of the Neotropical region.

Family 64.-OCTODONTID \#. (8 Genera, 19 Species.)

\begin{tabular}{|c|c|c|c|c|c|}
\hline \multicolumn{6}{|c|}{ Gexeral Distribution. } \\
\hline $\begin{array}{l}\text { NFOTROPICAL } \\
\text { SUB-REGIONS. }\end{array}$ & $\begin{array}{c}\text { NEARCT:C } \\
\text { SUB-REG:ONS. }\end{array}$ & $\begin{array}{l}\text { Palafarctic } \\
\text { Sub-hegions. }\end{array}$ & $\begin{array}{c}\text { ExhIOPIIN } \\
\text { SUB-REgIONS. }\end{array}$ & $\begin{array}{c}\text { ORIFATAL } \\
\text { Sub-hegions. }\end{array}$ & $\begin{array}{l}\text { Australiant } \\
\text { Sub-regionit. }\end{array}$ \\
\hline $1.2-4$ & $-\cdots-$ & $-2--$ & $1---$ & ---- & ---- \\
\hline
\end{tabular}


The Octodontide include a number of curions and obscure rat-like animals, mostly confined to the mountains and open plains of Sonth America, but having a few stragglers in other parts of the world, as will be seen by our notes on the genera. The most remarkable print in their distribution is, that two genera are peculiar to the West Indian islands, while no species of the family inhabits the northern half of Sonth America. The distribution of the genera is as follows:-Habrocomus (2 sp.), Chili; Capromys (3 sp.), two of which inhabit Cuba, the third Jamaica (Plate XVII. vol. ii. p. 67) ; Plagiodontia (1 sp.), only known from Hayti; Spalacopus, including Schizodon (2 sp.), Chili, and east side of Southern Andes; Octodon (3 sp.), Peru, Bolivia, and Chili ; Ctcnomys (6 sp.), the tuco-tuco of the Pampas, the Campos of Brazil to Bolivia and Tierra del Fuego; Ctcnodactylus (1 sp.), Tripoli, North Africa; Pcctinator (1 sp.), Last Africa, Abyssinia, $-4,000$ to 5,000 feet.

Capromys and Plagiodontia, the two West Indian genera, were classed among the Echimyidæe by Mr. Waterhouse, but Professor Lilljeborg removes them to this family.

Extinct Octodontidce.-Species of Ctenomys have been found in the Pliocene of La Plata, and an extinct genus Megamys, said to be allied to Capromys, in the Eocene of the same country. In Europe, Palcoomys and Archccomys from the lower Miocene of Germany and France, are also said to be allied to Capromys.

\section{Family 65.-ECHIMYID A. (10 Genera, 30 Species.)}

\begin{tabular}{|c|c|c|c|c|c|}
\hline \multicolumn{6}{|c|}{ General Distribution. } \\
\hline $\begin{array}{l}\text { NFotropical } \\
\text { St'B-REGIOXS. }\end{array}$ & $\begin{array}{c}\text { NEARCTIC } \\
\text { SUB-REGIONS. }\end{array}$ & $\begin{array}{l}\text { PALEARCTIC } \\
\text { SUE-REGIONS. }\end{array}$ & $\begin{array}{l}\text { ETHIOPIAN } \\
\text { SUB-REGIONS. }\end{array}$ & $\begin{array}{c}\text { ORIENTAL } \\
\text { SUB-REGIONS. }\end{array}$ & $\begin{array}{l}\text { ATSTRALIAN } \\
\text { SUB-REGIONi. }\end{array}$ \\
\hline 1. $2--$ & --- & -- & $1-3-$ & --- & - \\
\hline
\end{tabular}

The Echimyidae, or spiny rats, are a family, chiefly Sonth American, of which the Coypu, a large beaver-like water-rat frow Peru and Chili is the best known. Two of the genera are found in South Africa, lut all the rest inhabit the continent of South America, East of the Andes, none being yet known north 
of Panama. The genera are as follows:-Dactylomys (2 sp.), Guiana and Brazil ; Cercomys (1 sp.), Central Brazil ; Lasiuromys (1 sp.), San Paulo, Brazil; Pctromys (1 sp.), South Africa; Myopotamus (1 sp.), the coypu, on the East side of the Andes from Peru to $42^{\circ} \mathrm{S}$. lat., on the West side from $33^{\circ}$ to $48^{\circ} \mathrm{S}$. lat.; Carterodon (1 sp.), Minaes Geraes, Brazil ; Aulacodcs (1. sp.), West and South Africa; Mesomys (1 sp.), Borba on the Amazon; Echimys (11 sp.), from Guiana and the Ecuadorian Andes to Paraguay; Loncheres (10 sp.), New Granada to Brazil.

Fossil and Extinct Echimyidce.-The genus Carterodon was established on bones found in the Brazilian caves, and it was several years afterwards that specimens were obtained showing the animal to be a living species. Extinct species of Myopotamus and Loncheres have also been found in these caves, with the extinct genera Lonchophom and Phyllomys.

No remains of this family have been discovered in North America; but in the Miocene and Upper Eocene deposits of France there are many species of an extinct genus Thcridomys, which is said to be allied to this group or to the next (Cercolabidæ). Aulacodon, from the Upper Miocene of Germany, is allied to the West African Aulcicodes; and some other remains from the lower Miocene of Auvergne, are supposed to belong to Echimys.

FAnily 66-CERCOLABIDE. (3 Genern, 13-15 Species.)

\begin{tabular}{|c|c|c|c|c|c|}
\hline \multirow[b]{2}{*}{$\begin{array}{l}\text { NEOTBOPICAL } \\
\text { SuB-REGIONS. }\end{array}$} & \multicolumn{4}{|c|}{ Gexeral Distribution. } & \\
\hline & $\begin{array}{c}\text { NEARCT:C } \\
\text { SUB-REGIONS. }\end{array}$ & $\begin{array}{l}\text { PaLeanctic } \\
\text { SUB-REgIONS. }\end{array}$ & $\begin{array}{c}\text { ErHIOPIIN } \\
\text { SUB-REGIONS. }\end{array}$ & $\begin{array}{c}\text { ORIENTAL } \\
\text { SUB-kEGIONS. }\end{array}$ & $\begin{array}{l}\text { AUSTRALIAN } \\
\text { SUB-REGIONS. }\end{array}$ \\
\hline$-2 \cdot 3-$ & 1.2 .3 .4 & $---\cdots$ & --- & $---\cdots$ & $--\cdots$ \\
\hline
\end{tabular}

The Cercolabidæ, or arboreal porcupines, are a group of rodents entirely confined to America, where they range from the northern limit of trees on the Mackenzie River, to the southern limit of forests in Paraguay. There is however an intervening district, the Southern United States, from which they are absent. Erothizon (3 sp.), the Canadian porcupine, is found throughout 
Canada and as far south as Northern Peunsylvania, and west to the Mississippi (Plate XX., vol. ii. p. 135); an allied species inhabiting the west coast from California to Alaska, and inland to the head of the Missouri River; while a third is found in the north-western part of South America; Cercolabes (12 sp.), ranges from Mexico and Guatemala to Paraguay, on the eastern side of the Andes; Chcetomys (1 sp.), North Brazil.

Extinet Cereolabidce.-A large species of Cereolabes has been found in the Brazilian caves, but none have been discovered in North America or Europe. We may conclude therefore that this is probably a South American type, which has thence spread into North America at a comparatively recent epoch. The peculiar distribution of Cereolabes may be explained by supposing it to have migrated northwards along the west coast by means of the wooded slopes of the Rocky Mountains. It could then only reach the Eastern States by way of the forest region of the great lakes, and then move sonthward. This it may be now doing, but it has not yet reached the Southern States of Eastern North America.

\section{Family 67.-HYSTRICIDA. (3 Genera, 12 Species.)}

\begin{tabular}{|c|c|c|c|c|c|}
\hline \multicolumn{6}{|c|}{ Gexeral Distribution. } \\
\hline $\begin{array}{l}\text { NEOTROPICAL } \\
\text { SUB-REGLONS. }\end{array}$ & $\begin{array}{c}N_{\text {EARCTIC }} \\
\text { SUB-REGIONS. }\end{array}$ & $\begin{array}{l}\text { PalaARCTYC } \\
\text { SUB-REGIONS. }\end{array}$ & $\begin{array}{l}\text { ETHIOPIIN } \\
\text { SUB-REGIONS. }\end{array}$ & $\begin{array}{c}\text { ORIENTAL } \\
\text { SUB-KEGIONS. }\end{array}$ & $\begin{array}{l}\text { AUSTRALIAN } \\
\text { SUB-REGTONS. }\end{array}$ \\
\hline---- & $-\cdots$ & $-2-$ & $11.2 .3-$ & 1.2 .3 .4 & ---- \\
\hline
\end{tabular}

The true Porcupines have a very compact and well-marked distribution, over the whole of the Oriental and Ethiopian regions (except Madagascar), and the second Palrarctic sub-region. There is some confusion as to their sub-division into genera, but the following are those most usually ailmitted :- $H_{y s t r i x}(5 \mathrm{sp}$.), South Europe to the Cape of Goorl Hope, all India, Ceylon, and South China; Atherura (5 sp.), "brush-tailed porcupines," inhabit West Africa, India, to Siam, Sumatra, and Borneo ; Acanthion (2 sp.), Nepal and Malacea, to Sumatra, Borneo, and Java. Extinct Hystricidee. - Several extinct species of $H_{y y s t r i x}$ have 
been found in the Pliocene and Miocene deposits of Europe, and one in the Pliocene of Nebraska in North America.

Fanily 68.-CAVIIDA. (6 Genera, 28 Species.)

\begin{tabular}{|c|c|c|c|c|c|}
\hline \multirow[b]{2}{*}{$\begin{array}{l}\text { NEOTROPICAL } \\
\text { Sr'B-REGIONS. }\end{array}$} & \multicolumn{4}{|c|}{ General Distribution. } & \multirow[b]{2}{*}{$\begin{array}{l}\text { AUSTRALIAN } \\
\text { SUb-REGIONS. }\end{array}$} \\
\hline & $\begin{array}{l}\text { NeARCTIC } \\
\text { SUB-REGIONS. }\end{array}$ & $\begin{array}{l}\text { Palearctic } \\
\text { Sub-iegions. }\end{array}$ & $\begin{array}{c}\text { ETHIOPIAN } \\
\text { SUB-REGIONS. }\end{array}$ & $\begin{array}{c}\text { Oriental } \\
\text { Sub-REgions. }\end{array}$ & \\
\hline $1.2 .3 \cdot 4$ & $-\cdots$ & $--\cdots-$ & $-\cdots$ & $-\cdots-$ & --- \\
\hline
\end{tabular}

The Cavies and Agoutis were placed in distinct families by Mr. Waterhouse, in which he is followed by Professor Carus, but they have been united by Professor Lilljeborg, and without pretending to decide which classification is the more correct I follow the latter, because there is a striking extermal resemblance between the two groups, and they have an identical distribution in the Neotropical region, and with one exception are all found east of the Andes. Dasyprocta (9 sp.), the agouti, ranges from Mexico to Paraguay, one species inhabiting the small West Indian islands of St. Vincent, Lucia, and Grenada ; Ccelogenys ( $2 \mathrm{sp}$.), the paca, is found from Guatemala to Paraguay, and a second species (some-what doubtful) in Eastern Peru; Hydrochcerus (1 sp.), the capybara, inhabits the banks of rivers from Guayana to La Plata; Cavia (9 sp.), the guinea-pigs, Brazil to the Straits of Magellan, and one species west of the Andes at Yça in Peru ; Kcrodon (6 sp.), Brazil and Peru to Magellan; Dolichotis (1 sp,), the Patagonian cavy; from Mendoza to $48^{\circ} 30^{\prime}$ south latitude, on sterile plains.

Extinct Caviido.-Hydrochœrus, Ccelogenys, Dasyprocta, and Kerodon, have occurred abundantly in the caves of Brazil, and the last-named genus in the Pliocene of La Plata. Hydrochorus has been found in the Post-Pliocene deposits of South Carolina. Cavic and Dasyprocta are said to have been found in the Miocene of Switzerland and France. No well-marked extinct genera of this family have been recorded.

If the determination of the above-mentioned fossil species of Cavia and Dasyprocta are correct, it would show that this now VOL. II. 
exclusively South American family is really derived from Europe, where it has long been extinct.

Fanily 69.-LAGOMYIDA. (1 Genus, 11 Species.)

\begin{tabular}{|c|c|c|c|c|c|}
\hline $\begin{array}{l}\text { NirotROPICAL } \\
\text { St'B-REGIONS. }\end{array}$ & $\begin{array}{c}\text { NEARCTIC } \\
\text { SuB-REGIONS. }\end{array}$ & $\begin{array}{l}\text { PaLAanctic } \\
\text { SUB-KEGIONS. }\end{array}$ & $\begin{array}{c}\text { ETHIOPIAN } \\
\text { SUB-REGIONS. }\end{array}$ & $\begin{array}{l}\text { ORIENTAL } \\
\text { SUB-REGIONS. }\end{array}$ & $\begin{array}{l}\text { Avistralian } \\
\text { SUb-REGIONS. }\end{array}$ \\
\hline---- & $-2-4$ & $--3-$ & ---- & --- & $-\cdots$ \\
\hline
\end{tabular}

The Lagomyidæ, or pikas, are small alpine and desert animals which range from the south of the Ural Mountains to Cashmere and the Himalayas, at heights of 11,000 to 14,000 feet, and northward to the Polar regions and the north-eastem extremity of Siberia. They just enter the eastern extremity of Europe as far as the Volga, but with this exception, seem strictly limited to the third Palæarctic sub-region. In America they are confined to the Rocky Mountains from about $42^{\circ}$ to $60^{\prime}$ north latitude.

Extinct Lagomyidce.-Extinct species of Lagomys have occurred in the southern parts of Europe, from the Post-Pliocene to the Miocene formations. Titanomys, an extinct genus, is found in the Miocene of France and Germany.

Fanily 70.-LEPORID E. (1 Genus, 35-40 Species.)

\begin{tabular}{|c|c|c|c|c|c|}
\hline \multicolumn{6}{|c|}{ Gexeral Distribution. } \\
\hline $\begin{array}{l}\text { NEOTROPICAL } \\
\text { SUB-REGIONS. }\end{array}$ & $\begin{array}{l}\text { NEARCTIC } \\
\text { SUB-REGIONS. }\end{array}$ & $\begin{array}{l}\text { PalaAarctic } \\
\text { Sub-REGIONS }\end{array}$ & $\begin{array}{l}\text { ETHiopian } \\
\text { SUB-REGIONS. }\end{array}$ & $\begin{array}{l}\text { ORIENTAL } \\
\text { SUB-REGIONS. }\end{array}$ & $\begin{array}{l}\text { Australian } \\
\text { Sub-rFations. }\end{array}$ \\
\hline$-2 \cdot 3-$ & 1.2 .3 .4 & 1.2 .3 .4 & $1-3-$ & $1.2 .3-$ & $-\cdots-$ \\
\hline
\end{tabular}

The Hares and Rabbits are especially characteristic of the Nearctic and Palrarctic, but are also thinly scattered over the Ethiopian and Oriental regions. In the Neotropical region they are very scarce, only one species being found in South Anerica, in the mountains of Brazil and various parts of the Andes, while one or two of the North American species extend into Mexico 
and Guatemala. In the Nearctic region, they are most abundant in the central and western parts of the continent, and they extend to the Arctic Ocean and to Greenland. They are found in every part of the Palæarctic region, from Ireland to Japan; three species range over all India to Ceylon, and others occur in Hainan, Formosa, South China, and the mountains of Pegu; the Ethiopian region has only four or five species, mostly in the southern extremity and along the East coast. An Indian species is now wild in some parts of Java, but it has probably been introduced.

Extinet Leporidce.-Species of Lepus occur in the Post-Pliocene and Newer Pliocene of France; but only in the PostPliocene of North America, and the caves of Brazil.

General Remarks on the Distribution of the Rodentia.

With the exception of the Australian region and Madagascar, where Muridæ alone have been found, this order is one of the most universally and evenly distributed over the entire globe. Of the sixteen families which compose it, the Palæarctic region has 10 ; the F.thiupian, Nearctic, and Neotropical, each 9 ; and the Oriental only 5. These figures are very curious and suggestive. We know that the rodentia are exceedingly ancient, since some of the living genera date back to the Eocene period ; and some ancestral types might thus have reached the remote South American and South African lands at the time of one of their earliest unions with the northern continents. In both these countries the rodents diverged into many special forms, and being small animals easily able to conceal themselves, have largely survived the introduction of higher Mammalia. In the Palrarctic and Nearctic regions, their small size and faculty of hibernation may liave enabled them to maintain themselves during those great physical changes which resulted in the extermination or banishment of so many of the larger and more highly organised Mammalia, to which, in these regions, they now bear a somewhat inordinate proportion. The reasons why they are now less numerous and varied in the Oriental region, may be of two kinds. The comparatively small area of that region and its 
umiformity of climate, would naturally lead to less development of such a group as this, than in the vastly more extensive and varied and almost equally luxuriant Palæarctic region of Eocene and Miocene times; while on the other hand the greater number of the smalier Carnivora in the tropies during the Pliocene and Post-Pliocene epochs, would be a constant check upon the increase of these defenceless animals, and no doubt exterminate a number of them.

The Rodents thus offer a striking contrast to the Ungulates; and these two great orders afford an admirable illustration of the different way in which physical and organic changes may affect large and small herbivorous Mammalia; often leading to the extinction of the former, while favouring the comparative development of the latter.

Order XI.-EDENTATA.

Family 71.-BRAD YPODID $\mathbb{E} . \quad$ (3 Genera, 12 Species.)

\begin{tabular}{|c|c|c|c|c|c|}
\hline \multicolumn{6}{|c|}{ General Distribution. } \\
\hline $\begin{array}{l}\text { NEOTROPICAL } \\
\text { SUR-REGIONS. }\end{array}$ & $\begin{array}{c}\text { NEARCTIC } \\
\text { SUB-REGIONS. }\end{array}$ & $\begin{array}{l}\text { PAL.EARCTIC } \\
\text { SUD-REGIONS. }\end{array}$ & $\begin{array}{c}\text { ETHIOPIAN } \\
\text { SUB-REATONS. }\end{array}$ & $\begin{array}{l}\text { ORTENTAL } \\
\text { SUB-REQIONS. }\end{array}$ & $\begin{array}{l}\text { AOGTRALIAN } \\
\text { SUB-REGIONS. }\end{array}$ \\
\hline$-2.3-$ & $-\cdots$ & $-\cdots-\cdots$ & $--\cdots$ & $--\cdots$ & --- \\
\hline
\end{tabular}

The Sloths are a remarkable group of arboreal mammals, strictly confined to the great forests of the Neotropical region, from Guatemala to Brazil and Eastern Bolivia. None are found west of the Andes, nor do they appear to extend into Paraguay, or beyond the Tropic of Capricorn on the east coast. The genera as defined by Dr. Gray in 1871 are :-C'holcepus (2 sp.), "Sloths with two toes on fore limbs, sexes alike," Costa Rica to Brazil; Bradypus (2 sp.), "Sloths with three toes on fore limbs, sexes alike," Central Brazil, Amazon to Rio de Janeiro; Arctopithecus (8 sp.), "Sloths with three toes on fore limbs, males with a coloured patch on the back," Costa Rica to Brazil and Eastern Bolivia (Plate XIV., vol. ii. p. 24). 
Exinct Bradypodidce.-In the caves of Brazil are found three extinct genera of Sloths-Colodon, Sphenodon, and Ochotherium. More distantly allied, and probably. forming distinct families, are Scelidotherium and Megatherium, from the caves of Brazil and the Pliocene deposits of La Plata and Patagonia.

FAMILY 72.-MANIDID $A . \quad(1$ Genus, 8 Species.)

\begin{tabular}{|c|c|c|c|c|c|}
\hline \multicolumn{6}{|c|}{ General Distpibution. } \\
\hline $\begin{array}{l}\text { NEOTROPICAI } \\
\text { SUB-REQIONS. }\end{array}$ & $\begin{array}{c}\text { NEARCTIC } \\
\text { SUB-REGIONS. }\end{array}$ & $\begin{array}{l}\text { PALAEARCTIC } \\
\text { SUB-REGIONS. }\end{array}$ & $\begin{array}{l}\text { ErHiopian } \\
\text { SUB-REarons. }\end{array}$ & $\begin{array}{l}\text { ORIENTAL } \\
\text { SUB-REGIONS. }\end{array}$ & $\begin{array}{l}\text { AUSTraLIAN } \\
\text { SUB-REGIONS. }\end{array}$ \\
\hline---- & $---\infty$ & $---\cdots$ & $1.2 .3-$ & $1 \cdot 2 \cdot 3 \cdot 4$ & $-\cdots-$ \\
\hline
\end{tabular}

The Manididæ, or scaly ant-eaters, are the only Edentate Mammalia found out of America. They are spread over the Ethiopian and Oriental regions; in the former from Sennaar to West Africa and the Cape; in the latter from the Himalayas to Ceylon, and Eastward to Borneo and Java, as well as to South China, as far as Amoy, Hainan, and Formosa. They have been sub-divided, according to differences in the scaly covering, into five groups, Manis, Phatagin, Smutsia, Pholidotus and Pangolin, the three former being confined to Africa, the last common to Africa and the East, while Pholidotus seems confined to Java. It is doubtful if these divisions are more than sub-genera, and as sush they are treated here.

No extinct species referable to this family are yet known.

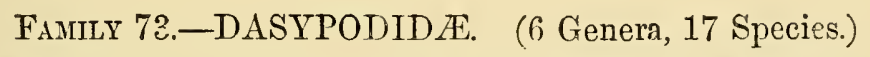

\begin{tabular}{|c|c|c|c|c|c|}
\hline \multicolumn{6}{|c|}{ General Distribution. } \\
\hline $\begin{array}{l}\text { NEOTROPICAL } \\
\text { SUB-REGIONS. }\end{array}$ & $\begin{array}{c}\text { NEARCTIC } \\
\text { SUB-REOIONS. }\end{array}$ & $\begin{array}{l}\text { PaLAaARctic } \\
\text { SUB-hEOIONS. }\end{array}$ & $\begin{array}{l}\text { ETHIOPIAN } \\
\text { SUB-REGIONS. }\end{array}$ & $\begin{array}{l}\text { OR.ENTAL } \\
\text { SUB-EEOIONS. }\end{array}$ & $\begin{array}{l}\text { AuSTralian } \\
\text { SUB-REgIONS. }\end{array}$ \\
\hline $1.2 .3-$ & ---- & $---\infty$ & ---- & ---- & --- \\
\hline
\end{tabular}

The Dasypodidæ, or armadillos, are a highly characteristic Neotropical family, ranging from the northern extremity of the region 
in south Texas, to $50^{\circ}$ south latitude on the plains of Patagonia. The distribution of the genera is as follows:-Tutusia (5 sp.), has the range of the whole family from the lower Rio Grande of Texas to Patagonia; Prionodontes (1 sp.), the giant armadillo, Surinam to Paraguay; Dasypus (4 sp.), Brazil to Bolivia, Chili, and La Plata; Xcnurus (3 sp.), Guiana to Paraguay ; Tolypeutes (2 sp.), the three-banded armadillos, Bolivia and La Plata; Chlamydophorus (2 sp.), near Mendoza in La Plata, and Santa Cruz de la Sierra in Bolivia.

Extinct Armadillos.-Many species of Dasypus and Xemumus have been found in the caves of Brazil, together with many extinct genera-Hoplophorus, Euryodon, Hcterodon, Pachytherium, and Chlamydotherium, the latter as large as a rhinoceros. Eutatus, allicd to Tolypeutes, is from the Pliocene deposits of La Flata.

Family 74.--ORYCTEROPODIDE. (1 Genus, 2 Species.)

\begin{tabular}{|c|c|c|c|c|c|}
\hline \multicolumn{6}{|c|}{ General Distribution. } \\
\hline $\begin{array}{l}\text { NeOTROPICAL } \\
\text { StB-REGIONS. }\end{array}$ & $\begin{array}{c}\text { Nearctic } \\
\text { Sub-REgross. }\end{array}$ & $\begin{array}{l}\text { Palianarctic } \\
\text { Sub-liEglons. }\end{array}$ & $\begin{array}{c}\text { Ethropian } \\
\text { Sub-REGIONS. }\end{array}$ & $\begin{array}{l}\text { Oriental } \\
\text { Sub-kEgtoNs. }\end{array}$ & $\begin{array}{l}\text { AUSTRALLAN } \\
\text { SUB-R EGIONS. }\end{array}$ \\
\hline--- & ---- & ---- & $1-3-$ & ---- & --- \\
\hline
\end{tabular}

The Aard-vark, or Cape ant-eater (Orycteropus capensis) is a curious form of Edentate animal, with the general form of an ant-eater, but with the bristly skin and long obtuse snout of a pig. A second species inhabits the interior of North-East Africa and Senegal, that of the latter country perhaps forming a third species (Plate IV. vol. i. p. 261).

Extinct Orycteropodidce.-The genus Macrotherium, remains of which occur in the Miocene deposits of France, Germany, and Greece, is aliied to this group, though perhaps forming a separate family. The same may be said of the Ancylotherium, a huge animal found only in the Miocene deposits of Greece. 
Family 75.-MYRMeCOPHAGID Æ. (3 Genera, 5 Species.)

\begin{tabular}{|c|c|c|c|c|c|}
\hline \multirow[b]{2}{*}{$\begin{array}{l}\text { NEOTROPICAL } \\
\text { SUB-REGIONS. }\end{array}$} & \multicolumn{4}{|c|}{ Gejeral Distribution. } & \multirow[b]{2}{*}{$\begin{array}{l}\text { Australian } \\
\text { Sub-REGIONS. }\end{array}$} \\
\hline & $\begin{array}{c}\text { NEARCTIC } \\
\text { SUB-REGIONS. }\end{array}$ & $\begin{array}{l}\text { PalaAarctic } \\
\text { Sub-REGIONS. }\end{array}$ & $\begin{array}{c}\text { ETHIOPIAN } \\
\text { SUB-REGIONS. }\end{array}$ & $\begin{array}{l}\text { ORIENTAL } \\
\text { SUB-KEGIONS. }\end{array}$ & \\
\hline $1.2 .3-$ & $---\cdots$ & ---- & --- & ---- & ---- \\
\hline
\end{tabular}

The true ant-eaters are strictly confined to the wooded portions of the Neotropical region, ranging from Honduras to Paraguay on the East side of the Andes. The three genera now generally admitted are: Mymmeeophaga (1 sp.), the great ant-eater, Northern Brazil to Paraguay; Tamandua (2 sp.), 4-toed anteaters, Guatemala, Ecuador to Paraguay (Plate XIV. vol. ii. p. 24); Cyclothurus (2 sp.), 2-toed ant-eaters, Honduras and Costa Rica to Brazil.

Extinct Ant-eaters.-The only extinct form of this family seems to be the Glossotherium, found in the caves of Brazil, and the Tertiary deposits of Uruguay. It is said to be allied to Myrmecophaga and Manis.

\section{General Remarks on the Distribution of the Edentata.}

These singular animals are almost confined to South America, where they constitute an important part of the fauna. In Africa, two family types are scantily represented, and one of these extends over all the Oriental region. In Pliocene and PostPliocene times the Edentata were wonderfully developed in South America, many of them being huge animals, rivalling in bulk, the rhinoceros and hippopotamus. As none of these forms resemble those of Africa, while the only European fossil Edentata are of African type, it seems probable that South Africa, like, South America, was a centre of development for this group of mammalia ; and it is in the lighest degree probable that, should extensive fluviatile deposits of Pliocene or Miocene age be discovered in the former country, an extinct fauna, not less strange and grotesque than that of South America, will be brought to 
light. From the fact that so few remains of this order occur in Europe, and those of one family type, and in Miocene deposits only, it seems a fair conclusion, that this represents an incursion of an ancient Ethiopian form into Europe analogous to that which invaded North America from the south during the Post-Pliocene epoch. The extension of the Manididæ, or scaly ant-eaters, over tropical Asia may have occurred at the same, or a somewhat later epoch.

For a summary of the Numerous Edentata of North and South America which belong to extinct families, see vol. i. p. 147.

Order XII.-MARSUPIALIA.

Family 76.-DIDELPHYID Æ. (3 Genera, 22 Species.)

\begin{tabular}{|c|c|c|c|c|c|}
\hline \multicolumn{6}{|c|}{ General Distribution. } \\
\hline $\begin{array}{l}\text { NeOTROPICAL } \\
\text { St:B-REGIONS. }\end{array}$ & $\begin{array}{c}\text { NEARCTIC } \\
\text { SUB-REGIONS. }\end{array}$ & $\begin{array}{l}\text { PALEARCTIC } \\
\text { SUB-REGIONS. }\end{array}$ & $\begin{array}{l}\text { ETHIOPIAN } \\
\text { SUB-REGIONS. }\end{array}$ & $\begin{array}{l}\text { ORIENTAL } \\
\text { SUB-REGIONS. }\end{array}$ & $\begin{array}{l}\text { AUSTRALIAN } \\
\text { SUB-REGIONS. }\end{array}$ \\
\hline $1.2 .3-$ & $1-3-$ & ---- & --- & $-\cdots-$ & ---- \\
\hline
\end{tabular}

The Didelphyidæ, or true opossums, range throughout all the wooded districts of the Neotropical region from the southern boundary of Texas to the River La Plata, and on the west coast to $42^{\circ} \mathrm{S}$. Lat., where a species of Didelphys was obtained by Professor Cunningham. One species only is found in the Nearctic region, extending from Florida to the Hudson River, and west to the Missouri. The species named Didelphys californica inhabits Mexico, and only extends into the southern extremity of California. The species are most numerous in the great forest region of Brazil, and they have been recently found to the west of the Andes near Guayaquil, as well as in Chili. The exact number of species is very doubtful, owing to the difficulty of determining them from dried skins. All but two belong to the genus Didelphys, which has the range above given for the family (Plate XIV., vol. ii. p. 24); Chironectes (1 sp.), the yapock or water opossum, inhabits Guiana and Brazil; Hyracodon (1 sp.), is a small 
rat-like animal discovered by Mr. Fraser in Ecuador, and which may perhaps belong to another family.

Extinct Didelphyidce.-No less than seven species of Didelphys have been found in the caves of Brazil, but none in the older formations. In North America the living species only, has been found in Post-Pliocene deposits. In Europe, however, many species of small opossums, now classed as a distinct genus, Peratherium, have been found in various Tertiary deposits from the Upper Miocene to the Upper Eocene.

We have here a sufficient proof that the American Marsupials have nothing to do with those of Australia, but were derived from Europe, where their ancestors lived during a long series of ages.

FAMily 77.-DASYURIDE. (10 Genera, 30 Species.)

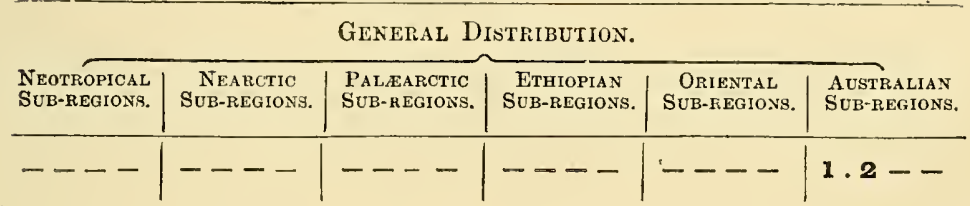

The Dasyuridæ, or native cats, are a group of carnivorous or insectivorous marsupials, ranging from the size of a wolf to that of a mouse. They are found all over Australia and Tasmania, as well as in New Guinea and the adjacent Papuan islands. Several new genera and species have recently been described by Mr. G. Krefft, of the Sydney Museum, and are included in the following enumeration. Phasgogale (3 sp.), New Guinea, West, East, and South Australia; Antechinomys (1 sp.), Interior of South Australia; Antechinus (12 sp.), Aru Islands, all Australia, and Tasmania; Chcetocercus (1 sp.), South Australia; Dactylopsila (1 sp.), Aru Islands and North Australia; Podabrus (5 sp.), West, East, and South Australia, and Tasmania ; Myoictis (1 sp.), Aru Islands; Sarcophilus (1 sp.), Tasmania; Dasyurus (4 sp.), North, East, and South, Australia, and Tasmania; Thylacinus (1 sp.), Tasmania (Plate XI., vol. i. p. 439).

Extinct species of Rasyurus and Thylacinus have been found in the Post-Pliocene deposits of Australia. 
Family 78.-MYRMECobiId $2 . \quad$ (1 Genus, 1 Species.)

\begin{tabular}{|c|c|c|c|c|c|}
\hline \multicolumn{6}{|c|}{ General Distribution. } \\
\hline $\begin{array}{l}\text { NFOTROPICAL } \\
\text { STB-REOIONS. }\end{array}$ & $\begin{array}{c}\text { NEARCTIC } \\
\text { SUB-REGIONS. }\end{array}$ & $\begin{array}{l}\text { PaLAEARCTIC } \\
\text { Sub-ILEGIONS. }\end{array}$ & $\begin{array}{c}\text { ETHIOPIAN } \\
\text { SUB-REGIONS. }\end{array}$ & $\begin{array}{c}\text { ORIENTAL } \\
\text { SUB-REGIONS. }\end{array}$ & $\begin{array}{l}\text { AUSTRALIAN } \\
\text { SUB-REGIONS. }\end{array}$ \\
\hline---- & ---- & ---- & ---- & $--\cdots$ & $-2--$ \\
\hline
\end{tabular}

The only representative of this family is the Myrmecobius fasciatus, or native ant-eater, a small bushy-tailed squirrel-like animal, found in the South and West of Australia.

FAMily 79.-PERAMELID E. (3 Genera, 10 Species.)

\begin{tabular}{|c|c|c|c|c|c|}
\hline \multirow[b]{2}{*}{$\begin{array}{l}\text { NEOTROPICAL } \\
\text { SUB-REGIONS. }\end{array}$} & \multicolumn{4}{|c|}{ General Distribution. } & \multirow[b]{2}{*}{$\begin{array}{l}\text { Australian } \\
\text { Sub-REgIons }\end{array}$} \\
\hline & $\begin{array}{c}\text { NEARCTIG } \\
\text { SUB-REGIONS. }\end{array}$ & $\begin{array}{l}\text { PALEARCTIC } \\
\text { SUB-HEGIONS. }\end{array}$ & $\begin{array}{l}\text { ETHIOPIAN } \\
\text { SUB-REGIOLS. }\end{array}$ & $\begin{array}{l}\text { ORIENTAL } \\
\text { SUB-hEGIONS. }\end{array}$ & \\
\hline---- & $--\cdots$ & $-\cdots-$ & $--\cdots-$ & ---- & $1.2--$ \\
\hline
\end{tabular}

The Peramelidæ, or bandicoots, are small insectivorous Marsupials, liaving something of the form of the kangaroos. They range over the whole of Australia and Tasmania, as well as the Papuan Islands. The genus Pcrameles (8 sp.), has the range of the family, one species being found in New Guinea and the Aru Islands (Plate XI., vol. i. p. 440); Peragalea (1 sp.), inhabits West Australia only; and Choeropus (1 sp.), a beautiful little animal with something of the appearance of a mouse-deer, is found in both South, East, and West Australia.

FAMIIY 80.-MACROPODIDE. (10 Genera, 56 Species.)

\begin{tabular}{|c|c|c|c|c|c|}
\hline \multicolumn{6}{|c|}{ Gexeral Distribution. } \\
\hline $\begin{array}{l}\text { NEOTROPICAL } \\
\text { SitB-REGIONS. }\end{array}$ & $\begin{array}{c}\text { NEARCTIC } \\
\text { SUB-REGLONS. }\end{array}$ & $\begin{array}{l}\text { PaLAARCTIC } \\
\text { SUB-REGIONS. }\end{array}$ & $\begin{array}{c}\text { ETHIOPIIN } \\
\text { SUB-REGIONS. }\end{array}$ & $\begin{array}{l}\text { ORIFNTAL } \\
\text { SUE-REGIONS. }\end{array}$ & $\begin{array}{l}\text { AUSTRALIAN } \\
\text { SUB-REGIONS. }\end{array}$ \\
\hline$\cdot--\cdots$ & --- & ---- & ---- & ---- & $1.3--$ \\
\hline
\end{tabular}


The well-known Kangaroos are the most largely developed family of Marsupials, and they appear to be the form best adapted for the present conditions of life in Australia, over every part of which they range. One genus of true terrestrial kangaroos (Dorcopsis), inhabits the Papuan Islands, as do also the curious tree kangaroos (Dendrolagus) which, without much apparent modification of form, are able to climb trees and feed upon the foliage. The genera, as established by Mr. Waterhouse, are as follows: Macropus (4 sp.), West, South, and East Australia, and Tasmania (Plate XII., vol. i. p. 441); Osphranter (5 sp.), all Australia; Halmaturus (18 sp.), all Australia and Tasmania; Petrogale (7 sp.), all Australia; Dendrolagus (2 sp.), New Guinea (Plate X., vol. i. p. 414); Dorcopsis (2 sp.) Aru and Mysol Islands, and New Guinea; Onychogalca (3 sp.), Central Australia; Lagorchestes (5 sp.), North, West, and South Australia ; Bettongia (6 sp.), West, South, and East, Australia, and Tasmania; Hypsiprymnus (4 sp.), West and East Australia, and Tasmania.

Extinct Macropodida.-Many species of the genera Macropus and Hypsiprymmus lave been found in the cave-deposits and other Post-Tertiary strata of Australia. Among the extinct genera are Protemnodon and Sthenurus, which are more allied to the tree-kangaroos of New Guinea than to living Australian species; the gigantic Diprotodon, a kangaroo nearly as large as an elephant; and Nototherium, of smaller size.

\section{FAnily 81.--PHALANGISTID Æ. (8 Genera, 27 Species.)}

\begin{tabular}{|c|c|c|c|c|c|}
\hline \multicolumn{6}{|c|}{ General Distribution. } \\
\hline $\begin{array}{l}\text { NEOTROPICAL } \\
\text { SUB-REGIONS. }\end{array}$ & $\begin{array}{c}\text { NEARCTiC } \\
\text { SUB-REGIONS. }\end{array}$ & $\begin{array}{l}\text { PALAARCTIC } \\
\text { SUB-REGIONS. }\end{array}$ & $\begin{array}{c}\text { ETHIOPIIN } \\
\text { SUB-REGIONS. }\end{array}$ & $\begin{array}{c}\text { ORIENTAL } \\
\text { SUB-KEGIONS. }\end{array}$ & $\begin{array}{l}\text { AUSTRALIAN } \\
\text { SUB-REGIONS. }\end{array}$ \\
\hline--- & $--\cdots-$ & $-\rightarrow-\cdots$ & --- & ---- & $1 \cdot 2--$ \\
\hline
\end{tabular}

The Phalangistidæ, or phalangers, are one of the most varied and interesting groups of Marsupials, being modified in a variety of ways for an arboreal life. We have the clumsy-looking tail-less koala, or native sloth; the prehensile-tailed opossum-like phalangers; the beautiful fying oppossums, so closely resembling 
in form the flying squirrels of North America and India, but often no larger than a mouse; the beautiful dormouse-like Dromicio, one species of which is only 21 inches long or less than the harvest-mouse; and the little Tarsipes, a true honeysucker with an extensile tongue, and of the size of a mouse. These extreme modifications and specializations within the range of a single family, are sufficient to indicate the great antiquity of the Australian fauna; and they render it almost certain that the region it occupied was once much more extensive, so as to supply the variety of conditions and the struggle between competing forms of life, which would be required to develop so many curiously modified forms, of which we now probably see only a remnant.

The Phalangistidie not only range over all Australia and Tasmania, but over the whole of the Austro-Malayan sub-region from New Guinea to the Moluccas and Celebes. The distribution of the genera is as follows:-Phascolarctos (1 sp.), the koala, East Australia; Phalangista (5 sp.), East, South, and West Australia, and Tasmania; Cuscus (8 sp.), woolly phalangers, New Guinea, North Australia, Timor, Moluccas and Celebes; Petaurista (1 sp.) large flying phalanger, East Australia ; Belideus (5 sp.), flying opossums, South, East, and North Australia, New Guiana and Moluccas; Acrobata (1 sp.), pigmy flying opossum, South and East Australia; Dromicia (5 sp.), dormouse-phalangers, West and East Australia, and Tasmania; Tarsipcs (1 sp.), West Australia.

Thylacoleo, a large extinct marsupial of doubtful affinities, seems to be somewhat intermediate between this family and the kangaroos. Professor Owen considered it to be carnivorous, and able to prey upon the huge Diprotodon, while Professor Flower and Mr. Gerard Krefft, believe that it was herbivorous.

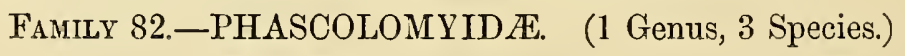

\begin{tabular}{|c|c|c|c|c|c|}
\hline \multicolumn{6}{|c|}{ General Distribution. } \\
\hline $\begin{array}{l}\text { NEOTROPICAL } \\
\text { St:B-REGIONS. }\end{array}$ & $\begin{array}{c}\text { NEARCTIO } \\
\text { SuB-REGIONS. }\end{array}$ & $\begin{array}{l}\text { PaLmarctic } \\
\text { Sub-REgrons. }\end{array}$ & $\begin{array}{c}\text { ETHIOPIAN } \\
\text { SUB-REGIONS. }\end{array}$ & $\begin{array}{c}\text { ORIENTAL } \\
\text { SUB-REGIONS. }\end{array}$ & $\begin{array}{l}\text { AUSTRALIAN } \\
\text { SUB-REGIONS. }\end{array}$ \\
\hline---- & ---- & --- & ---- & $\cdots---$ & $-3--$ \\
\hline
\end{tabular}


'The Wombats are tail-less, terrestrial, burrowing animals, about the size of a badger, but feeding on roots and grass. 'They inhabit South Australia and Tasmania (Plate XI. vol. i. p. 439).

An extinct wombat, as large as a tapir, has been found in the Australian Pliocene deposits.

General Remarks on the Distribution of Marsupialia.

We have here the most remarkable case, of an extensive and highly varied order being confined to one very limited area on the earth's surface, the only exception being the opossums in America. It has been already shown that these are comparatively recent immigrants, which have survived in that country long after they disappeared in Europe. As, however, no other form but that of the Didelphyidæ occurs there during the Tertiary period, we must suppose that it was at a far more remote epoch that the ancestral forms of all the other Marsupials entered Australia; and the curious little mammals of the Oolite and Trias, offer valuable indications as to the time when this really took place.

A notice of these extinct marsupials of the secondary period will be found at vol. i. p. 159.

Order XIII.-MONOTREMATA.

FAMILY 83.--ORNITHORHYNCHIDÆ. (1 Genus, 1 Species.)

\begin{tabular}{|c|c|c|c|c|c|}
\hline \multicolumn{6}{|c|}{ General Distribution. } \\
\hline $\begin{array}{l}\text { NFOTROPICAL } \\
\text { St'B-REGIONG. }\end{array}$ & $\begin{array}{c}\text { NEARCTIC } \\
\text { SUB-REGIONS. }\end{array}$ & $\begin{array}{l}\text { PaLiearctic } \\
\text { Sub-regions. }\end{array}$ & $\begin{array}{c}\text { ETHIOPIAN } \\
\text { SUB-REGIONS. }\end{array}$ & $\begin{array}{c}\text { ORIENTAL } \\
\text { SUB-REGIONS. }\end{array}$ & $\begin{array}{l}\text { AUSTRALian } \\
\text { SUE-REGTONS. }\end{array}$ \\
\hline--- & $\ldots-\cdots$ & $-\ldots-$ & ---- & $-\cdots$ & $-2--$ \\
\hline
\end{tabular}

The Ornithorhynchus, or duck-billed Platypus, one of the most remarkable and isolated of existing mammalia, is found in East and South Australia, and Tasmania. 
Family 84.-ECHIDNID E. (1 Genus, 2 Species.)

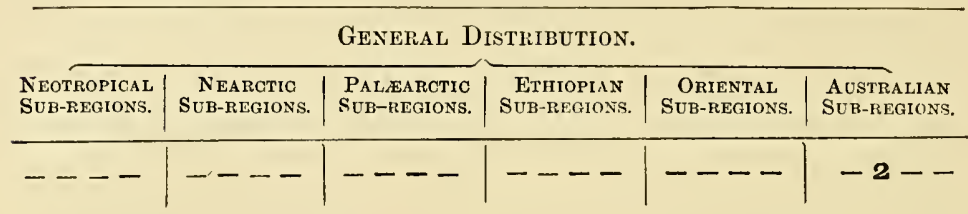

The Echidna, or Australian Hedgehog, although quite as remarkable in internal structure as the Ornithorhynchus, is not so peculiar in external appearance, having very much the aspect of a hedgehog or spiny armadillo. The two species of this genus are very closely allied; one inhabits East and South Australia, the other Tasmania.

Extinct Echidnidce.-Remains of a very large fossil species of Echidna have lately (1868) been discovered at Darling Downs in Australia.

Remark on the Distribution of the Monotremata.

This order is the lowest and must anomalous of the mammalia, and nothing resembling it has been found among the very numerous extinct animals discorered in any other part of the world than Australia. 


\section{CHAPTER XVIII.}

THE DISTRIBUTION OF THE FAMILIES AND GENERA OF BIRDS.

Order I.-PASSERES.

FaMily 1.-TURDID $\mathbb{E} . \quad$ (21 Genera, 205 Species.)

\begin{tabular}{|c|c|c|c|c|c|}
\hline \multicolumn{6}{|c|}{ Gexeral Distribution. } \\
\hline $\begin{array}{l}\text { NEOTROPICAL } \\
\text { SUB-REGIONS. }\end{array}$ & $\begin{array}{c}\text { NEARCTIC } \\
\text { SUB-REGIONS. }\end{array}$ & $\begin{array}{l}\text { PALAARCTIC } \\
\text { SUB-HEGIONS. }\end{array}$ & $\begin{array}{c}\text { ETHIOPIAN } \\
\text { SUB-REGIONS. }\end{array}$ & $\begin{array}{c}\text { ORIENTAL } \\
\text { SUB-REGIONS. }\end{array}$ & $\begin{array}{l}\text { AOSTRALIAN } \\
\text { SUB-REGIONS. }\end{array}$ \\
\hline $1 \cdot 2 \cdot 3 \cdot 4$ & 1.2 .3 .4 & 1.2 .3 .4 & 1.2 .3 .4 & 1.3 .34 & $1.2 .3-$ \\
\hline
\end{tabular}

The extensive and familiar group of Thrushes ranges over every region and sub-region, except New Zealand. It abounds most in the North Temperate regions, and has its least development in the Australian region. Thrushes are among the most perfectly organized of birds, and it is to this cause, perhaps, as well as to their omnivorous diet, that they have been enabled to establish themselves on a number of remote islands. Peculiar species of true thrush are found in Norfolk Island, and in the small Lord Howes' Island nearer Australia; the Island of St. Thomas in the Gulf of Guinea has a peculiar species; while the Mid-Atlantic island Tristan d'Acunha,-one of the most remote and isolated spots on the globe,- - has a peculiarly modified form of thrush. Several of the smaller West Indian Islands have also peculiar species or genera of thrushes.

The family is of somewlat uncertain extent, blending insensibly with the warblers (Sylviidæ) as well as with the. Indian bulbuls 
(Pyenonotidie), while one genus, usually placed in it (Myiophonus) seems to agree better with Enicurus among the Cinclidie. The genera here admitted into the thrush family are the following, the numbers prefixed to some of the genera indicating their position in Gray's Hand List of the Genera and Species of Birds :-

(143) Brachypteryx (8 sp.), Nepaul to Java and Ceylon (this may belong to the Timaliidæ); Turdus (100 sp.) has the range of the whole family, abounding in the Palearctic, Oriental and Neotropical regions, while it is less plentiful in the Nearctic and Ethiopian, and very scarce in the Australian; $\left({ }^{934}\right)$ Orcocincla (11 sp.), Palæarctic and Oriental regions, Australia and Tasmania; ( ${ }^{942}$ ) Rhodinocichla (1 sp.), Venezuela; $\left({ }^{946}\right)$ Mclanoptila (1 sp.), Honduras ; $\left({ }^{917}{ }^{948}\right.$ ) Cutharus (10 sp.) Mexico to Equador ; (949 950) Maryarops (4 sp.), Hayti and Porto Rico to St. Lucia. ( ${ }^{551}$ ) Ncsccichla (1 sp.), Tristan d'Acunha; ( ${ }^{952}$ ) Geocichla (8 sp.), India to Formosa and Celebes, Timor and North Australia; (954 955) Monticola (8 sp.), Central Europe to South Africa and to China, Philippine Islands, Gilolo and Java; $\left({ }^{956}\right)$ Oroccetes (3 sp.), Himalayas and N. China; Zoothera (3 sp.) Himalayas, Aracan, Java, and Lombok ; Minus (20 sp.) Canada to Patagonia, West Indies and Galapagos ; $\left({ }^{962}\right)$ Oreoscoptes (1 sp.), Rocky Mountains and Mexico; ( $\left.{ }^{963}\right)$ Melanotis (2 sp.), Soutl Mexico and Guatemala; ${ }^{\left({ }^{6 t}\right)}$ Galcoscoptes (1 sp.), Canada and Eastern United States to Cuba and Panama; ( $\left.{ }^{965}{ }^{966}\right)$ Mimocichla (5 sp.), Greater Antilles; ( ${ }^{967}{ }^{968}$ ) Harporhynchus (7 sp.), North America, from the great lakes to Mexico; Cinclocerthic (3 sp.), Lesser Antilles; ( ${ }^{970}$ ) Rhamphocinclis (1 sp.), Lesser Antilles; Chcetops (3 sp.), South Africa; Cossypha = Bessonornis (15 sp.) Ethiopian region and Palestine.

\section{Fanily 2.-SYLVIIDÆ. (74 Genera, 640 Species.)}

\begin{tabular}{|c|c|c|c|c|c|}
\hline \multicolumn{6}{|c|}{ General Distribution. } \\
\hline $\begin{array}{l}\text { NEOTROPICAL } \\
\text { SUB-REGIONS. }\end{array}$ & $\begin{array}{c}\text { NEARCTIC } \\
\text { SUb-REGIONS. }\end{array}$ & $\begin{array}{l}\text { PAL-FarCTIC } \\
\text { SUB-hEGIONS. }\end{array}$ & $\begin{array}{c}\text { ETHIOPIAN } \\
\text { SUB-REGIONS. }\end{array}$ & $\begin{array}{c}\text { ORIENTAL } \\
\text { SUB-hEGIONS. }\end{array}$ & $\begin{array}{l}\text { AUStralian } \\
\text { Sub-Regions. }\end{array}$ \\
\hline$-2.3 \cdot 4$ & $1.2 .3 \cdot 4$ & 1.2 .3 .4 & $1.2 \cdot 3 \cdot 4$ & 1.2 .3 .4 & $1.2 .3 \cdot 4$ \\
\hline
\end{tabular}


This immense family, comprising all the birds usually known as "warblers," is, as here constituted, of almost universal distribution. Yet it is so numerous and preponderant over the whole Eastern Hemisphere, that it may be well termed on Old-TVorld group; only two undonbted genera with very few species belonging to the Nearctic region, while two or three others whose position is somewhat doubtful, are found in California and the Neotropical region.

Canon Tristram, who has paid great attention to this difficult group, has kindly communicated to me a MSS. arrangement of the genera and species, which, with a very few additions and alterations, I implicitly follow. He divides the Sylviidæ into seven sub-families, as follows :

1. Drymœcinæ (15 genera $194 \mathrm{sp}$.$) , confined to the Old World$ and Australia, and especially abundant in the three Tropical regions. 2. Calamoherpinæ (11 genera, 75 sp.), has the same general distribution as the last, but is scarce in the Australian and abundant in the Palæarctic region ; 3. Phylloscopinæ (11 genera, $139 \mathrm{sp}$.), has the same distribution as the entire family, but is most abundant in the Oriental and Palæarctic regions. 4. Sylviinæ (6 genera, 33 sp.), most abundant in the Palæarctic region, very scarce in the Australian and Oriental regions, absent from America. 5. Ruticillinæ (10 genera, $50 \mathrm{sp}$.); entirely absent from America and Australia; abounds in the Oriental and Palæarctic regions. 6. Saxicolinæ (12 genera, $126 \mathrm{sp.}$ ), absent from America (except the extreme north-west), abundant in the Oriental region and moderately so in the Palæarctic, Ethiopian, and Australian. 7. Accentorinæ (6 genera, $21 \mathrm{sp}$.), absent from the Ethiopian region and South America, most abundant in Australia, one small genus (Sialia), in North America.

The distribution of the several genera arranged under these sub-families, is as follows:

1. Drymcenne- $\left({ }^{736}\right)$ Orthotomus (13 sp.), all the Oriental region; ( $\left.{ }^{737}\right)$ Prinic (11 sp.), all the Oriental region; (738 740742 ${ }^{746}$ ) Drymaca (83 sp.), Ethiopian and Oriental regions, most abundant in the former; ( 743 to 745 and 749 to 752 ) Cisticola (32 sp.), Ethiopian and Oriental regions, with South Europe; China FOL. II. 
and Australia; ( ${ }^{741}$ ) Suya (5 sp.), Nepal to South China and Formosa; ( ${ }^{773}$ ) Sphenceacus (7 sp.), Australia, New Zealand, and Chatham Island, with one species (?) in South Africa; (770 772) Mcgalurus (4 sp.), Central India to Java and Timor; (774 775) Poodytes (2 sp.), Australia; ( ${ }^{766}$ ) Amytis (3 sp.), Australia ; ( ${ }^{768}$ ) Sphenura (4 sp.), Australia ; ( $\left.{ }^{764}\right)$ Malurus (16 sp.), Australia and Tasmania; ( ${ }^{762}{ }^{763}$ ) Chthonicola (3 sp.), Australia ; ( ${ }^{761}$ ) Calamanthus (2 sp.), Australia and Tasmania; ( ${ }^{759}$ ) Camaroptera (5 sp.), Africa and Fernando Po; $\left({ }^{753}\right)$ Apalis (1 sp.), South Africa.

2. Calamoherpin e.-(777 to 781 and sp. ${ }^{2968}$ ) Acrocephalus (35 sp.), Palæarctic, Ethiopian, continental part of Oriental region, Moluccas, Caroline Islands, and Australia ; (782 818 ) Dumeticola (4 sp.), Nepal to East Thibet, Central Asia, high regions; ( ${ }^{783} 790$ ) Potamodus (3 sp.), Central and South Europe, and East Thibet; (789 and sp. 2969) Lusciniola (1 sp.), South Europe; (791 792) Locustella (8 sp.), Palæarctic region to Central India and China; $\left({ }^{739}\right)$ Horites (5 sp.), Nepal to North-west China and Formosa; (784 - ${ }^{786}$ ) Bradyptetus = Cettic (10 sp.), South Europe, Palestine, and South Africa; ( (477 $^{748}$ ) Catriscus (3 sp.), Tropical and South Africa; Bernieria (2 sp.), and ( $\left.{ }^{756}\right)$ Ellisia (3 sp.), Madagascar; ( ${ }^{832}$ a) Mystacornis (1 sp.), Madagascar; $\left({ }^{787}\right)$ Calamodus (2 sp.), Europe and Palestine; ( $\left.{ }^{734}\right)$ Tatare (2 sp.) Samoa to Marquesas Islands.

3. Phylloscopin ${ }^{1}{ }^{1}$ - Phylloscopus (18 sp.), all Palæarctic and Oriental regions to Batchian; ( ${ }^{757} 7588^{820}$ ) Eremomela (16 sp.), Tropical and South Africa; $\left({ }^{754}\right)$ Eroessa (1 sp.), Madagascar ; ${ }^{1} H y$ polais (12 sp.), Palæarctic region, all India, Timor, North and South Africa; ( ${ }^{815} 816819$ ) Abrornis (26 sp.), Oriental region; $\left({ }^{814}\right)$ Reguloides (4 sp.), Palæarctic and continental Oriental regions; ${ }^{\left({ }^{82}\right)}$ Sericornis (7 sp.), Australia and Tasmania (823 824 1451) Acanthiza (14 sp.), Australia and New Caledonia ; ${ }^{821}$ ) Regulus (7 sp.), all Palæarctic and Nearctic regions and south to Guatemala; ${ }^{\left({ }^{80}\right)}$ Polioptila (13 sp.), Paraguay to New Mexico; ${ }^{825}$ ) Gerygone (22 sp.), Australia, Papuan and Timor groups, New Zealand and Norfolk Island.

1 The species of the genera Phylloscopus and Hypolais are so mixed up in the Hand List, that Mr. Tristram has furnished me with the following 
4. Srlvina - $\left({ }^{93}\right)$ Aedon (9 sp.), Spain and Palestine, to East and South Africa; $\left({ }^{858}\right)$ Drymodes (2 sp.), Australia; ${ }^{800}$ Pyrophthalma (2 sp.), South Europe and Palestine; ( $\left.{ }^{801}\right)$ Melizophilus (3 sp.), South-west Europe and North-east Africa; ( ${ }^{802804}$ ) Sylvia $=$ Alsecus (8 sp.), Palæaretic region to India and Ceylon, and North-east Africa; (806 ${ }^{809}$ ) Curruca (7 sp.), Central and South Europe, Madeira, Palestine, Central India, North-east Africa, and South Africa.

5. Ruticillinæ.-( $\left.{ }^{827}\right)$ Luscinice (2 sp.), West Asia, Europe, North Africa; $\left({ }^{839}\right.$ ) Cyanecula (3 sp.), Europe, North-east Africa, India, Ceylon, and China; $\left({ }^{810}\right)$ Calliope (2 sp.), North Asia, Himalayas, Central India, and China; (838) Erithacus (3 sp.), Europe, North-east Africa, Japan, and North China; ( 828830837 ) Ruticilla (20 sp.), Palæarctic and Oriental regions to Senegal and Abyssinia, and east to Timor; abounds in Himalayas; ${ }^{829}$ ) Chcemarrhornis (1 sp.), Himalayas; ( ${ }^{831} 832{ }^{834}$ ) Larvivora (10 sp.), Oriental region and Japan; ( $\left.{ }^{833}\right)$ Notodela (3 sp.), Himalayas, Pegu, Formosa, Java; ( ${ }^{835}$ ) Tarsiger (2 sp.), Nepal; ( ${ }^{841}$ ) Grandala (1 sp.), High Himalayas of Nepal.

6. SAXICOLINж.-( ${ }^{975}$ ) Copsychus (7 sp.), all Oriental region and Madagascar; ${ }^{976}$ ) Kittacincla (5 sp.), Oriental region to

enumeration of the species which in his view properly belong to them, by the numbers in that work :-

$\begin{array}{ll}\text { Phylloscopus. } & \text { Hypolais. } \\ 3032 & 3026 \\ 3033 & 3028 \\ 3048=3038 & 3029 \\ 3039 & 3054=3031=3036 \\ 3063=3047=3054=3061 & 3042 \\ 3048 & 3043 \\ 3049 & 304 \\ 3050 & 3062=3047 \\ 3051 & 3046=2932 \\ 3052 & 3035 \\ 3053 & 2976 \\ 3056=3081 & \\ 3057 & \\ 3059 & \\ 3060 & \end{array}$


Ceylon, Andaman Islands, Formosa, and Borneo ; (794- 799) Thamnobia (10 sp.), Ethiopian region and India to foot of Himalayas; ${ }^{977}$ ) Gcrvasic (2 sp.), Madagascar and Seychelle Islands ; ( ${ }^{845}{ }^{847}$ ) Dromolcea (18 sp.), Africa to South Europe, Palestine, Northwest India, and North China ; $\left({ }^{842843846}\right.$ ) Saxicola (36 sp.), Africa, North-west India, whole Palæarctic region, migrating to Alaska and Greenland; ( ${ }^{848}{ }^{849}$ ) Oreicola (5 sp.), Timor, Lombok, and Burmah; ( ${ }^{844}$ ) Cercomela (6 sp.), North-east Africa to North-west India; ( ${ }^{850}$ ) Pratincola (15 sp.), Europe, Ethiopian, and Oriental regions to Celebes and Timor; ( $\left.{ }^{917}\right)$ Ephthianura (3 sp.), Australia; $\left({ }^{851}-{ }^{856}\right)$ Pctroca (17 sp.), Australian region, Papua to New Zealand, Chatham and Auckiand Islands, and Samoa ; ( ${ }^{857}$ Miro (2 sp.), New Zealand (doubtfully placed here).

7. Accentorins.-(771) Cinclorhamphus (2 sp.), Australia; ${ }^{860}$ ) Origma (1 sp.), East Australia; $\left({ }^{850}\right)$ Sialia (8 sp.), United States to Guatemala; ( $\left.{ }^{801}\right)$ Accentor (12 sp.), Palæarctic region to Himalayas and North-west China; ( $\left.{ }^{703}\right)$ Orthonyx (4 sp.), East Australia and New Zealand (doubtfully placed here).

The following two genera, which have been usually classed as Ampelidæ, are arranged by Messris. Sclater and Salvin in the Sylviidæ :-

(1362) Myiadestes ( $8 \mathrm{sp}$. ), Peru and Polivia, along the Andes to Mexico and California, also the Antilles; ( ${ }^{1364}$ ) Cichlopsis (1 sp.), Brazil.

Famiry 3.-TIMALIID $\approx . \quad$ (35 Genera, 240 Species.)

\begin{tabular}{|c|c|c|c|c|c|}
\hline \multicolumn{6}{|c|}{ General Distribution. } \\
\hline $\begin{array}{l}\text { NEOTROPICAL } \\
\text { SUB-REAIONS. }\end{array}$ & $\begin{array}{c}\text { NEarctic } \\
\text { Sub-REoIONS. }\end{array}$ & $\begin{array}{l}\text { PALFARCTIC } \\
\text { SUB-REGIONS. }\end{array}$ & $\begin{array}{c}\text { ETHYopian } \\
\text { SUB-REGIONS. }\end{array}$ & $\begin{array}{c}\text { ORIENTAL } \\
\text { SUB-REGIONS. }\end{array}$ & $\begin{array}{l}\text { AUSTRALIAN } \\
\text { SUB-REGIONS. }\end{array}$ \\
\hline-- & --- & $-2-4$ & $1.2 \cdot 3.4$ & 1.2 .3 .4 & $1 \cdot 2-4$ \\
\hline
\end{tabular}

The Timaliidx, or babbling thrushes, are a group of small strong-legged active birds, mostly of dull colours, which are especially characteristic of the Oriental region, in every part of which they abound, while they are much less plentiful in 
Australia and Africa. The Indo-Chinese sub-region is the head quarters of the family, whence it diminishes rapidly in all directions in variety of both generic and specific forms. Viscount Walden has kindly assisted me in the determination of the limits of this family, as to which there is still much difference of opinion. The distribution of the genera here admitted is as follows; and as the genera are widely scattered in the Hand List, reference numbers are prefixed in every case.

$(1023$ - 10261008$)$ Pomatorhinus (27 sp.), the whole Oriental region (excluding Philippines), Australia and New Guinea; (1027) Pterohinus (3 sp.), North China, East Thibet; (1029 1030) Malacocircus (9 sp.), Continental India and Ceylon, Arabia, Nubia; (1031) Chatarrhoca (5 sp.), Abyssinia, Palestine, India, Nepal, Burmalı, and Philippines; ( $\left.{ }^{1038}\right)$ Layardia (3 sp.), India and Ceylon; ( ${ }^{1033}$ ) Acanthoptila (1 sp.), Nepal ; ( ${ }^{1034}$ ) Cinclosoma (4 sp.), Australia and Tasmania: (1035 $\left.{ }^{1030}\right)$ Crateropus (18 sp.), all Africa, Persia; (1037) Hypergerus (1 sp.), West Africa : ${ }^{1038}$ ) Cichladusa (3 sp.), Tropical Africa; ( ${ }^{1030}$ ) Garrulax (23 sp.), the Oriental region (excluding Philippines); $\left({ }^{1040}\right)$ Janthocincla (10 sp.), Nepal, to East Thibet, Sumatra, Formosa ; (1041 1042) Gampsorhynchus (2) sp.), Himalayas ; $\left({ }^{1049}\right)$ Grammatoptila (1 sp.) North India ; (1043 ${ }^{1045}$ ) Trochalopteron (24 sp.), all India to China and Formosa ; ( $\left.{ }^{1046}\right)$ Actinodura (4 sp.), Nepal to Burmah, 3,000 - 10,000 feet; ( ${ }^{1047}$ ) Pellorneum (4 sp.), Nepal to Ceylon, Tenasserim ; (1158 1159) Timalia (12 sp.), Malaya; ${ }^{1}\left({ }^{1160}\right)$ Dumetia (2 sp.), Central India and Ceylon; (1162) Stachyris (6 sp.), Nepal to Assam, Sumatra, Formosa; (1164) Pyctorhis (3 sp.), India to Ceylon and Burmah; (1165) Mixornis (8 sp.), Himalayas and Malaya ; (1167) Malacopteron (3 sp.), Malaya; $\left({ }^{1168}{ }^{1169}\right)$ Alcippe (15 sp.), Ceylon and South India, Himalayas to Aracan, Malaya, Formosa, New Guinea; (1170) Macronus (2 sp.), Malaya; ( ${ }^{1171}$ ) Cacopitta (5 sp.), Malaya; ( ${ }^{1172}$ ) Trichastoma (11 sp.), Nepal, Burmah, Malaya, Celebes; $\left({ }^{1173}\right)$ Napothera (6 sp.), Malaya; (1174) Drymocataphus (8 sp.), Burmah, Malaya, Ceylon,

1 The term "Malaya" is used here to include the Malay Peninsula, Sumatra, Borneo, and Java, a district to which many species and genera are confined. "Malay Archipelago" will be used to include both Indo-Malaya and Austro-Malaya. 
Timor; (1175) Turdinus (5 sp.), Khasia Hills, Nalacca, 'Tenasserim ; ( $\left.{ }^{1176}\right)$ Trichixos (1 sp.), Borneo, Malacca ; (1004) Sibia (6 sp.), Nepal to Assam, Tenasserim, Formosa; (1177 1178) Alethe (4 sp.), West Africa; (1178 a) Oxylabes (1 sp.), Madagascar; (1050) Psophodes (2 sp.), South, East, and West Australia; (1048) Turnagra (3 sp.), New Zealand.

Family 4.-PANURID E. (4 Genera, 13 Species).

\begin{tabular}{|c|c|c|c|c|c|}
\hline \multicolumn{6}{|c|}{ General Distribution. } \\
\hline $\begin{array}{l}\text { NEOTROPICAL } \\
\text { SUB-REGIONS. }\end{array}$ & $\begin{array}{c}\text { NEARCTIC } \\
\text { SUB-REGIONS. }\end{array}$ & $\begin{array}{l}\text { PALEARCTIC } \\
\text { SUB-REGroirs. }\end{array}$ & $\begin{array}{l}\text { ETHIOPIAN } \\
\text { SUB-REGIONS. }\end{array}$ & $\begin{array}{l}\text { ORIENTAL } \\
\text { SUB-REGIONS. }\end{array}$ & $\begin{array}{l}\text { AUSTRALIAN } \\
\text { SUB-REGIONS. }\end{array}$ \\
\hline--- & $-\cdots-$ & $1.2-4$ & ---- & $--3-$ & ---- \\
\hline
\end{tabular}

This new family is adopted, at the suggestion of Professor Newton, to include some peculiar groups of Himalayan birds whose position has usually been among the Timaliidæ or the Paridæ, but which are now found to be allied to our Bearded Reedling. The supposed affinity of this bird for the Tits has been long known to be erroneous, and the family Panuridæ was formed for its reception (Yarrell's Britist Birds, 4th edit. p. 512). The genera having hitherto been widely scattered in systematic works, are referred to by the numbers of Mr. G. R. Gray's Hand List.

(1901) Paradoxornis (3 sp.), Himalayas and East Thibet; (1904) Conostoma (1 sp.), Himalayas and East Thibet; ( $\left.{ }^{876}\right)$ Suthora (8 sp ), Himalayas to North-west China, Formosa; ( ${ }^{877}$ ) Chlenasicus (1 sp.), Darjeeling; ( $\left.{ }^{887}\right)$ Panurus (1 sp.), Central and Southern Europe; ( ${ }^{1902}$ ) Heteromorpha (1 sp.), Nepal, 10,000 feet altitude; Cholornis (1 sp.), Moupin in Eașt Thibet.

FAMILY 5.-CINCLID ÆE. (4 Genera, 27 Species.)

\begin{tabular}{|c|c|c|c|c|c|}
\hline \multicolumn{6}{|c|}{ General Distribution. } \\
\hline $\begin{array}{l}\text { NEUTROPICAL } \\
\text { SUB-REGIONS. }\end{array}$ & $\begin{array}{c}\text { NeArCtic } \\
\text { SUB-REGIONS. }\end{array}$ & $\begin{array}{l}\text { PALAEARCTIC } \\
\text { SUB-KEGIONS. }\end{array}$ & $\begin{array}{l}\text { ETHIOPIAN } \\
\text { SUB-REGIONS. }\end{array}$ & $\begin{array}{c}\text { ORIENTAL } \\
\text { SUB-REGIONS. }\end{array}$ & $\begin{array}{l}\text { AUSTRALIAN } \\
\text { SUB-REGIONS. }\end{array}$ \\
\hline$-2 \cdot 3-$ & $-2-4$ & 1.2 .3 .4 & $---? 4$ & 1.2 .3 .4 & $1-\cdots$ \\
\hline
\end{tabular}


The Cinclidæe consist of a number of more or less thrush-like ground-birds, of which the most remarkable are the Dippers, forming the genus Cinclus. These are curiously distributed, from the Palæarctic region as a centre, to the alpine districts of North and South America; while the three genera which are here included as somewhat allied to Cinclus, all inhabit the Oriental region. The genera which I class in this family are the following :-

$\left({ }^{978}\right)$ Cinclus (9 sp.), Palæarctic region to West China and Fornosa, Rocky Mountains, and Mexico in North America, and southward to the Andes of Peru ; ${ }^{916}$ ) Enicurus (9 sp.), Himalayas to Tava and West China; ( ${ }^{979}$ ) Eupetes (4 sp.), Indo-Malay sub-region and New Guinea; ${ }^{971}$ ) Myiophonus (5 sp.), Himalayas to Ceylon, Java, South China, and Formosa.

(981) Mesites (1 sp.), Madagascar, is an anomalous bird placed with Eupetes by Mr. G. R. Gray, but of very uncertain affinities.

$$
\text { FAMLY 6.-TROGLODYTID } \nRightarrow . \quad(17 \text { Genera, } 94 \text { Species.) }
$$

\begin{tabular}{|c|c|c|c|c|c|}
\hline \multicolumn{6}{|c|}{ General Distribution. } \\
\hline $\begin{array}{l}\text { INEOTROPICAL } \\
\text { SUB-REGIONS. }\end{array}$ & $\begin{array}{c}\text { NeArCtic } \\
\text { SUB-REgions. }\end{array}$ & $\begin{array}{l}\text { PaLAfarctic } \\
\text { SUb-hegions. }\end{array}$ & $\begin{array}{l}\text { ETHIOPIAN } \\
\text { SUB-REGIONS. }\end{array}$ & $\begin{array}{c}\text { ORIENTAL } \\
\text { SuB-REGIONS. }\end{array}$ & $\begin{array}{l}\text { AUSTRALIan } \\
\text { SUB-REGIONS. }\end{array}$ \\
\hline 1.2 .3 .4 & $1 \cdot 2 \cdot 3 \cdot 4$ & $1.2 \cdot 3 \cdot 4$ & $1.2 .3-$ & $--3 \cdot 4$ & $1-\ldots$ \\
\hline
\end{tabular}

The Troglodytidæ, or Wrens, are small birds, rather abundant and varied in the Neotropical region, with a few species scattered through the Nearetic, Palæaretic, and parts of the Oriental regions, and one doubtful genus in Africa. The constitution of the family is by no means well determined. The South American genera are taken from Messrs. Sclater and Salvin's Nomenclator Avium Neotropicalium.

Tesia (2 sp.), Eastern Himalayas; Pnoepyga (6 sp.), Himalayas to East Thibet, Tava; (716 and 723$)$ Troglodytes (15 sp.), Neotropical, Nearetic, and Palæarctic regions to the Higher Himalayas ; $\left({ }^{697}\right)$ Rimator (1 sp.), Darjeeling; Thryothorus (13 sp.), South Brazil to Mexico, Martinique, and Nearctic region; Thryophilus (13 sp.), Brazil to Mexico, and North-west America; Cistothorus 
(5 sp.), Patagonia to Greenland; Uropsila (1 sp.), Mexico; Donacolius (2 sp.), Tropical America; Campylorhynchus (18 sp.), Brazil, and Bolivia to Mexico and the Gila valley; Cyphorlinus (5 sp.), Equatorial South America to Costa Rica; Microcerculus (5 sp.), Brazil and Peru to Mexico; Henicorhina (2 sp.), Peru and Guiana to Costa Iica; Salpinctes (1 sp.), High Plains of Rocky Mountains; Cathcrpes (1. sp.), Mexico and Rio Grande; Cimnicertlia (2 sp.), Ecuador and Columbia. ( ${ }^{360}$ ) Sylvietta (2 sp.), Tropical and South Africa,-is placed in this family by Mr. Tristram.

FAMily 7.-CHAMÆID床. (1 Genus, 1 Species).

\begin{tabular}{|c|c|c|c|c|c|}
\hline \multicolumn{6}{|c|}{ General Distribution. } \\
\hline $\begin{array}{l}\text { NEOTROPICAL } \\
\text { SUB-REGIONS. }\end{array}$ & $\begin{array}{c}\text { NEaRCTIC } \\
\text { Sub-REOIONS. }\end{array}$ & $\begin{array}{l}\text { PaLfanctic } \\
\text { SUb-hEGIONS. }\end{array}$ & $\begin{array}{l}\text { EthIopian } \\
\text { SUB-REGIONS. }\end{array}$ & $\begin{array}{l}\text { ORIENTAL } \\
\text { SUB-EEGIONS. }\end{array}$ & $\begin{array}{l}\text { AUSTRALIAN } \\
\text { Suz-PEgIONS. }\end{array}$ \\
\hline$-\cdots-$ & $1---$ & ---- & ---- & ---- & --- \\
\hline
\end{tabular}

The bird which forms the genus Chanced inhabits California; and though allied to the wrens it has certain peculiarities of structure which, in the opinion of many ornithologists, require that it should be placed in a distinct family.

Fanily 8.-CERTHIIDE. (6 Genera, 18 Species.)

\begin{tabular}{|c|c|c|c|c|c|}
\hline \multicolumn{6}{|c|}{ General Distribution. } \\
\hline $\begin{array}{l}\text { NEOTROPICAL } \\
\text { StiB-REGIONS. }\end{array}$ & $\begin{array}{c}\text { NEARGTIC } \\
\text { SUB-REGIONS. }\end{array}$ & $\begin{array}{l}\text { PALEARCTIC } \\
\text { SUB-REQIONS. }\end{array}$ & $\begin{array}{c}\text { ETHIOPIAN } \\
\text { SUB-REGIONS. }\end{array}$ & $\begin{array}{l}\text { ORIENTAL } \\
\text { SUB-REGIONS. }\end{array}$ & $\begin{array}{l}\text { AUSTRALIAN } \\
\text { SUB-BEGIONS. }\end{array}$ \\
\hline---- & $--3-$ & 1.2 .3 .4 & --- & $2-3.4$ & I. 2 \\
\hline
\end{tabular}

The Certhiidæ, or Creepers, form a small family whose species are thinly scattered over North America from Mexico, the Palæarctic region, parts of the Oriental region, and Australia, where they are somewhat more abundant. The distribution of the genera is as follows:

Certhic (6 sp.), Nearctic and Palæarctic regions, Nepal, and Sikhim; Salpornis (1 sp.), Central India; Tichodroma (1 sp.), South 
Europe to Abyssinia, Nepal, and North China; Rhabdornis (1 sp.), Philippine Islands; Climacteris (8 sp.), Australia and New Guinea.

Famil 9.-SITTID无. (6 Genera, 31 Species.)

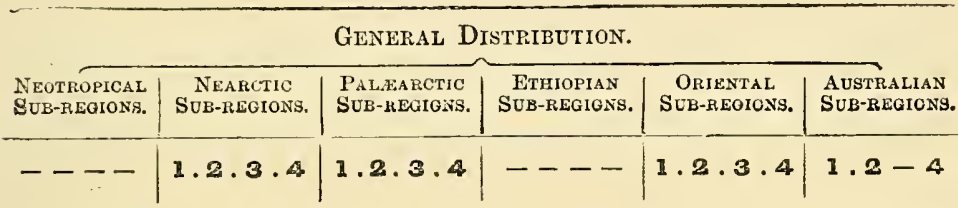

The Sittidæ, or Nuthatches, are another small family of treecreeping birds, whose distribution is very similar to that of the Certhiidæ, but with a more uniform range over the Oriental region, and extending to New Zealand and Madagascar. The genera are as follows:-

Sitta (17 sp.), Palæarctic and Nearctic regions to South India and Mexico; Dendrophila (2 sp.), Ceylon and India to Burmah and Malaya; Hypherpes (1 sp.), Madagascar; Sittella (6 sp.), Australia and New Guinea. Acanthisitta (1 sp.) and Xenicus (4 sp.), New Zealand, are placed with some doubt in this family.

Fanily 10.-PARII) E. (14 Genera, 92 Species.)

\begin{tabular}{|c|c|c|c|c|c|}
\hline \multicolumn{6}{|c|}{ Gexeral Distribution. } \\
\hline $\begin{array}{l}\text { NEOTROPICAL } \\
\text { SUB-REOIONS. }\end{array}$ & $\begin{array}{c}\text { NEARCTIC } \\
\text { SUB-REaIONS. }\end{array}$ & $\begin{array}{l}\text { Paliaarctic } \\
\text { SUB-REgIONS. }\end{array}$ & $\begin{array}{c}\text { ETHIOPIAN } \\
\text { SUB-REGIONS. }\end{array}$ & $\begin{array}{c}\text { Oriental } \\
\text { SUb-REgIONS. }\end{array}$ & $\begin{array}{l}\text { AUSTRALIAN } \\
\text { SUB-REGIONS. }\end{array}$ \\
\hline$--3-$ & $1.2 \cdot 3 \cdot 4$ & $1.2 .3 \cdot 4$ & $1.2 .3-$ & $1.2 \cdot 3 \cdot 4$ & $-2-4$ \\
\hline
\end{tabular}

The Paridx, or Tits, are very abundant in the Nearctic and Palæarctic regions ; many fine species are found in the Himalayas, but they are sparingly scattered through the Etliopian, Oriental, and Australian regions. The genera usually admitted into this family are the following, but the position of some of them, especially of the Australian forms, is doubtful.

$(864-867870$ ) Parus (46 sp.), North America, from Mexico, Palæarctic, and Oriental regions, Tropical and South Africa; 
(868 ${ }^{869}$ ) Lophophanes (10 sp.), Europe, the Higher Himalayas to Sikhim, North America to Mexico ; Acrciulc = Orites (6 sp.), Palæarctic region; Melanochlora (2 sp.), Nepal to Sumatra; Psaltria (1 sp.), Java; Psaltriparus (3 sp.), Guatemala to California, and Rocky Mountains; Auriparus (1 sp.), Rio Grande; (881 882) Parisoma (5 sp.), Tropical and South Africa; (883 884) Agithalus (6 sp.), South-east Europe to South Africa; ( ${ }^{885}{ }^{889}$ ) AEgithaliscus (6 sp.), Afghanistan and Himalayas to Amoy; Cephalopyrus (1 sp.), North-west Himalayas ; Sylviparus (1 sp.), Himalayas and Central India; Certhiparus (2 sp.), New Zealard; $\left({ }^{879}{ }^{880}\right)$ Sphenostoma (2 sp.), East and South Australia.

\section{Family 11.-LIOTRICHID $\approx . \quad$ (11 Genera, 35 Species.)}

\begin{tabular}{|c|c|c|c|c|c|}
\hline $\begin{array}{l}\text { NEOTROPICAL } \\
\text { SUB-REGIONS. }\end{array}$ & $\begin{array}{c}\text { NEARCTIC } \\
\text { SUB-REGIONS. }\end{array}$ & $\begin{array}{l}\text { PALAARCTIC } \\
\text { SUB-REGIONS. }\end{array}$ & $\begin{array}{l}\text { ETHIOPIAN } \\
\text { SUB-REGIONS. }\end{array}$ & $\begin{array}{c}\text { ORIENTAL } \\
\text { SUB-REGIONS. }\end{array}$ & $\begin{array}{l}\text { AOSTRALIAN } \\
\text { SUB-REGions. }\end{array}$ \\
\hline---- & ---- & ---- & ---- & $--3 \cdot 4$ & ---- \\
\hline
\end{tabular}

The Liotrichidæ, or Hill-Tits, are small, active, delicatelycoloured birds, almost confined to the Himalayas and their extension eastward to China. They are now generally admitted to form a distinct family. The genera are distributed as follows :

${ }^{(1146)}$ Liothrix (3 sp.), Himalayas to China ; Siva (3 sp.), Himalayas; Minla ( 4 sp.), Himalayas and East Thibet; Proparus (7 sp.), Nepal to East Thibet and Aracan ; (1153) Pteruthius (6 sp.), Himalayas to Java and West China; (1155) Cutice (2 sp.), Nepal; ${ }^{(1019)}$ Yuhina (3 sp.), High Himalayas and Moupin; ( ${ }^{\text {iv20 }) ~ I x u l u s ~}$ (3 sp.), Himalayas to Tenasserim; ( ${ }^{1021}$ ) Myzornis (1 sp.), Darjeeling.

Famly 12.-PHYLLORNITHID AE. (3 Genera, 14 Species.)

\begin{tabular}{|c|c|c|c|c|c|}
\hline \multicolumn{6}{|c|}{ Gexeral Distribution. } \\
\hline $\begin{array}{l}\text { NEOTROPICAL } \\
\text { SUB-REGIONS. }\end{array}$ & $\begin{array}{c}\text { NEARCTIC } \\
\text { SUB-REGIONS. }\end{array}$ & $\begin{array}{l}\text { PaLAaARCTIC } \\
\text { SUB-REgIONS. }\end{array}$ & $\begin{array}{c}\text { ETHIOPINN } \\
\text { SUB-REGIONS. }\end{array}$ & $\begin{array}{c}\text { ORIENTAL } \\
\text { SUB-REGIONS. }\end{array}$ & $\begin{array}{l}\text { AUSTRALIAN } \\
\text { SUB-REGIONS. }\end{array}$ \\
\hline---- & --- & $-\cdots$ & ---- & 1.2 .3 .4 & $---\cdots$ \\
\hline
\end{tabular}


The Phyllornithidæ, or "Green Bulbuls," are a small group of fruit-eating birds, strictly confined to the Oriental region, and ranging over the whole of it, with the one exception of the Philippine Islands. The genera are :-

(1022) Phyllornis (12 sp.), India to Java, Ceylon, and Hainan; ${ }^{(1166)}$ Iora (4 sp.), the whole Oriental region; (1163) Erpornis (2 sp.), Himalayas, Hainan, and Formosa.

FAMILY 13.-PYCNONOTIDE. (9 Genera, 139 Species.)

\begin{tabular}{|c|c|c|c|c|c|}
\hline \multicolumn{6}{|c|}{ General Distribution. } \\
\hline $\begin{array}{l}\text { NEOTROPICAL } \\
\text { SUB-REGIONS. }\end{array}$ & $\begin{array}{c}\text { NEARCTIC } \\
\text { SUB-REGIONS. }\end{array}$ & $\begin{array}{l}\text { PaLdearctic } \\
\text { Sub-REgions. }\end{array}$ & $\begin{array}{c}\text { Ethiopian } \\
\text { Sub-REgIONS. }\end{array}$ & $\begin{array}{c}\text { ORIENTAL } \\
\text { SUB-REGIONS. }\end{array}$ & $\begin{array}{l}\text { AUSTRALian } \\
\text { Sub-REgIONS. }\end{array}$ \\
\hline--- & ---- & $-2-4$ & $1.2 .3 \cdot 4$ & $1.2 .3 \cdot 4$ & $2--$ \\
\hline
\end{tabular}

The Pycnonotidæ, Bulbuls, or fruit-thrushes, are highly characteristic of the Oriental region, in every part of which they abound; less plentiful in the Ethiopian region, and extending to Palestine and Japan in the Palæarctic, and to the Moluccas in the Australian region, but absent from the intervening island of Celebes. The genera are:-

Microscelis (6 sp.), Burmah, the Indo-Malay Islands, and Japan; Pycnonotus (52 sp., in many sub-genera), Palestine to South Africa, the whole Oriental region, China and Japan; Alcurus (1 sp.), Himalayas; Hemixus (2 sp.), Nepal, Bootan, Hainan; Phyllastrephus (4 sp.), West and South Africa; Hypsipetes (20 sp.), the whole Oriental region, Madagascar and the Mascarene Islands; Tylas (1 sp.), Madagascar ; Criniger (30 sp.), the whole Oriental region (excluding Philippines), West and South Africa, Moluccas; Ixonotus (7 sp.), West Africa; (1015 1017) Setornis (3 sp.), Malacca, Sumatra, and Borneo; Iole (4 sp.), Aracan and Malaya; Andropadus (9 sp.), Tropical Africa; (1157) Lioptilus (1 sp.), South Africa. 
Family 14.-ORIOLID \&. (5 Genera, 40 Species.)

\begin{tabular}{|c|c|c|c|c|c|}
\hline \multicolumn{6}{|c|}{ General Distribution. } \\
\hline $\begin{array}{l}\text { NEOTROPICAL } \\
\text { SUR-REGIONS. }\end{array}$ & $\begin{array}{l}\text { NEARCTIC } \\
\text { SUB-REOIONS. }\end{array}$ & $\begin{array}{l}\text { PALLeARCTIC } \\
\text { SUB-hEGIONS. }\end{array}$ & $\begin{array}{c}\text { ETHYOPIAN } \\
\text { SUB-REgIONS. }\end{array}$ & $\begin{array}{l}\text { ORIENTAL } \\
\text { SUB-EEGIONS. }\end{array}$ & $\begin{array}{l}\text { Augtralias: } \\
\text { Sub-regions. }\end{array}$ \\
\hline--- & ---- & $1.2-4$ & 1.2 .3 .4 & 1.2 .3 .4 & $1.2--$ \\
\hline
\end{tabular}

The Orioles, or Golden Thrushes, are a small group characteristic of the Oriental and Ethiopian regions, migrating into the western Palæarctic region, and with some of the less typical forms in Australia. The genera are :-

Oriolus (24 sp.), Central Europe, throughout Africa, and the whole Oriental region, northward to Pekin, and eastward to Flores; ( ${ }^{1073}$ ) Analcipus (3 sp.), Himalayas, Formosa, Java and Borneo; Mimeta (9 sp.), the Moluccas and Australia; Sphecothercs (3 sp.), Timor and Australia. Artamia (1 sp.), Madagascar;perhaps belongs to the next family or to Laniidæ.

FAMILY 15.-CAMPEPHAGID Æ. (3 Genera, 100 Species.)

\begin{tabular}{|c|c|c|c|c|c|}
\hline \multicolumn{6}{|c|}{ General Distribution. } \\
\hline $\begin{array}{l}\text { NEOTROPICAL } \\
\text { StiB-REOIONS. }\end{array}$ & $\begin{array}{l}\text { NEARCTIC } \\
\text { SUB-BEGIONS. }\end{array}$ & $\begin{array}{l}\text { Palearctic } \\
\text { Sub-lieolons. }\end{array}$ & $\begin{array}{c}\text { ETHIOPIAN } \\
\text { SUB-REGIONS. }\end{array}$ & $\begin{array}{c}\text { ORIENTAL } \\
\text { SuB-REGIONS. }\end{array}$ & $\begin{array}{l}\text { AUSTRALIAN } \\
\text { SUB-REGIONS. }\end{array}$ \\
\hline--- & --- & --- & 1.2 .3 .4 & 1.2 .3 .4 & $1.2 .3-$ \\
\hline
\end{tabular}

The Campephagidæ, or Cuckoo Shrikes, (Campephaginæ of the Hand List, with the addition of Cochoa) are most abundant in the Australian region (especially in the Austro-Malay subregion) less so in the Oriental, and still less in the Ethiopian region. The genera, for the most part as adopted by Dr. Hartlaub, are as follows:-

Pericrocotus (22 sp.), the whole Oriental region, extending north to Pekin, and east to Lombok; $\left({ }^{1242}-1244\right)$ Lanicterus (4 sp.), West and South Africa; (1245 1246) Graucalus (25 sp.), the whole Oriental region, and eastward to Austro-Malaya, the New 
Hebrides, and Tasmania; Artamides (1 sp.), Celebes; Pteropodocys (1 sp.), Australia ; (1248 12501257 1258) Campcphaga (16 sp.), Austro-Malaya, and New Caledonia, Philippines, the Ethiopian region; Volvocirora (8 sp.) the Oriental regisn (excluding Philippines); Lalage (18 sp.), the whole Malay Archipelago to New Caledonia and Australia; Symmorphus (1 sp.), Australia; Oxynotus (2 sp.), Mauritius and Bourbon; (1204) Cochoa (3 sp.), Himalayas, Java. The position of this last genus is doubtful. Jerdon puts it in the Liotrichidre; Sundeval in the Sturnidi; Bonaparte in the Dicruridie; Professor Newton suggests the Pycnonotidæ; but it seems on the whole best placed here.

FAmir 16.-DICRURID $\approx$. (6 Genera, 58 Species.)

\begin{tabular}{|c|c|c|c|c|c|}
\hline \multicolumn{6}{|c|}{ General Distribution. } \\
\hline $\begin{array}{l}\text { Neotropical } \\
\text { Stib-REgioxs. }\end{array}$ & $\begin{array}{c}\text { NeARCTIC } \\
\text { SUB-REGIONS. }\end{array}$ & $\begin{array}{l}\text { PalXarctic } \\
\text { Sub-reggions. }\end{array}$ & $\begin{array}{c}\text { ETHIOPIAN } \\
\text { SU B-REGIONS. }\end{array}$ & $\begin{array}{l}\text { ORIENTAL } \\
\text { SUB-RIGIONS. }\end{array}$ & $\begin{array}{l}\text { Australian } \\
\text { SUB-REgIONS. }\end{array}$ \\
\hline$-\cdots-$ & $-\cdots-$ & $---\cdots$ & 1.2 .3 .4 & $1.2 \cdot 3 \cdot 4$ & $1.2-$ \\
\hline
\end{tabular}

The Dicruridæ, or Drongo Shrikes (Dicruridre of the Hand List, omitting the genus Aelconornis), have nearly the same distribution as the last family, with which they are sometimes united. They are, however, most abundant and varied in the Oriental region, much less so both in the Australian and Ethiopian regions. The distribution of the genera is as follows :-

Dicrurus ( $46 \mathrm{sp}$., in several sub-genera), has the range of the whole family, extending east to New Ireland, and one species in Australia ; Chcetorhynchus (1. sp.), New Guinea; Bhringa (2 sp.), Himalayas to Borneo (Plate IX. vol. i. p. 339); Chitic (2 sp.) Himalayas eastward to North China; Chaptia (3 sp.), all India to Malacea and Formosa; Irena (4 sp.), Central India, Assam, and Burmah to Borneo and the Philippine Islands. This last genus is placed by Jerdon among the Pycnonotidx, but seems to come most naturally here or in the last family. 


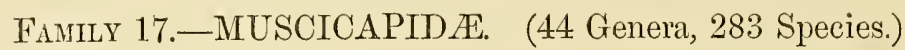

\begin{tabular}{|c|c|c|c|c|c|}
\hline \multicolumn{6}{|c|}{ General Distribution. } \\
\hline $\begin{array}{l}\text { NEOTROPICAL } \\
\text { SUB-REGIONS. }\end{array}$ & $\begin{array}{c}\text { NEARCTIC } \\
\text { SUb-REGIONS. }\end{array}$ & $\begin{array}{l}\text { PaL-earctic } \\
\text { Sub-hegions. }\end{array}$ & $\begin{array}{l}\text { ETHIOPIAN } \\
\text { SUB-REGIONS. }\end{array}$ & $\begin{array}{l}\text { ORIENTAL } \\
\text { SUB-REGIONS. }\end{array}$ & $\begin{array}{l}\text { Australian } \\
\text { Sub-REgions. }\end{array}$ \\
\hline---- & ---- & 1.2 .3 .4 & 1. 2.3 .4 & $1.2 \cdot 3 \cdot 4$ & 1.2 .3 .4 \\
\hline
\end{tabular}

The Muscicapidæ, or Flycatchers (Muscicapinæ and Myiagrinæ of the Hand List, omitting Cochoa and including Pogonocichla) form an extensive family of usually small-sized and often brightcoloured birds, very abundant in the warmer regions of the Old World and Australia, but becoming scarce as we approach the temperate and colder regions. They are wholly absent from North and South America. The genera, many of which are not well defined, are distributed as follows:-

Peltops (1 sp.), Papuan Islands ; Monarcha (28 sp.), Moluccas to the Carolines and Marquesas Islauds, Australia and Tasmania; Leucophantes (1 sp.), New Guinea; Butalis (4 sp.), Ethiopian and Palæarctic regions, Moluccas and Formosa ; Muscicapa (12 sp.), Europe and Africa; Muscicapula (6 sp.), India to Western China; Alseonax (1 sp.), South Africa; Erythrosterna (7 sp.), Europe to China and Java; Newtonia (1 sp.), Madagascar ; Xanthopygia (2 sp.), Japan, China, Malacca; Hemipus (1 sp.), Iṇdia and Ceylon; Pycnophrys (1 sp.), Java; Hyliota (2 sp.), West Africa; Erythrocercus (2 sp.), West Africa and Zambesi; Microce (6 sp.), Australia, Timor, and Papuan Islands ; Artomyices (2 sp.), West Africa; Pseudobias (1 sp.), Madagascar; Hemichelidon (3 sp.), the Oriental region and North China; Smithornis (2 sp.), West and South Africa; Mcgabias (1 sp.), West Africa; Cassinia (2 sp.), West Africa; Bias, (1 sp.),Tropical Africa; Niltava (3 sp.), Himalayas to West China; Cyornis (16 sp.), the whole Oriental region; Cyanoptila (1 sp.), Japan, China, Hainan; Eumyias (7 sp.), India to South China, Ceylon, and Sumatra; (1213 and 1216) Siphia (8 sp.), North India, Formosa, Timor; Anthipes (1 sp.), Nepal; Seisura (5 sp.), Australia and Austro- 
Malaya (excluding Celebes); (Myiagra (16 sp.), Australia and Moluccas to Caroline and Samoa Islands: Hypothymis (2 sp.), Oriental region and Celebes; Elminica (2 sp.), Tropical Africa; Muscitodus (2 sp.), Fiji Islands ; Machocrirhynchus (4 sp.), Papuan Islands and North Australia; Platystira (12 sp.), Tropical and South Africa; Rhipidura (45 sp.), the Oriental and Australian regions to the Samoa Islands and Tasmania ; Chelidorynx (1 sp.), North India; Myialestes (2 sp.), India to Ceylon, China, Java and Celebes ; Tchitrea (26 sp.), the entire Ethiopian and Oriental regions, and to North China and Japan; Philentoma (4 sp.) Malacca, Sumatra, Borneo, and Philippine Islands; Todopsis (6 sp.), Papuan Islands; ( ${ }^{836}$ ) Pogonocichla (1 sp.), South Africa; $\left({ }^{1061}\right.$ - 1063)Bradyornis (7 sp.), Tropical and South Africa; $\left({ }^{1460}\right)$ Chasiempis (2 sp.), Sandwich Islands.

FAMILY 18.-PACHYCEPHALID E. (5 Genera, 62 Species.)

\begin{tabular}{|c|c|c|c|c|c|}
\hline \multicolumn{6}{|c|}{ General Distribution. } \\
\hline $\begin{array}{l}\text { NEOTROPICAL } \\
\text { SUB-REGIONS. }\end{array}$ & $\begin{array}{c}\text { NEARCTIC } \\
\text { SUB-REGIONS. }\end{array}$ & $\begin{array}{l}\text { PaLfeARCTIC } \\
\text { SUB-REGIONS. }\end{array}$ & $\begin{array}{c}\text { ETHIOPIAN } \\
\text { SUB-REGIONS. }\end{array}$ & $\begin{array}{l}\text { ORIENTAL } \\
\text { SUB-REGIONS. }\end{array}$ & $\begin{array}{l}\text { AUSTRALIAN } \\
\text { SUB-REGIONS. }\end{array}$ \\
\hline$-\cdots-$ & $-\cdots-$ & $--\cdots$ & ---4 & --3.4 & $1.2 .3-$ \\
\hline
\end{tabular}

The Pachycephalidæ, or Thick-headed Shrikes (Pachycephalinæ of the Hand List omitting Colluricincla, Cracticus, and Pardalotus) are almost confined to the Australian region, a single species extending to Java and Aracan, and another (?) to Madagascar. The family has generally been united with the Laniidæ, but most modern ornithologists consider it to be distinct. The distribution of the genera is as follows :-

Oreaca (1 sp.), Australia; Falcunculus (2 sp.), Australia; Pachycephala (44 sp.), Sula Islands (east of Celebes) to the Fiji Islands, and Australia; Hylocharis (4 sp.), Timor, Celebes, IndoMalaya, and Aracan; Calicalicus (1 sp.), Madagascar; Eopsaltria (14 sp.), Australia, New Caledonia, and the New Hebrides; $A r$ tamia (4 sp.), Madagascar,-may belong to this family, or to Lanijdæ, Oriolidæ, or Artamidæ, according to different authors. 
Family 19.-LANIID Æ. (19 Genera, 145 Species.)

\begin{tabular}{|c|c|c|c|c|c|}
\hline \multicolumn{6}{|c|}{ General Distribution. } \\
\hline $\begin{array}{l}\text { NEOTROPICAL } \\
\text { SUB-REGIONS. }\end{array}$ & $\begin{array}{c}\text { NEARCTIC } \\
\text { Sub-REGIONS. }\end{array}$ & $\begin{array}{l}\text { Palainctic } \\
\text { SUb-regions. }\end{array}$ & $\begin{array}{l}\text { ETHIOPIAN } \\
\text { SUB-REGIONS. }\end{array}$ & $\begin{array}{c}\text { ORIENTAL } \\
\text { SUb-REGIONS. }\end{array}$ & $\begin{array}{l}\text { AUSTRALIAan } \\
\text { SUB-REGIONS. }\end{array}$ \\
\hline--- & 1.2 .3 .4 & 1.2 .3 .4 & 1.2 .3 .4 & .1 .2 .3 .4 & $1.2 .3-$ \\
\hline
\end{tabular}

The Laniidæ, or Shrikes (Laniinæ and Malaconotinæ of the Hand List, and including Colluricincla), are most abundant and varied in Africa, less plenififul in the Oriental, Australian, and Palæarctic regions, with a few species in the Nearctic region as far as Mexico. The constitution of the family is, however, somewhat uncertain. The genera here admitted are :-

Colluricincla (4 sp.), Anstralia and Tasmania; Rectes (18 sp.), Papuan Islands, North Australia, to Pelew and Fiji Islands; (1462 - 1464146614701471 - ${ }^{1473}$ ) Lanius (50 sp.), the whole Nearctic, Palæarctic, Ethiopian, and Oriental regions, one species reaching Timor, none in Madagascar; Laniellus (1 sp.), Java; Hypocolius (1 sp.), Abyssinia and Upper Nile; Corvinella (1 sp.), South and West Africa; Urolestes (1 sp.), South and East Africa; Tephrodornis (4 sp.), Oriental region to Hainan and Java; Hypodes (1 sp.), West Africa; Fraseria (2 sp.), West Africa; Cuphopterus (1 sp.), Princes' Island; Nilaus (1 sp.), South and West Africa; Prionops (9 sp.), Tropical A frica; Eurocephalus (2 sp.), North, East, and South Africa, and Abyssinia; Chaunonotus (1 sp.), West Africa; Vanga (4 sp.), Madagascar (Plate VI. vol. i. p. 278); Laniarius (36 sp.), the whole Ethiopian region; Tclephonus (10 sp.), all Africa and South Europe; Meristes (2 sp.), Tropical and Sonth Africa; Nicator (1 sp.), East Africa.

FAMILY 20.-CORVID 2 E. (24 Genera, 190 Species.)

\begin{tabular}{|c|c|c|c|c|c|}
\hline \multicolumn{6}{|c|}{ General Distribution. } \\
\hline $\begin{array}{l}\text { Nromopical } \\
\text { StiB-REOIONS. }\end{array}$ & $\begin{array}{c}\text { NEARCTIC } \\
\text { SUB-REGIONS. }\end{array}$ & $\begin{array}{c}\text { PaLearctic } \\
\text { SUB-IEEGIONSS }\end{array}$ & $\begin{array}{c}\text { ETHIOPIAN } \\
\text { SU'B-REGIONS. }\end{array}$ & $\begin{array}{c}\text { ORIENTAL } \\
\text { SUB-REGIONS. }\end{array}$ & $\begin{array}{l}\text { AUSTRALIAN } \\
\text { SUB-REGIONS. }\end{array}$ \\
\hline $1.2 .3 \cdot 4$ & 1.2 .3 .4 & $1 \cdot 2 \cdot 3 \cdot 4$ & 1.2 .3 .4 & $1.2 .3 \cdot 4$ & $1 \cdot 2 \cdot 3-$ \\
\hline
\end{tabular}


The Corvida, or Crows, Jays, \&c., form an extensive and somewhat heterogeneous group, some members of which inhabit almost every part of the globe, although none of the genera are cosmcpolitan. The true crows are found everywhere but in South America; the magpies, choughs, and nutcrackers are characteristic of the Palæarctic region; the jays are Palæarctic, Oriental, and American; while the piping crows are peculiarly Australian. The more detailed distribution of the genera is as follows :

Sub-family I. Gymnorhininæ (Piping Crows).-Strcpera (4 sp.), and Gymnorhina (3 sp.), are Australian only; Cracticus (9 sp.), ranges from New Guinea to Tasmania (this is usually put with the Shrikes, but it has more affinity with the preceding genera); Pityriasis (1 sp.), Borneo (an extraordinary bird of very doubtful affinities); Grallina (1 sp.), Australia, is put here by Sundevall,-among Motacillidæ, by Gonld.

Sub-family II. Garrulinæ (Jays).-Platylophus = Lophocitte (4 sp.), Malaya; Garrulus (12 sp.), Palæaretic region, China and Himalayas ; Perisorcus (2 sp.), North of Palæarctic and Nearctic regions; Cyanurus (22 sp.), American, from Bolivia to Canada, most abundant in Central America, but absent from the Antilles; Cyanocorax (15 sp.), La Plata to Mexico; Calocitta (2 sp.), Guatemala and Mexico; Psilorhinus (3 sp.), Costa Rica to Texas; Urocissa (6 sp.), Western Himalayas to China and Formosa; Cissa (3 sp.), South-eastern Himalayas to Tenasserim, Ceylon, Sumatra, and Java.

Sub-family III. Dendrocittinæ (Tree Crows).-Tcmnumus (3 sp.), Cochin China, Malacea to Borneo (not Java); Dendrocitta (9 sp.), the Oriental region to Sumatra, Hainan, and Formosa; Crypsirhina (3 sp.), Pegu, Siam, and Java; Ptilostomus (2 sp.), West, East, and South Africa.

Sub-family IV. Corvinæ (Crows and Magpies). - Nucifraga (4 sp.), Palæarctic region to the Himalayas and North China; Ficicorvus (1 sp.), the Rocky Monntains and California; Gymnokitta (1 sp.), Rocky Mountains and Arizona (Plate XVIII., Vol. II., p. 12S); Pica (9 sp.), Palæarctic -region, Arctic America, and California; Cyanopiea. (3 sp.), Spain, North-east Asia, Japan;

VOL. II. 
Streptocitta (2 sp.), Celebes; Charitomis (1 sp.), Sula Islands; Curus (55 sp.), universally distributed except South America and New Zealand, but found in Guatemala and the Antilles to Porto Rico; reaches the extreme north of Europe and Asia; Gymnocorvus (2 sp.), Papuan Islands; Picathartes (1 sp.), West Africa ; Corvultur (2 sp.), Tropical and Sonth Africa.

Sub-family V. Fregilinæ (Choughs).-Fregitus (3 sp.), mountains and cliffs of Palearetic region from West Europe to the Himalnyas and North China, Abyssinia (Plate I., Vol. I., p. 195); Corcorax (1 sp.), Australia.

Fanily 21.-PARADISEID E. (19 Genera, 34 Species.)

\begin{tabular}{|c|c|c|c|c|c|}
\hline \multicolumn{6}{|c|}{ General Distribution. } \\
\hline $\begin{array}{l}\text { NrotropicaL } \\
\text { StiB-REtions. }\end{array}$ & $\begin{array}{c}\text { NEARCTIC } \\
\text { SUB-REGIONS. }\end{array}$ & $\begin{array}{l}\text { PaLmarctic } \\
\text { Sub-REgions. }\end{array}$ & $\begin{array}{l}\text { ETHIOPIAN } \\
\text { SUB-REGIONS. }\end{array}$ & $\begin{array}{c}\text { ORIENTAL } \\
\text { Sub-regions. }\end{array}$ & $\begin{array}{l}\text { AUSTRALIAN } \\
\text { SUB-REGIONS. }\end{array}$ \\
\hline$--\cdots$ & $-\ldots$ & $-\cdots-$ & $-\cdots-$ & ---- & $1.2-$ \\
\hline
\end{tabular}

The Paradiseidie, or " Birds of Paradise," form one of the most remarkable families of birds, unsurpassed alike for the singularity and the beanty of their plumage. Till recently the family was restricted to about eight species of the more typical Paradise bircls, but in lis splendid monograph of the group, Mr. Elliot has combined together a number of allied forms which had been doubtfully placed in several adjacent farniiies. The various speeies of true Paradise birds, having ornamental plumes developed from different parts of the body, are almost wholly confined to New Guinea and the adjacent Papuan Islands, one species only being found in the Moluccas and one in North Australia; while the less typical Bower-birds, having no such developments of plumage, are most characteristic of the north and east of Australia, with a few species in New Guinea. The distribution of the genera according to Mr. Elliot's monograph is as follows :-

Sub-family I. Paradiseinæ.-Paradisea (4 sp.), Papuan Islands; Manucodia (3 sp.), Papuan Islands and North Australia; Astrapia (1 sp.), New Guinea; Parotia (1 sp.), New Guinea; Lophorhinn (1 sp.), New Guinea; Diphyllodes (3 sp.), Papuan 
Islands ; Xunthomelus (1 sp.), New Guinea; Cicimnums (1 sp.), Papuan Islands; Paradigalla (1 sp.), New Guinea; Semiopter a (1 sp.), Gilolo and Batchian.

Sub-family II. Epimachinæ.-Epimachus (1 sp.), New Guinea; Diepanornis (1 sp.), New Guinea; Selencides (1 sp.), New Guinea (Plate X., Vol. I., p. 414) ; Ptilortic (4 sp.), New Guinea and North Australia:

Sub-family III. Tectonarchinæ (Bower-birds).---Sericulus (1 sp.), Eastern Australia; Ptilonorluynchus (1 sp.), Eastern Australia; Chlamydoderce (4 sp.), North and East Australia; AElurodus (3 sp.), Papuan Islands and East Australia; Amblyornis (1 sp.), New Guinea.

\section{Family 22.-MELIPHAGID E. (23 Genera, 190 Species.)}

\begin{tabular}{|c|c|c|c|c|c|}
\hline $\begin{array}{l}\text { NIOTROPICAL } \\
\text { St'B-REGHONS. }\end{array}$ & $\begin{array}{c}\text { NEARCTIC } \\
\text { SUB-REGIONS. }\end{array}$ & $\begin{array}{l}\text { PAL-EARCTIC } \\
\text { SUB-REGIONS. }\end{array}$ & $\begin{array}{c}\text { ETHIOPIAN } \\
\text { SUB-REGIONS. }\end{array}$ & $\begin{array}{c}\text { ORIENTAL } \\
\text { Sub-REGioNs. }\end{array}$ & $\begin{array}{l}\text { AvSTRALIAN } \\
\text { SUB-REGIONS. }\end{array}$ \\
\hline---- & ---- & ---- & ---- & ---- & 1.2 .3 .4 \\
\hline
\end{tabular}

(As in the Hand List, but omitting Zosterops, and slightly altering the arrangement.)

The extensive group of the Meliphagidæ, or Honey-suckers, is wholly Australian, for the genus Zosterops, which extends into the Oriental and Ethiopian regions, does not naturally belong to it. Several of the genera are confined to Australia, others to New Zealand, while a few range over the whole Australian region. The geuera are distributed as follows:-

Myzomela (is sp.), has the widest range, extending from Celebes to the Samoa Islands, and to Timor and Eastern Australia; Entomophila (4 sp.), Anstralia and New Guinea; Gliciphila (10 sp.), Australia, Timor, New Guinea, and New Caledonia; Acanthorhynchus (2 sp.), Australia and Tasmania; Meliphaga (1 sp.), Australia; Ptilotis (40 sp.), Gilolo and Lombok to Australia and Tasmania, and to the Samoa and Tonga Islands ; Meliornis (5 sp.). Australia and Tasmania; Prosthemadera (1 sp.), Pogonornis (1 sp.), New Zealand; Anthornis (4 sp.), New Zealand and Chatham Islands; Anihockera (4 sp.), Australia and Tasmania; Xan- 
thotis (4 sp.), Papuan Islands and Australia; Leptornis (2 sp.), Samoa Islands and New Caledonia; Philemon = Tropidorhyncus (18 sp.), Moluccas and Lombok to New Guinea, Australia, Tasmania and New Caledonia; Entomiza (2 sp.), Australia; Manorhina (5 sp.), Australia and Tasmania; Euthyphynchus (3 sp.), New Guinea; Melirrhophetes (2 sp.), New Guinea; Melidectcs (1 sp.), New Guinea; Melipotes (1 sp.), New Guinea; Melithreptus (8 sp.), New Guinea, Australia, and Tasmania; ( $\left.{ }^{397}\right)$ Moho (3 sp.), Sandwich Islands; Chotoptila (1 sp.), Sandwich Islands.

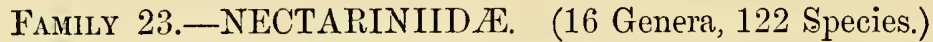

\begin{tabular}{|c|c|c|c|c|c|}
\hline $\begin{array}{l}\text { NLOTROPICAL } \\
\text { SUB-REGHONS. }\end{array}$ & $\begin{array}{c}\text { N EARCTIC } \\
\text { SUB-BEGLONS. }\end{array}$ & $\begin{array}{l}\text { PalaAarctic } \\
\text { SUB-hEGIONS. }\end{array}$ & $\begin{array}{c}\text { ErhIOPIIN } \\
\text { SUB-REGions. }\end{array}$ & $\begin{array}{l}\text { ORIRNTAL } \\
\text { SUB-REGIONS. }\end{array}$ & $\begin{array}{l}\text { Austratians } \\
\text { Sub-riglons. }\end{array}$ \\
\hline--- & ---- & $-2--$ & 1.2 .3 .4 & $1.2 \cdot 3 \cdot 4$ & 1.2 \\
\hline
\end{tabular}

The Nectariniidæ, or Sun-birds, form a rather extensive group of insectivorous honey-suckers, often adorned with brilliant metallic plumage, and bearing a superficial resemblance to the American humming-birds, although not in any way related to them. They abound in the Ethiopian, Oriental, and Australian regious, as far east as New Ireland, and south to Queensland, while one species inhabits the hot Jordan Valley in the Palæarctic region. For the Eastern genera I follow Lord Walden's classification (Ibis, 1870); the African species not having been so carefully studied are mostly placed in one genus. The genera adopted are as follows:-

Promerops (1 sp), South Africa; Nectarinia (60 sp.), the whole Ethiopian region ; Cinnyricinclus (5 sp.), West Africa; Drepanornis (1 sp.), Madagascar ; Arachnecthra (13 sp.), Palestine, all India to Hainan, the Papuan Islands, and North-east Australia ; Atthopyga (15 sp,), Himalayas and Central India to West China, Hainan, Java, and Northern Celebes; Nectarophila ( $5 \mathrm{sp}$.), Central India and Ceylon, Assam and Aracan to Java, Celebes and the Philippines; Chalcostetha (6 sp.), Malay Peninsula to New Guinea; Anthreptes (1 sp.), Siam, Malay Peninsula to 
Sula Islands, and Flores; Cosmeteira (1 sp.), Papuan Islands; Arachnothera (15 sp.), the Orieutal region (excluding Pbilippines) Celebes, Lombok, and Papuan Islands.

Family 24.-DICAID Æ. (5 Genera, 107 Species.)

\begin{tabular}{|c|c|c|c|c|c|}
\hline $\begin{array}{l}\text { NiOTROPICAL } \\
\text { StiB-REGIONS. }\end{array}$ & $\begin{array}{c}\text { NeARCTIC } \\
\text { SUB-REGIONS. }\end{array}$ & $\begin{array}{l}\text { Pal Eanctic } \\
\text { Sub-leEgroxs }\end{array}$ & $\begin{array}{c}\text { ETHIOPIAN } \\
\text { SUB-REGIONS. }\end{array}$ & $\begin{array}{c}\text { ORIFNTaL } \\
\text { Sub-hEgions. }\end{array}$ & $\begin{array}{l}\text { AUSTRALIAN } \\
\text { SUB-REGIOYS. }\end{array}$ \\
\hline$--\cdots$ & ---- & ---4 & 1.2 .3 .4 & 1.2 .3 .4 & 1.2 .3 .4 \\
\hline
\end{tabular}

The Dicæidæ, or Flower-peckers, consist of very snall, gailycoloured birds, rather abundant over the whole Oriental and much of the Australian regions, and one genus extending over the Ethiopian region. The genera here adopted are the following :-

(622) Zosterops (68 sp.), the whole Ethiopian, Oriental, and Australian regions, as far east as the Fiji Islands, and north to Pekin and Japan ; $\left({ }^{400}-{ }^{403}\right)$ Dicceum (25 sp.), the whole Oriental region, except China, with the Australian region as far as the Solomon Islands; ( ${ }^{404}$ ) Pachyglossa (2 sp. ${ }^{1437}{ }^{1442}$ ), Nepal and Northern Celebes ; $\left({ }^{405}\right)$ Piprisoma (2 sp ), Himalayas to Ceylon and Timor; ( $\left.{ }^{1450}\right)$ Pardalotus (10 sp.), Australia and Tasmania; $\left({ }^{407}-{ }^{409}\right)$ Prionochilus (5 sp.), Indo-Malay sub-region and Papuan Islands.

Fanily 25.-DREPANIDID $\mathbb{E} . \quad$ (4 Genera, 8 Species.)

\begin{tabular}{|c|c|c|c|c|c|}
\hline \multicolumn{6}{|c|}{ Gexeral Distribution. } \\
\hline $\begin{array}{l}\text { NEOTROPICAL } \\
\text { SUB-REGIONS. }\end{array}$ & $\begin{array}{c}\text { NEARCTIC } \\
\text { SUB-REGIONS. }\end{array}$ & $\begin{array}{l}\text { PAL-EARCTIC } \\
\text { SUB-HEGIONS. }\end{array}$ & $\begin{array}{c}\text { ETHIOPIAN } \\
\text { SUb-REGIONS. }\end{array}$ & $\begin{array}{l}\text { ORIENTAL } \\
\text { Sub-fiEGIONS. }\end{array}$ & $\begin{array}{l}\text { ATSTRALIAN } \\
\text { SUB-RELIONS. }\end{array}$ \\
\hline---- & --- & $-\cdots--$ & ---- & --- & $--3-$ \\
\hline
\end{tabular}

The Drepanididæ are confined to the Sandwich Islands, and I follow Mr. Sclater's suggestion in bringing together the following genera to form this family :-

Drepanis (3 sp.) ; Hemignathus (3 sp.) ; Loxops (1 sp.) ; Psittirostre (1 sp.). If these are correctly associated, the great 
differences in the bill indicate that they are the remains of a larger and more varied family, once inhabiting more extensive land surfaces in the Pacific.

\section{Famir 26.-COEREBID E. (11 Genera, 55 Species.)}

\begin{tabular}{|c|c|c|c|c|c|}
\hline \multicolumn{6}{|c|}{ Gexeral Distribution. } \\
\hline $\begin{array}{l}\text { NEOTROPICAL } \\
\text { SUB-REgLONS. }\end{array}$ & $\begin{array}{c}N_{\text {EARCTIC }} \\
\text { SUZR-REGIONS. }\end{array}$ & $\begin{array}{l}\text { PaLAarctic } \\
\text { SUB-REGIONS. }\end{array}$ & $\begin{array}{c}\text { ETHIOPIAN } \\
\text { SUB-REGIONS. }\end{array}$ & $\begin{array}{c}\text { ORIENTAL } \\
\text { SUB-REGIONS. }\end{array}$ & $\begin{array}{l}\text { AUstralian } \\
\text { SUb-REGIONS. }\end{array}$ \\
\hline$-2.3 \cdot 4$ & $--3-$ & ---- & ---- & ---- & --- \\
\hline
\end{tabular}

(According to the arrangement of Messrs. Sclater and Salvin.)

The Cœrebidæ, or Sugar-birds, are delicate little birds allied to the preceding families, but with extensile honey-sucking tongues. They are almost wholly confined to the tropical parts of America, only one species of Certhiola ranging so far north as Florida. The following is the distribution of the genera:-

Diglossa (14 sp.), Peru and Bolivia to Guiana and Mexico; Diglossopis (1 sp.), Ecuador to Venezuela; Oreomanes (1 sp.), Ecuador ; Conirostrum (6 sp.), Bolivia to Ecuador and Columbia ; Hemidacnis (1 sp.), Upper Amazon and Columbia; Dacnis (13 sp.), Brazil to Ecuador and Costa Rica ; Certhidea (2 sp.), Galapagos Islands; Chlorophanes (2 sp.), Brazil to Central America and Cuba ; Coereba (4 sp.), Brazil to Mexico; Certhiola (10 sp.), Amazon to Mexico, West Indies, and Florida; Glossoptila (1 sp.), Jamaica.

FAMILY 27.-MNIOTIITIDAE. (18 Genera, 115 Species.)

\begin{tabular}{|c|c|c|c|c|c|}
\hline \multirow[b]{2}{*}{$\begin{array}{l}\text { NeOTropical } \\
\text { SUb-REgIONS. }\end{array}$} & \multicolumn{4}{|c|}{ Gexeral Distribution. } & \multirow{2}{*}{$\begin{array}{l}\text { AUSTRALIAN } \\
\text { SUB-REGIONS. }\end{array}$} \\
\hline & $\begin{array}{c}\aleph_{\text {EARCTIC }} \\
\text { SUB-REGIONS. }\end{array}$ & $\begin{array}{l}\text { PaLAEARCtic } \\
\text { SUB-REgions. }\end{array}$ & $\begin{array}{c}\text { ETHIOPI.IN } \\
\text { SUB-REGIONS. }\end{array}$ & $\begin{array}{c}\text { ORIENTAL } \\
\text { SUB-REGEONS. }\end{array}$ & \\
\hline$-2 \cdot 3 \cdot 4$ & 1.2 .3 .4 & ---- & ---- & ---- & ---- \\
\hline
\end{tabular}

(Messrs. Sclater and Salvin are followed for the Neotropical, Baird and Allen for the Nearctic region.)

The Mniotiltida, or Wood-warblers, are an interesting group of small and elegant birds, allied to the preceding family and to the greenlets, and perhaps also to the warblers and tits of Europe. 
They range orer all North America from Panama to the Arctic regions, but do not extend far beyond the tropic in Southern America. They are almost as abundant in the Nearctic as in the Neotropical region; and considering the favourable conditions of existence in Tropical America, this fact, in comnection with their absence from the South Temperate zone would lead us to suppose that they originated in North Temperate America, and subsequently spread southward into the tropics. This supposition is strengthened by the fact that their metropolis, in the breeding season, is to the north of the United States. The genera adopted by Messrs. Sclater and Salvin are as follows:-

$\left({ }^{918}\right)$ Siurus (4 sp.), Venezuela and West Indies to Eastern States and Canada; Mniotilta (1 sp.), Venezuela, Mexico, and Antilles to the Eastern States; Parula (5 sp.), Brazil to Mexico, and the Eastern States, and Canada; Protonotaria (1 sp.), Antilles to Ohio; Helminthophaga (s sp.), Columbia to Arctic America Helminthcrus (2 sp.), Central America to Eastern States; Pcrissoglossa (1 sp.), Antilles and Eastern States; Dendreeca (33 sp.), Amazon to Antilles, and Arctic Anerica, and south to Chili; Oporomis (2 sp.), Guatemala to Eastern States; Geothlypis (11. sp.), all North America and Brazil ; Myiodioctes (5 sp.), all North America and Columbia ; Betsileuterus (22 sp.), Bolivia and Brazil to Mexico; Sctophaga (15 sp.), Brazil to Canada ; Ergaticus (2 si.), Guatemala and Mexico; Cardellina (1 sp.), Guatemala and Mexico; ( $\left.{ }^{1440}\right)$ Granatellus (3 sp.), Amazon to Mexico ; (1441) Terctristis (2 sp.), Cuba; $\left({ }^{1439}\right)$ Icterice (2 sp.), Costa Rica and United States to Canada.

Family 2S.-VIREONIDE. (7 Genera, 63 Species.)

\begin{tabular}{|c|c|c|c|c|c|}
\hline \multicolumn{6}{|c|}{ GENERAL DISTHIBUtION. } \\
\hline $\begin{array}{l}\text { NEOTROPICAL } \\
\text { SUB-RFGIONS. }\end{array}$ & $\begin{array}{c}\text { NEARCTIC } \\
\text { SUB-REGIONS. }\end{array}$ & $\begin{array}{l}\text { Paldarctic } \\
\text { Sub-hegions. }\end{array}$ & $\begin{array}{c}\text { ETHIOPIAN } \\
\text { SUB-REGIONS. }\end{array}$ & $\begin{array}{c}\text { ORIENTAL } \\
\text { SUB-hEgIONS. }\end{array}$ & $\begin{array}{l}\text { AUSTRALIAN } \\
\text { SUB-RE'GIONS. }\end{array}$ \\
\hline$-2 \cdot 3 \cdot 4$ & $1.2 \cdot 3 \cdot 4$ & ---- & ---- & ---- & --- \\
\hline
\end{tabular}

(Messrs. Sclater and Salvin are followed for the Neotropical genera; Professor Baird and $\mathrm{Mr}$. Allen for those of the Nearctic region.) 
The Vireonidxe, or Greenlets, are a family of small fly-catching birds wholly restricted to the American continent, where they range from Paraguay to Canada. They are allied to the Mniotiltide and perhaps also to the Australian Pachycephalidr. Only two of the genera, with about a dozen species, inhabit the Nearctic region. The distribution of the genera is as follows:-

Vircosylvia (13 sp.), Venezuela to Mexico, the Antilles, the Eastem States and Canada ; Vireo (14 sp.), Central America and the Antilles to Canada; Neochloe (1 sp.), Mexico; Hylophilus (20 sp.), Brazil to Mexico; Laletes (1 sp.), Jamaica; Vireolanius (5 sp.), Amazonia to Mexico; Cychlorhis (9 sp.), Paraguay to Mexico.

Fanily 29.-AMPELID A. (4 Genera, 9 Species.)

\begin{tabular}{|c|c|c|c|c|c|}
\hline \multicolumn{6}{|c|}{ Gexeral Distribution. } \\
\hline $\begin{array}{l}\text { NEOTROPICAL } \\
\text { SUB-REGIONS. }\end{array}$ & $\begin{array}{c}N_{\text {EARCTIC }} \\
\text { SUB-REGIONS. }\end{array}$ & $\begin{array}{l}\text { PaLEARCTIC } \\
\text { SUB-KEGIONS. }\end{array}$ & $\begin{array}{c}\text { ETHIOPIAN } \\
\text { SUB-REOIONS. }\end{array}$ & $\begin{array}{c}\text { ORIENTAL } \\
\text { SUB-REGIONS. }\end{array}$ & $\begin{array}{l}\text { AUSTRalian } \\
\text { SUb-REgIUNS. }\end{array}$ \\
\hline--34 & 1.2 .3 .4 & $1.2 .3 \cdot 4$ & ---- & ---- & -- \\
\hline
\end{tabular}

The Ampelidæ, represented in Europe by the waxwing, are a small family, characteristic of the Nearctic and Palæarctic regions, but extending southward to Costa Rica and the West Indian islands. The genera are distributed as follows:-

$\left({ }^{1539}\right)$ A mpelis (3 sp.), the Palæarctic and Nearetic regions, and southward to Guatemala; ( $\left.{ }^{1360}\right)$ Ptilogonys (2 sp.), Central America ; ( ${ }^{14+2}$ ) Dulus (2 sp.), West Indian Islands; ( $\left.{ }^{1361}\right)$ Phanopepla (1 sp.), Mexico and the Gila Valley.

Family 30.-HIRUNDINIDE. ( 9 Genera, 91 Species.)

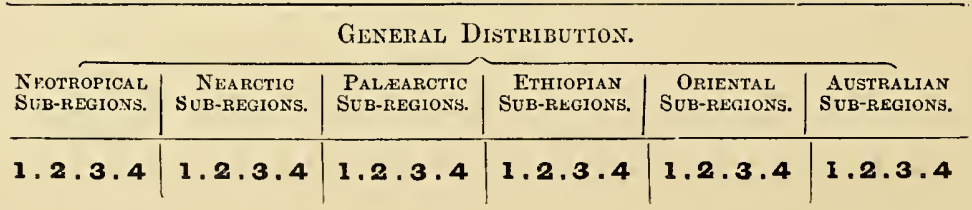


The Hirundinidie, or Swallows, are true cosmopolites. Although they do not range quite so far north (except as stragglers) as a few of the extreme polar birds, yet they pass beyond the Arctic Circle both in America and Europe, Cotyle riparia having been observed in the Parry Islands, while Hirundo rustiea has been seen both in Spitzbergen and Nova Zembla. Cotyle riparia and Chelidon urbiea also breed in great numbers in northern Lapland, latitude $67^{\circ}$ to $70^{\circ}$ north. Many of the species also, have an enormous range, the common swallow (Hirundo rustica) inhabiting Europe, Asia and Africa, from Lapland to the Cape of Good Hope and to the Moluccas. The genera of swallows are not well determined, a number having been established of which the value is uncertain. I admit the following, referring by numbers to the Hand List:-

$(215-221226-228)$ Hirundo (40 sp.), the range of the entire family ; $\left({ }^{222} 223\right.$ ) Psalidoprogne (10 sp.), Tropical and South Africa ; ${ }^{(224)}$ Phedina (1 sp.), Madagascar and Mascarene Islands; $\left({ }^{225}\right)$ Petrochelidon (5 sp.), North and South America and Cape of Good Hope; $(229-232$ ?234) Atticora (8 sp.), the Neotropical region and ? Australia ; ( ${ }^{235}{ }^{237}$ ) Cotyle (11 sp.), Europe, India, Africa, North America, Antilles and Ecuador; ${ }^{(236)}$ Stelgidopteryx (5 sp.), La Plata to United States; ( ${ }^{238}$ and ${ }^{239}$ ) Chelidon (6 sp.), Palæarctic region, Nepal, Borneo; $(240-242)$ Progne (5 sp.), all North and South America.

Family 31.-ICTERID A. (24 Genera, 110 Species.)

Gejeral Distibution.

\begin{tabular}{|c|c|c|c|c|c|}
\hline $\begin{array}{l}\text { Neotropical } \\
\text { Sub-REgloNs. }\end{array}$ & $\begin{array}{c}\text { NEARGTIC } \\
\text { SuB-REGIONS. }\end{array}$ & $\begin{array}{l}\text { PaLAaARCTIC } \\
\text { SUB-HEGIONS. }\end{array}$ & $\begin{array}{c}\text { ETHIOPI.IN } \\
\text { SUB-REGIONS. }\end{array}$ & $\begin{array}{c}\text { ORIENTAL } \\
\text { Sub-REgIONS. }\end{array}$ & $\begin{array}{l}\text { Australian } \\
\text { Sub-REgions. }\end{array}$ \\
\hline 1.2 .3 & 1.2 .3$. & ---- & $---\cdots$ & ---- & ---- \\
\hline
\end{tabular}

The Icteridæ, or American hang-nests, range over the whole continent, from Patagonia and the Falkland Islands to the Arctic Circle. Only about 20 species inhabit the Nearctic region, while, as usual with exclusively American families, the larger proportion of the genera and species are found in the 
tropical parts of Sonth Anerica. The genera adopted by Messrs. Sclater and Salvin are the following :-

Clypeicterus (1 sp.), Upper Amazon; Ocyalus (2 sp.), Upper Amazon to Mexico; Ostinops (8 sp.), Brazil and Bolivia to Mexico; C'assiculus (1 sp.), Mexico; Cassicus (10 sp.), South Brazil and Bolivia to Costa Rica; Icterus (34 sp.), La Plata to the Antilles and United States; Dolichonyx (1 sp.), Paraguay to Canada; Molothrus (8 sp.), La Plata to Northern United States; Agelcus (7 sp.), La·Plata and Chili to Northern United States; Tanthocephalus (1 sp ), Mexico to California and Canada ; Xanthosomus (4 sp.), La Plata to Venezuela; Amblyrhamphus (1 sp.), La Plata and Bolivia; Gymnomystax (1 sp.), Amazonia and Guiana; Pscudoleistcs (2 sp.), La Plata and Brazil ; Lcistcs (3 sp.), La Plata to Venezuela; Sturnclla (5 sp.), Patagonia and Falkland Islands to Middle United States; Curceus (1 sp.), Chili ; Nesopsar (1 sp.), Jamaica ; Scolecophgaus (2 sp.), Mexico to Arctic Circle; Lampropsar (4 sp.), Amazonia and Ecuador to Mexico; Quiscalus (10 sp.), Venezuela and Columbia to South and Central United States; Hypopyrrhus (1 sp.), Columbia; Aphobus (1 sp.), Brazil and Bolivia; Cassidix (2 sp.), Brazil to Mexico and Cuba.

\section{Family 32.-TANAGRID A. (43 Genera, 304 Species.)}

\begin{tabular}{|c|c|c|c|c|c|}
\hline \multicolumn{6}{|c|}{ General Distribution. } \\
\hline $\begin{array}{l}\text { NEOTROPICAL } \\
\text { SEB-REGIONS. }\end{array}$ & $\begin{array}{c}\text { NEARCTIC } \\
\text { SUB-REGIONS. }\end{array}$ & $\begin{array}{l}\text { PALAARCTIC } \\
\text { SUB-HEGTONS. }\end{array}$ & $\begin{array}{c}\text { EthIOPIAN } \\
\text { SUB-REGIONS. }\end{array}$ & $\begin{array}{l}\text { ORIENTAL } \\
\text { SUb-EEGIONS. }\end{array}$ & $\begin{array}{l}\text { AUSTRALIAN } \\
\text { SUB-REGIONS. }\end{array}$ \\
\hline 1.2 .3 .4 & $-2 \cdot 3-$ & $-\ldots$ & ---- & ---- & -- \\
\hline
\end{tabular}

The Tanagers are an extensive family of varied and beantiful fruit-eating birds, almost peculiar to the Neotropical region, only four species of a single genus (Pyranga) extending into the Eastern United States and Rocky Mountains. Sonthward they range to La I'lata. They are especially abundant in the forest regions of South America east of the Andes, where no less than 40 out of the 43 genera occur; 23 of the genera are peculiar to this sub-region, while only 1 (Phlogothrangis) is 
peculiar to Central America and Mexico, and 2 (Spindalis and Phcenicophilus) to the West Indian islands. The genera adopted by Messrs. Sclater and Salvin with their distribution will be found at Vol. II., p. 99, in our account of Neotiopical Zoology.

\section{FAMLY 33.-FRINGILLID E. (74 Genera, 509 Species.)}

\begin{tabular}{|c|c|c|c|c|c|}
\hline $\begin{array}{l}\text { NEOTROPICAL } \\
\text { SUB-REGiONS. }\end{array}$ & $\begin{array}{c}\text { NEARCrIC } \\
\text { SüB-kEGLUX́s. }\end{array}$ & $\begin{array}{l}\text { PaLAarCTIC } \\
\text { SUB-nEGIOAS. }\end{array}$ & $\begin{array}{c}\text { ETHIOPIAN } \\
\text { SUB-REGIONS. }\end{array}$ & $\begin{array}{c}\text { ORIENTAL } \\
\text { SUB-KEGIONS. }\end{array}$ & $\begin{array}{l}\text { Aisfraltay, } \\
\text { SLB-REGiOns, }\end{array}$ \\
\hline 1.2 .3 .4 & $1 \cdot 2 \cdot 3 \cdot 4$ & 1.2 .3 .4 & 1.2 .3 .4 & $1.2 \cdot 3 \cdot 4$ & $-\ldots$ \\
\hline
\end{tabular}

The great family of the Fringillidæ, or finches, is in a very ninsettled state as regards their division into genera, the most divergent views being held by oruithologists as to the constitution and affinities of many of the groups. All the Australian finchlike birds appear to belong to the Ploceidæ, so that the finches, as here constituted, are found in every region and sub-region, except the Australian region from which they are entirely absent - a peculiar distribution hardly to be fornd in any other family of birds.

Many European ornithologists separate the Emberizidie, or buntings, as a distinct family, but as the American genera have not been so divided I am obliged to keep them together; but the genera usnally classed as "buntings" are placed last, as a subfumily. In the following arrangement of the genera, I have done what I conld to harmonize the views of the best modern writers. For convenience of reference the succession of the genera is that of the Hand List, and the numbers of the sub-genera are given whenever practicable:-

(1793 1795) Fringilla (6 sp.), the whole Palæarctic region, including the Atlantic Islands ; ( $\left.{ }^{1794}\right)$ Acanthis (3 sp), Europe to Siberiat, Persia, and North-West Himalayas; ( ${ }^{1796}$ ) Procarduelis (1 sp.), High Himalayas and East Thibet; $\left({ }^{1797}-1803\right)$ Chrysomitris (18 sp.), Neotropical and Nearctic regions, Europe, and Siberia; (1804) Metoponia (1 sp.), East Europe to North West Himalayas; (1805 and ${ }^{809}$ ) Chlorospica (9 sp.), I'alsearctic region and Africa to the 
Cape of Good Hope ; $\left({ }^{1806}-{ }^{1809}\right)$ Dryospiza (14 sp.), South Europe, Palestine, Canaries, and all Africa; $\left.{ }^{1810}\right)$ Sycalis (18 sp.), the whole Neotropical region; (1811 - 18131816 - 1819) Pyrgita (34 sp.), Palæarctic and Oriental regions, and all Africa; $\left({ }^{1814}\right)$ Montifiringilla (4 sp.), Palæarctic region; ( ${ }^{1815}$ ) Fringillauda (2 sp.), NorthWest Himalayas to East Thibet; $(1820-1822$ ) Coccothraustes (6 sp.), Palæarctic region and Nepal, Nearctic region to Mexico; $\left({ }^{1823}\right)$ Eophona (2 sp.), China and Japan ; (1824) Mycerobas (2 sp.), Central Asia to Persia, High Himalayas, and East Thibet; ( ${ }^{1825}$ ) Chaunoproctus (1 sp.), Bonin Islands, sonth-east of Japan, (probably Palæarctic); ( $\left.{ }^{1826}\right)$ Geospiza (7 sp.), Galapagos Islands ; $\left({ }^{1827}\right)$ Camarhynchus (5 sp.), Galapagos Islands; ${ }^{1828}$ ) Cactornis (4 sp.), Galapagos Islands ; $(1830$ - 1832) Phrygilus (10 sp.), Columbia to Fuegia and the Falkland Islands ; $\left({ }^{1833}\right)$ Xenospingus (1 sp.), Peru; (1834) Dinca (3 sp.), Peru to Chili and Patagonia; (1835 and ${ }^{1837}$ ) Emberizoides (3 sp.), Venezuela to Paraguay ; $\left.{ }^{1836}\right)$ Donacospiza (1 sp.), South Brazil and La Plata; $\left({ }^{1839}\right)$ Chamceospiza (1 sp.), Mexico; ( ${ }^{1838}$ and ${ }^{1840}$ ) Embernagra (9 sp.), Arizona to La Plata; ( $\left.{ }^{1841}\right)$ Hamophila (6 sp.), Mexico to Costa Rica; $\left({ }^{1842}\right)$ Atlapetes (1 sp.), Mexico; (1843) Pyrgisoma (5 sp.). Mexico to Costa Rica; (1844 and 1845) Fipilo (12 sp.), all North America to Guatemala; $\left({ }^{1846}\right)$ Junco (6 sp.), all the United States to Guatemala; (1847) Zonotriehia (9 sp.), the whole Nearctic and Neotropical regions ; (1848 1849) Melospiza (7 sp.), Sitka and United States to Guatemala; $\left({ }^{1850}\right)$ Spizella (7 sp.), Canada to Guatemala ; ${ }^{1851}$ ) Passerella (4 sp.), the Nearctic region and Northern Asia; $\left({ }^{1852}\right)$ Passerculus (6 sp.), Nearctic region and to Guatemala ; (1853) Poocetes (1 sp.), all United States and Mexico; (1854) Ammodromus (4 sp.), all United States to Guatemala ; ( ${ }^{1855}$ ) Coturniculus (6 sp.), north and east of North America to Jamaica and Bolivia ; ( $\left.{ }^{1856}\right)$ Penccea (6 sp.), South Atlantic States and California to Mexico; ${ }^{\left({ }^{1857}\right)}$ ) Tiaris (1 sp.), Brazil ; ( $\left.{ }^{1858}\right)$ Volatinia (1 sp.), Mexico to Brazil and Bolivia; $\left.{ }^{1859}\right)$ Cyanospiza (5 sp.), Canada to Guatemala ; (1860 1861) Paroaria (6 sp.), Tropical South America, east of the Andes; (1862) Coryphospingus (4 sp.), Tropical South America; (1863) Haplospiza (2 sp.), Mexico and Brazil ; (1864 1891) Phonipara (8 sp.), Mexico to Columbia, the greater Antilles; $\left({ }^{1865}\right)$ Poospiza 
(13 sp.), California and South Central States to Bolivia and La Plata ; ( ${ }^{424}$ ) Spodiornis (1 sp.), Andes of Quito ; (1866 1867) Pyrrhula (9 sp.), the whole Palæarctic region to the Azores and High Himalayas; ( ${ }^{1868}$ ) Crithagra (17 sp.), Tropical and South Africa, Mauritius, Syria; ( ${ }^{1869}$ ) Ligurnus (2 sp.), West Africa; (1870 1871) Carpodacus (18 sp.), Nearctic and Palæarctic regions to Mexico and Central India; $\left({ }^{1872}-{ }^{1874}\right)$ Erythrospizc (6 sp.), Southern parts of Palæarctic region; ( ${ }^{1875}$ ) Uragus (2 sp.), Siberia and Japan; ( $\left.{ }^{1876}\right)$ Cardinalis (2 sp.), South and Central States to Venezuela: (1877) Pyrrhuloxic (1 sp.), Texas and Rio Grande; (1878 $\left.{ }^{1879}\right)$ Guiracc (6 sp.), Southern United States to La Plata; (1880) Amaurospiza (2 sp.), Costa Rica and Brazil ; (1881) Hedymeles (2 sp.), all United States to Columbia; ${ }^{1882}$ ) Pheucticus (5 sp.), Mexico to Peru and Bolivia; ( ${ }^{1883}$ ) Oryzoborus (6 sp.), Mexico to Ecuador and South Brazil; ( $\left.{ }^{1884}\right)$ Mclopyrrha (1 sp.), Cuba; ${ }^{1885}$ ) Loxigilla (4 sp.), Antilles; (1886 1887 ) Spermophila (44 sp.), Texas to Bolivia and Uruguay; ( ${ }^{1888}$ ) Catamenia (4 sp.), Columbia to Bolivia; ${ }^{1889}$ ) Neorhynchus (3 sp.), West Peru; $\left({ }^{1892}\right)$ Catamblyrlyyncus (1 sp.), Columbia; $\left({ }^{1893}\right)$ Loxia (7 sp.), Europe to North-west India and Japan, Arctic America to Pennsylvania, Mexico; ( ${ }^{1894}$ ) Pinicola (3 sp.), Arctic America, Northeast Europe to the Amoor, Camaroons Mountains West Africa; (1895) Propyrrhula (1 sp.), Darjeeling in the winter, ? Thibet; $\left({ }^{1896}\right)$ Pyprrhospizc (1 sp.), Snowy Himalayas; ${ }^{1897}$ ) Hcmatospiza (1 sp.), South-east Himalayas, 5,000 - 10,000 feet; ( $\left.{ }^{1898}{ }^{1899}\right)$ Linota (12 sp.), Europe to Central Asia, north and east of North America; ${ }^{1900}$ ) Leucosticte (7 sp.), Siberia and Thibet to Kamschatka, and from Alaska to Utah.

Sub-family Emberizinæ.- $\left({ }^{1995}\right)$ Calamospiza (1 sp.), Arizona and Texas to Mexico; ${ }^{1906}$ ) Chondestes (2 sp.), Western, Central, and Southern States to Mexico and Nicaragua; $(1907-1910)$ Euspiza (9 sp.), Palæarctic region, India, Burmah, and South China, South-east United States to Columbia; $(1911-1920)$ Emberiza (28 sp.), the whole Palæarctic region (continental), to Central India in winter; ( ${ }^{1921)}$ Gubernatrix (1 sp.), Paraguay and La Plata, (according to Messrs. Sclater and Salvin this comes next to Pipilo); ( $\left.{ }^{1922}\right)$ Fringillaria (8 sp.), Africa and South Europe; 
$(1923-1925)$ Plectrophanes (6 sp.), Aretic Zone to Northern Europe and North China, Aretic America, and east side of Rocky Mountains; $\left({ }^{1926}\right)$ Centionyx (1 sp.), Mouth of Yellowstone River.

Family 34-PLOCEIDE. (29 Genera, 252 species.)

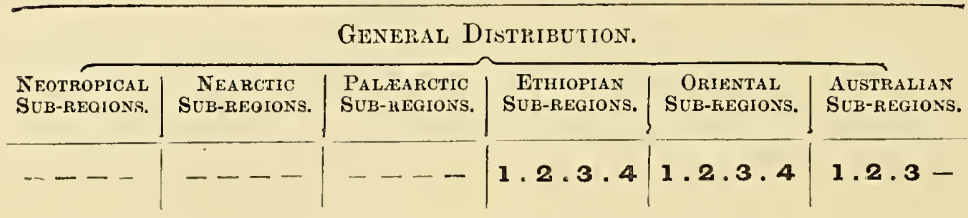

The Ploceidæ, or Weaver-finches, are especially characteristic of the Ethiopian region, where most of the genera and nearly four-fifths of the species are found; the remainder being pretty equally divided between the Oriental and Australian regions. Like the true finches these have never been properly studied, and it is exceedingly difficult to ascertain what genera are natural and how far those of Alistralia and Africa are distinct. The following enumeration must therefore be taken as altogether tentative and provisional. When the genera adopted differ from those of the Hand List they will be referred to by numbers.

Textor (5 sp.), Tropical and South Africa; (1650 - 1654 165i) Hyphantornis (32 sp.), Tropical and South Africa; ( $\left.{ }^{1655} 1656\right)$ Symplectes ( $8 \mathrm{sp}$ ), Tropical and South Africa; Malimbus (9 sp.), West Africa; (1659 1661) Ploceus (6 sp.), West and East Africa, the Oriental region (excluding Philippines); $\left({ }^{1660}\right)$ Nelieurvius (1 sp.), Madagascar ; Foudia (12 sp.), Madagascar and Mascarene Islands, Tropical Africa ; $\left({ }^{1663}{ }^{166 \pm}\right)$ Sporopipes (2 sp.), Tropical and Soutl Africa; $(1665$ - 1667) Pyromelana (14 sp.), Tropical and South Africa, Abyssinia to 10,500 feet; Philetcerus (1 sp.), South Africa; Nigrita (7 sp.), West Africa to Upper Nile; Plocepasser (4 sp.), East and South Africa; $\left({ }^{1672}-1674\right)$ Vidua (7 sp.), Tropical and South Africa (Plate V., Vol. I., p. 264); $\left({ }^{1675}-1677\right)$ Coliuspassev. (9 sp.), Tropical and South Africa; Cherc (1 sp.), South Africa; Spermospiza (2 sp.), West Africa; Pyrenestes (6 sp.), Tropical and South Atrica ; (1682 - 16871639169216931698 ) Estrilda (26 sp.), Tropical and South Africa, India, Burmah, and Java to Australia; (1688 1690 
16911695 1696) Pytelia (24 sp.), Tropical and South Africa; ( $\left.{ }^{1694}\right)$ Hypargos (2 sp.), Mozambique and Madagascar; $\left({ }^{1697}\right)$ Emblema (1 sp.), North-west Australia (1699 1712 - 1717) A madina (15 sp.), Tropical and South Africa, Moluccas to Australia and the Samoa Islands ; (1700 1701 1710) Spermestes (8 sp.), Tropical Africa and Madagascar; (1702) A mauresthes (1 sp.), East and West Africa; (1703 1707 - 1709 1711) Mrunia (30 sp.), Oriental region to Timor and New Guinea; ( $\left.{ }^{1704}\right)$ Donacola (3 sp.), Australia ; $\left.1{ }^{1705}{ }^{1706}\right)$ Poephila (6 sp.), Australia; $\left({ }^{1718}\right.$ - 1721) Erythrura (7 sp.), Sumatra to Java, Moluccas, Timor, New Guinea, and Fiji Islands; ( ${ }^{1722}$ ) Hypoehera (3 sp.), Tropical and South Africa.

FAmLy 35.-STURNID E. (29 Genera, 121 Species.)

\begin{tabular}{|c|c|c|c|c|c|}
\hline \multicolumn{6}{|c|}{ General Distribution. } \\
\hline $\begin{array}{l}\text { Nrotropical } \\
\text { Srib-REGIONS. }\end{array}$ & $\begin{array}{c}\text { NEARCTIC } \\
\text { SUB-REGIOYS. }\end{array}$ & $\begin{array}{l}\text { Pal Earctic } \\
\text { SÚB-flegroNs. }\end{array}$ & $\begin{array}{l}\text { ETHIOPIA } \\
\text { SUB-RLGIONS. }\end{array}$ & $\begin{array}{c}\text { ORI NTIL } \\
\text { SUB-ring GISS. }\end{array}$ & $\begin{array}{l}\text { AUSTRALIAN } \\
\text { SUB-REGIONS. }\end{array}$ \\
\hline--- & --- & $1.2 .3 \cdot 4$ & $1 \cdot 2 \cdot 3 \cdot 4$ & $1.2 .3 \cdot 4$ & $1-3.4$ \\
\hline
\end{tabular}

The Sturnidx, or Starlings, are a highly characteristic OldWorld group, extending to every part of the great Eastern continent and its islands, and over the Pacific Oceau to the Samoa Islands and New Zealand, yet wholly absent from the mainland of Australia. The family appears to be tolerably well-defined, and the following genera are generally considered to belong to it: (1558 1559 1562) Eulabes (13 sp.), the Oriental region to South-west China, Hainan, and Java,-and Flores, New Guinea and the Solomon Islands in the Australian region; Ampeliceps (1 sp.), Tenasserim, Burmah, and Cochin China; Gymnops (1 sp.), l'hilippine Islands; Basilornis (2 sp.), Celebes and Ceram; Pastor (1 sp.), South-east Europe to India, Ceylon, and Burmah; Acridotheries (7 sp.), the whole Oriental region and Celebes ; (1568 1569) Sturnia (12 sp.), the whole Oriental region, North China, Japan, and Siberia, Celebes ; Dilophus (1 sp.) South Africa ; Sturnus (6 sp.), Palæarctic region, to India and South China in winter; Sturnopastor (4 sp.), India to Burmah and East Java ; Creadion (2 sp.) New Zealand; Heteroloclea (1 sp.), New Zealand ; $\left({ }^{1520}\right)$ Callceas 
(2 sp.), New Zealand; Buphaga (2 sp.), Tropical and South Africa; Euryceros (1 sp.), Madagascar (see Plate VI., Vol. I., p. 278.) This genus and the last should perhaps form distinct families. (1577) Juida (5 sp.), Central, West, and South Africa; ${ }^{578}$ ) Lamprocolius (20 sp.), Tropical and South Africa; Cinnyricinclus (2 sp.), Tropical and South Africa; Onychognathus (2 sp.), West Africa; ( $\left.{ }^{1581}\right)$ Spreo (4 sp.), Tropical and South Africa ; (i582 - 1585) Amydrus (7 sp.), South and East Africa, Palestine; Aplonis (9 sp.), New Caledonia to the Tonga Islands ; $(1587-1589)$ Calornis (18 sp.), the whole Malay Archipelago and eastward to the Ladrone and Samoa Islands ; $\left({ }^{1590}\right)$ Enodes (1 sp.), Celebes ; Scissirostrum (1 sp.), Celebes ; ( ${ }^{1592)}$ Saroglossa (1 sp.), Himalayas ; (1593) Hartlaubius (1 sp), Madagascar ; Fregilupus (1 sp.), Bourbon, but it has recently become extinct; ${ }^{363}$ ) Falculia (1 sp)., Madagascar.

Fanily 36.-ARTAMID Æ. (1 Genus, 17 Species.)

\begin{tabular}{|c|c|c|c|c|c|}
\hline $\begin{array}{l}\text { NEOTROPICAL } \\
\text { SUB-REGIONS. }\end{array}$ & $\begin{array}{c}\text { NEARCTIC } \\
\text { SUB-REGIONS. }\end{array}$ & $\begin{array}{l}\text { PALEARCTIC } \\
\text { SUB-HEGIONS. }\end{array}$ & $\begin{array}{c}\text { Ethiopian } \\
\text { SUB-REGTONS. }\end{array}$ & $\begin{array}{l}\text { ORIENTAL } \\
\text { SUB-FEFIONS. }\end{array}$ & $\begin{array}{l}\text { Australiax } \\
\text { SuB-RFrions. }\end{array}$ \\
\hline---- & ---- & ---- & $----?$ & 1.2 .3 .4 & $1.2 .3-$ \\
\hline
\end{tabular}

The Artamidæ, or Swallow-shrikes, are a curious group of birds, ranging over the greater part of the Oriental and Australian regions as far east as the Fiji Islands and south to Tasmania. Only a single species inhabits India, and they are more plentiful in Australia than in any other locality. The only well-marked genus is Artamus.

There are a few Madagascar birds belonging to the genus Artamia, which some ornithologists place in this family, others with the Laniidæ, but which are here classed with the Oriolidæ. 


\section{FAMILY 37.-ALAUDID A. (15 Genera, 110 Species.)}

\begin{tabular}{|c|c|c|c|c|c|}
\hline \multicolumn{6}{|c|}{ General Distribution. } \\
\hline $\begin{array}{l}\text { NEOTROPICAL } \\
\text { St:B-REGIONS. }\end{array}$ & $\begin{array}{c}\text { NEARCTIC } \\
\text { SUB-REGIONS. }\end{array}$ & $\begin{array}{l}\text { Palafarctic } \\
\text { Sub-REgions. }\end{array}$ & $\begin{array}{l}\text { ETHIOPIAN } \\
\text { SUB-REGIONS. }\end{array}$ & $\begin{array}{c}\text { ORIENTAL } \\
\text { SUB-REGIONS. }\end{array}$ & $\begin{array}{l}\text { AUSTRALIAN } \\
\text { SUB-REGIONS. }\end{array}$ \\
\hline$-2 \cdot 3-$ & $-2 \cdot 3 \cdot 4$ & 1.2 .3 .4 & 1.2 .3 .4 & 1.2 .3 .4 & $1.2--$ \\
\hline
\end{tabular}

The Alaudidæ, or Larks, may be considered as exclusively belonging to the great Lastern continent, since the Nearctic, Neotropical, and Australian regions have each only a single species. They abound most in the open plains and deserts of Africa and Asia, and are especially numerons in South Africa. The genera, including those recently established by Mr. Sharpe, are as follows:-

Otocorys (8 sp.); the Palæarctic region, North America and south to the Andes of Columbia, North India; $\left({ }^{1928} 1929\right)$ Alauda (17 sp.), Palæarctic region, all Africa, the Peninsula of India, and Ceylon ; (1931) Galerita (10 sp.), Central Europe to Senegal and Abyssinia, Persia, India and North China; (1932) Calendula (2 sp.), Abyssinia and South Africa; (1933 1934) Calandrella (6 sp.), Europe, North Africa, India, Burmah, North China, and Mongolia ; $(1935$ - 1937) Melanocorypha (7 sp.), South Europe to Tartary,

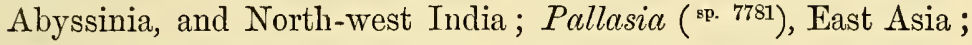
(1938) Certhilaua $a$ (4 sp.), South Europe, South Africa; Heterocorys ( ${ }^{\text {sp. } 7792}$ ) South Africa; $\left({ }^{1939}\right)$ Alcemon (3 sp.), South-east Europe to Western India, and South Africa; ( $\left.{ }^{1940}\right)$ Mirafra (25 sp.), the Oriental and Ethiopian regions to Australia; ( ${ }^{1941}$ ) Ammomanes (10 sp.), South Europe to Palestine and Central India, and to Cape Verd Islands and Sonth Africa; (1942 1943) Megalophonus (6 sp.), Tropical and South Africa; Tephrocorys (1 sp.), South Africa; Pyrrhulauda (9 sp.), all Africa, Canary Islands, India and Ceylon. 
Family 38.- MOTACILLIDA. (9 Genera, 80 Species.)

\begin{tabular}{|c|c|c|c|c|c|}
\hline \multirow[b]{2}{*}{$\begin{array}{l}\text { NEOTROPICAL } \\
\text { SUB-REGIONS. }\end{array}$} & \multicolumn{3}{|c|}{ General Distribution. } & \\
\hline & $\begin{array}{c}\text { NEARCTIC } \\
\text { SUB-REGIONS }\end{array}$ & $\begin{array}{l}\text { PALAaARCTIC } \\
\text { SUB-REGIONS. }\end{array}$ & $\begin{array}{c}\text { ETHIOPIAN } \\
\text { SUB-REGIONS. }\end{array}$ & $\begin{array}{c}\text { ORIENTAL } \\
\text { SUB-REGIONS. }\end{array}$ & $\begin{array}{l}\text { AUSTRALIAN } \\
\text { SUB-REGIONS. }\end{array}$ \\
\hline 1.2 .3 .4 & 1.2 .3 .4 & $1 \cdot 2 \cdot 3 \cdot 4$ & $1 \cdot 2 \cdot 3 \cdot 4$ & 1.2 .3 .4 & 1.2. -4 \\
\hline
\end{tabular}

The Motacillidæ, or Wagtails and Pipits, are universally distributed, but are most abundant in the Palæarctic, Ethiopian, and Oriental regions, to which the true wagtails are almost confined. The following genera are usually adopted, but some of them are not very well defined :-

Motacilla (15 sp.), ranges over the greater part of Europe, Asia, and Africa, and to Alaska in North-west America ; Budytes (10 sp.), Europe, Africa, Asia to Philippines, Moluccas, Timor, and North Australia; Calobates (3 sp.), South Palæarctic and Oriental regions to Java; Nemoricola (1 sp.), Oriental region; Anthus (30 sp.), all the great continents ; Neocorys (1 sp.), Central North America; Corydailla (14 sp.), South Europe to India, China, the Malay Islands, Australia, New Zealand and the Auckland Islands: Macronyx (5 sp.), Tropical and South Africa; Heterura (1 sp.), Himalayas.

FAmily 39.-TYRANNID AE. (71 Genera, 329 Species.)

\begin{tabular}{|c|c|c|c|c|c|}
\hline \multicolumn{6}{|c|}{ General Distribution. } \\
\hline $\begin{array}{l}\text { NEOTROPIOAL } \\
\text { StB-REGIONS. }\end{array}$ & $\begin{array}{l}\text { Nearotic } \\
\text { Sub-REgIONS. }\end{array}$ & $\begin{array}{l}\text { Palearartic } \\
\text { Sub-liegroNs. }\end{array}$ & $\begin{array}{c}\text { ETHIOPIAN } \\
\text { SUb-REGIONS. }\end{array}$ & $\begin{array}{c}\text { ORIENTAL } \\
\text { SUB-REGIONS. }\end{array}$ & $\begin{array}{l}\text { AUSTRALIAN } \\
\text { SUB-REGIONS. }\end{array}$ \\
\hline 1.2 .3 .4 & 1.2 .3 .4 & --- & ---- & ---- & --- \\
\hline
\end{tabular}

The Tyrannidæ, or Tyrant Shrikes, form one of the most extensive and truly characteristic American families of birds; as they extend over the whole continent from Patagonia to the Aretic regions, and are found also in all the chief American islands-the Antilles, the Galapagos, the Falkland Islands, and 
Juan Fernandez. As the genera are all enumerated in the table, at p. 101 of this volume, I shall here confine myself to the distribution of the sub-families, only referring to such genera as are of special geographical interest.

Sub-family I. Conophagine (2 genera, 1.3 species). Confined to tropical South America, from Brazil and Bolivia to Guiana and Columbia.

Sub-family II. Teniopterinæ (19 genera, 76 species). This group ranges from Patagonia and the Falkland Islands to the northern United States; yet it is almost wholly South American, only 2 genera and 4 species passing north of Panama, and none inhabiting the West Indian islands. Sayornis has 3 species in North America, while Tcenioptera, Cnipolegus, Muscisaxicola, and Centrites, range south to Patagonia.

Sub-family III. Platyrhynichine (16 genera, 60 species). This sub-family is wholly Neotropical and mostly South American, only 7 of the genera passing Panama and but 3 reaching Mexico, while there are none in the West Indian islands. Only 3 genera extend south to the temperate sub-region, and one of these, Ancertes, has a species in Juan Fernandez.

Sub-family IV. Elainein a (17 genera, 91 species). This subfamily is more exclusively tropical, only two genera extending south as far as Chili and La Plata, while none enter the Nearctic region. No less than 10 of the genera pass north of Panama, and one of these, Elainea, which ranges from Chili to Costa Rica has several species in the West Indian islands. About one fourth of the species of this sub-family are found north of Panama.

Sub-family V. Trrannin ( 17 genera, 89 species). This subfamily is that which is best represented in the Nearctic region, where 6 genera and 24 species occur. Milvulus reaches Texas; Tyrannus and Myiarchus range over all the United States; Sayornis, the Eastern States and California; Contopus extends to Canada; Empidonax ranges all over North America; and Pyrocephalus reaches the Gila Valley as well as the Galapanos Islands. No less than 5 genera of this sub-family occur in the West Indian islands. 
FAMiLy 39a.-OXYRHAMPHIDE. (1 Genus, 2 Species.)

\begin{tabular}{|c|c|c|c|c|c|}
\hline \multicolumn{6}{|c|}{ General Distribution. } \\
\hline $\begin{array}{l}\text { NEOTROPICAL } \\
\text { SUB-REGLONS. }\end{array}$ & $\begin{array}{c}\text { NEARCrIIC } \\
\text { SUB-REGIONS. }\end{array}$ & $\begin{array}{l}\text { PALAaARCTIC } \\
\text { SUB-UEGIONS. }\end{array}$ & $\begin{array}{c}\text { Ethiopian } \\
\text { Sub-REgIONS. }\end{array}$ & $\begin{array}{c}\text { ORIENTAL } \\
\text { SUB-EEGIONS. }\end{array}$ & $\begin{array}{l}\text { Australian } \\
\text { Sub-REtions. }\end{array}$ \\
\hline$-2.3-$ & $---\cdots$ & ---- & ---- & ---- & ---- \\
\hline
\end{tabular}

The genus Oxyrhamphus (2 sp.) which ranges from Brazil to Costa Rica, has usually been placed in the Dendrocolaptidæ; but Messrs Sclater and Salvin consider it to be the type of a distinct family group, most allied to the Tyrannidæ.

FAmily 40.-PIPRID $A . \quad$ (15 Genera, 60 Species.)

\begin{tabular}{|c|c|c|c|c|c|}
\hline & & \multicolumn{2}{|c|}{ General Distribution. } & \multicolumn{2}{|c|}{-} \\
\hline $\begin{array}{l}\text { NEOTROPICAL } \\
\text { SUB-REGIONS. }\end{array}$ & $\begin{array}{c}\text { NEARCTIC } \\
\text { SUB-REOIONS. }\end{array}$ & $\begin{array}{l}\text { PALAARCTIC } \\
\text { SUB-REGIONS. }\end{array}$ & $\begin{array}{c}\text { ETHIOPIAN } \\
\text { SUB-REGIONS. }\end{array}$ & $\begin{array}{l}\text { ORIENTAL } \\
\text { SUB-REGIONS. }\end{array}$ & $\begin{array}{l}\text { AUSTralian } \\
\text { Sub-REgIONS. }\end{array}$ \\
\hline$-2 \cdot 3-$ & ---- & ---- & ---- & ---- & ---- \\
\hline
\end{tabular}

The Pipridæ, or Manakins, have generally been associated with the next family, and they have a very similar distribution. The great majority of the genera and species are found in the equatorial regions of South America, only 9 species belonging to 5 genera ranging north of Panama, while 2 or 3 species extend to the southern limit of the tropical forests in Paraguay and Brazil. The genera which go north of Panama are Piprites, Pipra, Chiroxiphia, Chiromachceris, and Hetoropelma. Pipro is the largest genus, containing 19 species, and having representatives throughout the whole range of the family. As in all the more extensive families peculiar to the Neotropical region, the distribution of the genera will be found in the tables appended to the chapter on the Neotropical region in the Third Part of this work. (Vol. II. p. 103). 
FAmily 41._COTINGIDA. (28 Genera, 93 Species.)

\begin{tabular}{|c|c|c|c|c|c|}
\hline $\begin{array}{l}\text { NEOTROPICAL } \\
\text { Sub-REGIONS. }\end{array}$ & $\begin{array}{c}\text { NEARCTIC } \\
\text { SứB-REGIONS. }\end{array}$ & $\begin{array}{l}\text { PALAARCTIC } \\
\text { SUB-REGIONS. }\end{array}$ & $\begin{array}{c}\text { Ethiopian } \\
\text { Sub-REgIONS. }\end{array}$ & $\begin{array}{c}\text { ORIENTAL } \\
\text { SUB-REGIONS. }\end{array}$ & $\begin{array}{l}\text { AUSTRALIAN } \\
\text { SUB-REGIONS. }\end{array}$ \\
\hline-2.3 .4 & ---- & $-\cdots-$ & ---- & --- & ---- \\
\hline
\end{tabular}

The Cotingidæ, or Chatterers, comprise some of the most beautiful and some of the most remarkable of American birds, for such we must consider the azure and purple Cotingas, the wine-coloured white-winged Pompadour, the snowy carunculated Bell-birds, the orange-coloured Cocks-of-the-Rock, and the marvellously-plumed Umbrella-bircls, (Plate XV. Vol. II. p. 28). The Cotingidæ are also one of the most pre-eminently Neotropical of all the Neotropical families, the great mass of the genera and species being concentrated in and around the vast equatorial forest region of the Amazon. Only 13 species extend north of Panama, one to the Antilles, and not more than 20 are found to the south of the Amazon Valley. Messrs. Sclater and Salvin divide the family into six sub-families, the distribution of which will be briefly indicated.

Sub-family I. Tityrine (3 genera, 22 species). Ranges from Brazil to Mexico, one species of Hadrostomus inhabiting Jamaica.

Sub-family II. LIPAUGIN \& (4 genera, 14 species) also ranges from Brazil to Mexico; one genus (Ptilochloris) is confined to Brazil.

Sub-family III. AtTaline (2 genera, 10 species). Ranges from Paraguay to Costa Rica; one genus (Casiornis) is confined to South Brazil and Paraguay.

Sub-family IV. Rupicoline (2 genera, 5 species). This subfamily is restricted to the Amazonian region and Guiana, with one species extending along the Andean valleys to Bolivia. The genera are Rupicola (3 species) and Phonicocercus (2 species).

Sub-family V. Cotinginæ (10 genera, 28 species). Ranges from Sonthern Brazil and Bolivia to Nicaragua; only two species 
(belonging to the genera Carpodectes and Cotinga) are found north of Panama, and there are none in the West Indian islands. The great majority of these, the true Chatterers, are from the regions about the Equator.

Sub-family VI. Gimnoderine (7 genera, 14 species). Ranges from Brazil to Costa Rica; two species, of the genera Chasmorhynchus and Cephalopterus, are found north of Panama, while there are none in the West Indian islands. Only 2 species are found south of the Amazon valley.

\section{Family 42.-PHYTOTOMID A. (1 Genus, 3 Species.)}

\begin{tabular}{|c|c|c|c|c|c|}
\hline \multicolumn{6}{|c|}{ General Distribution. } \\
\hline $\begin{array}{l}\text { NEOTROPICAL } \\
\text { SUB-REGIONS. }\end{array}$ & $\begin{array}{c}\text { NEARCTIC } \\
\text { SUB-REGIONS. }\end{array}$ & $\begin{array}{l}\text { Palamarctic } \\
\text { Sub-nEGIons. }\end{array}$ & $\begin{array}{c}\text { ETHIOPIAN } \\
\text { SUB-REGIONS. }\end{array}$ & $\begin{array}{l}\text { ORIENTAL } \\
\text { SUB-FiEGIONS. }\end{array}$ & $\begin{array}{l}\text { AUSTRALIAN } \\
\text { SUB-REGIONS. }\end{array}$ \\
\hline $1---$ & $-\cdots-$ & $=---$ & --- & ---- & -- \\
\hline
\end{tabular}

The Phytotomidæ, or Plant-cutters, are singular thick-billed birds, strictly confined to the temperate regions of South America. The single genus, Phytotoma, is found in Chili, La Plata, and Bolivia. Their affinities are uncertain, but they are believed to be allied to the series of families with which they are here associated. (Plate XVI. Vol. II. p. 128).

FAMILY 43.-EURYLAMID Æ. (6 Genera, 9 Species.)

\begin{tabular}{|c|c|c|c|c|c|}
\hline \multicolumn{6}{|c|}{ General Distribution. } \\
\hline $\begin{array}{l}\text { NEOTROPICAL } \\
\text { SUB-REGIONS. }\end{array}$ & $\begin{array}{c}\text { NEARCTIC } \\
\text { SUB-REGIONS. }\end{array}$ & $\begin{array}{l}\text { Palafarctic } \\
\text { SUd-REGions. }\end{array}$ & $\begin{array}{l}\text { ETHIOPIIN } \\
\text { SUB-REGIONS. }\end{array}$ & $\begin{array}{c}\text { ORIENTAL } \\
\text { SUB-REGIONS. }\end{array}$ & $\begin{array}{l}\text { AUSTRALIAN } \\
\text { SUB-REGIONS. }\end{array}$ \\
\hline---- & $\ldots--$ & --- & $-\cdots$ & $--3 \cdot 4$ & ---- \\
\hline
\end{tabular}

The Eurylæmidæ, or Broad-bills, form a very small family of birds, often adorned with striking colours, and which have their nearest allies in the South American Cotingidæ. They have a very limited distribution, from the lower slopes of the Himalayas through Burmah and Siam, to Sumatra, Borneo, and Java. They are evidently the remains of a once extensive group, and from the small number of specific forms remaining, seem to be on 
the road to extinction. Thus we may understand their isolated geographical position. The following are the names and distribution of the genera :-

Eurylcemus (2 species), Malay Peninsula, Sumatra, Java, and Borneo; Corydon (1 species), Malacea, Sumatra and Borneo (Plate IX. Vol. I. p. 339); Psarisomus (1 species), Himalayas to Burmah, up to 6,000 feet; Serilophus (2 species), Nepal to Tenasserim; Cymbirhynchus (2 species), Siam to Sumatra and Borneo; Calyptomena (1 species), Penang to Sumatra and Borneo.

FAMily 44.-DENDROCOLAPTID A. (43 Genera, 217 Species.)

\begin{tabular}{|c|c|c|c|c|c|}
\hline $\begin{array}{l}\text { STORROPICAL } \\
\text { SrB-REGIOXS. }\end{array}$ & $\begin{array}{l}\text { NEARCTIC } \\
\text { SUB-REGTONS. }\end{array}$ & $\begin{array}{l}\text { PAL_earctic } \\
\text { Sub-liEg IONS. }\end{array}$ & $\begin{array}{c}\text { ETHIOPIAN } \\
\text { SUB-REGIONS. }\end{array}$ & $\begin{array}{l}\text { ORIENTAL } \\
\text { SUB-REGIONS. }\end{array}$ & $\begin{array}{l}\text { AUSTRALIAN } \\
\text { SUB-REGIONS. }\end{array}$ \\
\hline $1.2 .3-$ & $---\cdots$ & $-\cdots-$ & ----- & $-\cdot---$ & ---- \\
\hline
\end{tabular}

The Dendrocolaptidæ; or American Creepers, are curious brown-coloured birds with more or less rigid tail feathers, strictly confined to the continental Neotropical region, and very numerous in its south-temperate extremity. They are divided by Messrs. Sclater and Salvin into five sub-families, to which $\mathrm{I}$ shall confine my remarks on their distribution. The details of the numerous genera, being only interesting to specialists, will be given in the table of genera of the Neotropical region. No less than 13 of the genera are confined to South-Temperate America and the High Andes; 14 are restricted to Tropical South America, while not one is peculiar to Tropical North America, and only 15 of the 43 genera extend into that sub-region, showing that this is one of the pre-eminently South American groups.

Sub-family I. Furvarinn e (8 genera, 30 species). Ranges over all South America, 4 genera and 18 species being restricted to the temperate sub-region; one species is found in the Falkland Islands.

Sub-family II. Sclerurina (1 genus, 6 species). Brazil to Guiana, Columbia, and north to Mexico.

Sub-family III. Syxallaxin 2 (12 genera, 78 species). Ranges from Patagonia to Mexico; 7 genera and 28 species are confined 
to the temperate sub-region; species occur in the islands of Mas-a-fuera, Trinidad, and Tobago.

Sub-family IV. Philydorine (6 genera, 35 species). Confined to Tropical America from Brazil to Mexico; 4 genera and 8 species occur in Tropical North America.

Sub-family V. Dendrocolaptine (14 genera, 59 species). Ranges from Chili and La Plata to Mexico; only 3 species occur in the South Temperate sub-region, while 9 of the genera extend into Tropical North America. Two of the continental species occur in the island of Tobago, which, together with Trinidad, forms part of the South American rather than of the true Antillean sub-region.

FAMILY 45.-FORMICARIID $Æ . \quad$ (32 Genera, 211 Species.)

\begin{tabular}{|c|c|c|c|c|c|}
\hline \multicolumn{6}{|c|}{ Generai, Distribution. } \\
\hline $\begin{array}{l}\text { NEOTROPICAL } \\
\text { SUB-REGIONS. }\end{array}$ & $\begin{array}{c}\text { NEARCTIC } \\
\text { SUB-REGIONS. }\end{array}$ & $\begin{array}{l}\text { PaLEarctic } \\
\text { SUB-REGIONS. }\end{array}$ & $\begin{array}{l}\text { ETHIOPIAN } \\
\text { SUB-REGIONS. }\end{array}$ & $\begin{array}{l}\text { ORIENTAL } \\
\text { SUB-HEGIONS. }\end{array}$ & $\begin{array}{l}\text { AUSTRALIAN } \\
\text { SuB-regions. }\end{array}$ \\
\hline$-2.3-$ & ---- & ---- & ---- & ---- & -- \\
\hline
\end{tabular}

The Formicariidæ, comprising the Bush-Shrikes and Antthrushes, form one of the most exclusively Neotropical families; and the numerous species are rigidly confined to the warm and wooded districts, only a single species extending to La Plata, and none to the Antilles or to the Nearctic region. Less than 30 species are found north of Panama. Messrs. Sclater and Salvin divide the group into three sub-families, whose distribution may be conveniently treated, as in the Dendrocolaptidæ, without enumerating the genera.

Sub-family I. Thamnophininæ.-(10 genera, 70 species.) One species of Thamnophilus inhabits La Plata; only 3 genera and 12 species are found north of Panama, the species of this sub-family being especially abundant in the Equatorial forest districts.

Sub-family II. ForMICIVorin -.-(14 genera, 95 species.) Only 8 species occur north of Panama, and less than one-third of the species belong to the districts south of the Equator. 
Sub-family III. Formicarines,-(8 genera, 46 species.) About 12 species occur north of Panama, and only 5 south of the Equatorial district.

It appears, therefore, that this extensive family is especially characteristic of that part of South America from the Amazon valley northwards.

FAMily 46.-PTEROPTOCHID Æ. (8 Genera, 19 Species.)

\begin{tabular}{|c|c|c|c|c|c|}
\hline \multirow[b]{2}{*}{$\begin{array}{l}\text { NFotropical } \\
\text { St:B-REGIONS. }\end{array}$} & \multicolumn{4}{|c|}{ General Distribution. } & \multirow[b]{2}{*}{$\begin{array}{l}\text { AUSTRALIAN } \\
\text { SUB-REGIONS. }\end{array}$} \\
\hline & $\begin{array}{c}\text { NEARCTIC } \\
\text { SUB-REGIONS. }\end{array}$ & $\begin{array}{c}\text { PALEARCTIC } \\
\text { SuB-REGIONS. }\end{array}$ & $\begin{array}{c}\text { ETHIOPIAN } \\
\text { SUB-REGIONS. }\end{array}$ & $\begin{array}{l}\text { ORIENTAL } \\
\text { SUB-REGIONS. }\end{array}$ & \\
\hline $1 \cdot 2--$ & ---- & ---- & ---- & --- & --- \\
\hline
\end{tabular}

The Pteroptochidæ are a group of curious Wren-like birds, almost confined to the temperate regions of South America, extending along the Andes beyond the Equator, and with a few species in South-east Brazil, and one in the valley of the Madeira. The genera are as follows :-

Scytalopus (8 sp.), Chili and West Patagonia to the Andes of Columbia ; Merulaxis (1 sp.), South-east Brazil ; Rhinocrypta (2 sp.), Northern Patagonia and La Plata ; Lioscclis (1 sp.), Madeira valley; Pteroptochus (2 sp.), Chili; Hylactes (3 sp.), Western Patagonia and Chili; Acropternis (1 sp.), Andes of Ecuador and Columbia; Triptorhinus (1 sp.), Chili.

FAmily 47.-PITTID Æ. (4 Genera, 40 Species.)

\begin{tabular}{|c|c|c|c|c|c|}
\hline \multicolumn{6}{|c|}{ General Distribution. } \\
\hline $\begin{array}{l}\text { NEOTROPICAL } \\
\text { SUB-REGIONS. }\end{array}$ & $\begin{array}{c}\text { NEARCTIC } \\
\text { SUB-REGIONS. }\end{array}$ & $\begin{array}{l}\text { PaLAaARCtic } \\
\text { SUB-REGIONS. }\end{array}$ & $\begin{array}{l}\text { ETHIOPIAN } \\
\text { SUB-REGIONS. }\end{array}$ & $\begin{array}{c}\text { ORIENTAL } \\
\text { SUB-REGIONS. }\end{array}$ & $\begin{array}{l}\text { Australian } \\
\text { SUB-REgIONS. }\end{array}$ \\
\hline---- & ---- & ---4 & $-2--$ & $1.2 \cdot 3 \cdot 4$ & $1.2-$ \\
\hline
\end{tabular}

The Pittas comprise a number of beautifully-coloured Thrushlike birds, which, although confined to the old World, are more nearly allied to the South American Pteroptochidæ than to any other family. They are most abundant in the Malay Archipelago, 
between the Oriental and Australian divisions of which they are pretty equally divided. They seem, however, to attain their maximum of beauty and variety in the large islands of Borneo and Sumatra; from whence they diminish in numbers in every direction till we find single species only in North China, West Africa, and Australia. The genera here adopted are the following:-

(1087 108810901092 1093) Pitta (33 sp.), has the range of the family; $\left.{ }^{1089}\right)$ Hydrornis (3 sp.), Himalayas and Malaya; Eucichla (3 sp.), Malaya; Melampitta (1 sp.), recently discovered in New Guinea.

Family 48.-PAICTIDE. (1 Genus, 2 Species.)

\begin{tabular}{|c|c|c|c|c|c|}
\hline \multicolumn{6}{|c|}{ General Distribution. } \\
\hline $\begin{array}{l}\text { NEOTROPICAL } \\
\text { SUB-REGIONS. }\end{array}$ & $\begin{array}{c}\text { NEARCTIC } \\
\text { SUB-REGIONS. }\end{array}$ & $\begin{array}{l}\text { PALAAARCTIC } \\
\text { SUB-KEGIOISS. }\end{array}$ & $\begin{array}{l}\text { ETHIOPIAN } \\
\text { SUB-REGIONS. }\end{array}$ & $\begin{array}{c}\text { ORIENTAL } \\
\text { SUB-REGIONS. }\end{array}$ & $\begin{array}{l}\text { AUSTRALIan } \\
\text { SUB-REgIONS. }\end{array}$ \\
\hline$---\cdots$ & $--\cdots$ & --- & ---4 & --- & ---- \\
\hline
\end{tabular}

This family was established by Professor Sundevall, for an anomalous bird of Madagascar, which he believes to have some affinity for the American Formicariidæ, but which perhaps comes best near the Pittas. The only genus is Philepitta, containing two species.

\section{FAmily 49.-MENURID E. (1 Genus, 2 Species.)}

\begin{tabular}{|c|c|c|c|c|c|}
\hline \multicolumn{6}{|c|}{ General Distribution. } \\
\hline $\begin{array}{l}\text { NFotROPICAL } \\
\text { St:B-REGIONS. }\end{array}$ & $\begin{array}{c}\text { NEARCTIC } \\
\text { SUB-REGIONS. }\end{array}$ & $\begin{array}{c}\text { PALEAARCTIC } \\
\text { SUB-REGIONS. }\end{array}$ & $\begin{array}{l}\text { ETHIOPIAN } \\
\text { SUB-REGIONS. }\end{array}$ & $\begin{array}{c}\text { ORIENTAL } \\
\text { SUB-REGIONS. }\end{array}$ & $\begin{array}{l}\text { Avstralian } \\
\text { SUb-REgions. }\end{array}$ \\
\hline$-\rightarrow--$ & ---- & ---- & ---- & ---- & -2 \\
\hline
\end{tabular}

The Menuridæ, or Lyre Birds, remarkable for the extreme elegance of the lyre-shaped tail in the species first discovered, are birds of a very anomalous structure, and have no near affinity to any other family. Two species of Menura are known, confined to South and East Australia (Plate XII. Vol. I. p. 411). 
FaMILY 50.-ATRICHIIDÆE. (1 Genus, 2 Species.)

\begin{tabular}{|c|c|c|c|c|c|}
\hline & & General D & STRIBUTION. & & \\
\hline $\begin{array}{l}\text { NeOTROPICAL } \\
\text { SUB-REGIONS. }\end{array}$ & $\begin{array}{c}\text { NEARCTIC } \\
\text { SUB-REGIONS. }\end{array}$ & $\begin{array}{l}\text { PALEARCTIC } \\
\text { SUB-KEGIONS. }\end{array}$ & $\begin{array}{c}\text { EthIOPIAN } \\
\text { SUB-REGIONS. }\end{array}$ & $\begin{array}{c}\text { ORIENTAL } \\
\text { SUB-EEGIONS. }\end{array}$ & $\begin{array}{l}\text { Australian } \\
\text { Sub-REgIONS. }\end{array}$ \\
\hline---- & $-\cdots-$ & ---- & ---- & ---- & $-2-$ \\
\hline
\end{tabular}

The genus Atrichic, or Scrub-birds of Australia, have been formed into a separate family by Professor Newton, on account of peculiarities in the skeleton which separate them from all other Passeres. Only two species are known, inhabiting East and West Ausiralia respectively. They are very noisy, browncoloured birds, and have been usually classed with the warblers, near Amytis and other Australian species.

\section{General remarks on the distribution of the Passeres.}

The order Passeres, is the most extensive among birds, comprehending about 5,700 species grouped in 870 genera, and 51 families. The distribution of the genera, and of the families considered individually, has been already sufficiently given, and we now have to consider the peculiarities of distribution of the families collectively, and in their relations to each other, as representing well-marked types of bird-structure. The first thing to be noted is, how very few of these families are truly cosmopolitan; for although there are seven which are found in each of the great regions, yet few of these are widely distributed throughout all the regions, and we can only find three that inhabit every sub-region, and are distributed with tolerable uniformity; these are the Hirundinidæ, or swallows, the Motacillidæ or wagtails and pipits, and the Corvidæ or crows,-but the latter is a family of so heterogeneous a nature, that it possibly contains the materials of several natural families, and if so divided, the parts would probably all cease to be cosmopolitan. The Sylviidx, the 
Turdidx, and the Paridx, are the only other families that approach universality of distribution, and all these are wanting in one or more sub-regions. If, now, we divide the globe into the New and the Old World, the former including the whole American continent, the latter all the rest of the earth, we find that the Old World possesses exclusively 23 families, the New World exclusively 14, of which 5 are common to North and South America. But if we take the division proposed by Professor Huxley-a northern world, comprising our first four regions (from Nearctic to Oriental), and a southern world comprising our last two regions (the Australian and Neotropical)-we find that the northern division possesses only 5 families exclusively, and the southern division 13 exclusively, of which not one is common to Australia and South America. This plainly indicates that, as far as the Passeres are concerned, the latter bipartite division is not so natural as the former. Again, if we compare temperate with tropical families (not too rigidly, but as regards their general character), we find in the northern hemisphere only two families that have the character of being typically temperate-the Cinclidæ, and in a less degree the Ampelidæ-both of small extent. In the southern hemi-

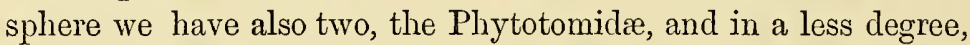
the Pteroptochidæ; making two wholly and two mainly temperate families. Of exclusively tropical families on the other hand, we have about 12, and several others that are mainly tropical.

The several regions do not differ greatly in the number of families found in each. The Nearctic has 19, the Palæarctic 21, the Ethiopian 23, the Oriental 28, the Australian 29, and the Neotropical 23. But many of these families are only represented by a few species, or in limited districts; and if we count only those families which are tolerably well represented, and help to form the ornithological character of the region, the richness of the several tropical regions will appear to be (as it really is) comparatively much greater. The families that are confined to single regions are not very numerous, except in the case of the Neotropical region, which has 5. The Anstralian has only 
3, the Oriental 1, the Ethiopian 1, and the other regions have no peculiar families.

The distribution of the Passeres may be advantageously considered as divided into the five series of Turdoid, Tanagroid, Sturnoid, Formicarioid, and Anomalous Passeres. The Turdoid Passeres, consisting of the first 23 families, are especially characteristic of the Old World, none being found exclusively in America, and only two or three being at all abundant there. The Tanagroid Passeres (Families 24-33) are very characteristic of the New World, five being confined to it, and three others being quite as abundant there as in the Old World; while there is not a single exclusively old World family in the series, except the Drepanididæ confined to the Sandwich Islands. The Sturnoid Passeres (Families 34-38) are all exclusively Old World, except that two larks inhabit parts of North America, and a few pipits South America. The Formicarioid Passeres (Families 39-48) are strikingly characteristic of the New World, to which seren of the families exclusively belong; the two old World groups being small, and with a very restricted distribution. The Anomalous Passeres (Families 49-50) are confined to Australia.

The most remarkable feature in the geographical distribution of the Passeres is the richness of the American continent, and the large development of characteristic types that occurs there. The fact that America possesses 14 altogether peculiar families, while no less than 23 Old-World families are entirely absent from it, plainly indicates, that, if this division does not represent the most ancient and radical separation of the land surface of the globe, it must still be one of very great antiquity, and have modified in a very marked way the distribution of all living things. Not less remarkable is the richness in specific forms of the 13 peculiar American families. These contain no less than 1,570 species, leaving only about 500 American species in the 13 other Passerine families represented in the New World. If we make a deduction for those Nearctic species which oucur only north of Panama, we may estimate the truly Neotropical species of Passerine birds at 1,900, which is almost exactly 
one-third of the total number of Passeres; a wonderful illustration of the Ornithological riches of South America.

\section{Order II.-PICARIAE.}

FAMILY 51.-PICID Æ. (36 Genera, 320 Species.)

\begin{tabular}{|c|c|c|c|c|c|}
\hline \multicolumn{6}{|c|}{ General Distribution. } \\
\hline $\begin{array}{l}\text { NEOTROPICAL } \\
\text { SUB-REGIONS. }\end{array}$ & $\begin{array}{c}\text { NEARCTIC } \\
\text { SUB-REGIONS. }\end{array}$ & $\begin{array}{l}\text { PaLFaRCTIC } \\
\text { SUB-KEGIONS. }\end{array}$ & $\begin{array}{l}\text { ETHIOPIAN } \\
\text { SUB-REGIONS. }\end{array}$ & $\begin{array}{c}\text { ORIENTAL } \\
\text { SUB-REGIONS. }\end{array}$ & $\begin{array}{l}\text { AUSTraLIAN } \\
\text { SUB-REGIONS. }\end{array}$ \\
\hline 1.2 .3 .4 & 1.2 .3 .4 & $1 \cdot 2 \cdot 3 \cdot 3$ & $1 \cdot 2 \cdot 3-$ & 1.2 .3 .4 & $1--$ \\
\hline
\end{tabular}

The Woodpeckers are very widely distributed, being only absent from the Australian region beyond Celebes and Flores. They are most abundant in the Neotropical and Oriental regions, both of which possess a number of peculiar genera; while the other regions possess few or no peculiar forms, even the Ethiopian region having only three genera not found elsewhere. The softtailed 'Picunnninæ inhabit the tropical regions only, Picumnus being Neotropical, Vivia and Sasia Oriental, and Verreauxia Ethiopian. Picoides, or Apternus, is an Arctic form peculiar to the Nearctic and Palæarctic regions. Ccleus, Chrysoptilus, Chloronerpes, and some smaller genera, are Neotropical exchusively, and there are two peculiar forms in Cuba. Yungipicus, Chrysocolaptes, Hemicercus, Mulleripicus, Brachypternus, Tiga, and Microptcrnus, are the most important of the peculiar Oriental genera. Dendropicus and Geocolaptes are Ethiopian; but there are no woodpeckers in Madagascar. The Palæarctic woodpeckers belong to the genera Picus-which is widely distributed, Gecinus -which is an Oriental form, and Dryocopus-which is South American. Except Picoides, the Nearctic woodpeckers are mostly of Neotropicalgenera; but Sphyrapicus and Hylatomus are peculiar. The geological record is, as yet, almost silent as to this family ; but remains doubtfully referred to it have been found in the Miocene of Europe and the Eocene of the United States. Yet the group is evidently one of very high antiquity, as is shown by 
its extreme isolation, its great specialization of structure, its abundant generic forms, and its wide distribution. It originated, probably, in Central Asia, and passed through the Nearctic region to South America, in whose rich and varied forests it found the conditions for rapid development, and for the specialization of the many generic forms now found there.

A large number of genera have been established by various authors, but their limitations and affinities are not very well made out. Those which seem best established are the following :-

(2107 - 2112) Picumnus (22 sp.), Tropical South America to Honduras; ( ${ }^{2113}$ ) Vivia (1 sp.), Himalayas to East Thibet; ${ }^{2114}$ ) Sasia (2 sp.), Nepal to Java; (2115) Verrcauxia (1 sp.), West Africa; Picoides (5 sp.), northern parts of Nearctic and Paliearctic regions, and Mountains of East Thibet; Picus (42 sp.), the whole Palæarctic, Oriental, Nearctic, and Neotropical regions ; ( $\left.{ }^{2123}\right)$ Hyopicus (2 sp.), Himalayas and North China ; ( $\left.{ }^{2124}\right)$ Yungipicus (16 sp.), Oriental region, and to Flores, Celebes, North China, and Japan ; $(2127-2129)$ Sphyrapicus (7 sp.), Nearetic region, Mexico, and Bolivia; (2130 - 21332139 ) Campephilus (14 sp.), Neotropical and Nearctic regions; Hylatomus (1 sp.), Nearctic region; (2137 2140) Dryocopus ( $\tilde{5}$ sp.), Mexico to South Brazil, Central and Northern Europe; ( $\left.{ }^{2134}\right)$ Reinwardtipicus (1 sp.), Penang to Borneo; $\left({ }^{2135}{ }^{2136}\right)$ Venilia (2 sp.), Nepal to Borneo; Chrysocolaptes (8 sp.), India and Indo-Malaya; Dendropicus (16 sp.), Tropical and South Africa; Hemicercus (5 sp.), Malabar and Pegu to Malaya; Gecinus (18 sp.), Palæarctic and Oriental regions to Java; $\left({ }^{2151}-{ }^{2156}\right)$ Dendromus (15 sp.), West and South Africa, Zanzibar, and Abyssinia; $\left({ }^{2157}-{ }^{2159}\right)$ Mulleripicus (6 sp.), Malabar, Pegu, Indo-Malaya, and Celebes ; Celeus (17 sp.), Paraguay to Mexico; Nesoceleus ( ${ }^{\text {sp. }}{ }^{8833}$ ) Cuba ; (2162) Chrysoptilus (9 sp.), Chili and South Brazil to Mexico; Brachypternus (5 sp.), India, Ceylon, and China ; (165 2166) Trigo (5 sp.), all India to Malaya; ( $\left.{ }^{2167}\right)$ Gccinulus (2 sp.), South-east Himalayas to Burmah; Centumes (13 sp.), Nearctic Region to Antilles and Venezuela; Chloronerpes (35 sp.), Tropical America, Hayti; (2171) Xiphidiopicus (1 sp.), Cuba; Melancrpes (11 sp.), Brazil to 
Canada, l'orto Rico; Leuconerpes (1 sp.), Bolivia to North Brazil ; Colaptes (9 sp.), La Plata and Bolivia to Arctic America, Greater Antilles; Hypoxanthus (1 sp.), Venezuela and Ecuador; (2187) Geocolaptes (1 sp.), South Africa; Miglyptes (3 sp.), Malaya; Micropternus (8 sp.), India and Ceylon to South China, Sumatra and Borneo.

Family 52.-YUNGID E. (1 Genus, 5 Species.)

\begin{tabular}{|c|c|c|c|c|c|}
\hline \multicolumn{6}{|c|}{ General Distribution. } \\
\hline $\begin{array}{l}\text { NFotROPICAL } \\
\text { St:B-REGIONS. }\end{array}$ & $\begin{array}{c}\text { NEARCTIC } \\
\text { SUB-REGIONS. }\end{array}$ & $\begin{array}{l}\text { PaLiEARCTII } \\
\text { SUB-REGIONS. }\end{array}$ & $\begin{array}{c}\text { ETHIOPIAN } \\
\text { SUB-RLGIONS. }\end{array}$ & $\begin{array}{l}\text { ORIENTAL } \\
\text { SUB-REGiIONS. }\end{array}$ & $\begin{array}{l}\text { AUbTRALIAN } \\
\text { SUB-REGIONS. }\end{array}$ \\
\hline$-\cdots-$ & $--\cdots$ & 1.2 .3 .4 & $1-3-$ & $1--\cdots$ & --- \\
\hline
\end{tabular}

The Wrynecks (Yunx), which constitute this family, are small tree-creeping birds characteristic of the Palæarctic region, but extending into North and East Africa, over the greater part of the peninsula of India (but not to Ceylon), and just reaching the lower ranges of the Himalayas. There is also one species isolated in South Africa.

Famix 53.-INDICATORIDA. (1 Genus, 12 Species.)

\begin{tabular}{|c|c|c|c|c|c|}
\hline \multirow[b]{2}{*}{$\begin{array}{l}\text { NEOTROPICAL } \\
\text { SUB-REGIONS. }\end{array}$} & \multicolumn{4}{|c|}{ General Distribution. } & \multirow[b]{2}{*}{$\begin{array}{l}\text { AUSTRALIAN } \\
\text { Sub-REgions. }\end{array}$} \\
\hline & $\begin{array}{c}\text { NEARCTIC } \\
\text { SUB-REGIONS. }\end{array}$ & $\begin{array}{l}\text { PALAAARCTIC } \\
\text { SUB-REGIONS. }\end{array}$ & $\begin{array}{c}\text { ETHIOPIAN } \\
\text { SUB-REGIONS. }\end{array}$ & $\begin{array}{c}\text { ORIENTAL } \\
\text { SUB-REGIONS. }\end{array}$ & \\
\hline--- & ---- & ---- & $1.2 \cdot 3-$ & --3.4 & ---- \\
\hline
\end{tabular}

The Honey-guides (Indicator) constitute a small family of doubtful affinities; perhaps most nearly allied to the woodpeckers and barbets. They catch bees and sometimes kill small birds; and some of the species are parasitical like the cuckoo. Their distribution is very interesting, as they are found in every part of the Ethiopian region, except Madagascar, and in the Oriental region only in Sikhim and Borneo, being absent from the peninsula of India which is nearest, buth geographically and zoologically, to Africa. 


\section{FAMILY 54.-MEGALAMID Æ. (13 Genera, 81 Species.)}

\begin{tabular}{|c|c|c|c|c|c|}
\hline \multirow[b]{2}{*}{$\begin{array}{l}\text { NEOTROPICAL } \\
\text { SUB-REGIONS. }\end{array}$} & \multicolumn{4}{|c|}{ Gexeral Distribution. } & \multirow[b]{2}{*}{$\begin{array}{l}\text { AUSTRALIAN } \\
\text { SUB-RFGIONS. }\end{array}$} \\
\hline & $\begin{array}{c}\text { NEARCTIC } \\
\text { SUB-REGIONS. }\end{array}$ & $\begin{array}{l}\text { PALAaARtic } \\
\text { SUB-REGIONS. }\end{array}$ & $\begin{array}{c}\text { ETHIOPIAN } \\
\text { SUB-REGIONS. }\end{array}$ & $\begin{array}{l}\text { ORIENTAL } \\
\text { SUB-REGIONS. }\end{array}$ & \\
\hline$-2.3-$ & ---- & ---- & $1.2 .3-$ & 1.2 .3 .4 & --- \\
\hline
\end{tabular}

The Megalæmidæ, or Barbets, consist of rather small, fruiteating birds, of heavy ungraceful shape, but adorned with the inost gaudy colours, especially about the head and neck. They form a very isolated family; their nearest allies being, perhaps, the still more isolated Toucans of South America. Barbets are found in all the tropics except Australia, but are especially characteristic of the great Equatorial forest-zone; all the most remarkable forms being confined to Equatorial America, West Africa, and the Indo-Malay Islands. They are most abundant in the Ethiopian and Oriental regions, and in the latter are universally distributed.

In the beautiful monograph of this family by the Messrs. Marshall, the barbets are divided into three sub-families, as follows :-

Pogonorhynchinæ (3 genera, 15 sp.), which are Ethiopian except the 2 species of Tetragonops, which are Neotropical; Megalæminæ (6 genera, $45 \mathrm{sp}$.), which are Oriental and Ethiopian; and Capitoninæ ( 4 genera, 18 sp.), common to the three regions.

The genera are each confined to a single region. Africa possesses the largest number of peculiar forms, while the Oriental region is richest in species.

This is probably a very ancient group, and its existing distribution may be due to its former range over the Miocene South Palæarctic land, which we know possessed Trogons, Parrots, Apes, and Tapirs, groups which are now equally abundant in Equatorial countries. 
The following is a tabular view of the genera with their distribution :-

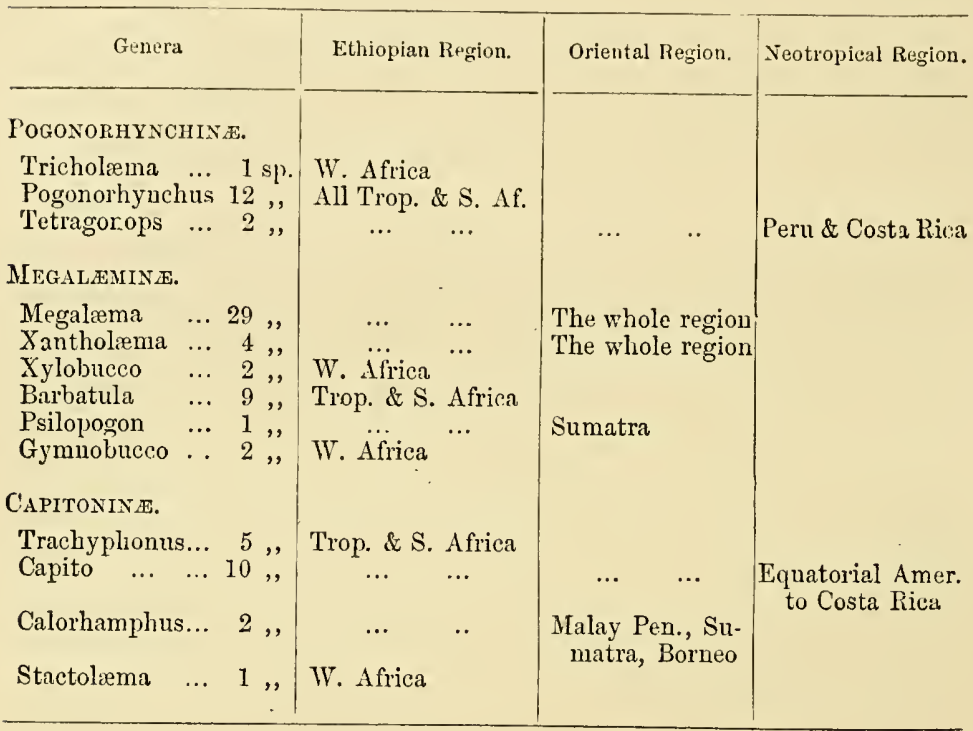

\section{Family 55.-RHAMPHASTID $\mathbb{E}$. (5 Genera, 51 Species.)}

\begin{tabular}{|c|c|c|c|c|c|}
\hline $\begin{array}{l}\text { NEOTROPIC } \\
\text { SUD-REGIONS. }\end{array}$ & $\begin{array}{c}\text { A EARCTIC } \\
\text { SUB-REG ONS. }\end{array}$ & $\begin{array}{l}\text { PAILEARCTIC } \\
\text { SUB-HEGIONS. }\end{array}$ & $\begin{array}{l}\text { ETHIOPIIN } \\
\text { SUB-PFGIONS. }\end{array}$ & \begin{tabular}{c|} 
ORIRNTaL \\
SUB-rEGIUSS.
\end{tabular} & $\begin{array}{l}\text { AUSTRALIAN } \\
\text { SUB-KEGIONS. }\end{array}$ \\
\hline$-2.3-$ & $---\cdots$ & $-\cdots-$ & --- & $-\cdots-\cdots$ & ---- \\
\hline
\end{tabular}

The Tolicans form one of the most remarkable and characteristic families of the Neotropical region, to which they are strictly confined. They differ from all other birds by their long feathered tongues, their huge yet elegant bills, and the peculiar texture and coloration of their plumage. Being fruit-eaters, and strictly adapted for an arboreal life, they are not found beyond the forest regions; but they nevertheless range from Mexico to Paragiay, and from the Atlantic to the Pacific. One genus, 
Andigena, is confined to the forest slopes of the South American Andes. The genera are:-

Rhamphastos (12 sp.), Mexico to South Brazil; Pteroglossus (16 sp.), Nicaragua to South Brazil (Plate XV. Vol. II. p. 28); Selenidera (7 sp.), Veragua to Brazil, east of the Andes; Andigena $(6 \mathrm{sp}$.), the Andes, from Columbia to Bolivia, and West Brazil ; Aulacorhamphus (10 sp.), Mexico to Peru and Bolivia.

\section{Family 56.-MUSOPHAGIDÆ. (2 Genera, 18 Species.)}

\begin{tabular}{|c|c|c|c|c|c|}
\hline \multicolumn{6}{|c|}{ General Distribution. } \\
\hline $\begin{array}{l}\text { NeOTROPICAL } \\
\text { SUD-REGIOAS. }\end{array}$ & $\begin{array}{c}\text { NEARCTIC } \\
\text { SUB-REGIONS. }\end{array}$ & $\begin{array}{l}\text { PaLAearctic } \\
\text { SUB-KEGIONS. }\end{array}$ & $\begin{array}{c}\text { ETHIOPIIN } \\
\text { SUB-REGIONS. }\end{array}$ & $\begin{array}{l}\text { ORIENTAL } \\
\text { SUB-KEGIONS. }\end{array}$ & $\begin{array}{l}\text { A USTRALIAN } \\
\text { SUB-REGIONS. }\end{array}$ \\
\hline$\cdots---$ & ---- & --- & $1.2 .3-$ & ---- & ---- \\
\hline
\end{tabular}

The Musophagidæ, or Plantain-eaters and Turacos, are handsome birds, somewhat intermediate between Toucans and Cuckoos. They are confined to the Ethiopian region and are most abundant in West Africa. The Plantain eaters (Musophaga, $2 \mathrm{sp}$.), are confined to West Africa; the Turacos (Turacus, 16 sp., including the sub-genera Corythaix and Schizorhis) range over all Africa from Abyssinia to the Cape (Plate V. Vol. I. p. 264).

\section{Family 57.-COLIII RE. (1 Genus, 7 Species.)}

\begin{tabular}{|c|c|c|c|c|c|}
\hline \multicolumn{6}{|c|}{ General Distribution. } \\
\hline $\begin{array}{l}\text { NEOTROPICAL } \\
\text { SUB-REGIONS. }\end{array}$ & $\begin{array}{c}\text { NEARCTIC } \\
\text { SUB-REGIONS. }\end{array}$ & $\begin{array}{l}\text { PaLafarctic } \\
\text { SUB-REGIONS. }\end{array}$ & $\begin{array}{c}\text { ETHIOPIAN } \\
\text { SUB-REGIONS. }\end{array}$ & $\begin{array}{c}\text { ORIENTaL } \\
\text { SUB-kEaIONS. }\end{array}$ & $\begin{array}{l}\text { AUSTRALIAN } \\
\text { SUB-REGIONs. }\end{array}$ \\
\hline---- & --- & ---- & $1.2 .3-$ & $-\cdots-$ & $---\cdots$ \\
\hline
\end{tabular}

The Colies, consisting of the single genus Colius, are an anomalous group of small finch-like birds, occuping a position between the Picariæ and Passeres, but of very doubtful affinities. Their range is nearly identical with that of the Musophagidæ, but they are most abundant in South and East Africa. 
Family 58.-CUCULID A. (35 Genera, 180 Species.)

\begin{tabular}{|c|c|c|c|c|c|}
\hline \multicolumn{6}{|c|}{ General Distribution. } \\
\hline $\begin{array}{l}\text { NEOTROPICAL } \\
\text { SUB-REGIONS. }\end{array}$ & $\begin{array}{c}\text { Neaketie } \\
\text { Sub-REgIONS. }\end{array}$ & $\begin{array}{l}\text { PALAEARCTIC } \\
\text { SUB-REGIONS. }\end{array}$ & $\begin{array}{c}\text { ETHIOPIAN } \\
\text { SUB-REGIONS. }\end{array}$ & $\begin{array}{l}\text { ORIENTAL } \\
\text { SUB-REGIONS. }\end{array}$ & $\begin{array}{l}\text { AUSTRALIAN } \\
\text { SUB-REGIONS. }\end{array}$ \\
\hline 1.2 .3 .4 & $1.2 .3-$ & 1.2 .3 .4 & $1.2 .3 \cdot 4$ & 1.2 .3 .4 & 1.2 .3 .4 \\
\hline
\end{tabular}

The Cuculidæ, of which our well-known Cuckoo is one of the most widely distributed types, are essentially a tropical group of weak insectivorous birds, abounding in varied forms in all the warmer parts of the globe, but very scarce or only appearing as migrants in the temperate and colder zones. Many of the smaller Eastern species are adorned with the most intense golden or violet metallic lustre, while some of the larger forms have gaily-coloured bills or bare patches of bright red on the cheeks. Many of the cuckoos of the Eastern Hemisphere are parasitic, laying their eggs in other birds' nests ; and they are also remarkable for the marner in which they resemble other birds, as hawks, pheasants, or drongo-shrikes. The distribution of the Cnckoo family is rather remarkable. They abound most in the Oriental region, which produces no less than 18 genera, of which 11 are peculiar ; the Australian has 8, most of which are also Oriental, but 3 are peculiar, one of these being confined to Celebes and closely allied to an Oriental group; the Ethiopian region has only 7 genera, all of which are Oriental but three, 2 of these being peculiar to Madagascar, and the other common to Madagascar and Africa. America has 11 genera, all quite distinct from those of the Eastern Hemisphere, and only three enter the Nearctic region, one species extending to Canada.

Remembering our conclusions as to the early history of the several regions, these facts enable us to indicate, with considerable probability, the origin and mode of dispersal of the cuckoos. They were almost certainly developed in the Oriental and Palæarctic regions, but reached the Neotropical at a very early date, where they have since been completely isolated. Africa must have long remained without cuckons, the earliest immigration 
being to Madagascar at the time of the approximation of that sub-region to Ceylon and Malaya. A later infusion of Oriental forms took place probably by way of Arabia and Persia, when those countries were more fertile and perhaps more extensive. Australia has also received its cuckoos at a somewhat late date, a few having reached the Austro-Malay Islands somewhat earlier.

The ciassification of the family is somewhat unsettled. For the American genera I follow Messrs. Sclater and Salvin; and, for those of the Old World, Mr. Sharpe's suggestive paper in the Proceedings of the Zoological Society, 1873, p. 600. The following is the distribution of the various genera:-

${ }^{(2195)}$ Phonicophäes (1 sp.), Ceylon; (2196) Rhamphococcyx (1 sp.), Celebes; ( $\left.{ }^{2196}\right)$ Rhinococcyx (1 sp.), Java; (2196 pt. aud 2203) Rhopodytes (6 sp.), Himalayas to Ceylon, Hainan, and Malaya; (2203 pt.) Poliococcyx (1 sp.), Malacca, Sumatra, and Borneo ; ${ }^{2197}$ ) Dasylophus (1 sp.), Philippine Islands; ${ }^{2198}$ ) Lepidogrammus (1 sp.), Philippine Islands; $\left({ }^{2200}\right)$ Zanclostomus (1 sp.), Malaya; ${ }^{(2201)}$ Ceuthmochares (2 sp.), Tropical and Soutl 1 Africa and Madagascar; ( ${ }^{2202}$ ) Taccocua (4 sp.), Himalayas to Ceylon and Malacca ; ${ }^{2204}$ ) Rhinortha (1 sp.), Malacca, Sumatra, Borneo ; ${ }^{(2199)}$ Carpococcyx (1 sp.), Borneo and Sumatra; $\left({ }^{2220}\right)$ Neomorphus (4 sp.), Brazil to Mexico; (2205 ${ }^{2206}$ ) Coua (10 sp.), Madagascar; $\left({ }^{2207}\right)$ Cochlothraustes (1 sp.), Madagascar; $\left({ }^{2221}\right)$ Centropus (35 sp.), Tropical and South Africa, the whole Oriental region, Austro-Malaya and Australia ; $\left({ }^{2213}\right)$ Crotophaga (3 sp.), Brazil to Antilles and Pennsylvania ; ( ${ }^{2212}$ ) Guira (1 sp.), Brazil and Paraguay ; ${ }^{2209}$ ) Geococcyx (2 sp.), Guatemala to Texas and California; $\left({ }^{2211}\right)$ Dromococcyx (2 sp.), Brazil to Mexico; $\left({ }^{2210}\right)$ Diplopterus (1 sp.), Mexico to Ecuador and Brazil ; (2208) Saurothera (4 sp.), Greater Antilles; $\left({ }^{2219}\right)$ Hyetornis (2 sp.), Jamaica and Hayti; ${ }^{(2215}$ ) Piaya (3 sp.), Mexico to West Ecuador and Brazil ; $\left({ }^{2218}\right)$ Morococcyx (1 sp.), Costa Rica to Mexico; (2214) Coccygus (10 sp.), La Plata to Antilles, Mexico and Pennsylvania, Cocos Island; $\left({ }^{2227}\right)$ Cuculus (22 sp.), Palæarctic, Ethiopian, and Oriental regions, to Moluccas and Australia; (2229) Caliecthrus (1 sp.), Papuan Islands; $\left({ }^{2230-3232}\right.$ ) Cacomantis (15 sp.), Oriental aud Australien 
regions to Fiji Islands and Tasmania; $\left({ }^{2233-2237}\right)$ Chrysococcys (16 sp.), Tropical and South Africa, the Oriental and Australian regions to New Zealand and Fiji Islands ; (2238) Surniculus (2 sp.), India, Ceylon, and Malaya ; $\left.{ }^{2239}\right)$ Hicrococcyx (7 sp.), the Oriental region to Amoorland and Celebes; (2240 2241) Coccystes (6 sp.), Tropical and South Africa, the Oriental region, excluding Philippines; (2242) Eudynamis (8 sp.), the Oriental and Australian regions, excluding Sandwich Islands; ( ${ }^{2243}$ ) Scythrops (1 sp.), East Australia to Moluccas and North Celebes.

Family 59.-LEPTOSOMID F. (1 Genus, 1 Species.)

\begin{tabular}{|c|c|c|c|c|c|}
\hline \multicolumn{6}{|c|}{ General Distributron. } \\
\hline $\begin{array}{l}\text { NFOTROPICAL } \\
\text { ST'B-REGIONS. }\end{array}$ & $\begin{array}{c}\text { NEARCTIC } \\
\text { SUB-REGIONS. }\end{array}$ & $\begin{array}{l}\text { PALEARCTic } \\
\text { Sub-REGIONS. }\end{array}$ & $\begin{array}{c}\text { ETHIOPIAN } \\
\text { SUB-REGIONS. }\end{array}$ & $\begin{array}{l}\text { ORIENTAL } \\
\text { SUB-REGIONS. }\end{array}$ & $\begin{array}{l}\text { AUSTRALIAN } \\
\text { SUB-REGIONS. }\end{array}$ \\
\hline--- & $-\cdots$ & --- & ---4 & ---- & --- \\
\hline
\end{tabular}

The Leptosomus discolor, which constitutes this family, is a bird of very abnormal characters, having some affinities both with Cuckoos and Rollers. It is confined to Madagascar (Plate VI. Tol. I. p. 278).

Famili 60.-BUCCONID无. (5 Genera, 43 Species.)

\begin{tabular}{|c|c|c|c|c|c|}
\hline \multicolumn{6}{|c|}{ General Distribution. } \\
\hline $\begin{array}{l}\text { NfotroptCal } \\
\text { Stb-REgIoNs. }\end{array}$ & $\begin{array}{c}\text { NEARCTIC } \\
\text { SuB-REGIONS. }\end{array}$ & $\begin{array}{l}\text { Palmarctic } \\
\text { Sub-refions. }\end{array}$ & $\begin{array}{l}\text { ETHIOPIAN } \\
\text { SUB-REGIONS. }\end{array}$ & $\begin{array}{c}\text { ORIENTAL } \\
\text { SUB-RECIONS. }\end{array}$ & $\begin{array}{l}\text { AUSTRALIAN } \\
\text { SUB-REGIONS. }\end{array}$ \\
\hline$-2.3-$ & --- & $-\cdots-$ & $--\cdots$ & $-\cdots$ & $\cdots--\cdots$ \\
\hline
\end{tabular}

The Pucconidæ, or Puff-birds, are generally of small size and dull colours, with rather thick bodies and dense plumage. They form one of the characteristic Neotropical families, being most abundant in the great Equatorial forest plains, but extending as far north as Guatemala, though absent from the West Indian Islauds.

The genera are:-Bucco (21 sp.), Guatemala to Paraguay, and West of the Andes in Ecuador; Malacoptila (10 sp.), Guatemala 
to Bolivia and Brazil ; Nonnula (3 sp.), Amazon and Columbia; Monasa (7 sp.), Costa Rica to Brazil ; Chelidoptera (2 sp.), Columbia and Guiana to Brazil.

Fanily 61.-GaLbUlid E. (6 Genern, 19 Speciss.)

\begin{tabular}{|c|c|c|c|c|c|}
\hline \multirow[b]{2}{*}{$\begin{array}{l}\text { NEOTROPICAL } \\
\text { SUB-REGIONS. }\end{array}$} & \multicolumn{4}{|c|}{ Gexeral Distribution. } & \multirow[b]{2}{*}{$\begin{array}{l}\text { AUSTRALIAN } \\
\text { SUB-REGIONS. }\end{array}$} \\
\hline & $\begin{array}{l}\text { NEARCTIG } \\
\text { SUB-HEGIONS. }\end{array}$ & $\begin{array}{l}\text { PALEAARCTIC } \\
\text { SUB-KEGIONS. }\end{array}$ & $\begin{array}{c}\text { Ethiopian } \\
\text { SCB-REGIONS. }\end{array}$ & $\begin{array}{l}\text { ORIENTAL } \\
\text { SUB-FEGIONS. }\end{array}$ & \\
\hline$-2 \cdot 3-$ & $---\cdots$ & ---- & --- & ---- & --- \\
\hline
\end{tabular}

The Galbulidæ, or Jacamars, are small slender birds, of generally metallic plumage; somewhat resembling in form the Beeeaters of the Old World but less active. They have the same general distribution as the last family, but they do not occur west of the Equatorial Andes. The genera are:-

Galbula (9 sp.), Guatemala to Brazil and Bolivia; Urogulba (2 sp.), Guiana and the lower Amazon; Brachygalba (4 sp.), Venezuela to Brazil and Bolivia; Jacamaralcyon (1 sp.), Brazil ; Jacamerops (2 sp.), Panama to the Amazon; Galbalcyrhynchus (1 sp.), Upper Amazon.

Family 62.-CORACIID E. (3 Genera, 19 Species.)

\begin{tabular}{|c|c|c|c|c|c|}
\hline \multirow[b]{2}{*}{$\begin{array}{l}\text { NEGTROPICAL } \\
\text { StE-REG ONS. }\end{array}$} & \multicolumn{4}{|c|}{ General Distribution. } & \multirow[b]{2}{*}{$\begin{array}{l}\text { At:STRALIAN } \\
\text { StE-RLE:IONS. }\end{array}$} \\
\hline & $\begin{array}{c}\text { NeArCtic } \\
\text { SUB-REgIONS. }\end{array}$ & $\begin{array}{l}\text { Palearctic } \\
\text { SUB- EEgIONS. }\end{array}$ & $\begin{array}{l}\text { ETHIOPIAN } \\
\text { SUB-REGIONS. }\end{array}$ & $\begin{array}{c}\text { ORIENTAL } \\
\text { SUL-FiEgions. }\end{array}$ & \\
\hline---- & ---- & 1.2 .3 .4 & 1.2 .3 .4 & 1.2 .3 .4 & $1.2--$ \\
\hline
\end{tabular}

The Rollers are a family of insectivorous birds allied to the Bee-eaters, and are very characteris'ic of the Ethiopian and Oriental regions; but one species (Corcacias garrula) spreads over the Palrearctic region as far north as Sweden and the Altai mountains, while the genus Eurystomus reaches the Amoor valley, Australia, and the Solomon Islands. The distribution of the genera is as follows:-

Coracias ( $8 \mathrm{sp}$.$) , the whole Ethiopian region, the Oriental$ 
region except Indo-Malaya, the Palæarctic to the abovenamed limits, and the island of Celebes on the confines of the Australian region; Eurystomus (8 sp.), West and East Africa and Madagascar, the whole Oriental region except the Peninsula of India, and the Australian as far as Australia and the Solomon Islands; Brachypteracias (possibly allied to Leptosomus ?) (4 sp.), Madagascar only, but these abnormal birds form a distinct sub-family, and according to Mr. Sharpe, three genera, Brachypteracias, Atelornis, and Geobiastes.

A most remarkable feature in the distribution of this family is the occurrence of a true roller (Coracias temminckii) in the island of Celebes, entirely cut off from the rest of the genus, which does not occur again till we reach Siam and Burmah.

The curious Pseudochelidon from West Africa may perhaps belong to this family or to the Cypselidæ. (Ibis. 1861, p. 321.)

Family 63.-MEROPID $\approx$. (5 Genera, 34 Species.)

\begin{tabular}{|c|c|c|c|c|c|}
\hline \multicolumn{6}{|c|}{ General Distribution. } \\
\hline $\begin{array}{l}\text { NEOTROPICAL } \\
\text { SUB-REGIONS. }\end{array}$ & $\begin{array}{c}\text { NEARCTIC } \\
\text { SUB-REGIONS. }\end{array}$ & $\begin{array}{l}\text { PALEARCTIC } \\
\text { SUB-REGIONS. }\end{array}$ & $\begin{array}{l}\text { ETHIOPIIN } \\
\text { SUD-REGIONS. }\end{array}$ & $\begin{array}{c}\text { ORIFATAL } \\
\text { SUB-KEGIONS. }\end{array}$ & $\begin{array}{l}\text { AUSTRALIAN } \\
\text { SUB-REGIONS. }\end{array}$ \\
\hline$-\cdots-$ & ---- & $1.2--$ & 1.2 .3 .4 & 1.2 .3 .4 & $1.2--$ \\
\hline
\end{tabular}

The Meropidæ, or Bee-eaters, have nearly the same distribution as the Rollers, but they do not penetrate quite so far either into the Eastern Palæarctic or the Australian regions. The distribution of the genera is as follows:-

Merops (21 sp.), has the range of the family extending on the north to South Scandinavia, and east to Australia and New Guinea; Nyctiornis (3 sp.), the Oriental region, except Ceylon and Java; Meropogon (1 sp.), Celebes; Meropiscus (3 sp.), West Africa; Melittophagus (6 sp.), Ethiopian region, except Madagascar. 
Family $64 .-$ TODIDE. (1 Genus, 5 Species.)

\begin{tabular}{|c|c|c|c|c|c|}
\hline \multicolumn{6}{|c|}{ Gexeral Distribution. } \\
\hline $\begin{array}{l}\text { NeOTROPICIL } \\
\text { SUR-REGLUNS. }\end{array}$ & $\begin{array}{c}\text { \EARCT C } \\
\text { SUB-LEG ONS. }\end{array}$ & $\begin{array}{l}\text { PaLLEARCTIC } \\
\text { : UB-KEGTONS. }\end{array}$ & $\begin{array}{c}\text { ETHIOPIAN } \\
\text { SUB-REGIONS. }\end{array}$ & $\begin{array}{c}\text { OntENTAL } \\
\text { SUB-HEGTONS. }\end{array}$ & $\begin{array}{l}\text { AERTRALIAN } \\
\text { SEB-REGIONS. }\end{array}$ \\
\hline---4 & $--\cdots-$ & $-\cdot--$ & ---- & ---- & --- \\
\hline
\end{tabular}

The Todies are delicate, bright-coloured, insectivorous birds, of small size, and allied to the Motmots, although externally more resembling flycatchers. They are wholly confined to the greater Antilles, the islands of Cuba, Hayti, Jamaica, and Porto Rico having each a peculiar species of Todus, while another species, said to be from Jamaica, has been recently described (Hlate XVI. Vol. II. p. 67).

Family 65.-MOMOTID $\approx . \quad$ (6 Genera, 17 Species.)

\begin{tabular}{|c|c|c|c|c|c|}
\hline \multicolumn{6}{|c|}{ General Distribution. } \\
\hline $\begin{array}{l}\text { NEOTROPIC IL } \\
\text { SUB-REGIONS. }\end{array}$ & $\begin{array}{c}\text { NEARCT-C } \\
\text { SUB-REGIONS. }\end{array}$ & $\begin{array}{c}\text { PALEARCTIC } \\
\text { SUB-HEGIONS. }\end{array}$ & $\begin{array}{l}\text { ETHIOPIIN } \\
\text { SUB-REGIONS. }\end{array}$ & $\begin{array}{l}\text { ORIENTAL } \\
\text { SUB-HEGIONS. }\end{array}$ & $\begin{array}{l}\text { Australian } \\
\text { SUb-rEgiuNs. }\end{array}$ \\
\hline$-2 \cdot 3-$ & --- & $--\cdot-$ & ---- & --- & -- \\
\hline
\end{tabular}

The Motmots range from Mexico to Paraguay and to the west coast of Ecuador, but seem to have their head-quarters in Central America, five of the genera and eleven species occurring from Panama northwards, two of the genera not occurring in South America. The genera are as follows:-

Momotus (10 sp.), Mexico to Brazil and Bolivia, one species extending to Tobago, and one to Western Ecuador ; Urospatha (1 sp.), Costa Rica to the Amazon ; Baryphthengus (1 sp.), Brazil and Paraguay; Hylomanes (2 sp.), Guatemala; Prionirhynchus (2 sp.), Guatemala to Upper Amazon; Eumomota (1 sp.), Honduras to Chiriqui. 
Fanily 66.--TROGONIDAE. (7 Gemara, 44 Species.)

\begin{tabular}{|c|c|c|c|c|c|}
\hline \multicolumn{6}{|c|}{ Geveral Distribution: } \\
\hline $\begin{array}{l}\text { NEOTROPICAL } \\
\text { S'B-KEGIONS. }\end{array}$ & $\begin{array}{c}\text { NEARCTIC } \\
\text { Sub-REGions. }\end{array}$ & $\begin{array}{l}\text { Paldarctic } \\
\text { Sub-1. Ecions. }\end{array}$ & $\begin{array}{l}\text { ETHLPPAN } \\
\text { Stb-REGLOS. }\end{array}$ & $\begin{array}{c}\text { ORARTTAL } \\
\text { SUB-fiEstovs. }\end{array}$ & 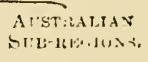 \\
\hline$-2 \cdot 3 \cdot 4$ & --- & $--\cdots$ & $1.2 .3-$ & $1 \cdot 2 \cdot 3 \cdot 4$ & $--\cdots$ \\
\hline
\end{tabular}

The Trogons form a well-marked family of insectivorous forest-haunting bircls, whose dense yet puffy plumage exhibits the most exquisite tints of pink, crimson, orange, brown, or metallic green, often relieved by delicate bands of pure white. In one Guatemalan species the tail coverts are enormously lengthened into waving plumes of rich metallic green, as graceful and nurvellous as those of the Paradise-birds. Trogons are tolerably abundant in the Neotropical and Oriental regions, and are represented in Africa by a single species of a peculiar genus. The genera now generally admitted are the following :Trogon (24 sp.), Paragnay to Mexico, and west of the Andes in Ecuador; Temnotrogon (1 sp.), Hayti; Prionoteles (1 sp.), Cuba (Plate XVII. Vol. II. p. 67); Apaloulerma (2 sp.), Tropical and South Africa; Harpactes (10 sp.), the Oriental region, excluding China; Pharomasrus (5 sp.), Amazonia to Guatemala; Euptilotis (1 sp.), Mexico.

Remains of Trogon have been found in the Miocene deposits of France; and we are thus able to understand the existing distribution of the family. At that exceptionally mild period in the northern hemisphere, these birds may have ranged over all Europe and North America; but, as the climate became more severe they gradually became restricted to the tropical regions, where alone a sufficiency of fruit and insect-food is found all the year round. 


\section{Family 67.-AICEI)INID E. (19 Genera, 125 Species.)}

\begin{tabular}{|c|c|c|c|c|c|}
\hline \multicolumn{6}{|c|}{ Gimereral Distribution. } \\
\hline $\begin{array}{l}\text { Nrotropical } \\
\text { StB-REGIONS. }\end{array}$ & $\begin{array}{l}\text { NEARCTIC } \\
\text { SUB-REGLONS. }\end{array}$ & $\begin{array}{l}\text { Paldiarctic } \\
\text { SUE-IiEg Ionss. }\end{array}$ & $\begin{array}{l}\text { ETHIOPIAN } \\
\text { SUB-REGIONS. }\end{array}$ & $\begin{array}{l}\text { ORIENTal } \\
\text { SUb-rEgions. }\end{array}$ & $\begin{array}{l}\text { AUSTRALIAN } \\
\text { SUB-REgIONS. }\end{array}$ \\
\hline 1.2 .3 .4 & 1.2 .3 .4 & 1.2 .3 .4 & $1 \cdot 2 \cdot 3 \cdot 4$ & 1.2 .3$. & $1 \cdot 2 \cdot 3 \cdot 4$ \\
\hline
\end{tabular}

The Kingfishers are distributed universally, but very unequally, over the globe, and in this respect present some of the most curious anomalies to be found among birds. They have their metropolis in the eastern half of the Malay Archipelago (our first Australian sub-region), from Celebes to New Guinea, in which district no less than 13 out of the 19 genera occur, 8 of them being peculiar; and it is probable that in no other equally varied group of universal distribution, is so large a proportion of the generic forms confined to so limited a district. From this centre kingfishers decrease rapidly in every direction. In Australia itself there are only 4 genera with 13 species; the whole Oriental region has only 6 genera, 1 being peculiar; the Ethiopian also 6 genera, but 3 peculiar; and each of these have less than half the number of species possessed by the Australian region. The Palæarctic region possesses only 3 genera, all derived from the Oriental region; but the most extraordinary deficiency is shown by the usually rich Neotropical region, which possesses but a single genus, common to the larger part of the Eastern Hemisphere, and the same genus is alone found in the Nearctic region, the only difference being that the former possesses eight, while the latter has but a single species. These facts almost inevitably lead to the conclusion that America long existed without kingfishers; and that in comparatively recent times (perhaps during the Miocene or Pliocene period), a species of the old World genus, Ceryle, found its way into North America, and spreading rapidly southward along the great river-valleys has become differentiated in South America into the fer closely allied forms that alone inhabit that vast country-the richest in the world in 
fresh-water fish, and apparently the best fitted to sustain a varied and numerous body of kingfishers.

The names of the genera, with their distribution and the number of species in each, as given by Mr. Sharpe in his excellent monograph of the family, is as follows:-

Alcedo (9 sp.), Palæarctic, Ethiopian, and Oriental regions (but absent from Madagascar), and extending into the Austro-Malayan sub-region; Corythornis (3 sp.), the whole Ethiopian region; Alcyone (7 sp.), Australia and the Austro-Malayan sub-region, with one species in the Philippine Islands ; Ceryle (13 sp.), absent only from Australia, the northern half of the Palæarctic region, and Madagascar ; Pelargopsis (9 sp.), the whole Oriental region; and extending to Celebes and Timor in the Austro-Malayan subregion; Ceyx (11 sp.), the Oriental region and Austro-Malayan subregion, but absent from Celebes, and only one species in continental India and Ceylon; Ceycopsis (1 sp.), Celebes; Myioceyx (2 sp.), West Africa; Ipsidina (4 sp.), Ethiopian region; Syma (2 sp.), Papua and North Australia; Halcyon (36 sp.), Australian, Oriental, and Ethiopian regions, and the southern part of the Palæarctic ; Dacelo (6 sp.), Australia and New Guinea; Todirhamphus (3 sp.), Eastern Pacific Islands only; Monachalcyon (1 sp.), Celebes; Caridonax (1 sp.), Lombok and Flores; Carcineutes (2 sp.), Siam to Borneo and Java ; Tanysiptera (14 sp.), Moluccas New Guinea, and North Australia (Plate X. Vol. I. p. 414); Cittura (2 sp.), Celebes group; Melidora (1 sp.), New Guinea.

\section{Family 68.-BUCEROTIDIE. (12 Genera, 50 Species.)}

\begin{tabular}{|c|c|c|c|c|c|}
\hline $\begin{array}{l}\text { NFotropiCal } \\
\text { StrB-REGIONS. }\end{array}$ & $\begin{array}{c}\text { NEARCTIC } \\
\text { Sub-REGIONS. }\end{array}$ & $\begin{array}{l}\text { PAL_EARCTIC } \\
\text { SUB-REGIONS. }\end{array}$ & $\begin{array}{c}\text { ETHIOPIAN } \\
\text { SUB-REGIONS. }\end{array}$ & $\begin{array}{c}\text { ORIENTAL } \\
\text { SUB-REGIONS. }\end{array}$ & $\begin{array}{l}\text { AUSTRALIAN } \\
\text { SUB-REGIONS. }\end{array}$ \\
\hline---- & ---- & ---- & $1.2 .3-$ & 1.2 .3 .4 & $1---$ \\
\hline
\end{tabular}

The Hornbills forn an isolated group of generally large-sized birds, whose huge bills form their most prominent feature. They are popularly associated with the American Toucans, but have no close relationship to them, and are now generally 
considered to show most resemblance, thongh still a very distant one, to the kingfishers. They are abundant in the Ethiopian and Oriental regions, and extend eastward to the Solomon Islands. Their classification is very unsettled, for though they have been divided into more than twenty genera they have not yet been carefully studied. The following grouping of the genera-referring to the numbers in the Hand List-must therefore be considered as only provisional :-

(1957 1958 1963) Buceros (6 sp.), all Indo-Malaya, Arakan, Nepal and the Neilgherries (Plate IX. Vol. I. p. 339); (1959 - 1961) Hydrocissa (7 sp.), India and Ceylon to Malaya and Celebes; ${ }^{\left({ }^{1962}\right)}$ Berenicornis (2 sp.), Sumatra and West Africa; (1964) Calao (3 sp.), Tennaserim, Malaya, Moluccas to the Solomon Islands ; (1965) Aceros (1 sp.), South-east Himalayas ; (1966 1967) Cranorrhinus (3 sp.), Malacca, Sumatra, Borneo, Philippines, Celebes; ( ${ }^{1968)}$ Penelopides (1 sp.), Celebes ; (1969 - 1971) Tockus (15 sp.), Tropical and South Africa; (1972) Rhinoplax (1 sp.), Sumatra and Borneo; $(1973-1975)$ Bycanistes (6 sp.), West Africa with East and South Africa; (1976 1977) Meniceros (3 sp.), India and Ceylon to Tenasserim; ( $\left.{ }^{1978}\right)$ Bucorvus (2 sp.), Tropical and south Africa.

Family 69.-UPUPID Æ. (1 Genus, 6 Species.)

\begin{tabular}{|c|c|c|c|c|c|}
\hline \multicolumn{6}{|c|}{ General Distribution. } \\
\hline $\begin{array}{l}\text { NrOTROPICAL } \\
\text { ST:B-REGIONS. }\end{array}$ & $\begin{array}{l}\text { NEARCTIC } \\
\text { SUB-REGIONS. }\end{array}$ & $\begin{array}{l}\text { PaLAaRCTIC } \\
\text { SUB-REGIONS. }\end{array}$ & $\begin{array}{c}\text { ETHIOPIAN } \\
\text { SUB-REGIONS. }\end{array}$ & $\begin{array}{l}\text { ORIENTAL } \\
\text { SUB-REGIONS. }\end{array}$ & $\begin{array}{l}\text { AUSTRALIAN } \\
\text { SUB-REGIONS. }\end{array}$ \\
\hline--- & --- & $-2-4$ & 1.2 .3 .4 & $1.2 .3-$ & -- \\
\hline
\end{tabular}

The Hoopoes form a small and isolated group of semi-terrestrial insectivorous birds, whose nearest affinities are with the Hornbills. They are most characteristic of the Ethiopian region, but extend into the South of Europe and into all the continental divisions of the Oriental region, as well as to Ceylou, and northwards to Pekin and Mongolia. 
Fayily 70.-TRRiSORID R. (I Genus, 12 Species.)

\begin{tabular}{|c|c|c|c|c|c|}
\hline \multicolumn{6}{|c|}{ General Distribution. } \\
\hline $\begin{array}{l}\text { Neotropical } \\
\text { SUd-REgIONS. }\end{array}$ & $\begin{array}{c}\text { Nearctic } \\
\text { SUB-REGIONS. }\end{array}$ & $\begin{array}{l}\text { Palizarctic } \\
\text { Sub-nEgions. }\end{array}$ & $\begin{array}{c}\text { ETHIOPIAN } \\
\text { SUB-REgloNs. }\end{array}$ & $\begin{array}{c}\text { ORIENTal } \\
\text { SUR-kEgloNs. }\end{array}$ & $\begin{array}{l}\text { AUSTR.ALIAN } \\
\text { SUB-REIIONS. }\end{array}$ \\
\hline---- & --- & ---- & $1.2 .3-$ & --- & --- \\
\hline
\end{tabular}

The Irrisors are birls of generally metallic plumage, which have often been placed with the Epunachidæ and near the Sunbirds, or Birds of Paradise, but which are undoubtedly allied to the Hoopoes. They are strictly confined to the continent of Africa, ranging from Abyssinia to the west coast, and southward to the Cape Colony. They have been divided into several subgenera which it is not necessary here to notice (Plate IV. Vol. I. p. 261).

FAMILy 71.-PODARGID在. (3 Genera, 20 Species.)

\begin{tabular}{|c|c|c|c|c|c|}
\hline $\begin{array}{l}\text { NFOTROPICAL } \\
\text { St'B-REGIONS. }\end{array}$ & $\begin{array}{l}\text { NEARCTIC } \\
\text { SUB-REGIONS. }\end{array}$ & $\begin{array}{c}\text { PaL.EARCTIC } \\
\text { Sub-ILEGIONS. }\end{array}$ & $\begin{array}{c}\text { ETHIOPIAN } \\
\text { SUB-REGIONS. }\end{array}$ & $\begin{array}{c}\text { ORIENTAL } \\
\text { SUB-REGioNs. }\end{array}$ & $\begin{array}{c}\text { AUstralian } \\
\text { SUB-REGIONG. }\end{array}$ \\
\hline$--\cdots$ & $\ldots-$ & --- & --- & 1.2 .3 .4 & $1.2-$ \\
\hline
\end{tabular}

The Podargidæ, or Frog-mouths, are a family of rather largesized nocturnal insectivorous birds, elosely allied to the Goatsuckers, but distinguished by their generally thicker bills, and especially by hunting for their food on trees or on the ground, instead of seizing it on the wirg. They abound most in the Australian region, but one genus extends over a large part of the Oriental region. The following are the genera with their distribution :Podargus (10 sp.), Australia, Tasmania, and the Papuan Islands (Plate XII. Vol. I. p. 441); Batrachostomus (6 sp.), the Oriental region (excluding Philippine Islands and China) and the northern Moluccas ; AEgotheles (4 sp.), Australia, Tasmania, and Papuan Islands. 


\section{Fanily 72.-STEATORNITHID E. (1 Genus, 1 Species.)}

\begin{tabular}{|c|c|c|c|c|c|}
\hline \multirow[b]{2}{*}{$\begin{array}{l}\text { NeOTROPICAL, } \\
\text { Sr-B-REGIONS. }\end{array}$} & \multicolumn{4}{|c|}{ Gexmral Disthinution. } & \multirow[b]{2}{*}{$\begin{array}{l}\text { AUSTRALIAN } \\
\text { SUB-REgIONS }\end{array}$} \\
\hline & $\begin{array}{c}\text { NEARCTC } \\
\text { SUB-REGIONS. }\end{array}$ & $\begin{array}{l}\text { Pal.earctic } \\
\text { Seb-hegions. }\end{array}$ & $\begin{array}{c}\text { ETHIOPIIN } \\
\text { SUB-REGIONS. }\end{array}$ & $\begin{array}{c}\text { ORIENTAL } \\
\text { SUE-HEGIONS. }\end{array}$ & \\
\hline$-2--$ & ---- & --- & --- & ---- & ---- \\
\hline
\end{tabular}

This family contains a single bird - the Guacharo-forming the genus Steatornis, first discovered by Humboldt in a cavern in Venezuela, and since found in deep ravines near Bogota, and also in Trinidad. Although apparently allied to the Goat-suckers it is a vegetable-feeder, and is altogether a very anomalous bird whose position in the system is still undetermined.

\section{Fanily 73.-CAPfiMULGIDAE. (17 Genera, 91 species.)}

\begin{tabular}{|c|c|c|c|c|c|}
\hline \multicolumn{6}{|c|}{ General Distribution. } \\
\hline $\begin{array}{l}\text { NEOTROPICAL } \\
\text { SUB-REGIONS. }\end{array}$ & $\begin{array}{c}\text { Nearctic } \\
\text { SUb-REgions. }\end{array}$ & $\begin{array}{l}\text { PALAARCTIC } \\
\text { SUB-HEGIONS. }\end{array}$ & $\begin{array}{c}\text { Ethiopian } \\
\text { Strb-REgions. }\end{array}$ & $\begin{array}{c}\text { Oriental. } \\
\text { Sub-FiEgIONS. }\end{array}$ & $\begin{array}{l}\text { AUSTRALIAN } \\
\text { SUB-REGIONS. }\end{array}$ \\
\hline 1.2 .3 .4 & $1.2 .3 \cdot 4$ & 1.2 .3 .4 & 1.2 .3 .4 & 1.2 .3 .4 & $1.2--$ \\
\hline
\end{tabular}

The Goat-suckers, or Night-jars, are crepuscular insectivorous birds, which take their prey on the wing, and are remarkable for their soft and beautifully mottled plumage, swift and silent flight, and strange cries often imitating the human voice. They are universally distributed, except that they do not reach New Zealand or the remoter Pacific Islands. The South American genus, Nyctibius, differs in structure and habits from the other goat-suckers and should perhaps form a distinct family. More than half the genera inhabit the Neotropical region. The genera are as follows:-

Nyctibius (6 sp.), Brazil to Guatemala, Jamaica; Caprimulgus (35 sp.), Palæarctic, Oriental, and Ethiopian regions, with the Austro-Malay Islands and North Australia; Hydropsalis (8 sp.), Tropical South America to La Plata; Antrostomus (10 
sp.), La Plata and Bolivia to Canada, Cuba; Stenopsis ( $t$ sp.), Martinique to Columbia, West Peru and Chili ; Siphonorhis (1 sp.), Jamaica; Heleothreptus (1 sp.), Demerara ; Nyctidromus (2 sp.), South Brazil to Central America; Scortornis (3 sp.), West and East Africa; Macrodipteryx (2 sp.), West and Central Africa; Cosmetornis (1 sp.), all Tropical Africa ; Podager (1 sp.), Tropical South America to La Plata; Lurocalis (2 sp.), Brazil and Guiana; Chordeiles (8 sp.), Brazil and West Peru to Canada, Porto Rico, Jamaica; Nyctiprogne (1 sp.), Brazil and Amazonia; Eurostopodus (2 sp.), Australia and Papuan Islands; Lyncornis (4 sp.), Burmah, Philippines, Borneo, Celebes.

Family 74 -CYPSELID $\nRightarrow . \quad$ (7 Genera, 53 Species.)

\begin{tabular}{|c|c|c|c|c|c|}
\hline \multicolumn{6}{|c|}{ General Distribution. } \\
\hline $\begin{array}{l}\text { NEOTROPIOAL } \\
\text { StB-REGIONS. }\end{array}$ & $\begin{array}{c}\text { NEARCTIC } \\
\text { SUB-REGIONS. }\end{array}$ & $\begin{array}{l}\text { PaLfaARCTIC } \\
\text { SUb-rEGIONS. }\end{array}$ & $\begin{array}{c}\text { ETHIOPIAN } \\
\text { SUB-REGIONS. }\end{array}$ & $\begin{array}{c}\text { ORIENTAL } \\
\text { SUB-REGIONS. }\end{array}$ & $\begin{array}{l}\text { AUSTRALIAN } \\
\text { SUB-REGIONg }\end{array}$ \\
\hline 1.2 .3 .4 & 1.2 .3 .4 & $1.2 .3 \cdot 4$ & 1.2 .3 .4 & 1.2 .3 .4 & $1.2 .3-$ \\
\hline
\end{tabular}

The Swifts can almost claim to be a cosmopolitan group, but for their absence from New Zealand. They are most abundant both in genera and species in the Neotropical and Oriental regions. The following is the distribution of the genera:-

Cypselus ( $1 \mathrm{sp}$. ), absent only from the whole of North America and the Pacific; Panyptila (3 sp.), Guatemala and Guiana, and extending into North-west America; Collocalia (10 sp.), Madagascar, the whole Oriental region and eastward through New Guinea to the Marquesas Islands; Dendrochelidon (5 sp.), Oriental region and eastward to New Guinea; Chotura (15 sp.), Continental America (excluding South Temperate), West Africa and Madagascar, the Oriental region, North China and the Amoor, Celebes, Australia; Hemiprocne (3 sp.), Mexico to La Plata, Jamaica and Hayti ; Cypseloides (2 sp.), Brazil and Peru ; Nephocetes (2 sp.), Cuba, Jamaica, North-west America. 


\section{FAMILY 75.-TROCHILID Æ. (118 Genera, 390 Species.)}

\begin{tabular}{|c|c|c|c|c|c|}
\hline \multirow[b]{2}{*}{$\begin{array}{l}\text { NEOTROPICAL } \\
\text { SUB-REOIONS. }\end{array}$} & \multicolumn{4}{|c|}{ Geseral Distribution. } & \multirow[b]{2}{*}{$\begin{array}{l}\text { Australian } \\
\text { SUb-REgIONS. }\end{array}$} \\
\hline & $\begin{array}{c}\text { NEARCTIC } \\
\text { SUB-REOIONS. }\end{array}$ & $\begin{array}{l}\text { PalaARCTIC } \\
\text { SUB-REOIONS. }\end{array}$ & $\begin{array}{l}\text { ETHIOPIAN } \\
\text { SUB-REGIONS. }\end{array}$ & $\begin{array}{l}\text { ORIENTAL } \\
\text { SUB-REGIONS. }\end{array}$ & \\
\hline $1.2 .3 \cdot 4$ & 1.2 .3 .4 & ---- & ---- & ---- & --- \\
\hline
\end{tabular}

The wonderfully varied and beautiful Humming-Birds are. confined to the American continent, where they range from Sitka to Cape Horn, while the island of Juan Fernandez has two peculiar species. Only 6 species, belonging to 3 genera, are found in the Nearctic region, and most of these have extended their range from the south. They are excessively abundant in the forest-clad Andes from Mrexico to Chili, some species extending up to the limits of perpetual snow; but they diminish in number and variety in the plains, however luxuriant the vegetation. In place of giving here the names and distribution of the numerous genera into which they are now divided (which will be found in the tables of the genera of the Neotropical regiou), it may be more useful to present a summary of their distribution in the sub-divisions of the American continent, as follows:-

Genera in each Sub-region

Peculiar Genera $\quad \ldots \quad \ldots$

Species in each Sub-region

\begin{tabular}{|c|c|c|c|c|}
\hline $\begin{array}{c}\text { Sub- } \\
\text { region I. } \\
\text { (Patagonia } \\
\& \mathrm{~S} \text {. Andes.) }\end{array}$ & $\begin{array}{l}\text { Sub- } \\
\text { region II. } \\
\text { (Tropical } \\
\text { S. Amer.) }\end{array}$ & $\begin{array}{l}\text { Sub. } \\
\text { region iII. } \\
\text { (Tropical } \\
\text { (N. Amer.) }\end{array}$ & $\begin{array}{l}\text { Sub- } \\
\text { region IV. } \\
\text { (Antilles.) }\end{array}$ & $\begin{array}{l}\text { Nearctic } \\
\text { region. } \\
\text { (Temip. } \\
\text { N. Amer.) }\end{array}$ \\
\hline 10 & 90 & 41 & 8 & 3 \\
\hline 3 & 58 & 14 & 5 & 0 \\
\hline 15 & 275 & 100 & 18 & 6 \\
\hline
\end{tabular}

The island of Juan Fernandez has two species, and Masafuera, an island beyond it, one; the three forming a peculiar genus. The island of Tres Marias, about 60 miles from the west coast of Mexico, possesses a peculiar species of humming-bird, and the Bahamas two species; but none inhabit either the Falkland Islands or the Galapagos.

Like most groups which are very rich in species and in generic forms, the humming-birds are generally very local, small VOL. II. 
generic groups being confined to limited districts; while single mountains, valleys, or small islands, often possess species found nowhere else. It is now well ascertained that the Trochilidæe are really insectivorous birds, although they also feed largely, but probably never exclusively, on the nectar of flowers. Their nearest allies are undoubtedly the Swifts; but the wide gap that now separates them from these, as well as the wonderful variety of form and of development of plumage, that is found among them, alike point to their origin, at a very remote period, in the forests of the once insular Andes. There is perhaps no more striking contrast of the like nature, to be found, than that between the American kingfishers-confined to a few closely allied forms of one OId World genus-and the American humming-birds with more than a hundred diversified generic forms unlike everything else upon the globe; and we can hardly imagine any other cause for this difference, than a (comparatively) very recent introduction in the one case, and a very high antiquity in the other.

\section{General Remarks on the Distribution of the Piearioe.}

The very heterogeneous mass of birds forming the Order Picariæ, contains 25 families, 307 genera and 1,604 species. This gives abont 64 species to each family, while in the Passeres the proportion is nearly double, or 111 species per family. There are, in fact, only two very large families in the Order, which happen to be the first and last in the series-Picidæ and Trochilidæ. Two others-Cuculidæ and Alcedinidæ-are rather large; while the rest are all small, seven of them consisting only of a single genus and from one to a dozen species. Only one of the families-Alcedinidx-is absolutely cosmopolitan, but three others are nearly so, Caprimulgida and Cypselidæ being only absent from New Zealand, and Cuculidæ from the Canadian sub-region of North America. Eleven families inhabit the Old World only, while seven are confined to the New World, only one of these-Trochilidæ-being common to the Neotropical and Nearctic regions.

The Picariæ are highly characteristic of tropical fạnas, for 
while no less than 15 ont of the 25 families are exclusively tropical, none are confined to, or have their chief development in, the temperate regions. They are best represented in the Ethiopian region, which possesses 17 families, 4 of which are peculiar to it; while the Oriental region has only 14 families, none of which are peculiar. The Neotropical region has also 14 families, but 6 of them are peculiar. The Australian region has 8, the Palæarctic 9 and the Nearctic 6 families, but none of these are peculiar. We niay see a reason for the great specialization of this tropical assemblage of birds in the Ethiopian and Neotropical regions, in the fact of the large extent of land on both sides of the Equator which these two regions alone possess, and their extreme isolation either by sea or deserts: from other regions, - an isolation which we know was in both cases much greater in early Tertiary times. It is, perhaps, for a similar reason that we here find hardly any trace of the connection between Australia and South America which other groups exhibit; for that connection has most probably been effected by a former communication between the temperate southern extremities of those two continents. The most interesting and suggestive fact, is that presented by the distribution of the Megalæmidæ and Trogonidæ over the tropics of America, Africa, and Asia. In the absence of palæontological evidence as to the former history of the Megalæmidæ, we are unable to say positively, whether it owes its present distribution to a former closer union between these continents in intertropical latitudes, or to a much greater northern range of the group at the period when a luxuriant sub-tropical vegetation extended far toward the Aretic regions; but the discovery of Trogon in the Miocene deposits of the South of France renders it almost certain that the latter is the true explanation in the case of both these families.

The Neotropical region, owing to its enormous family of loumming-birds, is by far the richest in Picariæ, possessing nearly half the total number of species, and a still larger proportion of genera. Three families, the Bucerotidæ, Meropidæ and Coraciida are equally characteristic of the Oriental and 
Fthiopian regions, a few ontlying species only entering the Australian or the Palæarctic regions. One family (Todidæ) is confined to the West Indian Islands; and another (Leptosomidæ) consisting of but a single species, to Madagascar; parallel cases to the Drepanididre among the Passeres, peculiar to the Sandwich Islands, and the Apterygidæ among the Struthiones, peculiar to New Zealand.

\section{Order III.-PSITTACI.}

The Parrots have been the subject of much difference of opinion among ornithologists, and no satisfactory arrangement of the order into families and genera has yet been reached. Professor Garrod has lately examined certain points in the anatomy of a large number of genera, and proposes to revolutionize the ordinary classifications. Until, however, a general examination of their whole anatomy, internal and external, has been made by some competent authority, it will be unsafe to adopt the new system, as we have as yet no guide to the comparative value of the characters made use of. I therefore keep as much as possible to the old groups, founded on external characters, only using the indications furnished hy Professor Garrod's paper, to determine the position of doubtful genera.

\section{FAmily 76.-CACATUID正. (5 Genera, 35 Species.)}

\begin{tabular}{|c|c|c|c|c|c|}
\hline \multicolumn{6}{|c|}{ General Distribution. } \\
\hline $\begin{array}{l}\text { NFOTROPICAL } \\
\text { STB-REGIONS. }\end{array}$ & $\begin{array}{l}\text { NEARCTIC } \\
\text { SUB-REGIONS. }\end{array}$ & $\begin{array}{l}\text { PALEARCTIC } \\
\text { SUB-IiEGIONS. }\end{array}$ & $\begin{array}{l}\text { ETHIOPIAN } \\
\text { SUB-REGIONS. }\end{array}$ & $\begin{array}{l}\text { ORIENTAL } \\
\text { SUB-REGIONS. }\end{array}$ & $\begin{array}{l}\text { AUSTRALIAN } \\
\text { SUB-REGIONS. }\end{array}$ \\
\hline--- & ---- & ---1 & ---- & ---4 & $1.2--$ \\
\hline
\end{tabular}

The Cacatuidæ, Plyctolophidæ, or Camptolophidæ, as they have been variously termed, comprise all those crested parrots usually termed Cockatoos, together with one or two doubtful forms. They are very abundant in the Australian region, more especially in the Austro-Malayan portion of it, one species inhabiting 
the Philippine Islands; but they do not pass further east than the Solomon Islands and are not found in New Zealand. The distribution of the genera is as follow:-

Cacatua (18 sp.) ranges from the Philippine Islands, Celebes and Lombolk, to the Solomon Islands and to Tasmania; Calopsitta (1 sp.) Australia; Calyptorhynchus (8 sp.) is confined to Australia and Tasmania ; Microglossus (2 sp.) (perhaps a distinct family) to the Papuan district and North Australia; Licmetis (3 sp.) Australia, Solomon Islands, and (?) New Guinea; Nasiterna (3 sp.), a minute form, the smallest of the whole order, and perhaps not belonging to this family, is only known from the Papuan and Solomon Islands.

\section{Family 77.-PLATYCERCID $\mathbb{E} . \quad$ (11 Genera, 57 Species.)}

\begin{tabular}{|c|c|c|c|c|c|}
\hline \multicolumn{6}{|c|}{ General Distribution. } \\
\hline $\begin{array}{l}\text { NEOTROPICAL } \\
\text { SUB-REOIONS. }\end{array}$ & $\begin{array}{c}\text { NEARCTIC } \\
\text { SUB-REGIORS. }\end{array}$ & $\begin{array}{l}\text { Palearctic } \\
\text { Sub-REGIONS. }\end{array}$ & $\begin{array}{c}\text { EThIOPIAN } \\
\text { SUB-REGIONS. }\end{array}$ & $\begin{array}{c}\text { ORIENTAL } \\
\text { SUB-REGIONS. }\end{array}$ & $\begin{array}{l}\text { AUSTRALIAN } \\
\text { SUB-REGIONS. }\end{array}$ \\
\hline---- & $-\ldots$ & $---\cdots$ & --- & $-\cdots-$ & $1.2 \cdot 3 \cdot 4$ \\
\hline
\end{tabular}

The Platycercidæ comprise a series of large-tailed Parrots, of weak structure and gorgeous colours, with a few ground-feeding genera of more sober protective tints; the whole family being confined to the Australian region. The genera are:-

(1996 19992000 ) Platycercus (14 sp.), Australia, Tasmania, and Norfolk Island; Psephotus (6 sp.), Australia; Polytelis (3 sp.), Australia; Nymphicus (1 sp.), Australia and New Caledonia; (2002 2003) Aprosmictus (6 sp.), Australia, Papua, Timor, and Moluccas; Pyrrhulopsis (3 sp.), Tonga and Fiji Islands; Cyanoramphus (14 sp.), New Zealand, Norfolk Island, New Caledonia, and Society Islands; Melopsittacus (1 sp.), Australia; Euphema (7 sp.), Australia; Pezoporus (1 sp.), Australia and Tasmania; Geopsittacus (1 sp.), West Australia. The four last genera are ground-feeders, and are believed by Professor Garrod to be allied to the Owl-Parrot of New Zealand (Stringops). 
Fanily 78.-PALAORNITHIDAE. (8 Genera, 65 Species.)

\begin{tabular}{|c|c|c|c|c|c|}
\hline \multicolumn{6}{|c|}{ General Distribution. } \\
\hline $\begin{array}{l}\text { NFotropiCal } \\
\text { StiB-REgIONS. }\end{array}$ & $\begin{array}{l}\text { NEARCTIC } \\
\text { SUB-REGIONS. }\end{array}$ & $\begin{array}{l}\text { PALAaARCTIC } \\
\text { SUU-ILEGIONS. }\end{array}$ & $\begin{array}{l}\text { Ethiopian } \\
\text { SUB-REGIONS. }\end{array}$ & $\begin{array}{c}\text { ORIENTal } \\
\text { SUB-REGIONS. }\end{array}$ & $\begin{array}{l}\text { AUSTRALIAN } \\
\text { SUB-REGIONS. }\end{array}$ \\
\hline---- & --- & ---- & $1.2-4$ & 1.2 .3 .4 & $1.2--$ \\
\hline
\end{tabular}

I class here a group of birds brought together, for the most part, by geographical distribution as well as by agreement in internal structure, but which is nevertheless of a very uncertain and provisional character.

Palocornis (18 sp.), the Oriental region, Mauritius, Rodriguez, and Seychelle Islands, and a species in Tropical Africa, apparently identical with the Indian $P$. torquatus, and therefore-considering the very ancient intercourse between the two countries, and the improbability of the species remaining unchanged if originating by natural causes-most likely the progeny of domestic birds introduced from India. Prioniturus (3 sp.), Celebes and the Philippine Islands ; ( ${ }^{2061}$ ) Geoffroyıs (5 sp.), Bouru to Timor and the Solomon Islands; Tanygnathus (5 sp.), Philippines, Celebes, and Moluccas to New Guinea; Eclectus (8 sp.), Moluccas and Papuan Islands ; Psittinus (1 sp.), Tenasserim to Sumatra and Borneo; Cyclopsitta (8 sp.), Papuan Islands, Philippines and North-east Australia ; Loriculus (17 sp.), ranges over the whole Oriental region to Flores, the Moluccas, and the Papuan island of Mysol; but most of the species are concentrated in the district including the Philippines, Celebes, Gilolo, and Flores, there being 1 in India, 1 in South China, 1 in Ceylon, 1 in Java, 1 in Malacca, Sumatra, and Borneo, 3 in Celebes, 5 in the Philippines, and the rest in the Moluccas, Mysol, and Flores. This genus forms a transition to the next family. 
Fanily 79.-TRICHOGLOSSID Æ. (6 Genera, 57 Species.)

\begin{tabular}{|c|c|c|c|c|c|}
\hline \multicolumn{6}{|c|}{ General Distribution. } \\
\hline $\begin{array}{l}\text { NFOTROPTCAL } \\
\text { StiB-REGIOAS. }\end{array}$ & $\begin{array}{l}\text { NeARCTIC } \\
\text { SUB-REGIONS. }\end{array}$ & $\begin{array}{l}\text { PALEARCTIC } \\
\text { SUB-REGIONS. }\end{array}$ & $\begin{array}{c}\text { ETHIOPIAN } \\
\text { SUB-REGIONS. }\end{array}$ & $\begin{array}{l}\text { ORIENTAL } \\
\text { SUB-REGIONS. }\end{array}$ & $\begin{array}{l}\text { Australian } \\
\text { Sub-Regions. }\end{array}$ \\
\hline--- & $--\cdots$ & --- & ---- & --- & $1.2 .3-$ \\
\hline
\end{tabular}

The Trichoglossidæ, or Brush-tongued Paroquets, including the Lories, are exclusively confined to the Australian region, where they extend from Celebes to the Marquesas Islands, and south to Tasmania. The genus Nanodes (= Lathamus) has been shown by Professor Garrod to differ from Trichoglossus in the position of the carotid arteries. I therefore make it a distinct genus but do not consider that it should be placed in another family. The genera here admitted are as follows :-

Trichoglossus (29 sp.), ranges over the whole Austro-Malay and Australian sub-regions, and to the Society Islands; $\left({ }^{2047}\right)$ Nanodes (1 sp.), Australia and Tasmania; Charmosyna (1 sp.), New Guinea (Plate X. Vol. I. p. 414); Eos (9 sp.), Bouru and Sanguir Island north of Celebes, to the Solomon Islands, and in Puynipet Island to the north-east of New Ireland; $\left({ }^{2039} 2040\right)$ Lorius (13 sp.), Bouru and the Solomon Islands; (2041 2043) Coriphilus (4 sp.), Samoa, Tonga, Society and Marquesas Islands.

FAMILY 80.-CONURID E. (7 Genera, 79 Species.)

\begin{tabular}{|c|c|c|c|c|c|}
\hline \multicolumn{6}{|c|}{ Gexeral Distribution. } \\
\hline $\begin{array}{l}\text { NEOTROPICAL } \\
\text { SUB-REGIONS. }\end{array}$ & $\begin{array}{l}\text { NeARCI:C } \\
\text { SÜB-REGIONS. }\end{array}$ & $\begin{array}{l}\text { PaL.EARCTIC } \\
\text { SUE-1EEGIONS. }\end{array}$ & $\begin{array}{c}\text { ETHIOPI.IN } \\
\text { SUD-REGIONS. }\end{array}$ & $\begin{array}{c}\text { ORIENTAL } \\
\text { SUB-REGIONS. }\end{array}$ & $\begin{array}{l}\text { Australian } \\
\text { Sub-REgIONS. }\end{array}$ \\
\hline 1.2 .3 .4 & $--3-$ & --- & ---- & ---- & - \\
\hline
\end{tabular}

The Conuridre, which consist of the Macaws and their allies, are wholly confined to America, ranging from the Straits of Magellan to South Carolina and Nebraska, with Cuba and Jamaica. Professor Garrod places Pyrrhura (which has generally 
been classed as a part of the genus Conurus) in a separate family, on account of the absence of the ambiens muscle of the knee, but as we are quite ignorant of the classificational value of this character, it is better for the present to keep both as distinct genera of the same family. The genera are:-

Ara (15 sp.), Paraguay to Mexico and Cuba; Rhyncopsitta (1 sp.), Mexico ; Henicognathus (1 sp.), Chili ; Conurus (30 sp.), the range of the family; Pyrrhura (16 sp.), Paraguay and Bolivia to Costa Rica; Bolborhynchus (7 sp.), La Plata, Bolivia and West Peru, with one species in Mexico and Guatemala; Brotogerys (9 sp.), Brazil to Mexico.

FAMILY 81.-PSITTACID E.-(12 Genera, 87 Species.)

\begin{tabular}{|c|c|c|c|c|c|}
\hline $\begin{array}{l}\text { NrotropicAL } \\
\text { StiB-REGIONS. }\end{array}$ & $\begin{array}{c}\text { NEARCTIC } \\
\text { SUB-RE:IONS. }\end{array}$ & $\begin{array}{l}\text { PAL_ELECTIC } \\
\text { SUB-LEETONS. }\end{array}$ & $\begin{array}{c}\text { ETHIOPIAN } \\
\text { SUB-REGIONS. }\end{array}$ & $\begin{array}{l}\text { ORIENTAL } \\
\text { SUB-IEESIONS. }\end{array}$ & $\begin{array}{l}\text { ACSTIRALIAV } \\
\text { SUB-REGIOV. }\end{array}$ \\
\hline$-2.3 \cdot 4$ & ---- & $--\cdots$ & 1.2 .3 .4 & ---- & -- \\
\hline
\end{tabular}

The Psittacidæ comprise a somewhat heterogeneous assemblage of Parrots and Paroquets of the Neotropical and Ethiopian regions, which are combined here more for convenience than because they are believed to form a natural group. The genera Chrysotis and Pionus have no oil-gland, while Psittacula and Agapornis have lost the furcula, but neither of these characters are probably of more than generic value. The genera are:-

Psittacus (2 sp.), West Africa; Coracopsis (5 sp.), Madagascar, Comoro, and Seychelle Islands ; Pceocephalus (9 sp.), all Tropical

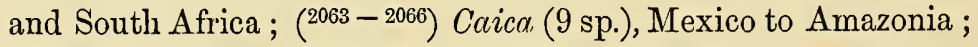
Chrysotis (32 sp.), Paraguay to Mexico and the West Indian Islands; Triclaria (1 sp.), Brazil : Deroptyus (1 sp.), Amazonia; Pionus (9 sp.), Paraguay to Mexico; Urochroma (7 sp.), Tropical South America; Psittacula (6 sp.), Brazil to Mexico; Poliopsitta (2 sp.), Madlagascar and West Africa; Agapornis (4 sp.), Tropical and South Africa. 


\section{FAMILY 82.-NESTORIDE. (? 2 Genera, 6 Species.)}

\begin{tabular}{|c|c|c|c|c|c|}
\hline \multicolumn{6}{|c|}{ General Distributifun. } \\
\hline $\begin{array}{l}\text { NEOTROPICAL } \\
\text { SUB-REGIONS. }\end{array}$ & $\begin{array}{c}\text { NEARCTIC } \\
\text { SUB-REGIONS. }\end{array}$ & $\begin{array}{l}\text { PALAARCTIC } \\
\text { SUB-hEGIONS. }\end{array}$ & $\begin{array}{c}\text { ETHIOPIAN } \\
\text { SUb-REGIONS. }\end{array}$ & $\begin{array}{l}\text { ORIENTAL } \\
\text { SUB-EEGIONS. }\end{array}$ & $\begin{array}{l}\text { AUSTRALIAN } \\
\text { SUB-REGiIONS. }\end{array}$ \\
\hline---- & ---- & ---- & --- & ---- & $1--4$ \\
\hline
\end{tabular}

The present family is formed to receive the genus Nestor ( 5 sp.), confined to New Zealand and Norfolk Island. Its affinities are doubtful, but it appears to have relations with the American Conuridæ and the Australian Trichoglossidæ. With it is placed the rare and remarkable Dasyptilus (1 sp.), of New Guinea, of which however very little is known.

Family 83.-STRINGOPID $\nRightarrow . \quad$ (1 Genus, 2 Species.)

\begin{tabular}{|c|c|c|c|c|c|}
\hline \multicolumn{6}{|c|}{ General Distribution. } \\
\hline $\begin{array}{l}\text { NFOTROPICAL } \\
\text { SIB-REGIONS. }\end{array}$ & $\begin{array}{c}\text { NEARCTIC } \\
\text { SUB-REGIONS. }\end{array}$ & $\begin{array}{l}\text { PAL.EARCTIC } \\
\text { SUB-REGIONS. }\end{array}$ & $\begin{array}{c}\text { ETHIOPIAN } \\
\text { SUB-REGIONS. }\end{array}$ & $\begin{array}{l}\text { ORIENTAL } \\
\text { SUB-REGIONS. }\end{array}$ & $\begin{array}{l}\text { AUSTRALIAN } \\
\text { SUB-REGIONS. }\end{array}$ \\
\hline---- & $-\cdots-$ & $--\cdots$ & $-\cdots-$ & $---\cdots$ & ---4 \\
\hline
\end{tabular}

This family contains only the curious owl-like nocturnal Parrot of New Zealand, Stringops habroptilus (Plate XIII. Vol .I. p. 455). An allied species is said to inhabit the Chatham Islands, if not now extinct.

\section{General Remarks on the Distribution of the Psittaci.}

Although the Parrots are now generally divided into several distinct families, yet they form so well marked and natural a group, and are so widely separated from all other birds, that we may best discuss their peculiarities of geographical distribution by treating them as a whole. By the preceding enumeration we find that there are about 386 species of known parrots, which are divided into 52 genera. They are preeminently a tropical group, for although a few species extend a considerable distance into the temperate zone, these are 
marked exceptions to the rule which limits the parrot tribe to the tropical and sub-tropical regions, roughly defined as extending about $30^{\circ}$ on each side of the equator. In America a species of Conumes reaches the straits of Magellan on the south, while another inhabits the United States, and once extended to the great lakes, althongh now confined to the sonth-eastern districts. In Africa parrots do not reach the northern tropic, owing to the desert nature of the country; and in the south they barely reach the Orange River. In India they extend to about $35^{\circ} \mathrm{N}$. in the western Himalayas; and in the Australian region, not only to New Zealand but to Macquarie Islands in $54^{\circ} \mathrm{S}$., the farthest. point from the equator reached by the group. But although found in all the tropical regions they are most unequally distributed. Africa is poorest, possessing only 6 genera and 25 species; the Oriental region is also very poor, having but 6 genera and 29 species; the Neotropical region is much richer, having 14 genera and 141 species; while the smallest in area and the least tropical in climate-the Australian region, possesses 31 genera and 176 species, and it also possesses exclusively 5 of the families, Trichoglossidæ, Platycercidæ, Cacatuidæ, Nestoridæ, and Stringopidæ. The portion of the earth's surface that contains the largest number of parrots in proportion to its area is, undoubtedly, the Austro-Malayan sub-region, including the islands from Celebes to the Solomon Islands. The area of these islands is probably not one-fifteenth of that of the four tropical regions, yet they contain from one-fifth to one-fourth of all the known parrots. In this area too are found many of the most remarkable forms, - all the crimson lories, the great black Cockatoos, the pigmy Nasiterna, the raquet-tailed Prioniturus, and the bareheaded Dasyptilus.

The almost universal distribution of Parrots wherever the climate is sufficiently mild or uniform to furnish them with a perennial supply of food, no less than their varied details of organization, combined with a great uniformity of general type, - tell us, in unmistakable language, of a very remote antiquity. The only early record of extinct parrots is, however, in the Miocene of France, where remains apparently allied to the Weșt 
African Psittacus, have been found. But the origin of so widespread, isolated, and varied a group, must be far earlier than this, and not improbably dates back beyond the dawn of the Tertiary period. Some primeval forms may have entered the Australian region with the Marsupials, or not long after them; while perhaps at a somewhat later epoch they were introduced into South America. In these two regions they have greatly flourished, while in the two other tropical regions only a few types have been found, capable of maintaining themselves, among the higher forms of mammalia, and in competition with a more varied series of birds. This seems much more probable than the supposition that so highly organized a group should have originated in the Australian region, and subsequently become so widely spread over the globe.

$$
\text { Order IV.-COLUMBAE. }
$$

Family 84.-COLUMBID $\approx . \quad$ (44 Genera, 355 Species.)

\begin{tabular}{|c|c|c|c|c|c|}
\hline \multicolumn{6}{|c|}{ General Distribution. } \\
\hline $\begin{array}{l}\text { NeOTROPICAL } \\
\text { SUB-REGIONS. }\end{array}$ & $\begin{array}{c}\text { N EARCTIC } \\
\text { SUB-REGIONS. }\end{array}$ & $\begin{array}{l}\text { PALFARCTIC } \\
\text { SUB-REGIONS. }\end{array}$ & $\begin{array}{c}\text { ETHIOPIAN } \\
\text { SUB-REGIONS. }\end{array}$ & $\begin{array}{l}\text { ORIENTAL } \\
\text { SUB-REGIONS. }\end{array}$ & $\begin{array}{l}\text { Aostralian } \\
\text { SUB-REGIONS. }\end{array}$ \\
\hline 1.2 .3 .4 & 1.2 .3 .4 & 1.2 .3 .4 & 1.2 .3 .4 & 1.2 .3 .4 & 1.2 .3 .4 \\
\hline
\end{tabular}

The Columbidæ, or Pigeons and Doves, are almost universally distributed, but very unequally in the different regions. Being best adapted to live in warm or temperate climates, they diminish rapidly northwards, reaching about $62^{\circ} \mathrm{N}$. Latitude in North America, but considerably farther in Europe. Both the Nearctic and Palæarctic regions are very poor in genera and species of pigeons, those of the former region being mostly allied to Neotropical, and those of the latter to Oriental and Ethiopian types. The Ethiopian region is, however, itself very poor, and several of its peculiar forms are confined to the Madagascar subregion. The Neotropical region is very rich in peculiar genera, though but moderately so in number of species. The Oriental 
region closely approaches it in both respects; but the Australian region is by far the richest, possessing nearly double the genera and species of any other region, and abounding in remarkable forms quite unlike those of any other part of the globe. The following table gives the number of genera and species in each region, and enables us readily to determine the comparative richness and isolation of each, as regards this extensive family :-

$\begin{array}{lllccc}\quad \text { Regions. } & & & \text { No, of Genera. } & \text { Peculiar Genera. } & \text { No. of Species. } \\ \text { Neotropical } & \ldots & \ldots & 13 & 9 & 75 \\ \text { Nearctic } & \ldots & \ldots & 5 & 1 & 7 \\ \text { Palæarctic } & \ldots & \ldots & 3 & 0 & 9 \\ \text { Ethiopian } & \ldots & \ldots & 6 & 1 & 37 \\ \text { Oriental } & \ldots & \ldots & 12 & 1 & 66 \\ \text { Australian } & \ldots & \ldots & 24 & 14 & 143\end{array}$

With the exception of Columba and Turtur, which have a wide "range, Treron, common to the Oriental and Ethiopian regions, and Carpophaga, to the Oriental and Australian, most of the genera of pigeons are either restricted to or very characteristic of a single region.

The distribution of the genera here admitted is as follows :-

Treron (37 sp.), the whole Oriental region, and eastward to Celebes, Amboyna and Flores, also the whole Ethiopian region to Madagascar; Ptilopus (52 sp.), the Australian region (excluding New Zealand) and the Indo-Malay sub-region; Alectrcenus (4 sp.), Madagascar and the Mascarene Islands: Carpophaga (50 sp.), the whole Australian and Oriental regions, but much the most abundant in the former; $\left({ }^{2274}\right)$ Ianthoenas (11 sp.), Japan, Andaman, Nicobar, and Philippine Islands, Timor and Gilolo to Samoa Islands; ${ }^{2278}$ ) Leucomelcena (1 sp.), Australia; Lopholaimus (1 sp.), Anstralia; (2279 and 2283) Alscecomus (2 sp.), Himalayas to Ceylon and Tenasserim; Columba (46 sp.), generally distributed over all the regions except the Australian, one species however in the Fiji Islands ; Ectopistes (1 sp.), east of North America with British Columbia; Zenaidura (2 sp.), Veragua to Canada and British Columbia ; EEna (1 sp.), Tropical and South Africa; Geopelia (6 sp.), Philippine Islands and Java to Australia ; Macropygia (14 sp.), Nepal, Hainan, Nicobar, Java, 
and Philippines to Australia and New Ireland; Turacœena (3 sp.), Celebes, Timor, and Solomon Islands; Reinvardtcencs (1 sp.), Celebes to New Guinea; Turtur (24 sp.), Palæarctic, Ethiopian and Oriental regions with Austro-Malaya; Chomepelia (7 sp.), Brazil and Bolivia to Jamaica, California, and South-east United States; Columbula (2 sp.), Brazil and La Plata to Chili; Scardafella (2 sp.), Brazil and Guatemala; Zenaida (10 sp.), Chili and La Plata to Columbia and the Antilles, Fernando Noronha; Melupelia (2 sp.), Chili to Mexico and California; Peristera (4 sp.), Brazil to Mexico; Mctriopelia (2 sp.), West America from Ecuador to Chili; Gymnopelia (1 sp.), West Peru and Bolivia; Leptoptila (11 sp.), Paraguay to Mexico and the Antilles; (2317 2318 and 2320 ) Geotrygon (14 sp.), Paraguay to Mexico and the Antilles; Aplopelia (5 sp.), Tropical and South Africa, St. Thomas and Princes Island; Chalocopelia (4 sp.), Tropical and South Africa; Starnoenas (1 sp.), Cuba; Ocyphaps (1 sp.), Australia (Plate XII. Vol. I. p. 441) ; Petrophassa (1 sp.), North-west Australia; Chalocophaps (8 sp.), the Oriental region to New Guinea and Australia; Trugon (1 sp.), New Guinea; Henicophaps (1 sp.), Waigiou and New Guinea; Phaps (3 sp.), Australia and Tasmania; Leucosarcia (1 sp.), East Australia; Phapitreron (2 sp.), Philippine Islands ; Geophaps (2 sp.), North and East Australia; Lophophaps (3 sp.), Australia; Calcenas $(1 \mathrm{sp}$.$) , scattered on the smaller islands from the Nicobars and$ Philippines to New Guinea; Otidiphaps (1 sp.), New Guinea; Phlogcenas (7 sp.), Philippine Islands and Celebes to the Marquesas Islands; Goura (2 sp.), New Guinea and the islands on the north-east (Plate X. Vol. I. p 414).

\section{Fanily 84a.-DIDUNCULID E. (1 Genus, 1 Species.)}

\begin{tabular}{|c|c|c|c|c|c|}
\hline \multicolumn{6}{|c|}{ General Distribution. } \\
\hline $\begin{array}{l}\text { NEOTROPICAL } \\
\text { SUb-REQOONS. }\end{array}$ & $\begin{array}{c}\text { NEARCTIC } \\
\text { SUB-REGIONS. }\end{array}$ & $\begin{array}{l}\text { PALFARCTIC } \\
\text { SUB-HEGIONS. }\end{array}$ & $\begin{array}{c}\text { ETHIOPIAN } \\
\text { SUB-REGIONS. }\end{array}$ & $\begin{array}{c}\text { ORIENTAL } \\
\text { SUB-REOIONS. }\end{array}$ & $\begin{array}{l}\text { AUSTRALIAN } \\
\text { Sub-REOIONS. }\end{array}$ \\
\hline$---\dot{-}$ & $-\cdots$ & ---- & $--\cdots$ & --- & --3 \\
\hline
\end{tabular}


The Didunculus stigirostris, a hook-billed ground-pigeon, found only in the Samoa Islands, is so peculiar in its structure that it is considered to form a distinct family.

FAMily 85.-DIDIDA.-(2 Genera, 3 Species.)

\begin{tabular}{|c|c|c|c|c|c|}
\hline \multicolumn{6}{|c|}{ General Distribution. } \\
\hline $\begin{array}{l}\text { NEOTROPICAL } \\
\text { SUB-REGIONS. }\end{array}$ & $\begin{array}{c}\text { NEARCTIC } \\
\text { SUB-REGIONS. }\end{array}$ & $\begin{array}{l}\text { Pal_farctic } \\
\text { Sub-REgions. }\end{array}$ & $\begin{array}{l}\text { ETHIOPIAN } \\
\text { SUB-REGIONS. }\end{array}$ & $\begin{array}{c}\text { ORIENTAL } \\
\text { SUB-REGIONS. }\end{array}$ & $\begin{array}{l}\text { AUSTRALIAN } \\
\text { SUB-REGIONS. }\end{array}$ \\
\hline$-\cdots-$ & ---- & $-\cdots-$ & ---4 & ---- & ---- \\
\hline
\end{tabular}

The birds which constitute this family are now all extinct; but as numerous drawings are in existence, taken from living birds some of which were exhibited in Europe, and a stuffed specimen, fragments of which still remain, was in the Ashmolean Museum at Oxford down to 1755 , they must be classed annong recent, as opposed to geologically extinct species. The Dodo (Didus ineptus) a large, unwieldy, flightless bird, inhabited Mauritius down to the latter part of the 17th century; and an allied form, the Solitaire (Pezophaps solitaria), was found only in the island of Rodriguez, where it survived about a century later. Old voyagers mention a Dodo also in Bourbon, and a rude figure of it exists; but no remains of this bird have been found. Almost complete skeletons of the Dodo and Solitaire have, however, been recovered from the swamps of Mauritius and the caves of Rodriguez, proving that they were both extremely modified forms of pigeon. These large birds were formerly very abundant, and being excellent eating and readily captured, the early voyagers to these islands used them largely for food. As they could be caught by man, and very easily by dogs, they were soon greatly diminished in numbers; and the introduction of swine, which ran wild in the forests and fed on the eggs and young birds, completed their extermination.

The existence in the Mascarene Islands of a group of such remarkable terrestrial birds, with aborted wings, is parallel to that of the Apteryx and Dinornis in New Zealand, the Cassowaries of Austro-Malaya, and the short-winged Rails of New 
Zedand, Tristan d'Acunha, and other oceanic islands; and the phenomenon is clearly dependent on the long-continued absence of enemies, which allowed of great increase of bulk and the total loss of the power of flight, without injury. In some few cases (the Ostrich for example) birds incapable of flight co-exist with large carnivorous mammalia; but these birds are large and powerful, as well as very swift, and are thus able to escape from some enemies and defend themselves against others. The entire absence of the smaller and more defenceless ground-birds from the adjacent island of Hadagascar, is quite in accordance with this view, because that island has several small but destructive carnivorous animals.

\section{General Remarks on the Distribution of the Columba.}

The striking preponderance of Pigeons, both as to genera and species, in the Anstralian region, would seem to indicate that at some former period it possessed a more extensive land area in which this form of bird-life took its rise. But there are other considerations which throw doubt upon this view. The western half of the Malay Archipelago, belonging to the Oriental region, is also rich in pigeons, since it has 43 species belonging to 11 genera, rather more than are found in all the rest of the Oriental region. Again, we find that the Mascarene Islands and the An-. tilles both possess more pigeons than we should expect, in proportion to those of the regions to which they belong, and to their total amount of bird-life. This looks as if islands were more favourable to pigeon-development than continents; and if we group together the Pacific and the Malayan Islands, the Mascarene group and the Antilles, we find that they contain together about 170 species of pigeons belonging to 24 out of the 47 genera here adopted; while all the great continents united only produce abont the same number of species belonging (if we omit those peculiar to Australia) to only 20 genera. The great development of the group in the Australian region may, therefore, be due to its consisting mainly of islands, and not to the order having originated there, and thus having had a longer period in which to develop. I have elsewhere suggested (Ibis 1865, p. 366) 
a physical cause for this peculiarity of distribution. Pigeons build rude, open nests, and their young remain helpless for a considerable period. They are thus exposed to the attacks of such arboreal quadrupeds or other animals as feed on eggs or young birds. Monkeys are very destructive in this respect; and it is a noteworthy fact that over the whole Australian region, the Mascarene Islands and the Antilles, monkeys are unknown. In the Indo-Malay sub-region, where monkeys are generally plentiful, the greatest variety of pigeons occurs in the Philippines, where there is but a single species in one island; and in Java, where monkeys are far less numerous than in Sumatra or Borneo. If we add to this consideration the fact, that mammalia and rapacious birds are, as a rule, far less abundant in islands than on continents; and that the extreme development of pigeon-life is reached in the Papuan group of islands, in which mammalia (except a few marsupials, bats, and pigs) are wholly absent, we see further reason to adopt this view. It is also to be noted that in America, comparatively few pigeons are found in the rich forests (comparable to those of the Anstralian insular region in which they abound), but are mostly confined to the open campos, the high Andes, and the western coast districts, from which the monkey-tribe are wholly absent.

This view is further supported by the great development of colour that is found in the pigeons of these insular regions, culminating in the golden-yellow fruit-dove of the Fiji Islands, the metallic green Nicobar-pigeon of Malaya, and the black and crimson Alectrcenas of Mauritius. Here also, alone, we meet with crested pigeons, rendering the possessors more conspicuous; such as the Lopholaimus of Australia and the crowned Goura of New Guinea; and here too are more peculiar forms of terrestrial pigeons than elsewhere, though none have completely lost the power of flight but the now extinct Dididæ.

The curious liking of pigeons for an insular habitat is well shown in the genera Ianthonas and Calonas. The former, containing 11 species, ranges over a hundred degrees of longitude, and forty-five of latitude, extending into three regions, yet nowhere inhabits a continent or even a large island. It is 
found in the Andaman and Nicobar Islands; in the Philippines, Gilolo, and the smaller Papuan Islands, and in Japan; yet not in any of the large Malay Islands or in Australia. The other genus, Calcenas, consists of but a single species, yet this ranges from the Nicobar Islands to New Guinea. It is not, however, as far as known, found on any of the large islands, but seems to prefer the smaller islands which surround them. We here have the general preference of pigeons for islands, further developed in these two genera into a preference for small islands; and it is probable that the same cause-the greater freedom from dangerhas produced both phenomena.

Of the geological antiquity of the Columbæ we have no evidence; but their wide distribution, their varied forms, and their great isolation, all point to an origin, at least as far back as that we have assigned as probable in the case of the Parrots.

$$
\text { Order } V .-G A L L I N A E \text {. }
$$

FAMLly 86.-PTEROCLID正. (2 Genera, 16 Species.)

\begin{tabular}{|c|c|c|c|c|c|}
\hline \multicolumn{6}{|c|}{ General Distribution. } \\
\hline $\begin{array}{l}\text { NEOTROPICAL } \\
\text { StiB-REGIONS. }\end{array}$ & $\begin{array}{l}\text { NEARCTIC } \\
\text { SUB-REGIONS. }\end{array}$ & $\begin{array}{l}\text { PaL/EARC'TIC } \\
\text { SUB-REGIONS. }\end{array}$ & $\begin{array}{l}\text { ETHIOPIAN } \\
\text { SUB-REGIONS. }\end{array}$ & $\begin{array}{l}\text { ORIENTAL } \\
\text { SUB-REGIONS. }\end{array}$ & $\begin{array}{l}\text { AUstralian } \\
\text { SUB-REGIONS. }\end{array}$ \\
\hline--- & ---- & -2.3 .4 & $1-3.4$ & $1---$ & $\ldots-\ldots$ \\
\hline
\end{tabular}

The Pteroclidæ, or Sand-grouse, are elegantly formed birds with pointed tails, and plumage of beautifully varied protective tints, characteristic of the Ethiopian region and Central Asia, though extending into Southern Europe and Hindostan. Being preeminently desert-birds, they avoid the forest-districts of all these countries, but abound in the most arid situations and on the most open and barren plains. The distribution of the genera is as follows:-

Pterocles (14 sp.), has the same range as the family; Syrrhaptes (2 sp.), normally inhabits Tartary, Thibet, and Mongolia to the country around Pekin, and occasionally visits Eastern Europe. But a few years back (1863) great numbers suddenly appeared in VOL. II. 
Europe and extended westward to the shores of the Atlantic, while some even reached Ireland and the Færoes. (Plate III. Vol. I. p. 226.)

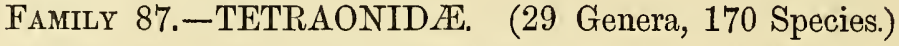

\begin{tabular}{|c|c|c|c|c|c|}
\hline \multicolumn{6}{|c|}{ General Distribution. } \\
\hline $\begin{array}{l}\text { NEOTROPICAL } \\
\text { SUB-REGIONS. }\end{array}$ & $\begin{array}{l}\text { NEARCTIC } \\
\text { SUB-REGIONS. }\end{array}$ & $\begin{array}{l}\text { PALAAARCTIC } \\
\text { SUB-REGIONS. }\end{array}$ & $\begin{array}{c}\text { ETHIOPIAN } \\
\text { SUB-REGIONS. }\end{array}$ & $\begin{array}{c}\text { ORIENTAL } \\
\text { SOB-REGIONS. }\end{array}$ & $\begin{array}{l}\text { AUSTRALIAN } \\
\text { SUB-REGIONG. }\end{array}$ \\
\hline-2.3 .4 & $1.2 .3 \cdot 4$ & 1.2 .3 .4 & 1.2 .3 .4 & $1.2 \cdot 3.4$ & $1.2-$ \\
\hline
\end{tabular}

The Tetraonidæ, including the Grouse, Partridges, Quails, and allied forms, abound in all parts of the Eastern continents; they are less plentiful in North America and comparatively scarce in South America, more than half the Neotropical species being found north of Panama; and in the Australian region there are only a few of small size. The Ethiopian region probably contains most species; next comes the Oriental-India proper from the Himalayas to Ceylon having twenty; while the Australian region, with 15 species, is the poorest. These facts render it probable that the Tetraonidæ are essentially denizens of the great northern continents, and that their entrance into South America, Australia, and even South Africa, is, comparatively speaking, recent. They have developed into forms equally suited to the tropical plains and the arctic regions, some of them being among the few denizens of the extreme north, as well as of the lighest alpine snows. The genera are somewhat unsettled, and there is even some uncertainty as to the limits between this family and the next; but the following are those now generally admitted :-

Ptilopachus (1 sp.), West Africa; Francolinus (34 sp.), all Africa, South Europe, India to Ceylon, and South China; Ortygornis (3 sp.), Himalayas to Ceylon, Sumatra, and Borneo: Peliperdix (1 sp.), West Africa; Perdix (3 sp.), the whole Continental Palæarctic region; Margaroperdix (1 sp.), Madagascar ; Oreoperdix (1 sp.), Formosa; Arborophila (8 sp.), the Oriental Continent and the Philippines ; Pelcperdix (4 sp.), Tenasserim and Malaya; Coturnix (21 sp.), Temperate Palæarctic, Ethiopian and 
Oriental regions, and the Anstralian to New Zealand; Rollulus (2 sp.), Siam to Sumatra, Bormeo, and Philippines; Caloperdix (1 sp.), Malacca and Sumatra; Odontophorus (17 sp.), Brazil and Peru to Mexico; Dendrortyx (3 sp.), Guatemala and Mexico; Cyrtonyx (3 sp.), Gnatemala to New Mexico ; Ortyx (8 sp.), Honduras and Cuba to Canada; Eupsychortyx (6 sp.), Brazil and Ecuador to Mexico; Callipepla (3 sp.), Mexico to California; Lophortyx (2 sp.), Arizona and California ; Oreortyx (1 sp.), California and Oregon (Plate XVIII., Vol. II. p. 128); Lerwa (1 sp.), Snowy Himalayas and East Thibet; Caccabis (10 sp.), Palæarctic region to Abyssinia, Arabia and the Punjaub; Tetraogallus (4 sp.), Caucasus and Himalayas to Altai Mountains; Tetrao (7 sp.), northern parts of Palæaretic and Nearctic regions ; Centrocercus (1 sp.), Rocky Mountains; Pediocotes (2 sp.), North and North-west America (Plate XVIII. Vol. II. p. 128); Cupidonia (1 sp.), East and North-Central United States and Canada ; Bonasa (3 sp.), north of Nearctic and Palæarctic regions; Lagopus (6 sp.), Arctic Zone and northern parts of Nearctic and Palæarctic regions.

\section{FAMily 88.-PHASIANID Æ. (18 Genera, 75 Species.)}

\begin{tabular}{|c|c|c|c|c|c|}
\hline & & General & ISTRIBUTION. & & \\
\hline $\begin{array}{l}\text { Neutropical } \\
\text { Sub-REgroNs. }\end{array}$ & $\begin{array}{c}\text { NEARCTIC } \\
\text { SUB-REGIONS. }\end{array}$ & $\begin{array}{l}\text { PaLAEARCTIC } \\
\text { SUB-REGIONS. }\end{array}$ & $\begin{array}{c}\text { ETHIOPIAN } \\
\text { SUB-REGIONS. }\end{array}$ & $\begin{array}{l}\text { ORIENTAL } \\
\text { SUB-EEGIONS. }\end{array}$ & $\begin{array}{l}\text { AUSTRaLian } \\
\text { SUb-REgIONS. }\end{array}$ \\
\hline$--3-$ & $-2.3-$ & -2.3 .4 & 1.2 .3 .4 & 1.2 .3 .4 & $1---$ \\
\hline
\end{tabular}

The Phasianidæ, including the Pea-fowl, Pheasants, and Junglefowl, the Turkeys, and the Guinea-fowl, are very widely distributed, but are far more abundant than elsewhere in the Eastern parts of Asia, both tropical and temperate. Leaving out the African guinea-fowls and the American turkeys, we have 13 genera and 63 species belonging to the Oriental and Palæarctic regions. These are grouped by Mr. Elliot (whose arrangement we mainly follow) in 5 sub-families, of which 3-Pavonniæ, Euplocaminæ, and Gallinæ-are chiefly Oriental, while the Lophophornix and Phasianinæ are mostly Palæarctic or from the highlands on the 
borders of the two regions. The genera adopted by Mr. Elliot in his Monograph are the following :-

Pavonine, 4 genera.-Pavo (2 sp.), Himalayas to Ceylon, Siam, to South-west China and Java; Argusianus (4 sp.), Siam, Malay Peninsula, and Borneo (Plate IX. Vol. I. p. 339); Polyplectron (5 sp.), Upper Assam to South-west China and Sumatra; Crossoptilon (4 sp.), Thibet and North China. (Plate III. Vol. I. p. 226.)

LopHOPHORINA, 4 genera.-Lophophorus (3 sp.), High woody region of Himalayas from Cashmere to West China; Tetraophasis (1 sp.), East Thibet; Ceriornis (5 sp.), Highest woody Himalayas from Cashmere to Bhotan and Western China (Plate VII. Vol. I. p. 331) ; Pucrasia (3 sp.), Lower and High woody Himalayas from the Hindoo Koosh to North-west China.

Phasianinfi, 2 genera.-Phasianus (12 sp.), Western Asia to Japan and Formosa, south to near Canton and Yunan, and the Western Himalayas, north to the Altai Mountains; Thaumalea (3 sp.), North-western China and Mongolia. (Plate III. Vol. I. p. 226.)

Euplocamine, 2 genera.-Euplocamus (12 sp.), Cashmere, along Southern Himalayas to Siam, South China and Formosa, and to Sumatra and Borneo; Ithaginis (2 sp.), High Himalayas from Nepal to North-west China.

Gallin 2,1 genus.-Gallus (4 sp.), Cashmere to Hainan, Ceylon, Borneo, Java, and eastwards to Celebes and Timor. (Central India, Ceylon, and East Java, have each a distinct species of Jungle-fowl.)

Meledarine, 1 genus.-Meleagris (3 sp.), Eastern and Central United States and south to Mexico, Guatemala and Yucatan.

Agelastine, 2 genera.-Phasidus (1 sp.), West Africa; Agelastes (1 sp.), West Africa.

Numidin ex, 2 genera.-Acryllium (1 sp.), West Africa; $N u$ mida (9 sp.), Ethiopian region, east to Madagascar, south to Natal and Great Fish River. 


\section{Fanily 89.-TURNICID $\mathbb{E}$. (2 Genera, 24 Species.)}

\begin{tabular}{|c|c|c|c|c|c|}
\hline \multicolumn{6}{|c|}{ General Distribution. } \\
\hline $\begin{array}{l}\text { NEOTROPICAL } \\
\text { StiB-REGIONS. }\end{array}$ & $\begin{array}{c}\text { NEARCTIC } \\
\text { SUB-REGIONS. }\end{array}$ & $\begin{array}{l}\text { PaLfarctic } \\
\text { Sub-REgions. }\end{array}$ & $\begin{array}{c}\text { ETHIOPIAN } \\
\text { SUB-REGIONS. }\end{array}$ & $\begin{array}{l}\text { ORIENTAL } \\
\text { SÜB-REGIONS. }\end{array}$ & $\begin{array}{l}\text { AUSTRALIAN } \\
\text { SUB-REGIONS. }\end{array}$ \\
\hline---- & --- & $-2-4$ & 1.2 .3 .4 & $1.2 .3 \cdot 4$ & $1.2--$ \\
\hline
\end{tabular}

The Turnicidæ are small Quail-like birds, supposed to have remote affinities with the American Tinamous, and with sufficient distinctive peculiarities to constitute a separate family. They range over the Old World, from Spain all through Africa and Madagascar, and over the whole Oriental region to Formosa, and then north again to Pekin, as well as south-eastward to Australia and Tasmania. The genus Turnix (23 sp.), has the range of the family; Ortyxelos (1 sp.), inhabits Senegal; but the latter genus may not belong to this family.

FAMILY 90.-MEGAPODIIDE. (4 Genora, 20 Species.)

\begin{tabular}{|c|c|c|c|c|c|}
\hline \multicolumn{6}{|c|}{ General Distribution. } \\
\hline $\begin{array}{l}\text { NrOTROPICAL } \\
\text { StiB-REGIONS. }\end{array}$ & $\begin{array}{c}\text { NEARCTIC } \\
\text { SUB-REGIONS. }\end{array}$ & $\begin{array}{l}\text { PaLAaARCTIC } \\
\text { SUB-REG IONS. }\end{array}$ & $\begin{array}{c}\text { ETHIOPIAN } \\
\text { SUB-REGIONS. }\end{array}$ & $\begin{array}{l}\text { ORIENTAL } \\
\text { SUB-RFGIONS. }\end{array}$ & $\begin{array}{l}\text { AUSTRALIAN } \\
\text { SUB-REGIONS. }\end{array}$ \\
\hline--- & ---- & --- & ---- & $1.2 .3-$ & ---4 \\
\hline
\end{tabular}

The Megapodiidæ, or Mound-makers and Brush-turkeys, are generally dull-coloured birds of remarkable habits and economy, which have no near allies, but are supposed to have a remote affinity with the South American Curassows. They are highly characteristic of the Australian region, extending into almost every part of it except New Zealand and the remotest Pacific islands, and only sending two species beyond its limits,-a Megapodius in the Philippine Islands and North-west Borneo, and another in the Nicobar Islands, separated by about 1,800 miles from its nearest ally in Lombok. The Philippine species offers little difficulty, for these birds are found on the smallest 
islands and sand-banks, and can evidently pass over a few miles of sea witlı ease; but the Nicobar bird is a very different case, because none of the numerous intervening islands offer a single example of the family. Instead of being a well-marked and clearly differentiated form, as we should expect to find it if its remote and isolated habitat were due to natural causes, it so nearly resembles some of the closely-allied species of the Moluccas and New Guinea, that, had it been found with them, it would hardly have been thought specifically extinct. I therefore believe that it is probably an introduction by the Malays, and that, owing to the absence of enemies and general suitability of conditions, it has thriven in the islands and has become slightly differentiated in colour from the parent stock. The following is the distribution of the genera at present known :-

Talegallus (2 sp.), New Guinea and East Australia; Megacephalon (1 sp.), East Celebes; Lipoa (1 sp.), South Australia; Megapodius (16 sp.), Philippine Islands and Celebes, to Timor, North Australia, New Caledonia, the Marian and Samoa Islands, and probably every intervening island,-also a species (doubtfully indigenous) in the Nicobar Islands.

FAmily 91.-CRACID $\mathbb{E}, \quad(12$ Genera, 53 Species.)

\begin{tabular}{|c|c|c|c|c|c|}
\hline \multicolumn{6}{|c|}{ General Distribution. } \\
\hline $\begin{array}{l}\text { NEOTROPICAL } \\
\text { SUB-REGIONS. }\end{array}$ & $\begin{array}{c}\text { NEARCTIC } \\
\text { SUB-REGIONS. }\end{array}$ & $\begin{array}{l}\text { PALAARCTIC } \\
\text { SUB-REGIONS. }\end{array}$ & $\begin{array}{l}\text { ETHIOPIAN } \\
\text { SUB-REGIONS. }\end{array}$ & $\begin{array}{l}\text { ORIENTAL } \\
\text { SUB-REGIONS. }\end{array}$ & $\begin{array}{l}\text { AUSTRALIAN } \\
\text { SUB-REGIONS. }\end{array}$ \\
\hline$-2.3-$ & $-2--$ & --- & ---- & --- & ---- \\
\hline
\end{tabular}

(Messrs. Sclater and Salvin's arrangement is here followed). The Cracidæ, or Curassows and Guans, comprise the largest and handsomest game-birds of the Neotropical region, where they take the place of the grouse and pheasants of the old World. They are almost all forest-dwellers, and are a strictly Neotropical family, only one species just entering the Nearctic region as far as New Mexico. They extend southward to Paraguay and the extreme south of Brazil, but none are found in the 
Antilles, nor west of the Andes south of the bay of Guayaquil. The sub-families and genera are as follows:-

Cracinfe, 4 genera.-Crax (8 sp.), Mexico to Paraguay (Plate XV., Vol. II. p. 28); Nothocrax (1 sp.), Guiana, Upper Rio Negro, and Upper Amazon; Pauxi (1 sp.), Guiana to Venezuela; Mitua (2 sp.), Guiana and Upper Amazon.

Penelopin \&, 7 genera.-Stegnoloema (1 sp.), Columbia and Ecuador; Penelope (14 sp.), Mexico to Paraguay and to western slope of Ecuadorian Andes; Penelopina (1 sp.), Guatemala; Pipile (3 sp.), Venezuela to Eastern Brazil ; Aburria (1 sp), Columbia; Chamcepetes (2 sp.), Costa Rica to Peru; Ortalida (18 sp.), New Mexico to Paraguay, also Tobago.

Oreophasinæ, 1 genus.-Oreophasis (1 sp.), Guatemala.

It thus appears that the Cracinæ are confined to South America east of the Andes, except one species in Central America; whereas nine Penelopinæ and Oreophasis are found north of Panama. The species of the larger genera are strictly representative, each having its own distinct geographical area, so that two species of the same genus are rarely or never found in the same locality.

FAMily 92.-TINAMID $\mathbb{E}$. (9 Genera, 39 Species.)

\begin{tabular}{|c|c|c|c|c|c|}
\hline \multirow[b]{2}{*}{$\begin{array}{l}\text { NEOTROPICAL } \\
\text { SUB-REGIONS. }\end{array}$} & \multicolumn{4}{|c|}{ General Distribution. } & \multirow[b]{2}{*}{$\begin{array}{l}\text { AUSTRALIAN } \\
\text { Sub-REgIONS. }\end{array}$} \\
\hline & $\begin{array}{c}\text { NEARCTIC } \\
\text { SuB-REOIONS. }\end{array}$ & $\begin{array}{l}\text { PALAEARCTIC } \\
\text { SUB-REGIONS. }\end{array}$ & $\begin{array}{c}\text { ETHIOPIAN } \\
\text { SUB-REGIONS. }\end{array}$ & $\begin{array}{c}\text { ORIENTAL } \\
\text { SUB-REOIONS. }\end{array}$ & \\
\hline $1.2 .3-$ & --- & ---- & ---- & ---- & -- \\
\hline
\end{tabular}

The Tinamous are a very remarkable family of birds, with the general appearance of partridges or hemipodes, but with the tail either very small or entirely wanting. They differ greatly in their organization from any of the Old World Gallinæ, and approach, in some respects, the Struthiones or Ostrich tribe. They are very terrestrial in their habits, inhabiting the forests, open plains, and mountains of the Neotropical region, from Patagonia and Chili to Mexico; but, like the Cracidæ, they are absent from the Antilles. Their colouring is very sober and protective, as is the case with so many ground-birds, and they are seldom adorned 
with crests or other ornamental plumes, so prevalent in the order to which they belong. The sub-families and genera, according to the arrangement of Messrs. Sclater and Salvin, are as follows :-

Tinamine, 7 genera,-Tinamus (7 sp.), Mexico to Paraguay; Nothocercus (3 sp.), Costa Rica to Venezuela and Ecuador; Crypturus (16 sp.), Mexico to Paragnay and Bolivia ; Rhynchotus (2 sp.), Bolivia and South Brazil to La Plata; Nothoprocta (4 sp.), Ecuador to Bolivia and Chili ; Nothura (4 sp.), Brazil and Bolivia to Patagonia ; Taoniscus (1 sp.), Brazil to Paraguay.

Tinamotine, 2 genera.-Calodromas (1 sp.), La Plata and Patagonia; Tinamotis (1 sp.), Andes of Peru and Bolivia.

\section{General Remarles on the Distribution of Gallince.}

There are about 400 known species of Gallinaceous birds grouped into 76 genera, of which no less than 65 are each restricted to a single region. The Tetraonidæ are the only cosmopolitan family, and even these do not extend into Temperate South America, and are very poorly represented in Australia. The Cracidæe and Tinamidæ are strictly Neotropical, the Megapodiidæ almost as strictly Australian. There remains the extensive family of the Phasianidæ, which offers some interesting facts. We have first the well-marked sub-families of the Numidinæ and Meleagrinæ, confined to the Ethiopian and Nearetic regions respectively, and we find the remaining five sub-families, comprising about 60 species, many of them the most magnificent of known birds, spread over the Oriental and the south-eastern portion of the Palæarctic regions. This restriction is remarkable, since there is no apparent cause in climate or vegetation why pheasants should not be found wild throughout southern Europe, as they were during late Tertiary and Post-Tertiary times. We have also to notice the remarkable absence of the Pheasant tribe from Hindostan and Ceylon, where the peacock and jungle-fowl are their sole representatives. These two forms also alone extend to Java, whereas in the adjacent islands of Borneo and Sumatra we have Argusianus, Polyplectron, and Euplocamus. The common jungle-fowl (the origin of our domestic poultry) is the only 
species which enters the Australian region as far as Celebes and Timor, and another species (Gallus ceneus) as far as Flores, and it is not improbable that these may have been introduced by man and become wild.

We have very little knowledge of the extinct forms of Gallinæ, but what we have assures us of their high antiquity, since we find such distinct groups as the jungle-fowl, partridges, and Pterocles, represented in Europe in the Miocene period; while the Turkey, then as now, appears to have been a special American type.

$$
\text { Order VI.-OPISTHOCOMI. }
$$

Family 93.-OPISTHOCOMID ÆE. (1 Genus, 1 Species.)

General Distribution.

\begin{tabular}{|c|c|c|c|c|c|}
\hline $\begin{array}{l}\text { NEOTROPICAL } \\
\text { SUB-REGIONS. }\end{array}$ & $\begin{array}{c}\text { NEARCTIC } \\
\text { SUB-REGIONS. }\end{array}$ & PALAEARCTIC & ETHIOPIAN & ORIENTAL & AUSTRALIAN \\
\hline$-2--$ & --- & --- & $--\cdots$ & --- & $---\cdots$ \\
\hline
\end{tabular}

The Hoazin (Opisthocomus cristatus) is the sole representative of this family and of the order Opisthocomi. It inhabits the eastern side of Equatorial America in Guiana and the Lower Amazon; and at Pará is called "Cigana" or gipsy. It is a large, brown, long-legged, weakly-formed and loosely-crested bird, having such anomalies of structure that it is impossible to class it along with any other family. It is one of those survivors, which tell us of extinct groups, of whose past existence we should otherwise, perhaps, remain for ever ignorant.

Order VII.-ACCIPITRES.

Family 94.-VULTURIDÆ. (10 Genera, 25 Species.)

\begin{tabular}{|c|c|c|c|c|c|}
\hline \multirow[b]{2}{*}{$\begin{array}{l}\text { NEOTROPICAL } \\
\text { SUB-REQIONS. }\end{array}$} & \multicolumn{4}{|c|}{ General Distribution. } & \multirow[b]{2}{*}{$\begin{array}{l}\text { AUSTRaLian } \\
\text { SUb-REGIONS. }\end{array}$} \\
\hline & $\begin{array}{c}\text { NEARCTIC } \\
\text { SUB-REGIONS. }\end{array}$ & $\begin{array}{l}\text { PALAAARCTIC } \\
\text { SUL-HEGIONS. }\end{array}$ & $\begin{array}{c}\text { ETHIOPIAN } \\
\text { SUB-REGIONS. }\end{array}$ & $\begin{array}{c}\text { ORIENTAL } \\
\text { SUB-REGIONS. }\end{array}$ & \\
\hline 1.2 .3 .4 & 1.2 .3 .4 & 1.2 .3 .4 & $1.2 .3-$ & $1.2 .3-$ & ---- \\
\hline
\end{tabular}


Vultures range over all the great continents south of the Arctic Circle, being only absent from the Australian region, the Malay Islands, Ceylon, and Madagascar. The Old and New World forms are very distinct, belonging to two well-marked divisions, often ranked as families. The distribution of the genera is as follows :-

Sub-family I. VultuRIN \& (6 genera, 16 species), confined to the Old World.-Vultur (1 sp.), Spain and North Africa through Nepal to China north of Ningpo; Gyps (5 sp.), Europe south of $59^{\circ}$, Africa, except the western sub-region, India, Siam, and I Northern China; Pseudogyps (2 sp.), North-east Africa and Senegal, India and Burmah; Otogyps (2 sp.), South Europe, North-east and South Africa, India, and Siam; Lophogyps (1 sp.), North-east and South Africa and Senegal; Neophron (4 sp.), South Europe, India and the greater part of Africa.

Sub-family II. Sarcorhamphine (4 genera, 9 species), confined to the New World.-Sarcorhamphus (2 sp.), "The Condor," Andes of South America, and southern extremity below $41^{\circ}$ south latitude; Cathartes ( $1 \mathrm{sp}$.), America from $20^{\circ}$ south latitude to Trinidad and Mexico; Catharistes (1 sp.), America from $40^{\circ}$ north to $40^{\circ}$ south latitude, but not on Pacific coast of United States; Pseudogryphis (5 sp.), South America and Falkland Islands, and to $49^{\circ}$ north latitude in North America, also Cuba and Jamaica.

Family 95.—SERPENTARIID Æ. (1 Genus, 1 Species.)

\begin{tabular}{|c|c|c|c|c|c|}
\hline \multicolumn{6}{|c|}{ General Distribution. } \\
\hline $\begin{array}{l}\text { NEOTROPICAL } \\
\text { SUB-REGIONS. }\end{array}$ & $\begin{array}{c}\text { NEARCTIC } \\
\text { SUB-REGIGNS. }\end{array}$ & $\begin{array}{l}\text { PaLAarctic } \\
\text { Sub-REgions. }\end{array}$ & $\begin{array}{c}\text { ETHIOPIAN } \\
\text { SUB-REGIONS. }\end{array}$ & $\begin{array}{l}\text { ORIENTAL } \\
\text { SUB-REgians. }\end{array}$ & $\begin{array}{l}\text { AUSTRALIAN } \\
\text { SUB-REGIONS. }\end{array}$ \\
\hline--- & --- & ---- & $1.2 .3-$ & ---- & $-\cdots-$ \\
\hline
\end{tabular}

The singular Secretary Bird (Serpentarius) is found over a large part of Africa. Its position is uncertain, as it has affinities both with the Accipitres, through Polyboroides (?) and with Cariama, which we place near the Bustards. (Plate IV. Vol. I. p. 261.) 
FAMILY 96.-FALCONID\&. (69 Genera, 325 Species.)

\begin{tabular}{|c|c|c|c|c|c|}
\hline \multicolumn{6}{|c|}{ General Distribution. } \\
\hline $\begin{array}{l}\text { NEOTROPICAL } \\
\text { StiB-REGIONS. }\end{array}$ & $\begin{array}{c}\text { NEARCTIC } \\
\text { SuB-BEGIONS. }\end{array}$ & $\begin{array}{l}\text { PALEARCTIC } \\
\text { SUB-REGIONS. }\end{array}$ & $\begin{array}{c}\text { ETHIOPIAN } \\
\text { SUB-REGIONS. }\end{array}$ & $\begin{array}{c}\text { ORIENTAL } \\
\text { SUB-REGIONS. }\end{array}$ & $\begin{array}{l}\text { AUSTRALIAN } \\
\text { SUB-REGIONS. }\end{array}$ \\
\hline 1.2 .3 .4 & 1.2 .3 .4 & $1 \cdot 2 \cdot 3 \cdot 4$ & $1.2 .3 \cdot 4$ & $1 \cdot 2 \cdot 3 \cdot 4$ & $1 \cdot 2 \cdot 3 \cdot 4$ \\
\hline
\end{tabular}

The Falconidæ, including the various groups of Hawks, Kites, Buzzards, Eagles, and Falcons, are absolutely cosmopolitan, ranging far into the arctic zone and visiting the most remote oceanic islands. They are abundant in all the great continents and larger islands, preferring open to woody regions. They are divided into several sub-families, the range of some of which are restricted. For this family as well as the preceding I follow the arrangement of Mr. Sharpe's British Museum Catalogue, and shall give the approximate distribution of each sub-family, as well as of the several genera.

Sub-family I. Polyborinæe (2 genera, 10 species), the Neotropical region with California and Florida, Tropical and South Africa.-Polyborus (2 sp.), South America, and to California and Florida; 1bycter (8 sp.), Tierra del Fuego to Honduras and Guatemala.

Cariama and Serpentarius, which Mr. Sharpe puts here, are so anomalous that I think it better to class them in separate families-Serpentariidæ among the Accipitres, and Cariamidæ near the Bustards.

Sub-family II. ACcIPITRIN ж (10 genera, 87 species).-Cosmopolitan.-Polyboroides (2 sp.), Africa and Madagascar ; Circus(15 sp.), Old and New Worlds, widely scattered, but absent from Eastern Equatorial America, and the Malay Archipelago except Celebes ; Micrastur (7 sp.), and Geranospiza (2 sp.), Tropical parts of Neotropical region ; Urotriorchis (1 sp.), West Africa ; Erythrocnema (1 sp.), Chili and La Plata to California and Texas ; Melierax (5 sp.), Africa except West African sub-region ; Astur (30 sp.), cosmopolitan, except the Temperate South American sub-region; 
Nisoides (1 sp.), Madagascar; Lutriorchis (1 sp.), Madagascar; Accipiter (23 sp.), cosmopolitan, except Eastern Oceania.

Sub-family III. ButEonines (13 genera, 51 sp.), cosmopolitan, except the Malay and Pacific Islands.-Urospizias (1 sp.), East and Central Australia; Heterospizias (1 sp.), Tropical South America east of the Andes; Tachytriorchis (2 sp,), Paraguay to California ; Buteo (18 sp.), cosmopolitan, except the Australian region and the Indo-Malayan sub-region; Archibuteo (4 sp.), North America to Mexico and the cooler parts of the Palæarctic region; Buteola (1 sp.), Veragua to the Amazon Valley; Asturinc (7 sp.), Paraguay and Bolivia to South-east United States; Busarellus (1 sp.), Brazil to Guiana; Buteogallus (1 sp.), Guiana and Columbia; Urubutinga (12 sp.), South Brazil and Bolivia to Mexico; Harpyhaliceetus (1 sp.), Chili and North Patagonia to Veragua; Morphnus (1 sp.), Amazonia to Panama; Thrasaëtus (1 sp.), Paraguay and Bolivia to Mexico.

Sub-family 1V. AquiLin \& (31 genera, 94 species), cosmopolitan.-Gypaëtus (2 sp.), south of Palæarctic region from Spain to North China, Abyssinia, and South Africa; Uroaëtus (1 sp.), Australia and Tasmania; Aquila (9 sp.), Nearctic, Palæarctic, and Ethiopian regions and India; Niscëtus (4 sp.), Africa and South Europe, India, Ceylon, and Australia; Lophotriorchis (2 sp.), Indo-Malay sub-region, and Bogotá in South America; Neopus (1 sp.), India and Ceylon to Burmah, Java, Celebes and Ternate; Spiziostur (1 sp.), Guatemala to Brazil ; Spizcëtus (10 sp.), Central and South America, Africa, India, and Ceylon, to Celebes and New Guinea, Formosa, and Japan; Lophocëtus (1 sp.), all Africa ; Asturinula (1 sp.), Africa, except extreme south ; Herpetotheres (1 sp.), Bolivia and Paraguay to Southern Mexico; Dryotriorchis (1 sp.), West Africa; Circaëtus (5 sp.) Africa to Central Europe, the Indian Peninsula, Timor ; Spilornis (6 sp.), Oriental region and Celebes; Butastur (4 sp.), Oriental region to New Guinea and North-east Africa; Helotarsus (2 sp.), Africa south of the Sahara; Halicetus (7 sp.), cosmopolitan, except the Neotropical region; Gypohierax (1 sp.), West Africa and Zanzibar ; Haliastur (2 sp.), Indian Peninsula to Ceylon, New Cale- 
donia, and Australia; Nauclerus (= Elanoides) (1 sp.), Brazil to Southern United States ; Elanoides (= Nauclerus) (1 sp.), Western and North-eastern Africa; Milvus (6 sp.), the Old World and Australia: Lophoictinia (1 sp.), Australia; Rostrhamus (3 sp.), Antilles and Florida to Brazil and Peru; Leptodon (4 sp.), Central America to South Brazil and Bolivia; Gypoictinia (1 sp.), South and West Australia; Elanus (5 sp.), Africa, India, and Malay Archipelago to Australia, South America to California; Gampsonyx (1 sp.), Trinidad to Brazil ; Henicopernis (1 sp.), Papuan Islands; Machorhamphus (2 sp.), South-west Africa, Madagascar, and Malacca; Pernis (3 sp.), Palæarctic, Oriental, and Ethiopian regions.

Sub-family V. FALConin $\mathbb{E}$ (11 genera, 80 species), cosmopolitan. -Baza (10 sp.), India and Ceylon to the Moluccas and North Australia, West Coast of Africa, Natal, and Madagascar; Harpagus (3 sp.), Central America to Brazil and Peru ; Ictinia (2 sp.), Brazil to Southern United States; Hierax (=Microhierax, Sharpe), (4 sp.), Eastern Himalayas to Borneo and Philippines; Poliohierax (2 sp.), East Africa and Burmah; Spiziapteryx (1 sp.), La Plata; Harpa (1 sp.), New Zealand and the Auckland Islands; Falco (27 sp.), cosmopolitan, except the Pacific Islands ; Hierofalco (6 sp.), Nearctic and Palæarctic regions; Hieracidea (2 sp.), Australia ; Cerchneis (22 sp.), cosmopolitan, except Oceania.

\section{FAMily 97.-PANDIONIDA. (2 Genera, 3 Species.)}

\begin{tabular}{|c|c|c|c|c|c|}
\hline $\begin{array}{l}\text { NEOTROPICAL } \\
\text { SUB-REOIONS. }\end{array}$ & $\begin{array}{c}\text { NEARCTIC } \\
\text { SUB-REGIONS. }\end{array}$ & $\begin{array}{l}\text { PaLAEARCTIO } \\
\text { SUB-REGIONS. }\end{array}$ & $\begin{array}{c}\text { ETHIOPIAN } \\
\text { SUB-REGIONS. }\end{array}$ & $\begin{array}{c}\text { ORIENTAL } \\
\text { SUB-REGIONS. }\end{array}$ & $\begin{array}{l}\text { AUSTRALIAN } \\
\text { SuB-REGIONS. }\end{array}$ \\
\hline-2.3 .4 & 1.2 .3 .4 & 1.2 .3 .4 & I. 2.3 .4 & 1.2 .3 .4 & 1.2 .3 .4 \\
\hline
\end{tabular}

The Pandionidæ, or Fishing Hawks, are universally distributed, with the exception of the Southern Temperate parts of South America. The genera are :-

Pandion (1 sp.), the range of the entire family ; Polioceetus (2 sp.), India through Malay Archipelago to Celebes and Sandwich Islands. 
FAMiLy 98.-STRIGID Æ. (23 Genera, 180 Species.)

\begin{tabular}{|c|c|c|c|c|c|}
\hline \multicolumn{6}{|c|}{ General Distribution. } \\
\hline $\begin{array}{l}\text { NEOTROPICAL } \\
\text { SUB-REGIONS. }\end{array}$ & $\begin{array}{c}N_{\text {EARCTIC }} \\
\text { SUB-REGIONS. }\end{array}$ & $\begin{array}{l}\text { PaLAarCtiC } \\
\text { Sub-REGIONS. }\end{array}$ & $\begin{array}{c}\text { ETHIOPIAN } \\
\text { SUB-REGIONS. }\end{array}$ & $\begin{array}{c}\text { ORIENTAL } \\
\text { SUB-REGIONS. }\end{array}$ & $\begin{array}{l}\text { AUstralian } \\
\text { SUb-REgIONS. }\end{array}$ \\
\hline 1.2 .3 .4 & 1.2 .3 .4 & 1.2 .3 .4 & 1.2 .3 .4 & 1.2 .3 .4 & 1.2 .3 .4 \\
\hline
\end{tabular}

The Strigidæ, or Owls, form an extensive and well-known family of nocturnal birds, which, although invariably placed next the Hawks, are now believed to be not very closely allied to the other Accipitres. They range over the whole globe, extending to the extreme polar regions and to the remotest oceanic islands. Their classification is very unsettled, and we therefore place the genera, for convenience, in the order in which they follow each other in the Hand List of Birds. Those adopted by most ornithologists are the following:-

Surnia (1 sp.), the Arctic regions of both hemispheres; Nyctea (1.sp.), South Carolina to Greenland and Northern Europe; Athene (40 sp.), the Eastern hemisphere to New Zealand and the Solomon Islands; Ninox (7 sp.), the Oriental region, North China and Japan; Glaucidium (7 sp.), Neotropical region, California, and Oregon, Europe to North China; Micrathene (1 sp.), Mexico and Arizona; Pholeoptynx (2 sp.), Neotropical region, Texas, and North-west America ; Bubo (16 sp.), universally distributed, excluding the Australian region; Ketupa (3 sp.), the Oriental region, Palestine; Scotopelia (2 sp.), West and South Africa; Scops (30 sp.), universally distributed, excluding Australia and Pacific Islands ; Gymnoglaux (2 sp.), Antilles; Lophostrix (2 sp.), Lower Amazon to Guatemala; Syrnium (22 sp.), all regions but the Australian; Ciccaba (10 sp.), Paraguay to Mexico ; Nyctalatinus (1 sp.), Columbia; Pulsatrix (2 sp.), Brazil and Peru to Guatemala; Asio (6 sp.), all regions but the Australian, Sandwich Islands; Nyctalops (1 sp.), Cuba and Mexico to Brazil and Monte Video; Pseudoscops (1 sp.), Jamaica; Nyctala (4 sp.), the North Temperate zone; Strix (18 sp.), universally distributed; Phodilus (1 sp.), Himalayas and Malaya. 
In Mr. Sharpe's Catalogue (published while this work was passing through the press) the genera of Owls are reduced to 19, arranged in two families--Strigidæ, containing our last two genera, and Bubonidæ, comprising the remainder. The species are increased to 190 ; but some genera are reduced, as Strix, which is said to contain only 5 species.

General Remarks on the Distribution of the Accipitres.

The Birds of Prey are so widely distributed over the world's surface that their general distribution calls for few remarks. Of the four families all but one are cosmopolites, Vultures alone being absent from the Australian region, as well as from Indo-Malaya and Madagascar. If we take the sub-families, we find that each region has several which are confined to it. The only parts of the world where there is a marked deficiency of Accipitres is in the islands of the Pacific; and it may be noted, as a rule, that these birds are more abundant in continents than in islands. There is not so much difference between the number of Birds of Prey in tropical and temperate regions, as is found in most other groups of land-birds. North America and Europe have about 60 species each, while India has about 80, and South America about 120. The total number of Accipitres is 550 comprised in 104 genera, and 4 (or perhaps more properly 5) families. In this estimate I have not included the Serpentariidæ, containing the Secretary Bird of Africa, as there is some doubt whether it really belongs to the Order.

Order VIII.-GRALL $2 E$.

FAMily 99.-RALLIDÆ. (18 Genera, 153 Species.)

\begin{tabular}{|c|c|c|c|c|c|}
\hline \multicolumn{6}{|c|}{ General Distribution. } \\
\hline $\begin{array}{l}\text { NEOTROPICAL } \\
\text { SUB-REGIONS. }\end{array}$ & $\begin{array}{c}\text { NEARCTIC } \\
\text { SUB-REOIONS. }\end{array}$ & $\begin{array}{l}\text { PALFARCTIC } \\
\text { SUB-REGIONS. }\end{array}$ & $\begin{array}{c}\text { ETHIOPIAN } \\
\text { SUB-REGIONS. }\end{array}$ & $\begin{array}{c}\text { ORIENTAL } \\
\text { SUB-REGIONS. }\end{array}$ & $\begin{array}{l}\text { AUSTRALIAN } \\
\text { SUB-REGIONS. }\end{array}$ \\
\hline 1.2 .3 .4 & $1 \cdot 2 \cdot 3 \cdot 4$ & 1.2 .3 .4 & 1.2 .3 .4 & $1 \cdot 2 \cdot 3 \cdot 4$ & $1.2 \cdot 3 \cdot 4$ \\
\hline
\end{tabular}

The Rails are among the most widely distributed families of birds, many of the genera being cosmopolitan, and several of the 
species ranging over half the globe. They are found in many remote islands; and in some of these-as the Gallinula of 'Tristan d'Acunha, and the Notornis of Lord Howe's Island and New Zealand,- they have lost the power of flight. The classification of the Rallidæ is not satisfactory, and the following enumeration of the genera must only be taken as affording; a provisional sketch of the distribution of the group :-

Rallus (18 sp.), Porzana (24 sp.), Gallinula (17 sp.), and Fulica (10 sp.), have a world-wide range; Ortygometra (1 sp.), ranges over the whole North Temperate zone; Porphyrio (14 sp.), is more especially Oriental and Australian, but occurs also in South America, in Africa, and in South Europe; Eulabeornis (15 sp.), is Ethiopian, Malayan, and Australian; Himantornis (1 sp.), is West African only; Aramides (24 sp.), is North and South American; Rallina (16 sp.), is Oriental, but ranges eastward to Papua; Habroptila (1 sp.), is confined to the Moluccas; Pareudiastes (1 sp.), the Samoa Islands; Tribonyx (4 sp.), is Australian, and has recently been found also in New Zealand; Ocydromus (4 sp.); Notornis (2 sp.), (Plate XIII. Vol. I. p. 455); and Cabalus (1 sp.), are peculiar to the New Zealand group.

The sub-family, Heliornithinæ (sometimes classed as a distinct family) consists of 2 genera, Heliornis (1 sp.), confined to the Neotropical region; and Podica (4 sp.), the Ethiopian region excluding Madagascar, and with a species (perhaps forming $\mathrm{n}$ nother genus) in Borneo.

Extinct Rallidoe.-Remains of some species of this family have been found in the Mascarene Islands, and historical evidence shows that they have perhaps been extinct little more than a century. They belong to the genus Fulica, and to two extinct genera, Aphanapteryx and Erythromachus. The Aphanapteryx was a large bird of a reddish colour, with loose plumage, and perhaps allied to Ocydromus. Erythromachus was much smaller, of a grey-and-white colour, and is said to have lived chiefly on the eggs of the land-tortoises. (See Ibis, 1869, p. 256; and Proc. Zool. Soc., 1875, p. 40.) 
Family 100.-SCOLOPACII) E. (21 Genera, 121. Species.)

\begin{tabular}{|c|c|c|c|c|c|}
\hline & . & General D & STRIBUTION. & & \\
\hline $\begin{array}{l}\text { NEOTROPICAL } \\
\text { SuB-REgIONS. }\end{array}$ & $\begin{array}{c}N_{\text {EARCTIC }} \\
\text { SUB-REQZONS. }\end{array}$ & $\begin{array}{l}\text { PaLAarctic } \\
\text { SUB-REGiods. }\end{array}$ & $\begin{array}{l}\text { ETHIOPIAN } \\
\text { SUB-REGIONS. }\end{array}$ & $\begin{array}{l}\text { ORIENTAL } \\
\text { SUB-KEGIONS. }\end{array}$ & $\begin{array}{l}\text { AUSTRalian } \\
\text { SUB-REGIONS. }\end{array}$ \\
\hline 1.2 .4 .4 & 1.2 .3 .4 & $1 \cdot 3 \cdot 3 \cdot 4$ & 1.2 .3 .4 & 1.2 .3 .4 & 1.2 .3 .4 \\
\hline
\end{tabular}

The Scolopacidæ, comprehending the Snipes, Sandpipers, Curlews, and allied genera, are perhaps as truly cosmopolitan as any family of birds, ranging to the extreme north and visiting the remotest islands. The genera of universal distribution are the following :-

Numenius (16 sp.); Limosa (6 sp.); Totanus (12 sp.) ; Tringoides, (6 sp.); Himantopus (6 sp.); Tringa (20 sp.); and Gallinago (24 sp.). Those which have a more or less restricted distribution are:-

Ibidorhyncha (1 sp.), Central Asia and the Himalayas (Plate VII. Vol. I. p. 331); Hclodromas (1 sp.), Palæarctic region and North India; Terekia (1 sp.), East Palæarctic, wandering to India and Australia; Recurvirostra (6 sp.), Nearctic region to the High Andes, South Palæarctic, East and South Africa, Hindostan and Australia; Micropelama (1 sp.), North America to Chili; Machetes (1 sp.), Palæarctic region and Hindostan (Plate I. Vol. I. p. 195); Ereunetes (3 sp.), Nearctic and Neotropical; Eurinorhynchus (1 sp.), North-east Asia and Bengal; Calidris (1 sp.), all regions but Australian; Macrorhamphus (3 sp.), Palæarctic and Nearctic, visits Brazil and India; Scolopax (4 sp.), the whole Palæarctic region, to India, Javd, and Australia ; Philohela (1 sp.), East Nenrctic; Rhynchwe (4 sp.), Ethiopian and Oriental, Australia, and Temperate South America; Phalaropus (3 sp.), North Temperate zone, and West Coast of America to Chili. 
Family 101.-CHIONIIDIDA. (1 Cenus, 2 Species.)

\begin{tabular}{|c|c|c|c|c|c|}
\hline \multicolumn{6}{|c|}{ General Distributiox. } \\
\hline $\begin{array}{l}\text { NEOTROPICAL } \\
\text { SUB-REG.ONS. }\end{array}$ & $\begin{array}{l}\text { NEARGTIC } \\
\text { SUB-REOIONS. }\end{array}$ & $\begin{array}{l}\text { Palafarctic } \\
\text { SUB-HEGHOAS. }\end{array}$ & $\begin{array}{c}\text { ETHIOPIAN } \\
\text { SUB-REGIONS. }\end{array}$ & $\begin{array}{l}\text { ORIENTAL } \\
\text { SUB-REOIONS. }\end{array}$ & $\begin{array}{l}\text { AUsrralian } \\
\text { SUB-REGIONA. }\end{array}$ \\
\hline $1---$ & ---- & $---\cdots$ & ---- & ---- & ---- \\
\hline
\end{tabular}

The Sheath-bills, Chionis ( 2 sp.), are curious white birds, whose thick bill has a horny sheath at the base. Their nearest ally is Hcematopus, a genus of Charadriidie. These birds are confined to the Antarctic Islands, especially the Falkland Islands, the Crozets and Kerguelen's Land.

\section{Famly 102.-THINOCORIDA. (2 Genera, 6 Species.)}

\begin{tabular}{|c|c|c|c|c|c|}
\hline \multicolumn{6}{|c|}{ General Disthibution. } \\
\hline $\begin{array}{l}\text { Nrotropical } \\
\text { Stib-REGION. }\end{array}$ & $\begin{array}{c}\text { NEARCTIC } \\
\text { SUB-REGIONS. }\end{array}$ & $\begin{array}{l}\text { Palafearctic } \\
\text { Sub-kEgions. }\end{array}$ & $\begin{array}{l}\text { ETHIOPIAN } \\
\text { SUB-REGIONS. }\end{array}$ & $\begin{array}{l}\text { ORIENTAL } \\
\text { SUB-HEGIONS. }\end{array}$ & $\begin{array}{l}\text { AtstraliaN } \\
\text { SUB-REGIONS. }\end{array}$ \\
\hline $1---$ & ---- & $--\cdots$ & --- & --- & $-\cdots-$ \\
\hline
\end{tabular}

The Thinocoridæ, or Quail-snipes, are small birds, confined to Temperate South America. They have much the appearance of Quails but are more nearly allied to Plovers. The two genera are :-

Attagis (4 sp.), Falkland Islands, Straits of Magellan, Chili, Bolivia, and the High Andes of Peru and Ecuador; Thinocorus (2 sp.), La Plata, Chili, and Peru. (Plate XVI. Vol. II. p. 40.)

Fanfly 103.-PARRIDÆ. (2 Genera, 11 Species.)

\begin{tabular}{|c|c|c|c|c|c|}
\hline \multicolumn{6}{|c|}{ General Distribution. } \\
\hline $\begin{array}{l}\text { NEOTROPICAL } \\
\text { SUB-REgIONS. }\end{array}$ & $\begin{array}{c}\text { AEARCTIC } \\
\text { SUB-REGIONS. }\end{array}$ & $\begin{array}{l}\text { PaLAaACTIC } \\
\text { SUB-REGIONS. }\end{array}$ & $\begin{array}{c}\text { ETHIOPIIN } \\
\text { SUB-REGIONS. }\end{array}$ & $\begin{array}{c}\text { ORIENTAL } \\
\text { SUB-REgIONS. }\end{array}$ & $\begin{array}{l}\text { AUSTRALIAN } \\
\text { SUB-REGIONS. }\end{array}$ \\
\hline$-2.3-$ & --- & --- & 1.2 .3 .4 & $1 \cdot 2 \cdot 3 \cdot 4$ & $1.2--$ \\
\hline
\end{tabular}


The Parridæ, or Jacanas, are remarkable long-toed birds, often of elegant plumage, frequenting swamps and marshes, and walking on the floating leaves of aquatic plants. They are found in all the tropics. Parra $(10 \mathrm{sp}$.), has the distribution of the family; Hydrophasianus (1 sp.), is confined to the Oriental region.

Family 104.-GLAREOLIDE. (3 Genera, 20 Species.)

\begin{tabular}{|c|c|c|c|c|c|}
\hline \multicolumn{6}{|c|}{ General Distribution. } \\
\hline $\begin{array}{l}\text { NEOTROPICAL } \\
\text { SUB-REGIONS. }\end{array}$ & $\begin{array}{l}\text { NEARCTIC } \\
\text { SUB-REGIONS. }\end{array}$ & $\begin{array}{l}\text { PaLAaACTIC } \\
\text { SUB-hegIOANS. }\end{array}$ & $\begin{array}{c}\text { ETHIOPIAN } \\
\text { SUB-REGIONS. }\end{array}$ & $\begin{array}{c}\text { Oriental } \\
\text { SUB-kEgIoNs. }\end{array}$ & $\begin{array}{l}\text { AUSTRaLIaN } \\
\text { SUB-REGiONS. }\end{array}$ \\
\hline--- & $--\cdots$ & 1.2 .3 .4 & $1.2 \cdot 3 \cdot 4$ & 1.2 .3 .4 & 1.2 \\
\hline
\end{tabular}

This family, comprising the Pratincoles and Coursers, is universally distributed over the Old World and to Australia.

Glareola (9 sp.), has the distribution of the family; Plurictnus (1 sp.), is confined to North Africa; Cursorius (10 sp.), ranges over Africa, South Europe and India.

The position of the genus Glareola is uncertain, for thongh generally classed here, Prof. Lilljeborg considers it. to be an aberrant form of the Caprimulgidæ! It differs, in its insectivorous habits and in many points of external structure, from all its allies, and should probably form a distinct family.

Fanily 105.-CHARADIID $Æ . \quad(19$ Genera, 101 Species.)

Geseral Distribution.

\begin{tabular}{|c|c|c|c|c|c|}
\hline $\begin{array}{l}\text { Nrotropical } \\
\text { StiB-REGIONS. }\end{array}$ & $\begin{array}{c}\text { NEARCTIC } \\
\text { SUB-REGIONS. }\end{array}$ & $\begin{array}{l}\text { Pal.earctic } \\
\text { Sub-ilegrons. }\end{array}$ & $\begin{array}{c}\text { ETHIOPIAN } \\
\text { SUB-REGIUNS. }\end{array}$ & $\begin{array}{l}\text { ORiENTAL } \\
\text { SUB-REGIONS. }\end{array}$ & $\begin{array}{l}\text { AUSTRaLIAN } \\
\text { SUB-REGIONG. }\end{array}$ \\
\hline & 1 & 2. & 1.2 .3 & .2 .3 & 2 \\
\hline
\end{tabular}

The extensive family of the Plovers and their numerous allies, ranges over the whole globe. The genera now usually admitted into this family are the following :-

Edicnemus (9 sp.), is only absent from North America; Asacus (2 sp.), India to Ceylon, Malay Islands and Australia; 
Vanellus (3 sp.), Palaarctic and Neotropical regions; Chotusic (15 sp.), the whole Eastem Hemisphere; Erythrogonys (1 sp.), Australia; Hoplopterus (10 sp.), widely scattered, but absent from North America; Squatarola (1 sp), all the regions; Charadrius (14 sp.), cosmopolitan ; Eudromias (5 sp.), Eastern Hemisphere and South Temperate America; Egialitis (22 sp.), cosmopolitan; Orcophilus (1 sp.), South Temperate America; Thinomis (2 sp.), New Zealand; Anarhynchus (1 sp.), New Zealand (Plate XIII. Vol I. p. 455); Homctopus (9 sp.), cosmopolitan; Strepsilas (2 sp.) almost cosmopolitan; Aphriza .1 sp.), West Coast of America; Pluvianellus (1 sp.), Straits of Magellan; Dromas (1 sp.), India, Madagascar, and North-east Africa; Pedionomus (1 sp.), Australia. This last genus has usually been placed with the Turnicidæ.

Family 106.—OTIDID E. (2 Genera, 26 Species.)

\begin{tabular}{|c|c|c|c|c|c|}
\hline \multicolumn{6}{|c|}{ General Destribution. } \\
\hline $\begin{array}{l}\text { NFotRopical } \\
\text { SLB-REGioNS. }\end{array}$ & $\begin{array}{c}\text { NEARCTIC } \\
\text { SUB-REGIONS. }\end{array}$ & $\begin{array}{l}\text { Palafarctic } \\
\text { Sub-riegions. }\end{array}$ & $\begin{array}{c}\text { ETHIOPIAN } \\
\text { SUB-REGIONS. }\end{array}$ & $\begin{array}{l}\text { ORIENTAL } \\
\text { SUB-REGIONS. }\end{array}$ & $\begin{array}{l}\text { Australiar } \\
\text { Sub-REgions. }\end{array}$ \\
\hline---- & --- & $1 \cdot 2 \cdot 3 \cdot 4$ & $1.2 .3-$ & $1.2 \cdot 3-$ & $-2--$ \\
\hline
\end{tabular}

The Otididæ, or Bustards, occur in all parts of the Old World and Australia where there are open tracts, being only absent from Madagascar and the Malay Archipelago.

Otis (2 sp.), ranges over most of the Palæarctic region; while Eupodotis (24 sp.), has the range of the family, but is most abundant in the Ethiopian region, which contains three-fourths of the whole number of species.

Family 107.-GRUID $\approx . \quad$ (3 Genera, 16 Species.)

\begin{tabular}{|c|c|c|c|c|c|}
\hline \multicolumn{6}{|c|}{ General Distribut ron. } \\
\hline $\begin{array}{l}\text { NEOTROPICAL } \\
\text { SUB-REQIONS. }\end{array}$ & $\begin{array}{l}\text { NEARCTIC } \\
\text { SUB-LEGGIONS. }\end{array}$ & $\begin{array}{l}\text { PaLAEARCTIC } \\
\text { SUB-hEGIONS. }\end{array}$ & $\begin{array}{c}\text { ETHIOPIAN } \\
\text { SUb-REGIONS. }\end{array}$ & $\begin{array}{l}\text { ORIENTAL } \\
\text { SUB-KEGIONS. }\end{array}$ & $\begin{array}{l}\text { Australian } \\
\text { Sub-REgions. }\end{array}$ \\
\hline$-\ldots$ & $1.2 .3-$ & 1.2 .3 .4 & $1 \cdot 2 \cdot 3-!$ & $1.2 .3-$ & $-2--$ \\
\hline
\end{tabular}


The Gruirlæ, or Cranes, are found in all the regions except the Neotropical.

Grus (12 sp.) inhabits the southern and western United States, the whole Palæarctic region, South-east Africa, India, and Australia; Anthropoides (2 sp.), Europe, North and South Africa and India; Balearica (2 sp.), the Ethiopian region (except Madagascar).

FAMILY 108-CARIAMID Æ. (1 Genus, 2 Species.)

\begin{tabular}{|c|c|c|c|c|c|}
\hline \multicolumn{6}{|c|}{ General Distribution. } \\
\hline $\begin{array}{l}\text { NEOTROPICAL } \\
\text { SUB-REGIONS. }\end{array}$ & $\begin{array}{c}\text { NEARCTIC } \\
\text { SUB-REIONS. }\end{array}$ & $\begin{array}{l}\text { PALAAARCTIC } \\
\text { SUB-REGIONS. }\end{array}$ & $\begin{array}{c}\text { ETHIOPIAN } \\
\text { SUB-REGIONS. }\end{array}$ & $\begin{array}{l}\text { ORIENTAL } \\
\text { SUB-KEGIONS. }\end{array}$ & $\begin{array}{l}\text { AUSTRALIRAN } \\
\text { SUB-REGIONS. }\end{array}$ \\
\hline $1.2--$ & ---- & --- & ---- & ---- & -- \\
\hline
\end{tabular}

The genus Cariama (2 sp.), consists of remarkable crested birds inhabiting the mountains and open plains of Brazil and La Plata. In the British Museum Catalogue of the Birds of Prey, they are classed as aberrant Falconidæ, but their anomalous characters seem to require them to be placed in a distinct family, which seems better placed among the Waders.

Family 109.-ARAMID Æ. (1 Genus, 2 Species.)

\begin{tabular}{|c|c|c|c|c|c|}
\hline \multicolumn{6}{|c|}{ General Distribution. } \\
\hline $\begin{array}{l}\text { NEOTROPICAL } \\
\text { SUB-REGIONS. }\end{array}$ & $\begin{array}{c}\text { NEARCTIC } \\
\text { SUB-REGIONS. }\end{array}$ & $\begin{array}{l}\text { PaLfaARCTIC } \\
\text { SUB-kEGIONS. }\end{array}$ & $\begin{array}{l}\text { ETIIOPIAN } \\
\text { SUB-REGloNs. }\end{array}$ & $\begin{array}{l}\text { ORIRNTAL } \\
\text { SUb-REgIOXS. }\end{array}$ & $\begin{array}{l}\text { AUSTRALIAN } \\
\text { SUB-RBATON. }\end{array}$ \\
\hline$-2 \cdot 3 \cdot 4$ & $--\cdots$ & $--\cdots$ & ---- & ---- & $-\cdots-$ \\
\hline
\end{tabular}

The Guaraünas are birds which have somewhat the appearance of Herons, but which are usually classed with the Rails. They are now, however, considered to form a distinct family. The only genus, Aramus ( 2 sp.), inhabits the Neotropical region, - from Mexico and Cuba to Central Brazil. 
Family 110.-PSOPHIIDA. (1 Genis, 6 Species.)

\begin{tabular}{|c|c|c|c|c|c|}
\hline \multicolumn{6}{|c|}{ Gexeral Distribution. } \\
\hline $\begin{array}{l}\text { NEOTROPICAL } \\
\text { S'B-REGIONS. }\end{array}$ & $\begin{array}{c}\text { AEARCT:C } \\
\text { SrB-REGIONS. }\end{array}$ & $\begin{array}{l}\text { PaLfaARCTIC } \\
\text { SUB-REGIONS. }\end{array}$ & $\begin{array}{c}\text { ErhIOPIIN } \\
\text { SUB-REGIONS. }\end{array}$ & $\begin{array}{l}\text { ORIENTAL } \\
\text { SUB-ILGIONS. }\end{array}$ & $\begin{array}{l}\text { AUSTralian } \\
\text { SUB-REgIUN.s. }\end{array}$ \\
\hline$-2--$ & $-\cdots-$ & ---- & --- & $--\cdots$ & -- \\
\hline
\end{tabular}

The remarkable and beautiful birds called Trumpeters, are confined to the various parts of the Amazon valley; and it is an interesting fact, that the range of each species appears to be bounded by some of the great rivers. Thus, Psophia crepitans inhabits the interior of Guiana as far as the south bank of the Rio Negro; on the opposite or north bank of the Rio Negro Psophia ochroptera is found; beyond the next great rivers, Japura and Iça, Psophia napensis occur's; on the south bank of the Amazon, west of the Madeira, we have the beautiful Psophia leucopter ; east of the Madeira this is replaced by Psophia viridis, while near Pará, beyond the Tapajoz, Xingu and Tocantins, there is another species, Psophia obscura. Other species may exist in the intervening river districts; but we have here, apparently, a case of a number of well-marked species of birds capable of flight, yet with their range in certain directions accurately defined by great rivers. (Plate XV. Vol. II. p. 28.)

\section{Family 111.-EURYPYGID E. (1 Genus, 2 Species.)}

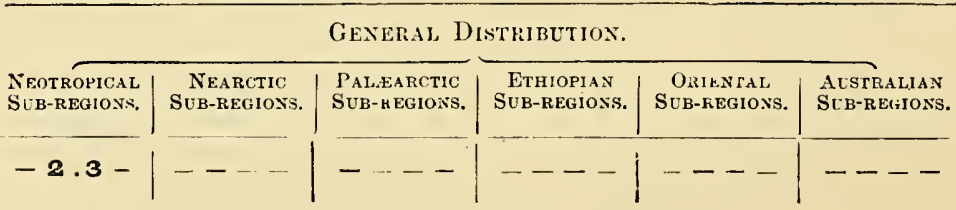

The Eurypygida, or Sun-Bitterns, are small leron-like birds with beautifully-coloured wings, which frequent the muddy and wooded river-banks of tropical America. The only genus, Eurypyga (2 sp.), ranges from Central America to Brazil. 
Fanily 112.-RHINOCHETIDE. (1 Genus, 1 species.)

\begin{tabular}{|c|c|c|c|c|c|}
\hline \multicolumn{6}{|c|}{ General Distribution. } \\
\hline $\begin{array}{l}\text { NEOTROPICAL } \\
\text { FUB-REGIOAS. }\end{array}$ & $\begin{array}{c}\text { NEARCTIG } \\
\text { SUB-REGIONS. }\end{array}$ & $\begin{array}{l}\text { PALEARCII } \\
\text { SUB-REGTONS. }\end{array}$ & $\begin{array}{c}\text { ETHIOPIIN } \\
\text { SUB-REGIONS. }\end{array}$ & $\begin{array}{c}\text { ORIEATAL } \\
\text { SUB-REGIONS. }\end{array}$ & $\begin{array}{l}\text { AUStralian } \\
\text { Sub-reglons. }\end{array}$ \\
\hline$--3-$ & --- & ---- & --- & --- & - \\
\hline
\end{tabular}

The genus Rhinochetus (1 sp.), consists of a singular bird called the Kagu, which inhabits New Caledonia, ar island which may be placed with almost equal propriety in our 1st, 2nd, or 3rd Australian sub-regions. It is a bird of a bluish ash-colour, with a loose plumage, partaking something of the appearance of Rail, Plover, and Heron, but with peculiarities of structure which require it to be placed in a distinct family. Its anatomy shows that its nearest aliies are the South American genera, Eurypyga and Isophice.

\section{FAMILY 113.-ARDEID $\nRightarrow . \quad(5$ Genera, 80 Species.)}

\begin{tabular}{|c|c|c|c|c|c|}
\hline \multicolumn{6}{|c|}{ Gmenal Distiabution. } \\
\hline $\begin{array}{l}\text { NeOtRopical } \\
\text { SUb-REgloNs. }\end{array}$ & $\begin{array}{c}\text { NEARCTIC } \\
\text { SUB-REGIONS. }\end{array}$ & $\begin{array}{l}\text { PALLEARCTIC } \\
\text { SUb-kEgLOINS. }\end{array}$ & $\begin{array}{c}\text { ETHIOPIAN } \\
\text { SUB-REGIONS. }\end{array}$ & $\begin{array}{c}\text { ORIENTAL } \\
\text { SUB-FEGIONS. }\end{array}$ & $\begin{array}{l}\text { Atsratalian } \\
\text { StB-REgions. }\end{array}$ \\
\hline $1 \cdot 2 \cdot 3 \cdot 4$ & $1 \cdot 2 \cdot 3.4$ & $1 \cdot 2 \cdot 3 \cdot 4$ & 1.2 .3 .4 & 1.2 .3 .4 & 1.2 .3 .4 \\
\hline
\end{tabular}

The well-known Herons and Bitterns are found in every part of the globe, and everywhere closely resemble each other. Omitting the minuter sub-divisions, the genera are as follows:Ardea (60 sp.), cosmopolitan ; Botaume (6 sp.), almost cosmopolitan ; Tigrisoma ( $4 \mathrm{sp}$.), Tropical America and West A frica ; Nycticorax (9 sp.), cosmopolitan; Cancroma (1 sp.), Tropical America. 
Family 114.-PLATALEIDA. (6 Genera, 30 Species.)

\begin{tabular}{|c|c|c|c|c|c|}
\hline \multicolumn{6}{|c|}{ General Distuibution. } \\
\hline $\begin{array}{l}\text { NFotroptCaL } \\
\text { St'B-REGLONS. }\end{array}$ & $\begin{array}{c}\text { NEARCTIC } \\
\text { SUB-REgIONS. }\end{array}$ & $\begin{array}{l}\text { PalaARctic } \\
\text { Sub-kEgIONS. }\end{array}$ & $\begin{array}{c}\text { ETHIOPIAN } \\
\text { SUE-REGIONS. }\end{array}$ & $\begin{array}{c}\text { ORIENTAL } \\
\text { SUB-RECIONS. }\end{array}$ & $\begin{array}{l}\text { AUSTRALIAN } \\
\text { SuB-REgLONS. }\end{array}$ \\
\hline $1.2 \cdot 3 \cdot 4$ & 1.2 .3 .4 & $1.2 \cdot 3 \cdot 4$ & 1.2 .3 .4 & 1.2 .3 .4 & $1.2--$ \\
\hline
\end{tabular}

The Plataleidr, including the Spoonbills and Ibises, have been classed either with the Herons or the Storks, but have most affinity with the latter. Though not very numerous they are found over the greater part of the globe, except the colder zones and the Pacilic Islands. The following is the distribution of the genera :-

Platalea (6 sp.), all the warmer parts of the globe except the Moluccas and Pacific Islands; Ibis (2 sp.), Temperate North America and Tropical South America; Falcinellus (2 sp.), almost cosmopolitan; Geronticus (19 sp.), all Tropical countries and Temperate South America; Scopus (1 sp.), Tropical and South Africa; Balconiceps (1 sp.), the Upper Nile. This last genus the "Shoe-bird," nr boat-billed heron, perhaps forms a distinct family.

Family 115.-CICONIID $\mathbb{E} . \quad$ (5 Genera, 20 Species.)

\begin{tabular}{|c|c|c|c|c|c|}
\hline \multicolumn{6}{|c|}{ General Distribution. } \\
\hline $\begin{array}{l}\text { NEOTROPICAL } \\
\text { SUU-REGIONS. }\end{array}$ & $\begin{array}{c}\text { NEARCTIC } \\
\text { SUB-REGIONS. }\end{array}$ & $\begin{array}{l}\text { Palearctic } \\
\text { SUB-MEgIONS. }\end{array}$ & $\begin{array}{c}\text { ErHIOPIAN } \\
\text { SUB-REGIONS. }\end{array}$ & $\begin{array}{c}\text { ORIENTAL } \\
\text { SUB-EEGTONS. }\end{array}$ & $\begin{array}{l}\text { Australian } \\
\text { Sib-REGions. }\end{array}$ \\
\hline $1.2 .3-$ & $--3-$ & $1.2 .3 \cdot 4$ & 1.2 .3 .4 & 1.2 .3 .4 & $1.2--$ \\
\hline
\end{tabular}

The Ciconiida, or Storks, are mostly an Old World family, only three species inhabiting the Neotropical, and one, the Nearctic region. They are also absent from the islands of the Pacific, the Antilles, and, with one exception, from Madagascar. The genera are as follows:-

Ciconia (6 sp.), ranges through the Palæarctic, Ethiopian and 
Oriental regions as far as Celebes, and in South America; Mycteria (4 sp.), inhabits Africa, India, Australia and the Neotropical region; Leptopiltus (3 sp.), the Ethiopian and Oriental regions to Java; Tantalus (5 sp.), the Ethiopian, Oriental and Neotropical regions, and the Soutl-east of North America; Anastomus ( $2 \mathrm{sp}$.), the Ethiopian region, and India to Ceylon.

Fanily 116.-PALAMEDEID Æ. (2 Genera, 3 Species.)

\begin{tabular}{|c|c|c|c|c|c|}
\hline \multicolumn{6}{|c|}{ General Distribution. } \\
\hline $\begin{array}{l}\text { NFotRopical } \\
\text { StiB-REgIONS. }\end{array}$ & $\begin{array}{c}\text { NEARCTIC } \\
\text { SUB-REGIONS. }\end{array}$ & $\begin{array}{l}\text { PaLearctic } \\
\text { Sub-ILGIONS. }\end{array}$ & $\begin{array}{c}\text { ETHIOPIAN } \\
\text { SUB-REGIONS. }\end{array}$ & $\begin{array}{l}\text { ORIENTAL } \\
\text { SUB-REGIONS. }\end{array}$ & $\begin{array}{l}\text { AUSTRALIAN } \\
\text { Sub-REGIONS. }\end{array}$ \\
\hline $1.2--$ & ---- & $---\cdots$ & ---- & ---- & - \\
\hline
\end{tabular}

The Palamedeidæ, or Screamers, are curious semi-aquatic birds of doubtful affinities, perhaps intermediate between Gallinæ and Anseres. They are peculiar to South America. The genera are:-

Palamedea (1 sp.), which inhabits the Amazon valley; Chauna (2 sp.), La Plata, Brazil and Columbia.

Family 117.-PHCENICOPTERID \#. (1 Genus, 8 Species.)

\begin{tabular}{|c|c|c|c|c|c|}
\hline \multicolumn{6}{|c|}{ General Distribution. } \\
\hline $\begin{array}{l}\text { Neotropical } \\
\text { Sub-REGIONS. }\end{array}$ & $\begin{array}{c}\text { Nearctic } \\
\text { Sub-REgions. }\end{array}$ & $\begin{array}{l}\text { PALEARCTIC } \\
\text { SUB-hEGIOiNS. }\end{array}$ & $\begin{array}{c}\text { ETHIOPIAN } \\
\text { SUB-REGIONS. }\end{array}$ & $\begin{array}{c}\text { Oriental } \\
\text { Sub-fiegions. }\end{array}$ & $\begin{array}{l}\text { At'stralian } \\
\text { Stz-REGIONS. }\end{array}$ \\
\hline $1-3.4$ & --- & $-2--$ & 1.2 .3 .4 & I. $2--$ & --- \\
\hline
\end{tabular}

The Flamingoes (Phœnicopterus) seem peculiar to the Ethiopian and Neotropical regions, ranging from the former into India and South Europe. America has four species, inhabiting Chili and La Plata, the Galapagos, Mexico and the West Indian islands; the others range over all Africa, South Eurore, India and Ceylon. These singular birds are placed by some authors near the Spoonbills and Ibises, by others with the Geese. Professor Huxley considers them to be "completely 
intermediate between the Anserine birds on the one side and the Storks and Herons on the other." The ptcrolysis according to Nitzsch is "completely stork-like."

General Remarks on the Distribution of the Gralle, or Wading and Running Birds.

The Waders, as a rule, are birls of very wide distribution, the four largest families Rallidæ, Scolopacidæ, Charadriidæe and Ardeide, being quite cosmopolitan, as are many of the genera. But there are also a number of small families of very restricted distribution, and these all occur in the two most isolated regions, the Neotropical and the Australian. The Neotropical region is by far the richest in varied forms of Waders, having representatives of no less than 15 out of the 19 families, while 7 are altogether peculiar to it. The Australian region has 11 families, with 1 peculiar. The other two tropical regions each possess 11 families, but none are peculiar. The Palæarctic region has 10 , and the Nearctic 7 families. No less than three families-Chionididie, Thinocoridæ, and Cariamidæeare confined to the Temperate regions and highlands of South America; while four others,-Aramidæ, Psophiidæe, Eurypygidæe and Palamedeidie,-are found in Tropical America only; and these present such an array of peculiar and interesting forms as no other part of the globe can furnish. The Phœnicopteridæ or Flamingoes, common to the Tropical regions of Asia, Africa and America, but absent from Australia, is the only other feature of general interest presented by the distribution of the Waders.

The Order contains about 610 species, which gives abont 32 species to each family, a smaller average than in the Gallinæ or Accipitres, and only about one-fourth of the average number in the Passeres. This is partly due to the unusual number of very small families, and partly to the wide average range of the species, which prevents that specialization of forms that occurs in the more sedentary groups of birds. 


\section{Order IX-ANSERES.}

Famil 118.-ANATIDE. (40 Genera, 180 Species.)

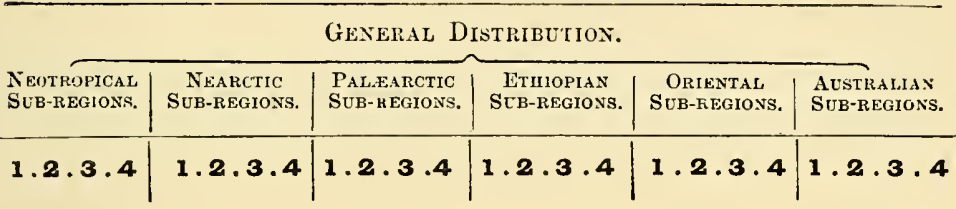

The Anatidæ, comprehending the Ducks, Geese, and Swans with their allies, are of such universal distribution that there is probably no part of the globe where some of them are not occasionally found. They are, however, most abundant in temperate and cold regions; and, contrary to what occurs in most other families, the most beautifully-coloured species are extratropical, and some even arctic. The distribution of the genera is as follows:-

Anseranas (1 sp.), Australia; Plectropterus (2 sp.), Tropical Africa; Sarkidionis (1 sp.), South America, Africa, and India; Chenalopex (1 sp.), Amazonia ; Callochen (1 sp.), South Europe, North, East, and South Africa; Cereopsis (1 sp.), Australia; Anser (13 sp.), Palæarctic and Nearctic regions to Central America and the Antilles; Eernicla (12 sp.), Temperate regions of the Northern and Sonthern Hemispheres; Chloephaga (5 sp.), South Temperate America and Aleutian IsIands; Nettapus (4 sp.), Tropical Africa and Madagascar, India and Ceylon to Malaya and Australia; Cygnus (10 sp.), Temperate regions of the Northern and Southern Hemispheres; Dendrocygna (10 sp.), Tropical and sub-tropical regions; Tadorna (3 sp.), Palaarctic and Australian regions; Casarea (5 sp.), Palæarctic, Oriental, Ethiopian, and Australian regions, to New Zealand; Aix (2 sp.), Temperate North America and Eastern Asia; Mareca (4 sp.), Palæarctic region, North America, Temperate South America, and Australia; Dafila (3 sp.), all America and the Palæarctic region; Anes (16 sp.), cosmopolitan ; Qucrquedula (17 sp.), 
cosmopolitan ; Chaulclasmus (2 sp.), Palæarctic region and North America; Spatula (5 sp.), all Temperate regions; Malacorlıynchus (1 sp), Australia; Cairina (1 sp.), Tropical South America; Branta (1 sp.), Palæarctic region and India; Fuligula (5 sp.), North Temperate regions and New Zealand; Ethya (5 sp.), Palæarctic and Nearctic regions, India, Australia, and South Africa; Metopiana (1 sp.), South Temperate America ; Bucepluala (4 sp.), Nearctic and Palæarctic regions; Harelda (2 sp.), Northern Palæartic and Nearctic regions; Hymenolaimus (1 sp.), New Zealand; Camptolaimus (1 sp.), North-east of North America; Micropterus (1 sp.), Temperate South America; Somateria (j sp.), Arctic and sub-aretic regions; $O E d c m i \alpha$ (5 sp.), Nearctic and Palæarctic regions; Biziura (1 sp.), Australia; Thalassornis (1 sp.), South Africa; Erismatura (6 sp.), all America, Southeast Europe and South Africa; Nesonetta (1 sp.), Auckland Islands ; Merganetta (3 sp.), Andes of Columbia to Chili; Mergus (6 sp.), Palæarctic and Nearctic regions, Brazil, and the Auckland Tslands.

Family 119.-LARID $Æ . \quad(13$ Genera, 132 Species )

\begin{tabular}{|c|c|c|c|c|c|}
\hline \multicolumn{6}{|c|}{ General Distribution. } \\
\hline $\begin{array}{l}\text { NEOTROPICAL } \\
\text { EUB-REGIONS. }\end{array}$ & $\begin{array}{c}\text { NEARCTiC } \\
\text { SUB-REGIONS. }\end{array}$ & $\begin{array}{l}\text { PaLAARCTIC } \\
\text { SUB-REGTONS. }\end{array}$ & $\begin{array}{c}\text { ETHTOPIAN } \\
\text { SUB-REGIONS. }\end{array}$ & $\begin{array}{c}\text { ORIFATAL } \\
\text { SUB-REGIONS. }\end{array}$ & $\begin{array}{l}\text { AUSTRALIAN } \\
\text { SUB-REGIUNS. }\end{array}$ \\
\hline 1.2 .3 .4 & $1 \cdot 2 \cdot 3 \cdot 4$ & $1 \cdot 2 \cdot 3 \cdot 4$ & $1 \cdot 2 \cdot 3 \cdot 4$ & 1.2 .3 .4 & 1.2 .3 .4 \\
\hline
\end{tabular}

The Laridæ, or Gulls and Terns, are true cosmopolites, inhabiting the shores and islands of every zone; and most of the genera have also a wide range. They are therefore of little use in the study of geographical distribution. The genera are as follows :-

Stercorarius (6 6 .), cosmopolitan, most abundant in cold and temperate zones; Rhodostethia (1 $\mathrm{sp}$ ), North America; Larus (60 sp.). cosmopolitan ; Xema (1 sp.), North Temperate zone; Creagrus (1 sp.), North Pacific; Pagophila (1 sp.), Arctic seas; Rissa (3 sp.), Arctic and Northern seas; Sterna (36 sp.), cosmopolitan ; Hydrochelidon (12 sp.), Tropical and Temperate zones; 
Gygis (1 sp.), Indian Ocean and Tropical Pacific Islands; Anous (6 sp.), Tropical and Temperate zones; Ncnia (1 sp.), South Temperate America; Khynchops (3 sp.), Tropical America, Africa, and India.

\section{FAMILY 120.-PROCELLARIID E. (6 Genera, 96 Species.)}

\begin{tabular}{|c|c|c|c|c|c|}
\hline \multicolumn{6}{|c|}{ General Distmibution. } \\
\hline $\begin{array}{l}\text { NEOTROPICAL } \\
\text { SUB-REGIONS. }\end{array}$ & $\begin{array}{c}\text { NEARCTIC } \\
\text { SUB-REGIONS. }\end{array}$ & $\begin{array}{l}\text { PaLfaArctic } \\
\text { SUb-kEGIONS. }\end{array}$ & $\begin{array}{c}\text { ETHIOPIAN } \\
\text { SC'B-REGIONS. }\end{array}$ & $\begin{array}{l}\text { ORIENTAL } \\
\text { SUB-REGIONS. }\end{array}$ & $\begin{array}{l}\text { AUSTRALIIN } \\
\text { SUB-REGIONS. }\end{array}$ \\
\hline $1.2 .3 \cdot 4$ & 1.2 .3 .4 & 1.2 .3 .4 & 1.2 .3 .4 & $1.2 \cdot 3 \cdot 4$ & 1.2 .34 \\
\hline
\end{tabular}

The Procellariidæ, comprising the Shearwaters, Petrels, and Albatrosses, are universally distributed, but some of the genera are local.

Puffinus (20 sp.), Procellaria (18 sp.), and Fulmarus (40 sp.), are cosmopolitan; Prion (5 sp.) and Pelecanoides (3 sp.), belong to the South Temperate and Antaretic regions; Diomedia (10 sp.), comprises the Albatrosses, which are tropical, occasionally wandering into temperate seas.

\section{FAMILY 121.-PELECANID $\approx . ~(6$ Genera, 61 Species.)}

\begin{tabular}{|c|c|c|c|c|c|}
\hline \multicolumn{6}{|c|}{ General Distribution. } \\
\hline $\begin{array}{l}\text { NFotropicas } \\
\text { St'-R-REaIGNS. }\end{array}$ & $\begin{array}{c}\text { NEARCTIC } \\
\text { SUB-REGIONS. }\end{array}$ & $\begin{array}{l}\text { PaLfaARCTIC } \\
\text { Sub-REGIONS. }\end{array}$ & $\begin{array}{c}\text { ETHIOPIAN } \\
\text { SUB-REGIONS. }\end{array}$ & $\begin{array}{c}\text { ORIENTAL } \\
\text { SUB-REGIONS. }\end{array}$ & $\begin{array}{l}\text { ALSTRALIAN } \\
\text { SUB-REGIONS. }\end{array}$ \\
\hline 1.2 .3 .4 & 1.2 .3 .4 & 1.2 .3 .4 & 1.2 .3 .4 & 1.2 .3 .4 & $1.2 .3 \cdot 4$ \\
\hline
\end{tabular}

The Pelecanidæ, comprising the Gannets, Pelicans, Darters, and Frigate-Birds, although universally distributed, are more abundant in tropical and temperate regions.

Sula (8 sp.) and Phalacrocorax (35 sp.), are cosmopolitan; Pelecanus (9 sp.) is tropical and temperate; Fregetta (2 sp.) and Phaeton (3 sp.) are confined to Tropical seas; Ptotus (4 sp.) to Tropical and warm Temperate zones. 
Family 122.-SPHENISCII)A. (3 Genera, 18 Species.)

\begin{tabular}{|c|c|c|c|c|c|}
\hline \multirow[b]{2}{*}{$\begin{array}{l}\text { NeOTROPICAL } \\
\text { SUE-REgIONS. }\end{array}$} & \multicolumn{4}{|c|}{ Gexeral Disthibution. } & \multirow[b]{2}{*}{$\begin{array}{l}\text { Australias } \\
\text { SuB-REgIONS. }\end{array}$} \\
\hline & $\begin{array}{c}\text { N EARCTIC } \\
\text { SÜB-REG LONS. }\end{array}$ & $\begin{array}{l}\text { Palfanctic } \\
\text { SUb-HEGtons. }\end{array}$ & $\begin{array}{l}\text { ErHIOPIAN } \\
\text { Sub-REGIONS. }\end{array}$ & $\begin{array}{c}\text { ORIENTAL } \\
\text { SUB-HEGIONE. }\end{array}$ & \\
\hline $1.2--$ & $-\quad--$ & ---- & $--3-$ & $-\cdots-$ & $-2-4$ \\
\hline
\end{tabular}

The Penguins are entirely confined to the Antarctic and South Temperate regions, except two species which are found on the const of Peru and the Galapagos. They are most plentiful in the southern parts of South America, Australia, New Zealand, and most of the Antarctic islands, and one or two species are found at the Cape of Good Hope. The genera as given in the Hand List are:-

Spheniscus (1 sp.), South Africa and Cape Horn; Eudyptes (15 sp.), with the range of the family; Aptenodytes (2 sp.), Antarctic Islands.

Fayily 123.-COLYMBID Æ. (1 Genus, 4 Species.)

\begin{tabular}{|c|c|c|c|c|c|}
\hline \multicolumn{6}{|c|}{ General Distribution. } \\
\hline $\begin{array}{l}\text { NEOTROPICAL } \\
\text { SUB-REGIONS. }\end{array}$ & $\begin{array}{c}\text { NEARCTIC } \\
\text { SUB-REGIONS. }\end{array}$ & $\begin{array}{l}\text { Palearctic } \\
\text { Sub-hEGIONS. }\end{array}$ & $\begin{array}{c}\text { ETHIOPIAN } \\
\text { SUB-REGIONS. }\end{array}$ & $\begin{array}{l}\text { ORIENTAL } \\
\text { SUB-REGIONS. }\end{array}$ & $\begin{array}{l}\text { AUSTRalias } \\
\text { SuB-REOIONS. }\end{array}$ \\
\hline$---\cdots$ & ---4 & $1-3.4$ & ---- & $---\cdots$ & ---- \\
\hline
\end{tabular}

The Northern Divers are confined to the Arctic and North Temperate Seas. The only genus, Colymbus, has one species confined to the West Coast of North America, the others being common to the two northerm continents.

\section{Family 124.-PODICIPID无. (2 Genera, 33 Species.)}

\begin{tabular}{|c|c|c|c|c|c|}
\hline \multicolumn{6}{|c|}{ Gexeral Distribution. } \\
\hline $\begin{array}{l}\text { NEOTROPICAL } \\
\text { SUB-REOIONS. }\end{array}$ & $\begin{array}{c}\text { NEARCTIC } \\
\text { SUB-REQIONS. }\end{array}$ & $\begin{array}{l}\text { PAL_EARCTIC } \\
\text { SUB-REGIONS. }\end{array}$ & $\begin{array}{c}\text { EThIOPIAN } \\
\text { SUB-REQIONS. }\end{array}$ & $\begin{array}{c}\text { ORIENTAL } \\
\text { SUB-REGIONS. }\end{array}$ & $\begin{array}{l}\text { Australian } \\
\text { SUB-REdions. }\end{array}$ \\
\hline $1.2 .3 \cdot 4$ & 1.2 .3 .4 & $1.2 \cdot 3 \cdot 4$ & $1.2 .3 \cdot 4$ & 1.2 .3 .4 & 1.2 .3 .4 \\
\hline
\end{tabular}


The Grebes are universally distributed. The genera are Podiceps (26 sp.), cosmopolitan; and Podilymbus (2 sp.), confined to North and South America. Some ornithologists group these birds with the Colymbidre.

Fayily 125.-ALCID压. (7 Genera, 28 Species.)

\begin{tabular}{|c|c|c|c|c|c|}
\hline \multicolumn{6}{|c|}{ Gexeral Distribution. } \\
\hline $\begin{array}{l}\text { NEOTROPICAL } \\
\text { SUB-REGIONS. }\end{array}$ & $\begin{array}{c}\text { NeARCTIC } \\
\text { StB-REG:ONS. }\end{array}$ & $\begin{array}{l}\text { Palearctio } \\
\text { Sute-kEgions. }\end{array}$ & $\begin{array}{l}\text { ETHIOPIAN } \\
\text { SUD-REGIONS. }\end{array}$ & $\begin{array}{c}\text { ORIENTAL } \\
\text { SuB-REgIONS. }\end{array}$ & $\begin{array}{l}\text { Australian } \\
\text { Sub-REgions. }\end{array}$ \\
\hline---- & $1--4$ & $1-3.4$ & ---- & $--\cdots$ & $-\cdots$ \\
\hline
\end{tabular}

The Alcidæ, comprising the Auks, Guillemots, and Puffins, are confined to the North Temperate and Arctic regions, where they represent the Penguins of the Antarctic lands. One of the most remarkable of these birds, the Great Auk, formerly abundant in the North Atlantic, is now extinct. The genera are as follows :-

Alca (2 sp.), North Atlantic and Arctic seas; Fratercula (4 sp.), Arctic and North Temperate zones; Ceratorhina (2 sp.), North Pacific; Simorhynchus (8 sp.), North Pacific; Brachyrhamphus (3 sp.), North Pacific to Japan and Lower California; Uria (8 sp.), Arctic and North Temperate zones; Mergulus (1 sp.), North Atlantic and Arctic Seas. The last three genera constitute the family Uriidæ, of some ornithologists.

Gcneral Remarks on the Distribution of the Anseres.

The Anseres, or Swimmers, being truly aquatic birds, possess, as might be expected, a large number of cosmopolitan families and genera. No less than 5 out of the 8 families have a worldwide distribution, and the others are characteristic either of the North or the South Temperate zones. Hence arises a peculiarity of distribution to be found in no other order of birds; the Temperate being richer than the Tropical regions. The $\mathrm{Ne}-$ arctic and Palæarctic regions each have seven families of Anseres, two of which, the Colymbidæe and Alcidæ, are peculiar to them. The Ethiopian, Australian, and Neotropical regions, which all 
extend into the South Temperate zone, have six families, with one peculiar to them; while the Oriental region, which is wholly tropical, possesses the five cosmopolitan families only.

There are about 78 genera and 552 species of Auseres, giving 69 species to a family, a high number compared with the Waders, and due to there being only one very small family, the Colymbidæ. The distribution of the Anseres, being more determined by temperature than by barriers, the great regions which are so well indicated by the genera and families of most other orders of birds, hardly limit these, except in the case of the genera of Anatidæ.

$$
\text { Order X.-STRUTHIONES. }
$$

Family 126.-STRUTHIONIDA. (2 Genera, 4 Species.)

\begin{tabular}{|c|c|c|c|c|c|}
\hline \multicolumn{6}{|c|}{ General Distribution. } \\
\hline $\begin{array}{l}\text { NEOTROPICAL } \\
\text { SUB-REGIONS. }\end{array}$ & $\begin{array}{c}\text { NEARCTIC } \\
\text { SUB-REGIONS. }\end{array}$ & $\begin{array}{l}\text { PaLfearctic } \\
\text { Sub-hegions. }\end{array}$ & $\begin{array}{c}\text { ETHIOPIAN } \\
\text { SUB-REGIONS. }\end{array}$ & $\begin{array}{c}\text { Oriental } \\
\text { Sub-REoIONS. }\end{array}$ & $\begin{array}{l}\text { AUSTRALIaN } \\
\text { SUB-gEgIONS. }\end{array}$ \\
\hline $1-\cdots-$ & ---- & $-2--$ & $1-3-$ & --- & ---- \\
\hline
\end{tabular}

The Ostriches consist of two genera, sometimes formed into distinct families. Struthio $(2 \mathrm{sp}$.) inhabits the desert regions of North, East, and South Africa, as well as Arabia and Syria. It therefore just enters the Palæarctic region. Rhea (3 sp.) inhabits Temperate South America, from Patagonia to the confines of Brazil.

$$
\text { FAmILY 127.-CASUARIIDÆE. (2 Genera, } 11 \text { Species.) }
$$

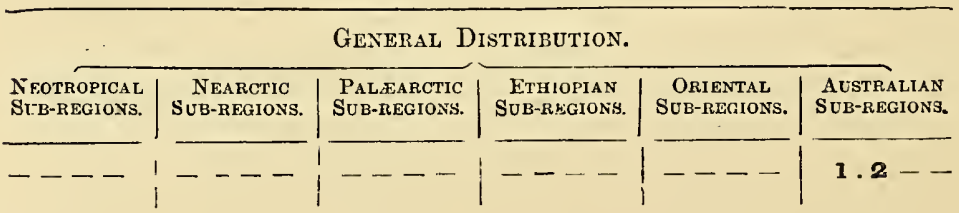

The Cassowaries and Emeus are confined to the Australian region. The Emeus, Dromceus (2 sp.), are found only on the 
main-land of Australia (Plate XII. Vol. I. p. 441). Casuarius (9 sp.) inhabits the islands from Ceram to New Britain, with one species in North Australia; it is most abundant in the Papuan Islands.

FAMILY 128.-APTERYGIDA. (1 Genus, 4 Species.)

\begin{tabular}{|c|c|c|c|c|c|}
\hline $\begin{array}{l}\text { NEOTROPICAL } \\
\text { SUE-RBGIONS. }\end{array}$ & $\begin{array}{c}\text { NEARCYIC } \\
\text { SOB-REGIONS. }\end{array}$ & $\begin{array}{l}\text { PALEARCTIC } \\
\text { SUB-HEGIONS. }\end{array}$ & $\begin{array}{c}\text { ETHIOPIAN } \\
\text { SUB-REGIONS. }\end{array}$ & $\begin{array}{c}\text { ORIENTAL } \\
\text { SUB-REGIONS. }\end{array}$ & $\begin{array}{l}\text { Australian } \\
\text { Sub-regions. }\end{array}$ \\
\hline - & ---- & $-\cdots--$ & ---- & ---- & -- \\
\hline
\end{tabular}

The species of Apteryx are entirely confined to the two larger islands of New Zealand. They are supposed to have some remote affinity with Ocydromus, a genus of Rails peculiar to Australia and New Zealand; but they undoubtedly form one of the most remarkable groups of living birds (Plate XIII. Vol. I. p. 445).

\section{Struthious Birds recently extinet.}

A number of sub-fossil remains of birds, mostly large and some of gigantic size, having affinities to the Apteryx and, less closely, to the Cassowaries, have been discovered in New Zealand. These are all classed by Professor Owen in the genus Dinornis and family Dinornithidoe; but Dr. Haast, from the study of the rich collections in the Canterbury (New Zealand) Museum, is convinced that they belong to two distinct families and several genera. His arrangement is as follows. (See Ibis, 1874, p. 209).

\section{Family 129.-DINORNITHID AE. (2 Genera, 7 Species.)}

\section{Dinornis (5 sp.); Meionornis (2 sp.).}

These had no hind toe, and include the largest species. Professor Newton thinks that they were absolutely wingless, being the only birds in which the fore limbs are entirely wanting.

VOL. II. 


\section{Family 130.-PALAPTERYGID E. (2 Genera, 4 Species.)}

Palapteryx (2 sp.); Euryapteryx (2 sp.).

These had a well-developed hind toe, and rudimentary wings.

\section{Family 131.-}

A gigantic Struthious bird (EPyornis), belonging to a distinct family, inhabited Madagascar.

It was first made known by its enormous eggs, eight times the bulk of those of the ostrich, which were found in a subfossil condition. Considerable portions of skeletons have since been discovered, showing that these huge birds formed an altogether peculiar family of the order.

\section{General Remarks on the Distribution of the Struthiones.}

With the exception of the Ostrich, which has spread northward into the Palæarctic region, the Struthious birds, living and extinct, are confined to the Southern hemisphere, each continent having its peculiar forms. It is a remarkable fact that the two most nearly allied genera, Struthio and Rhea, should be found in Africa and South Temperate America respectively. Equally remarkable is the development of these large forms of wingless birds in Australia and the adjacent islands, and especially in New Zealand, where we have evidence which renders it probable that about 20 species recently coexisted. This points to the conclusion that New Zealand must, not long since, have formed a much more extensive land, and that the diminution of its area by subsidence has been one of the causes-and perhaps the main one-in bringing about the extinction of many of the larger species of these wingless birds.

The wide distribution of the Struthiones may, as we have already suggested (Vol. I., p. 287.), be best explained, by supposing them to represent a very ancient type of bird, developed at a time when the more specialized carnivorous mammalia had 
not come into existence, and preserved only in those areas which were long free from the incursions of such dangerous enemies. The discovery of Struthious remains in Europe in the Lower Eocene only, supports this view ; for at this time carnivora were few and of generalized type, and had probably not acquired sufficient speed and activity to enable them to exterminate powerful and quick-running terrestrial birds. It is, however, at a much more remote epoch that we may expect to find the remains of the earlier forms of this group; while these Eocene birds may perhaps represent that ancestral wide-spread type which, when isolated in remoter continents and islands, became modified into the American and African ostriches, the Emeus and Cassowaries of Australia, the Dinornis and Apyomis of New Zealand. 


\section{CHAPTER XIX.}

THE DISTRIBUTION OF THE FAMILIES AND GENERA OF REPTILES AND AMPHIBIA.

\section{REPTILIA.}

Order I.-OPHIDIA.

Family 1.-TYPHLOPID E.-(4 Genera, 70 Species.)

\begin{tabular}{|c|c|c|c|c|c|}
\hline \multicolumn{6}{|c|}{ General Distribution. } \\
\hline $\begin{array}{l}\text { NEOTROPICAL } \\
\text { SUB-REQIONS. }\end{array}$ & $\begin{array}{c}\text { NEARCTIC } \\
\text { SUB-REGIONS. }\end{array}$ & $\begin{array}{l}\text { PALAAARCTIC } \\
\text { SUB-HEGIONS. }\end{array}$ & $\begin{array}{c}\text { ETHIOPIAN } \\
\text { SUB-REGIONS. }\end{array}$ & $\begin{array}{l}\text { ORIENTAL } \\
\text { SUB-FEGIONS. }\end{array}$ & $\begin{array}{l}\text { AUSTRALIaN } \\
\text { SUB-REgIONS. }\end{array}$ \\
\hline$-2 \cdot 3 \cdot 4$ & ---- & $-2-4$ & 1.2 .3 .4 & 1.2 .3 .4 & $1.2--$ \\
\hline
\end{tabular}

The Typhlopidæ, or Plind Burrowing Snakes, are widely scattered over the warmer regions of the earth, but are most abundant in the Oriental and Australian regions, and least so in the Neotropical. They are absent from the Nearctic region; and in the Palæarctic are found only in South-eastern Europe and Japan.

The most extensive genus is Typhlops, comprising over 60 species, and having a range almost as extensive as the entire family. The other well characterised genera are :-

Typhlina (1 sp.), ranging from Penang to Java and Hong Kong ; Typhline (1 sp.), the Cape of Good Hope; Dibamus (1 sp.), New Guinea. 


\section{FaMiLY 2.-TORTRICID E. (3 Genera 5 Species.)}

\begin{tabular}{|c|c|c|c|c|c|}
\hline \multicolumn{6}{|c|}{ Geseral Distribution. } \\
\hline $\begin{array}{l}\text { N̦EOTROPICAL } \\
\text { SUB-R EGIOAS. }\end{array}$ & $\begin{array}{c}\text { NEARCTIC } \\
\text { SUB-KEGIONS. }\end{array}$ & $\begin{array}{l}\text { PALAEARCTIC } \\
\text { SUB-REGIONS. }\end{array}$ & $\begin{array}{c}\text { ETHIOPIAN } \\
\text { SUE-REGioNs. }\end{array}$ & $\begin{array}{l}\text { ORIENTAL } \\
\text { SUB-FiEGIONS. }\end{array}$ & $\begin{array}{l}\text { Atstralias } \\
\text { Stb-RELiOLIS. }\end{array}$ \\
\hline$-2.3-$ & $1---$ & ---- & ---- & $1.2 .3 \cdot 4$ & $1---$ \\
\hline
\end{tabular}

The Tortricidæ, or Short-tailed Burrowing Snakes, are a small family, one portion of which ranges from India to Cambodja, and through the Malay islands as far as Celebes and Timor; these form the genus Cylindrophis. Another portion inhabits America, and consists of :-

Charina (1 sp.), found in California and British Columbia; and Tortrix (1 sp.), in Tropical America.

We have here a case of discontinuous distribution, indicating, either very imperfect knowledge of the group, or that it is the remuant of a once extensive family, on the road to extinction.

\section{Fanily 3.-XENOPELTID Æ. (1 Genus, 1 Species.)}

\begin{tabular}{|c|c|c|c|c|c|}
\hline \multicolumn{6}{|c|}{ Gexeral Distribution. } \\
\hline $\begin{array}{l}\text { NEOTROPICAL } \\
\text { SUB-REGIONS. }\end{array}$ & $\begin{array}{c}\text { NEARCTIC } \\
\text { SUB-REGIONS. }\end{array}$ & $\begin{array}{l}\text { PaLAarctic } \\
\text { SUb-KEGIONS. }\end{array}$ & $\begin{array}{l}\text { ETHIOPIAN } \\
\text { SOB-EEGIONS. }\end{array}$ & $\begin{array}{c}\text { ORIENTAL } \\
\text { SUB-REgioNs. }\end{array}$ & $\begin{array}{l}\text { Australian } \\
\text { Sub-REgIonis. }\end{array}$ \\
\hline$-\cdots-$ & $--\cdots$ & ---- & ---- & --3.4 & $1--$ \\
\hline
\end{tabular}

The curious nocturnal carnivorous Snake, forming the genus Xenopeltis, and the sole representative of this family, ranges from Penang to Cambodja, and through the Malay Islands to Celebes.

\section{FAMILY 4.-UROPELTID E. (5 Genera, 18 Species.)}

\begin{tabular}{|c|c|c|c|c|c|}
\hline \multicolumn{6}{|c|}{ General Distpibution. } \\
\hline $\begin{array}{l}\text { NeOTROPICAL } \\
\text { SUB-RFoIONS. }\end{array}$ & $\begin{array}{c}\text { NEARCTIC } \\
\text { SUB-REOIOXS. }\end{array}$ & $\begin{array}{l}\text { PALAEARCTIC } \\
\text { SUB-REGIONS. }\end{array}$ & $\begin{array}{c}\text { ETHIOPIAN } \\
\text { SUB-REGIONS. }\end{array}$ & $\begin{array}{c}\text { ORIENTAL } \\
\text { SUB-kEGIOXYS. }\end{array}$ & $\begin{array}{l}\text { ALSTRALIAN } \\
\text { SUB-REGIONS. }\end{array}$ \\
\hline---- & ---- & ---- & $---\cdots$ & $-\dot{2}--$ & $--\cdots$ \\
\hline
\end{tabular}


The Uropeltille, or Rongh-tailed Burrowing Snakes, are strictly confined to Ceylon and the adjacent parts of Southern India, and would almost alone serve to mark out our second Oriental sub-region. The genera are :-

Ihinophis (7 sp.), Ceylon; Uropeltis (1 sp.), Ceylon; Silybura (3 sp.), Anamally Hills and Neilgherries; Plecturus (3 sp.), Neilgherries and Madras; and Melanophidium (1 sp.), the Wynand.

Fanily 5.-CALAMARIID $2 . \quad$ (32 Genera, 75 Species.)

\begin{tabular}{|c|c|c|c|c|c|}
\hline \multicolumn{6}{|c|}{ General Distributiox. } \\
\hline $\begin{array}{l}\text { NEOTROPICAL } \\
\text { StiB-REGJONS. }\end{array}$ & $\begin{array}{l}\text { NEARCTIC } \\
\text { SUB-REGIONS. }\end{array}$ & $\begin{array}{l}\text { PaLEARCTIC } \\
\text { SUB-ILEGIONS. }\end{array}$ & $\begin{array}{l}\text { ETHIOPIAN } \\
\text { SUB-REGIONS. }\end{array}$ & $\begin{array}{c}\text { ORIENTAL } \\
\text { SuB-REGioNs. }\end{array}$ & $\begin{array}{l}\text { AUSTRALIAN } \\
\text { SUB-REGIONS. }\end{array}$ \\
\hline 1.2 .3 .4 & $1.2 .3-$ & $-2--$ & $1.8 .3-$ & 1.2 .3 .4 & $1.2--$ \\
\hline
\end{tabular}

The Calamariidæ, or Dwarf Ground Snakes, are found in all warm parts of the globe, extending north into the United States as far as British Columbia and Lake Superior; but they are absent from the Palæarctic region, with the exception of a species found in Persia. The species are in a very confused state. The best characterised genera are the following :-

Calamaria (20 sp.), Persia, India to Java and the Philippine Islands, Celebes, and New Guinea; Rhabdosoma (18 sp.), Mexico and South America, and also the Malay Islands as far east as Amboyna, Timor, and New Guinea; Typhlocalamus (1 sp.), Borneo; Macrocalamus (1 sp.), India; Aspidura (3 sp.), India and Ceylon; Haplocerus (1 sp.), Ceylon; Streptophorus (3 sp.), Central and South America;--with a host of others of less importance or ill-defined.

Famiry 6.-OLIGOdontidæ. (4 Genera, 40 Species.)

\begin{tabular}{|c|c|c|c|c|c|}
\hline \multicolumn{6}{|c|}{ Geseral Distribution. } \\
\hline $\begin{array}{l}\text { NEOTROPICAL } \\
\text { SUE-REgIONS. }\end{array}$ & $\begin{array}{c}\text { NEARCTIC } \\
\text { SUB-REGIONS. }\end{array}$ & $\begin{array}{l}\text { PalaEarctic } \\
\text { SUE-hEGIONS. }\end{array}$ & $\begin{array}{c}\text { ETHIOPIAN } \\
\text { SUB-REGIONS. }\end{array}$ & $\begin{array}{c}\text { ORIENTAL } \\
\text { SUB-EEGIONS. }\end{array}$ & $\begin{array}{l}\text { AUSTralian } \\
\text { SUd-REgIONS. }\end{array}$ \\
\hline$-2.3-$ & ---3 & ---4 & $-x-2$ & 1.2 .3 .4 & --- \\
\hline
\end{tabular}


The Oligodontidæ are a small family of Ground Snakes which have been separated from the Calamariidæ, and, with the exception of a few species, are confined to the Oriental region. The best characterised genera are :-

Oligodon (12 sp.), India, Ceylon, and Philippines ; and, Simotes (24 sp.), India to China and Borneo. In addition to these, Achalinus is founded on a single species from Japan; and Teleolepis consists of three species from North and South America.

Family 7.-COLUBRID死. (50 Genera, 270 Species.)

\begin{tabular}{|c|c|c|c|c|c|}
\hline \multicolumn{6}{|c|}{ Gexeral Distribution. } \\
\hline $\begin{array}{l}\text { NEOTROPICAL } \\
\text { SUB-REGIONS. }\end{array}$ & $\begin{array}{c}\text { NEARCTIC } \\
\text { SUB-REGIONS. }\end{array}$ & $\begin{array}{c}\text { PaLAfarctic } \\
\text { SUB-REGIONS. }\end{array}$ & $\begin{array}{c}\text { ETHIOPIAN } \\
\text { SUB-REGIONS. }\end{array}$ & $\begin{array}{c}\text { ORIENTAL } \\
\text { SUB-REGIONS. }\end{array}$ & $\begin{array}{l}\text { AUSTralias } \\
\text { SUB-REgIUNS. }\end{array}$ \\
\hline 1.2 .3 .4 & 1.2 .3 .4 & 1.2 .3 .4 & 1.2 .3 .4 & 1.2 .3 .4 & $1.2--$ \\
\hline
\end{tabular}

The Colubrine Snakes are universally distributed over the globe, and they reach the extreme northem limits of the order. They are, however, almost absent from Australia, being there represented only by a few species of Tropidonotus and Coronella in the northern and eastern districts. This great family consists of four divisions or sub-families : the Coronellinæ (20 genera, 100 species), the Colubrinæ (16 genera, 70 species), the Dryadinæ (7 genera, 50 species), and the Natricinæ (7 genera, 50 species). The more important genera of Colubridæ are the following :-

Ablabes, Coronella, Ptyas, Coluber, and Tropidonotus-all have a very wide distribution, but the two last are absent from South America, although Tropidonotus reaches Guatemala; Tomodon, Xenodon, Liopis, Stenorhina, Erythrolampus, Elapochrus, Callirhinus, Enophrys, and Dromicus-are confined to the Neotropical region; Hypsirhynchus, Cryptodacus, Jaltris, and Coloragia, are confined to the West Indian Islands; Chilomeniscus, Conophis, Pituophis, and Ischcognathus, to North America, the latter going as far south as Guatemala; Compsosoma, Zamenis, Zaocys, Atretium, Xenochrophys, and Herpetoreas, are peculiarly Oriental, but Zamenis extends into South Europe; 
Lytorhynchus, Rhamnophis, Herpetcthiops and Grayia, are Ethiopian ; Rhincchis is peculiar to Europe; Megablabes to Celebes, and Styporhynchus to Gilolo; Cyclophis, is found in the Oriental region, Japan, and North America; Spilotes, in the Nearctic and Neotropical regions; Xenelaphis in the Oriental, Ethiopian, and Palrearctic regions; Philodryas, Heterodon and Herpetodryas in America and Madagascar, the latter genus being also found in Clinina.

Fanili 8.-HOMalopsid E. (24 Genera, 50 Species.)

\begin{tabular}{|c|c|c|c|c|c|}
\hline \multirow[b]{2}{*}{$\begin{array}{l}\text { NEOTROPICAL } \\
\text { Stib-REgIONS. }\end{array}$} & \multicolumn{4}{|c|}{ General Distribution. } & \multirow[b]{2}{*}{$\begin{array}{l}\text { Australian } \\
\text { Sub-REgions. }\end{array}$} \\
\hline & $\begin{array}{c}\text { NEARCTIC } \\
\text { SUB-REGIONS. }\end{array}$ & $\begin{array}{l}\text { Pal.earctic } \\
\text { Sub-ILEGons. }\end{array}$ & $\begin{array}{c}\text { ETHIOPIAN } \\
\text { SUB-REGIONS. }\end{array}$ & $\begin{array}{c}\text { ORII ITTAL } \\
\text { SUR-RI GIONS. }\end{array}$ & \\
\hline $1-3-$ & $--3-$ & $-2 \cdot 3 \cdot 4$ & $-2--$ & $1.2 .3 \cdot 4$ & $1.2-$ \\
\hline
\end{tabular}

The Homalopsidæ, or Fresh-water Snakes, liave been separated from the Hydridæe by Dr. Günther, and they include some groups which have been usually classed with the Natricinæ. They are especially characteristic of the Oriental region, where considerably more than half the genera and species are found; next comes the Neotropical region which has 6 species; while none of the other regions have more than 4 or 5 . It is to be observed that the Ethiopian species occur in West Africa only, and mostly constitute peculiar genera, so that in this family the separation of the Ethiopian and Oriental regions is very well marked. The best characterised genera of the family are the following:-

Cantoria (10 sp.), ranging from Europe to Japan, the Philippines, and Timor, with one species in Guinea; Hypsirh ina (6 sp.), Bengal, China, and Borneo; Fordonia (3 sp.), Rangoon to Borneo and Timor; Homalopsis (2 sp,), Cambodja to Java; Cerberus (2 sp.), Ceylon and Siam, the Malay Islands, New Guinea, and North Australia; Herpeton (1 sp.), Siam; Ferania (1 sp.), Bengal to Penang; Pythonopsis (1 sp.), Borneo; Myron (2 sp.), India and North Australia; Homalophis (1 sp.), Borneo; Hipistes (1 sp.), Penang; Xenodermus (1 sp.), Java; Neusterophis and Limnophis, with one species each, are peculiar to West 
Africa; Helicops (2 sp.), North and South America; Farancia and Dimodes, with one species each, are from New Orleans; and a few others imperfectly known from Tropical America.

FAMILY 9.-ISAMMOPHID $\nRightarrow . \quad$ (5 Genera, 20 Species.)

\begin{tabular}{|c|c|c|c|c|c|}
\hline \multicolumn{6}{|c|}{ General Distribution. } \\
\hline $\begin{array}{l}\text { NEOTROPICAL } \\
\text { SUB-REGIONS. }\end{array}$ & $\begin{array}{c}\text { NEARCTIC } \\
\text { SUB-REGIONS. }\end{array}$ & $\begin{array}{l}\text { PaLEaRCTIC } \\
\text { Sub-REoIONS. }\end{array}$ & $\begin{array}{c}\text { ETHIOPIAN } \\
\text { SUB-REGIONS. }\end{array}$ & $\begin{array}{c}\text { ORIENTAL } \\
\text { SUB-REGIONS. }\end{array}$ & $\begin{array}{l}\text { Australian } \\
\text { Sub-REgions. }\end{array}$ \\
\hline---- & $-\cdots-$ & $-2--$ & 1.2 .3 .4 & $1-3.4$ & -- \\
\hline
\end{tabular}

The Psammophidre, or Desert Snakes, are a small group characteristic of the Ethiopian and Oriental regions, but more abundant in the former. The distribution of the genera is as follows :-

Psammophis (16 sp.), ranges from West Africa to Persia and Calcutta; Celopeltis (1 sp.), North and West Africa; Mimophis (1 sp.), Madagascar; Psammodynastes (2 sp.), Sikhim to Cochin China, Borneo and the Philippine Islands; and Dromophis (1 sp.), Tropical Africa.

\section{FAMILY 10.—RACHIODONTID $2 . \quad$ (1 Genus, 2 Species.)}

\begin{tabular}{|c|c|c|c|c|c|}
\hline \multicolumn{6}{|c|}{ General Distribution. } \\
\hline $\begin{array}{l}\text { NFOTROPICAL } \\
\text { StjB-REGIOYS. }\end{array}$ & $\begin{array}{c}\text { NEARCTIC } \\
\text { SuB-REGIONS. }\end{array}$ & $\begin{array}{l}\text { PALLEARCTIC } \\
\text { SUb-ILEG IONS. }\end{array}$ & $\begin{array}{c}\text { ETHIOPIAN } \\
\text { SUB-REGIONS. }\end{array}$ & $\begin{array}{l}\text { ORIENTAL } \\
\text { SUB-REGIONS. }\end{array}$ & $\begin{array}{l}\text { AUSTRALIAN } \\
\text { SUB-REGIONS. }\end{array}$ \\
\hline$---\cdots$ & ---- & ---- & $-2 \cdot 3-$ & ---- & ---- \\
\hline
\end{tabular}

The Rachiodontidæe are a small and very isolated group of snakes of doubtful affinities. The only genus, Dasypeltis (2 sp.), is confined to West and South Africa. 
Family 11.-DENDROPHID A. (7 Genera, 35 Species.)

\begin{tabular}{|c|c|c|c|c|c|}
\hline \multicolumn{6}{|c|}{ General Distribution. } \\
\hline $\begin{array}{l}\text { NEOTROPICAL } \\
\text { StiB-REGIONS. }\end{array}$ & $\begin{array}{l}\text { NEARCTIC } \\
\text { SUB-REGIONS. }\end{array}$ & $\begin{array}{l}\text { PaLmarctic } \\
\text { Sub-REgions. }\end{array}$ & $\begin{array}{c}\text { ETHIOPIAN } \\
\text { SUB-REGIONS. }\end{array}$ & $\begin{array}{c}\text { ORIENTAL } \\
\text { SUB-REGIONS. }\end{array}$ & $\begin{array}{l}\text { AUSTRALIAN } \\
\text { SUB-REGIONS. }\end{array}$ \\
\hline 1.2 .3 .4 & ---- & $--\cdots$ & 1.2 .3 .4 & 1.2 .3 .4 & $1.2--$ \\
\hline
\end{tabular}

The Dendrophidæ, or Tree Snakes, are found in all the Tropical regions, but are most abundant in the Oriental. The genera are distributed as follows:-

Dendrophis ranges from India and Ceylon to the Pelew Islands and North Australia, and has one species in West Africa; Ahotulla is almost equally divided between Tropical Africa and Tropical America; Gonyosoma ranges from Persia to Java and the Philippines; Chrysopelea is found in India, Borneo, the Philippines, Amboyna, and Mysol; Hapsidrophis and Bucephalus are confined to Tropical Africa; and Ithycyphus: (1 sp.), is peculiar to Madagascar.

Family 12.-DRYIOPHID A. (5 Genera, 15 Species.)

Gexeral Distribution.

\begin{tabular}{|c|c|c|c|c|c|}
\hline $\begin{array}{l}\text { NEOTROPICAL } \\
\text { SUB-REGIONS. }\end{array}$ & $\begin{array}{c}\text { KEARCTIC } \\
\text { SUB-REGIONS. }\end{array}$ & $\begin{array}{l}\text { PALAARCTIC } \\
\text { SUB }- \text { REGIONS. }\end{array}$ & $\begin{array}{l}\text { ETHIOPIAN } \\
\text { SUB-REGIONS. }\end{array}$ & $\begin{array}{l}\text { ORIENTAL } \\
\text { SUR-REGIONS. }\end{array}$ & $\begin{array}{l}\text { AUStralian } \\
\text { SUb-REGions. }\end{array}$ \\
\hline 2 & $-\cdots$ & -- & $-2-4$ & 1.2 .3 .4 & $1-$ \\
\hline
\end{tabular}

The Dryiophidæ, or Whip Snakes, are a very well characterised family of slender, green-coloured, arboreal serpents, found in the three tropical regions but absent from Australia, although they just enter the Australian region in the island of Celebes. In Africa they are confined to the West Coast and Madagascar. The genera are:-

Dryiophis (4 sp.), Tropical America and West Africa: Tropidococcys (1 sp.), Central India; Tragops (4 sp.), Bengal to China, the Philippines, Java, and Celebes; Passeritc (2 sp.), Ceylon 
and the Indian Peninsula; and Langaha (2 sp.), confined to Madagascar.

Fayily 13.-DIPSADIDÆE. (11 Genera, 45 Species.)

\begin{tabular}{|c|c|c|c|c|c|}
\hline \multicolumn{6}{|c|}{ General Distribution. } \\
\hline $\begin{array}{l}\text { NEOTROPICAL } \\
\text { SUB-REGIONS. }\end{array}$ & $\begin{array}{c}\text { NEARCTIC } \\
\text { SUB-REGIONS. }\end{array}$ & $\begin{array}{l}\text { PaLAaACTIC } \\
\text { SUB-REGIONS. }\end{array}$ & $\begin{array}{c}\text { ErhioptaN } \\
\text { Sub-REgIONS. }\end{array}$ & $\begin{array}{c}\text { ORIENTAL } \\
\text { SUB-REGIONS. }\end{array}$ & $\begin{array}{l}\text { AUSTralian } \\
\text { SUB-REgIONS. }\end{array}$ \\
\hline$-2 \cdot 3-$ & --- & $-2--$ & $1.2 .3-$ & $1.2 \cdot 3 \cdot 4$ & $1.2-$ \\
\hline
\end{tabular}

The Dipsadidæ, or Nocturnal Tree Snakes, are distinguished from the last family by their clark colours and nocturnal habits. They are about equally abundant in the Oriental and Neotropical regious, less so in the Ethiopian, while only a single species extends to North Australia. The following are the best known genera :-

Dipsas, comprising all the Oriental species with one in AsiaMinor, and a few from the Moluceas, New Guinea, North Australia, West Africa, and Tropical America; Thamnodyastes, Tropidodipsas, and several others, from Tropical America; Dipsadoboa, from West Africa and Tropical America; Leptodeira, from Tropical and South Africa, South America, and Mexico; and Pythonodipsas, from Central Africa.

Fanily 14.-SCYTALIDÆ. (3 Genera, 10 Species.)

\begin{tabular}{|c|c|c|c|c|c|}
\hline \multirow[b]{2}{*}{$\begin{array}{l}\text { NEOTROPICAL } \\
\text { SUB-REGIONS. }\end{array}$} & \multicolumn{4}{|c|}{ Gexeral Distribution. } & \multirow[b]{2}{*}{$\begin{array}{l}\text { AUSTRalian } \\
\text { SUb-REgIONS. }\end{array}$} \\
\hline & $\begin{array}{c}\wedge_{\text {EARCTIC }} \\
\text { SCB-REG.ONS. }\end{array}$ & $\begin{array}{l}\text { Palizarctio } \\
\text { Sub-REgions. }\end{array}$ & $\begin{array}{c}\text { ETHIOPIIN } \\
\text { SUB-REGIONS. }\end{array}$ & $\begin{array}{c}\text { ORIENTAL } \\
\text { SuR-REgIONS. }\end{array}$ & \\
\hline$-2.3-$ & ---- & --- & ---- & ---4 & $---\cdots$ \\
\hline
\end{tabular}

It is doubtful how far the three genera which constitute this family form a natural assemblage. We can therefore draw no safe conclusions from the peculiarity of their distributionScytale and Oxyrhopus being confined to Tropical America; while Hologerrhum inhabits the Philippine Islands. 
Family 15.-LYCODONTID A. (11 Genera, 35 Species.)

\begin{tabular}{|c|c|c|c|c|c|}
\hline \multicolumn{6}{|c|}{ General Distribution. } \\
\hline $\begin{array}{l}\text { NEOTROPICAL } \\
\text { SUB-REGIONS. }\end{array}$ & $\begin{array}{c}\text { NEARCTIC } \\
\text { SUB-REGIONS. }\end{array}$ & $\begin{array}{l}\text { PALAEARCTIO } \\
\text { SUB-AEGIONS. }\end{array}$ & $\begin{array}{c}\text { ETHIOPIAN } \\
\text { SUB-REGIONS. }\end{array}$ & $\begin{array}{l}\text { ORIENTAL } \\
\text { SUB-HEGIONS. }\end{array}$ & $\begin{array}{l}\text { AUSTRALIAN } \\
\text { SUB-REGIONS. }\end{array}$ \\
\hline- & ---- & ---- & $1.2 .3-$ & 1.2 .3 .4 & $1---$ \\
\hline
\end{tabular}

The Lycodontidæ, or Fanged Ground Snakes, are confined to the Ethiopian and Oriental regions, over the whole of which they range, except that they are absent from Madagascar and extend eastward to New Guinea. The genera have often a limited distribution:-

Lycodon ranges from India and Ceylon to China, the Philippines, and New Guinea; Tetragonosoma, the Malay Peninsula and Islands; Lcptorhytaon and Ophites, India ; Cercaspis, Ceylon; and Cyclocorus, the Philippines. The African genera are Bocedon, Lycophidion, Holuropholis, Simocephalus, and Lamprophis, the latter being found only in South Africa. The species are nearly equally abundant in both regions, but no genus is common to the two.

FAMily 16.-AMBLYCEPHALID $\approx . \quad$ (5 Genera, 12 Species.)

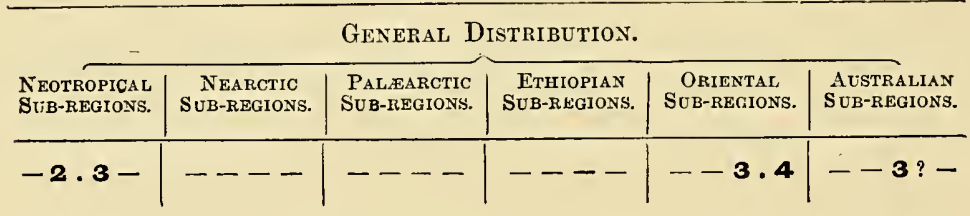

The Amblycephalidæ, or Blunt Heads, are very singularly distributed, being nearly equally divided between Tropical America and the eastern half of the Oriental region, as will be seen by the following statement of the distribution of the genera :-

Amblycephalus (1 sp.), Malay Peninsula to Borneo and the Philippines; Pareas (3 'sp.), Assam, China, Java, and Borneo; 
Asthenodipsas (1 sp.), Malacca ; Leptognathus (6 sp.), Central and South America; and Anoplodipsas (1 sp.), supposed to come from New Caledonia, and, if so, furnishing a link, though a very imperfect one, between the disconnected halves of the family.

Family 17.-PYTHONID E. (21 Genera, 46 Species.)

\begin{tabular}{|c|c|c|c|c|c|}
\hline \multicolumn{6}{|c|}{ General Distribution. } \\
\hline $\begin{array}{l}\text { NEOTROPICAL } \\
\text { SUB-REGIONS. }\end{array}$ & $\begin{array}{c}\text { NeARCTIC } \\
\text { SUB-REGIONS. }\end{array}$ & $\begin{array}{l}\text { PALAEARCTIC } \\
\text { SUB-REGIONS. }\end{array}$ & $\begin{array}{c}\text { E'THIOPIAN } \\
\text { SUB-REGIONS. }\end{array}$ & $\begin{array}{l}\text { ORIENTAL } \\
\text { SUB-REGIONS. }\end{array}$ & $\begin{array}{l}\text { AUSTRALIAN } \\
\text { SUB-REGIONS. }\end{array}$ \\
\hline 1.2 .3 .4 & $1---$ & $-\cdots--$ & 1.2 .3 .4 & $1.2 \cdot 3 \cdot 4$ & $1.2 .3-$ \\
\hline
\end{tabular}

The Pythonidæ, comprising the Rock Snakes, Pythons, and Boas, are confined to the tropics, with the exception of one species in California. They are very abundant in the Neotropical region, where nearly half the known species occur; the Australian region comes next, while the Oriental is the least prolific in these large serpents. The genera which have been described are very numerous, but they are by no means well defined. The following are the most important:-

Python is confined to the Oriental region; Morelia, Liasis, and Nardoa are Australian and Papuan; Enygrus is found in the Moluccas, New Guinea and the Fiji Islands ; Hortulia is African ; Sanzinia is peculiar to Madagascar; Boa, Epicrates, Corallus, Ungalia, and Eunectes are Tropical American; Chilabothrus is peculiar to Jamaica and Mexico; and Lichanotus to California.

An extinct species belonging to this family has been found in the Brown-coal formation of Germany, of Miocene age.

Family 18.-ERYCID Æ. (3 Genera, 6 Species.)

\begin{tabular}{|c|c|c|c|c|c|}
\hline \multicolumn{6}{|c|}{ Gexeral Distribution. } \\
\hline $\begin{array}{l}\text { NEOTROPICAL } \\
\text { SUB-REGIONS. }\end{array}$ & $\begin{array}{c}\text { NEARCTIC } \\
\text { SUB-REGIONS. }\end{array}$ & $\begin{array}{l}\text { Palafarctic } \\
\text { SUb-REQIONS. }\end{array}$ & $\begin{array}{l}\text { ETHIOPIAN } \\
\text { SUB-REGIONS. }\end{array}$ & $\begin{array}{c}\text { ORIENTAL } \\
\text { SUB-REGIONS. }\end{array}$ & $\begin{array}{l}\text { AUSTRALIAN } \\
\text { SUB-REGIONS. }\end{array}$ \\
\hline---- & ---- & $-2--$ & $-2--$ & $1-3-$ & ---- \\
\hline
\end{tabular}


The Erycidæ, or Land Snakes, form a small but natural family, chiefly found in the desert zone on the confines of the Palæarctic, Oriental, and Ethiopian regions. They range from South Europe to West Africa and to Sikhim. The three genera are distributed as follows:-

Cursoria (1 sp.), Afghanistan ; Gonyylophis (1 sp.), India and Sikhim; Eryx (4 sp.), has the range of the entire family.

Family 19.-ACROCHORDIDÆ. (2 Genera, 3 Spec ies)

\begin{tabular}{|c|c|c|c|c|c|}
\hline \multirow[b]{2}{*}{$\begin{array}{l}\text { NEOTROPICAL } \\
\text { SUB-REGIONS. }\end{array}$} & \multicolumn{3}{|c|}{ General Distribution. } & & \multirow[b]{2}{*}{$\begin{array}{l}\text { AUSTRALIAN } \\
\text { SUB-REgIONS. }\end{array}$} \\
\hline & $\begin{array}{c}\text { NEarCTIC } \\
\text { SUB-REgIONS. }\end{array}$ & $\begin{array}{l}\text { PaLAarCtiC } \\
\text { SÜ-REGIONS. }\end{array}$ & $\begin{array}{c}\text { ETHHIOPIAN } \\
\text { SUB-REGIONS. }\end{array}$ & $\begin{array}{c}\text { ORIENTAL } \\
\text { SuB-hEGIONS. }\end{array}$ & \\
\hline--- & --- & ---- & --- & $-2-4$ & $1-\cdots$ \\
\hline
\end{tabular}

The Acrochordidæ, or Wart Snakes, form a small and isolated group, found only in two sub-divisions of the Oriental regionthe South Indian and the Malayan, and in New Guinea.

Acrochordus, inhabits Penang, Singapore, and Borneo; Chersydrus, Southern India and the Malay Peninsula, with a species recently discovered in New Guinea.

Family 20.-ELAPIDA:. (23 Genera, 100 Species.)

\begin{tabular}{|c|c|c|c|c|c|}
\hline \multicolumn{6}{|c|}{ General Distribution. } \\
\hline $\begin{array}{l}\text { NEOTROPICAL } \\
\text { St'B-REGIONS. }\end{array}$ & $\begin{array}{l}\text { NEARCTIC } \\
\text { SUB-REQIONS. }\end{array}$ & $\begin{array}{l}\text { PaLfanctic } \\
\text { Sub-REolons. }\end{array}$ & $\begin{array}{l}\text { ETHIOPIAN } \\
\text { SUB-REGIONY. }\end{array}$ & $\begin{array}{c}\text { ORIENTAL } \\
\text { SUB-REQIONS. }\end{array}$ & $\begin{array}{l}\text { AUSTRALIAN } \\
\text { SUB-REGIONS. }\end{array}$ \\
\hline $1.2 .3-$ & $--3-$ & ---4 & $1.2 .3-$ & 1.2 .3 .4 & $1.2 .3-$ \\
\hline
\end{tabular}

The Elapidæ, or Terrestrial venomous Colubrine Snakes, are an extensive group, spread over the tropics of the whole world, but especially abundant in Australia, where half the known species occur, some of them being the most deadly of venomous serpents. In the Oriental region they are also abundant, containing amongst other forms, the well-known Cobras. The American species are almost equally numerous, but they all belong to one 
genus, and they are annulated with rings of various colours in a manner quite distinct from any other members of this family. The genera, which are all very distinct, are distributed as follows :-

Diemenia, Acanthophis, Hoplocephalus, Brachiurophis, Tropidechis, Pseudechis, Cacophis, Pseudonaje, Denisonia, and Vermicella, are Australian, the first two ranging to the Moluccas and New Guinea; Ogmodon occurs in the Fiji Islands; Naja, Bungarus, Ophiophagus, Pseudonaje, Xenurelaps, Doliophis, Megoerophis, and Callophis are Oriental, one species of the latter genus being found in Japan, while an Ophiophagus has been discovered in New Guinea; Cyrtophis, Elapsoidea, and Pcecilophis are African: Elaps is American, ranging as far north as South Carolina, but not to the West Indian Islands.

\section{FAMILY 21.-DENDRASPIDID $Æ . \quad$ (1 Genus, 5 Species.)}

\begin{tabular}{|c|c|c|c|c|c|}
\hline \multicolumn{4}{|c|}{ Gesersl Distribution. } & \\
\hline $\begin{array}{l}\text { NEOTROPICAL } \\
\text { SUB-REGIONS. }\end{array}$ & $\begin{array}{c}\text { Nearctic } \\
\text { Sub-REgIoNs. }\end{array}$ & $\begin{array}{l}\text { PaLAaARCTIC } \\
\text { SUB-REGIONS. }\end{array}$ & $\begin{array}{c}\text { ETHIOPIAN } \\
\text { SUB-REGIONS. }\end{array}$ & $\begin{array}{c}\text { ORIENTAL } \\
\text { SUB-REGIONS. }\end{array}$ & $\begin{array}{l}\text { AUSTRALIAN } \\
\text { SUB-REOIONS. }\end{array}$ \\
\hline--- & $-\cdots-$ & $-\cdots$ & $1.2--$ & ---- & $--\cdots$ \\
\hline
\end{tabular}

The single genus Dendraspis, constituting the family, is confined to Tropical Africa.

\section{FAMILY 22.-ATRACTASPIDIDA. (1. Genus, 4 Species.)}

\begin{tabular}{|c|c|c|c|c|c|}
\hline \multicolumn{6}{|c|}{ General Distribution. } \\
\hline $\begin{array}{l}\text { NEOTROPICAL } \\
\text { SUB-REGIONS. }\end{array}$ & $\begin{array}{c}\text { NEARCTIC } \\
\text { SUB-REOOIONS. }\end{array}$ & $\begin{array}{l}\text { PALAaActic } \\
\text { SUB-REGIONS. }\end{array}$ & $\begin{array}{c}\text { ETHIOPIAN } \\
\text { SUB-REGIONS. }\end{array}$ & $\begin{array}{l}\text { ORIENTAL } \\
\text { SUB-REGIONS. }\end{array}$ & $\begin{array}{l}\text { AUSTRALIAN } \\
\text { SUB-REGIONS. }\end{array}$ \\
\hline---- & ---- & --- & $-2 \cdot 3-$ & --- & -- \\
\hline
\end{tabular}

This small family, consisting of the genus Atractaspis, is also confined to Africa, but has hitherto only been found in the West and South. 
Family 23.-HYDROPHIDA. (8 Genera, 50 Species.)

\begin{tabular}{|c|c|c|c|c|c|}
\hline \multicolumn{6}{|c|}{ General Distribution. } \\
\hline $\begin{array}{l}\text { NFotropical } \\
\text { St'B-REGIONS. }\end{array}$ & $\begin{array}{l}\text { NEARCTIC } \\
\text { SUB-REGIONS. }\end{array}$ & $\begin{array}{l}\text { PaLfearctic } \\
\text { Sub-REgIONS. }\end{array}$ & $\begin{array}{l}\text { ETHIOPIAN } \\
\text { SUB-REGIONS. }\end{array}$ & \begin{tabular}{c|} 
ORIENTAL \\
SUB-REGIONS.
\end{tabular} & $\begin{array}{l}\text { AUETRALIAN } \\
\text { SUB-REGIONS. }\end{array}$ \\
\hline---3 & --- & --- & ---4 & $1.2 \cdot 3 \cdot 4$ & $1.2 \cdot 3 \cdot 4$ \\
\hline
\end{tabular}

The Hydrophidæ, or Sea Snakes, are a group of "small-sized marine serpents, abundant in the Indian and Australian seas, and extending as far west as Madagascar, and as far east as Panama. They are very poisonous, and it is probable that many species remain to be discovered. The genera are distributed as follows :-

Hydrophis (37 sp.), ranging from India to Formosa and Australia; Platurus (2 sp.), from the Bay of Bengal to New Guinea and New Zealand; Aipysurus (3 sp.), Java to New Guinea and Australia; Disteira (1 sp.), unknown locality; Acalyptus (1 sp.), South-west Pacific ; Enhydrina (1 sp.), Bay of Bengal to New Guinea; Pelamis (1 sp.), Madagascar to New Guinea, New Zealand, and Panama; Emydocephalus (1 sp.), Australian Seas.

Family 24-CROTALID AE. (11 Genera, 40 Species.)

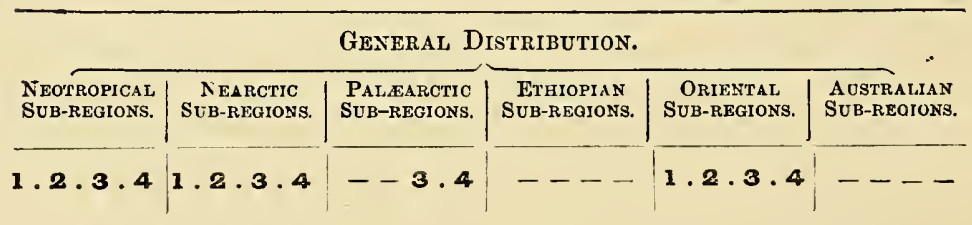

The Crotalidæ, or Pit Vipers, including the deadly Rattlesnakes, form a well-marked family of fanged serpents, whose distribution is very interesting. They abound most in the Oriental region, at least 5 of the genera and 20 species being found within its limits, yet they are quite unknown in the Ethiopian region - a parallel case to that of the Bears and Deer. A few species are peculiar to the eastern portion of the Palæarctic region, while 
the Nearctic is actually richer than the Neotropical region both in genera and species. This would point to the conclusion, that the group originated in the Indo-Chinese sub-region and spread thence north-east to North America, and so onward to South America, which, having been the last to receive the group, has not had time to develop it largely, notwithstanding its extreme adaptability to Reptilian life. The genera are divided among the several regions as follows:-

Craspedocephalus (7 sp.), Tropical America and the West Indian Islands; Cenchris, Crotalophorus, Uropsophorus, and Crotalus, inhabiting North America from Canada and British Columbia to Texas, one species (Crotalus horridus) extending into South America; Trimeresurus (16 sp.), all India from Ceylon to Assam, Formosa, the Philippines and Celebes; Peltopelor and Hypnale (1 sp. each), peculiar to India ; Calloselasma (1 sp.), Siam ; Atropos (1 sp.), Java and Borneo; Halys (3 sp.), peculiar to Tartary, Thibet, Japan, North China, and Formosa.

Family 25.-VIPEKIDA. (3 Genera, 22 Species.)

\begin{tabular}{|c|c|c|c|c|c|}
\hline \multicolumn{6}{|c|}{ General Distribution. } \\
\hline $\begin{array}{l}\text { NEOTROPICAL } \\
\text { SUB-REGHONS. }\end{array}$ & $\begin{array}{c}\text { NEAHCTIC } \\
\text { SUE-REGIONS. }\end{array}$ & $\begin{array}{l}\text { PiL.EARCTIC } \\
\text { SUB-kEGION3. }\end{array}$ & $\begin{array}{c}\text { ETHIOPIAN } \\
\text { SUB-REGIONS. }\end{array}$ & $\begin{array}{l}\text { ORIENTAL } \\
\text { SUB-EEGIONS. }\end{array}$ & $\begin{array}{l}\text { AUSTRALIAN } \\
\text { SUB-BEGIUNS. }\end{array}$ \\
\hline$-\cdots$ & $--\cdots$ & $1 \cdot 2 \cdot 3 \cdot 4$ & $1 \cdot 2 \cdot 3 \cdot 4$ & 1.2 .3 .4 & $-\cdots$ \\
\hline
\end{tabular}

The Viperidæ, or True Vipers, are especially characteristic of the Palæarctic and Ethiopjan regions, only one species being found over a large part of the Oriental region, and anothei' reaching Central India. They are especially abundant in Africa, and the Palæarctic confines in South-western Asia. The common Viper ranges across the whole Palæarctic region from Portugal to Saghalien Island, reaching to $67^{\circ}$ North Latitude, in Scandinavia, and to $58^{\circ}$ in Central Siberia. The genera, according to Dr. Strauch's synopsis, are distributed as follows :-

Viperc (17 sp.), which has the range of the family, extending over the whole of the Palæarctic and Ethiopian regions, except Madagascar, and as far as Ceylon, Siam, and Java, in the Oriental YOL. II. 
region; Echis (2 sp.), inhabiting North Africa to Persia and to Continental India; and Atheris (3 sp.), confined to West Africa.

\section{Remarks on the General Distribution of Ophidia.}

The Ophidia, being preeminently a Tropical order-rapidly diminishing in numbers as we go north in the Temperate Zone, and wholly ceasing long before we reach the Arctic Circle-we cannot expect the two Northern regions to exhibit any great variety or peculiarity. Yet in their warmer portions they are tolerably rich; for, of the 25 families of snakes, 6 are found in the Nearctic region, 10 in the Palæarctic, 13 in the Australian, 16 in the Neotropical, 17 in the Ethiopian, and no less than 22 in the Oriental, which last is thus seen to be by far the richest of the great regions in the variety of its forms of Ophidian life. The only regions that posisess altogether peculiar families of this order, are the Ethiopian (3), and the Oriental (2); the usually rich and peculiar Neotropical region not possessing exclusively, any family of snakes; and what is still more remarkable, the Neotropical and Australian regions together, do not possess a family peculiar to them. Every family inhabiting these two regions is found also in the Oriental; and this fact, taken in connection with the superior richness of the latter region both in families and genera, would indicate that the Ophidia had their origin in the northern hemisphere of the Old World (the ancient Palæarctic region) whence they spread on all sides, in successive waves of migration, to the other regions. The distribution of the genera peculiar to, or highly characteristic of, the several regions is as follows :-

The Nearctic possesses 9 ; four of these belong to the Colubridæ, one to the Pythonidæ, and four to the Crotalidæ. The Palæarctic region has only 2 peculiar genera, belonging to the Colubridæe and Crotalidæ. The Etliopian has 25, belonging to 11 families; four to Colubridæ, five to Lycodontidæ, and three to Elapidæ. The Oriental has no less than 50, belonging to 15 families; five are Colubridæ, five Uropeltidæ, twelve Homalopsidæ, six Lycodontidæ, three Amblycephalidæ, eight Elapidæ, and four Crota- 
lidx. The Australian has 16 , belonging to three families only; eleven being Elapidæ, and four Pythonidæ. The Nentropical has about 24, belonging to eight families; ten are Colubridæ, six Pythonidæ, and the rest Dipsadidæ, Scytalidæ, Amblycephalidæ, Elapidæ, and Crotalidæ.

We find then, that in the Ophidia, the regions adopted in this work are remarkably distinct; and that, in the case of the Oriental and Ethiopian, the difference is strongly marked, a very large number of the genera being confined to each region. It is interesting to observe, that in many cases the affinity seems to be rather between the West Coast of $A$ frica and the Oriental region, than between the East Coast and the plains of India; thus the Homalopsidæ-a highly characteristic Oriental familyoccur on the West Coast of Africa only; the Dryiophidæ, which range over the whole Oriental region, only occur in Madagascar and West Africa in the Ethiopian; the genus Dipsas is found over all the Oriental region and again in West Africa. A cause for this peculiarity has been suggested in our sketch of the past history of the Ethiopian region, Vol. I. p. 288. In the Lycodontidæ, which are strictly confined to these two regions, the genera are all distinct, and the same is the case with the more widely distributed Elapidæ; and although a few desert forms, such as Echis and the Erycidæ, are common to Africa and the dry plains of India, this is evidently due to favourable climatic conditions, and cannot neutralise the striking differences in the great mass of the family and generic forms which inhabit the two regions. 'The union of Madagascar with the South-western part of the Oriental region under the appellation Lemuria, finds no support in the distribution of Ophidia; which, however, strikingly accords with the views developed in the Third Part of this work, as to the great importance and high antiquity of the Euro-Asiatic continent, as the chief land-centre from which the higher organisms have spread over the globe.

Fossil Ophidia.-The oldest known remains of Ophidia occur in the Eocene formation in the Isle of Sheppey; other's are found in the Miocene (Brown Coal) of Germany, and in some Tertiary beds in the United States. Most of these appear to have been 
large species belonging to the Pythonidæ, so that we are evidently still very far from knowing anything of the earliest forms of this order. In some of the later Tertiary deposits the poison fangs of venomous species have been found; also a Colubrine snake from the Upper Miocene of the South of France.

\section{Order II.-LACERTILIA.}

FAMILY 26.-TROGONOPHID A. (1 Genus, 1 Species.)

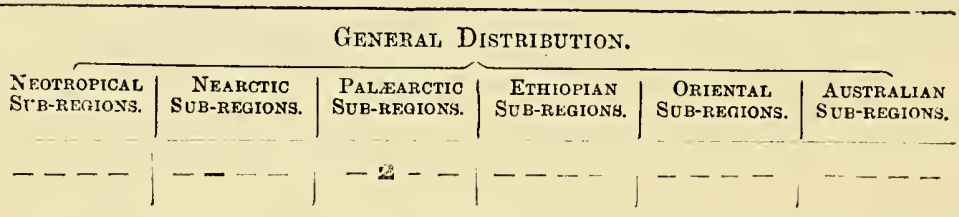

The single species of Trogonoptis, forming this family, is found only in North Africa.

Family 27.-CHIROTID Æ. (1 Genus, 1 Species.)

\begin{tabular}{|c|c|c|c|c|c|}
\hline \multicolumn{6}{|c|}{ General Distribution. } \\
\hline $\begin{array}{l}\text { TFOTROPICAL } \\
\text { StB-REGIONS. }\end{array}$ & $\begin{array}{l}\text { NEARCTIC } \\
\text { SUB-REGIONS. }\end{array}$ & $\begin{array}{l}\text { PALAaARCTIC } \\
\text { Sub-REGIONS. }\end{array}$ & $\begin{array}{l}\text { ETHIOPIAN } \\
\text { SUB-REGIONS. }\end{array}$ & $\begin{array}{c}\text { ORIENTAL } \\
\text { SUB-REGIONS. }\end{array}$ & $\begin{array}{l}\text { AUSTRALIAN } \\
\text { SUB-REGIONS. }\end{array}$ \\
\hline$--3-$ & $--3 \cdots$ & ---- & $-\cdots-$ & $-\cdots--$ & -- \\
\hline
\end{tabular}

Chirotes, the genus which constitutes this family, inhabits Mexico, and has also been found in Missouri, one of the Sonthern United States.

FAMn 28.-AMPHISBANID $\approx$. (1 Genus, 13 Species.)

\begin{tabular}{|c|c|c|c|c|c|}
\hline \multicolumn{6}{|c|}{ General Distribution. } \\
\hline $\begin{array}{l}\text { NEOTROPICAL } \\
\text { SUB-REQIONS. }\end{array}$ & $\begin{array}{c}\text { NEarCTIC } \\
\text { SUB-REGIONS. }\end{array}$ & $\begin{array}{l}\text { PALEARCTIC } \\
\text { SUB-KEGIONS. }\end{array}$ & $\begin{array}{l}\text { ETHIOPIAN } \\
\text { SUB-REGIONS. }\end{array}$ & $\begin{array}{l}\text { ORIENTAL } \\
\text { SUB-REGIONS. }\end{array}$ & $\begin{array}{l}\text { AUSTRALIAN } \\
\text { StB-REATONS. }\end{array}$ \\
\hline $1 \cdot 2-4$ & --- & $-2--$ & $1.2--$ & --- & --- \\
\hline
\end{tabular}


The Amphisbænidæ, which, in the opinion of Dr. Günther, are all comprised in the genus Amphisbcena, inhabit Spain and Asia Minor, North and Tropical Africa, South America as far as Buenos-Ayres and the West Indian Islands.

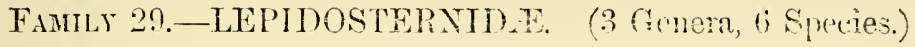

\begin{tabular}{|c|c|c|c|c|c|}
\hline \multicolumn{6}{|c|}{ General Distribution. } \\
\hline $\begin{array}{l}\text { NEotroopical } \\
\text { SUB-REGIONS. }\end{array}$ & $\begin{array}{c}\lambda_{\text {EARCTIC }} \\
\text { SUB-REGIONS. }\end{array}$ & $\begin{array}{l}\text { PaLiEarctic } \\
\text { SUb-REGIONS. }\end{array}$ & $\begin{array}{l}\text { ETHIOPIAN } \\
\text { SUB-REGIONS. }\end{array}$ & $\begin{array}{c}\text { ORIERTAL } \\
\text { SUB-REGIONS. }\end{array}$ & $\begin{array}{l}\text { AUSTRALIAX } \\
\text { SUB-REGIONS. }\end{array}$ \\
\hline $1.2--$ & $-\cdots-$ & ---- & $-2 \cdot 3-$ & ---- & --- \\
\hline
\end{tabular}

The small family of Lepidosternidæ has nearly the same distribution as the last, indicating a curious relationship between the Tropical parts of Africa and America. Lepidosternon and Cephalopeltis are American genera, while Monotrophis is African.

Famiry 30.-VARANID $\not$ E. (3 Genera, 30 Species.)

\begin{tabular}{|c|c|c|c|c|c|}
\hline \multicolumn{6}{|c|}{ General Distribution. } \\
\hline $\begin{array}{l}\text { NEOTROPICAL } \\
\text { SUB-REGIONS. }\end{array}$ & $\begin{array}{c}\text { NEAFCTIC } \\
\text { SUB-iETi ONS. }\end{array}$ & $\begin{array}{l}\text { PaLAaARCTIC } \\
\text { SEB-AEGioss. }\end{array}$ & $\begin{array}{c}\text { ETHIOPIAN } \\
\text { SUB-BEOIONS. }\end{array}$ & $\begin{array}{l}\text { ORIENTAI } \\
\text { SUB-REGIONS. }\end{array}$ & $\begin{array}{l}\text { AUSTRAIIAN } \\
\text { SUE-GEGIONS. }\end{array}$ \\
\hline$--\cdots$ & --- & $-2--$ & $1.2 .3-$ & 1.2 .3 .4 & $1.2-$ \\
\hline
\end{tabular}

The Varaniciæ, or Water Lizards, are most abundant in the Oriental region, whence they extend into the Austro-Malay Islands as far as New Guinea, and into Australia. Several species are found in Africa. Psammosaurus (1 sp.), is found in North Africa and North-western India; Monitor (18 sp.), has the range of the family; while Hydrosaurus (8sp) ranges from Siam to the Philippines, New Guinea, and Australia. 
Famly 31.-HELODERMIDAE. (1 Genus, 1 Species.)

\begin{tabular}{|c|c|c|c|c|c|}
\hline \multicolumn{6}{|c|}{ Gexerat Distribution. } \\
\hline $\begin{array}{l}\text { NEOTROPICAL } \\
\text { SUB-REGLONS. }\end{array}$ & $\begin{array}{c}\text { NEARCTIC } \\
\text { SUB-REGIONS. }\end{array}$ & $\begin{array}{c}\text { Paldearctic } \\
\text { Sub-kEgIoNs. }\end{array}$ & $\begin{array}{c}\text { ETHIOPIAN } \\
\text { SUB-REOIONS. }\end{array}$ & $\begin{array}{c}\text { ORIENTAL } \\
\text { SUB-REGIONS. }\end{array}$ & $\begin{array}{l}\text { AUSTRALIAN } \\
\text { SUB-REGIONS. }\end{array}$ \\
\hline$--3-$ & ---- & ---- & ---- & $---\cdots$ & ---- \\
\hline
\end{tabular}

The genus Heloderma, which constitutes this family, is found in Mexico.

Fanily.32.-TEID Æ. (12 Genera, 74 Species.)

\begin{tabular}{|c|c|c|c|c|c|}
\hline \multicolumn{6}{|c|}{ General Distribution. } \\
\hline $\begin{array}{l}\text { NEOTROPICAL } \\
\text { St:B-REGIONS. }\end{array}$ & $\begin{array}{c}\text { NEARCTIC } \\
\text { SUB-REGIONS. }\end{array}$ & $\begin{array}{l}\text { PaLEARCTIC } \\
\text { SUB-REGIONS. }\end{array}$ & $\begin{array}{c}\text { ETHIOPIAN } \\
\text { SUB-REGIONS. }\end{array}$ & $\begin{array}{l}\text { ORIENTAL } \\
\text { SUB-REGIONS. }\end{array}$ & $\begin{array}{l}\text { AUSTRALIAN } \\
\text { SUB-REGIONS. }\end{array}$ \\
\hline 1.2 .3 .4 & $1.2 .3-$ & --- & ---- & $---\cdots$ & -- \\
\hline
\end{tabular}

The Teidæe, or Teguexins-a group of Lizards allied to the European Lacertidie, but with differently formed superciliary scales-are highly characteristic of the Neotropical region, abounding almost everywhere from Patagonia to the Antilles and Mexico, and extending northwards to California on the west and to Pennsylvania on the east. The most extensive genus is Ameiva, containing nearly 60 species and having the range of the entire family; Teius (3 sp.), inhabits Brazil and Mendoza; Callopistes (2 sp.), Chili ; Centropyx (3 sp.), Paraguay to Alabama; Dicrodon (Peru); Monoplocus (Western Ecuador); with Acrantus, Acantropyga, Emminia, Crocodilurus, Custa, and Ada, which each consist of a single species, and all inhabit Tropical America.

\section{Family 33.-LACERTID卧. (18 Genera, 80 Species.)}

Gexeral Distribution.

\begin{tabular}{|c|c|c|c|c|c|}
\hline $\begin{array}{l}\text { NEOTROPICAL } \\
\text { SUB-REGIONS. }\end{array}$ & $\begin{array}{c}N_{\text {EARCTIC }} \\
\text { SUB-REGIONS. }\end{array}$ & $\begin{array}{l}\text { PaLAarartic } \\
\text { SUB-REGIONS. }\end{array}$ & $\begin{array}{c}\text { ETHIOPIAN } \\
\text { SUB-REGIONS. }\end{array}$ & $\begin{array}{c}\text { ORIENTAL } \\
\text { SUB-REGIONS. }\end{array}$ & $\begin{array}{l}\text { AUSTRALIAN } \\
\text { SUB-REGIONS. }\end{array}$ \\
\hline & - & 1.2. 3.4 & $1.2 .3-$ & 1.2 .3 .4 & -2 \\
\hline
\end{tabular}


The Lacertidx, or Land Lizards, are small-sized, terrestrial, nou-burrowing lizards, very characteristic of the Palrearctic region, which contains more than half the known species, and of the adjacent parts of the Oriental and Ethiopian regions, but extending also to South Africa, to Java, and even to Australia. The best-defined genera are the following :-

Lacerta (10 sp.), ranging over ail Central and South Europe to Poland, and farther north in Russia and Siberia, eastward to Persia, and southward to North and West Africa; Zootoca (8 sp.), has nearly the same range in Europe as the last genus, but has representatives in Madeira, South Africa, and Australia; Tachydromus (7 sp.) is widely scattered in Chinese Asia, Japan, Borneo, and West Africa; Acanthodactylus (10 sp.) is most abundant in North Africa, but has a species in South Africa, and two in Central India; Eremias (18 sp.) is found all over Africa, and aiso in the Crimea, Persia, Tartary and China; Psammodromus (2 sp.), is confined to Spain, France, and Italy; Ophiops (6 sp.), inhabits India, Persia, and Asia Minor to South Russia. Less strongly marked and perhaps less natural genera are the following:-

Thetia (1 sp.), Algiers; Teira (1 sp.), Madeira; Nucras (4 sp.), Caucasus and South Africa; Notopholis (4 sp.), South Europe and South Africa; Algira (3 sp.), North and South Africa ; Scrapteira (1 sp.), Nubia ; Aspidorhinus (1 sp.), Caspian district ; Messalina (4 sp.), North Africa, Persia, and North-west India Cabrita(1 sp.), Central India; Pachyrhynchus (1 sp.), Benguela.

FAMILY 34.-ZONURIDA. (15 Genera, 52 Species.)

\begin{tabular}{|c|c|c|c|c|c|}
\hline \multicolumn{6}{|c|}{ General Distribution. } \\
\hline $\begin{array}{l}\text { NEOTROPICAL } \\
\text { Sub-REGIONS. }\end{array}$ & $\begin{array}{c}\text { NEARCTIC } \\
\text { SUB-REGIONS. }\end{array}$ & $\begin{array}{l}\text { Palanarctic } \\
\text { Sub-hegions. }\end{array}$ & $\begin{array}{c}\text { EthIOPIAN } \\
\text { SUB-REGIONS. }\end{array}$ & $\begin{array}{c}\text { ORIENTAL } \\
\text { SUB-KEGIONB. }\end{array}$ & $\begin{array}{l}\text { AUSTRALIAN } \\
\text { SUB-REGIONS. }\end{array}$ \\
\hline$-2 \cdot 3 \cdot 4$ & $1.2 \cdot 3 \cdot 4$ & $-2--$ & 1.2 .3 .4 & $--3-$ & $-2--$ \\
\hline
\end{tabular}

'The Zonuridx, or Land Lizards, characterised by a longitudinal fold of skin on each side of the body, have a very remarkable 
distribution. Their head-quarters is the Ethiopian region, which contains more than half the known genera and species, most of which are found in South Africa and several in Madagascar. Next to Africa the largest number of genera and species are found in Mexico and Central America, with a few in the Antilles, South America, and California, and even as far north as British Columbia. Three of the genera form a distinct sub-group-the Glass Snakes,-the four species composing it being located in North Africa, North America, South-eastern Europe, and the Khasya Hills.

The prominent fact in the distribution of this family is, that the mass of the genera and species form two groups, one in South Africa, the other in Mexico,--countries between which it would be difficult to imagine any means of communication. We have here, probably, an example of a once much more extensive group, widely distributed over the globe, and which has continued to maintain itself only in those districts especially adapted to its peculiar type of organization. This must undoubtedly have been the case with the genus Pseudopus, whose two species now inhabit Sonth-eastern Europe and the Khasya Hills in Assam respectively.

The genera are,-Cordylus, Pscudocordylus, Platysaurus, Cordylosaurus, Pleurostrichus, and Saurophis, confined to South Africa; Zonurus, South and East Africa and Madagascar; Gerrhosaurus, ranges over the whole Ethiopian region; Cicigna is confined to Madagascar; Gerrhonotus (22 sp.), ranges from British Columbia, California, and Texas, to Cuba and South America, but is most abundant in Mexico and Central America; Abronia and Barissia, are two genera of doubtful distinctness, peculiar to Mexico; Ophisaurus (the Glass Snake) is found in the Southern United States as far as Virginia; the allied genus Hyalosaurus in North Africa; and Pseudopus, as above stated, in South-east Europe and the Khasya Hills. 


\section{FAMLl 35.-CHALCIDE. (3 Genera, S Species.)}

\begin{tabular}{|c|c|c|c|c|c|}
\hline \multicolumn{6}{|c|}{ General Distribution. } \\
\hline $\begin{array}{l}\text { N FoTROPICAL } \\
\text { St:B-REOIONS. }\end{array}$ & $\begin{array}{c}\text { NEARCTIC } \\
\text { SUB-REGIONS. }\end{array}$ & $\begin{array}{l}\text { PaLeanctic } \\
\text { SUB-REOIOAS. }\end{array}$ & $\begin{array}{c}\text { ETHIOPIAN } \\
\text { SUB-REGIONS. }\end{array}$ & $\begin{array}{c}\text { ORIENTAL } \\
\text { SUB-KEGIONS. }\end{array}$ & $\begin{array}{l}\text { AUsTRALIAN } \\
\text { SUB-REGIONS. }\end{array}$ \\
\hline $1.2 .3-$ & $--? 3-$ & ---- & $---\cdots$ & ---- & - \\
\hline
\end{tabular}

The Chalcidæ are a small group of Lizards characteristic of Tropical America, one species extending into the United States.

The genera are Chalcis (6 sp.), ranging from Central America to Chili; two other species, which have been placed in distinct genera, inhabit North America and Peru.

Family 36.-ANADIAD $2 . \quad$ (1 Geuus, 1 Species.)

\begin{tabular}{|c|c|c|c|c|c|}
\hline \multicolumn{6}{|c|}{ General Distribution. } \\
\hline $\begin{array}{l}\text { NEOTROPICAL } \\
\text { SEB-REGIONS. }\end{array}$ & $\begin{array}{c}\text { NeARCTIC } \\
\text { SUB-REGIONS. }\end{array}$ & $\begin{array}{l}\text { PALAAARCTIC } \\
\text { SUB-KEGIONS. }\end{array}$ & $\begin{array}{l}\text { ETHIOPIAX } \\
\text { SUB-REGIONS. }\end{array}$ & $\begin{array}{c}\text { ORIENTAL } \\
\text { SUB-KEGIONS. }\end{array}$ & $\begin{array}{l}\text { AUSTRALIAN } \\
\text { SUB-REGIONS. }\end{array}$ \\
\hline$-2--$ & $-\cdots-$ & ---- & ---- & $---\cdots$ & - \\
\hline
\end{tabular}

The single species of Anadia, constituting this family, inhabits Tropical America.

Family 37.-CHIROCOLIDE. (1 Genus, 2 Species.)

\begin{tabular}{|c|c|c|c|c|c|}
\hline \multicolumn{6}{|c|}{ Gexeral Distribution. } \\
\hline $\begin{array}{l}\text { NEOTROPICAL } \\
\text { SUb-REGIONS. }\end{array}$ & $\begin{array}{c}\lambda_{\text {EARCTIC }} \\
\text { SUB-REGIONS. }\end{array}$ & $\begin{array}{l}\text { PALAARCTIC } \\
\text { SUB-REGIONS. }\end{array}$ & $\begin{array}{c}\text { ETHIOPIIN } \\
\text { SUB-REGIONS. }\end{array}$ & $\begin{array}{c}\text { ORIENTAL } \\
\text { SUB-REGIONS. }\end{array}$ & $\begin{array}{l}\text { AUSTRALian } \\
\text { SUB-REgIONS. }\end{array}$ \\
\hline$-2--$ & --- & --- & --- & --- & --- \\
\hline
\end{tabular}

The genus Hetcrodactylus, which constitutes this family, inhabits Brazil. 
Family 38.-IPHISAD Æ. (1 Genus, 1 Species.)

\begin{tabular}{|c|c|c|c|c|c|}
\hline \multicolumn{6}{|c|}{ General Distibibution. } \\
\hline $\begin{array}{l}\text { NEOTROPICAL } \\
\text { SUB-REGIONS. }\end{array}$ & $\begin{array}{c}\text { NEARCTIC } \\
\text { SUB-REOIONS. }\end{array}$ & $\begin{array}{l}\text { PalfaARCTIC } \\
\text { SUb-hEGIONS. }\end{array}$ & $\begin{array}{c}\text { ETHIOPIAN } \\
\text { SUB-REGIONS. }\end{array}$ & $\begin{array}{c}\text { ORIENTAL } \\
\text { SUB-KEGIONS. }\end{array}$ & $\begin{array}{l}\text { AUSTRALTAN } \\
\text { SUB-REGIONS. }\end{array}$ \\
\hline$-2--$ & --- & --- & ---- & $-\cdots-$ & ---- \\
\hline
\end{tabular}

The single species of Iphisa, has been found only at Para in Equatorial America.

Family 39.-CERCOSAURIDÆ. (1 Genus, 5 Species.)

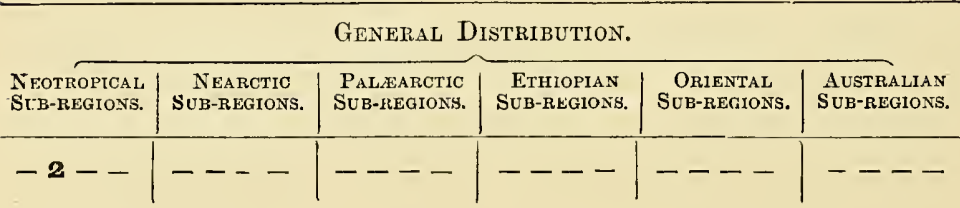

The genus Cercosaura, is known only from Brazil and Ecuador.

FAMILY 40.-CHAM ESAURID $\approx$. (1 Genus, 1 Species.)

\begin{tabular}{|c|c|c|c|c|c|}
\hline \multicolumn{6}{|c|}{ Gexeral Distribution. } \\
\hline $\begin{array}{l}\text { NEOTROPICAL } \\
\text { SUB-REGIONS. }\end{array}$ & $\begin{array}{c}\text { NEARCTIC } \\
\text { SUB-REGIONS. }\end{array}$ & $\begin{array}{c}\text { PALAEARCTIC } \\
\text { SUB-REGIONS. }\end{array}$ & $\begin{array}{c}\text { ETHIOPIAN } \\
\text { SUB-REGIONS. }\end{array}$ & $\begin{array}{l}\text { ORIENTAL } \\
\text { SUB-REGIONS. }\end{array}$ & $\begin{array}{l}\text { AUSTRalian } \\
\text { SUB-REGIONS. }\end{array}$ \\
\hline--- & ---- & $--\cdot-$ & $--3-$ & ---- & - \\
\hline
\end{tabular}

This family, consisting of a single species of the genus Chamcesaura, is confined to South Africa. 
FAMILY 41.-GYMNOPTHALMID Æ. ( 5 Genera, 14 Species.)

\begin{tabular}{|c|c|c|c|c|c|}
\hline \multicolumn{6}{|c|}{ General Distribution. } \\
\hline $\begin{array}{l}\text { NEOTROPIOAL } \\
\text { SUB-REGIONS. }\end{array}$ & $\begin{array}{c}\text { NEARCTIC } \\
\text { SUB-REGIONS. }\end{array}$ & $\begin{array}{l}\text { PaLAEARCTIC } \\
\text { SUb-kEgIONS. }\end{array}$ & $\begin{array}{c}\text { ETHIOPIAN } \\
\text { SUB-REGIONS. }\end{array}$ & $\begin{array}{c}\text { ORIENTAL } \\
\text { Sub-kEgIONS. }\end{array}$ & $\begin{array}{l}\text { Aostralian } \\
\text { Sub-REgTONas. }\end{array}$ \\
\hline$-2-4$ & $-\cdots--$ & $1.2 .3-$ & $-2-4$ & $-\cdots-$ & $1 \cdot 2 \cdot 3$ \\
\hline
\end{tabular}

The Gymnopthalmidæe, or Gape-eyed Scinks, so called from their rudimentary eyelids, form a small group, which is widely and somewhat erratically distributed, as will be seen by the following account of the distribution of the genera:-

Lerista ( $1 \mathrm{sp}$.) and three other species for which Dr. Gray has established the genera-Morethria (1 sp.), and Menetia (2 sp.), are confined to Australia; Cryptoblepharus (4 sp.), is found in West Australia, Timor, New Guinea, the Fiji Islands, and Mauritius; Ablepharus (4 sp.), inhabits Eastern and Southeastern Europe, Persia, Siberia, West Africa, and the Bonin Islands; and Gyminopthalmus (3 sp.), is found in Brazil and the West Indies.

FAMILY 42.-PYGOPODID Æ. (2 Genera, 3 Species.)

\begin{tabular}{|c|c|c|c|c|c|}
\hline \multicolumn{6}{|c|}{ Gexieral Distribution. } \\
\hline $\begin{array}{l}\text { NEOTROPICAL } \\
\text { SUR-REGLONS. }\end{array}$ & $\begin{array}{c}\text { NEARCTIC } \\
\text { SUB-REGIONS. }\end{array}$ & $\begin{array}{l}\text { PaLAaRctiC } \\
\text { SUB-REGIONS. }\end{array}$ & $\begin{array}{l}\text { ETHIOPIIN } \\
\text { SUB-REGIONS. }\end{array}$ & $\begin{array}{c}\text { ORILNTAL } \\
\text { SUB-KEGIONS. }\end{array}$ & $\begin{array}{l}\text { AUSTIRALIAN } \\
\text { SLbi-kEgIONS. }\end{array}$ \\
\hline---- & $--\cdots-$ & $-\cdot--$ & ---- & ---- & $-2--$ \\
\hline
\end{tabular}

This small family of two-legged Lizards, comprising the genera Pygopus and Delma, is found only in Australia proper and Tasmania. 
Fanily 43.-APRASIAD E. (1 Gelıus, 2 Species.)

\begin{tabular}{|c|c|c|c|c|c|}
\hline \multicolumn{6}{|c|}{ General Distribution. } \\
\hline $\begin{array}{l}\text { NFotRopical } \\
\text { StrB-REGIONS. }\end{array}$ & $\begin{array}{c}\text { NEARCTIC } \\
\text { SüB-REGIONS. }\end{array}$ & $\begin{array}{l}\text { Palearctic } \\
\text { Sub-liegions. }\end{array}$ & $\begin{array}{c}\text { ETHIOPIAS } \\
\text { SUB-REGIONS. }\end{array}$ & $\begin{array}{c}\text { ORIENTAL } \\
\text { SUB-REGIONS. }\end{array}$ & $\begin{array}{l}\text { AUstralian } \\
\text { SUb-hEgions. }\end{array}$ \\
\hline--- & ---- & ---- & ---- & --- & $-2--\cdot$ \\
\hline
\end{tabular}

The genus Aprasia, constituting this family, is found in West and South Australia.

Family 44.-LIALID RE. (1 Genus, 3 Species.)

\begin{tabular}{|c|c|c|c|c|c|}
\hline \multicolumn{6}{|c|}{ General Distribution. } \\
\hline $\begin{array}{l}\text { NFOTROPICAL } \\
\text { StB-REGIONS. }\end{array}$ & $\begin{array}{c}\text { NEARCTIC } \\
\text { SUB-REQIONS. }\end{array}$ & $\begin{array}{l}\text { PaLAarctic } \\
\text { SUB-KEGIONS. }\end{array}$ & $\begin{array}{l}\text { ETHIOPIAN } \\
\text { SUB-REGIONS. }\end{array}$ & $\begin{array}{c}\text { ORIENTAL } \\
\text { SUB-REGIONS. }\end{array}$ & $\begin{array}{l}\text { AUSTRALIAN } \\
\text { SUB-REGIONS. }\end{array}$ \\
\hline-- & ---- & ---- & ---- & ---- & $-2--$ \\
\hline
\end{tabular}

This family is also confined to Australia, the single genus, Lialis, inhabiting the Western and Northern districts.

Family 45.-SCINCID $\AA . \quad$ (60 Genera, 300 Species.)

\begin{tabular}{|c|c|c|c|c|c|}
\hline \multicolumn{6}{|c|}{ General Distribution. } \\
\hline $\begin{array}{l}\text { NEotropical } \\
\text { SUb-REGLONS. }\end{array}$ & $\begin{array}{l}\text { NEARCTIC } \\
\text { SUB-REGIONS. }\end{array}$ & $\begin{array}{l}\text { PALAARCTIC } \\
\text { SUd-hEGIONS. }\end{array}$ & $\begin{array}{c}\text { ETHIOPIAN } \\
\text { SUB-REGIONS. }\end{array}$ & $\begin{array}{c}\text { ORIENTAL } \\
\text { SUB-REQIONS. }\end{array}$ & $\begin{array}{l}\text { AUstralian } \\
\text { SUB-REgions. }\end{array}$ \\
\hline 1.2 .3 .4 & $1.2 .3-$ & 1.2 .3 .4 & 1.2 .3 .4 & 1.2 .3 .4 & 1.2 .3 .4 \\
\hline
\end{tabular}

The Scincidæ, or Scinks, are an extensive family of smoothscaled lizards, frequenting dry and stony places, and almost universally distributed over the globe, being only absent from the cold northern and sonthern zones. The family itself is a very natural one, and it contains many natural genera; but a large number have been established which probably require careful revision. The following include the more important and the best established groups:- 
Scincus (2 sp.), North Africa and Arabia; Hinulia (20 sp.), most of the Australian and Oriental regions ; Cyclodina (1 sp.), Hombronia (1 sp.), and Lygosomella (1 sp.), all from New Zealand; Keneuxic (1 sp.), Philippines, Molnccas, and Papuan Islands; Elania (1 sp.) New Guinea; Carlia (2 sp.), North Australia and New Guinea; Mocoa (16 sp.), Australia and New Zealand, with species in Bormeo, West Africa, and Central America; Lipinia (3 sp.), Philippine Islands and New Guinea; Lygosoma (12 sp.), Australia, New Caledonia, Pelew and Philippine Islands; Tetradactylus (1 sp.), Hemierges (2 sp.), Chelomeles (2 sp.), Omolepida (1 sp.), Lissolepis (1 sp.), Siaphos (1 sp.), Rhodona (3 sp.) Anomalpus (1 sp.), Soridia (2 sp.), and Ophioscincus (1 sp.) all confined to Australia; Cophoscincus (3 sp.), Philippine Islands, Celebes, and Queensland; Plestiodon (18 sp.), China and Japan, Africa, and America as far north as Pennsylvania and Nebraska; Eumeces (30 sp.), South Palæarctic, Oriental and Australian regions, to New Ireland and North Australia; Mabouya (20 sp.), Oriental region, AustroMalaya, North Australia, the Neotropical region, and to Lat. $42^{\circ} 30^{\prime}$ in North America; Amphixestus (1 sp.), Borneo; Hagria $1 \mathrm{sp}$. ), and Chiamela (1 sp.), India; Senira (1 sp.), Philippine Islands; Brachymeles (2 sp.). Philippine Islands and Australia; Ophiodes (1 sp.), Brazil ; Anguis (3 sp.), West Palæarctic region and South Africa; Tribolonotus (1 sp.), New Guinea; Tropidophorus (2 sp.), Cochin-China and Philippine Islands; Norbca (2 sp.), Borneo and Australia ; Trachyclosaurus (1 sp.), Australia ; Cyclodus (8 sp.), Australia, Aru Islands, and Ceram; Silubosaurus (2 sp.), Fgerina (2 sp.), and Tropidolepisma (6 sp.), all peculiar to Australia; Heteropus (7 sp.), Australia, Austro-Malaya, and Bourbon; Pygomeles (1 sp.), Madagascar; Dasia (1 sp.), Malaya ; Euprepes (70 sp.), Ethiopian and Oriental regions, AustroMalaya, South America (?); Celestus (9 sp.), peculiar to the Antilles, except a species in Costa Rica; Diploglossus (7 sp.), the Neotropical region; - with a number of other genera founded on single species from various parts of the world. 
Family 46.-OPHIOMORIDA. (2 Genera, 2 Species.)

\begin{tabular}{|c|c|c|c|c|c|}
\hline \multirow[b]{2}{*}{$\begin{array}{l}\text { NEOTROPICAL } \\
\text { SuB-REGIONS. }\end{array}$} & \multicolumn{4}{|c|}{ General Distribution. } & \multirow[b]{2}{*}{$\begin{array}{l}\text { Australian } \\
\text { Sub-REgions. }\end{array}$} \\
\hline & $\begin{array}{c}\text { NEARCTIC } \\
\text { SUB-REgIONS. }\end{array}$ & $\begin{array}{l}\text { PALEARCTYC } \\
\text { SUB-HEGIONS. }\end{array}$ & $\begin{array}{c}\text { ErHIOPIAN } \\
\text { SUB-REGIONS. }\end{array}$ & $\begin{array}{c}\text { ORIENTAL } \\
\text { SUB-FiEOIONS. }\end{array}$ & \\
\hline---- & ---- & $-2-\cdots$ & --- & --- & $-\cdots$ \\
\hline
\end{tabular}

The snake-like Lizard constituting the genus Ophiomorns, is found in Southern Russia, Greece, and Algeria; while Zygnopsis having four weak limbs, has been recently discovered by $\mathrm{Mr}$. Blanford in South Persia. The family is therefore confined to our Mediterranean sub-region.

FAMILY 47.-SEPID A. (7 Genera, 22 species.)

\begin{tabular}{|c|c|c|c|c|c|}
\hline \multicolumn{6}{|c|}{ General Distribution. } \\
\hline $\begin{array}{l}\text { NEOTROPICAL } \\
\text { STB-REG ONS. }\end{array}$ & $\begin{array}{l}\text { Nearctic } \\
\text { Sub-regions. }\end{array}$ & $\begin{array}{l}\text { PALAARCTIC } \\
\text { SUB-HEGIONS. }\end{array}$ & $\begin{array}{c}\text { ETHIOPIAN } \\
\text { SUB-REGIONS. }\end{array}$ & $\begin{array}{l}\text { ORIENTAL } \\
\text { SUB-FEGIONS. }\end{array}$ & $\begin{array}{l}\text { Australian } \\
\text { Sub-REgIONS, }\end{array}$ \\
\hline$\cdots---$ & ---- & $-2--$ & 1.2 .3 .4 & $-\cdots--$ & $-\cdots$ \\
\hline
\end{tabular}

The Sepidæ, or Sand-Lizards, a re a very natural group, almost confined to the Ethiopian region, but extending into the desert. country on the borders of the Oriental region, and into the south of the Palrearctic region as far as Palestine, Madeira, Spain, Italy, and even the South of France. The genera are:-

Seps (10 sp.), South Europe, Madeira, Teneriffe, Palestine, North Africa, Sonth Africa and Madagascar ; Sphenops (2 sp.), North Africa, Syria, West Africa; Scelotes (3 sp.), Angola to South Africa, Madagascar ; Thyrus (1 sp.), Bourbon and Mauritius; Amphiglossus (1 sp.), Madagascar; Sphenocephalus (1 sp.), Afghanistan; and Sepsine (4 sp.), South-west Africa. 
Family 48.-ACONTIADA. (3 Genera, 7 Species.)

General Distributiox.

\begin{tabular}{|c|c|c|c|c|c|}
\hline $\begin{array}{l}\text { Nirotrofopical } \\
\text { Sub-REGions. }\end{array}$ & $\begin{array}{r}\text { NEAI } \\
\text { SUB-RE }\end{array}$ & $\begin{array}{l}\text { PaLiE } \\
\text { SUB-k }\end{array}$ & $\begin{aligned} \text { ETHI } \\
\text { SUB-R }\end{aligned}$ & $\begin{array}{l}\text { ORIENTAL } \\
\text { SUB-FEGIONS. }\end{array}$ & $\begin{array}{l}\text { Australian } \\
\text { Sub-REGions. }\end{array}$ \\
\hline-- & - & - & 3. & 2 & 1 \\
\hline
\end{tabular}

'This small family of snake-like Lizards has a very curious distribution, being found in South and West Africa, Madagascar, Ceylon, and Ternate in the Moluccas. Acontias (4 sp.), is found in the four first-named localities; Nessia (2 sp.), is confined to Ceylon; Typhloscincus (1 sp.), to Ternate.

FAMILY 49.-GECKOTID瓜. (50 Genera, 200 Species.)

\begin{tabular}{|c|c|c|c|c|c|}
\hline \multicolumn{6}{|c|}{ General Distribution. } \\
\hline $\begin{array}{l}\text { NFotropical } \\
\text { St:B-REGIONS. }\end{array}$ & $\begin{array}{c}\text { NEARCTIC } \\
\text { SUB-REGIONS. }\end{array}$ & $\begin{array}{l}\text { Palazarctic } \\
\text { Sub-IiEgions. }\end{array}$ & $\begin{array}{c}\text { ETHIOPIAN } \\
\text { SUB-REGIONS. }\end{array}$ & $\begin{array}{c}\text { ORIENTAL } \\
\text { SUB-reEgIONS. }\end{array}$ & $\begin{array}{l}\text { AUSTRAlian } \\
\text { Sub-REGIONS. }\end{array}$ \\
\hline $1.2 \cdot 3 \cdot 4$ & $1.2 \cdot 3-$ & $1 \cdot 2 \cdot 3 \cdot 4$ & $1.2 \cdot 3 \cdot 4$ & $1 \cdot 2 \cdot 3 \cdot 4$ & 1.2 .3 .4 \\
\hline
\end{tabular}

The Geckoes, or Tall-Lizards, form an extensive family, of almost universal distribution in the warmer parts of the globe; and they must have some exceptional means of dispersal, since they are found in many of the most remote islands of the great oceans,-as the Galapagos, the Sandwich 1slands, Tahiti, New Zealand, the Loo-Choo and the Seychelle Islands, the Nicobar Islands, Mauritius, Ascension, Madeira, and many others. The following are the larger and more important genera :--

Oëdura (3 sp.), Australia; Diplodactylus (8 sp)., Australia, Sonth Africa, and California; Phyllodactylus (8 sp.), widely scattered in Tropical America, California, Madagascar, and Queensland; Hemidactylus (40) sp.), all tropical and warm countries; Peropus (12 sp.), the Oriental region, Papuan Islands, Mauritius, and Brazil ; Pentadactylus (7 sp.), Oriental region and Australia; Gerlin (12 sp.), Oriental region to New Guinea and 
North Australia; Gchyra (5 sp.), Australia, New Guinea and Fiji Islands; Tarentola (7 sp.), North Africa, North America, Madeira, Borneo, South Africa; Phelsuma (6 sp.), Madagasear, Bourbon, and Andaman Islands; Pachydactylus (5 sp.), South and West Africa, and Ascension Island; Sphocroductylus (5 sp.), the Neotropical region; Naultinus, (6 sp.), New Zealand; Goniodactylus (5 sp.), Australia, Timor, South America and Algiers; Heteronota (4 sp.), Australia, Fiji Islands, New Guinea and Borneo; Cubina (4 sp.), the Neotropical region; Gymnodactylus (16 sp.), all warm countries except Australia; Phyllurus (3 sp.), Australia; Stenodactylus (4 sp.), North and West Africa, and Rio Grande in North America.

The remaining genera mostly consist of single species, and are pretty equally distributed over the various parts of the world indicated in the preceding list. Madagascar, the Seychelle Islands, Chili, the Sandwich Islands, South Africa, Tahiti, the Philippine Islands, New Caledonia, and Australia-all have peculiar genera, while two new ones have recently been described from Persia.

Fanily 50.-IGUANIDE. (56 Genera, 236 Species.)

\begin{tabular}{|c|c|c|c|c|c|}
\hline \multicolumn{6}{|c|}{ Gexeral Distíliution. } \\
\hline $\begin{array}{l}\text { NeOTROPICAL } \\
\text { SUB-REGIONS. }\end{array}$ & $\begin{array}{c}\text { NEARGTIC } \\
\text { SuB-REgIONS. }\end{array}$ & $\begin{array}{l}\text { PaI.FARCTIC } \\
\text { SUB-KEGIONS. }\end{array}$ & $\begin{array}{c}\text { ETHIOPIIN } \\
\text { SUB-REGIONS. }\end{array}$ & $\begin{array}{c}\text { ORIFNTAL } \\
\text { SUB-KEGIONS. }\end{array}$ & $\begin{array}{l}\text { AUSTRALIAN } \\
\text { SUB-REGIONS. }\end{array}$ \\
\hline $1.2 \cdot 3 \cdot 4$ & $1.2 .3-$ & --- & $--\cdots$ & $-\ldots-$ & $--8-$ \\
\hline
\end{tabular}

The extensive family of the Iguanas is highly characteristic of the Neotropical region, in every part of which the species abound, even as far as nearly $50^{\circ}$ South Latitude in Patagonia. They also extend northwards into the warmer parts of the Nearctic region, as far as California, British Columbia, and Kansas on the west, and to $43^{\circ}$ North Latitude in the Eastern States. A distinct genus occurs in the Fiji Islands, and one has been described as from Australia, and another from Madagascar, but there is some doubt about these. The most extensive genera are :-

Anolius (84 sp.), found in most parts of Tropical America and 
north to California; Tropidolepis (15 sp.), which has nearly the same range; Leiocephalus (1t sp.), Antilles, Guayaquil, and Galapagos Islands; Leiolcemus (14 sp.), Peru to Patagonia; Sceloporus (9 sp.), from Brazil to California and British Columbia, and on the east to Florida ; Proctotretus (6 sp.), Chili and Patagonia; Phrynosoma (8 sp), New Mexico, California, Oregon and British Columbia, Arkansas and Florida; Iguana (5 sp.), Antilles and South America; Cyclusa (4 sp.), Antilles, Honduras, and Mexico.

Among the host of smaller genera may be noted:-

Brachylophus, found in the Fiji Islands; Trachycephalus and Oreocephalus, peculiar to the Galapagos; Oreodeira, said to be from Australia; Diplolcemus and Phymaturus, found only in Chili and Patagonia; and Callisaurus, Uta, Euphryne, Uma, and Holbrookia, from New Mexico and California. All the other genera are from various parts of Tropical America.

FAMily 51.-AGAMID \&. (42 Genera, 156 Species.)

\begin{tabular}{|c|c|c|c|c|c|}
\hline \multicolumn{6}{|c|}{ General Distribution. } \\
\hline $\begin{array}{l}\text { NEOTROPICAL } \\
\text { SUB-REGIONS. }\end{array}$ & $\begin{array}{c}\text { NEARCTIC } \\
\text { SUB-REGIONS. }\end{array}$ & $\begin{array}{l}\text { PALEARCTIC } \\
\text { SUB-REGIONS. }\end{array}$ & $\begin{array}{c}\text { ETHIOPIAN } \\
\text { SUB-REGIQNS. }\end{array}$ & $\begin{array}{c}\text { ORIENTAL } \\
\text { SUB-EEGIONS. }\end{array}$ & $\begin{array}{l}\text { AUSTRaLian } \\
\text { SUb-REgIONS. }\end{array}$ \\
\hline--- & --- & -2.3 .4 & 1.2 .3 .4 & 1.2 .3 .4 & 1.2 .3 \\
\hline
\end{tabular}

The extensive family Agamidæ-the Eastern representative of the Iguanas-is highly characteristic of the Oriental region, which possesses about half the known genera and species. Of the remainder, the greater part inhabit the Australian region; others range over the deserts of Central and Western Asia and Northeru Africa, as far as Greece and South Russia. One genus extends through Africa to the Cape of Good Hope, and there are three peculiar genera in Madagascar, but the family is very poorly represented in the Ethiopian region. Many of these creatures are adorned with beautifully varied and vivid colours, and the little "dragons" or flying-lizards are among the most interesting forms in the entire order. The larger genera are distributed as follows :-

VOL. II.

D D 
Draco (18 sp.), the Oriental region, excluding Ceylon; Otocryptis (4 sp.), Ceylon, North India, Malaya; Ceratophora (3 sp.), Ceylon; Gonyocephalus (8 sp.), Papuan Islands, Java, Borneo, Pelew Islands; Dilophyrus (7 sp.), Indo-Malaya and Siam; Japalura (6 sp.), Himalayas, Borneo, Formosa, and Loo Choo Islands; Sitana (2 sp.), Central and South India and Ceylon; Bronchocela (3 sp.), Indo-Malaya, Cambodja, and Celebes; Calotes (12 sp.), Continental India to China, Philippine Islands; Oriocalotes (2 sp.), Himalayas; Acanthosaura (5 sp.), Malacca and Siam; Tiaris (3 sp.), Andaman Islands, Borneo, Philippine and Papuan Islands; Physignathus (3 sp.), Cochin-China and Australia; Uromastix (5 sp.), South Russia, North Africa, Central India; Stellio (5 sp.), Caucasus and Greece to Arabia, High Himalayas and Central India; Trapelus (5 sp.), Tartary, Egypt, and Afghanistan; Phrynocephalus (10 sp.), Tartary and Mongolia, Persia and Afghanistan; Lophura (2 sp.), Amboyna and Pelew Islands; Grammatophorus (14 sp.), Australia and Tasmania; Agama (14 sp.), North Africa to the Punjaub, South Africa. The remaining genera each consist of a single species. Eight are peculiar to Australia, one to the Fiji Islands, one to the Aru Islands, three to Ceylon, five to other parts of the Oriental region, one to Persia, and one to South Russia.

FAMiLy 52.-CHAM ELEONID Æ. (1 Genus, 30 Species.)

\begin{tabular}{|c|c|c|c|c|c|}
\hline \multicolumn{6}{|c|}{ GEneral Distribution. } \\
\hline $\begin{array}{l}\text { NEOTROPICAL } \\
\text { SUB-REGIONS. }\end{array}$ & $\begin{array}{c}\text { NEARCTIC } \\
\text { SUB-REGIONS. }\end{array}$ & $\begin{array}{l}\text { Palearctic } \\
\text { Sub-hEGIONS. }\end{array}$ & $\begin{array}{c}\text { ETHIOPIAN } \\
\text { SUB-REGIONS. }\end{array}$ & $\begin{array}{l}\text { OIRIENTAL } \\
\text { SUB-EEGIONS. }\end{array}$ & $\begin{array}{l}\text { AUSTRALIAN } \\
\text { SUb-REGions. }\end{array}$ \\
\hline---- & ---- & $-2-\cdots$ & 1.2 .3 .4 & $1.2--$ & --- \\
\hline
\end{tabular}

The Chamæleons are an almost exclusively Ethiopian group, only-one species, the common Chamæleon, inhabiting North Africa and Western Asia as far as Central India and Ceylon. They abound all over Africa, and peculiar species are found in Madagascar and Bourbon, as well as in the Island of Fernando Po. 
General Remarks on the Distribution of the Lacertilia.

The distribution of the Lacertilia is, in many particulars, strikingly opposed to that of the Ophidia. The Oriental, instead of being the richest is one of the poorest regions, both in the number of families and in the number of peculiar genera it contains; while in both these respects the Neotropical is by far the richest. The distribution of the families is as follows :-

The Nearctic region has 7 families, none of which are peculiar to it; but it has 3 peculiar genera-Chirotes, Ophisaurus, and Phrynosoma.

The Palæarctic region has 12 families, with two (Ophiomoridæ and Trogonophidæ, each consisting of a single species) peculiar; while it has 6 peculiar or very characteristic genera, Trogonophis in North Africa, Psammodromus in South Europe, Hyalosaurus in North Africa, Scincus in North Africa and Arabia, Ophiomorus in East Europe and North Africa, and Phrynocephalus in Siberia, Tartary, and Afghanistan. We have here a striking amount of diversity between the Nearctic and Palearctic regions with hardly a single point of resemblance.

The Ethiopian region has 13 families, only one of which (the Chamæsauridæ, consisting of a single species) is altogether peculiar; but it possesses 21 peculiar or characteristic genera, 9 belonging to the Zonuridæ, 2 to the Sepidæ, 7 to the Geckotidæ, and 3 to the Agamidæ.

The Oriental region has only 8 families, none of which are peculiar; but there are 28 peculiar genera, 6 belonging to the Scincidæ, 1 to the Acontiadæ, 5 to the Geckotidæ, and 16 to the Agamidæ. Many lizards being sand and desert-haunters, it is not surprising that a number of forms are common to the borderlands of the Oriental and Ethiopian regions; yet the Sepidæ, so abundant in all Africa, do not range to the peninsula of India ; and the equally Ethiopian Zonuridæ have only one Oriental species, found, not in the peninsula but in the Khasya Hills. The Acontiadæ alone offer some analogy to the distribution of the Lemurs, being found in Africa, Madagascar, Ceylon, and the Moluccas.

The Australian region has 11 families, 3 of which are pecu- 
liar; and it has about 40 peculiar genera in ten families, about half of these genera belonging to the Scincidie. Only 3 families of almost universal distribution are common to the Australian and Neotropical regions, with one species of the American Iguanidæ in the Fiji Islands, so that, as far as this order is concerned, these two regions have little resemblance.

The Neotropical region has 15 families, 6 of which are peculiar to it, and it possesses more than 50 peculiar genera. These are distributed among 12 families, but more than half belong to the Iguanidæ, and half the remainder to the Teidæ, - the two families especially characteristic of the Neotropical region. All the Nearctic families which are not of almost universal distribution are peculiarly Neotropical, showing that the Lacertilia of the former region have probably been derived almost exclusively from the latter.

On the whole the distribution of the Lacertilia shows a remarkable amount of specialization in each of the great tropical regions, whence we may infer that Southern Asia, Tropical Africa, Australia, and South America, each obtained their original stock of this order at very remote periods, and that there has since been little intercommunication between them. The peculiar affinities indicated by such cases as the Lepidosternidæ, found only in the tropics of Africa and South America, and Tachydromus in Eastern Asia and West Africa, may be the results either of once widely distributed fanilies surviving only in isolated localities where the conditions are favourable,-or of some partial and temporary geographical connection, allowing of a limited degree of intermixture of faunas. The former appears to be the more probable and generally efficient earse, but the latter may have operated in exceptional cases.

\section{Fossil Lacertilia.}

These date back to the Triassic period, and they are found in most succeeding formations, but it is not till the Tertiary period that forms allied to existing genera occur. These are at present too rare and too ill-defined to throw much light on the geographical distribution of the order. 


\section{Order III.-RHYNCOCEPHALINA.}

FAMLly 53.-RHYNCOCEPHALID $2 . \quad$ (1 Genus, 1 Species.)

\begin{tabular}{|c|c|c|c|c|c|}
\hline \multicolumn{6}{|c|}{ General Distribution. } \\
\hline $\begin{array}{l}\text { NEOTROPICAL } \\
\text { SUB-REGIONS. }\end{array}$ & $\begin{array}{c}\text { NEARCTIC } \\
\text { SUB-REGIONS. }\end{array}$ & $\begin{array}{l}\text { PaLfaARCTIC } \\
\text { SUB-REOIONS. }\end{array}$ & $\begin{array}{c}\text { ETHIOPIAN } \\
\text { SUB-REGIONS. }\end{array}$ & $\begin{array}{l}\text { ORIENTAL } \\
\text { SUB-REGIONS. }\end{array}$ & $\begin{array}{l}\text { Aostralian } \\
\text { Sub-REGions. }\end{array}$ \\
\hline--- & ---- & $---\cdots$ & $---\cdots$ & $---\cdots$ & ---4 \\
\hline
\end{tabular}

The singular and isolated genus Hatteria - the "Tuatara" or fringed lizard - which alone constitutes this family, has peculiarities of structure which separate it from both lizards and crocodiles, and mark it out as an ancestral type, as distinct from other living reptiles as the Marsupials are from other Mammalia. It is confined to New Zealand, and is chiefly found on small islands near the north-east coast, being very rare, if not extinct, on the main land. A fossil reptile named Hyperodapedon, of Triassic age, has been found in Scotland and India, and is supposed by Professor Huxley to be more nearly allied to Hatteria than to any other living animal.

\section{Order IV.-CROCODILIA.}

Family 54.-GAVIALID $\mathbb{E}$. (2 Genera, 3 Species.)

\begin{tabular}{|c|c|c|c|c|c|}
\hline \multicolumn{6}{|c|}{ General Distribution. } \\
\hline $\begin{array}{l}\text { NEOTROPICAL } \\
\text { STB-REGIONS. }\end{array}$ & $\begin{array}{c}\text { NEARCTIC } \\
\text { SuB-REGIONS. }\end{array}$ & $\begin{array}{l}\text { PALAaARCTII } \\
\text { SUB-REGIONS. }\end{array}$ & $\begin{array}{c}\text { ETHIOPIAN } \\
\text { SUB-REGIONS. }\end{array}$ & $\begin{array}{l}\text { ORIENTAL } \\
\text { SUB-REGIONS. }\end{array}$ & $\begin{array}{l}\text { AUSTRALIAN } \\
\text { SUB-REGIONS. }\end{array}$ \\
\hline---- & ---- & ---- & ---- & $1--4$ & $1--\rightarrow$ \\
\hline
\end{tabular}

The Gavials are long-snouted Crocodiles with large front teeth, and canines fitting in notches of the upper jaw. They consist of two genera, Gavialis ( 1 sp.), inhabiting the Ganges ; Tomistoma (2 sp.), found in the rivers of Borneo and North Australia. 
Family 55.-CROCODILIDE. (1 Genus, 12 Species.)

\begin{tabular}{|c|c|c|c|c|c|}
\hline \multicolumn{6}{|c|}{ General Distribution. } \\
\hline $\begin{array}{l}\text { NEOTROPICAL } \\
\text { SUB-REGIONS. }\end{array}$ & $\begin{array}{c}\text { NEARCTIC } \\
\text { SUB-REGIONS. }\end{array}$ & $\begin{array}{l}\text { Paliearctic } \\
\text { Sub-REGIONS. }\end{array}$ & $\begin{array}{c}\text { ETHIOPIAN } \\
\text { SUB-REGIONS. }\end{array}$ & $\begin{array}{c}\text { ORIENTAL } \\
\text { SUB-REgIONS. }\end{array}$ & $\begin{array}{l}\text { AUSTRALIAN } \\
\text { SUB-REGIONS. }\end{array}$ \\
\hline-2.3 .4 & $--\cdots$ & ---- & 1.2 .3 .4 & 1.2 .3 .4 & $1---$ \\
\hline
\end{tabular}

The true Crocodiles, which have the canines in notches, and the large front teeth in pits in the upper jaw, are widely distributed over the tropical regions of the globe, inhabiting all the rivers of Africa, the shores and estuaries of India, Siam, and eastward to North Australia. Other forms inhabit Cuba, Yucatan, and Guatemala, to Ecuador and the Orinooko. Four species are Asiatic, one exclusively Australian, three African, and four American. These have been placed in distinct groups, but Dr. Günther considers them all to form one genus, Crocodilus.

Family 56.-ALLIGATORID A. (1 Genus, 10 Species.)

\begin{tabular}{|c|c|c|c|c|c|}
\hline \multicolumn{6}{|c|}{ General Distribution. } \\
\hline $\begin{array}{l}\text { NEOTROPICAL } \\
\text { StB-REGIOAS. }\end{array}$ & $\begin{array}{l}\text { NEARGTIO } \\
\text { SUB-REGIONS. }\end{array}$ & $\begin{array}{l}\text { PALAEARCTIC } \\
\text { SUB-REGIONS. }\end{array}$ & $\begin{array}{c}\text { ETHIOPIAN } \\
\text { SUB-REGIONS. }\end{array}$ & $\begin{array}{l}\text { ORIENTAL } \\
\text { SUR-REGIONS. }\end{array}$ & $\begin{array}{l}\text { AUSTPALIIAN } \\
\text { SUB-REGIONS. }\end{array}$ \\
\hline $2.3--$ & $--3-$ & ---- & ---- & ---- & --- \\
\hline
\end{tabular}

The Alligators, which are distinguished by having both the large front teeth and the canines fitting into pits of the upper jaw, are confined to the Neotropical, and the southern part of the Nearctic regions, from the lower Mississippi and Texas through all Tropical America, but they appear to be absent from the Antilles. They are all placed by Dr. Günther in the single genus, Alligator.

\section{General Remartis on the Distribution of Crocodilia.}

These animals, being few in number and wholly confined to the tropical and sub-tropical regions, are of comparatively 
little interest as regards geographical distribution. America possesses both Crocodiles and Alligators; India, Crocodiles and Gavials; while Africa has Crocodiles only. Both Crocodiles and Gavials are found in the northern part of the Australian region, so that neither of the three families are restricted to a single region.

\section{Fossil Crocodilia.}

The existing families of the order date back to the Eocene period in Europe, and the Cretaceous in North America. In the south of England, Alligators, Gavials and Crocodiles, all occur in Eocene beds, indicating that the present distribution of these families is the result of partial extinction, and a gradual restriction of their range-a most instructive fact, suggesting the true explanation of a large number of cases of discontinuous distribution which are sometimes held to prove the former union of lands now divided by the deepest oceans. In more ancient formations, a number of Crocodilian remains have been discovered which cannot be classed in any existing families, and which, therefore, throw no light on the existing distribution of the group.

\section{Order V.-CHELONIA.}

\section{FAnILY 57.-TESTUDINID $\mathbb{E} . \quad$ (14 Genera, 126 Species.)}

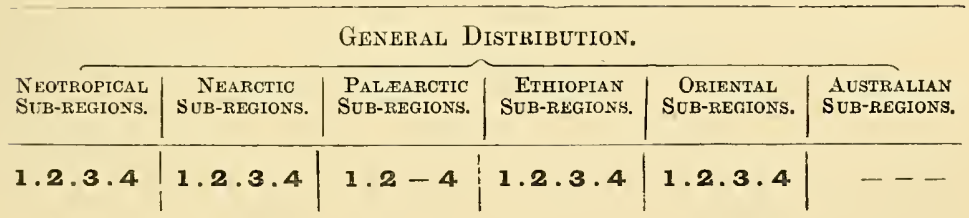

The Testudinidæ, including the land and many fresh-water tortoises, are very widely distributed over the Old and New worlds, but are entirely absent from Australia. They are especially abundant in the Nearctic region, as far north as Canada and British Columbia, and almost equally so in the 
Neotropical and Oriental regions; in the Ethiopian there is a considerable diminution in the number of species, and in the Palæarctic they are still less numerous, being confined to the warmer parts of it, except one species which extends as far north as Hungary and Prussia. The genera are:-

Testudo (25 sp.), most abundant in the Ethiopian region, but also extending over the Oriental region, into South Europe, and the Eastern States of North America; Emys (64 sp.), abundant in North America and over the whole Oriental region, less so in the Neotropical and the Palæarctic regions; Cinosternon (13 sp.), United States and California, and Tropical America; Aromochelys (4 sp.), confined to the Eastern States of North America; Staurotypus (2 sp.), Guatemala and Mexico; Chelydra (1 sp.), Canada to Louisiana; Claudius (1 sp.), Mexico; Dermatemys (3 sp.), South America, Guatemala, and Yncatan; Terrapene (4 sp.), Maine to Mexico, Sumatra to New Guinea, Shanghae and Formosa-a doubtfully natural group; Cinyxis (3 sp.), Pyxis (1 sp.), Chersina (4 sp.), are all Ethiopian ; Dumerilia (1 sp.), is from Madagascar only.

Family 58.-CHELYDID $\approx . \quad(10$ Genera, 44 Species.)

\begin{tabular}{|c|c|c|c|c|c|}
\hline \multicolumn{6}{|c|}{ General Distribution. } \\
\hline $\begin{array}{l}\text { NEOTROPICAL } \\
\text { SUB-REGIONS. }\end{array}$ & $\begin{array}{c}\text { NEARCTIC } \\
\text { SUB-REGIONS. }\end{array}$ & $\begin{array}{l}\text { PalaARCTIC } \\
\text { SUB-REGIONS. }\end{array}$ & $\begin{array}{c}\text { ETHIOPIAN } \\
\text { SUB-REGIONS. }\end{array}$ & $\begin{array}{l}\text { ORIENTAL } \\
\text { SUB-REGIONS. }\end{array}$ & $\begin{array}{l}\text { AUSTRALIAN } \\
\text { SUB-REGIONS. }\end{array}$ \\
\hline$-2--$ & $-\cdots$ & $-\cdots$ & 1.2 .3 .4 & $--\cdots$ & $-2--$ \\
\hline
\end{tabular}

The Chelydidx, or fresh-water tortoises with imperfectly retractile heads, have a remarkable distribution in the three great southern continents of Africa, Australia, and South America; the largest number of species being found in the latter country. The genera are:-

Peltocephalus (1 sp.), Podocnemis (6 sp.), Hydromedusa (4 sp.), Chelys (1 sp.), and Platemys (16 sp.), inhabiting South America from the Orinooko to the La Plata, the latter genus occurring also in Australia and New Guinea; Chelodina (5 sp.), Chelemys (1 sp.), and Elseya (2 sp.) from Australia; while Sternotheres 
(6 sp.), and Pelomedusa (3 sp.), inhabit Tropical and South Africa and Madagascar.

Family 59.-TRIONYCHID E. (3 Genera, 25 Species.)

\begin{tabular}{|c|c|c|c|c|c|}
\hline \multicolumn{6}{|c|}{ General Distribution. } \\
\hline $\begin{array}{l}\text { NeOTROPICAL } \\
\text { StB-REOIONS. }\end{array}$ & $\begin{array}{c}\text { NEARCTIC } \\
\text { SUB-REGIONS. }\end{array}$ & $\begin{array}{l}\text { PALEARCTIC } \\
\text { SUL-REG IONS. }\end{array}$ & $\begin{array}{l}\text { ETHIOPIAN } \\
\text { SUB-REGIONS. }\end{array}$ & $\begin{array}{l}\text { ORIENTAL } \\
\text { SUB-REGIONS. }\end{array}$ & $\begin{array}{l}\text { AUstralian } \\
\text { SUB-REgIONg. }\end{array}$ \\
\hline---- & $--3-$ & ---4 & $1.2 .3-$ & $1.2 \cdot 3 \cdot 4$ & ---- \\
\hline
\end{tabular}

The distribution of the Trionychidæ, or Soft Tortoises, is very different from that of the Chelydidæ, yet is equally interesting. They abound most in the Oriental region, extending beyond it to Northern China and Japan. In the Nearctic region they are only found in the Eastern States, corresponding curiously to the distribution of plants, in which the affinity of Japan to the Eastern States is greater than to California. The Trionychidæ are also found over the Ethiopian region, but not in Madagascar.

The genera are,-Trionyx (17 sp.), which extends over the whole area of the family as above indicated; Cycloderma (5 sp.), peculiar to Africa; Emyda (3 sp.), the peninsula of India, Ceylon, and Africa.

\section{FaMILY 60.-CHELONIID Æ. (2 Genera, 5 Species.)}

General Distribetion.-All the warm and tropical Seas.

The Marine Turtles are alnost universally distributed. Dermatochelys ( $1 \mathrm{sp}$. ), is found in the temperate seas of both the Northern and Southern Hemispheres; Chelone ( 4 sp.), ranges over all the tropical seas-C. viridis, the epicureans' species, inhabiting the Atlantic, while $C$. imbricata which produces the "tortoiseshell" of commerce is found in the Indian and Pacific oceans. 


\section{Remarks on the Distribution of the Chelonia.}

The four families into which the Chelonia are classed have all of them a wide distribution, though none are universal. The Ethiopian region seems to be the richest, as it possesses 3 of the four families, while no other region has more than 2 ; and it also possesses 7 peculiar genera. Next comes the Neotropical region with 2 families and 6 peculiar genera; the Australian with 3, and the Nearctic with 2 peculiar genera; while the Oriental and Palæarctic regions possess none that are peculiar. There are about 30 genera and 200 species in the whole order.

Fossil Chelonia.-The earliest undoubted remains of this order occur in the Upper Oolite. These belong to the Cheloniidæ and Emydidæ, which are also found in the Chalk. In the 'Tertiary beds Chelonia are more abundant, and the Trionychidæ now appear. The Testudinidæe are first met with in the Miocene formation of Europe and the Eocene of North America, the most remarkable being the gigantic Colossochelys Atlas of the Siwalik Hills. It appears, therefore, that the families of the order Chelonia were already specialised in the Secondary period, a fact which, together with their more or less aquatic habits, sufficiently accounts for their generally wide distribution. Species of Testudo, Emys, and Trionyx, are found in the Upper Miocene of the south of France. 


\section{AMPHIBIA.}

Order I.-PSEUDOPHIDIA.

Family 1.-CACILIAD $Æ . \quad$ (4 Genera, 10 Species.)

\begin{tabular}{|c|c|c|c|c|c|}
\hline \multicolumn{6}{|c|}{ Geneinl Distribution. } \\
\hline $\begin{array}{l}\text { NEOTROPICAL } \\
\text { SUB-REGIONS. }\end{array}$ & $\begin{array}{c}\text { NEARGTIC } \\
\text { SUE-REOIONS. }\end{array}$ & $\begin{array}{l}\text { PALFARCTIC } \\
\text { SUE } \cdots \text { REGTONS. }\end{array}$ & $\begin{array}{l}\text { ETHIOPIAN } \\
\text { SUB-REOIOAS. }\end{array}$ & \begin{tabular}{c|} 
ORIENTAL \\
SUB-REGIONS.
\end{tabular} & $\begin{array}{l}\text { Australian } \\
\text { Sub-REgiuns. }\end{array}$ \\
\hline$-2 \cdot 3-$ & ---- & $---\cdots$ & $-2--$ & $1 \cdot 2 \cdot 3-$ & ---- \\
\hline
\end{tabular}

The Cæciliadæ are a curious group of worm-like Amphibia sparingly scattered over the three great tropical regions. The genera are,-Cacilia, which inhabits West Africa, Malabar and South America; Siphonopsis, peculiar to Brazil and Mexico; Ichthyopsis, from Ceylon and the Khasya Mountains; and Rhincttrema from Cayenne.

Order II.-URODELA.

FAMILY 2.-SIRENID Æ. (1 Genus, 3 Species.)

\begin{tabular}{|c|c|c|c|c|c|}
\hline \multicolumn{6}{|c|}{ General Distribution. } \\
\hline $\begin{array}{l}\text { NEOTROPICAL } \\
\text { SUB-REGTONS. }\end{array}$ & $\begin{array}{c}\text { NEARCTIC } \\
\text { SUB-REGIONS. }\end{array}$ & $\begin{array}{l}\text { Pal-Earctic } \\
\text { SUB-REGIONS. }\end{array}$ & $\begin{array}{c}\text { Ethiopian } \\
\text { Sub-REGIONS. }\end{array}$ & $\begin{array}{c}\text { ORIENTAL } \\
\text { SUB-REGIONS. }\end{array}$ & $\begin{array}{l}\text { Australian } \\
\text { Sub-RFGION3. }\end{array}$ \\
\hline---- & $--3-$ & --- & $-\cdots-$ & ---- & $-\ldots-$ \\
\hline
\end{tabular}

The genus Siren, consisting of eel-like Batrachians with two anterior feet and permanent branchiæ, inhabits the SouthEastern States of North America from Texas to Carolina. 
Family 3.-PROTEIDA. (2 Genera, 4 Species.)

\begin{tabular}{|c|c|c|c|c|c|}
\hline \multicolumn{6}{|c|}{ General Distribution. } \\
\hline $\begin{array}{l}\text { NEOTROPICAL } \\
\text { SUB-REGIONS. }\end{array}$ & $\begin{array}{c}\text { Nearctic } \\
\text { Sub-regions. }\end{array}$ & $\begin{array}{l}\text { PaLAEARCTIC } \\
\text { Sub-REGIONS. }\end{array}$ & $\begin{array}{l}\text { EThHOPIAN } \\
\text { SUB-REOIONS. }\end{array}$ & $\begin{array}{l}\text { ORIENTAL } \\
\text { SUB-KEGIONS. }\end{array}$ & $\begin{array}{l}\text { AUSTralian } \\
\text { SUB-REgIONS. }\end{array}$ \\
\hline--- & $--3-$ & $1---$ & ---- & ---- & ---- \\
\hline
\end{tabular}

The Proteidæ have four feet and persistent external branchiæ. The two genera are,-Proteus (1 sp.), found only in caverns of Central Europe; and Menobranchus, which are like newts in form, and inhabit the Eastern States of North America.

Family 4.-AMPHIUMide. (1 Genus, 2 Species.)

\begin{tabular}{|c|c|c|c|c|c|}
\hline \multicolumn{6}{|c|}{ General Distribution. } \\
\hline $\begin{array}{l}\text { NEOTROPICAL } \\
\text { SUU-REGIONS. }\end{array}$ & $\begin{array}{c}\text { NEARCTIC } \\
\text { SUB-REGIONS. }\end{array}$ & $\begin{array}{l}\text { Palafarctic } \\
\text { Sub-REgions. }\end{array}$ & $\begin{array}{c}\text { ETHIOPIAN } \\
\text { SEB-REGIONS. }\end{array}$ & $\begin{array}{c}\text { ORIENTaL } \\
\text { SUR-fiEgIONS. }\end{array}$ & $\begin{array}{l}\text { AUSTralian } \\
\text { SUb-REGIONS. }\end{array}$ \\
\hline--- & $--3-$ & $--\cdots$ & ---- & ---- & ---- \\
\hline
\end{tabular}

The genus Amphiuma, or Murcenopsis, consists of slender eellike creatures with four rudimentary feet, and no external branchiæ. The species inhabit the Southern United States from New Orleans to Carolina.

\section{Family 5.-MENOPOMID $\approx . \quad$ (2 Genera, 4 Species )}

\begin{tabular}{|c|c|c|c|c|c|}
\hline \multicolumn{6}{|c|}{ General Distribution. } \\
\hline $\begin{array}{l}\text { NEOTropical } \\
\text { Sub-REGIONS. }\end{array}$ & $\begin{array}{c}\text { NEARCTIC } \\
\text { SUB-REGIONS. }\end{array}$ & $\begin{array}{l}\text { PALAEARCTIC } \\
\text { SUB-REGIONS. }\end{array}$ & $\begin{array}{c}\text { ETHIOPIAN } \\
\text { SUB-REGIONS. }\end{array}$ & $\begin{array}{c}\text { ORIENTAL } \\
\text { SUB-REGIONS. }\end{array}$ & $\begin{array}{l}\text { AUSTRALIAN } \\
\text { SUB-REGIONS. }\end{array}$ \\
\hline---- & $--3-$ & ---4 & ---- & ---- & ---- \\
\hline
\end{tabular}

There are large Salamanders of repulsive appearance, found only in Eastern Asia and the Eastern United States. The genera are,-Sieboldia (2 sp.), Japan and north-west China; Menopoma $=$ Protonopsis (2 sp.), Ohio and Alleghany rivers. 
Family 6.-SALAMANDRIDA. (20 Genera, 85 Species.)

\begin{tabular}{|c|c|c|c|c|c|}
\hline \multicolumn{6}{|c|}{ General Distribution. } \\
\hline $\begin{array}{l}\text { Neotrofical } \\
\text { SUb-REgIONS. }\end{array}$ & $\begin{array}{c}\text { NEARGTIC } \\
\text { SuB-REgIONS. }\end{array}$ & $\begin{array}{l}\text { Paldaarctic } \\
\text { Sub-kegions. }\end{array}$ & $\begin{array}{c}\text { EthIOPIAN } \\
\text { ScB-REgIONS. }\end{array}$ & $\begin{array}{c}\text { ORIENTAL } \\
\text { SUB-FEGIONS. }\end{array}$ & $\begin{array}{l}\text { AUSTralian } \\
\text { SUB-REgIONS. }\end{array}$ \\
\hline$-2 \cdot 3-$ & 1.2 .3 .4 & 1.2 .3 .4 & ---- & $--3-$ & ---- \\
\hline
\end{tabular}

The Salamandridæ, of which our common Newts are characteristic examples, form an extensive family highly characteristic of the North Temperate regions, a few species only extending into the Neotropical region along the Andes to near Bogota, and one into the Oriental region in Western China. The genera, as arranged by Dr. Strauch, are as follows :-

Salamandra (2 sp.), Central and South Europe and North Africa; Pleurodeles (1 sp.), Spain, Portugal, and Morocco; Bradybates (1 sp.), Spain; Triton (16 sp.), all Europe except the extreme north, Algeria, North China and Japan, Eastern States of North America, California and Oregon; Chioglossa (2 sp.) Portugal and South Europe ; Salamandrina (1 sp.), Italy to Dalmatia; Ellipsoglossa (2 sp.), Japan; Isodactylium (2 sp.), East Siberia; Onychodactylus (1 sp.), Japan; Amblystoma (21 sp.), Nearctic region from Canada and Oregon to Mexico,most abundant in Eastern States ; Ranodon (1 sp.), Tartary and North-east China ; Dicamptodon (1 sp.), California; Plethodon (5 sp.), Massachusetts to Louisiana, and Vancouver's Island to California; Desmognathus (4 sp.), Eastern United States south of latitude $43^{\circ}$; Anaides (1 sp.), Oregon and Northern California; Hemidactylium (2 sp.), South-eastern United States and Southern California; Heredia (1 sp.), Oregon and California ; Spelerpes (18 sp.), Eastern United States from Massachusetts to Mexico, Guatemala, Costa Rica and Andes of Bogota, with a species in South Europe; Batrachoseps (2 sp.), South-eastern United States and California; T'ylotriton (1 sp.), Yunan in West China. 
Order III.-ANURA.

Famili 7.-Rhinophrynid A. (1 Genus, 1 Species.)

\begin{tabular}{|c|c|c|c|c|c|}
\hline & & General I & STRIBUTION. & & . \\
\hline $\begin{array}{l}\text { NEOTROPICAL } \\
\text { ST:B-REGIONS. }\end{array}$ & $\begin{array}{c}\text { NEARCTIC } \\
\text { SUB-REGIONS. }\end{array}$ & $\begin{array}{l}\text { PALEARCTIC } \\
\text { Sub-REGIONS. }\end{array}$ & $\begin{array}{c}\text { ETHIOPIAN } \\
\text { SUB-REGIONS. }\end{array}$ & $\begin{array}{l}\text { ORIENTAL } \\
\text { SUB-REGIONS. }\end{array}$ & $\begin{array}{l}\text { Australian } \\
\text { Sub-REgions. }\end{array}$ \\
\hline$--3-$ & ---- & $--\cdots-$ & ---- & --- & $-\cdots$ \\
\hline
\end{tabular}

The Rhinophrynidæe are Toads with imperfect ears and a tongue which is free in front. The single species of Rhinophrymes, is a native of Mexico.

FAMily 8.-PHRYNISCID Æ. (5 Genera, 13 Species.)

\begin{tabular}{|c|c|c|c|c|c|}
\hline \multicolumn{6}{|c|}{ General Distribution. } \\
\hline $\begin{array}{l}\text { NEOTROPICAL } \\
\text { SUB-REGIONS. }\end{array}$ & $\begin{array}{c}\text { N EARCTIC } \\
\text { St'B-REGIONS. }\end{array}$ & $\begin{array}{l}\text { Palafarctic } \\
\text { SUB-REGIONS. }\end{array}$ & $\begin{array}{l}\text { Ethiopian } \\
\text { SUb-REgIONS. }\end{array}$ & $\begin{array}{c}\text { ORIENTAL } \\
\text { SUB-REGIONS. }\end{array}$ & $\begin{array}{l}\text { AUSTRALIAN } \\
\text { Sub-REGIONS. }\end{array}$ \\
\hline $1.2 .3-$ & ---- & ---- & $1.2-$ & ---4 & $-3--$ \\
\hline
\end{tabular}

The Phryniscidæ, or Toads with imperfect ears and tongue fixed in front, are widely distributed over the warmer regions of the earth, but are most abundant in the Neotropical region and Australia, while only single species occur in the Old World. The genera are :-

Phryniscus (7 sp.), from Costa Rica to Chili and Monte Video; Brachycephalus (1 sp.), Brazil ; Pseudophryne (3 sp.), Australia and Tasmania ; Hcmisus (1 sp.), Tropical Africa ; Micrhyla (1 sp.), Java.

Family 9.-HYL APLESID F. (1 Genus, 5 Species.)

\begin{tabular}{|c|c|c|c|c|c|}
\hline \multicolumn{6}{|c|}{ General Distribution. } \\
\hline $\begin{array}{l}\text { NEOTROPICAL } \\
\text { Stz-REGIONS. }\end{array}$ & $\begin{array}{c}\text { NEARCTIC } \\
\text { SUB-REGIONS. }\end{array}$ & $\begin{array}{l}\text { PaLearctic } \\
\text { Sub-REgIONS. }\end{array}$ & $\begin{array}{l}\text { ETHIOPIAN } \\
\text { SUB-RE'GIONS. }\end{array}$ & $\begin{array}{l}\text { ORIENTAL } \\
\text { SUR-REGIONS. }\end{array}$ & $\begin{array}{l}\text { AUSTRALIAN } \\
\text { SUB-REGIONS. }\end{array}$ \\
\hline $1.2-4$ & ---- & $\cdots--\cdots$ & ---- & ---- & ---- \\
\hline
\end{tabular}


The Hylaplesidæ are Toads with perfect ears, and they seem to be confined to the Neotropical region. The only genus, Hylaplesia (5 sp.), inhabits Brazil, Chili, and the Island of Hayti.

\section{Family 10.--BUEONID $\approx . \quad$ (6 Genera, 64 Species.)}

\begin{tabular}{|c|c|c|c|c|c|}
\hline & & GENERAL D & STIIBUTION. & & \\
\hline $\begin{array}{l}\text { NEOTROPICAL } \\
\text { SUB-REGIONS. }\end{array}$ & $\begin{array}{c}\text { NeARCTIC } \\
\text { Sub-REgIONS. }\end{array}$ & $\begin{array}{l}\text { Palakarctic } \\
\text { Sub-hEGIONS. }\end{array}$ & $\begin{array}{l}\text { ETHIOPIAN } \\
\text { ScL-REgIONS. }\end{array}$ & $\begin{array}{l}\text { ORIENTAL } \\
\text { SUB-FEGIONS. }\end{array}$ & $\begin{array}{l}\text { AUSTRALIAN } \\
\text { SUB-REgIONS. }\end{array}$ \\
\hline 1.2 .3 .4 & 1.2 .3 .4 & 1.2 .3 .4 & $1.2 .3-$ & 1.2 .3 .4 & $1.2 \ldots$ \\
\hline
\end{tabular}

The rather extensive family of the Bufonidæ, which includes our common Toad, and is characterised by prominent neck glands and tongue fixed in front, is almost universally distributed, but is very rare in the Australian region; one species being found in Celebes and one in Australia. The genera are:-

Kalophrynus (2 sp.), Borneo ; Bufo (58 sp.), has the range of the entire family, except Australia; Otilophus (1 sp.), South America; Peltaphryne (1 sp.), Porto Rico; Pseudobufo (1 sp.), Malay Peninsula; Schismaderma (1 sp.), Natal; Notaden (1 sp.), East Central Australia.

Family 11.-XENORHINID Æ. (1 Genus, 1 Species.)

\begin{tabular}{|c|c|c|c|c|c|}
\hline \multicolumn{6}{|c|}{ GENERAL DistRIBUTION. } \\
\hline $\begin{array}{l}\text { NEOTROPICAL } \\
\text { SUB-REGIONS. }\end{array}$ & $\begin{array}{l}\wedge \text { EARGTIG } \\
\text { SUB-REGIONS. }\end{array}$ & $\begin{array}{l}\text { PALAaARctic } \\
\text { SUD--REgToNs. }\end{array}$ & $\begin{array}{l}\text { ETHIOPIAN } \\
\text { SUB-REGIONS. }\end{array}$ & $\begin{array}{c}\text { ORIENTAL } \\
\text { SUB-REGIONS. }\end{array}$ & $\begin{array}{l}\text { AUSTRALIAN } \\
\text { SUE-REGIONS }\end{array}$ \\
\hline---- & ---- & ---- & $--\cdots$ & ---- & $1--\cdots$ \\
\hline
\end{tabular}

The Xenorhinidæ may be characterised as Toads with perfect ears and tongue free in front. The only species of Xenorhina is a native of New Guinea. 
Fanily 12.-ENGYSTOMID AE. (15 Genera, 31 Species.)

\begin{tabular}{|c|c|c|c|c|c|}
\hline \multicolumn{6}{|c|}{ General Distribution. } \\
\hline $\begin{array}{l}\text { NFOTROPICAL } \\
\text { St:B-REGIOAS. }\end{array}$ & $\begin{array}{l}\text { NEARCTIC } \\
\text { SUB-REGIONS. }\end{array}$ & $\begin{array}{l}\text { PaLfeARCTIC } \\
\text { SUB-REGIONS. }\end{array}$ & $\begin{array}{c}\text { ETHIOPIAN } \\
\text { SUB-REGIONS. }\end{array}$ & $\begin{array}{l}\text { ORIENTAL } \\
\text { SUB-REGIONS. }\end{array}$ & $\begin{array}{l}\text { AUSTRalian } \\
\text { SUB-REGIONS. }\end{array}$ \\
\hline $1.2 .3-$ & $--3-$ & $-\cdots$ & $-2 \cdot 3-$ & 1.2 .3 .4 & $-2--$ \\
\hline
\end{tabular}

The Engystomidse are Toads without neek-glands and with the tongue tied in front. They are most abundant in the Oriental and Neotropical regions, especially in the latter, which contains about half the known species, with isolated species in Australia, Africa, and the Southern States of North America. They appear to be the remnant of a once extensive and universally distributed group, which has maintained itself in two remote regions, but is dying out everywhere else. The genera are :-

Engystoma (9 sp.), Carolina to La Plata, with one species in South China; Diplopelma (3 sp.), South India to China and Java; Cacopus (2 sp.), Central India ; Glyphoglossus (1 sp.), Pegu ; Callula (4 sp.), Sikhim, Ceylon, China, and Borneo; Brachymerus 1 sp.), South Africa; Adenomera (1 sp.), Brazil ; Pachybatrachus (1 sp.), Australia; Breviceps (2 sp.), South and West Africa; Chelydobatrachus (1 sp.), West Australia; Hypopachus (1 sp.), Costa Rica; Rhinoderma (1 sp.), Chili ; Atelopus (1 sp.), Cayenne and Peru; Copea (1 sp.), South America; Paludicola (1 sp.), New Granada.

\section{FAMILY 13.-BOMBINATORID Æ. (8 Genera, 9 Species.)}

\begin{tabular}{|c|c|c|c|c|c|}
\hline \multicolumn{6}{|c|}{ General Distribution. } \\
\hline $\begin{array}{l}\text { NEOTROPICAL } \\
\text { SUD-REGIONS. }\end{array}$ & $\begin{array}{l}\text { NEARCTIC } \\
\text { SUB-REGIONS. }\end{array}$ & $\begin{array}{l}\text { PALEARCTIC } \\
\text { SUB-HEGIONS. }\end{array}$ & $\begin{array}{l}\text { ETHIOPIAN } \\
\text { SC'B-REGIONS. }\end{array}$ & $\begin{array}{l}\text { ORIENTAL } \\
\text { SUB-REGIONS. }\end{array}$ & $\begin{array}{l}\text { AUSTRALIAN } \\
\text { SUG-REGIONS. }\end{array}$ \\
\hline $1 \cdot 2-\cdots$ & ---- & $1.2--$ & ---- & ---- & ---4 \\
\hline
\end{tabular}

The Bombinatoridæ are a family of Frogs which have imperfect ears and no neck-glands, and they have a very peculiar and 
interesting distribution, being confined to Central and South Europe, the southern part of South America, and New Zealand. They consist of many isolated groups forming five separate subfamilies. The genera are :-

Bombinator, Central Europe and Italy; Pelobates and Didocus, Central Europe and Spain; Telmatobius (2 sp.), Peru and Brazil; Alsodes, Chonos Archipelago; Cacotus, Chili; Liopelma, New Zealand; Nannophryne, Straits of Magellan.

\section{FAmily 14.-PLECTROMANTID $A$. (1 Genus, 1 Species.)}

\begin{tabular}{|c|c|c|c|c|c|}
\hline \multicolumn{6}{|c|}{ General Distribution. } \\
\hline $\begin{array}{l}\text { NEOTROPICAL } \\
\text { SUB-REGIONS. }\end{array}$ & $\begin{array}{c}\text { NEARCTIC } \\
\text { SUB-REGIONS. }\end{array}$ & $\begin{array}{l}\text { PALAARCTIC } \\
\text { SUB-REGIONS. }\end{array}$ & $\begin{array}{c}\text { ETHIOPIAN } \\
\text { SUB-REGIONS. }\end{array}$ & $\begin{array}{l}\text { ORIENTAL } \\
\text { SUB-REGIONS. }\end{array}$ & $\begin{array}{l}\text { AOSTRALIAN } \\
\text { SUB-REGIONS. }\end{array}$ \\
\hline $1-\cdots$ & --- & $-\cdots--$ & --- & ---- & ---- \\
\hline
\end{tabular}

The Plectromantidæ, which are Frogs with neck-glands, and the toes but not the fingers dilated, consists of a single species of the genus Plectromantis. It inhabits the region west of the Andes, and south of the Equator.

Family 15.-ALYTID A. (5 Genera, 37 Species.)

\begin{tabular}{|c|c|c|c|c|c|}
\hline & & General D & TRIBUTION. & & \\
\hline $\begin{array}{l}\text { NEOTROPICAL } \\
\text { SUB-RBGIONS. }\end{array}$ & $\begin{array}{c}\text { NEARCTIC } \\
\text { SuB-REGIONS. }\end{array}$ & $\begin{array}{l}\text { PaLAaAkTiC } \\
\text { SUB-kEGIONS. }\end{array}$ & $\begin{array}{c}\text { ETHIOPIAN } \\
\text { SUB-REGIONS. }\end{array}$ & $\begin{array}{l}\text { ORIENTAL } \\
\text { SUB-REGIONS. }\end{array}$ & $\begin{array}{l}\text { AUSTRALIAN } \\
\text { SUB-REGIONS. }\end{array}$ \\
\hline$-2--$ & $1.2 .3-$ & $1---$ & $1.2 .3-$ & ---- & $1.2--$ \\
\hline
\end{tabular}

The Alytidæ are Frogs with neck-glands and undilated toes. They are most abundant in the Ethiopian region, with a few species in the Nearetic and Australian regions, and one in Europe and Brazil respectively. The genera are :-

Alytes (1 sp.), Central Europe; Scaphiopus (5 sp.), California to Mexico and the Eastern States; Hyperolius (29 sp.), all Africa, and two in New Guinea and North Australia; Hclioporus (1 sp.), in Anstralia; Nattereria (1 sp.), Brazil.

voL. II. 
Finily 16.-PlELOdiYADA. (3 Genera, 7 Species.)

\begin{tabular}{|c|c|c|c|c|c|}
\hline \multirow[b]{2}{*}{$\begin{array}{l}\text { NEOTROPICAL } \\
\text { SUB-REGIOAS. }\end{array}$} & \multicolumn{4}{|c|}{ Gexeral Distribetion. } & \multirow{2}{*}{$\begin{array}{l}\text { AUStralian } \\
\text { Sub-REgions. }\end{array}$} \\
\hline & $\begin{array}{c}\text { NEARCTIC } \\
\text { SUB-REGIOLS. }\end{array}$ & $\begin{array}{l}\text { PALFARCTIC } \\
\text { SUB-REGIONS. }\end{array}$ & $\begin{array}{c}\text { ErHIOPIAN } \\
\text { SUB-REGIONS. }\end{array}$ & $\begin{array}{l}\text { ORIENTAL } \\
\text { SUB-REGIONS. }\end{array}$ & \\
\hline $1.2--$ & $-\ldots-\cdots$ & --- & ---- & $-\cdots$ & $1.2-\cdots$ \\
\hline
\end{tabular}

The Pelodryade are Tree Frogs with neck-glands, and are confined to the Australian and Neotropical regions. The genera are :-

Phyllomedusa (3 sp.), South America to Paraguay; Chirodryas, Australia; and Pelodryas (3 sp.), Moluccas, New Guinea and Australia.

$$
\text { FuMILY 17.-HYLID F. (11 Genera, } 94 \text { Species.) }
$$

\begin{tabular}{|c|c|c|c|c|c|}
\hline \multicolumn{6}{|c|}{ General Distribution. } \\
\hline $\begin{array}{l}\text { NEOTROPICAL } \\
\text { SUB-REGIONS. }\end{array}$ & $\begin{array}{c}N_{\text {EARCTIC }} \\
\text { SUB-REGIONS. }\end{array}$ & $\begin{array}{l}\text { Palfarctic } \\
\text { Sub-REGIONS. }\end{array}$ & $\begin{array}{l}\text { ETHIOPIIN } \\
\text { SUD-REGIONS. }\end{array}$ & $\begin{array}{l}\text { ORIENTAL } \\
\text { SUB-REGIONS. }\end{array}$ & $\begin{array}{l}\text { AUStralian } \\
\text { Sub-RFGion;. }\end{array}$ \\
\hline 1.2 .3 .4 & 1.2 .3 .4 & $1.2 .3-$ & $-\cdots-$ & $--3-$ & 1.2 \\
\hline
\end{tabular}

The Hylide are glandless Tree Frogs with a broadened sacrum. They are most abundant in the Neotropical region, which contains more than two-thirds of the species; about twenty species are Australian; six or seven are Nearetic, reaching northward to Great Bear Lake; while one only is European, and one Oriental. The genera are:-

Hyla (62 sp.), having the range of the whole family; Hylella (1 sp.), Ololygon (1 sp.), Pohlia (2 sp.), Triprion (1 sp.), Opisthodelphys (1 sp.), and Nototrema (4 sp.), are South American; while Trachyeephalus ( $8 \mathrm{sp}$.), is peculiar to the Antilles, except one South American species; Pseudacris (1 sp.), ranges from Georgia, United States, to Great Pear Lake; Litoria (7 sp.), is Australian and Papuan, except one species in Paraguay ; Ceratohyla (4 sp.), is only known from Eenador. 
FAMILY 18.-POLTPEDATIDA. (24 Genera, 124 species.)

\begin{tabular}{|c|c|c|c|c|c|}
\hline \multicolumn{6}{|c|}{ Gexeral Distribution. } \\
\hline $\begin{array}{l}\text { NFothopical } \\
\text { Srib-pegrons. }\end{array}$ & $\begin{array}{c}\text { Nearatic } \\
\text { SUB-REGioNs. }\end{array}$ & $\begin{array}{l}\text { Pal.EARCTIC } \\
\text { SUb-REGIONY. }\end{array}$ & $\begin{array}{c}\text { ETHIOPIAN } \\
\text { SUB-REGIONS. }\end{array}$ & $\begin{array}{l}\text { OREENAL } \\
\text { SUB-REGIONS. }\end{array}$ & $\begin{array}{l}\text { Arstralian } \\
\text { SUi-REgion3. }\end{array}$ \\
\hline 1.2 .3 .4 & $--3-$ & --3.4 & 1.2 .3 .4 & $1.2 .3 \cdot 4$ & 1.2 \\
\hline
\end{tabular}

The Polypedatidæ, or glandless Tree Frogs with narrowed sacrum, are almost equally numerous in the Oriental and Neotropical regions, more than forty species inhabiting each, while in the Ethiopian there are about half this number, and the remainder are scattered over the other three regions, as shown in the enumeration of the genera:-

Ixalus (16 sp.), Oriental, except one in Japan, and one in Western Polynesin; Rhacophorus (7 sp.), and Theloderma (1 sp.), are Oriental; Hylarana (10 sp.), Oriental, to the Solomon Islands and Tartary, Nicobar Islands, West Africa, and Madagascar; Megalixalus (1 sp.), Seychelle Islands ; Leptomantis (1 sp.), Philippines; Platymantis (5 sp.), New Guinen, Philippines, and Fiji Islands; Cornufer (2 sp), Java and New Guinea ; Polypedates (19 sp.), mostly Oriental, but two species in West Africa, one Madagascar, two Japan, one Loo-Choo Islands, and one Hong Kong; Hylambates (3 sp.), Hemimantis (1 sp.), and Chiromantis (1 sp.), are Ethiopian; Rappia (13 sp.), is Ethiopian, and extends to Madagascar and the Seychelle Islands; Acris (2 sp.), is North American; Elosia (1 sp.), Epirhixis (1 sp.), Phyllobates (9 sp.), Hylodes (26 sp.), Hyloxalus (1 sp.), Pristimantis (1 sp.), Crossodactylus (1 sp.), Calostethus (1 sp.), Strabomantis (1 sp.), and Leiyla (1 sp.), are Neotropical, the last two being Central American, while species of Hylodes and Phyllobates are found in the West Indian Islands. 
Fasily 19.-RANID $\mathbb{E}$. (26 Genera, 150 Species.)

\begin{tabular}{|c|c|c|c|c|c|}
\hline \multirow[b]{2}{*}{$\begin{array}{l}\text { Nrotropical } \\
\text { StiB-REGIONS. }\end{array}$} & \multicolumn{4}{|c|}{ General Disthibution. } & \multirow[b]{2}{*}{$\begin{array}{l}\text { AUSTRALIAN } \\
\text { SUB-REgIONG. }\end{array}$} \\
\hline & $\begin{array}{c}\text { NeARCTIC } \\
\text { Sub-REGIONS. }\end{array}$ & $\begin{array}{l}\text { Palfarctic } \\
\text { Sub-ILEg IONS. }\end{array}$ & $\begin{array}{l}\text { ETHIOPIAN } \\
\text { SUB-REGIONS. }\end{array}$ & $\begin{array}{c}\text { ORIENTAL } \\
\text { SUB-REGIONS. }\end{array}$ & \\
\hline 1.2 .3 .4 & 1.2 .3 .4 & 1.2 .3 .4 & 1.2 .3 .4 & 1.2 .3 .4 & $1.2--$ \\
\hline
\end{tabular}

The Ranidæ, or true Frogs, are characterised by having simple undilated toes, but neither neck-glands nor dilated sacrum. They are almost cosmopolitan, extending to the extreme north and south from the North Cape to Patagonia, and they are equally at home in the tropics. They are perhaps most abundant in South America, where a large number of the genera and species are found; the Ethiopian region comes next, while they are rather less abundant in the Oriental and Australian regions; the Nearctic region has much less (about 12 species), while the Palæarctic has only five, and these two northern regions only possess the single genus Rana. The genera are distributed as follows :-

Rana (60 sp.), ranges all over the world, except Australia and South America, although it extends into New Guinea and into Mexico and Central America; it is most abundant in Africa. Pyxicephalus (7 sp.), extends over the whole Ethiopian region, Hindustan, the Himalayas, and Japan; Cystignathus (22 sp.), is mainly Neotropical, but has three species Ethiopian. All the other genera are confined to single regions. The Neotropical genera are:-Odontophrynus (1 sp.), Pseudis (1 sp.), Pithecopsis (1 sp.), Ensophleus (1 sp.), Limnocharis (1 sp.), Hemiphractus (1 sp.), all Tropical South American east of Andes; Ceratophrys (5 sp.), Panama to La Plata ; Cycloramphus (1 sp.), West Ecuador and Chili ; Pleurodema (6 sp.), Venezuela to Patagonia; Leiuperus (12 sp.), Mexico and St. Domingo to Patagonia; Hylorhina (1 sp.), Chiloe. The Australian genera are :-Myxophyes (1 sp.), Queensland ; Platyplectrum (2 sp.), Queensland and West Australia; Neobatrachus (1 sp.), South Australia; Limnodynastes 7 sp.), and Crinia (11 sp.), Australia and Tasmania. The 
Oriental genera are:-Dicroglossus (1 sp.), Western Himalayas ; Oxyglossus (2 sp.), Siam to Java, Philippines and China; Hoplobatrachus (1 sp.), Ceylon; Phrynoglossus (1 sp.), Siam. The Ethiopian genera are:-Phrynobatrachus (1 sp.), Stenorhynchus (1 sp.), both from Natal.

\section{Family 20.-DISCOGLOSSID $Æ, \quad(14$ Genera, 18 Species.)}

\begin{tabular}{|c|c|c|c|c|c|}
\hline \multicolumn{6}{|c|}{ General Distribution. } \\
\hline $\begin{array}{l}\text { NFOTROPICAL } \\
\text { StB-REGIONS. }\end{array}$ & $\begin{array}{c}\text { NEARCTIC } \\
\text { SuB-REGIONS. }\end{array}$ & $\begin{array}{l}\text { Palearcic } \\
\text { Sub-liEoIons. }\end{array}$ & $\begin{array}{l}\text { ETHIOPIAN } \\
\text { SUB-REGIONS. }\end{array}$ & $\begin{array}{l}\text { ORIENTAL } \\
\text { SUB-REGIONS. }\end{array}$ & $\begin{array}{l}\text { AUSTRALIAN } \\
\text { SUB-REGIONS. }\end{array}$ \\
\hline $1.2--$ & ---- & 1.2 .3 .4 & $-2.3-$ & $-2 \cdot 3 \cdot 4$ & $1.2--$ \\
\hline
\end{tabular}

The Discoglossidæ, or Frogs with a dilated sacrum, are remarkable for the number of generic forms scattered over a large part of the globe, being only absent from the Nearctic and the northern half of the Neotropical regions, and also from Hindostan and East Africa. The genera are:-

Chiroleptes (4 sp.), Australia; Calyplocephalus (1 sp.), allied to the preceding, from Chili; Cryptotis (1 sp.), Australia; Asterophys (2 sp.), New Guinea and Aru Islands; Xenophrys (1 sp.), Eastern Himalayas; Megalophrys (2 sp.), Ceylon and the Malay Islands; Nannophrys (1 sp.), Ceylon; Pelodytes (1 sp.), France only; Leptobrachium (1 sp.), Java ; Discoglossus (1 sp.), Vienna to Algiers; Laprissa (1 sp.), Latonia (1 sp.), Palæarctic region ; Arthroleptis (2 sp.), West Africa and the Cape; Grypiscus (1 sp.), South Brazil.

FAMily 21.-PIPID $Æ . \quad(1$ Genus, 1 Species.)

\begin{tabular}{|c|c|c|c|c|c|}
\hline \multicolumn{6}{|c|}{ General Distribution. } \\
\hline $\begin{array}{l}\text { NEOTROPICAL } \\
\text { SI'B-REGIONS. }\end{array}$ & $\begin{array}{c}\text { NEARCTIC } \\
\text { SUB-REOIONS. }\end{array}$ & $\begin{array}{l}\text { Palearctic } \\
\text { Sub-REgIONS. }\end{array}$ & $\begin{array}{c}\text { Ethiopian } \\
\text { Sub-REgIONS. }\end{array}$ & $\begin{array}{l}\text { ORIENTAL } \\
\text { SUB-REGIONS. }\end{array}$ & $\begin{array}{l}\text { AUSTRALIAN } \\
\text { SUB-REGIONS. }\end{array}$ \\
\hline$-2--$ & --- & $---\cdots$ & $--\cdots$ & $---\cdots$ & ---- \\
\hline
\end{tabular}


The P'ipidæ are toads without a tongue or maxillary teeth, and with enormonsly dilated sacrum. The only species of Pipa is a native of Guiana.

\section{Fanily 22.-DACTYLETHRiDA. (1 Genus, 2 Species.)}

\begin{tabular}{|c|c|c|c|c|c|}
\hline \multicolumn{6}{|c|}{ General Distribution. } \\
\hline $\begin{array}{l}\text { Neutropical } \\
\text { Sub-REGHoNs. }\end{array}$ & $\begin{array}{c}\text { NEARCTIC } \\
\text { SUB-REGIONS. }\end{array}$ & $\begin{array}{l}\text { PALAEARCTIC } \\
\text { SUB-hEGIOIS. }\end{array}$ & $\begin{array}{c}\text { ETHIOPIAN } \\
\text { SUB-REGIONS. }\end{array}$ & $\begin{array}{c}\text { ORIENTAL } \\
\text { SUB-REGIONS. }\end{array}$ & $\begin{array}{l}\text { AUSTralian } \\
\text { SUB-REGIONS. }\end{array}$ \\
\hline--- & ---- & --- & $1.2 .3-$ & --- & $-\cdots$ \\
\hline
\end{tabular}

The Dactylethridæ are Toads witl maxillary teeth but no tongue, and with enormously dilated sacrum. The species of Dactylcthrce are natives of West, East, and Soutl Africa.

General Remarks on the Distribution of the Amphitia.

The Amphibia, as here enumerated, consist of 22 families, 152 genera, and nearly 700 species. Many of the families have a very limited range, only two (Ranidæ and Polypedatidæ) being nearly universal ; five more extend each into five regions, while. no less than thirteen of the families are confined to one, two, or three regions each. By far the richest region is the Neotropical, possessing 16 families (four of them peculiar) and about 50 peculiar or very characteristic genera. Next comes the Australian, with 11 families (one of which is peculiar) and 16 peculiar genera. The Nearetic region has no less than 9 of the families (two of them peculiar to it) and 15 peculiar genera, 13 of which are tailed Batrachians which have here their metropolis. The other three regions lave 9 families each; the Palrarctic has no peculiar family but no less than 15 peculiar genera; the Ethiopian 1 family and 12 genera peculiar to it; and the Oriental, 19 genera but no family confined to it.

It is evident, therefore, that each of the regions is well characterised by its peculiar forms of Amphibia, there being only a few genera, such as Hyla, Rana, and Bufo which have a wide range. The connection of the Australian and Neotropical 
regions is well shown in this group, by the Phryniscidæ, Hylidæ, and Discoglossidæ, which present allied forms in both; as well as by the genus Liopelma of New Zealand, allied to the Bombinatoridie of South America, and the absence of the otherwise cosmopolitan genus Rana from both continents. The affinity of the Nearctic and Palæarctic regions is shown by the Proteida, which are confined to them, as well as by the genus Triton and almost the whole of the extensive family of the Salamandridæ. The other regions are also well differentiated, and there is no sign of a special Ethiopian Amphibian fauna extending over the peninsula of India, or of the Oriental and Palæarctic regions merging into each other, except by means of genera of universal distribution.

Fossil Amphibic.-The extinct Iabyrinthodontia form a separate order, which existed from the Carboniferous to the Triassic period. No other remains of this class are found till we reach the Tertiary formation, when Newts and Salamanders as well as Frogs and Toads occur, nost frequently in the Miocene deposits. The most remarkable is the Andrias scheuchzeri from the Miocene of (Eningen, which is allied to Sicboldia maxima the great salamander of Japan. 


\section{CHAPTER XX.}

THE DISTRIBUTION OF THE FAMILIES OF FISHES, WITH THE RANGE OF SUCH GENERA AS INHABIT FRESH WATER.

\section{Sub-class I.-TELEOSTEI.}

\section{Order I.-ACANTHOPTERYGII.}

Family 1.-GASTEROSTEID $\approx$. (1 Genus, 11 Species.)

"Fresh-water or marine scaleless fishes, with elongate compressed bodies and with isolated spines before the dorsal fin."

Distribution.-Palæaretic and Nearctic regions.

The species of Gasterosteus, commonly called Sticklebacks, are found in rivers, lakes, estuaries, and seas, as far south as Italy and Ohio. Four species occur in Britain.

FAMILY 2.-BERYCID $\mathbb{E}$. (10 Genera, 55 Species.)

"Marine fishes, with elevated compressed bodies covered with toothed scales, and large eyes."

Distribution.-CTropical and temperate seas of both hemispheres.

Their northern limit is the Mediterranean and Japan. Most abundant in the Malayan seas. 


\section{Fayily 3.-PERCIDA. (61 Genera, 476 Species.)}

"Marine or fresh-water carnivorous fishes, with oblong bodies covered with toothed scales."

Distribution.-DSeas, rivers and lakes, of all regions.

The genera which inhabit fresh-waters are the following:-

Perca (3 sp.), inhabits the Nearetic and Palæarctic regions as far south as Ohio and Switzerland; one species, the common perch, is British. Percichthys (5 sp.), Chili and Patagonia, with one species in Java; Paralabrax (2 sp.), California; Labrax (8 sp.), six species are marine, inhabiting the shores of Europe and North America, one being British, two species inhabit the rivers of the northern United States; Lates (2 sp.), Nile and large rivers of India and China ; Acerina (3 sp.), Europe, from England to Russia and Siberia ; Percarina (1 sp.), River Dniester ; Lucioperca (6 sp.), North America and Europe; Pileoma (2 sp.), North America, Texas to Lake Erie; Boleosoma (3 sp.), Texas to Lake Superior ; Aspro (2 sp.), Central Europe ; Huro (1 sp.), Lake Huron; Percilia, (1 sp.), Rio de Maypu in Chili; Centrarchus (10 sp.), North America and Cuba; Bryttus (8 sp.), South Carolina to Texas; Pomotis (8 sp.), North America, Lake Erie to Texas.

Of the exclusively marine genera a species of Polyprion and one of Serranus are British. The latter genus has nearly 150 species spread over the globe, but is most abundant in the Tropics. Mesoprion is another extensive genus confined to the Tropics. Apogon abounds from the Red Sea to the Pacific, but has one species in the Mediterranean and one in the coast of Brazil.

\section{Family 4.-APHREDODERID A. (1 Genus, 1 Species.)}

"Fresh-water fish, with oblong body covered with toothed scales, and wide cleft mouth."

Distribution.-Atlantic States of North America. 
Family 5.-PRISTIPOMATIDA. (25 Genera, 206 Species.)

"Marine carnirorous fishes, with compressed oblong bodies, and without molar or cutting teeth."

Distribution.-Seas of temperate and tropical regions, a few only entering fresh water.

Of the more extensive genera, nine, comprising more than half the species, are confined to the Indian and Australian seas, while only one large genus (Hocmulon) is found in the Atlantic on the coast of Tropical America. The extensive Pacific genus, Diagramma, has one species in the Mediterranean. One genus is confined to the Macquarie River in Australia. A species of Dentex has occurred on the English coast, and this seems to be the extreme northern range of the family, which does not regulirly extend beyond the coast of Portugal, and in the East to Japan. Australia seems to form the southern limit.

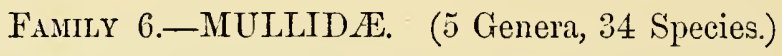

"Marine fishes, with elongate slightly compressed bodies covered with large scales, and two dorsal fins at a distance from each other."

Distribution.--All tropical seas, except the West Const of Anerica, extending into temperate regions as far as the Baltie, Japan, and New Zealand.

Two species of Mullus (Mullets) are British, and these are the only European tish belonging to the fimily.

FANILY 7.-SPARIDA. (22 Genera, 117 Species.)

"Herbivorous or carnivorous marine fishes, with oblong compressed bodies covered with minutely serrated scales, and with one clorsal fin."

Distribution.-Seas of temperate and tropical regions, a few entering rivers. 
Cantharus, Pagellus, and Chrysophrys, have occurred on the English Coast. Haplodactylus is confined to the West Coast of South America, and Australia; Sargus to the temperate and warm parts of the Atlantic and the shores of East Africa; Pagellus to the western coasts of Europe and Africa.

The other large genera have a wider distribution.

\section{FaMily 8.-SQUAMIPENNES. (12 Genera, 124 Species.)}

"Carnivorous marine fishes, with compressed and elevated bodies, and scaly vertical fins."

Distributron.-The seas between the tropics, most abundant in the Oriental and Australian regions, a few entering rivers or extending beyond the tropics.

The extensive genus Chatodon (67 sp.), ranges from the Red Sea to the Sandwich Islands, and from Japan to Western Australia, while two species are found in the West Indies. Holacanthus (36 sp.), has a similar distribution, one species only occurring in the West Indies and on the coast of Sonth America. Only one genus (Pomacanthus), with a single species, is confined to the West Atlantic.

\section{Fanily 9.-CIPRHITID E. (8 Genera, 34 Species.)}

"Carnivorous marine fishes, with a compressed oblong body, covered with cycloid scales."

Distributron.-The tropical and south temperate waters of the Indian and Pacific oceans, from Eastern Africa to Western America. Absent from the Atlantic.

Family 10.-TRIGLIDE. (50 Genera, 259 Species.)

"Carnivorous, mostly marine fishes, with oblong compressed or subcylindrical bodies, and wide cleft mouths. They live at. the bottom of the water."

Distriburion.-All seas, some entering fresh water, and a few inhabiting exclusively the fresh waters of the Arctic regions. 
They are divided by Dr. Günther into four groups. The Heterolepidina (comprising 4 genera and 12 species) are confined to the North Pacific. The Scorpænina (23 genera 113 species) have an almost universal distribution, but the genera are each restricted to one or other of the great oceans. Sebastes has occurred on the English coast. The Cottina (28 genera 110 species) have also a universal distribution; the numerous species of Cottus are found either in the seas or fresh waters of Europe and North America; four species are British, as well as seven species of the wide-spread genus Trigla. Ptyonotus (1 sp.) is confined to Lake Ontario. The Cataphracti (5 genera, 23 species) have also a wide range; one genus, Ayonus, is found in the British seas, and also in Kamschatka and on the coast of Chili. Peristethus is also British.

FAMIly 11.-TRACHINID A.. (24 Genera, 90 Species.)

"Carnivorous marine fishes, with elongate bodies, living at the bottom, near the shore."

Distribution.-Almost or quite universal.

Trachinus is a British genus. A species of Aphritis inhabits the fresh waters of Tasmania, while its two allies are found on the coasts of Patagonia.

FAmily 12. SCI 2 ENID $\# . \quad$ (13 Genera, 102 Species.)

"Marine or fresh-water fishes, with compressed and rather elongate bodies, covered with toothed scales."

Distribution.-Temperate and tropical regions, but absent from Australia.

Larimus is found in the Atlantic, and in African and American rivers. Corvina, Scicena, and Otilothus are also marine and freshwater, both in the Atlantic and Pacific. The other genera are of small extent and more restricted range. Umbrina and Scicena have occurred in British seas. 


\section{Family 13.-POLYNEMID $2 . \quad$ (3 Genera, 23 Species.)}

"Marine or fresh-water fishes, with compressed oblong bodies and entire or ciliated scales."

Distribution.-Tropical seas and rivers of both the great oceans, but most abundant in the Pacific.

\section{Family 14.-SPHYRENIDÆ. (1 Genus, 15 Species.)}

"Carnivorous marine fishes, with elongate sub-eylindrical bodies covered with small_cycloid scales."

Distribution.-The warm and tropical seas of the globe.

Fanily 15.-TRICHIURID E. (7 Genera, 18 Species.)

"Marine fishes, with elongate compressed bodies covered with minute scales or naked."

Distribution.-All the tropical and sub-tropical seas.

FAMILY 16.-SCOMBRID $\mathbb{E}$. (20 Genera, 108 Species.)

"Marine fishes, with elongate compressed bodies, scaled or naked."

Distribution.-All the temperate and tropical oceans. Mostly inhabiting the open seas.

Scomber, (the Mackerel) Thynnus, Naucrates, Zeus, Centrolophus, Brama, and Lampris, are genera which have occurred in the British seas.

Fanily 17.-CARANGID五. (27 Genera, 171 Species.)

"Marine fishes, with compressed oblong or elevated bodies covered with small scales or naked."

Distribution,-All temperate and tropical seas; some species occur in both the great oceans, ranging from New York to Australia.

Trachurus and Capros are genera which occur in British seas. 


\section{Fanily 18.-XIPHIID A. (2 Genera, 8 Species.)}

"Marine fishes, with elongate compressed body and a produced sword-shaped upper jaw."

Distribution.-Mediterranean, and open seas between or near the Tropics.

Xiphias (the Sword-fish) has occurred on the English coast.

\section{Fanily 19.-GOBIIDE. (24 Genera, 294 Species.)}

"Carnivorous fishes, with elongate low, naked, or scaly bodies, living at the bottom of the shallow seas or fresh waters of temperate or tropical regions. Individuals of the same species often differ in inhabiting exclusively fresh or salt water.

Distribution.-All temperate and tropical regions, from Scotland and Japan to New Zealand. Species of Gobius, Latrunculus, and Callionymus occur in Britain. Several genera are confined to the East Indian seas and rivers, but none seem peculiar to America. The genus Pcriopthalmus consists of the curious, large-headed, projecting-eyed fishes, so abundant on the muddy shores of African and Eastern tidal rivers, and which seem to spend most of their time out of water, hunting after insects, \&c.

\section{Fanily 20.-DISCOBOLT. (2 Genera, 11 Species.)}

"Carnivorous fishes, with oblong naked or tubercular bodies, living at the bottom of shallow seas, and attaching themselves to rocks by means of a ventral disc.

Distribution.-All northern seas, as far south as Belgium, England, and San Francisco.

Species of both genera (Cycloptcrus and Liparis) occur in British seas. 
Fanily 21.-OXUI)ERCIDE. (1 Genus, 1 Species.)

"A marine fish, with an elongate sub-cylindrical body and no ventral fins."

Distribution.-Macao, China.

Famil 22.-BATRACHID E. (3 Genera, 12 species.)

"Marine fishes, with sub-cylindrical body and broad depressed liead."

Distribution.--The coasts of nearly all tropical and south temperate regions, ranging from New York and Portugal to Chili and Tasmania.

Fanily 23.-PEDICULATI. (8 Genera, 40 Species.)

"Marine carnivorous fishes, with very large heads and without scales."

Distribution.-Seas of all temperate and tropical regions, extending south to New Zealand and north to Greenland.

A species of Lophius (the Fishing-frog or Sea-Devil) is found in British seas. The genus Antcnnarius, comprising two-thirds of the species, is wholly tropical.

\section{FAMII. 24.-BLENNIDAE. (33 Genera, 201 Species.)}

"Carnivorous fishes, with long sub-cylindrical naked bodies, living at the bottom of shallow water in seas, or tidal rivers."

Distribution.-All seas from the Arctic regions to New Zealand, Clili, and the Cape of Good Hope.

Species of Anarrlichas, Blennius, Blenniops, Centronotus and Zoarces occur in British seas. Chasmodes (3 sp.) is confined to the Atlantic coasts of Temperate North America; Petroscirtes (26 sp.) to the tropical parts of the Indian and Pacific Oceans; and Sticherus (9 sp.) to the Aretic Seas. 


\section{Family 25.-ACANTHOCLINIDE. (1 Genus, 1 Species.)}

"A carnivorous marine fish, with long flat body and very long dorsal fin."

Distribution._-Coasts of New Zealand.

Fayily 26.-COMEPHORID A. (1 Genus, 1 Species.)

"An elongate, naked, large-headed fish, with two dorsal fins."

Distribution.-Lake Baikal.

Dr. Günther remarks, that this fish approaches the Scombrina (Mackerel) in several characters. These are exclusively marine fishes, while Lake Baikal is fresh-water, and is situated among mountains, at an elevation of nearly 2000 feet, and more than a thousand miles from the ocean!

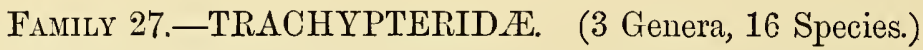

"Deep sea fishes, with elongate, much compressed, naked bodies."

Distribution.-Europe, East Indies, West Coast of South America, New Zealand. Dr. Giinther remarks, that little is known of these fishes, from their being so seldom thrown on shore, and then rapidly decomposing. The Ribbon-fish (Regalecus banksii) has occurred frequently on our shores. They have soft bones and muscles, small mouths, and weak dentition.

\section{FaniLy 28.-LOPHOTID $\mathbb{E}$. (1 Genus, 1 Species.)}

"A marine fish, with elongate compressed naked body, and high crested head."

Distribution.--Mediterranean Sea and Japan. 
FAMILY 29.-TEUTHIDID Æ. (1 Genus, 29 Species.)

"Marine, herbivorous fishes, with compressed, oblong, smallscaled bodies."

Distribution.-Eastern tropical seas, from Bourbon and the Red Sea to the Marianne and Fiji Islands.

Family 30.-ACRONURID E. (5 Genera, 64 Species.)

"Marine, herbivorous fishes, with compressed, minutely-scaled bodies."

Distribution.-All tropical seas, but most abundant in the Malay region, and extending to Japan and New Zealand.

FAmily 31.-HOPLEGNATHID E. (1 Genus, 3 Species.)

"Marine fishes, with compressed elevated bodies, covered with very small toothed scales."

Distribution._-Seas of Australia, China, and Japan.

FAMILY 32.-MALACANTHID $\nRightarrow . \quad$ (1 Genus, 3 Species.)

"Marine fishes, with elongate bedies covered with very small scales, and with very long dorsal and anal fins."

Distribution.-Atlantic coasts of Tropical America, Mauritius, and New Guinea.

\section{FAMILY 33.-NANDIDEE. (6 Genera, 14 Species.)}

"Marine or fresh-water carnivorous fishes, with oblong, compressed, scaly bodies."

Distribution.-From the Red Sea to the coasts of China and Australia; and the fresh waters of the Neotropical and Oriental regions. Badis, Nandus, and Catopra inhabit the VOL. II. 
rivers of India and the Malay Islands; Acharnes the rivers of British Guiana.

FAMILY 34.-POLYCENTRID F. (2 Genera, 3 Species.)

"Fresh-water carnivorous fishes, with compressed elevated scaly bodies, and many-spined dorsal and anal fins."

Distribution.-Rivers of Tropical America.

\section{Family 35.-LABYRINTHICI. (9 Genera, 25 Species.)}

"Fresh-water fishes, with compressed oblong bodies, and capable of living for some time out of water or in dried mud."

Distribution.-Freshwaters of South Africa and the East Indies from the Mauritius to China, the Philippines, Celebes, and Amboyna.

Family 36.-LUCIOCEPHALID $\approx$. (1 Genus, 1 Species.)

"Fresh-water fish, with elongate scaled body, and a dilated branchial membrane."

Distribution,--Rivers of Borneo, Biliton, and Banca.

FAMILY 37.-ATHERINID $Æ . \quad$ (3 Genera, 39 Species.)

"Marine or fresh-water carnivorous fishes, with subcylindrical scaled bodies, and feeble dentition."

Distribution.-All temperate and tropical seas, from Scotland and New York to the Straits of Magellan and Tasmania.

Atherina presbyter occurs in British seas. Species of Atherina and Atherinichthis are found in fresh-water lakes and rivers in Europe, America, and Australia. 
Family 38.-MUGILID $\mathbb{E}$. (3 Genera, 78 Species.)

"Fresh-water and marine fishes, with oblong compressed bodies, cycloid scales, and small mouths, often without teeth."

Distribution.-Coasts and fresh waters of all temperate and tropical regions.

Mugil (66 sp.) is mostly marine, and is very widely distributed; several species (Grey Mullets) occur on the British coasts. Agonostoma (9 sp.) is confined to the fresh waters of the West Indies, Central America, New Zealand, Australia, Celebes, and the Comoro Islands. Myxous (3 sp.) is marine, and occurs both in the Atlantic and Pacific.

\section{Family 39.-OPHIOCEPHALID \&. (2 Genera, 26 Species.)}

"Fresh-water fishes, with elongate subcylindrical scaled bodies; often leaving the water for a considerable. time."

Distribution.--Rivers of the Oriental region:-India, Ceylon, China, Malay Islands to Philippines and Borneo.

Family 40,-TRICHONOTID F. (2 Genera, 2 Species.)

"Marine carnivorous fishes, with elongate subcylindrical bodies, cycloid scales, and eyes directed upwards."

Distribution.-Coasts of Celebes, Ceram, and New Zealand.

Family 41.-CEPOLID E. (1 Genus, 7 Species.)

"Marine fishes, with very long, compressed, band-like bodies, covered with small cycloid scales."

Distribution.-Temperate seas of Western Europe and Eastern Asia, and one species in the Malayan Seas.

Cepola rubescens (the Band fish) ranges from Scotland to the Mediterranean. All the other species but one are from Japan. 
Family 42.--GOBIESOCIDA. (9 Genera, 21 Species.)

"Carnivorous marine fishes, elongate, anteriorly depressed and scaleless, with dorsal fin on the tail."

Distribution.-Temperate and tropical seas; Scandinavia to the Cape, California to Chili, West Indies, Red Sea, Australia, New Zealand, and Fiji Islands.

Three species of Lepadogaster have occurred in the English Channel.

FaMily 43.-PSYCHROLUTID $\approx$. (1 Genus, 1 Species.)

"A large-headed, elongate, naked marine fish, with small teeth, and dorsal fin on the tail."

Distribution.-West Coast of North America (Vancouver's Island.)

Family 44.-CENTRISCID $\mathbb{E} . \quad$ (2 Genera, 7 Species.)

"Marine fishes, with compressed, oblong or elevated bodies, elongate tubular mouth and no teeth."

Distribution.-West Coast of Europe and Africa, Mediterranean, Indian Ocean to Java, Philippines, and Japan.

A species of Centriseus has occurred on the South Coast of England, and another species is found both at Madeira and Japan.

FAMily 45.-FISTULARID $\approx . \quad$ (2 Genera, 4 Species.)

"Marine fishes, very elongate, with long tubular mouth and small teeth."

Distribution.--Tropical seas, both in the Atlantic and Indian Ocean, and as far east as the New Hebrides. 
Family 46.-MASTACEMBeLID $\approx$. (2 Genera, 9 Species.)

"Fresh-water fishes, with eel-like bodies and very long dorsal fin."

Distribution.-Rivers of the Oriental region, one species from Ceram (?).

Family 47.-NOTACANTHI. (1 Genus, 5 Species.)

"Marine fishes, with elongate bodies covered with very small scales, and snout protruding beyond the moutl."

Distribution.-Greenland, Mediterranean, and West Australia.

Order II.ACANTHOPTERYGII PHARYNGOGNATHI.

FaMily 48.-POMACENTRID $\mathbb{E}$. (3 Genera, 143 Species.)

"Marine fishes, with short compressed bodies covered with toothed scales, and with feeble dentition."

Distribution.-Tropical parts of Pacific and Indian Ocean, less numerous in Tropical Atlantic, a few reaching the Mediterranean, Japan, and South Australia. Pomacentrus, Glyphidodon, and Heliastes are Atlantic genera.

\section{Family 49.-LABRID瓜. (46 Genera, 396 Species.)}

"Herbivorous or carnivorous marine fishes, with elongate bodies covered with cycloid scales, and teeth adapted for crushing the shells of mollusca."

Distribution.-Temperate and tropical regions of all parts of the globe.

The genera Labrus, Crenilabrus, Ctenolabrus, Acantholabrus, Centrolabrus, and Coris, have occurred in British seas, and all of 
these, except the last, are confined to the Mediterranean and the Atlantic as far as Madeira. Eight other genera are characteristic of the Atlantic, most of them being West Indian, but one from the coasts of North America. Seven genera are common to all the great oceans; the remainder being confined to the Indian and Pacific Oceans, ranging from Japan to New Zealand, but being far more abundant between the Tropics.

\section{Family 50.-EMBRotoctD A. (2 Genera, 17 Species.)}

"Marine viviparous fishes, with compressed elevated bodies covered with cycloid scales, and with small teeth."

Distribution.-Pacific Ocean from Japan and California northwards. One species enters the fresh waters of California.

\section{Family 51.-GERRID无. (1 Genus, 28 Species.)}

"Marine fishes, with compressed oblong bodies covered with minutely serrated scales, and with small teeth."

Distribution.-Tropical seas; ranging south as far as the Cape of Good Hope and Australia, and north to Japan and (one species) to New Jersey, U.S.

Family 52.-CHROMID Æ. (19 Genera, 100 Species.)

"Fresh-water herbivorous or carnivorous fishes, with elevated or elongate scaly bodies, and small teeth."

Distribution.-The Oriental, Ethiopian, and Neotropical regions.

Eutroplus (2 sp.) is from the rivers of Sonthern India and Ceylon; Chromis (15 sp.), Sarotherodon (2 sp.), and Hemichromis (4 sp.), are from the rivers and lakes of Africa, extending to the Sahara and Palestine. The remaining 15 genera are American, and several of them have a restricted distribution. Acara (17 sp.) inhabits Tropical South America and the Antilies; Theraps (1 sp.), Guatemala; Heros (26 sp.), Texas and 
Mexico to La Plata; Mesonauta (1 sp.), Brazil ; Pctenia (1 sp.), Lake Peten, Guatemala; Uaru (2 sp.), Brazil; Hygrogonus (1 sp.), Brazil ; Cichla (4 sp.), Equatorial America; Crenicichla (9 sp.), Brazil and Guiana; Choetobranchus (3 sp.), Brazil and Guiana; Mesops (2 sp.), Brazil ; Satanoperce (7 sp.), Amazon Valley and Guiana; Geophagus (1 sp.), North Brazil and Guiana; Symphysodon (1 sp.), Lower Amazon; Pterophyllum (1 sp.), Lower Amazon.

\section{Order III.-ANACANTHINI.}

FAMILY 53.-GADOPSID $2 . \quad(1$ Genus, 1 Species.)

"Fresh-water fish, with rather elongate body covered with very small scales, the upper jaw overhanging the lower, forming an obtuse snout."

Distribution,-Rivers of Australia and Tasmania.

\section{Family 53a.-LYCODID E. (3 Genera, 14 Species.)}

"Marine fishes, with elongate bodies, and the dorsal united with the anal fin."

Distribution.-Arctic seas of America and Greenland, and Antarctic seas about the Falkland Islands and Chiloe Island.

Family 54.-GADID A. (21 Genera, 58 Species.)

"Marine fishes, with more or less elongate bodies covered with small smooth scales."

Distribution.-Cold and temperate regions of both hemispheres; in the North extending as far south as the Mediterranean, Canary Islands, New York and Japan (and one species to the Philippines and Bay of Bengal), and in the South to Chili and New Zealand.

Gadus (Cod), Merluccius (Hake), Phycis, Lota, Molva, Couchica, Motella, and Raniceps, are British. Lota inhabits fresh waters. 
FAnILy 55.-OPHIDIID Æ. (16 Genera, 43 Species.)

"Marine fishes, with more or less elongate bodies, the dorsal and anal fins united, and the ventral fins rudimentary or absent."

Distribution.-Almost universal; from Greenland to New Zealand, but most abundant in the Tropics.

Ophidium and Ammodytes occur in British seas; Lucifuga inhabits subterranean fresh waters in Cuba.

FAMILY 56.-MACROURIDA. (3 Genera, 21 Species.)

"Marine fishes, with the body terminating in a long, compressed tapering tail, and covered with spiny, keeled or striated scales."

Distribution.---North Atlantic from Greenland to Madeira and the Canary Islands, Mediterranean, Japanese and Australian seas.

None of these fishes have occurred in the British seas.

FAmily 57.-ATELEOPODID $\approx . \quad$ (1 Genus, 1 Species.)

"Marine fishes, with the naked body terminating in a long compressed, tapering tail."

Distribution._Japan.

Family 58.-PLEURONECTIDA:. (34 Genera, 185 Species.)

"Marine carnivorous fishes, with strongly compressed flat bodies, one side of which is colourless, and eyes unsymmetrically placed, both on the coloured side. They inhabit the sandy bottoms of shallow seas, and often ascend rivers."

Distribution.-Universal, on Arctic, Temperate, and Tropical coasts. 
Seven genera occur in British seas, viz. : Hippoglossus, Hippoglossoides, Rhombus, Phrynorhombus, Arnoglossus, Pleuronectes (Turbot), and Solea (Sole). There are 13 genera in the Atlantic and 23 in the Pacific, 4 being common to both; and 2 found only in the Mediterranean. A Pacific genus, Synaptura, has one species in the Mediterranean.

\section{Order IV.-PHYSOSTOMI.}

\section{Fanily 59._SILURID Æ. (114 Genera, 547 Species.)}

"Fresh-water or marine, scaleless fishes, often with bony shields, and the head always furnished with barbels."

Distribution.-The fresh waters of all the temperate and tropical regions, those which enter the salt water keeping near the coast.

This extensive family is divided by $\mathrm{Dr}$. Giinther into eight sub-families and seventeen groups, the distribution of which is as follows:-

Sub-family 1 (Silurid $\approx$ Homalopter $\approx$ ) is confined to the Old World. It consists of three groups: Clarina (2 genera, Clarias and Heterobranchus) ranges over the whole area of the Ethiopian and Oriental regions, to which it appears to be strictly confined; Plotosina (3 genera, Plotosus, Copidoglanis, and Cnidoglanis) ranges from the eastern coasts of Africa to Japan, Polynesia, and Australia, in seas and rivers; Chacina (1 genus, Chaca) ranges from India to Borneo.

Sub-family 2 (SILURId $\approx$ Heteropter ) is also confined to the Old World; it consists of one group,-Silurina, containing 19 genera, viz.:-Saccolranchus (4 sp.), India to Cochin China and Ceylon; Siturus (5 sp.), Palæarctic region from Central Europe to Japan, China, and Afghanistan, and a species in Cochin China; Silurichthys (3 sp.), Cashmere, Java, and Borneo ; Wallago (2 sp.), Hindostan, Sumatra, and Borneo; Belodontichthys (1 sp.), Sumatra and Borneo; Eutropiichthys (1 sp.), Bengal; Cryptopterus 
(15 sp.), Java, Sumatra, and Borneo, with a species in the Ganges, in Siam, and (?) in Amboyna; Callichrous (10 sp.), Afghanistan to Borneo and Java; Schilbe (5 sp.), Tropical Africa; Eutropius (6 sp.), Tropical Africa and Central India; Hemisilurus (2 sp.), Java and Sumatra; Siluranodon (1 sp.), Nile; Ailia (2 sp.), Bengal ; Schilbichthys (1 sp.), Bengal ; Lcï̌s (1 sp.), Java, Sumatra, Borneo; Pseudeutropius (6 sp.), India and Sumatra; Pangasius (7 sp.), Ganges, Sumatra, Java, Borneo; Helicophagus (2 sp.), Sumatra; Silondia (1 sp.), Ganges.

Sub-family 3 (Siluride Anomalopteres) is confined to Equatorial America; it consists of the group Hypopthalmina, containing 2 genera: Helogenes (1 sp.), Hypopthalmus (4 sp.), from the country north of the Amazon, Surinam, and the Rio Negro.

Sub-family 4 (Silurid \& Proteropter ) ranges over all the tropical and most of the temperate parts of the globe, except Europe and Australia. It consists of four groups: Bagrina (16 genera), ranging over most of the Old World and North America; Pimelodina (15 genera), confined to Tropical America, except one genus which is African; Ariina (10 genera), all Tropical regions; and Bagarina (3 genera), Oriental region. The distribution of the genera is as follows:-

Bagrus (2 sp.), Nile; Chrysichthys (5 sp.), Tropical Africa; Clarotes (1 sp.), Upper Nile; Macrones (19 sp.), India, Ceylon to Borneo, and one species in Asia Minor; Pseudobagrus (4 sp.), Japan, China, and Cochin China; Liocassis (5 sp.), Japan, China, Java, Sumatra, and Borneo; Bagroides (3 sp.), Sumatra and Borneo; Bagrichthys (1 sp.), Sumatra and Borneo; Rita (5 sp.), Continental India and Manilla; Acrochordonichthys (6 sp.), Java and Sumatra; Akysis (3 sp.), Java and Sumatra; Olyre (1 sp.), Khasya; Branchiosteus (1 sp.), Khasya; Amiurus (13 sp.), Nearctic region to Guatemala and China; Hopladelus (1 sp.), North America; Noturus (4 sp.), North America; Sorubim (1 sp.), Amazon ; Platystoma (11 sp.), Tropical South America; Hemisorubim (1 sp.) Rio Negro, Brazil; Platistomatichthys (1 sp.), Rio Branco, Brazil ; Phractocephalus (1 sp.), Amazon; Piramutana (2 sp.), Equatorial America; Platynematichthys 
(1 sp.), northern and southern tributaries of Amazon ; Piratinga (3 sp.), Amazon Valley; Sciades (2 sp.), Amazon; Pinelodus (42 sp.), Mexico to La Plata, single aberrant species from West Africa, Java and the Sandwich Islands; Pininampus (1 sp.), Brazil ; Conorhynchus (1 sp.), Brazil ; Notoglanis (1 sp.), Madeira, Amazon Valley; Callophysus (3 sp.), Tropical South America; Auchencspis (1 sp.), Tropical Africa; Arius (68 sp.), all Tropical regions; Galeichthys (1 sp.), Cape of Good Hope; Genidens (1 sp.), Brazil; Hemipimelodus (3 sp.), India, Sumatra, and Borneo; Ketingus (1 sp.), Sunda Islands; Elurichthys (4 sp.), Eastern United States to Guiana; Paradiplomystax (1 sp.), Brazil ; Diplomystax (1 sp.), Chili; Osteogeniosus (3 sp.), India to Java; Batrachocephalus (1 sp.), Java and Sumatra; Bagarius (1 sp.), India to Java; Euclyptosternum (1 sp.), India; Glyptosternum. (8 sp.), Himalayas, Central India, Java, and Sumatra; Hara (3 sp.), Continental India; Amblyceps (3 sp.), Continental India.

Sub-family 5 (Siluride Stenobranchia) is confined to South America and Africa, with one genus and species in the Ganges. It consists of three groups: Doradina (12 genera), South America and Africa; Rhinoglanina (3 genera), Central Africa and the Ganges; Malapterurina (1 genus), Tropical Africa. The distribution of the genera is as follows:-

Ageniosus (4 sp.), Surinam to La Plata; Tetranematichthys (1 sp.), Central Brazil, Rio Guaporé ; Eucmemus (1 sp.), Surinam and Brazil ; Auchenipterus (9 sp.), Equatorial America; Centromochlus (2 sp.), Equatorial America; Trachelyopterus (2 sp.), Equatorial America; Cetopsis (3 sp.), Brazil ; Asterophysus (1 sp.), Rio Negro, North Brazil ; Doras (13 sp.), Tropical South America east of Andes; Oxydoras (7 sp.), Amazon Valley and Guiana; Rhinodorces (3 sp.), Tropical South America east of Andes; Synodontis (12 sp.), Tropical Africa; Rhinoglanis (1 sp.), Upper Nile; Mochocus (1 sp.), Nile; Callomystax (1 sp.), Nile; Malapterurus (3 sp.), Tropical Africa.

Sub-family 6 (SILURID $A$ Proteropodes) 1 inhabits Tropical America and Northern India as far as Tenasserim. It consists of two groups: the Hypostomatina (17 genera), with the same distribution as the sub-family, and the Aspredinima (3 genera), 
confined to Equatorial America. The distribution of the genera is as follows:-

Arges (2 sp.), Andes of Peru and Ecuador; Stygogenes (2 sp.), Andes; Brontes (1 sp.), Andes; Astroblepus (1 sp.), Popayan; Callichthys (11 sp.), Tropical South America east of Andes, and Trinidad; Plecostomus (15 sp.), Tropical South America east of Andes, and Trinidad; Liposarcus (3 sp.), Surinam and Brazil; Chatostomus (25 sp.), Tropical America, Trinidad, and Porto Rico; Pterygoplichthys (4 sp.), Brazil ; Rhinelepis (1 sp.), Brazil; Acanthicus (2 sp.), Equatorial America; Loricaria (17 sp.), Tropical South America east of Andes; Acestra (4 sp.), Brazil and Guiana; Sisor (1 sp.), Northern Bengal; Erethistes (1 sp.), Assam; Pseudecheneis (1 sp.), Khasya Hills ; Exostoma (2 sp.), Assam and Tenasserim; Bunocephalus (2 sp.), Guiana; Bunocephalichtteys (1 sp.), Rio Branco, North Brazil ; Aspredo (6 sp.), Guiana.

Sub-family 7 (SIlurid 2 OPISThopter $A$ ) consists of two groups: Nematogenyina (2 genera), and Trichomycterina (3 genera), and is confined to South America. The distribution of the genera is as follows:-

Heptapterus (2 sp.), South America; Nematogenys (1 sp.), Chili; Trichomycterus (7 sp.), South America to 15,000 feet elevation; Eremophilus (1 sp.), Andes of Bogota; Pariodon (1 sp.), Amazon.

Sub-family 8 (Siluride Branchicoles) is confined to Tropical South America. It consists of one group, Stegophilina, and 2 genera: Stegophilus (1 sp.), Brazil; and Vandellia (2 sp.), Amazon Valley.

Family 60. CHARACINIDA. (47 Genera, 230 Species.)

"Fresh-water fishes, with scaly bodies and without barbels."

Distribution.-The Neotropical and Ethiopian regions.

This extensive family is divided by Dr. Günther into 10 groups, viz. : Erythrinina (5 genera), South America; Curumatina 
(6 genera), South America; Citharinina (1 genus), Tropical Africa ; Anostomatina (3 genera), South America; Tetragonopterina (16 genera), South America and Tropical Africa; Hydrocyonina (9 genera), Tropical America and Tropical Africa; Distichodontina (1 genus), Tropical Africa; Icthyborina (1 genus), Africa ; Crenuchina (1 genus), Equatorial America; Serrasalmonina (4 genera), South America.

The following is the distribution of the genera:-

Macrodon (4 sp.), Tropical America; Erythrinus (5 sp.), Brazil and Guiana; Lebiasina (1 sp.), West Equatorial America; Pyrrhulina (1 sp.), Guiana; Corynopoma (4 sp.), Trinidad only; Curimatus (15 sp.), Tropical South America and Trinidad; Prochilodus (12 sp.), South America to the La Plata; Ccentropus (2 sp.), East Equatorial America; Hemioalus (8 sp.), Equatorial America east of Andes; Saccodon (1 sp.), Ecuador; Parodon (1 sp.), Brazil; Citharinus (2 sp.), Tropical Africa; Anostomus (8 sp.), Tropical America; Rhytiodus (2 sp.), Equatorial America; Leporinus (14 sp.), South America East of Andes; Piabucina (2 sp.), Guiana; Alestes (4 sp.), Tropical Africa: Brachyalestes (5 sp.), Tropical Africa; Tetragonopterus (32 sp.), Tropical America; Scissor (1 sp.), South America; Pscudochalceus (1 sp.), West Ecuador; Chirodon (2 sp.), Chili ; Chalceus (1 sp.), Guiana; Brycon (10 sp.), South America east of Andes; Chalcinopsis (4 sp.), Central America and Ecuador; Bryconops (2 sp.), Tropical America; Creagrutus (1 sp.), Western Ecuador; Chalcinus (4 sp.), Tropical South America; Gastropelecus (8 sp.), Tropical South America; Piabuca (2 sp.), Equatorial America; Agoniates (1 sp.), Guiana; Anacyrtus (7 sp.), Central and South America; Hystricodon (1 sp.), Equatorial America; Salminus (3 sp.), South America; Hydrocyon (3 sp.), Tropical Africa; Sarcodaces (1 sp.), West Africa; Oligosarcus (1 sp.), Brazil ; Xiphoramphus (7 sp.), South America east of Andes; Xiphostoma (5 sp.), Equatorial America east of Andes; Cynodon (3 sp.), Tropical America East of Andes; Distichodus (7 sp.), Tropical Africa; Icthyborus (3 sp.), Nile; Crenuchus (1 sp.), Guiana; Mylesinus (1 sp.), Equatorial America; Serrasalmo (13 sp.), Tropical South America east of Andes; Myletes (18 sp.), 
Tropical South America east of Andes; Catoprion (1. sp.), Brazil and Guiana.

FAmily 61.-HAPLOCHITONIDA. (2 Genera, 3 Species.)

"Fresh-water fishes, with naked or scaly bodies and without barbels."

Distribution.-Temperate South America and South Australia.

The genera are, Haplochiton (2 sp.), Tierra del Fuego and the Falkland Islands; Prototroctes (2 sp.), Southern Australia and New Zealand.

FAMILY 62.-STERNOPTYCHID \#. (6 Genera, 12 Species.)

"Marine fishes, with very thin deciduous scales or none, and with a row of phosphorescent spots or organs on the under surface of the body."

Distribution.-Mediterranean and Atlantic.

These are deep-sea fishes found in the Mediterranean sea, and in the deep Atlantic from the coasts of Norway to the Azores and the Tropics.

FAMILY 63.—SCOPELID $A$. (11 Genera, 47 Species.)

"Marine fishes, somewhat resembling the fresh-water Siluridæ."

Distribution.-Almost universal, but most abundant in warm and tropical seas.

These are deep-sea fishes, abounding in the Mediterranean and the great oceans, a few extending north to near Greenland and south to Tasmania. 
FaMily 64.-STOMIATID \&. (4 Genera, 8 Species.)

"Small marine fishes, naked or with very fine scales."

Distribution.-The Mediterranean and Atlantic.

These are deep-sea fishes, ranging from Greenland to beyond the Equator.

\section{FAMILY 65.-SALMONID $\mathbb{E}$. (15 Genera, 157 Species.)}

"Fresh-water fishes, many species periodically descending to the sea and a few altogether marine :- Salmon and Trout."

Distribution.-The Palæarctic and Nearctic Regions, and one genus and species in New Zealand. A considerable number of species are confined to single lakes or rivers, others have a wide distribution.

The genera are distributed as follows :-

Salmo (83 sp.), rivers and lakes of the Palæarctic and Nearctic Regions, as far south as Algeria, Asia Minor, the HindooKoosh and Kamschatka, and to about $38^{\circ}$ North Latitude in North America, many of the species migratory; Onchorhynctius (8 sp.), American and Asiatic rivers entering the Pacific, as far sonth as San Francisco and the Amur; Brachymystax (1 sp.), Siberian rivers, from Lake Baikal and the Atlai Mountains northwards; Luciotrutta (2 sp.), Caspian Sea and Volga; Plecoglossus (1 sp.), Japan and Formosa; Osmerus (3 sp.), rivers of temperate Europe and North America entering the Atlantic, and one species in California; Thaleichthys (1 sp.), Columbia River, Vancouver's Island; Hypomesus (1 sp.), coasts of California, Vancouver's Island, and North-eastern Asia; Mallotus (1 sp.), coasts of Arctic America from Greenland to Kamschatka; Retropinna (1 sp.), fresh waters of New Zealand; Coregonus (41 sp.), fresh waters of northern parts of temperate Europe, Asia and North America, many of the species migratory: Thymallus (6 sp.), fresh waters of temperate parts of 
Europe, Asia, and North America; Argentina (4 sp.), Mediterranean and deep seas of Western Europe ; Microstoma (2 sp.), Mediterranean, and seas of Greenland; Salcrix (2 sp.), China and Japan, in seas and rivers. Salmo, Osmerus, Coregonus, and Thymallus, are British genera.

Family 66.-PERCOPSID $\mathbb{E}$. (1 Genus, 1 Species.)

"A fresh-water fish covered with toothed scales."

Distribution.-Lake Superior, North America.

Fanily 67.-GaLAXIDA. (1 Genus, 12 Species.)

"Fresh-water fishes, with neither scales nor barbels."

Distribution.-The temperate zone of the Sonthern Hemisphere.

The only genus, Galaxias, is found in New Zealand, Tasmania, and Tierra del Fuego, ranging north as far as Queensland and Chili; and one of the species is absolutely identical in the two regions.

Family 68.-MORMYRIDA. (3 Genera, 25 Species.)

"Fresh-water fishes, with scales on the body and tail but not on the head, and no barbels."

Distribution.-The Ethiopian Region.

Most abundant in the Nile, a few from the Gambia, the Congo, and Rovuma. The genera are :-

Mormyrus (1 sp.), Nile, Gambia, West Africa, Mozambique, Rovuma; Hyperopsius (2 sp.), Nile and West Africa; Mormyropss (4 sp.), Nile, West Africa and Mozambique. 


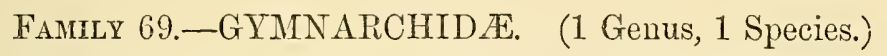

"Fresh-water fishes, resembling the Mormyridæ, but with tapering finless tail, and neither anal nor ventral fins."

Distributrox.-Ethiopian region.

The only genus, Gymnarchus, inhabits the Nile and the rivers of West Africa.

\section{FAMLY 70.-ESOCID㞼. (1 Genus, 7 Species.)}

"Fresh-water fishes, with scaly bodies, no barbels, and dorsal fins situated towards the tail."

Distribution.-The Nearctic and Palæaretic regions.

One species, the Pike (Esox laccius) ranges from Lapland to Turkey, and in America from the Arctic regions to the Albany river; the remainder are American species extending South as far as New Orleans.

\section{Family 71.-UMBRID Æ. (1 Genus, 2 Species.)}

"Small fresh-water scaly fishes, without barbels or adipose fin."

Distribution._-Central Europe and Temperate North America.

Famliy 72.-SCOMbRESOCID \&. (5 Genera, 136 Species.)

"Marine or fresh-water fishes, with scaly bodies and a series of keeled scales along each side of the belly."

Distribution,- - Temperate and tropical regions.

All the genera have a wide distribution. A species of Bclone and one of Scombresox are found on the British coast. The Flying fishes (Exocetus, $44 \mathrm{sp}$.), belong to this family. They abound in all tropical seas and extend as far as the Mediterranean and Australia. None of the genera are exclusively fresh-water, VOL. II. 
but a few species of Bclone and Hemiramphus are found in rivers in various parts of the world.

Family 73.-CYPRINODONTIDA. (20 Genera, 106 Species.)

"Fresh-water fishes, covered with scales, the sexes frequently differing, mostly viviparous."

Distribution.-Southern Europe, Asia, Africa and North America, but most abundant in Tropical America.

The distribution of the genera is as follows :-

Cyprinodon. (11 sp.), Italy, North Africa and Western Asia to Persia, also North America from Texas to New York; Fitzroya (1 sp.), Montevideo; Characodon (1 sp.), Central America; Tellia (1 sp.), Alpine pools of the Atlas: Limnurgus (1 sp.), Mexican plateau; Lucania (1 sp.), Texas; Haplochilus (18 sp.), India, Java, Japan, Tropical Africa, Madagascar, and the Seychelle Islands, Carolina to Brazil, Jamaica ; Fundulus (17 sp.), North and Central America and Ecuador, Spain and East Africa; Rivulus (3 sp.), Tropical America, Cuba and Trinidad; Orestias (6 sp.), Lake Titacaca, Andes; Jenynsia (1 sp.), Rio Plata ; Pseudoxiphophorus (2 sp.), Central America; Belonesox (1 sp.), Central America; Gambusia (8 sp.), Antilles, Central America and Texas; Anableps (3 sp.), Central and Equatorial America; Poccilia (16 sp.), Antilles, Central and South America; Mollicnesia (4 sp.), Louisiana to Mexico; Platypcecilus (1 sp.), Mexico; Girardinus (10 sp.), Antilles and South Carolina to Uruguay; Lepistes (1 sp.), Barbadoes.

\section{Family 74.-HETEROPYGII. (2 Genera, 2 Species.)}

"Fresh-water fishes, with posterior dorsal fin, and very smal". scales."

Distribution.-Fresh waters of the United States.

Amblyopsis (1 sp.) is a blind fish found in the caverns of Kentucky; while Chologastes (1 sp.), which only differs from it in having perfect eyes, is found in ditches in South Carolina. 


\section{FAMILY 75.-CYPRINID压. (109 Genera, 790 Species.)}

"Fresh-water fishes, generally scaly, with no adipose fin, and pharyngeal teeth only, the mouth being toothless."

Distributron.-Fresh waters of the Old World and North America, but absent from Australia and South America.

This enormous family is divided by Dr. Günther into fourteen groups, the distribution of which is as follows:-

Catostomina (4 genera), North America and North-east Asia ; Cyprinina (39 genera), same range as the family ; Rohteichthyina (1 genus), Malay Archipelago; Leptobarbina (1 genus), Malay Archipelago; Rasborina (5 genera), East Africa to China and Borneo; Semiplotina (2 genera), Western Asia; Xenocypridina (3 genera), Eastern Asia; Leuciscina (10 genera), Palæarctic and Nearctic regions; Phodeina (3 genera), Palæarctic region; Danionina (9 genera), India to China and Japan; Hypophthalmichthyina (1 genus), China; Abramidina (16 genera), same range as the family; Homalopterina (2 genera), India to Java ; Cobitidina (10 genera), Palearctic and Oriental regions.

The following is the distribution of the genera:-

Catostomus (16 sp.), Nearctic region and Eastern Siberia; Moxostoma (2 sp.), Eastern United States; Sclerognathus (5 sp.), Temperate North America to Guatemala, also Northern China; Carpiodes (1 sp.), United States; Cyprinus (2 sp.), Temperate parts of Palæarctic region (1 sp. British); Carassius (3 sp.), Temperate Palæarctic region (1 sp. British); Catla (1 sp.), Continental India ; Cirrhina (5 sp.), Continental India to China; Dangila (6 sp.), Java, Sumatra, Borneo; Osteochiilus (14 sp.), Siam to Java and Sumatra; Labeo (27 sp.), Tropical Africa and Oriental region; Tylognathus (10 sp.), Syria, India to Java; Abrostomus (2 sp.), South Africa; Discognathus (4 sp.), Syria to India and Java, mostly in mountain streams; Crossochilus (9 sp.), India to Sumatra and Java; Gymnostomus (7 sp.), Continental India; Epalzeorhynchus (1 sp.), Sumatra and Borneo; Capoeta (13 sp.), Western Asia ; Barbus (163 sp.), Temperate or Tropical 
parts of Europe, Asia, and Africa (1 sp. British); Thynnichthys (2 sp.), Pegu, Borneo, and Sumatra; Barbichthys (1 sp.), Java, Sumatra, and Borneo; Amblyrhynchichthys (1 sp.), Sumatra and Borneo; Albulichthys (1 sp.), Sumatra and Borneo; Oreinus (3 sp.), Himalayan region; Schizothorax (13 sp.), Himalayan region and west to Afghanistan and Persia; Ptychobarbus (1 sp.), Thibet; Gymnocypris (1 sp.), loc. unknown ; Schizopygopsis (1 sp.), Thibet; Diptychus (1 sp.), Himalayas and Thibet; Aulopyge (1 sp.), Western Asia ; Gobio (2 sp.), Temperate Europe (1 sp. British); Pseudogobio (4 sp.), China, Japan, and Formosa; Ceratichthys (9 sp.), Temperate North America; Bungia (1 sp.), Western Asia, Herat; Pimephales (2 sp.), Eastern United States; Hyborhynchus (3 sp.), Eastern United States; Ericymba (1 sp.), United States; Pscudorasborr (1 sp.), Japan, China; Cochlognathus (1 sp.), Texas; Exoglossum (2 sp.), United States; Rhinichthys (6 sp.), Eastern United States; Rohteichthys (1 sp.), Borneo and Sumatra; Leptobarbinc (1 sp.), Sumatra and Borneo; Rasborce (12 sp.), East Coast of Africa, India, to Java and Borneo; Luciosma (3 sp.), Java, Sumatra, and Borneo; Nuria (2 sp.), India, Tenasserim, and Ceylon; Aphyocypris (1 sp.), North China; Amblypharyngodon (3 sp.), India to Tenasserim; Cyprinion (3 sp.), Syria and Persia; Semiplotus (1 sp.), Assam; Xenocypris (1 sp.), China; Parccanthobrama (1 sp.), China; Mystacoleucus (1 sp.), Sumatra; Leuciscus (84 sp.), Nearctie and Palæarctic regions (5 sp. are British); Ctenopharyngodon (1 sp.), China; Mylopharodon (1. sp.), California ; Paraphoxinus (2 sp.), Sonth-eastern Europe; $M e d \alpha$ (1 sp.), River Gila; Tinee (1 sp.), Europe (Britain to Constantinople); Leucosomus (8 sp.), Nearetic region; Chondrostonea (7 sp), Europe and Western Asia; Orthodon (1 sp.), California; Acrochilus (1 sp.), Columbia River ; Achilognathus (6 sp.), China, Japan, and Formosa; Rhodeus (3 sp.), Central Europe and China; Pserdoperilampus (1 sp.), Japan; Danio (8 sp.), India and Ceylon ; Pterosarion (2 sp.), Central India and Assam ; Aspidoparia (3 sp.), Continental India ; Barilius (15 sp.), East Africa and Continental India; Bola (1 sp.), Ganges to Bramahputra; Schaera (1. sp.), Bengal; Opsariichthys (5 sp.), Japan and Formosa; Squaliobarbus (1 sp.), China; Ochctobius (1 sp.), North China; 
Hypophthalmichthys (2 sp.), China; Abramis (16 sp.), North America, Central Europe, and Western Asia (1 sp. is British); Aspius (3 sp.), East Europe, Western Asia, China; Alburnus (15 sp.), Europe and Western Asia (1_British sp.); Rasborichthys (1 sp.), Borneo; Elopichthys (1 sp.), China; Pclotrophus (2 sp.), East Africa; Acanthobrama (3 sp.), Western Asia; Osteobrama (5 sp.), Continental India; Chanodichthys (6 sp.), China and Formosa; Smiliogaster (1 sp.), Bengal; Culter (2 sp.), China; Pelecus (1 sp.), Eastern Europe ; Eustira (1 sp.), Ceylon; Chcla (16 sp.), India to Siam, Java and Borneo ; Psendolabuca (1 sp.), China; Cachius (1 sp.), Continental India; Homaloptera (8 sp.), India to Cochin China, Java, and Sumatra; Psilorhynchus (2 sp.), North-eastern India; Misgurnus (5 sp.), Europe to India, China, and Japan; Nemachilus (37 sp.), Europe and Asia; Cobitis (3 sp.), Europe, India, Japan; Lepidocepalichthys (3 sp.), India, Ceylon, and Java; Acanthopsis (2 sp.), Tenasserim, Sumatra, Java, and Borneo; Botia (7 sp.), India to Japan and Sunda Isles; Oreonectes (1 sp.), China; Lepidocephalus (1 sp.), Java and Sumatra ; Acanthopthalmus (2 sp.), Java and Sumatra; Apua (1 sp.), Tenasserim ; Kneria (2 sp.), Tropical Africa.

\section{Family 76.-GONORHYNCHID $\mathbb{E} . \quad$ (1 Genus, 1 Species.)}

"A marine fish with spiny scales, mouth with barbels, and with short dorsal fin opposite the ventrals."

Distribution.-Temperate parts of Southern Oceans, and Japan.

Family 77.-HYODONTID ZE. (1 Genus, 1 Species.)

"A fresh-water fish with cycloid scales and posterior dorsal fin."

Distribution.-Fresh waters of North America. 
Fanily 78.-OSTEOGLOSSID AE. (3 Genera, 5 Species.)

"Fresh-water fishes, with large hard scales, and dorsal fin opposite and equal to the anal fin."

Distribution.-Tropical rivers.

The genera are:-Osteoglossum (3 sp.), Eastern South America, Sunda Islands, and Queensland; Arapaima (1 sp.), Eastern South America-the "Pirarucin" of the Amazon; Heterotis (1 sp.), Tropical Africa.

Family 79.-CLUPEID $\approx . \quad$ (18 Genera, 161 Species.)

"Marine scaly fishes, without barbels, and with the abdomen often compressed and serrated."

Distribution.-Seas of the whole globe, many species entering rivers. They are most abundant in the Indian seas, less so in America, scarce in Africa, while they are almost absent from Australia. The Herring, Sprat, Shad, and Pilchard, are British species of Clupea, a genus which contains 61 species and ranges all over the world.

Family 80.-CHIROCENTRID $\not 2 . \quad$ (1 Genus, 1 Species.)

"A marine fish, with thin deciduous scales, no barbels, and posterior dorsal fin."

Distribution.-The Eastern seas from Africa to China.

Family 81.-ALEPOCEPHALID æ. (1 Genus, 1 Species.)

"A marine fish, covered with thin cycloid scales, no barbels, and posterior dorsal fin."

Distribution.-Deep waters of the Mediterranean. 


\section{FAMILY 82.-NOTOPTERID E. (1 Genus, 5 Species.)}

"Fresh-water fishes, without barbels, head and body scaly, long tapering tail, and short posterior dorsal fin."

Distribution.-Rivers of India, Siam, the Sunda Islands, and West Africa.

\section{FaMily 83.-HALOSAURID $2 . \quad$ (1 Genus, 1 Species.)}

"Marine fishes, with cycloid scales, a short median dorsal fin, and no barbels."

Distribution.-Deep waters of the Atlantic, Madeira.

FaMily 84.-GYMNOTID Æ. (5 Genera, 20 Species.)

"Fresh-water fishes, with elongate bodies, pointed tail, and no dorsal fin."

Distribution.-Tropical America from Trinidad to the River Parana.

The genera are distributed as follows :-

Sternarchus (8 sp.), Guiana and Brazil; Rhamphichthys (6 $\mathrm{sp}$.), Guiana and Brazil ; Sternophygus (4 sp.), Tropical America; Carapus (1 sp.), Trinidad to Brazil ; Gymnotus, (1 sp. -the Electric eel), Tropical South America.

\section{Family 85.-SYMBRANCHID Æ. (4 Genera, 6 Species.)}

"Marine and fresh-water fishes, having elongate bodies without fins, and very minute scales or none."

Distribution.-Fresh waters and coasts of Western Australia and Tasmania.

The genera are :-

Amphipnous (1 sp.), Bengal; Monopterus (1 sp.), Siam to Northern China and Sunda Islands ; Symbranchus (3 sp.), Tropical 
America, and India to Australia; Chilobranchus (1 sp.), Australia and Tasmania.

FuMily 86.-MURANID E. (26 G'enera, 230 Species.)

"Marine or fresh-water fishes, with cylindrical or band-like bodies and no ventral fins."

Distribution.-The seas and fresh waters of temperate and tropical regions. This family is divided by Dr. Günther into two sub-families and nine sections. The genus Anguilla, comprising our common Eel and a number of species from all parts of the world, is the only one which is found in fresh water, though even here most of the species are marine. Anguilla and Conger are the only British genera.

\section{FAMily 87.-PEGASID $\nRightarrow$. (1 Genus, 4 Species.)}

"Small marine fishes, covered with bony plates, and short opposite dorsal and anal fins."

Distribution.-Indian Ocean and seas of China and Australia.

\section{Order $V .-L O P H O B R A N C H I I$.}

"Fish with a segmented bony covering, long snout, and small toothless mouth."

Family 88.-SOLENOSTOMID $\approx . \quad$ (1 Genus, 3 Species.)

"Marine Lophobranchii, wi!h wide gill openings and two dorsal fins."

Distribution,-Indian Ocean, from Zanzibar to China and the Moluccas. 


\section{Fanily 89.—SYNGNATHID Æ. (15 Genera, 112 Species.)}

"Marine Lophobranchii, with very small gill opening and one soft dorsal fin."

Distribution.-All the tropical and temperate seas. Some species of Syngnathus, Doryichthys, and Celonotus enter fresh water, and a few live in it exclusively. Siphonostoma, Syngnathus, Nerophis, and Hippocampus are British genera. The Hippocampina (5 genera, 25 sp.), or Sea-horses, are peculiar to the Indian and Pacific Oceans, except three or four species of Hippocampus in the Atlantic and Mediterranean.

\section{Order VI.-PLECTOGNATHI.}

"Fishes covered with rough scales or shields, having a narrow mouth, and soft posterior dorsal fin."

Famly 90.-SCLERODERMI. (7 Genera, 95 Species.)

"Marine Plectognathi, with toothed jaws."

Distribution.-Temperate and Tropical seas, but much inore abundant in the Tropics.

\section{Famul 91.-GYMNODONTES. (10 Genera, 82 Species.)}

"Marine or fresh-water Plectognathi, with jaws modified into a beak."

DistribUtion.-Temperate and tropical regions.

Some species of Tetrodon are found in the rivers of Tropical America, Africa, and Asia. Species of Tctrodon and Orthagoriscus have been found on the British coasts. 


\section{SUB-CLASS II.-DIPNOI.}

Family 92.-Sirevoidei. (3 Genera, 3 Species.)

"Eel-shaped fresh-water fishes, covered with cycloid scales; the vertical fins forming a continuous border to the compressed tapering tail."

Distribution.-Rivers of Tropical Africa, South America, and Australia.

The genera are:-Protopterus (1 sp.), Tropical Africa ; Lepillosiren (1 sp.), Amazon Valley; Ceratodus (1 sp.), Queensland.

\section{SUb-CLASS III.-GANOIDEI.}

\section{Order I.-HOLOSTEI.}

"Body covered with scales."

Family 93.-AMIIDE. (1 Genus, 1 Species.)

"A fresh-water fish, with cycloid scales and a long soft dorsal fin."

Distribution.-United States.

FAMILY 94.-POLYPTERIDE. (2 Genera, 2 Species.)

"Fresh-water fishes, with ganoid scales and dorsal spines."

Distribution.-Central and Western Africa.

The genera are :-

Polypterus (1 sp.), the Nile and rivers of West Africa; Calamoichthys (1 sp.), Old Calabar. 


\section{Fanily 95.-LEPIDOSTEID $Æ . \quad(1$ Genus, 3 Species.)}

"Fresh-water fishes, with ganoid scales, and dorsal and anal fins composed of articulated rays."

Distribution.-The genus Lepidosteus, the Garfishes or Bony Pikes, inhabits North America to Mexico and Cuba.

\section{Order II.-CHONDROSTEI.}

"Sub-cartilaginous scaleless fishes with heterocercal tail, the skin with osseous bucklers or naked."

FAMILY 96.-ACCIPENSERIDE. (2 Genera, 20 Species.)

"Marine or fresh-water fishes with osseous bucklers and inferior mouth."

Distribution.-Temperate and Arctic regions of the northern hemisphere. Accipenser (19 sp.), comprising the Sturgeons, has the distribution of the family; most of the species are marine, but some are confined to the Caspian and Black Seas and the great American lakes with the rivers flowing into them, while the Danube, Mississippi, and Columbia River have peculiar species. The other genus, Scaphirhynchus (1 sp.), is confined to the Mississippi and its tributaries.

Faviry 97.-POLYDONTIDE. (1 Genus, 2 Species.)

"Fresh-water fishes, with wide lateral mouth and naked skin."

Distributrox.-The Mississippi and Yang-tse-kiang rivers. 


\section{Sub.class IV.-CHONDROPTERYGII. (Sharks AND RAYS.)}

\section{Order I.-HOLOCEPHALA. (Chimaras.)}

FaMily 98.-CHIM FRID E. (2 Genera, 4 Species.)

"Shark-like marine fishes, snout of the male with a prehensile organ."

Distribution.-Northern and Sonthern temperate seas. Chimara is British.

$$
\begin{gathered}
\text { Order II.-PLAGIOSTOMATA. } \\
\text { Sub-order_-SELACHOIDEA. (Sharks.) }
\end{gathered}
$$

FAMILY 99-CARCHARIID A. (11 Genera, 59 Species.)

"Sharks with two dorsals and a nictitating membrane."

Distribution.-Seas of the Arctic, temperate, and tropical regions. Species of Galeus and Mustelus have occurred on our coasts.

FAMILY 100.-LAMNID E. (5 Genera, 7 Species.)

"Sharks with two dorsals and no nictitating membrane."

Distribution.-Temperate and tropical seas. Species of Lamna, Alopecias, and Selache have occurred in British seas. 


\section{Family 101.-RHINODONTID压. (1 Genus, 1 Species.)}

"Sharks with two dorsal fins, the second small, and no nictitating membrane."

Distribution.--South and East Africa.

Family 102.-NOTIDANID E. (1 Genus, 4 Species.)

- "Sharks with one dorsal fin and no nietitating membrane."

Distribution.-Temperate and tropical seas, from the North Atlantic to the Cape of Good Hope and California. One species has occurred on our southern coasts.

FaMily 103.-SCYLLIID E. (7 Genera, 25 Species.)

"Sharks with one dorsal fin and no nictitating membrane."

Disiribution.-All temperate and tropical seas. Species of Scyllium and Pristiurus are British.

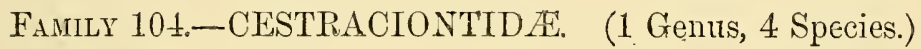

"Sharks with two dorsal fins and no nictitating membrane."

Distribution.-Pacific Ocean from Japan to New Zealand, Moluccan Sea.

Family 105.-SPINACIDE. (10 Genera, 21 Species.)

"Sharks with two dorsal fins and no nictitating membrane, no anal fin."

Distribution.-Arctic, temperate, and tropical seas. Species of Acanthias, Lcemargus, and Echinorhinus have occurred on our coasts. 


\section{Fanily 106--RHINID Æ. (1 Genus, 1 Species.)} fins."

"Sharks with depressed flat body and large expanded pectoral

Distribution.-Temperate and tropical seas, from Britain to California and Australia.

FAmily 107.-PRISTIOPHORID 无. (1 Genus, 4 Species.)

"Sharks with produced flat snout, armed with teeth on each edge."

Distribution.-Seas of Japan and Australia.

$$
\text { Sub-order BatoideI. (Rays.) }
$$

Family 108.-PRISTID $Æ . \quad$ (1 Genus, 5 Species.)

"Rays with produced snout and lateral saw-like teeth."

Distribution.--Seas of tropical and sub-tropical regions.

Family 109.-RHINOBATID E. (3 Genera, 15 Species.)

"Rays with long and strong tail, having a caudal and two dorsal fins."

Distribution.-Tropical and sub-tropical seas.

Family 110.-TORPEDINID Æ. (6 Genera, 15 Species.)

"Rays with broad smooth disc, and an electric organ."

Distribution.-Tropical and temperate seas, from Britain to Tasmania.

Family 111.-RAIID $Æ . \quad(4$ Genera, 29 Species.)

"Rays with broad rhombic disc and no serrated caudal spine."

Distribution.-All temperate and tropical seas. Several species of Raia are found on our coasts. 


\section{Family 112.-TRYGONIDA. (6 Genera, 43 Species.)}

"Rays with the pectoral fins extending to end of snout."

Distribution.- Seas of all temperate and tropical regions, and rivers of Tropical America. A species of Trygon has occurred on our Southern coast. Ellipesurus and Tceniura are found in the fresh waters of the interior of South America, while the latter genus occurs also in the Indian seas, but not in the Atlantic.

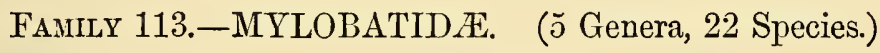

"Rays with very broad pectoral fins not extending to end of snout."

Distribution.-Temperate and tropical seas. A species of Myliobatis is British, but most of the species and genera are confined to tropical seas. Dicerobatis and Cerctoptera are very large Rays, commonly called Sea-devils.

\section{Sub-class V.-CYCLOSTOMATA.}

"Cartilaginous fishes, with suctorial mouths and without lateral fins."

Family 114.-PETROMYZONTIDA. (4 Genera, 12 Species.)

"Marine or fresh-water eel-like fishes, with suctorial mouths and without barbels."

Distribution.-Coasts and fresh waters of temperate regions of both hemispheres. Three species of Petromyzon (Lampreys), are British. 
FAmily 115.-MYXINIDA. (2 Genera, 5 Species.)

"Marino eel-like fishes, with four pairs of barbels."

Distribution.-Seas of the temperate regions of both hemispheres.

\section{Sub-class VI.-LEPTOCARDII.}

\section{Family 116.-CIRRHOSTOMI. (1 Genus, 1 Species.)}

"A small marine fish with no jaws or fins, and with rudimentary eyes."

Distribution.-The only species, the Lancelet (Amphioxus), is the lowest form of living vertebrate. It is found in the temperate regions of both hemispheres, and has occurred on our southern coast.

Remarlus on the Distribution of Fishes.

Marine Fish.-There are about 80 families of marine fishes, and of these no less than 50 are universally, or almost universally, distributed over the seas and oceans of the globe. Of the remainder many are widely distributed, some species even ranging from the North Atlantic to Australia. Six families are confined to the Northem Seas, but four of these consist of single species only, the other two being the Discoboli (2 genera, $11 \mathrm{sp}$.), and the Accipenseridæ (2 genera and 20 sp.). Only one family (Acanthoclinidæ) is confined to the Southern oceans, and that consists of but a single species. Four families (Sternoptychidæ), Stomiatidæ, Alepocephalidæ and Halosauridæ) are confined to the Atlantic Ocean, while 13 are found only in the Pacific; and of the remainder several are more abundant in the Pacific than the Atlantic. Two families (Lycodidre and Gadidæ) are found in the Arctic and Antarctic seas only, though the 
latter family has a single species in the Indian seas. Among the curiosities of distribution are,- - the extensive genus Diagramma, confined to the Pacific with the exception of one species in the Mediterranean ; the single species constituting the family Lophotidæ, found only in the Mediterranean and Japan; the small family of Notacanthi, confined to Greenland, the Mediterranean, and West Australia; and the four families, Sternoptychidæ, Stomiatidæ, Alepocephalidæ, and Halosauridæ, which are believed to inhabit exclusively the depths of the ocean, and are therefore very rarely obtained.

Fresh-water Fish.-There are 36 families of fishes which inhabit fresh water exclusively, and 5 others, which are both marine and fresh-water. These present many interesting peculiarities of distribution. The Neotropical region is the richest in families, and probably also in genera and species. No less than 22 families inhabit it, and of these 6 are altogether peculiar. The Ethiopian and Nearctic regions each have 18 families, the former with 3 , and the latter with 5 peculiar. Several isolated forms, requiring to be placed in distinct families, inhabit the great American lakes; and, no doubt, when the African lakes are equally well known, they will be found also to possess many peculiar forms. The Oriental region comes next, with 17 families, of which 3 are peculiar. The Palæarctic has 12 , and the Australian 11 families, each with only 1 altogether peculiar to it.

If we take those regions which are sometimes supposed to be so nearly related that they should be combined, we shall find the fresh-water fishes in most cases markedly distinct. The Nearctic and Palæarctic regions, for example, together contain 20 families, but only 11 of these occur in both, and only 5 are exclusive inhabitants of these two regions. This shows an amount of diversity that would not, perhaps, be exhibited by any other class of animals. The Ethiopian and Oriental regions together possess 24 families, only 11 of which are found in both, and only 1 exclusively characteristic of the two. The Australian and Neotropical regions possess together 27 families, of which 7 are found in both, and 3 are exclusively characteristic of the two. This last fact is very interesting: the marine family of VOL. II. 
Trachinidæe possessés a fresh-water genus, Aphritis, one species of which inhabits Tasmania, and two others Patagonia; the Haplochitonide (2 genera, $3 \mathrm{sp}$.) are found only in Tierra del Fuego, the Falkland Islands, and South Australia; and the Galaxidæ (1 genus, $12 \mathrm{sp}$.) inhabit the same regions, but extend to Chili, to New Zealand and to Queensland. We have here an illustration of that connection between South America and Australia which is so strongly manifested in plants, but of which there are only scattered indications in most classes of animals. The dividing line across the Malay Archipelago, separating the Oriental from the Australian regions, and which is so strikingly marked in mammalia and birds, is equally so in fresh-water fishes. No less than six families have their eastern limits in Java and Borneo; while the extensive family of Cyprinide has no less than 23 genera in Java and Borneo, but not a single species has been found in Celebes or the Moluccas.

The distribution of fresh-water fishes lends no support to the view that the peninsula of India belongs to the Ethiopian region. A large proportion of the Oriental families are common to the whole region; while there is hardly a single example, of a characteristic Ethiopian family or genus extending into the peninsula of India and no further.

Among the special peculiarities of distribution, is the curious fish, forming the family Comephoridæ, which is confined to Lake Baikal, among the mountains of Central Asia, 2,000 feet above the sea, and a thousand miles distant from the ocean; yet having its nearest allies in the exclusively oceanic family of the mackerels (Scomberidæ). The Characinidæ are confined to Africa and South America, distinct genera inhabiting each region. The Salmonidæ are confined to the two northern regions, except a single species of a peculiar genus in New Zealand. The genus Osteoglossum has a species in South America, another in the Sunda Islands, and a third in Queensland; while the curious Sirenoidei are represented by single species of peculiar genera in Tropical America, Tropical Africa, and Tropical Australia.

Fossil Fishes.-Fishes have existed from a very remote era, and it is remarkable that the first whose remains have been dis- 
covered belong to the Ganoidei, a highly developed group which has continued to exist down to our times, and of which the sturgeon is the best known example. We may therefore be sure that the Upper Silurian rocks in which these are found, although so very far back in geological history, do not by any means lead us to the time when the primitive fish-type appeared upon the earth. In the Carboniferous and Permian formations numerous remains of fishes are found, allied to the Lepidosteus or Gar-pike of North America. The next group in order of appearance, are the Plagiustomata, containing the existing Sharks and Rays. Traces of these are found in the highest Silurian beds, and become plentiful in the Devonian and Carboniferons formations and in all succeeding ages, being especially abundant in Cretaceous and Eocene strata. The Holocephali appear first in the Oolitic period, and are represented by the living Chimæridæ. The Dipnoi, to which belong the Lepidosiren and Ceratodus, are believed to have existed in the Triassic period, from the evidence of teeth almost identical with those of the existing Australian fish. All the ancient fossil fishes belong to the above-mentioned groups, and many of them have little resemblance to existing forms. The Teleostean fishes, which form the great bulk of those now living, cannot be traced back further than the Cretaceous period, while by far the larger number first appear in the Tertiary beds. The Salmonidæ, Scopelidæ, Percidæ, Clupeidæ, Scombresocidæ, Mugilidæ, and Siluridæ, or forms closely allied to them, are found in the Cretaceous formation. In the Eocene beds we first meet with Squammipennes, Cyprinidæ, Pleuronectidæ, Characinidæ, Murænidæ, Gadidæ, Pediculati, Syngnathidæ, and Hippocampidæ.

Most of these fossils represent marine fishes, those of freshwater origin being rare, and of little importance as an aid in determining the causes of the distribution of living forms. To understand this we must look to the various changes of the land surface which have led to the existing distribution of all the higher vertebrates, and to those special means of dispersal which Mr. Darwin has shown to be possessed by all fresh-water productions. 


\section{CHAPTER XXI.}

THE DISTRIBUTION OF SOME OF THE MORE IMPORTANT FAMILIES AND GENERA OF INSECTS.

Aцтнолgн insects are, for the most part, truly terrestrial animals, and illustrate in a very striking manner the characteristic phenomena of distribution, it is impossible here to treat of them in much detail. This arises chiefly from their excessive numbers, but also from the minuteness and obscurity of many of the groups, and our imperfect knowledge of all but the European species. The number of described species of insects is uncertain, as no complete enumeration of them has ever been made; but it probably exceeds 100,000 , and these may belong to somewhere about 10,000 genera-many times more than all vertebrate animals together. Of the eight Orders into which Insects are usually divided, only two-the Coleoptera and Lepidoptera -have been so thoroughly collected in all parts of the globe that they can be used, with any safety, to compare their distribution with that of vertebrate animals; and even of these it is only certain favourite groups which have been so collected. Among Lepidoptera, for example, although the extensive group of Butterflies may be said, in a general sense, to be thoroughly well known-every spot visited by civilized man having furnished its quota to our collections-yet the minute Tineidæ, or even the larger but obscure Noctuidæ, have searcely been collected at all in tropical countries, and any attempt to study their geographical distribution would certainly lead to erroneous results. The same thing occurs, though perhaps in a less degree, among the Coleoptera. While the Carabidæ, Bupresticæ, and 
Longicorns of the Tropics, are almost as well known as those of the Temperate Zones, the Staphylinidæ, the smaller Elateridæ, and many other obscure and minute groups, are very imperfectly represented from extra-European countries. I therefore propose to examine with some care the distribution of the Butterflies, and the Sphingina among Lepidoptera, and the following large and well-known families of Coleoptera :-Cicindelidæ, Carabidæ, Lucanidæ, Cetoniidæ, Buprestidæ, and the three families of Longicorns. These families together contain over 30,000 species, classed in nearly 3,000 genera, and comprise a large proportion of the best known and most carefully studied groups. We may therefore consider, that a detailed examination of their distribution will lead us to results which cannot be invalidated by any number of isolated facts drawn from the less known members of the class.

Range of Insects in Time.-In considering how much weight is to be given to facts in insect distribution, and what interpretation is to be put upon the anomalies or exceptional cases that may be met with, it is important to have some idea of the antiquity of the existing groups, and of the rate at which the forms of insect life have undergone modification. The geological record, if imperfect in the case of the higher animals, is fragmentary in the extreme as regards indications of former insect life; yet the positive facts that it does disclose are of great interest, and have an important bearing on our subject. These facts and the conclusions they lead to have been discussed in our first volume (p. 166), and they must be carefully weighed in all cases of apparent conflict or incongruity between the distribution of insects and that of the higher animals. 
Order-LEPIDOPTERA.

Sub-orde -Lepidoptera Rhopalocera, or Butterflies.

FaMILY 1.-DANAID Æ. (24 Genera, 530 Species.)

\begin{tabular}{|c|c|c|c|c|c|}
\hline \multicolumn{6}{|c|}{ General Distribution. } \\
\hline $\begin{array}{l}\text { NEOTROPICAL } \\
\text { StiB-REGIONS. }\end{array}$ & $\begin{array}{c}\text { NEARCTIC } \\
\text { SUB-REGIONS. }\end{array}$ & $\begin{array}{l}\text { PaLearartic } \\
\text { SUB-IEGIONS. }\end{array}$ & $\begin{array}{c}\text { ETHIOPIAN } \\
\text { SUB-REGIONS. }\end{array}$ & $\begin{array}{c}\text { ORIENTAL } \\
\text { SUB-REGIONS. }\end{array}$ & $\begin{array}{l}\text { AUSTRALIAN } \\
\text { S UB-REGIONS. }\end{array}$ \\
\hline $1.2 \cdot 3 \cdot 4$ & 1.2 .3 .4 & $-2--$ & 1.2 .3 .4 & $1 \cdot 2 \cdot 3 \cdot 4$ & 1.2 .3 \\
\hline
\end{tabular}

The Danaidæ are now held to comprehend, not only the whole of the gooup so named by Doubleday, but a large portion of the Heliconidæ of that author. Their range is thus extended over the whole of the tropical regions. A few species spread northwards into the Palæarctic and Nearctic regions, but these are only stragglers, and hardly diminish the exclusively tropical character of the group. The more remarkable genera are,-Hestia (10 sp.), and Ideopsis (6 sp.), confined to the Malayan and Moluccan districts ; Danais (50 sp.), which has the range of the whole family; Euploea (140 sp.), confined to the Oriental and Australian regions, but especially abundant in the Malayan and Moluccan districts; Hamadryas (4 sp.), Australian region only. The remaining genera constitute the Danaioid Heliconidæ, and are strictly confined to Tropical America, except a few species which "extend into the southern parts of the Nearctic region. The chief of these genera are :-

Ithomia (160 sp.), Melinoa (18 sp.), Napeogenes (20 sp.), Mechanitis (4 sp.), Ceratina (32 sp.), Dircenna (10 sp.), and Lycorea (4 sp.): Florida, Louisiana, and Southern California, mark the northern extent of these insects. 


\section{FAMIly 2.--SATYRIDE. (60 Genera, 835 Species.)}

\begin{tabular}{|c|c|c|c|c|c|}
\hline \multicolumn{6}{|c|}{ General Distribution. } \\
\hline $\begin{array}{l}\text { NFOTROPICAL } \\
\text { StiB-REGIONS. }\end{array}$ & $\begin{array}{c}\text { NEARCTIC } \\
\text { SuB-REGIONS. }\end{array}$ & $\begin{array}{l}\text { Pal-earctic } \\
\text { Sub-regions. }\end{array}$ & $\begin{array}{c}\text { EthIOPIAN } \\
\text { SUB-REGIONS. }\end{array}$ & $\begin{array}{c}\text { ORIENTAL } \\
\text { SUB-REGIONS. }\end{array}$ & $\begin{array}{c}\text { AUstralian } \\
\text { SUB-REGIONS. }\end{array}$ \\
\hline 1.2 .3 .4 & 1.2 .3 .4 & 1.2 .3 .4 & 1.2 .3 .4 & 1.2 .3 .4 & $1.2 \cdot 3 \cdot 4$ \\
\hline
\end{tabular}

This family has an absolutely universal distribution, extending even into the Arctic and Antarctic regions. Many of the genera are, however, restricted in their range.

Hatera, Lymanopoda, Calisto, Corades, Taygetis, Pronophila, Euptychia, and some allied forms (25 genera in all) are Neotropical, the last named extending north to Canada; Debis, Melanitis, Mycalesis and Ypthima, are mostly Oriental, but extending also into the Australian and the Ethiopian regions; Gnaphodes, Leptoneura, and a few other small genera, are exclusively Ethiopian ; Xenica, Hypocista, and Heteronympha, are Australian ; Erebia, Satyrus, Hipparchia, Cononympha, and allies, are mostly Palæarctic, but some species are Ethiopian, and others Nearctic; Chionabas, is characteristic of the whole Arctic regions, but is also found in Chili and the Western Himalayas. The peculiar genera in each region are,-Neotropical, 25; Australian, 7; Oriental, 11; Ethiopian, 5 ; Palæarctic, 3 ; Nearctic, 0.

\section{Family 3.-ELYMNIID Æ. (1 Genus, 28 Species.)}

\begin{tabular}{|c|c|c|c|c|c|}
\hline \multicolumn{6}{|c|}{ General Distribution. } \\
\hline $\begin{array}{l}\text { NEOTROPICAL } \\
\text { SUb-REGIONS. }\end{array}$ & $\begin{array}{l}\text { NEARCTIC } \\
\text { SUB-REGIONS. }\end{array}$ & $\begin{array}{l}\text { PaLEaRCTIC } \\
\text { Sub-REGIONS. }\end{array}$ & $\begin{array}{c}\text { ETHIOPIAN } \\
\text { SUB-REGIONS. }\end{array}$ & $\begin{array}{c}\text { ORIENTAL } \\
\text { SUB-REGIONS. }\end{array}$ & $\begin{array}{l}\text { AUSTRALIAN } \\
\text { SUB-REGIONS. }\end{array}$ \\
\hline--- & ---- & ---- & $-2--$ & --3.4 & $1---$ \\
\hline
\end{tabular}

The genus Elymnias, which constitutes this family, is characteristic of the Malayan and Moluccan districts, with some species in Northern India and one in Ashanti. It thus agrees with several groups of Vertebrata, in showing the resemblance 
of Malaya with West Africa independently of the Peninsula of India.

FAmily 4. MORPHID $\approx$. (10 Genera, 106 Species.)

\begin{tabular}{|c|c|c|c|c|c|}
\hline \multicolumn{6}{|c|}{ Gexeral Distribution. } \\
\hline $\begin{array}{l}\text { Neotropical } \\
\text { Sub-REgians. }\end{array}$ & $\begin{array}{c}\text { NEARCTIC } \\
\text { SUB-REGIONS. }\end{array}$ & $\begin{array}{l}\text { PALAARCTIC } \\
\text { SUB-REGIONS. }\end{array}$ & $\begin{array}{l}\text { ETHIOPIAN } \\
\text { SUB-REGIONS. }\end{array}$ & $\begin{array}{c}\text { ORIENTAL } \\
\text { SUB-REGIONS. }\end{array}$ & $\begin{array}{l}\text { AUSTRALIAN } \\
\text { SUB-REGIONS. }\end{array}$ \\
\hline$-2 \cdot 3-$ & $-\cdots-$ & $-\cdots$ & --- & --3.4 & $1-3-$ \\
\hline
\end{tabular}

The Morphidæ are a group of generally large-sized butterflies, especially characteristic of the Malayan and Moluccan districts, and of Tropical America; with a few'species extending to the Himalayas on the west, and to Polynesia on the east. The genera are :-

Amathusia (6 sp.), Northern India to Java ; Zeuxidia (9 sp.), the Malay district; Discophora (7 sp.), Northern India to Philippines, Java and Timor; Enispe (3 sp.), Northern India; Hyades (15 sp.), Moluccan and Polynesian districts, except one species in Java; Clerome (11 sp.), Northern India to Philippines and Celebes ; AEmona (1 sp.), Sikhim ; Hyantis (1 sp.), Waigiou; Thaumantis (10 sp.), Indo-Chinese and Malayan districts; Morpho (40 sp.), Neotropical region, Brazilian and Central American sub-regions.

Family 5. BRASSOLID $\nexists$. (7 Genera, 62 Species.)

\begin{tabular}{|c|c|c|c|c|c|}
\hline \multicolumn{6}{|c|}{ Generai Distribution. } \\
\hline $\begin{array}{l}\text { NEOTROPICAL } \\
\text { SUB-REGIONS. }\end{array}$ & $\begin{array}{c}\text { NEARCTIC } \\
\text { SUB-REGIONS. }\end{array}$ & $\begin{array}{l}\text { PALAfarctic } \\
\text { SUB-hEGions. }\end{array}$ & $\begin{array}{c}\text { ETHIOPIAN } \\
\text { SuB-REGIONS. }\end{array}$ & $\begin{array}{c}\text { ORIENTAL } \\
\text { SuB-REGIONS. }\end{array}$ & $\begin{array}{l}\text { AUSTRALIAN } \\
\text { SUB-REGIONS. }\end{array}$ \\
\hline$-2.3-$ & ---- & --- & ---- & ---- & --- \\
\hline
\end{tabular}

The Brassolidæ have the same distribution as the genus Morpho. The genera are :-

Brassolis (5 sp.); Opsiphanes (17 sp.); Dynastor (2 sp.); Penetes (1 sp.); Caligo (21 sp.); Narope (5 sp.); and Dasyopthalma (3 sp.) 
FaMily 6.-ACR EID E. (1 Genus, 90 Species.)

\begin{tabular}{|c|c|c|c|c|c|}
\hline \multicolumn{6}{|c|}{ General Distribution. } \\
\hline $\begin{array}{l}\text { NFOtROPICAL } \\
\text { Stib-REGIONS. }\end{array}$ & $\begin{array}{l}\text { NEARCTIC } \\
\text { SUB-REGIONS. }\end{array}$ & $\begin{array}{l}\text { Palearctic } \\
\text { Sub-IiEgions. }\end{array}$ & $\begin{array}{l}\text { ETHIOPIAN } \\
\text { SUB-REGIONS. }\end{array}$ & $\begin{array}{l}\text { ORIENTAL } \\
\text { SUB-REGIONS. }\end{array}$ & $\begin{array}{l}\text { AUSTRALIAN } \\
\text { SUB-REGIONS. }\end{array}$ \\
\hline$--2 \cdot 3$ & --- & --- & 1.2 .3 .4 & 1.2 .3 .4 & $1.2--$ \\
\hline
\end{tabular}

The genus Acrcea is especially abundant in the Ethiopian region, which contains two-thirds of all the known species; 3 or 4 species only, range over the whole Oriental, and most of the Australian regions; while all the rest inhabit the same districts of the Neotropical region as the Brassolidæ.

\section{FaMiLY 7.-HELICONID \&. (2 Genera, 114 Species.)}

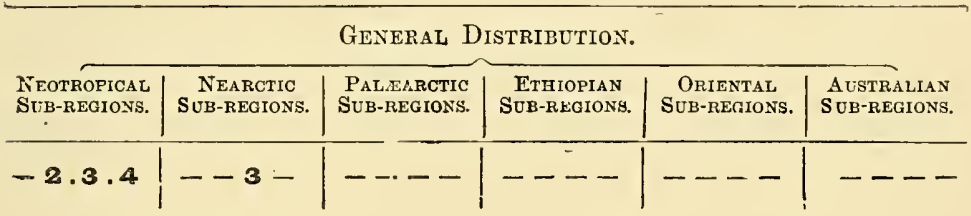

The true Heliconidæ are very characteristic of the Neotropical region; one species only extending into the Southern States of North America as far as Florida. The genus Heliconius (83 sp.), has the range of the family; while Eueides (19 sp.), is confined to the Brazilian and Central American sub-regions.

FAMily 8.-NYMPHALID Æ. (113 Genera, 1490 Species.)

\begin{tabular}{|c|c|c|c|c|c|}
\hline \multicolumn{6}{|c|}{ General Distribution. } \\
\hline $\begin{array}{l}\text { NEOTROPICAL } \\
\text { SUB-REGIONS. }\end{array}$ & $\begin{array}{c}\text { NEARCTIC } \\
\text { SUB-REGIONS. }\end{array}$ & $\begin{array}{l}\text { PaLFaRCTIC } \\
\text { SUB-REGIONS. }\end{array}$ & $\begin{array}{c}\text { ETHIOPIAN } \\
\text { SUB-REGIONS. }\end{array}$ & $\begin{array}{c}\text { ORIENTAL } \\
\text { SUB-REGIONS. }\end{array}$ & $\begin{array}{l}\text { AOSTRALIAN } \\
\text { SUB-REGIONS. }\end{array}$ \\
\hline 1.2 .3 .4 & $1.2 .3 \cdot 4$ & 1.2 .3 .4 & 1.2 .3 .4 & $1.2 .3 \cdot 4$ & 1.2 .3 .4 \\
\hline
\end{tabular}

This is the largest and most universally distributed family of butterflies, and is well illustrated by our common Fritillaries, 
Tortoise-shell, Peacock, Painted Lady, and Purple Emperor butterflies. They are found wherever butterfly-life can exist, and some single species-like the Painted Lady (Pyrameis cardui)-range almost over the globe. A few of the more extensive and remarkable genera only, can be here noticed:-

Colonis, Agraulis, Eresia, Synchloe, Epicalia, Eunica, Eubagis, Catagramma, Callithea, Ageronia, Timetes, Heterochroa, Prepona, Hypna, Paphia, and Siderone, are wholly Neotropical, as well as many others which have a smaller number of species. Euryphene, Romaleosoma, Aterica, and Harma, are exclusively Ethiopian. Terinos, Athyma, Adolias, and Tancecia, are Oriental, but they mostly extend into the Moluccan region; the last however is strictly Malayan, and Adolias only reaches Celebes. Mynes alone, is exclusively Australian, but Prothoe is almost so, having only one outlying species in Java. Eurytela and Ergolis are confined to the Oriental and Ethiopian regions, but the latter reaches the Moluccas. Cethosia, Cirrhochroa, Messaras, and Symphcedra, are both Oriental and Australian; while Junonia, Cyrestis, Diadema, Neptis, and Nymphalis, are common to the three tropical regions of the Fastern Hemisphere, the latter extending into the Mediterranean district, while Junonic occurs also in South America and the Southern United States.

The most cosmopolitan genus is Pyrameis, which has representatives in every region and every district. Apatura is found in all but the Ethiopian and the Australian, although it just enters the confines of the latter region in Celebes; Limenitis is abundant in the Oriental region, but extends eastward to Celebes and westward into Europe, North America, and even into South America. Argynnis, Melitoca, and Vanessa, are almost confined to the Palæarctic and Nearctic regions; the former however occurs in the Himalayas and in the mountains of Java, and also in Chili and in Jamaica. Two genera-Dicrorrhagia and Helcyra-have both one species in North India and another in the island of Ceram. The number of genera peculiar to each region is as follows:-Neotropical, 50; Australian, 2 ; Oriental 15 ; Ethiopian, 14 ; Palæarctic, 1; Nearctic, 0. 
Fanily 9.-LIBYTHeId $2 . \quad$ (1 Genus, 10 Species.)

\begin{tabular}{|c|c|c|c|c|c|}
\hline $\begin{array}{l}\text { NEOTROPICAL } \\
\text { SUB-REGTONS. }\end{array}$ & $\begin{array}{c}\text { NEARCTIC } \\
\text { SUB-REGIONS. }\end{array}$ & $\begin{array}{l}\text { PALEARCTIC } \\
\text { SUUB-REGIONS. }\end{array}$ & $\begin{array}{l}\text { ETHIOPIAN } \\
\text { SUB-REGIONS. }\end{array}$ & $\begin{array}{l}\text { ORIENTAL } \\
\text { SUB-EEGIONS. }\end{array}$ & $\begin{array}{l}\text { AUSTRALIAN } \\
\text { SUB-RELIOONS. }\end{array}$ \\
\hline $2--4$ & $-2 \cdot 3-$ & $12 \ldots$ & $-2-4$ & 1.2 .3 .4 & $1---$ \\
\hline
\end{tabular}

The genus Libythea, which constitutes this family, appears to have its head-quarters in the Oriental region, but extends on all sides in an erratic manner, into various remote and disconnected portions of the globe, as indicated above.

FAMILY 10.-NEMEOBIID \&. (12 Genera, 145 Species.)

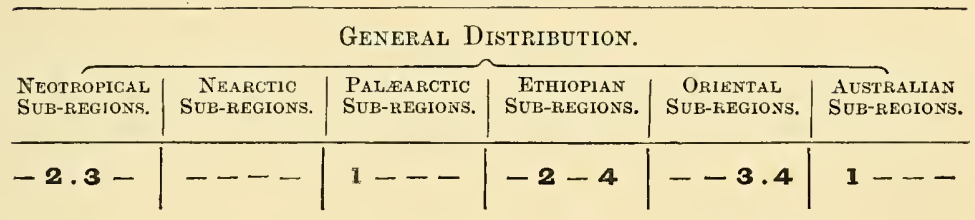

This group has been separated from the Erycinidæ of the older authors, and contains all the non-American genera and species. Half the genera and nearly four-fifths of the species of this group are, however, Neotropical; one is European; two or three African; and twenty-six Oriental and Australian. The genera are :-

Nemeotius (1 sp.), Europe; Dodona (6 sp.), North India; Zemeros (2 sp.), North India and Malaya; Abisara (11 sp.), North India, Malayan and Moluccan districts, Madagascar and West Africa; Taxila (8 sp.), North India and Malaya; Dicallaneura (2 sp.), Moluccan district; Alesa (6 sp.), Eunogyra (2 sp.), Cremna (7 sp.), Bocotis (3 sp.), are all from the Brazilian sub-region; Eurybia (10 sp.), Mesosemia (80 sp.), inhabit both the Brazilian and Mexican sub-regions. 
Family 11.-EURYGONID E. (2 Genera, 78 Species.)

\begin{tabular}{|c|c|c|c|c|c|}
\hline \multicolumn{6}{|c|}{ General Distribution. } \\
\hline $\begin{array}{l}\text { NEOTROPICAL, } \\
\text { SUB-REGIONS. }\end{array}$ & $\begin{array}{c}\text { NEARCTIC } \\
\text { SUB-REGIONS, }\end{array}$ & $\begin{array}{l}\text { PALAARCTIC } \\
\text { SUB-hEOIONS. }\end{array}$ & $\begin{array}{c}\text { EThIOPIAN } \\
\text { SUB-KEGIONG. }\end{array}$ & $\begin{array}{c}\text { ORIENTAL } \\
\text { SUB-KEOIONS. }\end{array}$ & $\begin{array}{l}\text { AUSTRALIAN } \\
\text { SUB-REOIONS. }\end{array}$ \\
\hline$-2.3-$ & ---- & ---- & --- & ---- & $-\cdots-$ \\
\hline
\end{tabular}

This small family, separated from the true Erycinidæ by Mr. Bates, is confined to the tropical forest-districts of continental America. The genera are :-

Eurygona (71 sp.); Methonella (1 sp.); the latter found in Equatorial South America.

\section{FAmily 12.-ERYCINID \&. (59 Genera, 560 Species.)}

\begin{tabular}{|c|c|c|c|c|c|}
\hline \multicolumn{6}{|c|}{ General Distribution. } \\
\hline $\begin{array}{l}\text { NEOTROPical } \\
\text { Stib-REgIONS. }\end{array}$ & $\begin{array}{c}\text { NEARCTIC } \\
\text { SUB-REGIONS. }\end{array}$ & $\begin{array}{l}\text { PaLAaARCTIC } \\
\text { SUB-REGIONS. }\end{array}$ & $\begin{array}{c}\text { ETHIOPIAN } \\
\text { SUB-KEGIONS. }\end{array}$ & $\begin{array}{l}\text { ORIENTAL } \\
\text { SUR-REGIONS. }\end{array}$ & $\begin{array}{l}\text { Australian } \\
\text { SUB-REGIONS. }\end{array}$ \\
\hline-2.3 .4 & 1.2.3- & ---- & ---- & ---- & --- \\
\hline
\end{tabular}

This extensive family of small, but exquisitely beautiful butterflies, is especially characteristic of the virgin forests of the Neotropical region, only a few species of three genera extending into the Nearctic region. The more important genera, and those which have an exceptional distribution, can alone be here noticed. Charis extends from Brazil to New York; Apodemia from Brazil to California, Utah, and Oregon; Amarynthis inhabits the Brazilian and Antillean sub-regions; Lepricornis and Metapheles are small genera found only in the Mexican sub-region ; Lymnas, Necyria, Ancyluris, Diorhina, Esthemopsis, Anteros, Emesis, Symmachia, Cricosoma, Calydna, Lemonias, Nymphidium, Theope, and Aricoris are common to the Brazilian and Mexican sub-regions. All the other genera (40 in number) are only known from the Brazilian sub-region, and of these a considerable proportion are confined to the damp equatorial forests of the Amazon Valley. 


\section{Family 13.-LYCANID \&. (39 Genera, 1,220 Species.)}

\begin{tabular}{|c|c|c|c|c|c|}
\hline \multicolumn{6}{|c|}{ General Distribution. } \\
\hline $\begin{array}{l}\text { NEOTROPICAL } \\
\text { SUB-REGIOAS. }\end{array}$ & $\begin{array}{l}\text { NEARCTIC } \\
\text { SUB-REGIONS. }\end{array}$ & $\begin{array}{l}\text { PAL_EARCTIC } \\
\text { SUB-REGIONS. }\end{array}$ & $\begin{array}{l}\text { ETHIOPIAN } \\
\text { SUB-REGIONS. }\end{array}$ & $\begin{array}{l}\text { ORIENTAL } \\
\text { SUB-REGIONS. }\end{array}$ & $\begin{array}{l}\text { AUSTRALIAN } \\
\text { SUB-REGIONS. }\end{array}$ \\
\hline 1.2 .3 .4 & 1.2 .3 .4 & 1.2 .3 .4 & 1.2 .3 .4 & 1.2 .3 .4 & 1.2 .3 .4 \\
\hline
\end{tabular}

The Lycænidæ—of the variety and beauty of which in tropical regions our own "Blues" and "Coppers" give but a faint idea -are a group of universal distribution. We shall therefore indicate those genera which are restricted to one or more regions, or are mearly cosmopolitan. The large genus Polyommatus (containing 325 species) has the same universal distribution as the entire family. Our common "Blues" well represent this genus. Lycena (comprising the "Coppers") is more especially characteristic of the Palæaretic and Nearctic regions, but straggling species occur also in North India, South Africa, Chili, and New Zealand. Thccla is especially characteristic of the Neotropical region, where there are about 370 species; in the Nearctic region, 36; in the Palæarctic 13; and in the Ethiopian 3. Miletus, Lucia, Hypolyccena, Myrina, and Deudorix are common to the three tropical regions of the Eastern Hemisphere-the Ethiopian, Oriental, and Australian. Aphneus and Iolaus are common to the Ethiopian and Oriental regions, the latter extending to Celebes. Ialmonus, Pseudocipsas, Curetis, and Amblypodia are common to the Oriental and Australian regions, but the first-named is found also in Madagascar. Zephyrus is found only in the Nearctic and Palæarctic, Eumcens in the Nearctic and Neotropical regions. The Nearctic region has one peculiar genus (Fenisece); the Palæaretic has two-Thestor and Lceosopis; the Ethiopian has nine-Pentila, Liptana, D'Urbania, Axiocerces, Capys, Phytala, Epitola, Hewitsonia, and Deloneura; the Oriental has five-Allotinus, Ilerda, Poritia, Camena, and Liphyra; the Australian has three-Hypochrysops, Utica, and Ogyris; and the Neotropical also three-Lamprospilus, Thcorema, and Trichonis. 
Family 14.-PIERID瓜. (35 Genera, 817 Species.)

\begin{tabular}{|c|c|c|c|c|c|}
\hline \multicolumn{6}{|c|}{ General Distribution. } \\
\hline $\begin{array}{l}\text { NEOTROPIOAL } \\
\text { SUB-REGIONS. }\end{array}$ & $\begin{array}{c}\text { NEARCTIC } \\
\text { SUB-REGIONS. }\end{array}$ & $\begin{array}{l}\text { Palfanctic } \\
\text { SUb-hEglons. }\end{array}$ & $\begin{array}{l}\text { ETUIOPIAN } \\
\text { SUB-REGIONS. }\end{array}$ & $\begin{array}{c}\text { ORIENTAL } \\
\text { SuB-REGIONS. }\end{array}$ & $\begin{array}{l}\text { Australian } \\
\text { Sub-REgions. }\end{array}$ \\
\hline $1.2 .3 \cdot 4$ & 1.2 .3 .4 & 1.2 .3 .4 & 1.2 .3 .4 & 1.2 .3 .4 & $1.2 .3-$ \\
\hline
\end{tabular}

The Pieridæ are distributed almost, if not quite, as widely over the globe as the last family, and we shall group the genera in the same manner. Pieris (130 sp.) is cosmopolitan; Terias and Callidryas are found in all the four tropical regions, and as far north as Pennsylvania in the Nearctic region; Pontia, Tachyris, Eroxia, and Thestias are common to the Ethiopian, Oriental, and Australian regions, the last-named, however, only extending as far as Timor; Colias is pre-eminently Palæarctic and Nearctic, with a few Ethiopian species, one Indian, two in Chili, and one in the Sandwich Islands; Anthocharis is wholly Palæarctic and Nearctic; Midea has two species Nearctic, and one in Japan; Gonepteryx is Palæarctic and Neotropical, extending into Texas; Idmais and Callosune are Ethiopian and Oriental; Thyca and Iphias are Oriental and Australian; Meganostoma is Nearctic and Neotropical; $\mathrm{Na}$ thalis and Kricogonia are Neotropical, ranging into Florida, Texas, and Colorado.

The peculiar genera are pretty equally distributed. The Neotropical region has ten, two being confined to Chili; Euterpe and Leptalis are the most remarkable, the latter containing a number of forms mimicking the Heliconidæe and Danaidæ. The Oriental region has two, Prioneris and Dercas; the Australian one, Elodina; the Ethiopian two, Teracolus and Pseudopontia; the Palæarctic two, Lencophasia and Zegris; the Nearctic one, , Neophasia. 
Family 15.-PAPILIONIDE. (13 Genera, 455 Species.)

\begin{tabular}{|c|c|c|c|c|c|}
\hline \multicolumn{6}{|c|}{ General Distribution. } \\
\hline $\begin{array}{l}\text { NEOTROPICAL } \\
\text { SUB-REGIOAS. }\end{array}$ & $\begin{array}{c}\text { NEARCTIC } \\
\text { SUB.REGIONS. }\end{array}$ & $\begin{array}{l}\text { PALAaRctic } \\
\text { SUB-REGIONS. }\end{array}$ & $\begin{array}{c}\text { ETHIOPIAN } \\
\text { SUB-REGIONS. }\end{array}$ & $\begin{array}{c}\text { ORIENTAL } \\
\text { SUB-REGIONS. }\end{array}$ & $\begin{array}{l}\text { AUSTRALIan } \\
\text { SUb-REgIONS. }\end{array}$ \\
\hline 1.2 .3 .4 & $1.2 .3 \cdot 4$ & 1.2 .3 .4 & 1.2 .3 .4 & 11. $2.3 \cdot 4$ & 1.2 .3 .4 \\
\hline
\end{tabular}

The Papilionidæ, comprising many of the noblest and richestcoloured butterflies, and long placed at the head of the group, are almost as universally distributed as the Pieridæ, but they do not extend to so many remote islands nor so far into the Arctic and Antarctic regions. Nine-tenths of the species belong to the genus Papilio, and these are especially abundant in tropical regions, although species occur in every region and every subregion. Well-marked sub-divisions of this large genus are characteristic of each great region-as the " Eneas" group in the Neotropical, the "Paris" group in the Oriental, the "Egeus" group in the Australian, the "Zenobius" group in the Ethiopian, and many others. The few species of the Palæarctic region belong, on the other hand, to a group of universal distribution, and the Nearctic has a good number of species allied to Neotropical forms.

The other genera have mostly a very restricted range. Parnassius is an Alpine genus, confined to the Palæarctic and Nearctic regions. The Palæarctic region further possesses 5 peculiar genera-Mesapia, Hypermnestra, Doritis, Sericinus, and Thais; the Oriental has 4, Calinaga, Teinopalpus, Bhutanitis, and Leptocircus, the latter going as far as Celebes; the Australian has 1, Eurycus; and the Neotropical 1, Euryades, confined to the Chilian sub-region. The Ethiopian and the Nearctic regions have no peculiar genera. 


\section{FAMILY 16.-HESPERIDE. (52 Genera (?), 1,200 Species.)}

\begin{tabular}{|c|c|c|c|c|c|}
\hline \multicolumn{6}{|c|}{ General Distribution. } \\
\hline $\begin{array}{l}\text { NEOTROPICAL } \\
\text { SUB-REGIONS. }\end{array}$ & $\begin{array}{l}\text { NeARCTIC } \\
\text { SUB-REGIONS. }\end{array}$ & $\begin{array}{l}\text { PALEARCTIC } \\
\text { SUB-HEGIONS. }\end{array}$ & $\begin{array}{l}\text { ETHIOPIAN } \\
\text { SUB-REGIONS. }\end{array}$ & $\begin{array}{c}\text { ORIENTAL } \\
\text { SUB-REGIONS. }\end{array}$ & $\begin{array}{l}\text { AUSTRALIAN } \\
\text { SUB-REGIONS. }\end{array}$ \\
\hline 1.2 .3 .4 & 1.2 .3 .4 & 1.2 .3 .4 & 1. 2.3 .4 & 1.2 .3 .4 & $1.2 .3 \cdot 4$ \\
\hline
\end{tabular}

The Hesperidæ, or Skippers, are an immense group of mostly small obscurely coloured butterflies, universally distributed, and of which hosts of species still remain to be discovered and described. As the grouping of these into genera is not yet satisfactorily accomplished, only the more extensive and best known groups will be here noticed. Pamphila and Hesperia are universally distributed; Nisoniádes seems to be only absent from the Australian region. The Neotropical region is preeminently rich in Hesperidæ, 33 genera being found there, of which 20 are peculiar to it; the Australian region has 12 genera, only 1 (Euschemon) being peculiar; the Oriental has 18, with 3 peculiar; the Ethiopian, 13, with 3 peculiar; the Palæarctic 6, with 1 (Erynnis) almost peculiar, a species occurring in Mexico; the Nearctic 9, with none peculiar, 4 being found also in the Neotropical region, 2 in the Palæarctic, and the rest being of wide distribution. Many new genera have, however, been recently described in the United States, but it is impossible yet to determine how many, if any, of these are peculiar. More than 100 species of the family are included in Mr. Edwards' "Synopsis of North American Butterflies,"-a very large number considering that Europe possesses only about 30 . 
Sub-order-Lepidoptera Heterocerd, or Moths.

The Lepidoptera Heterocera, or Moths, are of -such immense extent, and are, besides, so imperfectly known compared with. the Butterflies, that it would serve no purpose to go into the details of their distribution; especially as most of the families and a considerable number of the genera are cosmopolitan. We propose therefore to notice only the Sphingina, which, being generally of large size and finely marked or coloured, and many of them day-fliers, have been extensively collected; and whose numbers are more manageable than the succeeding groups.

\section{Group I.-SPHINGINA.}

Family 17-ZYGANID 24 (46 Genera, about 530 Species).

The Zygænidæ are universally distributed, but many of the genera are restricted in their range. Zygcena $(85 \mathrm{sp}$.) is mainly Palæarctic, but 2 species are South African, and 1 North American; Procris (22 sp.) has a scattered distribution, from the Palæarctic region to South America, South Africa and North India ; Heterogynis (3 sp.) and Dyscuxis (3 sp.) are European; Pollenisus (3 sp.) is Australian; Glaucopis (120 sp.) is mainly Neotropical, with a few Oriental; Syntomis (94 sp.) is found in all the Old-World regions; and Euchromia (150 sp.) is found in all warm countries, though especially abundant in South America.

\section{Family 18.-CASTNIDD E (7 Genera, 63 Species):"}

The Castniidæ have an interesting distribution, being. mainly Neotropical, with four genera in Australia and New Guinea. Custniu, Coronis, and Gazera, with 51 species, are Neotropical ; Synemon, Euschemon, Damias and Cocytia, with 12 species, are Australian, the litter being found only in the Papuan Islands.

VOL. II. 


\section{Family 19.-AGARISTID $\approx$ (13 Genera, 76 Species).}

The Agaristidx are beautiful diurnal moths, allied to the Castniidæ, but almost confined to the Australian and Oriental regions, with a few in the Ethiopian. The most important genera are,-Agarista (21 sp.), Australia and New Guinea ; Eusemia (3L sp.), EEocerc (7 sp.), Oriental and Ethiopian regions; the other genera being confined to the islands from Java to New Guinea.

\section{Family 20.-URANIID $\mathbb{E}$ (2 Genera, 12 Species).}

These magnificent insects have a singular distribution. The gold-spangled Uranica (6 sp.) is characteristic of Tropical America, but a singie species of great magnificence occurs in Madagascar. The large but sober-tinted $N^{\text {yctalemon }}$ (6 sp.) is found in the Neotropical, Oriental, and Australian regions.

\section{FAMILY 21.-STYGIIDÆ. (3 Genera, 14 Species.)}

These insects are confined to the Palrarctic and Neotropical regions, 2 genera in the former, 1 in the latter.

\section{FAMILY 22-—EGERIIDÆ. (24 Genera, 215 Species.)}

This family is found in all parts of the world except Australia. Egeria is most abundant in Europe, but is found also in North and South America.

\section{Family 23.-SPHINGID $\mathbb{E} . \quad$ (40 Genera, 345 Species.)}

The Sphinx Moths are cosmopolitan. The most important genera are,-Hiacroglossa (26 sp.), Chorocampa (46 sp.), and Macrosila (21 sp.), all cosmopolitan ; Sesia (12 sp.), Europe, Asia, and North America; Deilephila (19 sp.), Palæaretic and Oriental regions, Nearctic region, and Chili; SIlinx (21 sp.), Europe, 
North and South America; Smrrinthus (27 sp.), all regions except Australia. Our Daath's Head Moth (Acherontia atropos) rauges to Sierra Leone and the Philippine Islands.

\section{General Remarks on the Distribution of the Diurnal Lepidoptera and Sphingidea.}

The Diurnal Lepidoptera or Butterflies, comprehend 431 genera and 7,740 species, arranged in 16 families, according to Mr. Kirby's Catalogue pubished in 1871. The Sphingidea consist of 135 genera and 1,255 species, arranged in 7 families, according to the British Museum Catalogue dated 1864; and as this includes all Mr. Bates' collections in America and my own in the East, it is probable that no very large additions have since been made.

The distribution of the families and genera of Butterflies corresponds generally with that of Birds-and more especially with that of the Passerine birds - in showing a primary division of the earth into Eastern and Western, rather than into Northern and Southern landș. The Neotropical region is by far the richest and most peculiar. It possesses 15 families of butterflies, whereas the other regions have only from 8 , in the Palæarctic, to 12 in the Ethiopian and Oriental regions; and as none of the old World regions possess any peculiar families, the New World has a very clear superiority. In genera the preponderance is still greater, since the Neotropical region possesses about 200 altogether peculiar to it, ont of a total of 431 genera, many of which are cosmopolitan. Comparing, now, the Eastern regions with the Western, we have two peculiar families in the former to 4 in the latter; while the Southern regions (Australian and Neotropical) possess not a single peculiar family in common.

In the Sphingidea the same general features recur in a less marked degree, the Neotropical being the richest region; but here we have one family (Castniidæ) which appears to be confined to the two southern regions,-the Australian and Neotropical.

The distribution of the genera affords us some facts of special iuterest, which must be briefly noticed. There are several 
genera typically characteristic of the North Temperate regions which have a few species widely scattered on mountains, or in the temperate parts of the Southern Hemisphere. Chili possesses representatives of four of these genera-Argynnis, Lyccena, Colias, and Dcilcphila; and this has been thought by some naturalists to be of such importance as to outweigh the purely Neotropical character of a large portion of the Chilian fauna, and to render it advisable to join it or, as an outlying portion of a great North Temperate zoological region. But when we renember that Argynnis occurs also in Java, and Lycana in New Zealand, while Colias ranges to Southern Africa, Malabar, and the Sandwich Islands, we can hardly admit the argument to be a sound one. For a fuller discussion of this question see Vol. II., pp. $43-47$. The remarkable fact of the existence of the otherwise purely Neotropical genus, Urania, in Madagascar is even more striking, supported as it is by the Antillean, Solenedon, belonging to a family of Mammalia otherwise confinea to Madagascar, and by one or two Coleopterous genera, to be noticed farther on as common to the two countries. Our view as to the true explanation of this and analogous phenomena will be found at Vol. I., p. 284.

The division of the Castniidæ (a family almost confined to the Tropics), between the Neotropical and Australian regions, is also a very curious and important phenomenon, because it seems to point to a more remote connection between the two countries than that indicated by the resemblance between the productions of South Temperate America with those of Australia and New Zealand; but we have already shown that the facts may be explained in another way. (See Vol. I., pp. 398 and 404).

The division of the Malay Archipelago between the Oriental and Australian regions is clearly marked in the Lepidoptera, and it is very curious that it should be so, for in this, if in any group of animals, we should expect an almost complete fusion to have been effected. Lepidoptera fly readily across wide tracts of sea, and there is absolutely no climatal difference to interfere with their free migration from island to island. Yet we find no less than 10 genera abundant in the Indo-Malayan 
sub-region which never cross the narrow seas to the east of them; 6 others which only pass to Celebes; and 2 more which have extended from Java along the closely connected line of islands eastwards to Timor. On the other side, we find 5 strictly Austro-Malayan genera, and 2 others which have a single representative in Java. The following is a list of these genera:-

Indo-Malayan Gexera :-Amathusia, Thaumantis, Tanacia, Eurytela, Ilerda, Zemeros, Taxila, Aphneus, Prioneris, Dercas, Clerome, Adolias, Apatura, Limenitis, Iolaus, Leptocircus, (the last six reach Celebes); Discophora, Thestias; (the last two reach Timor.)

Austro-Malayan Genera:-Hamadryas, Hypocista, Myncs, Dicallancura, Elodina, Hyades, Prothoë (the last two reach Java).

The most characteristic groups, which range over the whole Archipelago and give it a homogeneous character, are the various genera of Danaidæ, the genus Elymnias, and Amblypodia with a few other Lycænidæ. These are all abundant and conspicuous groups, but they are nevertheless exceptions to the general rule of limitation to one or other of the regions. The cause of this phenomenon is probably to be found in the limitation of the larvæ of many Lepidoptera to definite species, genera, and families of plants; and we shall perhaps find, when the sulject is carefully investigated, that the groups which range over the whole Archipelago feed on genera of plants which have an equally wide range, while those which are limited to one region or the otber, have foodplants belonging to genera which are similarly limited. It is known that the vegetation of the two regions differs largely in a botanical sense, although its general aspect is almost identical; and this may be the reason why the proportion of wide-ranging genera is greater among such insects as feed upon dead wood, than among those which derive their support from the juices of the living foliage. This subject will be again discussed under the various fanilies of Coleoptera, and it will be well to bear in mind the striking facts of generic limitation which have been here brought forward. 
Fossil Butterties, apparently of existing genera, occur in the Miocene and Eocene formations, and an extinct form in the Lower Oolite; but these cannot be held to give any adequate idea of the antiquity of so highly specialised a group, which, in all probability, dates back to Palrozoic times, since one of the Bombycidre,-a gromp almost as highly-organised-has been discovered in the coal formation of Belgium. (See Vol. I. p. 168.)

\section{Order-COLEOPTERA.}

\section{Geonephaga, or Carinivorous Ground Beetles.}

The Geodephaga consist of two families, Cicindelidæ and Carabidæ, differing in their form and habits no less than in their numbers and distribution. The former, comprising about 800 species, are far more abundant and varied in Tropical regions; the latter, mole than ten times as numerous, are highly characteristic of the North $T$ tmperate zone, where fully half of all the known species occur.

\section{CICINDELID $A . \quad$ (35 Genera, 803 Species.)}

The Cicindelidx, or Tiger Beetles, are a moderately extensive group, spread over the whole globe, but much more abundant in tropical than in temperate or cold countries. More than half of the species (418) belong to the single genus Cicindela, the only one which is cosmopolitan. The other large genera are,Collyris (81 sp.), wholly Oriental ; Odontochile (57 sp.), South American, with species in Java and Celebes; Tetracha (46 sp.), mostly South American, but with species in South Europe, North America, and Australia ; Tricondyla (31 sp.), characteristic of the Oriental region, but extending eastward to New Guinea; Ctenostoma (26 sp.), wholly Neotropical; Iromica (24 sp.), wholly African, sonth of Lake Ngami and Mozambique; Therates (18 sp.), wholly Malayan, from Singapore to New Guinea.

The genera are distributed in the several regions as follows:tl.e Nearctic region las 5 genera, 3 of $w$ hich are peculiar to it; the 
Palæarctic has 2, but none peculiar; the Ethiopian 13, with 11 peculiar ; the Oriental 8 , with 3 peculiar; the Australian 9, with 2 peculiar; and the Neotropical 15, with 10 peculiar. The connection between South America and Australia is shown by the latter country possessing 9 species of the characteristic South American genus Tetracha, as well as one of Megacephala. The small number of peculiar genera in the Oriental and Australian regions is partly owing to the circumstance that two otherwise peculiar Oriental genera have spread eastward to the Moluccas and New Guinea, a fact to be easily explained by the great facilities such creatures have for passing narrow straits, and by the almost identical physical conditions in the Malayan portion of the two regions. The insects of Indo-Malaya were better adapted to live in the Austro-Malay Islands than those of Australia itself, and the latter group of islands have thus acquired an Oriental aspect in their entomology, though not without iudications of the presence of an aboriginal insect-fauna of a strictly Australian type. The relation of the Australian and Neotropical regions is exhibited by this family in an unusually distinct manner. Tetracha, a genus which ranges from Mexico to La Plata, has 9 species in Austrälia; while Megacephala has 2 American and 1 Australian species. Another curious, and more obscure relation, is that between the famas of Tropical Anerica and Tropical Africa. This is also illustrated by the genus Megacephala, which has 4 African species as well as 2 South American; and we have also the genus Peridexia, which has 2 species in South America and 2 in Madagascar.

Several of the sub-regions are also well characterised by peeuliar genera; as Aniblychila and Omus confined to Callifornia and the Rocky Mountains; Manticora, Ophryodera, Platychile and Dromica, characteristic of South Africa; Mcgalomma and Pogonostoma peculiar to the Mascarene Islands; and Caledonicr to the islands east of New Guinea. The extensive and elegant gemus Collyris is highly characteristic of the Oriental region, orer the whole of which it extends, only just passing the limits into Celebes and Timor.

The Cicindelidæ, therefore, fully conform to those divisions of 
the earth which have been found best to represent the facts of distribution in the higher animals.

\section{CARABIDA. (620 Genera, 8500 Species.)}

The enormous extent of this family, necessitates a somewhat general treatment. It has been very extensively collected, while its classification has been most carefully worked ont, and a detailed exposition of its geographical distribution by a competent entomologist wonld be of the greatest interest. A careful study of Gemminger and Harold's Catalogue, however, enables me to sketch out the main features of its distribution, and to detail many of its peculiarities with considerable accuracy.

The Carabidre are remarkable among insects, and perhaps among all terrestrial animals, as being a wonderfully numerous, varied, conspicuous, and beantiful group, which is pre-eminently cliaracteristic of the Palæarctic region. So strikingly and uumistakably is this the case, that it must be held completely to justify the keeping that region distinct from those to which it has at various times been proposed to join it. Although the Carabidæ are thoronghly well represented by hosts of peculiar genera and abmndant species in every part of the world without exception, yet the Paliearctic region alone contains fully onethird, or perhaps nearer two-fifths, of the whole. It may also be said, that the group is a temperate as compared with a tropical one; so that probably half the species are to be found in the temperate and cold regions of the globe, leaving about an equal number in the much more extensive tropical and warm regions. But, among the cold regions, the Palæarctic is pre-eminent. North America is also rich, but it contains, by far, fewer genera and fewer species.

The magnificent genus Carabus, with its allies Procerus and Procrustes, containing abont 300 species, all of large size, is almost wholly confined to the Palæarctic region, only 10 species inhabiting North America, and 11 Temperate South America, with one on the African mountain of Kilimandjaro. Twelve large genera, containing together more than 2000 species, are truly cosmopolitan, inhabiting both temperate and tropical 
countries all over the globe; but mauy of these are more abundant in the Palæarctic region than elsewhere. Such are Scarites, Calosoma, Biachinus, Cymindis, Lebia, Chlcnius, Platynus, Harpalus, Bembecidium, Pcecilus, and Argutor. Of tropical cosmopolites, or genera found in all the tropical regions, but not in the temperate zones, there seem to be only four,-Catascopus, Coptodera, Colopodes, and Caasmonia. Pheropsophus is confined to the tropics of the Old World; while Drimostoma, though widely scattered, is characteristic of the Southern Hemisphere.

The Palæarctic region has abont 50 genera of Carabidæ which are strictly confined to it, the most important being,-Lcistus (30 sp.), Procerus (5 sp.), Procrustes, (17 sp.), Zabrus (60 sp.), Pristonychus (42 sp.), and Ophonus (60 sp.); but it possesses a large number in common with the Nearctic region. The more remarkable of these are,-Carabus, Nebria, Amara, Cyrtonotus, Bradycellus, Anopthalmus, Celia, Cychrus, Patrobus, Elaphrus, Notioplitus, Bradytus, Callisthenus, Blethisa, and several others. Many too, though not strictly confined to the North Temperate regions, are very abundant there, with a few species isolated in remote comntries, or widely scattered, often in an eccentric manner. Among these may be mentioned, Trechus (120 sp.), all North Temperate but 8, which are scattered in Java, New Caledonia and South America ; Dyschirus (127 sp.), North Temperate, with 3 or 4 species in Australia, China and La Plata; Omaseus, (88 sp.), Steropus (90 sp.), Platysoma (114 sp.), and Pterostichus (138 sp.), are mostly North Temperate, but each has a few species in the South Temperate zone, New Zealand, Australia, Chili, and the Cape of Good Hope. Dromius ( $54 \mathrm{sp}$.), is about two-thirds Paliearctic, the rest of the species being scattered over the world, in Chili, North and Soutn America, Sonth Africa, Burmah, Ceylon, and New Zealand. The North Temperate genera Calathus and Olisthopus, have each one species in New Zealand; Percus has most of its species in South Europe, but 3 in Australia; $A b a x$ is confined to the north temperate zone, but with one species in Madagascar ; while Lcemosthenes is said to have a species identically the same in South Europe and Chili. Some of these apparent anomalies niay le due to wrong 
determination of the genera, but there can be little doubt that most of them represent important facts in distribution.

The Nearctic region is comparatively poor in Carabida. Its more important peculiar genera are,-Dicclus (22 sp.), Pasimachus (17 sp.), Eurytrichus (9sp.), Sphneroderus (7 sp.), Pinacodera (6 sp.), and others of smaller extent, about 30 in all. It also possesses representatives of a considerable number of Palæarctic genera, as already indicated; and a few of Sonth American genera, of which Helluomorpha and Galerita are the most important.

The Neotropical region is very rich in peculiar forms of Carabidæ, as in almost all other great groups. It possesses more than 100 peculiar genera, but about 30 of these are confined to the South Temperate sub-region. The inore impor!ant peculiar genera of Tropical Anierica are,-Agra (144 sp.), Ardistomus (44 sp.), Schizogenius (25 sp.), Pelecium, (24 sp.), Calophena (22 sp.), Ctcnodactyla (7 sp.). Among the Chilian and South Temperate peculiar forms are,-Antarctia (29 sp.), Scelodontis (10 sp.), Tropidopterus (4 sp.). Among the Neotropical genera with outlying species are,-Pachyteles (50 sp.), one of which is West African; Selcnophorus (70 sp.), with 4 African, 4 Oriental, and 1 from New Caledonia; Ega (11 sp.), with one in the East Indies, and one in New Caledonia; Galerita, with 36 American species, 8 African, and 3 Indian; Callida and T'tragonoderus, mostly American, but with a few African, Oriental and Australian species; and Pseudomorpha, common to America and Oceania.

The Australian region is almost equally rich, possessing about 95 peculiar genera of Carabila, no less than 20 of which are confined to New Zealand. The most important are, Carenum, Promccoderus, Scaraphites, Notonomus, Fnigma, Sphallomorpha, Silphomorpha, and Adelotopus. The gigantic Catadromus has 4 Australian species and 1 in Java; Homalosoma has 31 species in Australia and New Zealand, and 1 in Madagascar. Celebes and New Guinea have each peculiar genera, and one is common to Australia and the Cape of Good Hope.

The Oriental regiun possesses 80 peculiar genera, 10 of which are confined to Ceylon. The more importunt are,-Pericallus, Planetes, and Mormolyce. Distrigus is also characteristic of this 
region, with one species in Madagascar; while it has Orthogonins, Hexagonia, Macrochilus, and Thyreoptcrus in common with the Ethiopian region, and is rich in the fine tropical genus, Catascopus.

The Ethiopian region has 75 peculiar genera, 8 of which are confined to Madagascar. The more important are,-Polyhirma, Graphipterus, and Piesia. Anthia is chiefly African, with a ferw species in India; Abacctus is wholly African, except a species in Java, and another in South Europe; and Hypolithus is typically African, but with 7 species in Sonth America and 1 in Java.

The facts of distribution presented by this important family, looked at broadly, do not support any other division of the earth into primary regions than that deduced from a study of the higher animals. The amount of speciality in each of these regions is so great, that no two of them can be properly united; and in this respect the Carabide accord wonderfully with the Vertebrates. In the details of distribution there occur many singular anomalies; but these are not to be wondered at, if we take into consideration the immense antiquity of Coleopterous insects-which existed under specialised forms so far back as the Carboniferous epoch, - the ease with which they may be dispersed as compared with larger animals, and the facilities afforded by their small size, habits of concealment, and often nocturnal habits, for adaptation to the most varied conditions, and for surviving great changes of surface and of the surrounding organic forms. The wonder rather is, not that there are so many, but so few cases of exceptional and anomalons distribution; and the fact that these creatures, so widely different from Vertebrates in organisation and mode of life, are yet on the whole subject to the same limitations of range as were found to occur among the bigher animals, affords a satisfactory proof that the principles on which our six primary regions are founded, are sound; and that they are well adapted to exhibit the most interesting facts of geographical distribution, among all classes of animals.

Much stress has been laid on the fact of a few species of such typical European genera as Carabus, Dromius, and others, being 
found in Chili and Temperate South America; and it has been thought, that in a system of Entomological regions this part of the world must be united to the Northern Hemisphere. But these writers omit to take into account, either the large numbers of isolated and peculiar forms characteristic of South Temperate America, or the indications of affinity with Tropical America and Australia, both of which are really more important than the connection with Europe. The three important Chilian genera, Cascelius, Barypus, and Cardiopthulmus, are closely allied to the Australian Promecoderus; others, as Omostenus and Plagiotelinm, are quite isolated; while Antarctia and Metius, according to Lacordaire, form a distinct division of the family. Chili, too, has many species of Pachyteles, Coptodera, and other South American genera; and this affinity is far stronger in many other families than in the Carabidæ. The existence of representatives of typical northern forms in Chili, is a fact of great interest, and may be accounted for in a variety of ways; (see Vol. II. p. 44) but it is not of such a magnitude as to be of primary importance in geographical distribution, and it can only be estimated at its fair value, by taking into account the affinities of all the groups inhabiting that part of the world.

\section{LUCANIDA. (45 Genera, 529 Species.)}

Passing over a number of obscure families, we come to the remarkable group of the Lucanidæ, or Stag-beetles, which, beingr almost all of large size, and many of them of the most striking forms, have been very thoroughly collected and assiduously studied.

The most curious feature of their general distribution, is their scarcity in Tropical South America, and their complete absence from Tropical North America and the West Indian Islands, though they appear again in Temperate North America. In the New World they may, in fact, be looked upon as a temperate group characteristic of the extra-tropical regions and the highlands; while in the Old World, where they are far more abundant, they are distinctly tropical, being especially numerous 
in the Oriental and Australian regions. No genus has the range of the whole family, Dorcus and Lucanus being absent from Africa, while Cladognathus is unknown in the New World and on the continent of Australia. The Oriental region is the richest in peculiar forms, possessing 16 genera, 7 of which are wholly confined to it, while 3 others only just range beyond it to North China on the one side, or to the Austro-Malayan islands on the other. The Australian region comes next, with 15 genera, of which 7 are wholly peculiar. South America has 12 genera, 10 of which are peculiar. The Ethiopian region has 10 genera, 7 of which are peculiar, and 2 of these are confined to the island of Bourbon. The Palæarctic region has 8 genera, and the Nearctic 5; one genus being peculiar to Europe, and two confined to Europe and North America. The Ethiopian and Oriental regions have 3 genera in common and peculiar to them; the Oriental and Australian 3; while the Australian and Neotropical have 1 in common, to which may be added Streptocerus, which represents in Chili the Australian Lamprima.

Among the special features presented by the distribution of the Lucanidae, may be mentioned-the remarkable group of genera, Pholidotus, Chiasognathus, and Sphenognathus, confined to Temperate Sonth America, the Andes, and mountains of Brazil ; Lucanus (19 sp.), almost confined to the Oriental and Palæarctic regions, three species only inhabiting North America; Odontolabris (29 sp.), wholly Oriental, with $2 \mathrm{sp}$. in Celebes; Nigidius (11 sp.), Ethiopian, but with species in Formosa, the Philippines, and Malacca; Syndesus (11 sp.), common to Anstralia, New Caledonia, and South America; Figulus (20 sp.), divided between Africa and Madagascar on the one hand, and Australia, with the Malay and Pacific Islands, on the other.

The facts of distribution here sketched out are in perfect accordance with those of many groups of Vertebrates. The regions are sharply contrasted by their peculiar and characteristic genera; the several relations of those regions are truly inclicated; while there is a comparatively small proportion of cases of anomalous or eccentric distribution. 


\section{CETONIID A. (120 Genera, 970 Species.)}

As representative of the enormous group of the Lamellicorns, which, aceording to continental entomologists, forms a single family numbering nearly 7,000 species, we take the Cetoniida or Rose-Chafers. These comprise a number of the most brilliant and beautifully-coloured insects, including the gigantic Goliathi, which are among the largest of known beetles. They have been assiduously collected in every part of the world, and their classification has been elaborated by many of our most eminent entomologists.

The Cetoniidæe are especially abundant in tropical and warm countries, yet far more so in the old World than in the New; and in the Old World, the Ethiopian region exhibits a marvellous richness in this family, no less than 76 genera being found there, while 64 , or more than half the total number, are peculiar to it. Next in richness, though still very far behind, comes the Oriental region, with 29 genera, 17 of which are peculiar. The Neotropical has only 14 genera, but all except two are peculiar to it, and one of these is not found out of the New World. The Australian region has 11 genera, three only being peculiar. The Palrearctic region has 13 , with 4 peculiar; the Nearctic 7 , with 2 peculiar. The affinities of the regions for each other, as indicated by the genera confined to two arjacent regions, are in this family somewhat peculiar. The Ethiopian and Oriental show the most resemblance, 6 genera being common and peculiar to the two; the Oriental and the Australian are unusually well contrasted, having only one genus exclusively in common, while 8 genera are found in the Indo-Malay Islands which do not cross the boundary to the Austro-Malayan division, and several others only pass to the nearest adjacent islands ; on the other hand, the only large Australian genus, Schizorhina, is found in many parts of the Moluccas, but not further west. The Australian and Neotropical regions exhibit no direct affinity, the nearest ally to the South American Gymnetidre being Clinteria, an African and Asiatic genus; while not a single genus is common 
to Australia and South America. The Nearctic and Palæaretic regions have 3 genera in common, which are found in no other part of the world.

Among the special features of interest connected with the distribution of this family, we must first notice the exceptional richness of Madlagascar, which alone possesses 21 peculiar genera. South Africa is also very rich, having $\&$ peculiar genera. Stethodesma is very peculiar, being divided between South America and Mexico on the one hand, and West and South Africa on the other. Stalagmosoma is a desert genus, ranging from Persia to Dongola. No genus is cosmopolitan, or even makes any approach to being so, except Valgus, which occurs in all the regions except the Neotropical; and even the family seems to be not universally distributed, since no species are recorded either from New Zealand, the Pacific Islands, or the Antilles.

The facts liere brought forward, iead us to the conclusion that the Cetoniide are an Old-World tropical family, which had been well developed in Africa and Asia before it spread to Australia and America; and that it is only capable of being freely dispcrsed in the warmer regions of the earth. This view will explain the absence of affinity between the Australian and Neotropical regions, the only closer connection between which, has almost certainly occurred in the colder portions of the Temperate zone.

\section{BUPRESTID $Æ . \quad$ (109 Genera, 2,686 Species.)}

The next family suited to our purpose is that of the Buprestidæ, consisting as it does of many large and some gigantic species, generally adorned with brilliant metallic colours, and attracting attention in all warm countries. Although these insects attain their full development of size and beauty only in the Tropics, they are not much less abundant in the warmer parts of the Temperate zone. In the Catalogue of the Coleoptera of Europe and the Mediterranean Basin, by M. de Marseul (1863), we find 317 species of Buprestidæ enumerated, although 
the district in quéstion only forms a part of the Palrearctic region, which would thus seem to possess its full proportion of the species of this family. Confining ourselves to the generic forms, we find far less difference than usual between the numbers possessed by the tropical and the temperate regions; the richest being the Australian, with 47 genera, 20 of which are peculiar; and the poorest the Nearctic, with 24 genera, of which 7 are peculiar. The Oriental has 41 genera, 14 of which are peculiar; the Neotropical 39, of which the large proportion of 18 are peculiar; the Ethiopian 27, of which 6 are peculiar; and the Palæarctic also 27, but with 9 peculiar.

A most interesting feature in the distribution of this family, is the strong affinity shown to exist between the Australian and Neotropical regions, which have 4 genera common to both and found nowhere else; but besides this, the extensive and highly characteristic Australian genus, Stigmoderc, is closely related to a number of peculiar South American genera, such as Conognatha, Hyperantha, Dactylozodes,--the last altogether confined to Chili and Temperate South America. Here we havè a striking coutrast to the Cetoniidx, and we can hardly help concluding, that, as the latter is typically a tropical group, su the present family, although now so largely tropical, had an early and perhaps original development in the temperate regions of Australia, spreading thence to Temperate South America as well as to the tropical regions of Asia and Africa. The Australian and Oriental regions have 4 genera exclusively in common, but they also each possess a number of peculiar or characteristic genera, such as the Indo-Malayan Catoxantha (which has only a single species in the Moluceas) and nine others of less importance; and the exclusively Austro-Malayan genus, Sambus, with five smaller groups, and Cyphoyastra, with only 2 Indo-Malay species. The Oriental and Ethiopian regions are very distinct, only possessing the single genus, Sternocera, exclusively in common. The Nearctic and Palæarctic are also distinct, only one genus, Diccrca, being confined to America (North and South) and Europe, a fact which again points to a southern origin for this family, and its comparatively recent extension into the 
North Temperate zone. It must be remembered, however, that in view of the immense geological antiquity of the existing families of Beetles, dating back certainly to the Secondary and probably to the Palæozoic epoch, "comparatively recent" may still be of considerable antiquity.

It is somewhat singnlar that North and South America have no genera exclusively in common. The connection between South America and Africa seems to be shown,-by the genus Psilopter a, the mass of the species being divided between these regions, with a few widely scattered over the globe; and the American genus Actenodes, which has one species in West Africa. Somewhat allied, is the extensive geuns Polybothris, strictly confined to Madagascar. The genus Agrilus is perhaps cosmopolitan, although no speciss of the family is recorded from New Zealand. Among the peculiarities of distribution we may notice,-the genus Sponsor, with 8 species in the island of Mauritius, 1 in Celebes, and 1 in New Guinea; Ptosima, scattered between the United States, Mendoza in South Temperate America, South Europe, the Philippine Islands, and North China; Polycesta, which besides inhabiting South America, North America, and Europe, has a single species in Madagascar; and Belionota, which has 8 species African, 8 Indo-Maliyan, 2 Austro-Malayan, and 1 in California. The extensive gemus Acmceodera, is most abundant in the warm and dry portions of the Palæarctic, Ethiopian, and Nearctic regions, with some in the Andes and South 'Temperate America, a few in Brazil and the West Indies, and 1 said to be from the Philippines. About one-third of the genera (containing more than half the species) have a tolerably extensive range, while the genera confined to single regions contain only abont one-fourth of the total number of species.

It will, I think, be admitted, after a careful study of the preceding facts, that the regions and sub-regions here adopted, serve to exhibit, with great clearness, the chief phenomena of distribution presented by this interesting family. 


\section{LONGICORNIA. (1,488 Genera, 7,576 Species).}

The elegant and admired group of the Longicorn Beetles, is treated by continental anthors as a single family, consisting of three sub-divisions - the Prionidæ, Cerambycida, and Lamiidæe of English entomologists. These are so closely related, and are so similar in form, habits, and general distribution, that it will be best to consider the whole as one group, noticing whatever peculiarities occur in the separate divisions. The endless structural differences among these insects, have led to their being classed in an unusual number of genera, which average little more than 5 species each; a number far below that in any of the other families we have been considering, and probably below that which obtains in any of the more extensive groups of animals or plants. This excessive subdivision of the genera, a large number of which consist of only one or two species, renders it difficult to determine with precision the relations of the several regions, since the affinities of these genera for each other are in many cases undetermined. A group of such enormous extent as this, can only be properly understood after years of laborious study; we must therefore content ourselves with such results as may be obtained from a general survey of the group, and from a comparison of the range of the several genera, by means of a careful tabulation of the mass of details given in the recent Catalogue of Messrs. Gemminger and Harold and the noble work of Lacordaire.

The proportionate extent of the three families of Longicorns is very unequal; the Prionidæ comprising about 7 per cent., the Cerambycidæ 44 per cent., and the Lamiidæ 49 per cent. of the total number of species; and the genera are nearly in the same proportions, being almost exactly 10, 40 , and 50 per cent. of the whole, respectively ; or, 135 Prionidæ, 609 Cerambycidæ, and 746 Lamiidæ. The several regions, however, present marked differences in their proportions of these families. In the two North Temperate regions, the Cerambycidæ are considerably more numerous than the Lamiide, in the proportion of about 12 to 
9 ; and in this respect the Neotropical region agrees with them, though the superiority in the proportion of Cerambycidæ is somewhat less. In the Old World tropical regions, however, and in Australia, the Lamiidæ greatly preponderate-being nearly double in the Oriental and Ethiopian regions (or as 11 to 6 ), while in the Australian it is as 6 to 5. The Prionidas show a similar difference, though in a less degree; being proportionately more numerous in the North Temperate and Neotropical regions. Now, as regards the North Temperate regions, this difference can be, to some extent explained, by a difference in the habits of the insects. The Lamiidæ, which both in the larva and perfect state have exceedingly powerful jaws, exclusively frequent timber trees, and almust always such as are dead; while the Cerambycidre, are generally more delicate and have weaker mandibles, and many of the species live on shrubs, dead twigs, foliage, and even on flowers. The immense superiority of the Tropics in the number and variety of their timber trees, and the extent of their forests, sufficiently accounts for their superiority to the Temperate regions in the development of Lamiidæ; but the great excess of Cerambycidie in South America as compared with the rest of the Tropics, is not to be so readily explained.

Bearing in mind the different proportions of the families, as above noted, we may now consider the distribution of the Longicons as a whole. In number of generic forms, the Neotropical region, as in so many other groups, has a marked superiority. It possesses 516 genera, 489 of which (or about $\frac{19}{2} 0$ of the whole) are peculiar to it. The Australian and Oriental regions come next, and are exactly equal, both possessing 360 genera, and having almost exactly the same proportion (in each case a little less than $\frac{3}{4}$ ) peculiar. The Ethiopian region has 262 genera, with about $\frac{5}{6}$ peculiar; the Palæarctic 196, with 51 (rather more than $\frac{1}{4}$ ) peculiar; and the Nearctic 111, with 59 (a little more than half) peculiar. The more isolated of the sub-regions are also well characterised by peculiar genera. Thus, Chili with Temperate South America possesses 37, a large proportion being Cerambycidr; the Malagasi group 26, 
with a preponderance of Lamiidre; and New Zealand 12, of which the Cerambycidæe are only slightly in excess.

The relations between the Longicorn fauna of the several regions, are such as are in accordance with the dependence of the, group on a warm climate and abundant vegetation; and indicate. the efficiency of deserts and oceans as barriers to their migration. The Neotropical and Australian regions have only 4 genera in common, but these are sufficient to show, that there must probably once have been some means of communication between the two regions, better adapted to these insects than any they now possess. The Nearctic and Neotropical regions have 5, and the Nearctic and Palrearctic 1.3 genera in common and peculiar to them, the latter fact being the most remarkable, becanse no means of inter-communication now exists, except in high latitudes where the species of the Longicorns are very few. The Oriental and Australian regions, on the other hand, are closely connected, by having no less than 52 genera of Longicorns in common and peculiar to them. Most of these are specially characteristic of the Malay Archipelago, often extending over all the islands from Sumatra to New Guinea. This large number of wide-spread genera of course gives a character of uniformity to the entire area over which they extend; and, with analogous facts occurring in other families, has led many entomologists to reject that division of the Archipelago between the Australian and Oriental regions, which las been so overwhelmingly demonstrated to be the natural one in the case of the higher animals. The general considerations already advanced in Chapter II. enable us, however, to explain such anomalies as this, by the great facilities that exist for the transfer from island to island of such small animals, so closely connected with woody vegetation in every stage of their existence. That this is the true and sufficient explanation, is rendered clear by certain additional facts, which those who object to the sharp division of the IndoMalay and Austro-Malay sub-regions have overlooked.

An analysis of all the Malay Longicorns proves, that besides the 52 genera characteristic of the Archipelagn as a whole, there are 100 genera which are confined to one or other of its component 
sub-regions. Many of these, it is true, consist of single species confined to a single island, and we will not lay any stress on these ; but there are also several important groups, which extend over the Indo-Malay or the Austro-Malay islands only, stopping abruptly at the dividing-line between them. For example, or the Indo-Malay side we have Euryarthrum, Leprodera, Aristolia, Coelosterna, and Entelopes, and what is perhaps even more satisfactory, the large genera Agclusta and Astathes, abundant in all the Indo-Malay islands, but having only one or two species just passing the boundary into Celebes. On the other side we have Tethionea, Sphingnotus, Arrhenotus, Tmesisternus (the last three genera abounding from New Guinea to Celebes, but totally unknown further west), Hestima, Trigonoptera, Amblymora, Stesilea, Encs, and the large genus Micracantha, with but a single species beyond the boundary,-30 Austro-Malayan genera in all, each found in more than one island, but none of them extending west of Celebes. Here we have clear proof that the boundary line between the two great regions exists for Longicorns, as well as for all other animals; but in this case an unusually large number have been able to get across it. This, however, does not abolish the barrier, but only proves that it is not absolutely effectnal in all cases. Those who maintain that the Malay Archipelago forms a single Coleopterous region, must disprove or explain the instances of limited range here adduced.

Out of nearly 1500 known genera of these insects, only one genus, Clytus, appears to be cosmopolitan. Saperda and Callichro$m a$ ase the only others that perhaps occur in every region; but these are both wanting over wide tracts of the earth's surface, Saperda being absent from Tropical Africa and the Malay Archipelago; and Callichroma from the Australian region, except one species in Polynesia. Many of the genera of Longicorns have a somewhat wide and scattered distribution, indicative of decadence or great antiquity. Mallodon and Parandra are mostly South American, but have species in Australia and Africa; Oeme is found in Brazil and the United States, with one species in West Africa; Ceratophorus has 2 species in West Africa and 1 in New Zealand. Xystrocera is mostly African; but has single species in 
Borneo, Java, Amboyna and South Australia ; Phyton has one species in North America and the other in Ceylon; P'hilagetes has 2 in South Africa, and 1 in Malacca: Toxotus abounds in North America and Europe, with one species away in Madagascar. Lepture is also North Temperate, but has a species at the Cape, one at Singapore and a third in Celebes. Necydalis has species in North and South America, Europe and Australia. Hylotrupes has 1 species in North America and Europe, and 1 in Australia ; Leptocera prefers islands, being found only in Ceylon, Madagascar, Bourbon, Batchian, the New Hebrides, New Caledonia and North Australia; Hathliodes is Australian, with 1 species in Ceylon; Schcenionta has 3 Malayan species, and 1 in Natal. Many other cases equally curions conld be quoted, but these are sufficient. They cannot be held to indicate any close relation between the distant countries in which species of the same genus are now found, but perhaps serve to remind ns that groups of great antiquity, and probably of great extent, have dwindled away, leaving a few surviving relics scattered far and wide, the sole proofs of their former predominance.

\section{Gencral Observations on the Distribution of Coleoptera.}

We have now passed in review six of the most important and best known groups of the Coleoptera or Beetles, comprising about 2,400 genera, and more than 21,000 species. Although presenting certain peculiarities and anomalies, we have found that, on the whole, their distribution is in very close accordance with that of the ligher animals. We have seen reason to believe that these great and well-marked groups have a high geological antiquity, and by constantly bearing this fact in mind, we can account for many of the eccentricities of their distribution. They have probably survived changes of physical geography which have altogether extinguished many of the more highly organised animals, and we may perhaps gain some insight into the bearing of those changes, by considering the cross relations between the several regions indicated by them. On carefully tabulating the indications given by each of the groups here discussed, I arrive at the following approximate result. The 
best marked affinitics between the regions are those between the Nearctic and Palsearctic,-the Oriental and Australian, -the Australian and Neotropical,-which appear to be about equal in each case. Next comes that between the Ethiopian and Oriental on the one side, and the Ethiopian and Ncotropical on the other, which also appear about equal. Then follows that between the Nearctic and Neotropical regions; and lastly, and far the least marked, that between the North Temperate and South Temperate regions. That the relation between the Ethiopian and Neotropical region should be so comparatively well marked, is unexpected; but we must consider that in such a comparison as the present, we probably get the result, not of any recent changes or intermigrations, but of all the long series of changes and opportunities of migration that have occurred during many geological epochs,-probably during the whole of the Tertiary period, perhaps extending far back into the Secondary age.

It appears evident that Insects exhibit in a very marked degree in their actual distribution, the influence both of very ancient and very modern conditions of the earth's surface. The effects of the ancient geographical features of the earth, are to be traced, in the large number of cases of discontinuous and widely scattered groups which we meet with in almost every family, and which, to some extent, obscure the broader features of distribution due to the period during which the barriers which divide the several primary regions have continued to exist. And this, which we may consider as the normal distribution, is still further obscured in those cases where the barricrs between existing regions are of such a nature as to adnit of the free passage of insects or their larva in a variety of ways, and (what is perhaps of more importance) in which the physical features on both sides of the barrier are so nearly identical, as to admit of the ready establishment of such immigrants as may occasionally arrive. These conditions concur, for some families of insects, in the case of the Oriental and Australian portions of the Malay Archipelago; and it is there that the normal distribution has been sometimes greatly obscured, but never, as we have sufficiently shown, by any means obliterated. 


\section{CHAPTER XXII.}

AN OUTLINE OF THE GEOGRAPHICAL DISTRIBUTION OF MOLI.USCA.

The Mollusca being for the most part marine, it does not enter into the plan of this work to go into much detail as to their distribution. The orders and families will, however, be passed briefly in review, and all terrestrial and fresh-water groups discussed in somewhat more detail ; with the object of showing how far their distribution accords with that of the higher animals, and to what extent the anomalies they present can be explained by peculiarities of organisation and habits. If the views advocated in our fifth chapter are correct, the regions there marked out must apply to all classes of animals; and it will be the task of the students of each group, to work out in detail the causes which have led to any special features of distribution. All I can hope to do here, is to show, generally and tentatively, that such a mode of treatment is possible; and that it is not necessary, as it is certainly not convenient or instructive, to have a distinet set of "Regions" established for each class or order in the Animal and Vegetable Kingdoms.

For all the Marine groups I have merely summarised the information contained in Mr. Woodward's Manual of the Mollusca, but in the case of the Land Shells I have consulted the most recent general works, and endeavoured to yive an accurate, though doubtless a very incomplete, account of the most interesting facts in their distribution. As their classification is very unsettled, I have followed that of the two latest great works, by Martens and Pfeiffer. 


\section{Class. - CEPHALOPODA.}

Order I.-DIBRANCHIATA.

Fanily 1.-ARGONAUTID A. "Paper Nautilus." (1 Genus, 4 Species).

Distribution.-Open seas of all warm regions. Two species fossil in Tertiary deposits.

Family 2.-OCTOPODIDE. "Polypi." (7 Genera, 60 Species).

Distribution.-Norway to New Zealand, all tropical and temperate seas and coasts.

Family 3.-TEUTHID)E. "Squids or Sea-pens." (16 Genera, 102 Species.)

Distribution-CUniversal, to Greenland; 22 other gencra are fossil, in the Lias and Oolite.

FaMily 4-DEPIADÆ. "Cuttle Fish." (1 Genus, 30 Species).

Distribution.-All seas : 4 other genera are fossil, in Eocene and Miocene deposits.

Family 5.-SPIRULID E. (1 Genus, 3 Species).

Distribution.-All the warmer seas. 


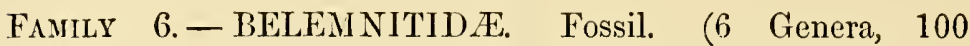
Species).

Distribution.-Lias to Chalk in Europe, India and North America.

\section{Order II.-TETRABRANCHIATA.}

Family 7.-NAUTILID 2 . (1 Genus, 3 Species, Living; 4 Genera, 300 Species, Fossil).

Distribution.-Indian and Pacific Oceans; and the fossil species from the Silurian Period to the Tertiary, in all parts of the world.

Family 8.-ORTHOCERATID $A$. Fossil. (8 Genera, 400 Species).

Distribut10N:-Lower Silurian to Lias.

Family 9.-AMMONITID $\approx$ Fossil. (14 Genera, 1100 Species).

Distribution.-Upper Silurian to Chalk. Found at 16,000 feet elevation in the Himalayas. 
Class.-Gasteropoda.

Order I.-PROSOBRANCHIATA.

Family 1.-STROMBID \&. (4 Genera, 86 Species.)

Distribution.-The Strombidæ, or Wing-shells, inhabit tropical and warm seas from the Mediterranean to New Zealand ; most abundant in the Indian and Pacific Oceans. There are nearly 200 fossil species, from the Lias to Miocene and recent deposits.

\section{Family 2.-MUURICID E. (12 Genera, 1000 Species.)}

Distribution.-All seas, most abundant in the Tropics. Trichotropis is confined to Northern seas; Murex and Fusus are cosmopolitan. There are about 700 fossil species, ranging from the Oolite to the Miocene and recent formations.

\section{Family 3.-BUCCINID dE. (24 Genera, 1100 Species.)}

Distributron.-The Buccinidæ, or "Whelks," range over the whole world, but some of the genera are restricted. Buccinum inhabits the north and south temperate seas; Monoceros the West Coast of America; Cassidaria the Mediterranean; Phos, Harpa, Eburna, and Ricinula, are confined to the Pacific ; Dolium inhabits the Mediterranean as well as the Pacific. There are about 350 fossil species, mostly from the Eocene and Miocene beds. 


\section{Fanity 4.-CONID E. (3 Genera, 850 Species.)}

Distribution.-The Cones are universally distributed, but this applies only to the genus Pleurotoma. Conus is tropical and sub-tropical, and Cithara is confined to the Philippine Islands. There are about 460 fossil species, from the Chalk formation to the most recent cleposits.

\section{Fanily 5.-VOLUTID $\mathbb{E}_{\text {( }}$ (5 Genera, 670 Species.)}

Distribution.-The Volutes are mostly tropical; but a small species of Mitra is found at Greenland, and a Marginella in the Mediterranean. Cymba is confined to the West Coast of Africa and Portugal. Voluta extends south to Cape Horn. There are about 200 fossil species, from the Chalk and Eocene to recent formations.

FAMLY 6.-CYPRßIDE. (3 Genera, 200 Species.)

Distriburion.--The well-known 'Cowries are found all over the world, but they are much more abundant in warm regions. One small species extends to Greenland. There are nearly 100 fossil species, from the Chalk to the Miocene and recent formations.

\section{Family 7.-NATICLD A. (5 Genera, 270 species.)}

Distribution.-The Naticidæ, or Sea-snails, though most abundaut in the Tropics, are found also in temperate seas, and far into the Arctic regions. Two other genera are fossil; and there are about 300 extinct species, ranging from the Devonian to the Pliocene formations. 
Family 8.-PYRAMIDELlid A. (10 Genera, 220 Species.)

Distributron.-These turreted shells are very widely distributed both in temperate and tropical seas; and most of the genera have also a wide range. There are about 400 extinct species, from so far back as the Lower Silurian to the Pliocene formations.

\section{Family 9.-CERITHIAD曆. (5 Genera, 190 Species.)}

Distribution.-These are marine, estuary, or fresh-water shells, of an elongated spiral form; they have a world-wide distribution, but are most abundant in the Tropics. Potamides (41 sp.), is the only fresh-water genus, and is found in the rivers of Africa, India and China, to North Australia and California. Another genus is exclusively fossil, and there are about 800 extinct species, ranging from the Trias to the Eocene and recent formations.

\section{Fayily 10.-MELANIAD E. (3 Genera, 410 Species.)}

Distribution--Fresh-water only: lakes and rivers in warm countries, widely scattered. South Palæarctic and Australian regions, from Spain to New Zealand; South Africa, West Africa, and Madagascar; United States. There are about 50 fossil species, from the Wealden and Eocene to recent formations.

\section{Family 11.-TURRITELliDA. (5 Genera, 230 Species.)}

Distribution.-Universal. Ceceum is found in north temperate seas only. The other genera are mostly tropical, but some species reach Iceland and Greenlind. There are near 300 species fossil, ranging from the Neocomian to the Pliocene formations. 


\section{Family 12.-LITTORINIDA. (9 Genera, 310 species.)}

Distribution.-The Littorinidie are mostly found on the coasts in shallow water; as the common Periwinkle (Littorina littorea). They are of world-wide distribution; but Solarium and Phorus are tropical; while Lacuna, Skenea, and most species of Rissoa are Northern. About 180 species are fossil, ranging from the Permian to the Pliocene formations.

\section{FAMILY 13.-PALUDINID $\npreceq . \quad$ (4 Genera, 217 Species.)}

Distuibution.-The Paludinidie, or River-snails, are all freshwater, and range over the whole world. Paludina (60 sp.), is confined to the Northern Hemisphere; Ampullaria. (136 sp.), is tropical ; Amphibola (3 sp.), inhabits New Zealand and the Pacific Islands; Valvata (18 sp.), North America and Britain. There are 72 fossil species of Paludina and Valvata, in the Wealden formation and more recent fresh-water deposits.

FAMILY 14.-NERITID.E. (10 Genera, 320 Species)

Distribution.-All warm seas, ranging north to Norway and the Caspian Sea. Neritina and Navicella inhabit fresh or brackish waters, the latter confined to the countries bortering the Indian Ocean and the islands of the Pacific. There are 80 fossil species, from the Trias, Lias, and Eocene formations down to recent deposits.

\section{Family 15.-TURBINIDÆ. (10 Genera, 425 Species).}

Distuibution.-The genus Trochus (200 sp.) has a world-wide range, but the other genera are mostly tropical, and are most abundant in the Indian and Pacific Oceans. There are more than 900 fossil species, found in all parts of the world, from the Lower Silurian to the Tertiary formations. 
Fayily 16.-HALIOTIDE. (6 Genera, 106 Species),

Distribution.-The Ear-shells are most abundant in the Indian and Pacific Oceans; some are found on the east coasts of the Atlantic, but there are very few in the West Indies. Ianthina (10 sp.) consists of floating oceanic snails found in the warm parts of the Atlantic. Three other genera are fossil, and there are near 500 fossil species of this family ranging from the Lower Silurian to the Pliocene formations.

Family 17.-FISSURELLIDE. (5 Genera, 200 Species).

Distribution.-All seas. Puneturella ( 6 sp.) is confined to Northern and Antaretic seas; Rimula to the Philippines; and Parmophorus (15 sp.) from the Cape of Good Hope to the Philippines and New Zealand. There are about 80 fossil species, ranging from the Carboniferous formation to the deposits of the Glacial epoch.

Family 18.-CALYPTREIDA. (4 Genera, 125 Species).

Distribution. - The Calptræidæ, or Bonnet-limpets, are found on the coasts of all seas from Norway to Chili and Australia; but are most abundant within the Tropics. The genera are all widely scattered. There are 75 fossil species, ranging from the Devonian to recent formations.

Family 19.-PATELLIDA. ( 4 Genera, $25 \pm$ Species).

Distribution.-The Patellida, or Limpets, are universally distributed, and are as abundant in the temperate as in tropical seas. 'There are about 100 fossil species, ranging from the Silurian to the Tertiary formations. 
Fanily 20.-DENTALIADA. (1 Genus, 50 Species).

Distribution.-CThe genus Dentalium is found in the North Atlantic, Mediterranean, West Indies and India. There are 125 fossil species, found in various formations as far back as the Devonian in Europe and in Chili.

Family 21.-CHITONID E. (1 Genus, 250 Species).

DisTRIBUTION.--On rocky shores in all parts of the world. There are 37 fossil species ranging back to the Silurian period.

\section{Order II.-PULMONIFERA. ("Terrestrial Molluscs.")}

The Land and Fresh-water snails are so important and extensive a group, and their classification has been so carefully studied, that their geographical distribution is a subject of much interest. The range of the genera will therefore be given in some detail. For the Helicidæ I follow the classical work of Albers-Die Helicien, Von Martens' Edition (1860); and for the Operculate families, Pfeiffer's Monographia Pneumonopomorum Viventium, 2nd Supplement, 1865. The number of species is, of course, very considerably increased since these works were published (and the probable amount of the increase I have in most cases indicated), but this does not materially affect the great features of their geographical distribution.

Family 22.-HELICID AE. (33 Genera, 3,332 Species) (1860).

General Distribution,-Universal.

The Helicidæ, or Snails, are a group of immense extent and absolutely cosmopolitan in their range, being found in the most barren deserts and on the smallest islands, all over the globe. They reach to near the line of perpetual snow on mountains, and 
to the limit of trees or even considerably beyond it, in the Arctic regions; but they are comparatively very scarce in all cold countries. The Antilles, the Philippine Islands, Equatorial America, and the Mediterranean sub-region are especially rich in this family. Comparatively few of the genera, and those generally small ones, are restricted to single regions; but on the other hand very few are generally distributed, only two-Helix and Pupa-occurring in all the six regions, while Helix alone is truly cosmopolitan, occurring in every sub-region, in every country, and perhaps in every island on the globe.

The Neotropical region is, on the whole, the richest in this family, the continental Equatorial districts producing an abundance of large and handsome species, while the Antilles are pre-eminent for the number of their peculiar forms. This region possesses 22 of the genera, and 6 of them are peculiar.

The Palæarctic region seems to come next in productiveness, but this may be partly owing to its having been so thoroughly explored. It possesses 16 of the genera, and 3 of them are confined to it. The great mass of the species are found in the warm and fertile countries surrounding the Mediterranean Sea.

The Ethiopian region has 13 genera, only one of which is peculiar.

The Australian region has 14 genera, 2 of which are confined to the Pacific Islands.

The Oriental has 15 genera and the Nearctic 12, but in neither case are there any peculiar generic types.

The following is the distribution of the several genera taken in the order of their magnitude:-

Helix (1,115 sp.), cosmopolitan. This genus is divided into 88 sub-genera, a number of which have a limited distribution. An immense quantity of species have been recently described, so that the number now exceeds 2,000 .

Nanina (290 sp.) is characteristic of the Oriental and Australian regions, over the whole of which it extends, just entering the Palrearctic region as far as North China and Japan. Isolated from this area is a small group of 4 species occurring YOL. II. 
in West Africa. The number of species in this genus have now been increased to about 400 .

Clausilia (272 sp.) is most abundant in Europe, with a few species widely scattered in India, Malaya, China, Japan, Equatorial America, and one in Porto Pico. The described species lave been increased to nearly 500 .

Bulimulus (210 sp.) is American, and almost exclusively Neotropical, ranging from Montevideo and Chili, to the West Indian Islands, California and Texas; with two sub-genera confined to the Galapagos Islands. About 100 new species have been described since the issue of the second edition of Dr. Woodward's Manual.

Pupa (210 sp.) abounds most in Europe and the Arctic regions, but has a very wide range, being scattered throughout Africa, continental India, Australia, the Pacific Tslands, North America to Greenland, and the Antilles; but it is absent from South America, the Himalayan and Malayan sub-regions, China ant Japan. An extinct species has occurred abundantly in the carboniferous strata of North America. About 160 arlditional species have been described.

Bulimus (172 sp.) abounds most in Tropical South America; it is also found from Burmah eastward through Malaya to the Solomon and Fiji Islands; there are also scattered species in Patagonia, St. Vincents, Texas, St. Helena, and New Zealand. More than 100 additional species have been described.

Buliminus (132 sp.) ranges from Central and South Europe over the whole Ethiopian and Oriental regions to North China, and through the Anstralian to New Zealand; there is also a single outlying species in the Galapagos Islands. About 50 more species have been described.

Cochlostyla (127 sp.) is almost peculiar to the Philippine Islands, beyond which, are a species in Borneo, one in Java, and two in Australia. Very few new species have been added to this genus.

Achatinella (95 sp.) is absolutely confined to the Sandwich Island group. Recent researches have more than tripled the number of leseribed species. 
Achatina (87 sp.) is most abundant and finest in the Ethiopian region, over the whole of which it ranges; but there are also species in Florida, the Antilles, the Sandwich Islands, Ceylon and India. The described species are now more than doubled.

Hyalina (84 sp.) inhabits all Tropical America and the Antilles, North America to Greenland, and Europe to the Aretic regions. Comparatively few new species have been described.

Cylindrella (83 sp.) inhabits the West Indian islands and Guatemala to Texas, with a sub-genus in the Philippine Islands. Species since described have more than trebled the number in this genus.

Cionella (67 sp.) is willely scattered; in India from Ceylon to the Khasia Mountains, Brazil, New Granada, the West Indian islands, Palæarctic, and northern part of Nearctic regions, Pacific Islands, New Zealand, and Juan Fernandez. About 20 new species have since been described.

Glandina (66 sp.), Peru to South Carolina and the Antilles, with three species in Central Africa and one in South Europe. About 40 species have been added to this genus.

Stenogyra (49 sp.), widely distributed: Tropical America and West Indies to Florida, South and West Africa, the Mediterranean region, India and the Philippines. About a dozen new species have been described.

Succinea (41 sp.), widely scattered in all the regions, and in St. Helena, Juan Fernandez, Tahiti, Chiloe, Greenland, West, Africa, Himalayas and Australia. The described species are now more than 100 .

Partula (39 sp.), Solomon Islands to Tahiti and Sandwich Islands. This genus has also been increased to near 100 spesies.

Streptaxis (34 sp.), most abundant in Tropical South America, but occurs in West Africa, the Seychelles and Rodrignez Islands, Ceylon and Burmah. It now contains over 100 described species. Spiraxis (33 sp.), Yucatan to Mexico, and less abundant in the West Indian Islands. $\Lambda$ bout 20 species have been added. 
Acacroceramus (27 sp.), Antilles, Florida, and Peru. The species have been more than doubled.

Vitrina (26 sp.), widely scattered through North and Central Europe, North-west America and Greenland, Abyssinia, Madagasear and South Africa, Himalayas to Burmah and Australia. Species since described have more than doubled the number in this genus.

Orthalicus (23 sp.), Bolivia to Mexico and Antilles. This genus has been increased to about 40 species.

Sagda (19 sp.), Antilles only. Very few new species, if any, have been described.

Zonites (12 sp.), South Europe, with one species of a distinct type in Guatemala. The number of species in this genus has been since about tripled.

Lencochroc (11 sp.), Mediterranean region to Syria and Arabia Petrea.

Simpulopsis (7 sp.), Bahia, Antilles, and far away in the Solomon Islands. Two or three have been added.

Balea (6 sp.), Niddle and North Europe, Brazil, and the Island of Tristan d'Acunha.

Daudebardia (6 sp.), Central and South Europe; and a species has since been discovered in New Zealand.

Macrocycles (4 sp.), Chili, California, Oregon and Central North America.

Columna (3 sp.), West Africa, Princes Islands and Madagascar.

Stenopus (2 sp.), Island of St. Vincent (West Indies.)

Pfeifferia (2 sp.), Philippines and Moluccas.

Testacella (2 sp.), West Europe and Teneriffe. About 8 species have been since described, including one from New Zealand.

Fossil species of Helix, Bulimus, Achatina, Balea, and Clausitic, are found in all the Tertiary formations; while a species of Pupa (as already stated) occurs in the carboniferous formation. For interesting details of the distribution of the subgenera and species of Achatinella in the Sandwich Islands, see a paper by Rev. J. T. Gulick in the Joumal of the Linnean Society. (Zoology, vol. xi. p. 496.) 


\section{FamiLY 23.-LIMACID $\approx$ E.-(12 Genera, 116 Species.)}

\begin{tabular}{|c|c|c|c|c|c|}
\hline \multicolumn{6}{|c|}{ Gexeral Distribution. } \\
\hline $\begin{array}{l}\text { NEOTROPICAL } \\
\text { SUB-REGIONS. }\end{array}$ & $\begin{array}{c}\text { NeARCTIC } \\
\text { SUB-REGIONS. }\end{array}$ & $\begin{array}{l}\text { PALAEARCTIC } \\
\text { SiUB-REGIONS. }\end{array}$ & $\begin{array}{c}\text { ETHIOPIAN } \\
\text { SUB-REGIONS. }\end{array}$ & $\begin{array}{l}\text { ORIENTAL } \\
\text { SUB-REGIONS. }\end{array}$ & $\begin{array}{l}\text { Australian } \\
\text { Sub-REgIONS. }\end{array}$ \\
\hline$-\cdots-$ & 1.2 .3 .4 & 1.2 .3 .4 & $--3-$ & 1.2 .3 .4 & 1.2 .3 \\
\hline
\end{tabular}

The Limacidæ, or Slugs, are widely distributed, but they are absent from South America, where they are represented by the next family. They also seem to be absent from the greater part of Africa. The genera are distributed as follows :-

Limax (51 sp.), Palæarctic region, Australia and the Sandwich Islands ; Anadenus (2 sp.), Himalayas; Philomychus (9 sp.), North America, China and Java; Arion (25 sp.), Norway to Spain and South Africa; Parmacella (7 sp.), South Europe, Canary Islands and North India; Janella (1 sp.), New Zealand; Aneitea (1 sp.), NewHebrides and New Caledonia; Parmarion (4 sp.), India; Triboniophorus (3 sp.), Australia ; Testacella (3 sp.), South Europe, Canary Islands, and New Zealand; Hyalimax (2 sp.), Bourbon and Mauritius; Krynickic (8 sp.), Eastern Europe and North America. A few species of Limax, Arion, and Testacella have been found fossil in Tertiary deposits.

FAimlir 24.-ONCIDIADA. (2 Genera, 36 Species.)

\begin{tabular}{|c|c|c|c|c|c|}
\hline $\begin{array}{l}\text { NFOTEOPICAL } \\
\text { StiB-REGIONS. }\end{array}$ & $\begin{array}{c}\text { NEARCTIC } \\
\text { SUB-REGIONS. }\end{array}$ & $\begin{array}{l}\text { PaLAaARctic } \\
\text { SUb-REGions. }\end{array}$ & $\begin{array}{l}\text { ETHIOPIAN } \\
\text { SUB-REGIONS. }\end{array}$ & $\begin{array}{c}\text { ORIENTAL } \\
\text { SUB-REGIONS. }\end{array}$ & $\begin{array}{l}\text { AUSTRALIRY } \\
\text { SUE-REGIOYS }\end{array}$ \\
\hline 1.2 .3 .4 & ---- & $1.2--$ & ---4 & 1.2 .3 .3 & $-2-4$ \\
\hline
\end{tabular}

The Oncidiadre, or Slugs with a coriaceous mantle, inhabit the Oriental region, Mauritius, Australia, the Pacific Islands, South America and Sonth Europe. The genera are:- 
Oncidium (16 sp.), South Europe (1 sp. British), Mauritius, Australia and Pacific Islands; Vaginulus (20 sp.), Neotropical and Oriental regions.

Famly 25.-LIMN FID A. (7 Genera, 332 Species.)

\begin{tabular}{|c|c|c|c|c|c|}
\hline \multicolumn{6}{|c|}{ General Disthibulion. } \\
\hline $\begin{array}{l}\text { NEOTROPICAL } \\
\text { SUB-REGLONS. }\end{array}$ & $\begin{array}{l}\text { NEARCTIC } \\
\text { SUB-REGIONS. }\end{array}$ & $\begin{array}{l}\text { PaLifarctic } \\
\text { SUB-hegions. }\end{array}$ & $\begin{array}{l}\text { ETHIOPIAN } \\
\text { SUB-REGiONS. }\end{array}$ & $\begin{array}{c}\text { ORIENTAL } \\
\text { SUB-EEGIONS. }\end{array}$ & $\begin{array}{l}\text { Australias } \\
\text { SuB-REgIONS. }\end{array}$ \\
\hline 1.2 .3 .4 & 1.2 .3 .4 & $1 \cdot 2 \cdot 3 \cdot 4$ & $--3-$ & 1.2 .3 .4 & --- \\
\hline
\end{tabular}

The Limnæidæ, or Fresh-water Snails, inhabit ponds and rivers in most parts of the world, but appear to be absent from the Australian region. The genera are distributed as follows:-

Limncea (95 sp.), Nearctic, Palrarctic, and Oriental regions; Choanomphalos (2 sp.), Lake Baikal; Pompholyx (2 sp.), Westeru America; Chilinia (18 sp.), South America; Physa (20 sp.), Nearctic, Palæarctic, Ethiopian and Oriental regions, and extends to above $73^{\circ}$ North Latitude in Siberia, being the most Arctic of land or fresh-water shells; Ancylus (49 sp.), Nearctic and Neotropical regions, Europe and New Zealand; Planorbis (145 sp.), Nearctic, Palæarctic and Oriental regions. Several genera are found fossil, chiefly in the Wealden, Eocene, and Miocene formations.

Fanily 26.-AURICULID AE. (3 Genera, 210 Species.)

\begin{tabular}{|c|c|c|c|c|c|}
\hline \multicolumn{6}{|c|}{ General Distribution. } \\
\hline $\begin{array}{l}\text { NEOTROPICAL } \\
\text { SUB-REGIONS. }\end{array}$ & $\begin{array}{c}\text { NEARCTIC } \\
\text { SUB-REGIONS. }\end{array}$ & $\begin{array}{c}\text { PaLEARCTIC } \\
\text { SUB-hEGIONS. }\end{array}$ & $\begin{array}{c}\text { ETHIOPI IN } \\
\text { SUB-REGIONS. }\end{array}$ & $\begin{array}{c}\text { ORIENTAL } \\
\text { SUB-REGIONS. }\end{array}$ & $\begin{array}{l}\text { AUSTRALIAN } \\
\text { SUB-REgIONS. }\end{array}$ \\
\hline $1--4$ & 1.2 .3 .4 & $1.2--$ & $1.2 .3-$ & 1.2 .3 .4 & $1.2-4$ \\
\hline
\end{tabular}

The Auriculidæ are chiefly found near the sea in hot countries, and are most abundant in the Eastern tropics. They are absent 
from the East coast of South America. The genera have a somewhat restricted distribution as follows:-

Auricula (128 sp.), India, Pacific Islands, Peru and West Indies; Melampus (56 sp.), West Indies and Europe; Carychium (9 sp.), Europe and North America; Plectrotrema (14 sp.), Australia, Malay Islands, China, Cuba ; Blauneria (2 sp.), WVest Indian and Sandwich Islands. There are many fossil species ranging back to the Eocene formation.

Fanily 27.-ACICULJDA. (4 Genera, 65 Species.) (1865.)

\begin{tabular}{|c|c|c|c|c|c|}
\hline \multirow[b]{2}{*}{$\begin{array}{l}\text { NEOTROPICAL } \\
\text { SUB-REGIONS. }\end{array}$} & \multicolumn{4}{|c|}{ General Distribution. } & \multirow[b]{2}{*}{$\begin{array}{l}\text { AUSTRALIAN } \\
\text { SUB-REgIUNS. }\end{array}$} \\
\hline & $\begin{array}{c}\lambda_{\text {EARCTIC }} \\
\text { SUB-REGIONS. }\end{array}$ & $\begin{array}{l}\text { PaLAarctic } \\
\text { Sub-REGIONS. }\end{array}$ & $\begin{array}{c}\text { ETHYOPIAN } \\
\text { SUB-REGIONS. }\end{array}$ & $\begin{array}{l}\text { ORIENTAL } \\
\text { SUB-REGlONS. }\end{array}$ & \\
\hline$-2 \cdot 3 \cdot 4$ & $1.2--$ & $1.2-4$ & ---4 & $-2-4$ & $12.3-$ \\
\hline
\end{tabular}

The Aciculidæ are small cylindrical shells chiefly found in the West Indian Islands, but with representatives widely scattered over the globe.

Acicula (5 sp.) is European only; Gcomelania (21 sp.), and Chittya (1 sp.), are confined to the Island of Jamaica; Truncatella (38 sp.), is most abundant in the Antilles, but is also found in some part of each of the six regions, as indicated by the diagram of the family. But few new species have been added to this group.

Family 28.-DIPLOMMATINID君. (3 Genera, 23 Species.) (1865.)

\begin{tabular}{|c|c|c|c|c|c|}
\hline \multicolumn{6}{|c|}{ Gexeral Distribution. } \\
\hline $\begin{array}{l}\text { NEOTROPICAL } \\
\text { SUB-REGIONS. }\end{array}$ & $\begin{array}{c}\lambda_{\text {EARCTIC }} \\
\text { SCBB-REGIONS. }\end{array}$ & $\begin{array}{l}\text { PALEARCTIC } \\
\text { SUB-REGIONS. }\end{array}$ & $\begin{array}{l}\text { ExHIOPIIN } \\
\text { SUB-REGIONS. }\end{array}$ & $\begin{array}{l}\text { ORIENTAL } \\
\text { SUB-HEGIONS. }\end{array}$ & $\begin{array}{l}\text { AUSTRaLian } \\
\text { SUB-REGIUNS. }\end{array}$ \\
\hline$-2--$ & --- & --- & ---- & $1-3.4$ & 1.2 .34 \\
\hline
\end{tabular}

The Diplommatinidæ are minute shells of the Oriental and Australian regions. 
Diplommatina (1S sp.) inhabits India to Burmah, and the greater part of the Australian region; the number of species has now been doubled, and one has been discovered in the island of Trinidad; Clostophis (1 sp.), Moulmein; Paxillus (3 sp.), Bornco, Hong Kong, and Loo Choo Islands.

Family 29.-CYCLOSTOMIDA. (41 Genera, 1009 Species.) (1865.)

\begin{tabular}{|c|c|c|c|c|c|}
\hline \multicolumn{6}{|c|}{ Genteral Distribution. } \\
\hline $\begin{array}{l}\text { NEOTROPICAL } \\
\text { SUB-REGIONS. }\end{array}$ & $\begin{array}{c}\text { Nearctic } \\
\text { Sub-REgions. }\end{array}$ & $\begin{array}{l}\text { PaLAFARCTIC } \\
\text { SUB-REGIONS. }\end{array}$ & $\begin{array}{c}\text { Ethropian } \\
\text { SUB-REGIONS. }\end{array}$ & $\begin{array}{c}\text { ORIENTAL } \\
\text { SUB-EEGIONS. }\end{array}$ & $\begin{array}{l}\text { Australian } \\
\text { Sub-regions. }\end{array}$ \\
\hline-2.3 .4 & $--a-$ & ---4 & --3.4 & $1 \cdot 2 \cdot 3 \cdot 4$ & $1---$ \\
\hline
\end{tabular}

This extensive group, comprising the largest of the operculated land-shells, is especially characteristic of the Oriental region, which possesses 25 genera, no less than 12 of them being wholly confined to it. The Neotropical region comes next, with 15 genera, 9 of which are peculiar; but a large number of these are confined to the West Indian Islands, South America itself being very poor in this group. The Palæarctic region has 3 peculiar genera; the Ethiopian and Australian 1 each. The Nearctic region has but a single West Indian species in Florida. The distribution of the genera is as follows :-

Peculiar to or characteristic of the Oriental region are, Opisthoporus (11 sp.), Rhiostoma (6 sp.), Alycaeus (39 sp.), Opisthostoma (1 sp.), Hybocistis (3 sp.), Pterocyclos (19 sp.), extending to the Moluccas ; Aulopoma (4 sp.), Dcrmatocera (4 sp.), Leptopoma (54 sp.), extending west to the Seychelles and east to the Moluccas and New Guinea; Cyclophorus (163 sp.), most abundant in the Oriental region, but ranges to Japan, to Chili, and all Tropical America, over the whole Australian region, and to Natal and Madagascar; Cataulus (15 sp.), confined to Ceylon, the Neilgherries and Nicobar Islands; Rhaphaulus ( $4 \mathrm{sp}$.), Penang to Ceram; Streptaulus (1 sp.), Arinia (3 sp.), Pupinella 2 sp.), Pupina (24 sp.), half in North India to Philippines and 
Japan, the other half in Moluccas, New Guinea and Australia ; Cyclotopsis (2 sp.), India and Malaya : Registoma (9 sp.), Philippines and Moluccas, New Caledonia and Pacific.

Characteristic of the Neotropical region are:-Cyclotus (111 sp.), half in the Antilles and Tropical America, the rest in the Moluccas, China, Malaya, India, Natal, and the Seychelle Islands; Megalomastoma (27 sp.), abundant in Cuba, West Indies and South America, others in India, Malaya, and Mauritius; Jemaicia (2 sp.), Jamaica; Licina (5 sp.), Antilles; Choanopoma (49 sp.), Antilles; Ctenopoma (25 sp.), Antilles; Diplopoma (1 sp.), Cuba; Adamsiclla (15 sp.), Jamaica, Cuba, Guatemala ; Cyclostomus (113 sp.), abundant in Antilles, also occurs in Madagascar, Arabia, Syria, Hungary and New Zealand; Tudora (34 sp.), Antilles, and one species in Algeria; Cistula (40 sp.), Chondropoma (94 sp.), Bourcieric (2 sp.), Tropical America.

Peculiar to or characteristic of the Palæarctic region are:Craspedopoma (5 sp.), confined to Madeira, the Azores and Canaries ; Leonia (1 sp.), Spain and Algeria; Pomaticas (22 sp.), Europe and Canaries with a species in the Himalayas; Cecina (1 sp.), Manchuria.

The Ethiopian region has the peculiar genus Lithodion (5 sp.), Madagascar, Socotra and Arabia; and Otopoma (19 sp.), Mascarene Islands and Socotra, with a species in Western India and another in New Ireland.

The Australian region is characterised by Callia (3 sp.), in Ceram, Australia, and the Philippines respectively ; Realia (7 sp.), New Zealand and the Marquesas Islands; Omphalotropis (38 sp.), the Australian region, with some species in India, Malaya, and the Mauritius.

The remaining genus, Hydrocena (27 sp.), has a very widely scattered distribution, being found in South Europe, Japan, the Cape, China, Malaya, New Zealand, the Pacific Islands and Chili. From 10 to 20 per cent. of new species have been since described in most of the genera of this family. 
Fanily 30.-HELICINID A. (7 Genera, 433 Species.) (1868.)

\begin{tabular}{|c|c|c|c|c|c|}
\hline \multicolumn{6}{|c|}{ General Distribution. } \\
\hline $\begin{array}{l}\text { NEOTROPICAL } \\
\text { SUB-REg:ONS, }\end{array}$ & $\begin{array}{c}\text { NEARCTIC } \\
\text { SUB-REGIONS. }\end{array}$ & $\begin{array}{l}\text { PaLAaRCTIC } \\
\text { SUB-KEGIOIS. }\end{array}$ & $\begin{array}{c}\text { Ethiopian } \\
\text { SUR-REGIO:Ss. }\end{array}$ & $\begin{array}{c}\text { Oriental } \\
\text { Sub-EEgions. }\end{array}$ & $\begin{array}{l}\text { Atsiralian } \\
\text { Sti-REgions. }\end{array}$ \\
\hline$-2.3 \cdot 4$ & $--3-$ & ---- & --- & $--3 \cdot 4$ & 1.2 \\
\hline
\end{tabular}

The Helicinidx are very characteristic of the Antilles, comparatively few being found in any other part of the world except the Islands of the Pacific. The genera are :-

Trochatella (33 sp.), Antilles with a species in Venezuela, and another in Cambodja; Lucidella (5 sp.), Antilles; Helicina (274 sp.), Antilles, Pacific Islands, Tropical America, Southern United States, Moluccas, Australia, Philippines, Java, Andaman Islands and North China; Schusichcila (5 sp.), Mexico, Guatemala and Bahamas; Alcadia (28 sp.), Antilles; Georissa (5 sp.) Moulmein to Burmah. About 10 per cent. of new species appear to have been since described in the larger genera of this family.

\section{General Observations on the Distribution of the Land Mollusea.}

A consideration of the distribution of the families and genera of land-shells shows us, that although they possess some special features, yet they agree in many respects with the higher animals in their limitation by great natural barriers, such as oceans, deserts, mountain ranges, and climatal zones. A remarkable point in the distribution of these animals, is the number of genera which have a very limited range, and also the prevalence of genera having species scattered, as it were at random, all over the earth. No less than 14 genera (or about one-sixth of the whole number) are confined to the Antilles, while the greater part of the sub-genera of modern authors are restricted to limited areas.

If we first compare the New World with the Old, we find the difference as regards genera quite as great as in most of the 
vertebrates. In the Helicidæ, 10 genera are confined to the New, and 7 to the Old World, 16 being common to both. In the Operculata the number of genera of restricted range is greater,the New World having 15, the Old World 32 genera, only 8 being common to both. Of the New World genera 12 out of the 15 do not occur at all in South America; and of those of the Old World, 22 out of the 32 occur in a single region only. If we take the morthern and southem division proposed by Professor Huxley (the latter comprising the Australian and Neotropical regions), we find a much less well-marked diversity. Among the Helicidæ only 4 are exclusively northern, 8 sonthern; while among the Operculata 22 are northern, 16 southern. The best way to compare these two kinds of primary division will be to leave out all those genera confined to a single region each, and to take account only of those characteristic of two or more of the combined regions; which will evidently show which division is the most natural one for this group. The result is as follows:-

Genera common to two or more Ragions in, And confined to, Each Primary Division of the Earth.

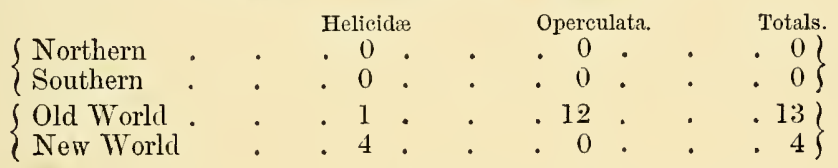

We find then that the morthern and sonthern division of the globe is not at all supported by the distribution of the terrestrial molluscs. It is indeed very remarkable, that the connection so apparent in many groups between Australia and South America is so scantily indicated here. The only facts supporting it seem to be, the occurrence of Geotrochus (a sub-gemus of Helix) in Brazil,"as well as in the Austro-Malayan and Test Pacific Islands and North Australia; and of Bulimus in the same two parts of the globe, but peculiar sub-genera in each. But in neither case is there any affinity shown between the temperate portions of the two regions, so that we must probably trace this resemblance to some more ancient diffusion of types than that which led to the similarity of plants and insects. Still more curious is the entire 
absence of genera confined to, and characteristic of Africa and India. One small sub-genus of Helix, (Rachis), and one of Achatina, (Homorus), appear to have this distribution,-a fact of but little significance when we find another sub-genus of Helix, (Hapalus), common and confined to Guinea and the Philippine Islands; and when we consider the many other cases of scattered distribution which cannot be held to indicate any real connection between the countries implicated. No genus is confined to the Palæarctic and Nearctic regions as a whole. A large number of sub-genera, many of them of considerable extent, are peculiar to one or other of these regions, but only 3 sub-genera of Helix and 2 of Pupa are common and peculiar to the two combined, and these are always such as have an Arctic range and whose distribution therefore offers no difficulty.

We find, then, that each of our six regions and almost all of our sub-regions are distinctly confirmed by the distribution of the terrestrial mollusca; while the different combinations of them which have at various times been suggested, receive little or no support whatever. Even those remarkably isolated sub-regions, New Zealand and Madagascar, have no strictly peculiar genera of land-shells, although they both possess several peculiar subgenera; being thus inferior in isolation to some single West Indian Islands, to the Sandwich Islands, and even to the North Atlantic Islands (Canaries, Madeira, and Azores), each of which have peculiar genera. This of course, only indicates that the means by which land mollusca have been dispersed are somewhat special and peculiar. To determine in what this speciality consists we must consider some of the features of the specific distribution of this group.

The range of genera, and even of sub-genera is, as we have seen, often wide and erratic, but as a general rule the species have a very restricted area.

Hardly a small island on the globe but has some land-shells peculiar to it. Juan Fernandez has 20 species, all peculiar. Madeira and Porto Santo have 109 peculiar species out of a total of 134. Every little valley, plain, or hill-top, in the Sandwich Islands, though only a few square miles in extent, has its 
peculiar species of Achatinella. Another striking feature of the distribution of land molluses, is the richness of islands as compared with continents. The Philippines contain more species than all India; and those of the Antilles according to Mr. Bland almost exactly equal the numbers found in the entire American continent from Greenland to Patagonia. Taking the whole world, it appears that many more species of land-shells are found in the islands than on the continents of the globe, a peculiarity that obtains in no other extensive group of animals.

Looking at these facts it seems probable, that the air-breathing molluses have been chiefly distributed by air- or water-carriage, rather than by voluntary dispersal on the land. Even seas and oceans have not formed impassable barriers to their diffusion; whereas they only spread on dry land with excessive slowness and difficulty. The exact mode in which their diffusion is effeeted is not known, and it may depend on rare and exceptional circumstances ; but it seems likely to occur in two ways. Snails frequently conceal themselves in crevices of trees or under bark, or attach themselves to stems or foliage, and either by their operculum or mucous diaphragm, are able to protect themselves from the injurious effects of salt water for long periods. They might therefore, under favourable conditions, be drifted across arms of the sea or from island to island; while wherever there are large rivers and occasional floods, they would by similar means be widely scattered over land areas. Another possible mode of clistribution is by means of storms and hurricanes, which would carry the smaller species for long distances, and might occasionally transport the eggs of the larger forms. Aquatic birds might occasionally get both shells and eggs attached to their feet or their plumage, and convey them across a wide extent of sea. But whether these, or some other unknown agency has acted, the facts of distribution clearly imply that some means of transport over water is, and has been, the chief agent in the distribution of these animals; but that its action is very rare or intermittent, so that its effects are hardly perceptible in the distribution of single species.

Another important factor in enabling us to account for the 
distribution of these animals is the geological antiquity of the group, and the amount of change exhibited in time, by species and genera. Now we find that most of the genera of land-shells range back to the Eocene period, while those inhabiting fresh water are found almost unchanged in the Wealden. In North America a species of Pupc and one of Zonites, have been discovered in the coal measures, along with Labyrinthodonts; and this fact seems to imply, that many more terrestrial molluscs would be cliscovered, if fresh-water cleposits, made under favourable conditions, were more frequently met with in the older rocks. If then the existing groups of land-molluscs are of such vast antiquity, and possess some means, however rarely occurring, of crossing seas and oceans, we need not wonder at the wide and erratic distribution now presented by so many of the groups; and we must not expect them to conform very closely to those regions which limit the range of animals of higher organization and less antiquity.

The total number of species of pulmoniferous mollusca is about 7,000, according to the estimate of Mr. Woodward, brought down to 1868 by Mr. Tate. But this number would be largely increased if the estimates of specialists were taken. Mr. Woodward for example, gives 760 as the number of species in the West Indian Islands; whereas Mr. Thomas Bland, who has made the shells of these islands a special study, considers that there were 1,340 species in 1866 . So, the land-shells of the Sandwich Islands are given at 267 ; but Mr. Gulick has added 120 species of Achatinellidæ, bringing the numbers up to nearly $400,-$ but no doubt several of these are so closely related that many conchologists would class them as varieties. The land-shell fauna of the Antilles is undoubtedly the most remarkable in the world, and it has been made the subject of much interesting discussion by Mr. Bland and others. This fauna differs from that of all other parts of the globe in the proportions of the operculate to the inoperculate shells. The Operculata of the globe are about one-seventh, the Inoperculata about six-sevenths of the whole; and some general approximation to this proportion (or a much sinaller one) exists in almost all the continents, islands, and 
archipelagoes. In the Philippines, for example, the proportion of the Operculata is a little more than one-seventh; in the Mauritius, between one-third and one-fourth; in Madeira, onefourteenth; in the whole American continent about one-eighth; but when we come to the Antilles we find them to amount to nearly five-sixths, about half the Operculata of the globe being found there!

Mr. Bland endeavours to ascortain the source of some of the chief genera found in the West Indian Islands, on the principle that "each genus has had its origin where the greatest number of species is found," and then proceeds to determine that some have had an African, some an Asiatic, and some an American origin, while others are truly indigenous. But we fear there is no such simple way of arriving at so important a result; and in the case of groups of extreme antiquity like the genera of mollusca, it would seem quite as possible that the origin of a genus is generally not where the greatest number of species are now found. For during the repeated changes of physical conditions that have everywhere occurred since the Eocene period (to go no further back) every genus must have made extensive migrations, and have often become largely developed in some other district than that in which it first appeared. As a proof of this, we not unfrequently find fossil shells where the species and even the genus now no longer exists; as Auricula, found fossil in Europe, but only living in the Malay and Pacific Islands; Anastoma and Megaspira, now peculiar to Brazil, but fossil in the Eocene of France; and Proserpinc of the West Indies, found in the Eocene formation of the Isle of Wight. The only means by which the origin of a genus can satisfactorily be arrived at, is by tracing back its fossil remains step by step to an earlier form; and this we have at present no means of doing in the case of the land-shells. Taking existing species as our guide we should certainly have imagined that the genus Equus originated in Africa or Central Asia; but recent discoveries of numerous extinct species and of less specialized forms of the same type, seem to indicate that it originated in North America, and that the whole tribe of "horses". may be, for anything we yet know 
to the contrary, recent immigrants into the old World! This example alone must convince us, that it is impossible to form any conclusion as to the origin of a genus, from the distribution of existing species only.

The general conclusion we arrive at, therefore, is, that the causes that have led to the existing distribution of the genera and higher groups of the terrestrial mollusca are so complex, and have acted through such long periods, that most of the barriers which limit the range of other terrestrial animals do not apply to them, although the species are, in most cases, strictly limited by them. Some means of diffusion-which, though probably acting very slowly and at long intervals, and more powerfully on continents than between islands, is yet highly efficient when we consider the long duration of genera-has, to a considerable extent, dispersed them across continents, seas, and oceans. On the other hand, those mountain barriers which separate many groups of the higher vertebrates, are generally less ancient than the genera of land-shells, which are thus often distributed independently of them. In order to compare the distribution of the terrestrial mollusca on equal terms with those of land animals generally, we must take genera of the former as equivalent to family groups of the latter; and we shall, I believe, then find that the distribution of the sub-genera and smaller groups of species do accord mainly with those divisions of the earth into regions and sub-regions which we have here indicated. Mr. Harper Pease, in a communication on Polynesian Land Shells in the Proceedings of the Zoological Society for 1871 (p. 449), marks out the limits of the Polynesian sub-region, so as exactly to agree with that arrived at here from a consideration of the distribution of vertebrata; and he says that this sub-region, (or region, as he terms it) is distinctly characterised by its landshells from all the surrounding regions. The genera (or subgenera) Partula, Pitys, Achatinella, Palaina, Omphalotropis, and many others, are either wholly confined to this sub-region or highly characteristic of it. Mr. Binuey, in his Catalogue of the Air-breathing Molluscs of North America, marks out our Nearctic region (with almost identical limits) as most clearly 
characterised. He also arrives at a series of sub-divisions, which generally (though not exactly) agree with the sub-regions which I have here adopted. The Palæarctic, the Ethiopian, and the Oriental regions, are also generally admitted to be well characterised by their terrestrial molluses. There only remain the Australian and the Neotropical regions, in which some want of homogeneity is apparent, owing to the vast development and specialisation of certain groups in the islands which belong to these regions. The Antilles, on the one hand, and the Polynesian Islands, on the other, are so rich in land-shells and possess so many peculiar forms, that, judged by these alone, they must form primary instead of secondary divisions. We have, however, already pointed out the inconvenience of any such partial systems of zoological geography, and the causes have been sufficiently indicated which have, in the case of land-shells as of insects, produced certain special features of distribution.

We therefore venture to hope, that conchologists will give us the advantage of their more full and accurate knowledge both of the classification and distribution of this interesting group of animals, not to map out new sets of regions for themselves, but to show what kind of barriers have been most efficient in limiting the range of species, and how their distribution is actually effected, so as to be able to explain whatever discrepancies exist between the actual distribution of land-shells and that of the higher animals.

\section{Order III-OPISTHO-BRANCHIATA.}

There are ten families in this order, all of which, as far as known, are widely or universally distributed. Some of them are found fossil, ranging back to the Carboniferous epoch. They are commonly termed Sea-slugs, and have either a thin small shell or none. We shall therefore simply enumerate the families, with the number of genera and species as given by $\mathrm{Mr}$. Woodward.

VOL. II, 
FayILY 31-TORNATELLIDA. (7 Genera, 62 Species living, 166 fossil.)

Family 32.-BULLID $Æ$ (12 Genera, 168 Species living, 88 fossil.)

Family 33.-APHYSIADE. (8 Genera, 84 Species living, 4 fossil.)

Familr 34.-PLEUROBRANCHIDA. (7 Genera, 28 Species living, 5 fossil.)

FAMILY 35.-PHYLLIDIAD E. (4 Genera, 14 Species living, 0 fossil.)

FaMily 36.-DORID EE. (23 Genera, 160 Species living, 0 fossil.)

Fayily 37.-TRITONIADA. (9 Genera, 38 Species living, 0 fossil.)

Fanily 38-—EOLID Æ. (14 Genera, 101 Species living, 0 fossil.)

Family 39.-PHYLLYRHOID E. (1 Genus, 6 Species living, 0 fossil.)

Family 40.-ELYSIAD压. (5 Genera, 13 Species living, 0 fossil.) 


\section{Order IV.-NUCLEO-BRANCHIATA.}

These are oceanic, swimming molluscs, of a delicate texture. They are found in all warm seas, and range back to the Lower Silurian epoch. There are only two families.

Family 41.-FIROLIDÆ. (2 Genera, 33 Species living, 1 fossil.)

Family 42.-ATLANTID $\mathrm{E} . \quad$ (5 Genera, 22 Species living, 159 fossil.)

\section{Class.-PTEROPODA.}

These are swimming, oceanic mollusca, inhabiting both Arctic, Temperate, and Tropical seas. The three families have each a wide distribution in all the great oceans. They range back to the Silurian period.

FAmily 1.-HYALEID 2. (9 Genera, 52 Species living, 95 fossil.)

FAmily 2.-LIMACINID $Æ$ (4 Genera, 19 Species living, 0 fossil.)

Family 3.-CLIONID E. (4 Genera, 14 Species living, 0 fossil.) 


\section{Class.-BRACHIOPODA.}

These are sedentary, bivalve, marine mollusca, having laterally symmetrical shells, but with unequal valves. Both in space and time they are the most widely distributed molluscs. They are found in all seas, and at all deptlis; and when any of the families or genera have a restricted range, it seems to be due to our imperfect knowledge, rather than to any real geographical limitations. In time they range back to the Cambrian formation, and seem to have had their maximum development in the Silurian period. It is not, therefore, necessary for our purpose, to do more than give the names of the families with the numbers of the genera and species, as before.

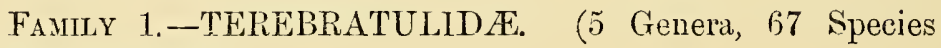
living, 340 fossil.)

Family 2.-SPIRIFERID E. (4 Genera, 0 Species living, 380 [ossil.)

Family 3.-RHYNCHONELLID R. (3 Genera, 4 Species living, 422 fossil.)

Fanily 4.-ORTHID E. (4 Genera, 0 Species living, 328 fossil.)

FAMILy 5.-PRODUCTIDA. (3 Genera, 0 Species living, 146 fossil.)

Famil 6.-CRANIADA. (1 Genus, 5 Species living, 37 fossil.)

Family 7.-DISCINID $\mathbb{Z}$. (2 Genera, 10 species living, 90 fossil.)

Family 8.-LINGULID R. (2 Genera, 16 Species living, 99 fossil.) 


\section{Class.-CONCHIFERA.}

The Conchifera, or ordinary Bivalve Molluses, may be distinguished from the Brachiopoda by having their shells laterally unsymmetrical, while the valves are generally (but not always) equal. They are mostly marine, but a few inhabit fresh water. As the distribution of some of the families presents points of interest, we shall treat them in the same manner as the marine Gasteropoda.

Family 1.-OSTREID A. (5 Genera, 426 Species.)

Distribution.-The Ostreidæ, including the Oysters and Scallops, are found in all seas, Arctic as well as Tropical. There are nearly 1,400 species fossil, ranging back to the Carboniferous period.

Family 2.-AVICULID Æ. (3 Genera, 94 Species.)

Distribution,-The Aviculida, or Wing-shells and Pearl Oysters, are characteristic of Tropical and warm seas, a few only ranging into temperate regions. Nearly 700 fossil species are known from various formations ranging back to the Devonian, and Lower Silurian.

\section{Family 3.-MYTILID $\approx . \quad$ (3 Genera, 217 Species.)}

Distribution,-The Mytilidæ, or Mussels, have a world-wide distribution. There is one fresh-water species, which inhabits the Volga. There are about 350 fossil species, ranging back to the Carboniferous epoch. 
Family 4.-ARCAD ÆE. (6 Genera, 360 Species.)

Distribution-The Arcadæ are universally distributed, and are most abundant in warm seas. The genus Leda is, however, abundant in Arctic and Temperate regions, and Solenella is confined to the South Temperate zone. There are near 1,200 fossil species, found in all strata as low as the Lower Silurian.

\section{Family 5.-TRIGONIADE. (1 Genus, 2 Species.)}

Distribution.-The living Trigonice are confined to Australia, but there are 5 other genera fossil, containing about 150 species, and found in various formations from the Chalk to the Lower Silurian.

\section{Family 6.--UNIONID瓜. (7 Genera, 549 Species.)}

Distribution.-The Unionidæ, or Fresh-water Mussels, are found in all the fresh waters of the globe, but some of the genera are restricted. Castalia, Mycetopus and Mulleria are confined to the rivers of South America; Anodon, to the Nearctic and Palæarctic regions; Iridina, and Etheria, to the rivers of Africa; Unio has a universal distribution, but is especially abundant in North America. About 60 fossil species are found in the Tertiary and Wealden formations.

\section{Family 7.-CHAMIDE. (1 Genus, 50 Species.)}

Distribution.-The Chamidæ, or Giant Clams, are confined to Tropical seas, chiefly among coral reefs. There are two other genera and 62 species fossil, ranging from the Chalk to the Oolite formations.

Family 8.-HIPPURITID E. (5 Genera, 103 Species.)

Fossils of doubtful affinity, from the Chalk formation. 


\section{Family 9.-TRIDACNIDE. (1 Genus, 8 Species.)}

Distribution.-The Tridacnidæ, or Clam-shells, are of very large size, and are confined to the Tropical regions of the Indian and Pacific Oceans. A few species have been found fossil in the Miocene formation.

Family 10,-CARDIAD \&. (1 Genus, 200 Species.)

Distribution.-The Cardiadæ, or Cockles, are of world-wide distribution. Another genus is fossil, and nearly 400 fossil species are known, ranging back to the Upper Silurian formation.

Family 11.-LUCINID 2 . (8 Genera, 178 Species.)

Distribution.--The Lucinidæ inhabit the Tropical and Temperate seas of all parts of the world; but the genus Corbis is confined to the Indian and Pacific Oceans, Montacuta and Lepton, to the Atlantic. There are nearly 500 extinct species, ranging from the Tertiary back to the Silurian formation.

\section{FaMily 12.-CYCLADID E. (3 Genera, 176 Species.)}

Distribution.-The Cycladidæ are small fresh- or brackishwater shells found all over the globe. The genus Cyclas is most abundant in the North Temperate zone, while Cyrena inhabits the warmer shores of the Atlantic and Pacific, but is absent from the West Coast of America. There are about 150 species fossil, ranging back from the Pliocene to the Wealden formations.

\section{FaMily 13.-CYPRINID Æ. (10 Genera, 176 Species). •}

Distribution.-Universal. Cyprina and Astarte are Arctic and North Temperate; Cardita is Tropical and South Temperate. There are several extinct genera and about 1,000 species found in all formations as far back as the Lower Silurian. 
Fanily 14.-VENERIDA, (10 Genera, 600 Species.)

Uistribution.-Universal. Lucinopsis is confined to the North Atlantic; Glauconeza to the mouths of rivers in the Oriental region; Meroe and Trigona to warm seas. There are about 350 fossil species, ranging back to the Oolitic period.

Family 15.-MACTRIDAE. (5 Genera, 147 Species.)

Distribution.-All seas, but more abundant in the Tropics. Gnathodon is found in the Gulf of Mexico; Anatinella in the Oriental region. There are about 60 fossil species, ranging back to the Carboniferous period.

Family 16._TELLINID Ae. (11 Gerera, 560 Species.)

Distribution.-All seas; most abundant in the Tropics. Galatea is confined to African rivers. There are about 60 fossil species, mostly Tertiary, but ranging back to the Carboniferous period.

Family 17.-SOLENIDA. (3 Genera, 63 Species.)

Distribution. - All Temperate and Tropical seas. There are 80 fossil species which range back to the Carboniferous epoch.

\section{FAMily 18.-MYACIDA. (6 Genera, 121 Species.)}

Distribution.-All seas. Panopaca inhabits both North and South Temperate seas ; Glycimeris, Arctic seas. There are near 350 fossil species, ranging back to the Lower Oolite formation.

Fayily 19.-ANATINID A. (8 Genera, 246 Species.)

Distribution.-All seas. Pholadomya is from Tropical Africa; Myadora from the Vestern Pacific; Myochama and Chamostroca are Australian. There are about 400 fossil species, ranging back to the Lower Silurian formation. 


\section{Family 20.-GASTROCH RiNIDA. (5 Genera, 40 Species.)}

Distribution.-Temperate and warm seas. Aspergillum ranges from the Red Sea to New Zealand. There are 35 fossil species, ranging back to the Lower Oolite.

\section{Family 21.-PHOLADIDE. (4 Genera, 81 Species.)}

Distriburion.-These burrowing molluses inhabit all Temperate and warm seas from Norway to New Zealand. There are about 50 fossil species, ranging back to the epoch of the Lias.

General Remarks on the Distribution of the Marine Mollusca.

The marine Mollusca are remarkable for their usually wide distribution. About 48 of the families are cosmopolitan, ranging over both hemispheres, and in cold as well as warm seas. About 15 are restricted to the warmer seas of the globe; but several of these extend from Norway to New Zealand, a distribution which may be called universal, and only 2 or 3 are absolutely confined to Tropical seas. Two small families only, are confined to the Pacific and Indian Oceans. Marine fishes, on the other hand, have a much less cosmopolitan character, no less than 30 families having a limited distribution, while 50 are universal. Some of these 30 families are confined to the Northern seas, some to the Atlantic and Mediterranean, and a considerable number to the Indian Ocean and Western Pacific. Many of these families, it is true, are much smaller than those of the Mollusca, which seem to possess very few of those small isolated families of two or three species only, which abound in all the Vertebrate classes. These differences are no doubt connected with the higher organisation of fishes, which renders them more susceptible to changed conditions of life; and this is indicated by the much less antiquity of existing families of fishes, the greater part of which do not date back beyond the Cretaceous epoch, and many of them only to the Eocene. In striking con. trast we have the vast antiquity of most of the families of Mol- 
lusca, as shown in the following table of their range taken from Mr. Woodward's work, but re-arranged, and somewhat modified.

\begin{tabular}{|c|c|c|c|c|c|c|c|c|c|c|c|c|c|c|}
\hline $\begin{array}{l}\text { Range of Families of Mollusea } \\
\text { in Time; arranged in their } \\
\text { order of appearance and } \\
\text { disappearance. }\end{array}$ & 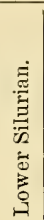 & 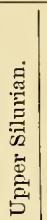 & 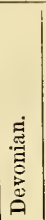 & 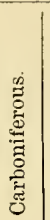 & 苛 & 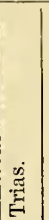 & 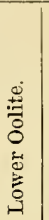 & 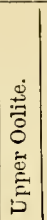 & 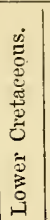 & 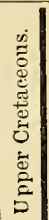 & 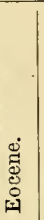 & 苋 & 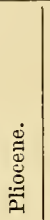 & 竞 \\
\hline & & & - & - & - & - & - & - & - & - & - & - & - & \\
\hline Productidæ $\quad \ldots$ & - & - & - & - & - & & & & & & & & & \\
\hline Orthoceratidæ ... & - & 一 & - & - & - & - & & & & & & & & \\
\hline Spiriferidæ, Orthidæ ... & - & - & - & - & - & - & - & & & & & & & \\
\hline Atlantidæ, Hyaleidæ ... & - & - & - & - & - & - & - & - & -1 & - & - & - & - & -- \\
\hline Pyramidellidæ, Turbinidæ & - & - & -- & - & - & - & -1 & - & - & - & - & - & - & - \\
\hline Ianthidæ, Chitonidæ ... & - & - & - & - & - & - & - & - & - & 一 & - & - & - & - \\
\hline Lingulidæ $\quad \ldots, \quad \ldots$ & 一 & - & - & - & - & - & - & 一 & - & 一 & - & - & - & - \\
\hline Avieulidre, Mytilidæ ... & - & - & - & - & - & - & & - & 一 & & & & - & - \\
\hline Arcadæ, Trigoniadæ ... & -- & - & -- & - & - & - & - & - & - & - & - & - & - & - \\
\hline Cyprinidæ, Anatinidæ... & - & - & - & - & - & - & - & - & - & - & - & - & - & 一 \\
\hline Nautilidæ $\quad \cdots \quad \ldots$ & & - & -1 & $1-1$ & - & -1 & -1 & -1 & -1 & - & & & $1-1$ & - \\
\hline $\left.\begin{array}{c}\text { Rhynchonellidæ, Cra- } \\
\text { niadæ, Discinidæ }\end{array}\right\}$ & & - & - & - & - & - & - & - & - & 一 & - & -1 & - & - \\
\hline Cardiadæ, Lucinidæ ... & & - & - & - & - & - & 一 & - & - & - & 一 & -1 & - & - \\
\hline Ammonitidæ $\ldots \ldots$ & & & - & - & - & - & - & - & - & -1 & & & & \\
\hline Naticidæ, Calyptræidæ.. & & & - & - & - & - & - & - & -1 & - & - & - & - & - \\
\hline Dentalidæ, Terebratulidæ & & & - & - & - & - & - & - & - & - & - & - & -1 & - \\
\hline Helicidæ & & & & - & & & & & & & - & - & - & - \\
\hline Fissurellidæ, Tornatellidæ & & & & - & - & - & - & - & - & 一 & - & 一 & - & 一 \\
\hline Pectinidæ, Solenidæ ... & & & & - & & & - & -1 & -1 & - & - & -1 & $1-1$ & - \\
\hline $\left.\begin{array}{l}\text { Cerithiadæ, Littorini- } \\
\text { dæ, Astartidæ }\end{array}\right\}$ & & & & & & & - & - & - & - & - & - & - & - \\
\hline Belemnitidæ & & & & & & & - & - & - & - & & & & \\
\hline Tenthidæ, Sepiadæ $\ldots$ & & & & & & & - & -1 & - & - & - & - & - & - \\
\hline $\left.\begin{array}{cc}\text { Neritidæ, } & \text { Patellidæ, } \\
\text { Bullidæ } & \ldots\end{array}\right\}$ & & & & & & & - & - & - & -. & - & - & - & - \\
\hline Gastrochænidæ,Pholadidæ & & & & & & & - & - & - & - & - & - & - & - \\
\hline Limnæidæ, Melaniadæ & & & & & & & & - & - & - & - & - & - & -. \\
\hline Chamidæ, Myadæ. & & & & & & & & - & -1 & -1 & - & - & - & - \\
\hline $\left.\begin{array}{c}\text { Cycladidæ, Veneridæ, } \\
\text { Tellinidæ } \\
\ldots\end{array}\right\}$ & & & & & & & & - & - & - & - & - & - & - \\
\hline Hippuritidæ $\quad$.. & & & & & & & & & - & - & & & & \\
\hline Unionidæ $\quad \ldots$ & & & & & & & & & 一 & - & - & 一 & - & - \\
\hline Strombidæ, Buccinidæ & & & & & & & & & & - & - & - & - & - \\
\hline Conidæ, Volutidæ $\ldots$ & & & & & & & & & & 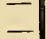 & - & - & - & - \\
\hline $\begin{array}{l}\text { Auriculidæ, Cyclostomidæ } \\
\text { Mactridæ }\end{array}$ & & & & & & & & & & - & - & - & - & - \\
\hline Limacidæ & & & & & & & & & & & - & - & - & - \\
\hline Argonautidæ $\quad \ldots$ & & & & & & & & & & & & & - & - \\
\hline Tridacnidæ & & & & & & & & & & & & & - & \\
\hline
\end{tabular}

Nor is this enormous antiquity confined to family types alone. Many genera are equally ancient. The genus Lingula has 
existed from the earliest Palæozoic times down to the present day; while Terebratula, Rhynchonella, Discina, Nautilus, Natica, Pleurotomaria, Patella, Dentalium, Mytilus and many other living forms, range back to the Palæozoic epoch. That groups of such immense antiquity, and having power to resist such vast changes of external conditions as they must have been subject to, should now be widely distributed, is no more than might reasonably be expected. It is only in the case of sub-genera and species, that we can expect the influence of recent geological or climatal changes to be manifest; and it must be left to special students to work out the details of their distribution, with reference to the general principles found to obtain among the more highly organised animals. 


\section{CHAPTER XXIII.}

SUMMARY OF THE DISTRIBUTION, AND LINES OF MIGRATION, OF THE SEVERAL CLASSES OF ANIMALS.

HAVING already given summaries of the distribution of the several orders, and of some of the classes of land animals, we propose here to make a few general remarks on the special phenomena presented by the more important groups, and to indicate where possible, the general lines of migration by which they have become dispersed over wide areas.

\section{Mamialia.}

This class is very important, and its past history is much better known than that of most others. We shall therefore briefly summarise the results we have arrived at from our examination of the distribution of extinct and living forms of each order.

Primates.-This order, being pre-eminently a tropical one, became separated into two portions, inhabiting the Eastern and Western Hemispheres respectively, at a very early epoch. In consequence of this separation it has diverged more radically than most other orders, so that the two American families, Cebidæ and Hapalidæ, are widely differentiated from the Apes, Monkeys, and Lemurs of the Old World. The Lemurs were probably still more ancient, but being much lower in organisation, they became extinct in most of the areas where the higher forms of Primates became developed. Remains found in the Eocene formation indicate, that the North American and European 
Primates had, even at that early epoch, diverged into distinct series, so that we must probably look back to the secondary period for the ancestral form from which the entire order was developed.

Chiroptera.-These are also undoubtedly very ancient. The most generalised forms - the Vespertilionidæ and Noctilionidæare the most widely distributed; while special types have arisen in America, and in the Eastern Hemisphere. Remains found in the Upper Eocene formation of Europe differ little from species still living in the same countries; so that we can form no conjecture as to the origin or migration. of the group. Their power of flight would, however, enable them rapidly to spread over all the great continents of the globe.

Insectivora.-This very ancient group, now probably verging towards extinction, appears to have originated in the Northern continent, and never to have reached Australia or South America. It may, however, have become extinet in the latter country owing to the competition of the numerous Edentata. The Insectivora now often maintain themselves amidst more highly developed forms, by means of some special protection. Some burrow in the earth,-like the moles; others have a spiny covering,-as the hedgehogs and several of the Centetidæ; others are aquatic,--as the Potamogale and the desman; others have a nauseous odour,-as the shrews; while there are several which seem to be preserved by their resemblance to higher forms,- as the elephant-shrews to jerboas, and the tupaias to squirrels. The same need of protection is shown by the numerous Insectivora inhabiting Madagascar, where the competing forms are few; and by one lingering in the Antilles, where there are hardly any other mammalia.

Carnivora.-Although perhaps less ancient than the preceding, this form of mammal is far more lighly organised, and from its earliest appearance appears to have become dominant in the world. It would therefore soon spread widely, and diverge into the various specialised types represented by existing families. Most of these appear to have originated in the Eastern Hemisphere, the only Carnivora occurring in North 
American Miocene deposits being ancestral forms of Canidæ and Felidæ. It seems probable, therefore, that the order had attained a considerable development before it reached the Western Hemisphere. The Procyonidæ, now confined to America, are not very ancient; and the occurrence of a few allied forms in the Himalayas (Allurus and AEluropus) render it probable that their common ancestors entered North America from the Palæarctic region during the Miocene period, but being a rather low type they have succumbed under the competition of higher forms in most parts of the Eastern Hemisphere. Bears and Weasels are probably still more recent emigrants to America. The aquatic carnivora (Seals, \&c.) are, as might be expected, more widely and uniformly distributed, but there is little evidence to show at what period the type was first developed.

Ungulata.-These are the dominant vegetable-feeders of the great continents, and they have steadily increased in numbers and in specialisation from the oldest Tertiary times to the present day. Being generally of larger size and less active than the Carnivora, they have somewhat more restricted powers of dispersal. We have good evidence that their wide range over the globe is a comparatively recent phenomenon. Tapirs and Llamas have probably not long inhabited South America, while Rhinoceroses and Antelopes were once, perhaps, unknown in Africa, although abounding in Europe and Asia. Swine are one of the most ancient types in both hemispheres; and their great hardiness, their omnivorous diet, and their powers of swimming, have led to their wide distribution. The sheep and goats, on the other hand, are perhaps the most recent development of the Ungulata, and they seem to have arisen in the Palæarctic region at a time when its climate already approximated to that which now prevails. Hence they are pre-eminently a Temperate group, never found within the Tropics except upon a few mountain ranges.

Proboscidea.-These huge animals (the Elephants and Mastodons) appear to have originated in the warmer parts of the Palæarctic region, but they soon spread over all the great 
continents, even reaching the southern extremity of America. Their extinction has probably depended more on physical than on organic changes, and we can clearly trace their almost total disappearance to the effects of the Glacial epoch.

Rodentia.-Rodents are a very dominant group, and a very ancient one. Owing to their small size and rapid powers of increase, they soon spread over almost every part of the globe, whence has resulted a great specialisation of family types in the South American continent which remained so long isolated. They are capable of living wherever there is any kind of vegetable food, hence their range will be determined rather by organic than by physical conditions; and the oceupation of a country by enemies or by competing forms, is probably the chief cause which has prevented many of the families from acquiring a wide range. The occurrence of isolated species of the South American families, Octodontidæe and Echimyidæ in the Ethiopian and Palæarctic regions, is an indication that the range of many of the families has recently become less extensive.

Edentata.-These singular and lowly-organised animals appear to have become almost restricted to the two great Southern lands-South Africa and South America-at an early period; and, being there free from the competition of higher forms, developed a number of remarkable types often of huge size, of which the Megatherium is one of the best known. The incursion of the highly-organised Ungulates and Carnivora into Africa during the Miocene epoch, probably exterminated most of them in that continent; but in America they continued in full force down to the Post-Pliocene period; and even now, the comparatively diminutive Sloths, Ant-eaters, and Armadillos, form a large and important portion of the fauna.

Marsupialia and Monotremata.-These are probably the representatives of the most ancient and lowly-organised types of mammal. They once existed in the northern continents, whence they spread into Australia; and being isolated, and preserved from the competition of the higher forms which soon arose in other parts of the world, they have developed into a variety of types, which, however, still preserve a general 
uniformity of organisation. One family, which continued to exist in Europe till the latter part of the Miocene period, reached Anerica, and has there been preserved to our day.

Lines of Migration of the Mammalia.-The whole series of phenomena presented by the distribution of the Mammalia, looked at broadly, are in harmony with the view that the great continents and oceans of our own epoch have been in existence, with comparatively small changes, during all Tertiary times. Each one of them has, no doubt, undergone considerable modifications in its area, its altitude, and in its connection with other lands. Yet some considerable portion of each continent has, probably, long existed in its present position, while the great oceans seem to have occupied the same depressions of the earth's crust (varied, perhaps, by local elevations and subsidences) during all this vast period of time. Hence, allowing for the changes of which we have more or less satisfactory evidence, the migrations of the chief mammalian types can be pretty clearly traced. Some, owing to their small size and great vitality, have spread to almost all the chief land masses; but the majority of the orders have a more restricted range. All the evidence at our command points to the Northern Hemisphere as the birth-place of the class, and probably of all the orders. At a very early period the land communication with Australia was cut off, and has never been renewed; so that we have here preserved for us a sample of one or more of the most ancient forms of mammal. Somewhat later the union with South Ameriea and South Africa was severed; and in both these countries we have samples of a somewhat more advanced stage of mammalian development. Later still, the union by a northern route between the Eastern and Western Hemispheres appears to have been broken, partly by a physical separation, but almost as effectually by a lowering of temperature. About the same period the separation of the Palrearctic region from the Oriental was effected, by the rise of the Himalayas and the increasing contrast of climate; while the formation of the great desert-belts of the Sahara, Arabia, Persia, and Central Asia, helped to complete the separation of 
the Temperate and Tropical zones, and to render further intermigration almost impossible.

In a few cases-of which the Rodents in Australia and the pigs in Austro-Malaya are perhaps the most striking examples - the distribution of land-mammals has been effected by a seapassage either by swimming or on floating vegetation; but, as a rule, we may be sure that the migrations of mammalia have taken place over the land; and their presence on islands is, therefore, a clear indication that these have been once connected with a continent. The present class of animals thus affords the best evidence of the past history of the land surface of our globe; and we have chiefly relied upon it in sketching out (in Part III.) the probable changes which each of our great regions has undergone.

\section{Birds.}

Although birds are, of all land-vertebrates, the best able to cross seas and oceans, it is remarkable how closely the main features of their distribution correspond with those of the Mammalia. South America possesses the low Formicaroid type of Passeres,-which, compared with the more highly developed forms of the Eastern Hemisphere, is analogous to the Cebidre and Hapalidæ as compared with the Old World Apes and Monkeys; while its Cracidæe as compared with the Pheasants and Grouse, may be considered parallel to the Edentata as compared with the Ungulates of the Old World. The Marsupials of America and Australia, are paralleled, among birds, in the Struthionidæe and Megapodiidæ; the Lemurs and Insectivora preserved in Madagascar are represented by the Mascarene Dididre; the absence of Deer and Bears from Africa is analogons to the absence of Wrens, Creepers, and Pheasants; while the African Hyracidæe and Chrysochloridæe among mammals, may well be compared with the equally peculiar Coliidæe and Musophagidee among birds.

From these and many other similarities of clistribution, it is clear that birds have, as a rule, followed the same great lines of migration as mammalia ; and that oceans, seas, and deserts, baro VOL. II. 
always to a great extent limited their range. Yet these barriers have not been absolute; and in the course of ages birds have been able to reach almost every habitable land upon the globe. Hence have arisen some of the most curious and interesting phenomena of distribution ; and many islands, which are entirely destitute of mammalia, or possess a very few species, abound in birds, often of peculiar types and remarkable for some unusual character or habit. Striking examples of such interesting birdfauuas are those of New Zealand, the Sandwich Islands, the Galapagos, the Mascarene Islands, the Moluceas, and the Antilles; while even small and remote islets,-such as Juan Fernandez and Norfolk Island, have more light thrown upon their past history by means of their birds, than by any other portion of their scanty famna.

Another peculiar feature in the distribution of this class is the extraordinary manner in which certain groups and certain external characteristics, have become developed in islands, where the smaller and less powerful birds have been protected from the incursions of maminalian enemies, and where rapacious birds-which seem to some degree dependent on the abundance of mammalia - are also scarce. Thus, we have the Pigeons and the Parrots most wonderfully developed in the Australian region, which is pre-eminently insular; and both these groups here acquire conspicuous colours very unusual, or altogether absent, elsewhere. Similar colours (black and red) appear, in the same two groups, in the distant Mascarene islands; while in the Antilles the parrots have often white heads, a character not found in the allied species on the South American continent. Crests, too, are largely developed, in both these groups, in the Australian region only; and a crested parrot formerly lived in Mauritius, - a coincidence too much like that of the colours as above noted, to be considered accidental.

Again, birds exhibit to us a remarkable contrast as regards the oceanic islands of tropical and temperate latitudes; for while most of the formor present harlly any cases of specific identity with the birds of adjacent continents, the latter often show hardly any differences. The Galapagos and Madagascar 
are examples of the first-named peculiarity; the Azores and the Bermudas of the last; and the difference can be elearly traced to the frequency and violence of storms in the one case and to the ealms or steady breezes in the other.

It appears then, that although birds do not afford us the same convincing proof of the former union of now disjoined lands as we obtain from mammals, yet they give us much curious and suggestive information as to the various and complex modes in which the existing peculiarities of the distribution of animals have been brought about. They also throw much light on the relation between distribution and the external charaeters of animals; and, as they are often found where mammalia are quite absent, we must rank them as of equal value for the purposes of our present sturly.

$$
\text { Reptiles. }
$$

These hold a somewhat intermediate place, as regards their distribution, between mammals and birds, having on the whole rather a wider range than the former, and a more restricted one than the latter.

Snakes appear to have hardly more facilities for erossing the ocean than mammals; hence they are generally absent from oceanic islands. They are more especially a tropical group, and have thus never been able to pass from one continent to anothex by those high northern and southern routes, which we have seen reason to believe were very effectual in the ease of mammalia and some other animals. Hence we find no resemblance between the Australian and Neotropical regions, or between the Palæ. arctic and Nearctic; while the Western Hemisphere is comparatively poor as regards variety of types, although rich in genera and species. Deserts and high mountains are also very effectual barriers for this group, and their lines of migration have probably been along river valleys, and occasionally across narrow seas by meaus of floating vegetation.

Lizards, being somewhat less tropical than snakes, may have passed by the northern route during warm epochs. They are also more suited to traverse deserts, and they possess some nnknown 
means of crossing the ocean, as they are not unfrequently formd in remote oceanic islands. These various causes have modified their distribution. The Western Hemisphere is much richer in lizards than it is in snakes; and it is also very distinct from the Eastern Hemisphere. The lines of migration of lizards appear to have been along the mountains and deserts of tropical countries, and, under special conditions, across tropical seas from island to island.

Crocodiles are a declining group. They were once more generally distributed, all the three families being found in British Eocene deposits. Being aquatic and capable of living in the sea, they can readily pass along all the coasts and islands of the warmer parts of the globe. Tortoises are equally ancient, and the restriction of certain groups to definite areas seems to be also a recent phenomenon.

\section{Amphibia.}

The Amphibia differ widely from Reptiles in their power of enduring cold; one of their chief divisions, the Urodela or Tailed-Batrachia, being confined to the temperate parts of the Northern Hemisphere. To this class of animals the northern and southern routes of migration were open; and we accordingly find a considerable amount of resemblance between South America and Australia, and a still stronger affinity between North America and the Palæarctic continent. The other tropical regions are more distinct from each other; clearly indicating that, in this group, it is tropical deserts and tropical oceans which are the barriers to migration. The class however is very fragmentary, and probably very ancient; so that descendants of once widespread types are now found isolated in various parts of the globe, between which we may feel sure there has been no direct transmission of Batrachia. Remembering that their chief lines of migration have been by northern and southern land-routes, by floating ice, by fresh-water channels, and perhaps at rare intervals by ova being carried by aquatic birds or by violent storms, - we shall be able to comprehend most of the features of their actual distribution. 


\section{Fresh-vater Fishes.}

Although it would appear, at first sight, that the means of dispersal of these animals are very limited, yet they share to some extent the wide range of other fresh-water organisms. They are found in all climates; but the tropical regions are by far the most productive, and of these Sonth America is perhaps the richest and most peculiar. There is a certain amount of identity between the two northern continents, and also between those of the Sonth Temperate zone; yet all are radically distinct, even North America and Europe having but a small proportion of their forms in common. The occurrence of allied fresh-water species in remote lands-as the Aphritis of Tasmania and Patagonia, and the Comephorus of Lake Baikal, distantly allied to the mackerels of Northern seaswould imply that marine fishes are often modified for a life in fresh waters; while other facts no less plainly show that permanent fresh-water species are sometimes dispersed in various ways across the oceans, more especially by the northern and southern routes.

The families of frosh-water fishes are often of restricted range, although cases of very wide and scattered distribution also occur. The great zoological regions are, on the whole, very well characterized; showing that the same barriers are effectual here, as with most other vertebrates. We conclude, therefore, that the chief lines of migration of fresh-water fishes have been across the Arctic and Antaretic seas, probably by means of floating ice as well as by the help of the vast flocks of migratory aquatic birds that frequent those regions. On continents they are, usually, widely dispersed ; but tropical seas, even when of small extent, appear to have offered an effectual barrier to their dispersal. The cases of affinity between Tropical America, Africa, Asia, and Australia, must therefore be imputed either to the survival of once widespread groups, or to analogous adaptation to a fresh-water life of wide-spread marine types; and these cases cannot be taken as evidence of any former land connection between such remote continents. 


\section{Insects.}

It has alrealy been shown (Vol. I. pp. 209-213 and Vol. II. pp. 44-48) that the peculiarities of elistribution of the various groups of insects depend very much on their habits and general economy. Their antiquity is so vast, and their more important modifications of structure have probably occurred so slowly, that modes of dispersal depending on such a combination of favourable conditions as to be of excessive rarity, may yet have had time to produce large eumulative effects. Their small specific gravity and their habits of flight render them liable to dispersal by winds to an extent unknown in other classes of animals; and thus, what are usually very effectual barriers have been overstepped, and sometimes almost obliterated, in the case of insects. A careful examination will, however, almost always show traces of an ancient fauna, agreeing in character with other classes of animals, intermixed with the more prominent and often more numerous forms whose presence is due to this unusual facility of dispersal.

The effectual migration of insects is, perhaps more than in any other class of animals, limited by organic and physical conditions. The vegetation, the soil, the temperature, and the supply of moisture, must all be suited to their habits and economy; while they require an immunity from enemies of various kinds, which immigrants to a new country seldom obtain. Few organisms have, in so many complex ways, become adapted to their special environment, as have insects. They are in each country more or less adapted to the plants which belong to it; while their colours, their habits, and the very nature of the juices of their system, are all modified so as to protect them from the special dangers which surround them in their native land. It follows, that while no animals are so well adapted to show us the various motes by which dispersal may be effected, none can so effectually teach us the true nature and vast influence of the organic barrier in limiting dispersal.

It is probable that insects have at one time or another taken advantage of every line of migration by which any terrestrial 
organisms have spread over the earth, but owing to their small size and rapid multiplication, they have made use of some which are exclusively their own. Such are the passage along mountain ranges from the Arctic to the Antarctic regions, and the dispersal of certain types over all temperate lands. It will perhaps be found that insects have spread over the land surface in directions depenilent on our surface zones-forests, pastures, and deserts; - and a study of these, with a due consideration of the fact that narrow seas are scarcely a barrier to most of the groups, may assist us to understand many of the details of insect-distribution.

\section{Teriestrial Molluse.}

The distribution of land-shells agrees, in some features, with that of insects, while in others the two are strongly contrasted. In both we see the effects of great antiquity, with some special means of dispersal ; but while in insects the general powers of motion, both voluntary and involuntary, are at a maximum, in land-molluses they are almost at a minimum. Althongh to some extent dependent on vegetation and climate, the latter are more dependent on imorganic conditions, and also to a large extent on the general organic environment. The result of these various causes, acting through countless ages, has been to spread the main types of structure with considerable uniformity over the globe; while generic and sub-generic forms are often wonderfully localized.

Land-shells, even more than insects, seem, at first sight, to require regions of their own; but we have already pointed out the disadvantages of such a method of study. It will be far more instructive to refer them to those regions and subregions which are found to accord best with the distribution of the higher animals, and to consider the various anomalies they present as so many problems, to be solved by a careful study of their habits and economy, and especially by a search after the hidden causes which have enabled them to spread so widely over land and ocean.

The lines of nigration which land-shells have followed, can 
hardly be determined with any definiteness. On continents they secm to spread steadily, but slowly, in every direction, checked probably by organic and physical conditions rather than by the burriers which limit the higher groups. Over the ocean they are also slowly dispersed, by some means which act perhaps at very long intervals, but which, within the period of the duration of genera and families, are tolerably effective. It thus happens that, although the powers of dispersal of land-shells and insects are so very unequal, the resulting geographical distribution is almost the opposite of what might have been expected,-the former being, on the whole, less distinctly localized than the latter.

\section{CONCLUSION.}

The preceding remarks are all I now venture to offer, on the distinguishing features of the various groups of land-animals as regards their distribution and migrations. They are at best but indications of the various lines of research opened up to us by the study of animals from the geographical point of view, and by looking upon their range in space and time as an important portion of the earth's history. Much work has yet to be done before the materials will exist for a complete treatment of the subject in all its branches; and it is the author's hope that his volumes may lead to a more systematic collection and arrangement of the necessary facts. At present all public museums and private collections are arranged zoologically. All treatises, monographs, and catalogues, also follow, more or less completely, the zoological arrangement; and the greatest difficulty the student of geographical distribution has to contend against, is the total absence of geographical collections, and the almost total want of complete and comparable local catalogues. Till every wellmarked district,-every archipelago, and every important island, has all its known species of the more important groups of animals catalogued on a uniform plan, and with a uniform nomenclature, a thoroughly satisfactory account of the Geographical Distribution of Animals will not be possible. But more than this is wanted. Many of the most curious relations between animal 
forms and their habitats, are entirely unnoticed, owing to the Iroductions of the same locality never being associated in our museums and collections. A few such relations have been brought to light by modern scientific travellers, but many more remain to be discovered; and there is probably no fresher and more productive field still unexplored in Natural History. Most of these curious and suggestive relations are to be found in the productions of islands, as compared with each other, or with the continents of which they form appendages; but these can never be properly studied, or even discovered, unless they are visibly grouped together. When the birds, the more conspicnous families of insects, and the land-shells of islands, are kept together so as to be readily compared with similar associations from the adjacent continents or other islands, it is believed that in almost every case there will be found to be peculiarities of form or colour running through widely different groups, and strictly indicative of local or geographical influences. Some of these coincident variations have been alluded to in various parts of this work, iut they have never been systematically investigated. They constitnte an unworked mine of wealth for the enterprising explorer; and they may not improbably lead to the discovery of some of the hidden laws (supplementary to Natural Selection), which seem to be required, in order to account for many of the external characteristics of animals.

In concluding his task, the author ventures to suggest, that naturalists who are disposed to turn aside from the beaten track of research, may find in the line of study here suggested a new and interesting pursuit, not inferior in attractions to the lofty heights of transcendental anatomy, or the bewildering mazes of modem classification. And it is a study which will surely lead them to an increased appreciation of the beauty and the harmony of nature, and to a fuller comprehension of the complex relations and mutual interdependence, which link together every animal and vegetable form, with the ever-changing earth which supports them, into one grand organic whole. 

GENERAL INDEX. 



\section{GENERAL INDEX.}

Alu names in Italies refer, either to the genera and othar groups of Extinet Animals in Part II. of the First Volume;--or to the genera whose distribution is given under Geographical Zoology (Part IV.) in the Second Volume; the Families and higher groups being in small eapitals. All other references are in ordinary type.

The various matters discussed under Zoological Geography (Part III.), are indexed as mueh as possible by subjects and localities. None of the genera mentioned in this Part are indexerl, as this would have more than doubled the extent of the Index, and would lave served no useful purpose, becanse the general distribution of each genus is given in Part IV., and the separate details eall always be found by refering to the region, sub-region, and class.

\section{A.}

Aard-vark of East Africa, figmre of, i. 261

Aard-vark, ii. 246

Aard-wolf, ii. 196

Abacetus, ii. 491

$A b a x$, ii. 489

Abisara, ii. 475

Allabes, ii. 375

Ablcpharnis, ii. 395

Abramis, ii. 453

Abronia, it. 392

Abrornis, ii. 258

Abrostomus, ii. 451

Aburria, ii. 343

Acalyptus, ii 384

Acanthias, ii. 461

Acanthicus, ii. 444

Acanthion, ii. 240

Acanthis, ii. 283

Acanthisitta, ii. 265

Acanthiza, ii. 258

Acanthobrama, ii. 453

ACANTHOCIINIDA, ii. 432

Acanthodactylus, ii. 391

Acanthodelphis, ii. 209

Acantholabrus, ii. 437

Acanthomys, ii. 229

Acanthophis, ii. 383

Acanthopsis, ii. 453

ACANTHOPTERYGII, ii. 424

ACANTHOPTERYGII PHARYNCOGNATHI, ii. 437

Acanthopthalmus, ii, 453

Acanthoptila, ii. 261

Acanthopyga, ii. 390

Aconthorhynchus, ii. 275

Acanthosaura, ii. 402
Acara, ii. 438

Accentor, ii. 260

Accentorinæ, ii. 257

Accipenser, ii. 459

ACCIPENSERID E, ii. 459

Accipiter, ii. 348

Accipitres, European Eocene, i. 163

Accipitres, classification of, i. 97

range of Palsearctic genera of, i. 248

range of Ethiopian genera of, i. 312

range of Oriental genera of, i. 385

range of Australian genera of, i. 486

ACCIPITRES, ii. 345

general remarks on the distribution of, ii. 351

ACCIPITRIN E, ii. 3.17

Acerina, ii. 425

Aceros, ii. 317

Acerotherium, ii. 214

Acerotherium, European Miocene, i. 119

N. American Tertiary, i. 136

Acestra, ii. 444

Acestura, ii. $10 \mathrm{~s}$

Achalinus, ii. 375

Acharnes, ii. 434

Achatina, ii. 515

Achatinella, ii. 514

Acherontia, ii. 483

Achilognathus, ii. 452

Achcenodon, N, American Tertiary, i $13 \mathrm{~S}$

Acicula, ii. 519

ACICULID $\mathbb{E}$, ii. 519

Acmoeodera, ii. 497

Acodon, ii. 230

ACONTIADÆ, ii. 399

Acontias, ii. 399

Acotherium, European Eocene, i. 126

Acotherium, ii. 215 
Acraca. ii. 473

ACRAID $A$, ii. 473

Acrantus, ii. 390

Acredula, ii. 266

Acrilotheres, ii. 287

Acris, ii. 419

Acrobata, ii. 252

Acrocepluelus, ii. 258

Acrochilus, ii. 452

ACROCHORDID E, ii. 383

Acrochordonichthys, ii. 442

Acrochordus, ii. 382

ACRONURIDA, ii. 433

Acronternis, ii. 297

Acryllium, ii. 340

Actenodes, ii. 497

Actinodura, ii. 261

$A d a$, ii. 390

Adamsiella, ii. 521

Adapis, European Eocene, i. 125

Addax, ii. 223

Adelomia, ii. 108

Adelotopus, ii. 490

Adenomera, ii. 410

Adolias, ii. 474

Aedon, ii. 259

Ágeria, ii. 482

AGERIID E, ii. 482

Agialitis, ii. 350

Agithaliscus, ii. 266

Agithalus, ii. 266

Egocera, ii. 482

Egotheles, ii. 318

Eluredus, ii. 275

Alurichthys, ii. 443

ELURID E, ii. 201

Alurogale, European Eocene, i. 125

Asluropus, ii. 201

Alures, ii. 201

Ámona, ii. 4i-

Enioma, ii. 490

Asolindce, ii. 530

Ejyceros, ii. 223

Apyornis, of Madagasuar, i. 164

Fipyornis, ii. 370

APYORNITHID $A$, ii. 370

Esacus, ii. 355

Ashina, from the Lias, i. 167

Athopyga, ii. 276

Ethya, ii. 364

Agama, ii. 402

AGAMI 1 ⿸厂⿷, ii. 401

Agapornis, ii 328

Agarista, ii. 482

Agaristida, ii. 482

Agelasta, ii. 501

AGELASTINA, ii. 340

Agelceus, ii. 282

Ageniosus, ii 443

Ageronia, ii. 474

Aglaractis, ii. 108

Agnopterus, European Eocene, i, 163

Agoniates, ii. 445

Agonostoma, ii, 435

Agonus, ii. 428

Agonti, ii. 241

Agra, ii. 490

Agraulis, ii. 474

Agrilus, ii. 497

Agriochcerus, N. American Tertiary, i. 139

Agrion, from the Lias, i. 167

Agriornis, ii. 100

Ahretulla, ii. 379

Ailia, ii. 442

Aipysurus, ii. 384

A ithurus, ii. 107
Aix, ii, 363

Aliysis, ii. 442

Aleemon, ii. 289

Alaska, birds of, ii. 136

Alauda, ii. 289

ALAUDIDE, ii. 289

Albatrosses, ii. 365

Albulichthys, ii. 452

Alburnus, ii. 453

Alca, ii. 367

Alcadia, ii. 522

ALCEDINID \&, ii. 315

Alcedo, ii. 316

ALCEPHA LIN F, ii. 224

Alcephalus, Indian Miocene, i. 122

Alcephalus, ii. 224

Alces, ii. 219

ALCID $\approx$, ii. 367

Alcippe, ii. 261

Alcurus, ii. 267

Aleyone, ii. 316

Aldabra Islands, land-tortoises of, i. 289

Alectorurus, ii. 100

Alectrenas, ii. 332

ALEPOCEPHALIDA, ii. 454

Alesa, ii. 475

Alestes, ii. 445

Alethe, ii. 262

Aletornis, N. American Eocene, i. 163

Alentian Islands, hirds of, ii. 137

Algeria, Post-Pliocene deposits and eaves of, i. 111

Algira, ii. 391

Alleghany sub-region, ii. 130

maummalia of, ii. 132

birds of, ii. 132

reptiles of, ii. 133

amplibia of, ii. 134

fishes of, ii. 134

islands of, ii. 134

Allen, Mr. J. A., on Zoological regions, i. 61 objections to his system of cireunipolar zones, i. 67

objections to his zoo-geographical nomenclature, i. 68

on hirds of N. America, ii. 133, 136

Alligator, ii. 406

ALLIGATORID $\mathrm{E}$, ii. 406

Alligators, ii. 406

Allotinus, ii. 477

Alopecias, ii. 460

Alscecomus, ii. 332

Alsecus, ii. 259

Alseonax, ii. 270

Alsodes, ii. 417

Altai monntains, fossils in caves, i, 111

Alytes, ii. 417

ALYTIDA, ii. 417

Amadina, ii. 287

Am+ra, ii. 489

Amarynthis, ii. 476

Amathusia, ii. 472

Amauresthes, ii. 287

Aman rospiza, ii. 285

Anazilia, ii. 109

Amblyrhiza, Plincene of Antilles, i. 148

AMBLYCEPHALIDE, ii 380

A mblycephalus, ii. 380

Amblyceps, ii. 443

Amblychila, ii. 487

Amblymora, ii. 501

Amblyopsis, ii. 450

Amblyornis, ii. 275

Amblypharyngodon, ii. 452

Amblypodia, ii 477

Amblyrhamphus, ii. 292 
Amblyrhiza, ii. 237

Amblyrhynchichthys, ii. 452

Amblystoma, ii. 413

Ameiva, ii. 390

America, recent separation of North and South, i. 40

extinet mammalia of, i. 129

N., Post-Pliocene fauna of, i. 129

American Creepers, ii. 295

AMIID E, ii. 458

Amiurus, ii. 442

Ammodromus, ii. 284

A mmodytes, ii. 440

Ammomanes, ii. 289

AMMONITID E, ii. 506

Amomys, N. American Tertiary, i. 134

Ampeliceps, ii. 287

A IPELIDE, ii. 280

Ampelio, ii. 102

Ampelis. ii. 250

Amphechinus, European Miocene, i. 117 ii. 188

Amphibia, means of dispersal of, i. 28 classification of, i. 100 peculiar to Palæarctie region, i. 186 of Central Europe, i. 196 of the Mediterranean sub-region, i. 205 of the Siberian sub-region, i. 220

of the Manchurian sub-region, i. 226 table of Palrarctie families of, i. 237 of the Ethiopian region, i. 255

of West Africa, i. 264

S. African, i. 268

of Madagascar, i. 280

table of Ethiopian families of, i. 298

of the Oriental region, i. 317

of the Indian sub-region, i. 326

of Ceylou, i. 327

of the Indo-Chinese sub-region, i. 331

of the Indo-Malay sub-region, i. 340

table of Oriental families of, i. 369

of the Australian region, i. 397

resemblances of Australian and South.

American, i. 400

of New Guinea, i. 416

of New Zealand, i. 457

Neotropical, i. 11

of South Temperate America, ii. 41

of the Mexican sub-region, ii. 54

of the Autilles, ii. 72

table of Neotropical families of, ii. 89

of the Nearetic region, ii. 120

of California, ii. 128

of Central North America, ii. 131

of Eastern United States, ii. 134

table of Nearetic families of, ii. 143

ANPHIBIA, ii. 411

general remarks on the distribution of, ii. 422

fossil, ii. 423

summary and conclusion, ii. 548

lines of migration of, ii. 548

Amphibola ii. 510

Amphibos, Indian Miocene, i. 122 ii. 225

Amphicyon, European Miocene, i. 118

Indian Hiocene, i. 121

N. American T'ertiary, i. 134

ii. 198

ii. 202

Amphiglossus, ii 398

Amphimericilce, European Miocene, i. 119

Amphimnschus, European Miocene, i. 1.0 ii. 220

Amphioxus, ii. 464

A mphipnons, ii. 455
Amphisbcena, ii. 389

AMPHISBANID E, ii. 388

Amphisorex, European Miocene, i. 118

ii. 191

Amphitragulus, European Miocene, i. 120 ii. 218

Amphiuma, ii 412

AMPHIUMID E, ii. 412

Amphixestus, ii. 397

Ampullaria, ii. 510

Amydrus, ii. $28 s$

Amytis, ii. 258

Anabatoides, ii. 103

Anabazenops, ii. 103

A nableps, ii 450

ANACANTHINI, ii. 439

Anacyrtus, ii. 445

Anadenus, ii. 517

Anadia, ii, 393

ANADIAD E, ii. 393

Anceretes, ii. 101, 291

Anaides, ii 413

Analcipues, ii. 268

Anarhynchus, ii. 356

Anarrhichas, ii. 431

Anas, ii. 363

Anastoma, Europcan Tertiary, i. 169 ii. 527

Anastomus, ii. 361

ANATID 2 , i. 363

ANATINIDE, ii. 536

Anatinella, ii. 536

Anausorex, ii. 191

Anchilophis, European Eocene, i. 125

Anchippodus, N. American Eocene, i. 139

Anchippus, N. American Tertiary, i. 135

Anchitheritle, N. Anerican Tertiary, i. 1:35 ii. 212

Anchitherium, European Miocene, i. 119

European Eocene, i. 1*5

N. American Tertiary, i. 135

Ancient fauna of New Zealand, i. 459

Ancistrops, ii. 103

Ancylotherium, Miocene of Greece, i. 110

European Miocene, i. 121

Ancylotherium, ii. 246

Ancyluris, ii. 470

Ancylus, ii. 518

Andaman Islands, zoology of, i. 333

probable past history of, i. 334

Andigena, ii. 307

Andrias, European Miocene, i. 165

Androdon, ii. 107

Andropadus, ii. 267

Aneiter, ii. 517

Anguilla, ii. 456

Anguis, ii. 397

Angwantibo, ii. 176

Animal kingdom, primary divisions of, i. 85

Animals, development of, affecting distribution, i. 7

dispersal and migration of, i. 10 rapid multiplication of, i. 10

Anisacodon, N. American Tertiary, i. 137

Anoa of Celebes, peculiarities of, i. 428

Anoa, ii. 222

Anodim, ii. 534

Anolius, ii. 400

Anomalurus, ii 235

Anomalpus, ii. 397

Anoplodipsas, ii. 381

A noplotheriicie, European Miocene, i. 119

Anoplotherium, European Miocene, i. 119

European Eocente, i. 120

S. American Enrene, i. 1

Anothrlmus, ii, $4<9$ 
Anostomus, ii. 445

Anous, ii. 365

Anser, ii. 363

Anserants, ii. 363

Anseres, arransement of, i. 98

peculiar Palæaretic genera of, i. 250

peeuliar Ethiopian genera of, i. 313

peculiar Australian genera of, i. 487

ANSERES, general remarks on the distribution of, ii. 367

Antarctia, ii. 490

ii. 492

Ant-eaters, ii. 247

Antechinomys, ii. 249

Antecininus, ii. 249

Antelopes in the Indian Miocene deposits, i. 122

birthplace and migrations of, i. 155

Palrarctic, i. 182

ii. 221

Antelotherium, Indian Hiocene, i. 122

Antennarius, ii. 431

Anteros, ii. 476

Anthia, ii. 491

Anthipes, ii. 270

Anthocharis, ii. 478

Anthochcera, ii. 275

Anthornis, ii. 275

Anthracotheridce, N. American Tertiary, i. 137

Anthracotherium, Emopean Miocene, i. 119 ii. 215

Anthreptes. ii. 276

Anthropoid apes, it. 170

Anthropoides, ii. 357

Anthus, ii. 290

Antiacodon, N. American Tertiary, i. 133

Antillean suó-region, ii. 61

mammalia of, ii. 62

birds of, ii. 64

illustration of zoology of, ii. 67

table of distribution of resident land-

birds of, ii. $6 \mathrm{~s}$

reptiles and amphibia of, ii. 72

fresll-water fish of, ii. 73

insects of, ii. 73

land-shells of, ii. 75

past history of, ii. 78

Antilles, Pliocene Nammalia of; i. 148

land-shells of, ii. 526

Antilocapra, ii. 223

ANTILOCAPRIN E, ii. 223

Antilope, Post-Pliocene, i. 112

in Brazilian caves, i. 144

ii. 223

ii. 226

Antiquity of the genera of insects, i. 166 of the genera of land and fr'csh-water shells, i. 168

Antrostomus, ii. 319

Ant-thruslies, ii. 297

Anumbius, ii. 103

ANURA ii, 414

Aururosorex, ii. 190

Aonyx, ii. 199

Apalis, ii. 258

A paloderma, ii. 314

A patura, ii. 474

Aphanapteryx of Mauritius, i. 164

$$
\text { ii. } 352
$$

Aphantocera, ii. 107

Aphelotherium, European Eoccnc, i. 125

Aphneus, ii. 477

Aphobus, ii. '283

APHREDODERID E, ii. 425

Apliritis, ii. 428

$$
\text { ii. } 549
$$

Aphriza, ii. 356

Aphysiadce, ii. 530

Aphyocypris, ii. 452

Aplocerus, ii. 224

Aplodontiu, ii. 236

Aplonis, ii. 288

Aplopelia, ii. 333

Apodemia, ii. 476

Apogon, ii. 425

Apresia, ii. 396

APRASIAD 2 , ii. $390^{\circ}$

Aprosmictus, ii. 325

Aptenodytes, ii. 366

APTERYGID E, ii. 360

Apteryx, ii. 369

Apua, ii. 453

Aquila, European Mivcene, i. 161 ii. 348

AQUILINA, ii. 248

Ara, ii. $32 \mathrm{~s}$

Arochnechthra, ii. 276

A rachnothera, ii. 277

ARA.11DE, ii. 357

Aramides, ii. 352

Aramus, ii. 357

A rapaima, ii. $45 t$

Arborophila, ii. 338

ARCAD E, ii. 534

Archuomys, ii. 238

Arehcenpteryx, Bavarian Oolite, i, 163

A rehibuteo, ii. $34 \mathrm{~S}$

Arctic shells, ii. $51 \mathrm{~s}$

zone not a separate region, i. $6 \mathrm{~s}$

Arctitis, ii. 195

Arctocebris, ii. 176

Arctocephalus, ii. 202

Arctocyon, Europtan Eocene, i. 125 ii. $206^{\circ}$

Arctodus, N. American Post-Pliocene, i. 130 ii. 202

Arctogale, ii. 195

Arctomys, European Pliocene, i. 113

ii. 235,236

Arctonyx, ii, 199

Arctopithecus, ii. 244

Arctotherium in Brazilian caves, i. 141

S. American Pliocene, i. 146

Ardea ii. 359

ARDEID $\mathrm{E}$, ii. 359

Ardistomus, ii. 490

Argentina, ii. 488

Arges, ii. 4 tt

ARGONAUTID FE, ii. 505

Argus phe:isant, tigure of, i. 339

peeuliarity in display of plnmage, and enr.firmation of Mr. Darwin's views, i. .340

Argusianus, ii. 340

Aryutor, ii. 489

Argynnis, ii. 474

Aricoris, ii. 476

Ariella, ii. 195

Arinia, ii. 520

Arion, ii. 517

A ristobia, ii. 501

Arius, ii. 443

Armadillos, ii. 245

Arnoglossiss, ii. 441

Aromochelys, ii. 408

Arremon, ii. 99

Arrhenotus, ii. 501

Artamia, ii. $26 \mathrm{~s}$

ii. 271

ii. 288 RTAM

Artamides, ii. 269

Artamus, ii. $2 \mathrm{SS}$ 
Arthroleptis, ii. 421

Artiodactyla, European Eocene, i. 126

N. American Tertiary, i. 137

S. American Pliocene, i. 146

Artomyias, ii. 270

Arundinicola, ii. 100

Arvicola, European Pliocene, i. 113

in Brazilian caves, i. 145

S. American Pliocene, i. 147

S. American Eocene, i. 148

Arvicola, ii. 230, 231

Asio, ii. 350

Aspergillum, ii. 537

Aspidoparia, ii. 452

Aspidorhinus, ii. 391

Aspidura, ii. 374

Aspius, ii. 453

Aspredo, ii. 444

Aspro, ii. 425

Astarte, ii. 535

Astathes, ii. 501

Asterophys, ii. 421

Asterophysus, ii. 443

Asthenodipsas, ii. 381

Astrapir, ii. 274

Astroblepus, ii. 444

Astur, ii. 348

Asturina, ii. 348

Asturinula, ii. 348

ATE LEOPODID无, ii. 440

Ateles, ii. 174

Atelopus, ii. 416

Atelornis, ii. 312

Aterica, ii. 474

Athene, ii. 350

Atherina, ii. 434

Atherinichthys, ii. 434

ATHERINIDA, ii. 434

Atheris, il. 386

Atherura, ii. 240

Athylax, ii. 195

Athyma, ii. 474

ATL A NTID AE ii. 531

Atl ıpetes, ii. 284

ATRACTASPIDID $\approx$, ii. 383

Atractaspis, ii. 383

Atretium, ii. 375

Atrichia, 299

ATRICHIID AE, ii. 299

Atropos, ii. 385

Attagis, ii. 354

ATTALIN , ii. 293

Atthis, ii. 108

Atticora, ii. 281

Attila, ii. 102

Auchenaspis, ii. 443

Auchenia, N, American Post-Pliocene, i. 130 ii. 217

Auchenipterus, ii. 443

Auckland Islands, birds of, i. 455

A uqastes, ii. 10 s

Auks, ii. 367

Auliu, ii. 102

Aulacodes, ii. 239

Aulacodon, ii. 239

A ulacorhamphus, ii, 307

A ulopoma, ii. 520

Aulopyge, ii. 452

Auricula, ii. 519, 527

AURICULID $\approx$, ii. 518

Auriparus, ii. 266

Australia, physical features of, i. 387

Australia and S. America, supposed land con nection between, i. 395

Australian region, deseription of, i. 387 zoological cbaracteristies of, i. 390

VOL. II.
Australian region, mammalia of, i 390

birds of, i. 391

reptiles of, i. 396

amjuhibia of, i. 397

fresh-water fish of, i. 397

summary of vertebrata of, i. 397

supposed land-connection of with S. Ame-

rica, i. 398

insects of, i. 403

lepidoptera of, i. 404

coleoptera of, i. 405

land-shells of, i. 407

sub-regions of, i. 408

early history of, i. 465

Australian sub-region, mammalia of, i. 438

illustration of mammalia of, i. 439

birds of", i. 440

illustration of fauna of, $i .441$

Australian hedgehog, ii. 254

Austro-Malayan sub-region, physical features of, i 388

zoology of, i. 409

Automolus, ii. 103

AVICULID E, ii. 533

Avocettula, ii. 107

Avocettinus, ii. 108

Aye-aye, figure of, i. 278 ii. 177

Axiocerces, ii. 477

Azores, visited by European birds, i. 17

birds of, i. 207

butterflies of, i. 207

beetles of, i. 207,209

peculiarly modified birds of, i. 207

stragglers to, i. 208

how stocked with animal life, i. 208

B

Babirusa of Celebes, peculiarities of, i. 428

Babirusa, ii. 215

Badger, figure of, i. 195

Badis, ii. 433

Bootis, ii. 475

Bagarins, ii. 443

Bagrichthys, ii. 442

Bagroides, ii. 442

Bagrus, ii. 442

Baird, Professor, on fauna of Cape St. Lucas ii. 130

on representative birds of United States, ii. 180

Baloena, European Pliocene, i. 112 ii. 207

Balceniceps, ii. 360

BALÆNID $Æ$, ii. 207

Balanodon, European Pliocene, i, 112

Balonoptera, 207

Balcenopterida, ii. 207

Balea, ii. 516

Balearica, ii, 357

Baly, Mr., on Phytophaga of Japan, i. 230

Banca, its peculiar species and solution of a problem in distribution, i. 3:6

Band-fish, ii. 435

Bandicoots, ii. 250

Barangia, ii. 199

Barbatula, ii. 306

Barbets, ii. 305

Barbichthys, ii. 452

Barbus, ii. 451

Barilius, ii. 452

Barissia, ii. 392

Barriers, as affecting distribution, i. 6 permanence of, as affecting distribution,i. 7 to the dispersal of birds, $\mathbf{i} .17$

O 0 
Buryphthengus, ii. 313

Barypus, ii. 492

sasileuterus, ii 279

Basilornis, ii. 287

Bassaris, ii, 200

Batara, ii. 104

Bates, Mr., on Carabidæ of Japan, i. 228 on Lougicorns of Japan, i. 230

Bathmodon, N. American Tertiary, i. 136

Bathrodon, N. American Tertiary, i. 133

Bathyerges, ii. 231

BATOIDEI, ii. 462

BATRACHID $\mathrm{A}$, ii. 431

Batrachocephalus, ii. 443

Batrachoseps, ii. 413

Batrachostomus, ii. 318

Bats, powers of tlight of, i. 15 elassification of, i. 87 of New Zealand, i. 450

Baucis, ii. 108

Baza, ii. 349

Bdeogale, ii. 195

Bearded Reedling, ii. 262

Bears, probable cause of absence of, from tropical Africa, i. 291 ii. 201

Beaver, N. American Tertiary, i. 140

Beavers, ii. 234

Bee-eaters, ii. 312

Beetles, families selected for study, i. 10 ? from the Lias, i. 167

of Azores, i. 207

of Japan, i. 228

of S. Temperate America. ii. 44

BELEMNI'TID E, ii. 506

Belemnoziphius, European Pliocene, i. 112

Belideus, ii. 252

Belionota, ii. 497

Belodontichthys, ii. 44]

Belone, ii. 450

Belonesox, ii. 450

Belt, Mr., his theory of a great Siberian lake during the glacial epoch. i. $21 \mathrm{~s}$; ii. 206

on change of elimate caused by diminution of obliquity of ecliptic, i. 466

Beluga, ii. 209

Bembecidium, ii. 489

Berardius, ii. 208

Berenicornis, ii 317

Bermudas, zoology of, ii. 134

Bernicla, ii. 363

Jernieria, ii. 258

BERYCID E, ii. 424

Bcssonornis, ii. 256

Bettongia, ii. 251

Bhringa, ii. 269

Bhutanitis, ii. 479

Bias, ii. 270

Biatas, ii. 104

Bibos, ii. 222

Bison, ii. 222, 225

Binney, Mr., on Air-breathing Molluses of N. America, ii 528

Birds, means of dispersal of, i 15 dispersal of by winds, $i .16$ American, found in Europe, i. 16 reaching the Azores, i. 17

barriers to dispersal of, i. 17

limited by forests, i. 17

elassification of, i. 93

Miocene of Greece, i. 116

extinct, i. 160

fossil of Palæarctic region, i. 161

European of Miocene period, i. 161

Eocene of Europe, i. 162

relations of, i. 162
Birds, extinct of North America, i. 163 recently extinet in New Zealand, i. 164 Cretaceous of N. America, i. 164 remains of in Brazilian caves, i. 164 recently extinct in Madagasear and the

Mascarcne Islands, i. 164

cosmopolitan groups of, i. 176

numerous Palæarctic genera, i. 183

of the European sub-region, i. 193

northern range of in Europe, i. 193

of the zone of pine forests, i. 194

of Iceland, i. 198

of the Mediterranean sub-region, i. 203

of Malta, i. 206 (note)

of the Azores, i. 207

of the Cape Verd Islands, i. 215

of the Siberian sub-region, i. 219

Oriental found in Siberia, i. 219

extreme northern Asiatic, i. 219

of northern Asiatic forests, i. 220

of the Manchurian sub-region, i. 223

Palæarctic genera of, in the Manchurian sub-region, i. 224

Oriental genera of, in the Manchurian sub-region, i. 224

characteristie of N.W. China and Mongolia, i. 226

table of Palæarctic families of, i. 235

of West Africa, i. 243

list of Palcarctic genera of, i. 243

of the Ethiopian region, i. 253

of the East African sub-region, i. 260

S. African, i. 267

genera of, peculiar to Madagascar, i. 275

common to Madagascar and Oriental or

Ethiopian regions, i. 276

species common to Madagascar and Africa or Asia, i. 277

table of Ethiopian families of, i. 295

table of Ethiopian genera of, i. 306

of the Oriental region, i. 316

of the Indian sub-reginn, i. 323

Oriental genera of in Central India, i. 324

Palæarctic and Ethiopian genera in

Central India, i. 325

of Ceylon, i. 327

of the Indo-Chinese sub region, i. 330

of the Indo-Hlalayan sub-region, i. 337

illustration of peculiar Malayan, i. 339

of the Philippine Islands, i. 346

table of Oriental families of, i. 366

table of Oriental genera of, i. 375

of Australian region, i. 391

specially organjzed Australian familics of, i. 392

of the Papuan Islands, i. 410

peculiarities of, i. 413

brilliant colours of, i. 413

remarkable forms of, i. 414

of the Moluceas, i. 418

peculiarities of, i. 421

of the Timor group, i. 423

of Celebes, i. 428

of Australia, i. 440

of New Zealand, i. 451

peculiar to New Zealand, i. 452

of Norfolk Island, i. 453

of Lord Howe's Island, i. 453

of the Chatham Islands, i. 454

of the Anckland Islands, i. 455

table of families of Australian, i. 471

table of genera of Australian, i. 478

of the Neotropical region, ii. 6

distinetive characters of Neotropical, ii. 7 of the Mexican sub region, ii. 52

of tlie Antilles, ii. 64 
Birds, table of distribution of, ii. 68 table of families of Neotropical, ii. 86 table of genera of Neotropical, ii. 86 of the Nearctic region, ii. 116 list of typical genera of, ii. 118 of California, ii. 127

of Central N. America, ii. 130

of Eastern United States, ii. 132 of Canada, ii. 136

table of Nearctic families of, ii. 141

table of Nearctic genera of, ii. 148 and Mammals, parallelism of distribntion of, ii 545

lines of migration of, ii. 545

peculiar development of, in islands, ii. 546

contrast of distribution in tropical and temperate oceanic islands, ii. 546

Biziura, ii. 364

Blacicus, ii. 102

Black ape of Celebes, i. 427

Bland, Mr. Thomas, on Antillean land-shells, ii. 19 ii. 526

Blanford, Mr. W. T., on the "Indian" region, i. 60

on relations of Indian sub-region with Africa, i. 321

Blapsidium, Oolitic insect, i. 167

Blarina, ii. 191

Blauneria, ii. 519

BLENNID גi, ii. 431

Blenniops, ii. 431

Blennius, ii, 431

Blethisa, ii. 489

Blind burrowing snakes, ii. 372

Blunt-heads, ii. 380

Blyth, Mr., on zoological regions, i. 60 on the relations of Indian sub-region with Africa, i. 821

Boa, ii. 381

Bocedon, ii. $3 \mathrm{S0}$

Boas, ii. 381

Bola, ii. 452

Bolborhynchus, ii. 328

Boleosoma, ii. 425

BOMBINATORID $A$, ii. 416

Bombinator, ii. 417

Bonasa, ii, 339

Bonnet-limpets, ii. 511

Bony Pikes, ii. 459

Bootherium, ii. 225

Borneo, probable recent ehanges in, i. 357

Bos, Post-Pliocene, i. 112

Indian Miocene, i. 122

ii. 222,225

Botaurus, ii. 359

Bothriodon, ii. 215

Botia, ii. 453

Bourbon, zoology of, i. 280 reptiles of, i. 281

Bonteieria, ii. 108 ii. 521

Bovidce, European Miocene, i. 120

BOVID $\nRightarrow$, ii. 221

BOVINæ, ii. 222

Brachinus, ii. 489

BRACHIOPODA, ii. 532

Brachiurophis, ii. 383

Brachiums, ii. 175

Brachyalestes, ii. 445

Brachycephalus, ii. 414

Brachygalba, ii. 311

Brachylophus, ii. 401

Brachymeles, ii. 397

Brachymerus, ii. 416
Brachymys, European Miocene, i. 120

ii. 232

Rachymystax, ii. 447

Brachyptery $x$, ii. 256

Brachypternus, ii. 303

Brachytarsomzys, ii. 230

Brachypteracias, ii. 312

Brachyrhamphus, ii. 367

Bradybates, ii. 413

Bradycellus, ii. 489

Bradyornis, ii. 271

BRADYPUDID $\approx$, ii. 244

Bradyptetus, ii. 258

Bradypus, ii. 244

Bradytus, ii. 489

Brama, ii. 429

Brumatherium, Hiocene of Perim Island, 1. 122 ii. 226

Branchiosteus, ii. 442

Branta, ii. 364

BRASSOLID AE, ii. 472

Brassolis, ii. 4 T2 $^{2}$

Brazilian cave-fauna, i. 143 remarks on, i. 145

Brazilian sub-region, description of, ii. 21 mammalia of, ii. 23 bilds of, ii. 24

illustration of mammalia of, ii. 23

illustration of birds of, ii. 28 islands of, ii. 29

Breviceps, ii. 416

Breyeria borinensis, Carboniferous insect, i. 168

Britain, peculiar species in, i. 197

British Isles, zoology of, i. 197

Broad-bill, Malayan, figure of, i. 340

Broad-bills, ii. 294

Bronchocela, ii. 402

Brontes, ii. 444

Brontotheride, N. American Tertiary, i. 137

Brontotherium, N. American Tertiary, i. 137

Brotogerys, ii. 328

Brush-turkeys, ii. 341

Brycon, ii. 415

Bryconol s, ii. 445

Bryttus, ii. 425

Buarremon, ii. 99

Bubalus, ii, 222

Bubo, European Miocene, i. 162 ii. 350

B UCCINID E, ii. 507

Buccinum, ii. 507

Bucco, ii. 310

BUCCONID ÆE, ii. 310

Bucephala, ii. 364

Bucephalus, it. 379

Buceros, ii. 317

BUCEROTID瓜, ii. 316

Bucorvus, ii. 317

Budoreas, ii. 224

BUTORCINA, ii. 224

Budytes, ii. 290

Buffaloes, ii. 221

Bufo, ii. 415

BUFONIDÆ, ii. 415

Bulbuls, ii. 267

BULLID $\approx$, ii. 530

Buliminus, ii. 514

Bulimulus, ii. 514

Bulimus, Eocene, i. 169 ii. 514,523

Buncelurus, N American Tertiary, 1. 134

Bungarus, ii. 383

Bungia, ii. 452

Bunocephalichthys, ii. 444

Bunocephalus, ii. 444 
Buphaga, ii. 288

BUPRESTIDA, ii. 495

Buprestidium, Oolitic insect, i. 167

Busarellus, ii, 348

Busll-slurikes, ii. 297

Bustards, ii. 356

Butalis, ii. 270

Butastur, ii. 348

Buteo, ii. 348

Buteogallus, ii. 348

BUTEONIN E, ii. 348

Buteola, ii. 348

Buthraupis, ii. 98

Butterfiies, arrangenent of, i. 103

Palæarctic, i. 187

of Central Europe, i. 196

of the Mediterranean sub-region, i. 205

of Azores, i. 207

peculiar to Siberian sub-region, i. 220

of Japan and North China, i. $22 \%$

of the Ethiopian region, i. 255

number of Ethiopian species, i. 256

of Indo-Malay sub-region, i. 342

of the Australian region, i. 404

of the Austro-Malay sub-region, i. 404

of the Moluccas, i. 419

of Celebes, peculiarities of, i. 434

of New Zealand, i. 457

ii. 470

general remarks on the distribution of, ii. 483

fossil, ii. 486

of S. Temperate America, ii. 43

Bycanistes, ii. 317

C.

Cabalus, ii. 352

Cabrita, ii. 391

Cacatua, ii. 325

CACATUIDAi, ii. 324

Caccabis, ii. 339

Cachius, ii. 453

Cacomantis, ii. 309

Cacophis, ii. 383

Cacopitta, ii. 261

Cacopus, ii. 416

Cacotus, ii. 417

Cactornis, ii. 284

Cadurcotherium, European Eocene, i. 125

Caecilia, ii. 411

CACILIADA, ii. 411

Crecum, ii. 509

Calndon, in Brazilian caves, i. 145

Calogenys, in Brazilian caves, i. 144 ii. 241

Canopithecus, European Eocene, i. 124 ii. 178

Ccentropus, ii. 445

Cainotherium, European Miocene, i. 120 European Eocene, i. 126

Cairina, ii. 364

Caica, ii. 328

Calamanthus, ii. 258

Calamaria, ii. 374

CALAMARIID $\nRightarrow$, ii. 374

Calamodon, N. American Eocene, i. 139

Calamodus, ii. 258

Cala moherpin E, ii. 287

Calamoichthys, ii. 458

Calamospiza, ii. 285

Calandrella, ii. 289

Calao, ii. 317

Calathus, ii. 489

Caledonica, ii. 487
Calendula, ii. 289

Calicalicus, ii. 271

Calictis, ii. 195

Calidris, ii. 353

Caliecthrus, ii. 309

California, illustration of zoology oî, ii. 128

Californian sub-region, ii. 127

mammalia of, ii. 127

birds of, ii. 127

reptiles of, ii. 128

amphibia of, ii. 128

fresh-water fishes of, ii. 128

Caligo, ii. 472

Calinaga, ii. 479

Calisto, ii. 471

Callceas, ii. 287

Callia, ii. 521

Callichroma, ii. 501

Callichronss, ii. 442

Callichthys, ii. 444

Callida, ii. 490

Callidryas, ii. 478

Callionymus, ii. 430

Calliope, ii. 259

Callipepla, ii. 339

Calliperidia, ii. 108

Calliphlox, ii. 198

Callirhynus, ii. 375

Callisaurus, ii, 401

Calliste, ii. 98

Callisthenus, ii. 489

Callithea, ii. 474

Callithrix, in Brazilian caves, i. 184

ii. 175

$$
\text { ii. } 178
$$

Callocephalus, ii. 204

Callochen, ii. 363

Callomystax, ii. 443

Callophis, ii. 383

Callophysus, ii. 443

Callopistes, ii. 390

Callorhinus, ii. 202

Calloselasma, ii 385

Callosune, ii. 478

Callula, ii. 416

Calobutes, ii. 290

Calocitta, ii. 273

Calodromas, ii. 344

Calcenas, ii. 333

Caloperdix, ii. 339

Calophena, ii. 490

Calopsitta, ii. 325

Caloragia, ii. 375

Calorhamphus, ii. $\mathbf{3 0 6}$

Calornis, ii. 288

Calosoma, ii. 489

Calostethus, ii 419

Calotes, ii. 402

Calothorax, ii. 108

Calydna, ii. 476

Calypte, ii. 108

Calyptocephalus, ii. 421

Calyptomena, ii. 295

Calyptorhynchus, ii. 325

CALYPTRAIDE, ii. 511

Calyptura, ii. 102

Camarhynchus, ii. 284

Camaroptera, ii. 258

Camel, fossil in Indian Miocene, i. 122 birth-place and migrations of, $i .155$ Palæarctic, i. 182

Camelida, essentially extra-tropical, 1. 112 N. American Tertiary, i. 138

CAMELTD $\approx$, ji. 216

CAMELOPARDALIDAE, ii. 221

Cumelopardalis, Miocene of Greece, 1.116 
Camelopardalis, Indian Miocene, i. 122 ii. 221

Camelotherium, S. American Pliocene, i. 147 ii. 217

Camels, ii. 216

Camelus, ii. 216

Camena, ii. 477

Campephaga, ii. 269

CAMPEPHAGIDÆ, ii. 268

Campephilus, ii. 303

Campsiempis, ii. 101

Camptolaimus, ii 364

Campylopterus, ii 107

Campylorhynchus, ii. 264

Canadian sub-region, mammalia of, ii, 135

birds of, ii. 136

reptiles and fishes of, ii. 137

insects of, 1i. 137

Canaries, birds of, i. 208

beetles of, i. 209

Cancroma, ii. 359

Canide, European Mincene, i. 118

European Eocene, i. 125

N. American Tertiary, i. 134

remarkable S. African, i. 267

CANIDÆ, ii. 197

Canis, European Pliocene, i. 112

Post-Pliocene, i. 112

European Miocene, i. 118

Indian Miocene, i. 121

European Eocene, i. 125

N. American Post-Pliocene, i. 129

N. American Tertiary, i. 134, 135

in Brazilian caves, i. 144

S. American Pliocene, i. 146 ii. 197

Cantharus, ii. 427

Cantoria, ii. 376

Cape Ant-cater, ii. 246

Cape of Good Hope, peculiar flora and fauns of, i, 266

Cape Verd Islands, zoology of, i. 214

Cape-hare, S. African, i. 267

Capito, ii. 306

CAPITONINÆ, ii. 306

Capoeta, ii. 451

Capra, ii. 224, 225

Capreolus, ii. 219

CAPRIMULGID $Æ$, ii. 319

Caprimulgus, ii. 319

UAPRINÆ, ii. 224

Capromys, ii. 238

Capys, ii. 477

CARABID丑, ii. 488

Carabus, ii. 488

$$
\text { ii. } 489
$$

CARANGIDÆ, ii. 429

Carassius, ii 451

CARCHARIID无, ii. 460

Carcineutes, ii. 316

Cardellina, ii. 279

CARDIdD业, ii. 535

Cardinatis, ii. 285

Cardiodus, S. American Pliocene, i. 147

Cardiopthalmus, ii. 492

Cardita, ii. 535

Carenum, ii. 490

Cariama, Brazilian caves, i. 164 ii. 357

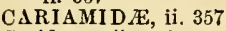

Caridon $\alpha x$, ii. 316

Carlia, ii. 397

Carnivora of European Pliocene, i. 112 Miocene of Greece, i. 115

European Miocene, i. 118

Indian Miocene, i. 121
Carnivora, European Eocene, i. 125

N. American Post-Pliocene, i. 128

N. American Tertiary, i. 134

of Brazilian caves, $i$. 144

S. American Pliocene, i. 146

Carnivora, elassification of, i. 88

antiquity of, i. 153

of the Palxarctic region, i. 182

list of Paliaretic genera of, i. 240

list of Ethiopian genera of, i. 302

range of Oriental genera of, i. 373

list of Australian genera of, i. 476

CARNIVORA, ii. 192

general remarks on the distribution of, 20

range of, in time, ii. 206

summary and conclusion, ii. 541

Caroline Islands, birds of, i. 444

Carpenter, Dr. Philip, on Panama shells, i1. 20

Carpiodes, ii. 451

Carpococcyx, ii. 309

Carpodacus, ii. 285

Carpodectes, ii. 102,294

Carpophaga, ii. 332

Carterodon in Brazilian caves, i. 145 ii. 239

Carus, and Gerstaeker on classification of animals, i. 85

Professor, on classification of the Cetacea, i. 88

Carychium, ii. 519

Casarca, ii. 363

Cascelius, ii. 492

Casiornis, ii. 102, 293

Casoryx, N. American Tertiary, i. 138 ii. 225

Casnonio, ii. 489

Cassiculus, ị.. 282

Cassicus, ii. 282

Cassidaria, ii. 507

Cassidix, ii. 283

Cassinia, ii, 270

Cassowaries, ii. 368

Castalia, ii. 534

Castnia, ii. 481

CASTNIID $\approx$, ii. 481

Castor, European Pliocene, i. 113

European Miocene, i. 120

ii. 234

CASTORID厯, ii. 234

Castoroides, ii. 234

Casuarius, ii. 369

CASUARIIDE, ii. 368

Catadromus, ii. 490

Catagramma, ii. 474

Catamblyrhynchus, ii. 285

Catamenia, ii. 285

Catoscopus, ii. 4 S9

ii. $49 \mathrm{I}$

Cataulus, ii. 520

Catharistes, ii. 346

Cathartes, Brazilian caves, i. 124 ii. 346

Catharus, ii. 256

Catherpes, it. 264

Catla, ii. 451

Catoblepas, ii. 224

Catodon, ii. 208

Catodontidce, ii. 207

Catopra, ii. 433

Catoprion, ii. 446

Catostomus, ii. 451

Catoxantha, ii. 496

Catriscus, ii. 258

Cats, ii. 192 . 
Cave-fauna of Brazil, i. 143

Cavia, Furopean Miocene, i. 121

in Brazilian eaves, i. 144

S. American Pliocene, i. 147

ii. 241

Cavies, ii. 241

CAVIID $\approx$, ii. 241

CEBID E, ii. 174

Cebochœrus, European Eocene, i. $126^{\circ}$ ii. 215

Cebus in Brazilian caves, i. 144

ii. 174

ii. 178

Cecina, ii. 521

Celebes, physical features of, i. $38 \theta$ mammalia of, i. 426

birds of, i. 428

insects of, $i .434$

origin of fauna of, i. 436

Celestus, ii. 327

Celeus, ii. 303

Celia, ii. 459

Cenchris, ii. 385

Centetes, ii. 188

Centetida, European Miocene, i. 118

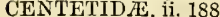

Centrarchus, ii. 425

CENTRISCID $A$, ii. 436

Centriseus, ii. 436

Centrites, ii. 101, 291

Centrocercus, ii. 339

Centrolabrus, ii. 437

Centrolophus, ii. 429

Centromochlus, ii. 443

Centronotus, ii. 431

Centropus, ii. 309

Centronyx, ii. 286

Centropyx, ii. 390

Centurus, ii. 303

Cephalepis, ii. 108

Cephalopeltis, ii. 389

CEPHALOPHIN $\approx$, ii. 224

Cephalophus, ii. 224

CEPHALOPODA, ii. 505

Cephalopterus, ii. 103, 294

Cephalopyrus, ii. 266

Cepola, ii. 435

CEPOLID $\mathrm{E}$, ii. 435

CERAMBYCID瓜, ii. 498

Ceratichthys, ii. 452

Ceratina, ii. 470

Ceratodus, remarkable Australian fish, i. 397

Ceratodus, ii. 458

Ceratohyla, ii. 418

Ceratophora, ii. 402

Ceratophorus, ii. 501

Ceraiophrys, ii. 420

Ceratoptera, ii. 463

Ceratorhina, ii. 367

Ceratorhinus, ii. 213

Ceratotherium, ii. 213

Cerberus, ii. 376

Cercaspis, ii. 380

Cerchneis, ii. 349

Cercocebus, ii. 173

Cercolabes in Brazilian caves, i. 145

$$
\text { ii. } 240
$$

CERCOLABID \&, ii. 239

Cercoleptes, ii. 200

Cercomacra, ii. 104

Cercomela, ii. 260

Cercomys, ii. 239

Cercopithecus in European Pliocent, I. 112 ii. 173

Cercosaura, ii. 394

CERCOSAURIDÆ, ii. 394
Cereopsis, ii. 363

Ceriornis, ii. 340

CERITHIAD A, ii. 509

Certhia, ii. 264

Certhidea, ii. 278

CERTHIIDE, ii. 264

Certhilauda, ii. 289

Certhiola, ii. 278

Corthiparus, ii. 266

Cervicapra, ii. 224

CERVICAPRINÆ, ii. 224

Cervida, European Miocene, i. 120

birtli-place and migrations of, i. 155

CERVID E, ii. 218

Cervulus, ii. 219

Cervus, European Pliocene, i. 113

Indian Pliocene and Miocene, i. 122

N. American Post-Pliocene, i. 130

N. American Tertiary, i. 138

in Braziliau caves, i. 144

S. American Pliocene, i. 147

ii. 219

Ceryle, ii 316

CESTRACIONTID $\approx$, il. 461

Cetacea, European Pliocene, i. 112

European Miocene, i. 119

N. American Post-Pliocene, i. 130

N. American Terbiary, i. 140

Cetacea, classification of, i. 89

range of Oriental genus, i. 374

CETACEA, ii. 207

Cethosia, ii. 474

CETONIID $A$, ii. 494

Cetopsis, ii. 443

Cettia, ii. 258

Ceuthmochares, ii. 309

Ceycopsis, ii. 316

Ceylon and Malaya, resemblance of insects of, 327

Ceylonese sub-region, i. 326

mammalia of, i. 327

birds of, i. 327

reptiles of, i. 327

amphibia of, i. 327

insects of, $i .327$

past history of, as indicated by its fauna, i. 328

Ceyx, ii. 316

Chaca, ii. 441

Chomarrhornis, ii. 259

Chomepelia, 333

Charocampa, ii. 482

Chatobranchus, ii, 439

Chotocercus, ii. 108 ii. 249

Chotodon, ii. 427

Chatomys, ii. 240

Chotops, ii. 256

Chotoptila, ii. 276

Chetorhynchus, ii. 269

Chcetostomus, ii. 444

Chotura, ii. 320

Chotusia, ii. 356

Chalceus, ii. 445

CHALCID AE, ii 393

Chalcinopsis, ii. 445

Chalcinus, ii. 445

Chalcis, ii. 393

Chalcochloris, ii. 189

Chalcopelia, ii. 333

Chalcophaps, i1. 333

Chalcostetha, ii. 276

Chalicomys, European Pliocene, i. 113

Chalicotherium, European Miocene, i, 119

Indian Miocene, i. 122

fossil in N. China, i. 123 
Chamoeleo, N. American Eocene, i. I65

Chalybur', ii. 107

Chameea, ii. 264

CHA M EID Æ, ii. 264

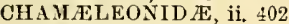

Chamieleons, ii. 402

Chamcepetes, ii. 343

Chamceospiza, ii. 284

Chamcesaura, ii. 394

CHAMESAURID $\approx$, ii. 394

Chameza, ii. 104

CHAMID $A$, ii. 534

Chamois, figure of, i. 195

ii. 224

Ch rmostrea, ii. 536

Chanodicluthys, ii. 453

CHAR ICINID $A$, ii. 444

Characodon, ii. 450

CHARADRIIDE, ii. 355

Ch radrius, ii. 356

Charinc, ii. 373

Charis, ii. $470^{\circ}$

Charitornis, ii. 27 \&

Charmosyna, ii. 327

Ch ssiempis, ii. 271

Chasmodes, ii. 431

Chasmorhynchus, ii. 103, 294

Chatarrhoea, ii. 261

Chatham Islands, birds of, i. 454

Chatterers, ii. 293

Chaulelasmus, ii. 364

Charenx, ii. 361

Chaunonotus, ii. $27^{2}$

Chaunoproctus, ii. 284

Chela, if. 453

Chelemys, ii. 408

Chelidon, î. 281

Chelidoptera, ii. 311

Chelidorynx, ii. 271

Chelodina, ii. 408

Chelometes ii. 397

Chelone, ii. 409

Cholonia, classification of, i. 100

CHELONIA, ii. 407

remarks on the distribution of, ii. 410 fossil, ii 410

CHELONIID E, ii. 409

CHELYDID $\mathrm{E}$, ii 408

Chelydobatrachus, ii. 416

Chelydra, European Pliocene, i. 165 ii. 405

Chelys, ii. 408

Chenalopex, ii. 363

Chera, ii. 286

Chersina, ii. $40 \mathrm{~s}$

Chersydrus, ii. 38

Chevrotain of Malaya, figure of, i. 336

Chevrotains, ii. 218

Chiamela, ii. 397

Chicsognathus, ii. 493

Chibie, ii. 269

Chilabothrus, ii. 381

Chili should not be placed in the Palæarctic or

Nearctic regions, ${ }^{2} .63$

Chili and Temperate S. America, distribution of Carabida in, ii. 492

Chiliau Andes, illustration of zoology of, ii. 40

Chilian sub-region, ii. 36

manmmalia of, ii. 36

birds of, ii. 37

illustration of zoology of, ii. 40

reptiles and amphibia of, ii. 40

fresh-water fishes of, ii 42

insects of ii. 42

origin and migrations of insects of, ii. 47
Chili, islands of, ii. $49^{\circ}$

Chilinia, ii. 518

Chilobranchus, ii. 456

Chilomeniscus, ii. 375

Chimora, ii. 460

CHIMIERID $A$, ii. 460

China, fossiI mammals in, resembling those of Indian and European Hiocene, i. 362

Nortl, mammalia of, i. 222

Chinchilla, ii. 237

Chinchillidoe in Brazilian eaves, i. 145

S. American Pliocene, i. 147

Pliocene of Antilles, i. 148

CHINCHILLIDE, ii. 237

Chioglossa, ii. 413

Chionabas, ii. 471

CHIONIDID E, ii. 354

Chionis, ii. 354

CHIROCENTRID $æ$, ii 454

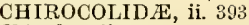

Chirodon, ii. 445

Chirodryos, ii. 418

Chirogaleus, ii. 176

Chiroleptes, ii. 421

Chiromacheris, ii. 102, 292

Chiromantis, ii. 419

CHIROMYID

Chironectes, ii. 248

Chiroptera, classification of, i. 87

list of Palæaretie genera of, i. 239

list of Ethiopian genera of, i. 300

range of Oriental geuera of, i. 371

list of Australian genera of, i. 475

Chiroptera, European Eocene, i. 125

in Brazilian caves, i. 144

CHIROPTERA, ii. 181

remarks on the distribution of, ii. 1S5

fossil, ii. 185

summary aud conelusion, ii. 441

Chirotes, ii. 388

CHIROTID E, ii. 358

Chiroxiphia, ii. 102, 292

CHITONID 2 , ii. 512

Chittya, ii. 519

Chloenius, ii. 489

Chlamydodera, ii. 275

Chlamydophorus, ii. 245

Chlamydotherium, ii. 246

in Brazilian caves, i. 145

Chlenasicus, ii. 262

Chloëphaga, ii. 363

Chlorochrysa, ii. 98

$$
\text { ii. } 99
$$

Chloronerpes, ii. 303

Chlorophanes, ii. 278

Chlorophonia, ii. 98 ii. 99

Chloropipo, ii. 102

Chlorospiza, ii. 263

Chlorospingus, ii. 99 ii. $\mathbf{1 0 0}$

Chlorostilbon, ii. 109

Choanomphalus, ii. 518

Choanopoma, ii. 521

Chorromorus, European Miocene, i. 119

Cheropotamus, European Eocene, i. 126 ii. 215

Choromus, ii. 250

Cherotherium, Indian Viocene, i. 122

Choloepus, ii. 244

Chologastes, ii. 450

Cholornis, ii. 262

Chondestes, ii. 28.5

Chandropoma, ii. 5:1

CHONDROPTER IGII, ii. 46 
CHONDROSTEI, ii. 459

Chondrostoma, ii. 452

Choneziphius, European Pliocene, 1. 112

Chordeiles, ii. 320

Chough, Alpine, figure of, i. 195

Choughs, ii. 274

CHRUMIDE, ii. 438

Chromis, ii. 438

Chrysichthys, ii. 442

Chrysobronchus, ii. 108

Chrysococcyx, ii. 310

CHRYSOCHLORIDÆ, ii. 189

Chrysochloris, ii. 189

Chrysocolaptes, ii. 303

Chrysocyon, ii. 197

Chrysolampis, ii. I0s

Chrysomitris; ii. 283

Chrysopelea, ii. 379

Chrysophrys, ii. 427

Chrysoptilus, ii. 303

Chrysothrix, ii. 175

Chrysotis, ii. 328

Chrysuronia, ii. 109

Chthonicole, ii. 258

Ciccaba, ii. 350

Cichla, ii. 439

Cichladusa, ii. 261

Cichlopsis, ii. 260

Cicigna, ii. 392

Cicindela, ii. 486

CICINDELID $E$, ii. 486

Cicinnurus, ii. 275

Ciconia, ii. 360

Ciconiide, ii. 360

CINCLID五, ii. 262

Cinclocerthia, ii. 256

Cinclodes, ii. 103

Cinclorhamphus, ii. 260

Cinclosoma, ii. 261

Cinclus, ii. 263

Cinnicerthia, ii. 264

Cinnyricinclus, ii. 276

$$
\text { ii. } 288
$$

Cinosternon, ii. 408

Cinyxis, ii. 408

Cionella, ii. 515

Circaëtus, ii. 348

Circe, ii. 109

Circunıpolar zones, objections to system of, i. 67

Circus, ii. 347

Cirrhina, ii. 451

CIRRHITIDÆ, ii 427

Cirrhochroa ii 474

CIRRHOSTOMI, ii. $46 \pm$

Cissa, ii. 273

Cissopis, ii. 99

Cisticola, ii. 257

Cistothorus, ii. 263

Cistula, ii. 521

Cithara, ii. 508

Citharinus, ii. 445

Cittura, ii. 316

Cladognathus, ii. 493

Clais, ii. 108

Clam-shells, ii. 535

Clarias, ii. 441

Clarotes, ii. 442

Classification as affecting the study of distribution, i. 83

Claudius, ii. 408

Clausilia, Eocene, 1. 169

$$
\text { ii. } 514
$$

Clerome, ii. 472

Clibanornis, ii. 103

Climacteris, ii. 265
Climate, as a limit to the range of mammalia, i. 11

gradual change of, before the glacial epoch, i. 41

Clinteria, ii. 494

CLIONIDA, ii. 531

Clostophis, ii. 520

Clupea, ii. 454

CLUPEID $\approx$, ii. 454

Clymenia, ii. 209

Clypeictcrus, ii. 282

Clytoctantes, ii. 104

Clytoleena, ii. 108

Clytus, ii. 501

Cnidoglanis, ii. 441

Cnipodectes, ii. 101

Cnipolegus, ii. 101, 291

Cobitis, ii. 453

Cobras, ii. 382

Coccothrausies, ii. 284

Coccygus, ii. 309

Coccystes, ii. 310

Cochlognathus, ii. 452

Cochlostyla, ii. 514

Cochlothraustes, ii. 309

Cochoo, ii. 269

Cockatoos, ii. 324

Cockles, ii. 535

Cocos IsIands, bird of, ii. 60

Cocytia, ii. 481

Ceneligena, ii. 107

Colodon, ii. 245

Coelonotus, ii. 457

Colopeltrs, ii. 377

Coelosterna, ii. 501

Cononympha, ii. 471

Coereba, ii. 278

CCEREBID $E$, ii. 278

Cogia, ii. 208

Colaptes, ii. 304

Coleoptera, farnilies selected fur study, i. 103 Palæarctic, i. 188

number of Palæarctic species, i. 189 of Central Europe, i. 196

of the Mlediterranean sub-region, i. 205

of the Cape Verd Islands, i. 215

of the Ethiopian region, i. 256

S. African, i. 268

of Madagascar, i. 282,283

of the Oriental region, 1. 319

of Indo-Mlalay sub-region, i. 342

of the Australian region, i. 405

affinity of Australian and South American, i. 406,407

of Celebes, i. 435

of New Zealand, i. 457

of the Neotropical region, ii. 15

of S. Temperate America, ii. 44

of the Mexican sub-region, ii. 56

of the Antilles, ii. 74

of the Nearetic region, ii. 123

COLEOPTERA, ii. $486^{\circ}$

general observations on the distribution of, ii. 502 (see also Beetles)

Colias, ii. 478

Colies, ii. 307

COLIIDÆ, ii. 307

Colius, ii. 307

Coliuspasser, ii. 286

Collocalia, European Miocene, i. 161 ii. 320

Colluricincla, ii. 272

Collyris, ii. 486,487

Colobus, European Miocenc, i. 117 ii. 172

Colcenis, ii. 474 
Colonoceras, N. American Tertiary, i. 130

Colopterus, ii. $10 \mathrm{I}$

Colossochelys of Indian Miocene, i. 123, 165

Colpodes, ii. 489

Coluber, ii. 375

COLUBRID $Æ$,ii. 375

COLUBRIN $\approx$, ii. 375

Columbæ, classification of, i. 90

range of Palæaretic genera of, i. 248

range of Ethiopian genera of, i. 311

range of Oriental genera of, i. 384

range of Australian genera of, i. 485

Columba, ii. 332

COLUMBA, ii. 331

general remarks on the distribution of, ii. 335

COLUMBIDE, ii. 331

Columbula, ii. 333

Columna, ii. 516

COLYMBIDÆ, ii. 366

Colymbus, ii. 366

COMEPHORIDF, ii, 432

Comephorus, ii. 549

Comoro islands, zoology of, i. 281

Compsosomr ii. 98,375

CONCHIFER 1 , ii. 533

Condylura, ii. 190

Cones, ii. 5us

Conger, ii. $450^{\circ}$

CONIDE, ii. 508

Conirostrum, ii. 278

Conognatha, ii. 496

Conopinaga, ii. 160

CONOPHAGINÆ, ii. 291

Conophis, ii. 375

Conopias, ii. 101

Conorhynchus, ii. 413

Conostoma, i1. 262

Continents, distribution of, i. 37 recent changes of, i. 38

ContinentaI extension in Mesozoic times, i. 150

Contopus, ii. 102, 291

CONURIDA, ii. 327

Conurus, ii. 328

Conus, ii. 508

Copea, ii. 416

Cophoscincus, ii. 397

Copidoglanis, ii. 441

Coptodera, ii. 489,492

Copurus, ii. 101

Copsychus, ii. 259

Coracias, ii. 311

CORACIID $\approx$, ii. 311

Coracopsis, ii. 328

Corades, ii. 471

Corallus, ii. 381

Corbis, ii. $\mathbf{5 3 5}$

Cordylosaurus, ii. 393

Cordylus, ii. 392

Coregonus, ii. 447

Coriphilus, ii. 327

Coris, ii. 437

Coronella, ii. 375

CORONELLIN $\approx$, ii. 375

Coronis, ii. 481

Cornufer, ii. 419

CORVIDÆ, ii. 272

Corvina, ii. 428

Corvinella, ii. 272

Corvultur, ii. 274

Corvus, European Miocene, i. 161

$$
\text { ii, } 274
$$

Corydalla, ii. 290

Corydon, ii. 295

Corynopoma, ii. 445

Coryphistera, ii. 103
Coryphodon, European Eocene, i. 126

Coryphospingus, ii. 284

Corythaix, ji. 307

Corythopis, ii. 100

Corythornis, ii. 316

Cosmeteira, ii. 277

Cosmetornis, ii. 320

Cosmopolitan gruups enumerated, i. 175

Cossypha, ii. 256

Cotinga, ii. 102, 294

COTINGIDÆ, ii. 293

Cottus, ii. 428

Coturniculus, ii. 284

Coturnix, ii. 338

Cotyle, ii. 281

Cour, ii. 309

Couchia, ii. 439

Coues, Dr., on the blue crow of the Rocky Mountains, ii. 128

Coursers, ii. 355

Cowries, ii. $50 \mathrm{~s}$

Coypu, ii. 238

CRACIDF, ii. 342

CRACIN $Æ$, ii. 343

Cracticus, ii. 273

Cranes, 1i. 357

CRANIADÆ, ii. 532

Cranorrhinus, ii. 317

Craspedocephalus, ii. 385

Craspedopoma, ii. 521

Crateropus, ii. 261

Crax, ii. 343

Creadion, ii. 287

Creagmis, ii. 364

Creagrutus, ii. 445

Creepers, ii. 264

Cremna, ii. 475

Crenicichla, ii. 439

Crenilabrus, ii. 437

Crenuchus, ii. 445

Creurgops, ii. 99

Cricetodon, European Miocene, i. 120 ii. 230

Cricetomys, ii. 230

Cricetulus, ii. 230

Cricetus, European Pliocenэ, i. 113 ii. 230

Cricosoma, ii. 476

Crinia, ii. 420

Criniger, ii. 267

Crithagra, ii. 285

Crocidura, ii. 191

Crocodilcs, Eocene, i. 165

ii. 406

lines of migration of, ii. 548

Crocndilia, cIassification of, i. 100

CROCODILIA, ii. 405

general remarks on the distribution of, ii. 406

fossil, ii. 407

CROCODILIDA, ii. 406

Crocodilurus ii. 390

Crocodilus, ii. 406

Crook-billed plovers of New Zealand, i. 456

Crossarchus, ii. 195

Crossochilus, ii. 451

Crossodactylus, ii. 419

Crossoptilon, ii. 340

Crossopus, ii. 191

CROTALID E, ii. 384

Crotalophorus, ii. 385

Crotalus, ii. 385

Crotch, Mr., on beetles of the Azores, i. 209

Crotophaga, ii. 309

Crowned-pigeon, figure of, i. 415

Crows, ii. 273 
Crypsirhina, ii. 273

Cryptoblepharus, ii. 395

Cryptodacus, ii. 375

Cryptoproct ', ii. 194

CRYPTOPRUC'TID AE, ii. 194

Cryptopterus, ii. 441

Cryptornis, European Eocene, i. 163

Cryptotis, ii. 421

Crypturus, ii. 311

Ctenodactyla, ii. 490

Ctcnodactylus, ii. 238

Ctennlabrus, ii. 437

Ctenomys, S. Awerican Pliocene, i. 147

$$
\text { ii. } 238
$$

Ctenopharyngodon, ii. 452

Ctenopoma, ii. 52I

Ctenostoma, ii. 486

Cuba, extinct mammalia of, i. 148

Curculionidium, Oolitic insect, i. 167

Cubina, ii. 400

CUCULID

Cuculus, ii. 309

Cuckoo-shrikes, ii. 268

Cuckoos, ii. 308

Culter, ii. 453

Cunningham, Professor, lizard discovered by, in Tierra-deI-Fuego, ii. 41

Cuniculus, ii. 230

Cuphopterus, ii. 272

Cupidonia, ii. 339

Curassows, ii. 342

Curceus, ii. 282

Curetis, ii. 477

Curimatus, ii. 445

Curruca, ii. 259

Cursoria, ii. 382

Cursorius, ii. 355

Cuscus, ii. 252

Custa, ii. 390

Cutia, ii. 266

Cuttle fish, ii. 505

Cyanecula, ii. 259

Cyanocorax, ii. 273

Cyanomyia, ii. 109

Cyanopica, ii. 273

Cyanoptila, ii. 270

Cyanorhamphus, ii. 325

Cyanospiza, ii. 284

Cyanotis, ii. 101

Cyanurus, ii. 273

Cybernetes, ii. 101

Cychloris, ii. $2 \mathrm{so}$

Cychrus, ii. 489

CYCLADIIIA, ii. 535

Cyclas, ii. 535

Cyclocorus, ii. 380

Cycloderma, ii. 409

Cyclodina, ii. 397

Cyclodus, ii. 397 .

C'yclophis, ii. 376

Cyclophorus, ii. 520

Cyclopterus, ii. 430

cyclopsitta, ii. 326

Cyclorhamphus, ii. 420

Cyclostoma, Eocene, i. 169

CYCLOSTOMATA, ii. 463

CYCLOSTOMID E, ii. 520

Cyclostomus, ii. 521

Cyclothoris, ii. 247

Cyclotopsis, ii. 521

Cyclotus, ii. 521

Cyclusa, ii. 401

Cygnus, ii. 363

Cylinarella, ii. 515

Cylindrophis, ii. 373

Cyllo sepulta, European Cretaceous, i. 167
Cymba, ii. 508

Cymbilanius, ii, 104

Cymbirhynchus, ii. 295

Cymindis, ii. 489

cyncelurus, in Brazilian caves, i, 144 ii. 193

Cynanthus, ii. 108

Cynictis, ii. 195

Cynocephatus, ii. 173

Cynodictis, 1i. 198

Cynodon, ii. 445

Cynogale, ii. 195

CYNOPITHECID $A$, ii. 172

Cynopithecus of Celebes, affinities of, i. 427

Cynopithecus, ii. 173

Cynomys, ii. 235

Cyornis, ii. 270

Cyotherium, European Eocene, i. 125 ii. 198

Cyphogastra, ii. 496

Cyphorhinus, ii. 204

CYPRA1DÆ, ii. 508

Cyprina, ii. 535

CYPRINID AE, ii. 451 ii. 535

Cyprinus, ii. 451

Cyprinion, ii. 452

Cyprinodon, ii. 450

CYPRINODONTID瓜, ii. 450

CYPSELID E, ii. 320

Cypseloidcs, ii. 320

Cypselus, ii. 320

Cypsnagra, ii. 99

Cyrena, ii. 535

Cyrestis, ii. 474

Cyrtonotus, ii. 489

Cyrtonyx, ii 339

Cyrtophis, ii. 383

Cystignathus, ii. 420

Cystophora, i. 204

D.

Dacclo, ii. 316

Dacnis, ii. 278

Dactylethra, ii. 422

DACTYLETHRIDÆ, ii. 422

Dactylomys, ii. 239

Dactylopsila, ii. 249

Dactylozodes, ii. 496

Dafila, ii. 363

Dama, ii, 219

Damias, ii 481

Damoplita, ii. 109

DANAID $B$, ii. 470

Danais, ii. 470

Dangila, ii. $45 \mathrm{I}$

Danio, ii. 452

Daptophilus, N. American Tertiary, i. 134

Darters, ii. 365

Darwin, Mr., his explanation of the cause of the abundance of apterous insects in Madeira, i. 2 ll

on the relation of flowers and insects, $i$. 468

amphibia collected by, in $\mathrm{S}$. Temperate America, ii. 41

mice collected by, in $\mathbf{S}$. Temperate America, ii. 37

on plyysical geography of the Galapagcs. ii. 33

Dasia, ii. 397

Dasylophus, ii. 309

Dasyopthalma, ii. 472

Dasypeltis, ii. 377 
DASYPODID $\mathbb{E}$, ii. 245

Dasyprocta, Enropean Miocene, i. 121

in Brazilian caves, i. 144

ii. 241

Dasyptilus, ii. 329

Dasypus, in Brazilian eaves, i. 145

S. American Pliocene, i. 147 ii. 246

DASYURID E, ii. 249

Dasyurus, Anstralian Post-Tertiary, i. 157 ii. 249

Daudebardia, ii. 516

David, Père, his researelses in China and Thibet, i. 221,222

on birds of N. China, i, 226

Debis, ii. 471

Deer, fossil in N. American Tertiary formations, i. 138

Palæaretic, i. 182

probable cause of absence from tropical Africa, i. 291 ii. 218

Deilephila, ii. 482

Deltatria, ii. 107

Delma, ii. 395

Deloneura, ii. 477

Delphinapterus, ii. 209

DELPHINID $Æ$, ii. 208

Delphinus, European Pliocene, i. 112 ii. 209

DENDRASPIDID $\approx$, ii. 383

Dendraspis, ii. 383

Dendrexetastes, ii. 104

Dendrochelidon, ii. $3 \approx 0$

Dendrocitta, ii. 273

Dendrocolaptes, ii. 103

DENDROCOLAPTIDE, ii. 295

DENDROCOLAPTIN E, ii. 295

Dendrocincla, ii. 103

Dendrocygna, European Miocene, i. 162 ii. 363

Dendroca, ii. 279

Dendrohyrax, ii. 229

Dendrolagus, ii. 251

Dendromus, ii. 303

Dendromys, ii. 230

Dendrophila, ii. 265

DENDROPHIDÆ, ii. 378

Dendrophis, ii. 378

Dendropicus, ii. 303

Dendroplex, ii. 103

Dendrornis, ii. 103

Dendrortyx, ii. 339

Denisonia, ii. 383

DENTALIADÆ, ii. 512

Dentatium, ii. 512 ii. 539

Dentex, ii. 426

Dercas, ii. 478

Dermatemys, ii. 408

Dermatocera, ii. 520

Dermatochelys, ii. 409

Deroptyus, ii. $32 \mathrm{~s}$

Dermognathus, ii. 413

Desert-snakes, ii. 377

Desman of S. Russia, figure of, i. 219

Desmodus, ii. 182

Deudorix, ii. 477

Diadema, ii. 474

Diagramma, ii. 426

Dibamus, ii. 372

DIBRANCHIATA, ii. 505

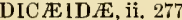

Diccelus, ii. 490

Dicceum, ii. 277

Dicallaneura, ii. 475
Dicamptodon, ii 413

Diceratherium, N. American Tertiary, i. 137

Dicerca, ii. 496

Dicerobatis, ii. 463

Dichobune, European Eocene, i. 126

Dicotyles, N. American Post-Pliocene, i. 130

N. American Tertiary, i. 137

in Brazilian caves, i. 144

S. American Pliocene, i. 146

birthplace and migrations of, i. 155 ii. 215

Dicotylince, ii. 214

Dierocerus, European Miocene, i. 120 ii. 220

Dicrodon, ii. 390

Dicroglossus, ii. 421

Dicrorrhagia, ii. 474

DICRURID $\pi$, ii. 269

Dicrurus, ii. 269

DIDELPHYIDÆ, ii. 248

Didelphys, European Eocene, i. 126 N. American Post-Pliocene, i. 130

in Brazilian caves, i. 145

ii. 248

Didide, i. 164

DIDID EE, ii. 334

Didoeus, ii. 417

DIDUNCULIDE, ii. 333

Didunculus, ii. 334

Didus, ii. 334

Dieba, ii. 197

Diemenia, ii. 383

Diglossa, ii. 278

Diglossopis, ii. 278

Dilophus, ii. 287

Dilophyrus, ii. 402

Dimodes, ii. 377

Dimylus, ii. 190

Dinictis, ii. 19

Dinoceras, N. American Eocene, i. 139

Dinocerata, N. American Tertiary, i. 139

Dinornis, allied form in European Eocene. i. 163

of New Zealand and Australia, i. 164 ii. 369

Dinornithidee of New Zealand, i. 164

DINORNITHID $A$, ii. 269

Dinotherium, Miocenc of Greece, i. 110

European Miocene, i. 120

Miocene of Perim Island, i. 123

Dinyctis, N. American Tertiary, i. $13 \pm$

Dinylus, European Miocene, i. 117

Diomedia, ii. 365

Dioplodon, ii. 208

Diorhina, ii. 476

Diphlogoena, ii. $10 \mathrm{~s}$

Diphylla, ii. 182

Diphyllodes, ii. 274

Diplacodon, N. American Tertiary, i. 180

Diplodactylus, ii. 399

Diploglossus, ii. 397

Diploloemus, ii. 401

Diplomesodon, ii. 191

DIPLOMMATINID E, ii. 519

Diplommatina, ii. 520

Diplomystax, ii. 443

Diplopelma, ii. 416

Diplopoma, ii. 521

Diplopterus, ii. 309

DIPNOI, ii. 458

DIPODID E, ii. 231

Dipodomys, ii. 233

Dippers, ii. 263

Diprotodon, Australian Post-Tertiary, i. 157 ii. 251

DIPSADID E, ii. 379 
Dipsadoboa, ii. 379

Dipsas, ii. 379

Diptychus, ii. 452

Dipus, ii. 232

Dircenna, ii. 470

Discina, ii. 539

DISCINID E, ii. 532

Discoboli, ii. 430

DISCOGLOSSID Æ, ii. 421

Discoglossus, ii. 421

Discognathus, ii. 451

Discophora, ii. 472

Discura, ii. 107

Dispersal of animals, i. 10 of unammalia, i. 10 of reptiles and amphibia, i. 28

Disteira, ii. 384

Distichodus, ii. 445

Distribution, aliected by climate, i. 5

affected by physical features, i. 5

contrasts of, in similar climates, i. 5 similarities of, in diverse climates, i. 6

barriers as affecting, i. 6

study of, dependent on a good classification, i. 83

of animals an adjunct to geology, i. 8

of animals requires certain preliminary studies, i. 8

of animals dependent on physical geography, i. 35

of animals, as affected by the glacial epoch, i. 40

of animals, as affected by changes of vegetation, i. 43

of animals, as affected by organic changes, i. 44

of animals, hypothetical illustration of, i. 46

of animals, complexity of the causes affecting the, i. 49

of animals, problems in, i. 51

of plants, as affected by the glacial epoch i. 42

Distrigus, ii. 490

Diuca, ii. 284

Dincopis, ii. 99

Diva, ii. 98

Divers, ii. 366

Docimastes, ii. 108

Dodo of Mauritius, i. 282

ii. 334

Dodon $x$, ii. 475

Dolerisca, ii. 107

Dolichodon, ii. 208

Dolichonyx, ii. 282

Dolichopterus, European Mísecene, i. 162

Dolichotis, ii. 241

Doliophis, ii. 3 S3

Dolium, ii. 507

Dommina, N. American Tertiary, i. 134

Donacobius, ii. 264

Donacola, ii. 287

Donacospiza, ii. 284

Doras, ii. 443

Dorcatherium, European Miocene, i. 120

Dorcopsis, ii. 251

Dorcus, ii. 493

Doricha, ii. 108

DORIDE, ii. 530

Doritis, ii. 479

Dormice, ii. 232

Doryichthys, ii. 457

Doryphore, ii. 107

Douroucoulis, ii. 175

Draco, ii. 402

Dremotherium, Miocene of Greece, i. 116
Dremotherium, European Miocene, i. 120 ii. 218

DREPANIDIDA, ii. 277

Drepanis, ii. 277

Drepanornis, ii. 275 ii. 276

Dresser, Mr. H. E., on northern range of European birds, i. 193

Drimostoma, ii. 489

Dromseus, ii. 368

Dromas, ii. 356

Dromatherium, N. Americau Triassic, i. 134 oldest American mammal, i. 160

Dromica, ii. 486,487

Dromicia, ii. 252

Dromicus, ii. 375

Dromius, ii. 489

Dromocaccyx, ii. 309

Dromolcea, ii. 260

Dromophis, ii. 377

Drongo-shrike, Malayaw, figure of, i. 340 ii. 269

DRYADIN E, ii. 375

DRYIOPHIDÆ, ii. 379

Dryiopinis, ii. 379

Drymocataphus, ii. 261

Drymodes, ii. 259

Drymaca, ii, 257

DRYMGCINA, ii. 257

Drymomys, ii. $230^{\circ}$

Drymornis, ii. 103

Dryocopus, ii 303

Dryopithecus, European Miocene, i. 117 ii. 178

Dryospiza, ti. 284

Dryotriorchis, ii. 348

Dubusiu, ii. 98

Ducks, ii 363

Dulus, ii. 280

Dumerilia, ii. 408

Dumetia, ii. 261

Dumeticola, ii. 258

Duncan, Dr., on fossil corals of the Antilles, ii. 21

D'Urbania, ii. 477

Dwarf-ground snakes, ii. 374

Dynastor, ii. 472

Dyschirus, ii. 489

Dysauxis, ii. 481

Dysithamnus, ii. 104

Dysopes, ii. 184

E.

Eagles, ii. 347

Eared Seals, ii. 202

Ear-shells, ii. 511

East Africa, geographical features of, i. 258 wide range of genera and species over, i. 259

few special types in, i. 260

East African sub-region, description of, i. 258

genera and species ranging over the whole of, i. 259

mammalia of, i. 260

birds of, i. 260

reptiles of, i. 260

amplibia and fishes of, i. 260

insects of, i. 260

few peculiar types in, i. 260

illustration of zonlogy of, i. 261

East Australia, peculiar birds of, i. 440 
East Thibet, mammalia of, i. 222

Eaton, Rev., A. E., on insects of Kerguelen IsIand, i. 211

Eburna, ii. 507

Echidna, ii. 254

ECHIDNID RE, ii. 254

Echimyidce, in Brazilian caves, i. 145

ECHI M YID $A$, ii. 238

Echimys, ii. 239

Echinogale, European Miocene, i. 118

Echinops, ii. 188, 189

Echinorhinus, ii. 461

Echiothrix, ii. 230

Echis, ii. 386

Eclectus, ii. 326

Ectognathus, No American Eocene, i. 139

Ectopistes, ii. 332

Edentata, Hiocene of Greece, i. 116

European Miocene, i. 121

N. American Post-Pliocene, ì. 120

N. American Pliocene, i. 140

of Brazilian caves, i. 145

S. American Pliocene, i. 147

Edentata, classification of, i. 90 probable birthplace of, i. 155 range of Ethiopian genera of, i. 305

range of Oriental genus of, i. 375

EDENTATA, ii. 244 general remarks on the distribution of, ii. 247

snmmary and conclusion, ii. 543

Ega, ii. 490

Egerina, ii. 397

Elainea, ii. 101, 291

ELAINEIN AE, ii. 291

Elania, ii. 397

Elanoides, ii. 349

Elanus, ii. 349

Elaphodus, ii. 220

Elaphrus, ii. 489

ELAPID E, ii. 382

Elapochrus, ii. 375

Elaps, ii 383

Elapsoidea, ii. 383

Elismognathus, ii. 212

Electra, ii. 209

ELEPHANTID Æ. ii. 227

Elephants, tossil, of Indian Miocene, i. 123

fossil in N. American Post-Pliocene formations, i. 130

birthplace and migrations of, i. 155 ii. 227

Elephant shrews, S. African, i. 267 ii. 186

Elephas, Post-Pliocene, i. 112

fossil in N. China, i. 123

N. American Tertiary, i. 138

ii. 227

Eliomys, ii. 232

Elliot, Mr., his great work on the birds of paradise, i. 415

on classification of the birds of paradise, ii. 274

Ellipesurus, ii. 463

Ellipsoglossa, ii. 413

Ellisia, ii. 258

Ellobius, ii. 231

Elminia, ii. 271

Elodina, ii. 478

Elopichthys, ii. 453

Elornis, European Miocene, i. 162

Elosia, ii. 419

Elotherium, N. American Tertiary, i. 137, 139 ii. 215,216

Elseya, ii. 408

EIwes, Mr., on birds of Persia, i. 204
Elwes, Mr., on true relations of the birds of Centrul India, i. 323

Elymnias, ii. 471

ELYHNIIDÆ, ii. 471

ELSIAD $Æ$, ii. 530

Embasis, N. American Tertiary, i. 134

Emberiza, ii. 285

EMBERIZIN E, ii. 285

Embcrizoides, ii. 284

Emblema, ii. 287

Embernagra, ii. 284

EMBROTOCJD $Æ$, ii. 438

Emesis, ii. 476

Emeu, figure of, i. 441

Emeus, ii. 368

Emminia, ii. 390

Empidagra, ii. 101

Empidias, ii. 102, 291

Empidochanes, ii. 102

Empidonax, ii. 102, 291

Empidonomus, ii. 102

Emyda, ii. 409

Emydida, Jndian Hiocene, i. 123

Emyäocephalus, ii. 38

Emys, Indian Miocene, i. 123

Miocene and Eocene, i. 165

ii. 408

Enes, ii. 501

Engystoma, ii. 416

ENGYSTOMIDE, ii. 416

Enhydrina, ii. 384

Enhydrion, Indian Miocene, 1. 121 ii. 200

Enhydris, ii. 199

Enicurus, ii. 263

Enispe, ii. 472

Enodes, ii. 288

Enophrys, ii. 375

Ensophleus, ii. 420

Entelopes, ii. 501

Entomiza, ii. 276

Entomophila, ii. 275

Enygrus, ii. 381

Eobasileus, N. American Eocene, 1. 139

Eocene period, i. 124

fauna of S. America, i. 148

Eophona, ii. 284

Eopsaltria, ii. 271

Eos, ii. 327

Epalzeorhynchus, ii. 451

Ephemera, from the Lias, i. 167

Ephthianura, ii, 260

Epicalia, ii. 474

Epicrates. ii. 381

WPIM ACHINÆ, ii. 275

Epimachus, ii. 275

Epiodon, ii. 208

Epirhixis, ii. 419

Epitola, ii. 47$\}$

Eporeodon, N. American Tertiary, i. 138

EQUID曆, ii, 211

Equide, European Pliocene, 1. 112

Miocene of Greece, i. 115

European Eocene, i. 125

Equus, European Pliocene, i. 112

Post-Fliocene, i. 112

Indian Miocene, i. 121

N. American Post-Pliocene, i. 130

N. American Tertiary, i. 135

Brazilian caves, i. 144

S. American Pliocene, 1. 146

ii. 211

Erebia, ii. 471

Eremias, ii. 391

Eremonela, ii 258

Eremophilus, ii, 4.4 
Ereptodon, N. American Post-Pliocene, i. 130 Eresic, ii. 474

Erethistes, ii. 444

Ercthizon, it. 239

Ereunctes, ii. 353

Ergaticus, ii. 279

Ergolis, ii. 474

Ericulus, ii. 188

Ericymba, ii. 452

ERINACEID 2 , ii 187

Erinaceus, European Miocene, i. 11t ii. 187

Eriocnemis, ii. 109

Eriodes, ii. 174

Erismatura, ii. 364

brithacus, ii. 259

Eroessa, ii. 258

Eronia, ii. 478

Erpornis, ii. 267

ERYCID \&, ii. 381

ERYCINIDÆ, ii. 476

Erynnis, ii. 480

Erythrinus, ii. 445

Erythrocercus, ii. 270

Erythrocnema, ii. 347

Erythrogonys, ii. 356

Erythrolampis, ii. 375

Erythromachus of Rodriguez, 1. 164 ii. 352

Erythrospiza, ii. 285

Erythrosterna, ii. 270

Erythrura, ii. 387

Eryx, ii. 382

ESOCID 2 , ii. 449

Esox, ii 449

Esthemopsis, ii. 470

Esthonyx, N. American Eocene, i. 139

Estrilda, ii. 286

Etheria, ii. 534

Ethiopian region should not include any part of India, i. 63

defined, i. 73

subdivisions of, i. 73

general features of, i. 251

zoological characteristics of, i. 252

mammalia of, i. 253

great speciality of, i. 253

birds of, i. 253

reptiles of, i. 254

amphibia of $i .255$

fresh-water fish of, i. 255

summary of vertebrates of, i. 255

insects of, i. 255

coleoptera of i. 256

terrestrial mollusea of, i. 257

sub-regions of, i. $25 \mathrm{~s}$

Atlantic islands of, i. 269

the probable past history of, i. 285

tables of distribution of animals of, $i$. 293

Euanemus, ii. 443

Eubagis, ii. 474

Eucephala, ii. 109

Euchcetes, ii. 98

Eucometis, ii. 99

Euchromia, ii. 48

Eucichla, ii. 298

Euclyptosternum, ii. 443

Eudromias, ii. 356

Eudynamis, ii. 310

Eudyptes, ii 366

E'teides, ii. 473

Eugenes, ii. 107

Eugenia, ii. 107

Euhyrax, ii. 200

Eulabeornis, ii. 352
Eulabes, ii. 287

Eulampis, ii. 107

Eumous, ii. 477

Eumeces, ii. 397

Eumetopias, ii. 203

Eumomota, ii. 313

Eumys, N. American Tertiary, 1. 140 ii. 231

Eumyias, ii. 270

Eunectes, ii. 381

Eunica, ii. 474

Eunogyra, ii. 475

Eupetes, ii. 263

Eupetomena, ii. 107

Euphema, ii. 325

Eupherusa, ii. 109

Euphonia, ii. 98

Euphractus, S. American Pliocene, i. 14 7

Euphryne, ii. 401

Euphysetes, ii. 208

Eupleres, ii. 195

Euploea, ii. 470

EUPPOCAMINE, ii. 340

Euplocamus, ii. 340

Eupodotis, ii. 356

Euprepes, ii. 397

Eupsychortyx. ii. 339

Euptilotis, ii. 314

Euptychia, ii. 471

Eurinorhynchus, ii. 353

Eurocephalus, ii. 272

Europe, recent changes in physical geography of, i. 39

Miocene fauna of Central, i. 117

Miocene fauna of, allied to existing fauna of tropical Asia and Africa, i. 124

European sub-region, description of, i. 191 forests of, i. 192

mammalia of, i. 192

birds of, i. 193

reptiles and amphibia of, $\mathbf{i} .195$

fresh-water fish of, i. 196

insects of, i. 196

islands of i. 197

Eurostopodus, ii. 320

Euryades, ii. 479

Euryapteryx, ii. 370

Euryarthrium, ii. 501

Eurybia, ii. 475

Furyceros of Madagascar, figure of, i. 278

Euryceros, ii. 288

Eurycus, ii. 479

Eurygona, ii. 476

EURYGONID A, ii. 476

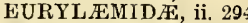

Eurylcemus, ii, 295

Euryodon, in Brazilian caves, i. 145 ii. 246

Euryphene, ii. 474

Eurypuga, ii. 358

EURYPYGIDÆ, ij. 358

Eurystomus, ii. 312

Eurytela, ii. 474

Eurytherium, Europenn Eocene, 1. 126

Eurytrichus, ii. 490

Euscarthmus, ii. 101

Euschemon, ii. 480

$$
\text { ii. } 481
$$

Eusemia, ii. 482

Euspiza, ii. 285

Eustephanus, ii. 108

Eustira, ii. 453

Eutatus, S. American Pliocene, i. 147 ii. 246

Eutelodon, European Eocene, i. 126

Eutemnodus, S. American Eocene, i. 148 
Euterpe, ii. 285

Euthyrhynchus, ii. 270

Eutoxeres, ii. 107

Eutriorchis, ii. 348

Eutropia, ii. 209

Eutropiichthys, ii. 441

Eutropius, ii. 442

Eutroplus, ii. 438

Exocetus, ii. 449

Exoglossum, ii. 452

Exostoma, ii. 444

Extinct mamualian fauna of Europe, general considerations on, i. 126

nrammalia of $\mathrm{N}$. America and Europe, comparison of, i. 140

mammalia of the Antilles, i. 148

mammalia of the Old and New Worlds, general remarks on. i. 148

fauna of New Zealand, i. 459

Amphibia, ii. 423

Ant-eaters, ii. 247

Armadillos, ii. 246

Bovidæ, ii. 225

Bradypodidæ, ii. 245

Camelidæ, ii. 217

Camelopardalidæ, ii. 221

Canidæ, ii. 197

Castoridæ, ii. 234

Caviidæ, 241

Centetidæ, ii. 189

Cercolabidæ, ii. 240

Cetacea, ii. 209

Chinehillidæe, ii. 237

Chiroptera, ii. 185

Crocodiles, ii. 407

Deer, ii. 220

Didelphyidæ, ii. 249

Dipodidæ, ii. 232

Echidnidae, ii. 254

Echimyidæ, ii. 239

Elephants, ii. 227

Equidæ, ii. 211

Erinaceidæ, ii. 188

Felidæ, ii. 193

Hippopotami, ii. 214

Hyænas, ii. 196

Hystricidæ, ii. 240

Insectivora, ii. 19\%

Lacertilia, ii. 404

Lagomyidæ, ii. 242

Leporidæe, ii. 243

Macropodidæe, ii. 251

Muridæ, ii. 230

II ustelidx, ii. 199

Mlyoxiclæ, ii. 232

Octodontidæ, ii. 238

Oplidia, ii. 387

Orycteropodidæ, ii. 246

Otariidæ, ii 203

Procyonidie, ii. 201

Quadrumana, ii. 178

Ralliılæ, ii. 252

Rhinocerotidæ, ii. 213

Sciuridæ, ji. 236

Seals, ii. 204

Sircnia, ii. 210

Struthionidæ, ii. 369

Suidæ, ii. 215

Talpidæ, ii. 190

Tapirs, ii. 212

Tortoises, ii. 410

Tragulidæ, ii. 218

Tupaiidæ, ii. 186

Urstdæ, ii. 202

Viverridæ, ii. 195

Extinction of large animals, causes of, i. 158
F.

Falcinellus, ii. 360

Falco, ii. 349

FALCONIDÆ, ii. 347

FALCONINAE, ii. 349

Falcons, ii. 347

Falculia, ii. 228

Falkland Islands, zoology of, ii. 49

Fanged ground-snakes, ii. 380

Furancia, ii. 377

Fauna of Japan, general character and affinities of, i. 230

of Palæarctic region, general conclusions as to, i. 231

extinct, of Madagascar and Mascarene Islands, i. $2 \mathrm{~S} 2$

Malayan, probable origin of, i. 359

Moluccan, peculiarities of, i. 419

Timorese, origin of, i. 422

of Celebes, origin of, i. 436

of New Zealand, origin of, i. 460

of Galapagos, origin of, ii. 33

of Central America, origin of, ii. 57

of Antilles, origin of, ii. 78

of Neotropical region, origin of, ii. 80

FELID瓜, ii. 192

Felis, Miocene of Greece, i. 115

European Miocene, i 118

Indian Miocene, i. 121

N. American Post-Pliocene, i 129

in Brazilian caves, i. 144

ii. 193

Felis spelcea, i. 110

Feniseca, ii. 477

Fennecus, ii. 197

Fcrania, ii. 376

Fernando Po, zoological features of, i. 265

Feroculus, ii. 191

Fiber, ii. 230

Figulus, ii. 493

Fiji, Tonga, and Samoa Islands, biıds of, i. 443

Finches, i1. 283

FIROLID E, ii. 531

Fishes, means of dispersal of, i. 59 classification of, i. 101

cosmopolitan groups of, i. 176

of the Palæaretic region, i. 186

of the European sub-region, i. 196

of the Mediterranean sub-region, i. 205

of the Manchurian sub-region, i. 227

fresh.water, table of Palæaretic families

of i. 227

of the Ethiopian region, i. 255

of South Africa, i. 268

fresh-water, table of Ethiogian families of, i. 298

fresh-water, of the Oriental region, i. $31 \mathrm{~s}$

of the Indo-Malay sub-region, i. 34]

fresh-water, table of Oriental families of i. 369

fresh-water, of the Australian region, i. 397

fresli-water, resemblance of Australian and S. American, i. 400

how the transmission may have taken place, i. 401

fresh-water, of New Zealand, i. 457

fresh-water, table of Neotropical families of, ii. 89

of Central N. America, ii. 131

of Eastern United States, ii. 134

of Canada, ii. 137

fresh-water, table of Nearctic families of,

ii. 143 
Fishes, remarks on the distribution of, ii. 464 fossil, ii. 466

Fishing-hawks, ii. 349

FISSURE LI.ID $\mathbb{E}$, ii. 511

FISTULARIDE, ii. 436

Fitzroya, ii. 450

Flamingoes, European Miocene, i. 162 ii. 361

Flora, of New Zealand, as influenced by scarcity of insects, i. 462 fossil of Australia, i. 467

Floras, cretaceous and tertiary, of North America, ii. 155

Florisuga, ii. 107

Flower-peckers, ii. 277

Flower, Professor, on classification of mammalia, i. 85 classification of carnivora, i. 87

Fluvicola, ii. 100

Flycatchers, ii. 270

Flying Lemur, Malayan, figure of, i. 337 ii. 186

Flying Lizards, ii. 401

Flying Opossum, figure of, i. 442

Fordonia, ii. 376

Forests, essential to existence of many European animals, i. 192 Siberian, greatest extent of, i. 216

FORMICARIIDÆ, ii. 297

FORMICARIIN $/$, ii. 298

Formicarius, ii. 104

Formicivora, ii. 104

FORMICIVORIN $\notin$, ii. 297

Formosa, zoology of, i. 332

Fossa, ii. 195

Foudia ii. 286

Francolinus, ii. 338

Fraseria, ii. 272

Fratercula, ii. 367

Fregetta, ii. 365

Fregilupus, ii. 288

Fregilus, ii. 27

Fresh-water fishes, Neotropical, ii. 12 of $\mathrm{S}$. Temperate America, ii. 49 of the Mexican sub-region, ii. 54 of the Antilles, ii 73

of the Nearctic region, ii. 120 of California ii. 128 summary and conclusion, ii. 549

Fresh-water mussels, ii. 53 shell, the most Aretic, ii. 518 snakes, ii. 376 snails, ii. 518

Fringilla, ii. 283

Fringillaria, ii. 285

Fringillauda, ii. 28

FRINGILLID $\nRightarrow$, ii. 284

Frog-mouths, ii. 318

Frogs, ii. 420

Fulica, ii. 35

Fuligula, ii. 364

Fulmarus, ii 365

Fundulus, ii. 450

FURNARIINÆ, ii, 295

Furnarius, ii. 103

Fusus, ii. 507

G.

GADID $\mathrm{E}$, it 439

GADOPSID $\mathrm{E}$, ii. 439

Gadus, ii. 439

Galago, ii. 177

Galapagos, scarcity of insects in, i. 463
Galapagos islands, ii. 29 mannmalia of, ii. 29

birds of, ii. 30

reptiles of, ii. 32

insects of, ii. 33

land-shells of, ii. 33

conclusions as to the origin of their fauna ii. 33

Galatea, ii. 536

Galaxias, ii 448

GALAXID $A$, ii. 448

Galbalcyrhynchus, ii. 3I1

Galbula, ii. 311

GALBULID $Æ$, ii. 311

Galecynus, in European Pliocene, 1. 112 ii. 198

Galeichthys, ii. 443

GALEOPITHECID \&E, ii. 186

Galeoscoptes, ii. 256

Galeospalax, European Miocene, i. 118 ii. 190

Galeotherium, Post-Pliocene, i. 111

Galera, N. American Post-Pliocene, i. 130

Galerella, ii. 195

Galerita, ii. 289

ii. 490

Galerix, ii. 188

Galethylax, European Eocene, i. 125

ii. 198

Galeus, ii. 460

Galictis, in Brazilian cares, i. 144 ii. 199

Galidia, ii. 195

Galidictis, ii. 195

Gallinæ, classification of, i. 96 range of Palæarctic genera of, i. 248 range of Ethiopiau genera of, i. 311 range of Oriental genera of, i. 384 range of Australian genera of, i. 485

GALLIN $F$, ii. 337

ii. 340

general remarks on the distribution of, it. 344

Gallinago, ii. 353

Gallinula, ii. 352

Gallus, Miocene of Greece, i. 116 ii. 340

Gallus bravardi, European Pliocene, i. 161

Galogale, ii. 195

Gambusia, ii. 450

Gampsonyx, ii. 349

Gampsorhynchus, ii. 261

Gannets, ii, 365

GANOIDEI, ii. 458

Gape-eyed Sciuks, ii. 395

Gar-fish, ii. 459

Garrod, Professor, on the Classification of Parrots, ii. 324

Garrulax, ii. 261

Garrulus, ii. 273

GASTEROPODA, ii. 507

GASTEROSTEIDÆ, ii. 424

Gasterosteus, ii. 424

Gastornis, Eurnpean Eocene, i. 163

GASTROCH ENID E, ii. 537

Gastropelecus, ii. 445

GAVIALIDA, ii. 405

Gavialis, ii. 405

Gavials, ii. 405

Gazella, ii. 223

GAZELLIN $Æ$, ii. 223

Gazera, ii. 481

Gecinulus, ii. 303

Gecinus, ii. 303

Gecko, ii. 399

GECKOTIDÆ, ii. 399 
Geese, ii. 363

Gehyra, ii. 400

Genera common to Post-Pliocene and Pliocene faunas of $\mathrm{N}$. America, i. 132

Genetta, ii. 195

Genidens, ii. 443

Geobates, ii. 103

Geobiastes, ii. 312

Geocichla, ii. 256

Geococcyx, ii. 309

Geocolaptes, ii. 304

GEODEPHAGA, ii. 486

Geoffroyus, ii. 326

Geographicel zoology, introduction, ii. 167 materials for, ii. 168

Geological history of Oriental region, i. 362

Geology and Physical Geography of the Antilles, ii. 62, 79

Geomelania, ii. 519

Geomys, ii. 233

Geopeliu, ii. 332

Geophaps, ii. 333

Geophagus, ii. 439

Gcopsittacus, ii. 325

Georissa, ii. 522

Georychus, ii. 231

(reositta, ii. 103

Geospiza, ii. 284

Geothlypis, ii. 279

Geotrochus, ii. 523

Geotryon, ii. 333

Geotrypus, ii. 190

Geranospiza, ii. 347

Gerbillus, ii. 230

$$
\text { ii. } 232
$$

Geronticus, ii. 360

Gerrhonotus, ii. 392

Gerrhosaurus, ii. 392

GERRIDÆ, ii. 438

Gervasia, ii. 260

Gerygone, ii. 258

Giant-Clams, ii. $53 \pm$

Gibbon, ii. 171

Gibraltar, cave fauna of, i. 114

Giraffes, ii. 221

Girardinus, ii. 450

Glacial epoch, as affecting the distribution of animals, i. 40

as a cause of the great change in the fanna of the temperate zones, since Pliocene times, i. 151

probably simultaneous in both henispheres, i. 151

causing a general subsidence of the ocean, i. 152

Glandina, Eocene, i. 169

ii. 515

Glareola, ii. 355

GLAREOLID $\approx$, ii. 355

Glaucis, ii. 107

Glaucidium, ii. 350

Glauconeza, ii. 530

(rlaucopis, ii. 481

Gliciphıla, ii. 275

Glis, ii. 232

Globiocephalus, ii. 209

Glossoptila, ii. 278

Glossotherium, in Brazilian caves, i. 145

S. American Pliocene, i. 147

ii. 247

Glycimeris, ii. 536

Glyphidodon, ii. 437

Glyphoglossus, ii. 416

Giyphorhynchus, ii. 103

Glyptodon, S. American Pliocene, i. I4T

Glyptosternum, ii. 44

VOL. II.
Gnaphodes, il. 471

Gnathodon, ii. 536

Gnothopsis, S. American Pliocene, i. 147

Goats, Palæaretic, i. 182

ii. 221

Goat-suckers, ii 519

GOBIESOCIDÆ, ii. 436

GOBIID无, ii. 430

Gobio, ii. 452

Gobius, ii. 430

Godman, Mr., on Natural History of the Azores, i. 207

Golden Moles, S. African, i. 267

Golicthi, ji. 494

Gonepteryx, ii. 478

Goniodactylus, ii. 400

Gongylophis, ii. 382

Gonorhynchide, ii 45 ?

Gonyocephalus, ii. 402

Gonyosoma, ii. 379

Gouldia, ii. 10 r

Goura, ii. 33

Graculav'us, N. American Cretaceous, i. 164

Gialle, arrangement of, i. 97 peculiar or characteristic Palæarctic genera, i. 249

peculiar Ethiopian genera of, i. 31

peculiar Oriental genera of, 386

peculiar Australian genera of, i. 486

GRALLÆ, ii. 351 general remarks on the distribution of, ii 362

Grallaria, ii. 104

Grallaricula, ii. 104

Grallina, ii. 273

Grammatophorus, ii. 402

Grammatoptiza, ii. 261

Grampus, ii. 209

Gronatellus, ii. 279

Grandala, ii. 259

Graphidurus, ii. 232

Graphipterus, ii. 491

Grauccelus, ii. 268

Gray, Dr. J. E., on classification of Cetacea, i. 88

Grayia, ii. 376

Grayson, $\mathrm{Col}$, on birds of Tres Marias, ii. 59

Grebes, ii. 367

Greece, Upper Miocene deposits of, i. 115 summary of lliocene fauua of, $i$. 116

Green BulbuIs, ii. 267

Greenland, zoology of, ii. 138

GreenIets, ii. 280

Groups peculiar to a region, how defined, ii. 184

Grouse, ii. 328

GRUID 2 , ii. 356

Grus, ii. 357

Grypsicvs, ii. 421

Grypus, ii. 107

Guacharo, ii. 107

Guans, ii. 342

Guaraunas, ii. $35 \pi$

Gubernatrix, ii. 285

Guillemots, ii. $26 \mathrm{i}$

Guira, ii. 309

Gurruea, ii. 285

Qudick, Rev. J. T., on Achatinellidæ of the sandwich Islands, i. 446

Gulls, ii, 364

Gulo, ii. 299

Giinther, Dr, his classification of reptiles, i. 98

his classification of fislies, i. 101

on gigantic tortoises of Galapagos and the Mascarene Islands, i. 289 
Ginther, Dr, on range of Indian reptiles in the Himalayas, $\mathbf{i}$. 329 on identieal Atlantiic and Pacfie fishes, ii. 21

on fresh-water fishes of Central Anierica, ii 54

Gygis, ii. 365

GYMNARCHID 2 , ii. 449

Gymnarchus, ii. 449

Grmatine, ii. 494

Gymnobucco, ii. 306

Gymnocephalus, ii. 103

Gymnocichla, ii. 104

Gymnocorvus, ii. 274

Gymnocypris, ii. 452

Gymnodactylus, ii. 400

GYMNODERIN RE, ii. 293

Gymnoderus, ii. 103

GXMNODONTES, ii. 457

Gymnoglaux, ii. 350

Gymnokitta, ii. 273

Gymnomystax, ii. 282

Gymnopelia, ii. 333

Gymnops, ii. 287

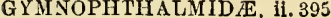

Gymnophthalmus, ii. 395

Gymnopus, ii. 199

Gymn orhina, ii. 273

Gymnostomus, ii. 451

GYMNOTIDE, ii. 455

Gymnotiss, ii. 455

Gymnura, ii. $18 \mathrm{~S}$

Gypaëtzs, ii. $3 \pm 8$

Gypohierax, ii. 348

Gypoictinia, ii. 349

Gyps, ii. 346

H.

Haast, Dr., on extinct birds of New Zealand, i. 460

Habitat, definition of, i. 4

Hubrocomus, ii. 239

Habroptila, ii. 352

Habrura, ii 101

Hadrostomus, ii. 102, 293

Hcematoderus, ii. 103

Homatopus, ii. 350

Hrematospizx, ii 25

Homophila, ii. 284

Hcemulon, ii. 426

Hotera, ii. 471

Hagria, ii. 397

Hainan, zoology of, i. 334

Halcyon, ii. 316

Halcyornis, European Eucene, i. 103

Halicyon, ii. 204

Halioeetus, ii. 348

Haliastur, ii. 348

Halichcerus, ii. 204

Halicore, ii. 210

HALIOTIDA, ii. 51$]$

Haltherium, European Pliocene, 1. 112 Europeun Miocene, i. 119 ii. 211

Halmaturus, ii. 251

HALOSAURIDÆ, ii 455

Halys, ii. 385

Hancadryas, ii. 470

Hang-nests, ii. 28

Hapale, ii. 176 ii. 178

Hapalemur, ii. 176

HAPALID Æ, ii. 175

Hapalctis, ii. 230

Hapalus, ii. 524
Haplocerus, ii. 374

Haplochilus, ii. 450

Huplochiton, ii. 446

HAPL()CHITONIDE, ii. 446

Haplodactylus, ii. 427

Haploodon, ii. 236

HAPLOODONTIDF, ii. 236

IIaplospiza, ii. 284

Hapsidrophis, 379

Harelda, ii 364

Hares, ii. 242

Harma, ii. 474

Harpa, ii. 349 ii. 507

Harpactes, ii. 314

Harpagus, ii. 349

Herpalus, ii. 489

Harporhynchus, ii. 256

Harpyhaliceetus, ii. 348

Hartlaubius, ii. 288

Hathliodes, ji. 502

Hatteria of New Zealand, 1. 456

Hatteria, ii. 405

Hawks, ii. 347

Hedgehogs, ii. 187

Hedymeles, ii. 285

Helarctos, ii. 202

Helcyra, ii. 474

Heleothreptus, ii. 320

Heliactin, ii. 108

Heliangelus, ii. 108

Helianthea, ii. 108

Heliastes, ii. 437

HELICIDÆ, ii. 512

Helicina, ii. 522

HELICONID $A$, ii. 473

$$
\text { ii. } 522
$$

Heliconius, ii. 473

Helicophagus, it. 442

Helicops, ii. 377

Helictis, Himalayan, flgure of, 1. 331

Helictis, ii. 199

Heliobletus, ii. 103

Heliochera, ii. 102

Heliodoxa, ii. 107

Heliomastes, ii. 108

Heliopeedica, ii. 107

Heliophobus, ii. 231

Helioporus, it. 417

Heliomis, ii. 352

Heliothrix, ii 108

Heliotrupha, ii. 108

Helix, Eocene, i. 169

$$
\text { ii. } 513
$$

Helladotherium, Miocene of Greece, 1. 113

European Miocene, i. 120

$$
\text { ii } 221
$$

Helluomorpha, ii. 490

Helmintherus, ii. 279

Helminthophaga, ii. 2:9

Heloderma, ii. 390

HELODERMIDA, ii. 390

Helodromas, ii. 353

Helogale, ii. 195

Helogenes, ii. 442

HELORNITHIN $\approx$, ii. 352

Helotarsus, ii. 348

Hemibos, Indian Miocene, i. 122 ii. 225

Hemicentetes, ii. 188

Hemicercus, ii. 303

Hemichelidon, ii. 290

Hemichromis, 438

Hemicyon, European Miocene, 1. 118 ii. 198

Hemidacnis, ii. 278 
Hemidactylium, ii. 413

Hemidactylus, ii. 399

Hemierges, ii. 397

Hemigalea, ii. 195

Hemignathus, ii. 277

Hemimantis, ii. 419

Hemiodus, ii. 445

Hemiphractus, ii. 420

Hemipimelodus, ii. 443

Hemiprocne, ii, 320

Hemipus, ii. 270

Hemirhamphus, ii. 450

Hemisilurus, ii. 442

Hemisorubim, ii. 442

Hemistilbon, ii. 109

Hemisus, ii. 414

Hemitriccus, ii. 101

Hemixus, ii. 267

Henicognathus, ii. 328

Henicopernis, ii. 349

Henicophaps, ii. 333

Henicorhina, ii. 264

Henicornis, ii. 103

Heptapterus, ii. 444

Heredia, ii. 413

Herons, ii. 359

Heros, ii. 438

Herpestes, ii. 195

Herpetethiops, ii. 376

Herpetodryas, ii. 376

Herpeton, ii. 376

Herpetoreas, ii. 375

Herpetotheres, ii. 348

Herpetotherium, N. American Tertiary, i. 134

Herpsilochmus, ii. 104

Herring, ii. 454

Hesperia, ii. $4 \mathrm{SO}$

HESPERID \&, ii. 480

Hesperomys, N. American Tertiary, i. 140

in Brazilian caves, $i .145$

$\mathrm{S}$. American Pliocene, i. 147

ii. 230,231

Hesperornis, N. American Cretaceous, i. 164

Hestia, ii. 470

Hestima, ii. 501

Heterobranchus, ii. 441

Heterocephalus, ii. 231

Heterocercus, ii. 102

Heterochroa, ii. 474

Heterocnemis, ii. 104

Heterocorys, ii. 259

Heterodactylus, ii. 393

Heterodon, in Brazilian caves, i. 145 ii. 246

$$
\text { ii. } 376
$$

Heterogynis, ii. 481

Hcterolocha, 287

Heteromorpha, it. 262

Heteromys, ii. 233

Heteronota, ii. 400

Heteronympha, ii. 471

Heteropelma, ii. 102, 292

Heteropus, if. 397

HETEROPYGII, ii. 450

Hetcrospizias, ii. 348

Heterotis, ii. 454

Heterura, ii. 290

Hewitsonia, ii. 477

Hexagonia, ii. 491

Hexaprotodon, Indian Miocene, i. 122

Hickman, Mr. John, on a cause of the extinetion of large animals, $i \quad 158$

Hieracidea, ii. 349

Hierax, ii. 349

Hierococcyx, ii. 310

Hierofalco, ii. $\mathbf{3 4 9}$
Hill-Tits, ii. 266

Himalayas, altitude reached by various groups in the, i. 329,333

Himantornis, ii. 352

Himantopus, ii. 353

Hinulia, ii. 397

Hipistes, ii. 376

Hipparchia, ii. 471

Hipparion, European Pliocene, 1. 112

Miocene of Greece, i. 115

European Miocene, i. 119

N. American Post-Pliocene, i. 130

N. American Tertiary, i. 135

ii. 211

Hippocampus, ii. 457

Hippoglossoides, ii. 441

Hippoglossus, 441

HIPPOPOTAMID $\approx$, ii. 214

Hippopotamus, Post-Pliocene, i. 112

Europe in Pliocene, i. 113

Indian Pliocene, i. 122

ii. 214

Hipposyus, N. American Tertiary, i. 133

Hippotherium, European Miocene, i. 119

Indian Miucene, i. 122

HIPPOTRAGINÆ, ii. 223

Hippotragus, European Miocene, i. 120 ii. 223

HIPPURITID $\approx$, ii. 534

Hirundinea, ii. 101

HIRUNDINID $Æ$, ii. 280

Hirundo, ii. 281

Hoazin , ii. 345

Holocanthus, ii. 427

Holbrookia, ii. 401

Holochilus, ii. 230

Hologerrhum, ii. 379

HOLOSTE1, ii. 458

Holurophis, ii. 380

Homalodontotheriam, S. American Pliocene, i. 146

Homalophis, ii. 376

Homalophus, European Miocene, 1. 161

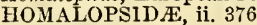

Homalopsis, ii. 376

Homaloptera, ii. 453

Homalosoma, ii. 490

Hombronia, ii. 397

Homocamelus, N. American Tertiary, j. 138 ii. 217

Homorus, ii. 103

ii. 524

Honey-gnides, ii. 304

Honeysuckers, birds specially adapted to Australia, i. 392 ii. 275

Hooker, Dr., on deficiency of odours in New Zealand plants, i. 464

Hoopoes, ii. 317

Hopladelus, ii. 442

HOPLEGNATHID $\approx$, ii. 433

Hoplobatrachus, ii. 421

HOPLOCEPHALA, ii. 460

Hoplocephalus, ii. $3 \mathrm{~S} 3$

Hoplocetus, European Pliocene, 1. 112

Hoplophoneus, N. Anjerican Tertiary, 1. 134

Hoplophorws, ii. 246

Hoplopterns, ii 356

Horites, ii. 258

Hornbills, ii. 316

Horses, fossil, in Indian Miocene, i. 121 perfect series of ancestral, in N. America, i. 136

probable birthplace of, i. 154

ii, 211

Horse-shoe bats, ii. 182

P $\mathrm{P} 2$ 
Hortulia, ii. 381

Howling monkeys, ii. 175

Hudson, Mrr., on land-birds of Patagonia, ii. 39 Humming-birds, ii. 321

Huro, if. 425

Hutton, Capt. F. W., on origin of New Zealanil falmn, i. 461

Huxley, Professor, on zoological regions, i. 59 division of aninal kingdom by, $\mathbf{i} .85$

Hyades, ii. 472

Hycena, Post-Pliocene, i. 112

Miocene of Greece, i. 115

European Miocene, i 118

Indian Miocene, i. 121

fossil in N. China, i. 123

ii. 196

Hyxnarctos in European Pliocene, i. 112

European Miocene, i. 118

Indian Miocene, i. 121

S. American Pliocene, i. 146

Hycenictis, Miocene of Greece, i. 115

European Miocenc, i. 118

ii. 196

Hyonido, European Niocene, i. 118

HY ENID F, ii. 196

Hyœnodon, European Miocene, i. 118

European Eocene, i. 125

N. American Tertiary, i. 134

Hycenodontidce, European Miocene, i. 118

HYALEID Æ, ii. 531

Hyalimex, ii. 517

Hyalina, ii. 515

Hyalosaurus, ii. 392

Hyantis, ii. 47.

Hybocystis, ii. 520

Hyborhynchus, ii. 452

Hudrocena, ii. 521

Hydrochelidon, ii. 364

Hydrochorus, N. American Post-Pliocene, i. 130

Hydrochoerus, ii. 241

Hydrocissa, ii. 317

Hydrocyon. ii. 445

Hydrogale, ii. 199

Hydromedusa, ii. 408

Hydromys, ii. 230

Hyitrophasianus, ii. 355

HYDROPHID \&, ii. 384

Hydrophis, ii. 384

Hydropotes, ii. 219

Hydropsalis, ii. 319

Hydrornis, European Miocene, i. 162 ii. 298

Hydrosaurus, ii. 389

Hyetornis, ii. 309

Hygrogonus, ii. 439

$H y l a$, ii. 418

Hylactes, ii. 297

Hylambates, ii. 419

Hylaplesia, ii. 415

HYLAPLESID $Æ$, ii. 41 t

Hylarana, ii. 419

Hylatomus, ii. 303

Hylella. $\mathrm{ii}$. $41 \mathrm{~s}$

II YLID $A$, ii. 418

Hyliota, ii. 270

Hylobates, ii. 171

Hylocharis, ii. 109 ii 271

Hylodes, ii. 419

Hylomanes, ii. 313

Hylomys, ii. 186

Hylophilus, ii. 280

Hylorhina, ii. 420

Hylotrupes, ii. 502

Hyloxalus, ii. 419

Hymenolrimus, ii. 364
HYODONTID $A$, ii. 453

Hyohimpus, N. Anerican Tertiary, i. 135

IIyomoschus, European Miocene, i. 120 ii. 218

IIyopicus, ii. 303

Hyopotamus, European Miocene, i. 119

N. American Tertiary, i. 137

ii. 216

Hyopsodus, N. American Tertiary, i. 133

Hyotherium, European Miocene, i. 119

ii. 215

Hypargos, ii. 287

Hyperanthe, ii, 496

Hypergerus, ii. 261

Hypermnestra, ii. 479

Hyperodapedon, ii. 405

Hyperolius, ii. 417

Hyperoodon, ii. 208

HYPEROODONTID $E$, ii. 208

Hyperopsius, ii. 448

Hypertragulus, N. American Tertiary, i. 138

Huphantorvis, ii. 286

Hypherpes, ii. 265

Hypisodus, N. American Tertiary, i. 138

$\mathrm{H}_{\text {, }}$ pna, ii. 474

Hypnale, ii. 385

Hypochera, ii. 287

Hypochrysops, ii. 477

Hypocista, ii 471

Hypocnemis. ii 104

Hypocolius, ii. 272

Hypodes, ii. 272

Hypogeomys, ii. 230

Hypolais, ii. 258

Hypolithus, ii. 4.91

Hypolycena, ii. 477

Hypomesus, ii. $47 i$

Hypopachus, ii. 416

Hypophthalmichthys, ii. 453

Hypophthalmus, ii. 442

Hypopyrrhus, ii. 282

Hyporissus, ii. 190

IIypothymis, ii. 271

Hypoxanthus, ii 304

Hypsipeies, ii 267

Hypsiprymnus, Australian Post-Tertiary, i. 157 ii. 251

Hypsirhina, ii. 376

Hypsirhynchus, ii. 375

Hyrachyus, N. American Tertiary, i. 126

HYRACID $F$, ii. 228

Hyracodon, N. American Tertiary, i, 136

ii. 214

ii. 248

Hyracoidea, elassification of, i. 90

Palæarctic, i. 242

Ethiopian, i. 304

HYRACOIDEA, ii. 228

Hyracotherium, supposed, in European Eocene, i. 125

European Eocene, i. 126

ii. 216

ii. 229

Hurax, ii. 228

HYSTRICID Æ, ii. 240

Hystricodon, ji. 445

Hystrix, European Pliocene, i. 113

Miocene of Greece, i. 116

N. American Tertiary, i. 140

ii. 240

I.

Ialmenus, ii 774

Ianthoenas, ii. 332

Ianthina, ii. 511 
Ibiclipodit, European Miocene, i. 162

Ibidorhynchus, ii. 353

Ibidorhyuchus, figure of, i. 331

Ibis, ii. 360

Ibises, ii. 360

Ibycter, ii. 347

Iceland, zoology of, j. 198

Ichneumia, ii 195

Ich thyoborus, ii. 445

Ichthyopsis, ii. 4 II

Icteria, ii. 279

ICTERIDÆ, ii. 281

Icterus, ii. 282

Icthyornis, N. American Cretaceous, i. I6t

Ieticyon in Brazilian caves, i. 144 ii. 197

Ictinia, ii. 349

Ictitherium, Miocene of Greece, i. 115

European Miocene, i. 118

ii. 195

ii. 197

Ictonyx, ii. 199

Ictops, N. American Tertiary, i. 133

Ideopsis, ii. 470

Idmais, ii. 478

Iguana, ii. 401

Iguanas, ii. 400

IGUANID $\&$, ii. 400

Ilerda, ii. 477

Ilicura, ii. 102

India, Miocene fauna of, allied to that of Europe, i. 123 geological features of, i. 328

Indian sub-region, descriptiou of, i. 321 supposed relation to Ethiopian region, i. 321

mamnalia of, i. 322

birds of, i. 323

reptiles and amphibia of, i. 326

Indicator, ii. 304

INDICATORIDE, ii. 304

Indo-Chinese sub-region, description of, i. 329 zoological characteristics of, i. 330

illustration of, i. 331

reptiles of, i. 331

amphibia of, i: 331

insects of, i. 332

islands belonging to, i. $3 .: 3$

Indo-Nalayau sub-region, description of, $i$. 334

mammalia of, i. 336

illustrations of, i. 336,339

birds of, i. 337

remote geographical relations of, i. 339

reptiles and amphibia of, i. $\$ 40$

fishes of, i. 341

insects of i. 341

coleoptera of, i. 342

terrestrial mollusea of, i. 343

zoological relations of islands of, i. 345

recent geographical ehanges in, i. 357

probable origin of fauna of, i. 359

Inia, ii. 209

Insectivora, European Mincene, i. 117

N. American Post-Pliocene, i. 129

N. American Tertiary, i. 133

Insectivora, classification of, i. 87

of the Falæarctic region, i. 181

of N. China and E. Thibet, i. 222

range of Palæaretic genera of, i. 239

of Madagascar, i. 273

range of Ethiopian genera of, i. 301

of the Oriental region, i. 315

range of Oriental genera of, i. 372

range of Australian genera of, i. 476

INSECTIVORA, ii. 186
INSECTIVORA, general remarks on the distribution of, ii. 191

summary and conclusion, ii. 541

Inscets, means of dispersal of, i. 32 tenacity of life of, i. 33

adapted to special conditions, i. 33 groups selected for the study of their geograplical distribution, i. 102 antiquity of the genera of, i. 160 fossil of European Miocene, i. 166 European Cretaceous, i. 167

European Wealden, i. 167

Palæozoic, i. 168

Palæaretic, i. 187

of Central Europe, i. 196

of the Mediterranean sub-region, i. 205

of the Siberian sub-region, i, 220

of the Manchurian sub-region, i. 227

of the Ethiopian region, i. 255

of the $\mathbf{E}$ African sub-region, i. 260

of W. African, i. 265

S. African, i. 268

of Hadagasear, i. 282

general renıarks on, i. 284

of tropical Africa and America, probable cause of similarities in, i. 291

of Indo-Chinese sub-region, i. 332

of the Orieutal region, i. 318

of Ceylon, i. 327

of Indo-Mlalay sub-region, i. 341

statisties of collecting in the various

islands of the Malay Archipelago, i. 343

of the Australian region, i. 403

of New Guinea, i. 417

of the Moluecas, i. 420

of the Timor group, i. 426

of Celebes, i. $45 t$

of New Zealand, i. 458

scarcity of, in New Zealand, i. 462

influence of, on the flora, i. 463

of the Neotropical region, ii. 13

of S. Temperate Anlerica, ii. 4

of S. Temperate America, Palæarctic affinity of, ii. 45

of the Nexitan sub-region, ii. 55

of the Antilles, ii. 73

of the Nearetic region, ii. 122

of Canarla, ii. 137

distribution of, ii. 468

range of, in time, ii. 469

summary and conclusion, ii. 550

lines of migration of, ii. 551

Iodopleura, ii. 102

Ioloma, ii. 107

Iolaus, ii. 477

Iole, ii. 267

Iora, ii. 267

Iphias, ii. 478

ii. 394

IPHISAD $\approx$, ii. 394

Irena, ii. 269

Iridina, ii. 534

Iridornis, ii. 98

Irrisor, ii. 318

IRRISORID $Æ$, ii. 318

Isacis, N. American Tertiary, i 133

Ischcognathus, ii. 375

Ischyromys, N. American Tertiary, i. 140 ii. 236

Islands, N. European, zoology of, i. 197

of the Mediterraneau sub-region, i. 206

of the W. African sub-region, i. 265

of the Ethiopian region, i. 269

Mascarene, i. 280

of the Indo-Chinese sub-region, i. 333

of the Indo-Malay sub-region, i. 345 
Islands, Fiji, Tonga, and Samoa, i. 443

Society and Marquesas, i, 444

New Caledonia and New Hebrides, i. 445

Sand wich, i. 446

of New Zealand sub-region, i. 453

Norfolk, i. 453

Lord Howe's, i. 454

Cluatham, i. 454

Auckland, i. 455

of Tropical S. America, ii. 29

of the Mexican sub-region, ii. 59

of Eastern United States, ii. 134

peculiar colours of pigeons in, ii. 336

abundance of land-shells in, ii. 525

Isodactylium, ii. 413

Ispidina, ii. 316

Issiodromys, European Pliocene, i. 113 ii. 232

Ithaginis, ii. 340

Ithomia, ii. 470

Ithycyph $u$, ii. 379

Ixalus, ii. 419

Ixonotus, ii. 267

Ixulus, ii. 266

\section{J.}

Jacamaralcyon, ii. 311

Jacamars, ii. 311

Jacamerops, ii. 311

Jacanas, ii. 255

Jacchus, in Brazilian caves, I. 144

Jaculus, ii. 232

Jaltris, ii. 375

Jamaicia, ii 521

Janella, ii. 517

Janthocincla, ii. 261

Japalura, ii. 402

Japan and North China, physical features of, i. 221

southern extrennity of perhaps belongs to the Oriental region, i. 226

Japan, general character of the fauna of, $i$. 230

former land-connexions of, i. 231

Java, mammalia of i. 349

productions of, well known, i. 350

birds of, i. 351

representative species of birds in, i. 352

origin of the anomalous features of its fauna, i. 352

Sumatra and Borneo, their geographical contrasts and zoological peculiarities explained, i. 357

Jays, ii. 273

Jenynsia, ii. 450

Jerboas, ji. 231

Juan Fernandez, Carabidæ of, ii. 44

birds of, ii. 49

beetles and land-shells of, ii. 51

Juida, ii. 288

Juliamyia, ji. 109

Junco, ii. 284

Junonia, European Miocerse, i. 167

ii. 474

K.

Karu, ii. 359

Kakapoe, of New Zealand, 1. 455

Kalophrynus, ii. 415

Kangaroos, extinct in Australia, i. 157 ii. 251

Keneuria, ii 397
Kerguelen Island, apterous insects of, i. 211 (note)

Kerodon, in Brazilian caves, i. 144

S. Anerican Pliocene, i. 147

ii. 241

Kctingus, ii. 443

Ketupa, ii. 350

King-fisher, racquet-tailed, of New Guinea, figure of, i. 415

King-fishers, ii. 315

Kittacincla, ii. 259

Kiwi of New Zealand, i. 455

Kneria, ii. 453

Kobus, ii. 224

Koodoo antelope, figure of, i. 261

Kricogonia, ii. 478

Krynickia, ii. 517

L.

Labeo, ii. 451

Labrax, ii. 425

LABRID $£$, ii. 437

Labrus, ii. 437

LABYRINTHICI, ii 434

Lacerta, ii. 391

LACERTIDA, ii. 390

Lacertilia, classification of, i. 99

LACERTILIA, ii. 388 general remarks on the distribution of, ii 403

fossil, ii. 404

Lacuna, ii. 510

Ladrone Islands, birds of, i. 444

Lemargus, ì 461

Lomosthenes, ii. 489

Luosopis, ii. 477

Lafresnaya, ii. 107

Lagenocetus, ii. 208

Lagenorhynchus, ii. 209

Lagidium, ii. 237

LAGOM XID

Lagomys. European Pliocene, i. 113

European Miocene, i. 120

ii. 242

Lagopas, ii. 339

Lagorchestes, ii. 251

Lagostomus, in Brazilian caves, i. 145

S. American Pliocene, i. 147

ii. 237

Lagothrix, ii. 174

Lais, ii. 442

Lake Baikal, seals of, i. 218 ii. 206

Lalage, ii. 269

Laletes, ii. 280

LA IIID F, ii. 498

Lamna, ii. 460

LAMNIDÆ, ii. 460

Lampornis, ii. 107

Lainpreys, ii. 463

Lamprima, ii. 493

Lampris, ii. 429

Lamprocolius, ii. 288

Lamproicema, ii. 107

Lamrophis, ii. 380

Lampropsar, ii. 282

Lampropygia, ii. 108

Lamprospilus, ii. 477

Lamprospiza, ii. 99

Lamprotes, ii. 98

Lancelet, ii. 464

Land-lizards, 1i. 391

Land and water, proportions of, i. 35

Land and fresh-water shells, antiquity of the genera of, i. 168 
Land-shells, Palæozuic, i. 169

Palearctic, i. 190

of Madeira, i. 209

of the Cape Verd Islands, i. 215

of the Ethiopian region, i. 257

of W. Africa, i. 265

of Madagascar and the Jascarene Islands, i. 285

of the Indo-Malay sub-region, i. 344

of the Australian region, i. 407

of the Sandwith Islands, i. 466

of New Zealand, i. 459

of the Neotropical region, ii. 19

of the Antilles, ii. 75

conditions favouring development of, ii. 75

of $\mathrm{N}$. Anterica, ii. 124

general observations on the distribution of, ii. 522

richness of islands in, ii. $5: 25$

their mode of diffusion, ii. 525, 528

comparative distribution of Operculate and In-operculate, ii. 526

estimated numbers of, ii. 526

Land-snakes, ii. 382

Langaha, ii. 379

Laniarius, ii. 272

Lanicterus, ii. 268

Laniellus, ii. 272

LANIIDA, ii. 272

Lanio, ii. 99

Lanius, European Miocene, i. 161 ii. 272

Laopithecus, N. American Tertiary, i. 133

Laornis, N. American Cretaceous, i. 164

Laprissa, ii. 421

LAR1D \&, ii. 364

Larimus, ii. 428

Larks, ii. 289

Larus, ii. 364

Larvivora, ii. 259

Lasiomys, ii. 229

Lasiuromys, ii. 239

Latax, ii. 199

Lates, ii. 425

Lathri $\alpha$, ii. 102

Latonia, ii. 421

Latrunculus, ii. 430

Layardia, ii. 261

Lea, Dr. Isaac, on N. American Unionidæ, ii.125

Lebia, ii. 489

Lebiasina, ii. 445

Legatus, ii. 101

Leiocephalus, ii. 401

Leiolomus, ii. 401

Leistes, ii. 282

Leistus, ii. 489

Leiuperus, ii. 420

Leiyla, ii. 419

Lemonias. ii. 476

Lemur, ii. 176

Lemur, fossil, ii. 178

Lemuravide, N. American Tertiary, i. 133

Lemuravus, N. American Tertiary, i. 133

Lemuria, a hypotlietical land, i. 76

Lemurido, European Eocene, i. 124

LEMURIDE, ii. 176

Lemuroidea, range of Ethiopian genera of, $i$. 300

range of Oriental genera of, 371

LEMUROIDEA, ii. 176

Lemurs, ii. 176

Leonia, ii. 521

Lepadogaster, ii. 436

Lepictis, N. American Tertiary, i. 133

Lepidoccpalichthys, ii, 453

Lepidocephalus, ii. 453
Lepids.jammas, ii. 309

Lepidolarynx, ii. 108

Lepidoptera, cosmopolitan families of, i. 177

table of Palrartic familits of, i. 238

S. African, i. 268

table of Ethiopian families of, i. 299

of the Oriental region, i. 318

table of Oriental families of, i. 369

of the Australian region, i. 404

table of Australian tanilies of, i. 472

of the Neotropical region, ii. 13

of the Antilles, ii. 73

table of Neotropical families of, ii. 90

of the Nearctic r'egion, ii. 122

Nearctic families of, ii, I43

LEPIDOPTERA, ii. 470

Lepidosiren, ii. 458

LEPIDOSTEI DÆ, ii. 459

Lepidosteus, ii. 459

LEPIDOSIERNID无, ii. 389

Lepidosternon, ii. 389

Lepilemur, ii. 176

Lepistes, ii. 450

LEPOKIDE, ii. 242

Leporinus, ii. 445

Lepricornis, ii. 470

Leprodera, ii. 501

Leptalis, ii. 478

Leptarchus, N. American Tertiary, i. I35 ii. 202

Leptasthenura, ii. 103

Leptouchenia, N. American Tertiary, i. 138

Leptobarbina ii. 452

Leptobrachium, ii. 421

LLPTOCARDII, ii. 461

Leptocer $\alpha$, ii. 502

Lcptochorus, N. American Tertiary: i. 137 ii. 215

Leptocircus, ii. 479

Lcptodeira, ii. 379

Leptodon, Miocene of Greece, i. 116

ii. 214

ii. 349

Leptognathus, ii. 3S1

Leptomantis, ii. 419

Leptomeryx, N. American Tertiary, i. 138 ii, 220

Lepton, ii. 535

Leptoneura, ii. 471

Leptonyx, ii. 204

Leptopogon, ii. 101

Leptoma, ii. 520

Leptoptila, ii. 333

Leptoptilus, European Miocene, i. 162 ii. 361

Leptorhytaon, ii. 380

Leptornis, ii. 276

LEPTOSONID $\approx$, ii. 310

Leptosomus, allied form in European Eocene, i. 168 ii. 310

Leptosomus of Madagascar i. 278

fignre of, i. 279

Leptotherium, in Brazilian caves, 1. 144 ii. 226

Leptotriccus, ii. 101

Leptura, ii. 502

Lepus, in Brazilian caves, i. 145

S American Pliocene, i. 147

Lerista, ii. 395

Lerwa, ii. 339

Lesbia, ii. 108

Lestodon, S. American Pliocene, i. 147

Leucippus, ji. 109

Lenciscus, ii. 452

Leucochroa, ii. 516 
Leucocyon, ii. 197

Leucomelona, ii. 332

Leuconerpes, ii 304

Leucophantcs, ii. 270

Leucophasia, ii. 478

Leucopleurus, ii. 209

Leucosarcia, ii. 333

Leucosomus, ii. 452

Leveosticte, ii. 285

Lewis, Mr. Georne, his collection of Japan insects, i. 228

LIA LIDE, ii. 396

Lialis, ii. 396

Liasis, ii. 381

Libcllula, from the Lias, i. 167

Libuthea, ii. 475

LIBYTHEIDE, ii. 475

Lichanotus, ii. 381

Lichenops, ii. 101

Licina, ii. 521

Licmptis, ii. 325

Lilljeborg, Professor, on classification of the Rodentia, i. 90

LIMACID $Æ$, ii. 5 I7

LIMACIN1Dæ, ii. 531

Limax, ii. 517

Limenitis, ii. 474

Limncea, Eocene, 169

European Secondary, i. 169 ii 518

LIMINAIDÆ, ii. 518

Limnatornis, European Miocene, i. I6I

Limnocharis, ii. 420

Limnocyon, N. American Tertiary, i. 134

Limnodynastes, ii. 420

Limnohyus, N. American Tertiary, i. 136

Limnophis, ii. 376

Limnornis, ii. 103

Limnotheridce, N. Americau Tertiary, i. 133

Limnotherium, N. American Tertiary, i. 133

Limnurgus, ii. 450

Limosa, ii 353

Limpets, ii. 511

Lingula, ii. 538

LINGULID $Æ$, ii. 532

Linota, ii. 285

Linsang, ii. 195

Liocassis, ii. 442

Liopelma, ii. 417

Liopis, ii. 375

Lioptilus, ii. 267

Lioscelis, ii. 297

LIOTRICHID $\approx$, ii. 266

Liothrix, ii. 266

Lipaugus, ii. 102

Liparis, ii. 430

Liphyre, ii, 477

Lipinia, ii. 397

Lipor, ii. 342

Liposarcus, ii. 444

Liptala, ii. 477

Lissolepis, ii. 397

Listriodon, European Miocene, i. 119

Lithiodon, ii. 521

Lithomys, European Hiocene, i. I20 ii. 236

Lithornis, European Eocene, i. 163

Litoria, ii. 418

Littorina, ii. 510

LITTORINID A, ii. 510

Lizurds, elassification of, i. 90

Tertiary, i. 165

wide range of a snecies in Polynesia, i. 448

distribution and lines of nigration of, ii. 547

Lobodon, ii. 204
Lochmias, ii. 103

Locustellu, ii. 258

Loddigesia, ii. 108

Loncheres, in Brazilian caves, i. 145 ii. 239

Lonchophorus, in Brazilian caves, i. 145 ii. 239

LONGICORNIA, ii. 498

Longienrnia, Palæaretic, i. 188

Ethiopian, i. 257

Oriental, i. 320

Australian, i. 407

Neotropical, ii. 17

of Chili, ii, 46

Nearctic, ii. 123

Lostra, ii. 199

Lophiodon, European Eocene, i. 125

N. American Tertiary, i. 136

ii. 212

Lophiomeryx, ii. 218

Lophiotherium, N. American Tertiary, i. 136

Lophius, ii. 431

Lophoaëtus, ii. 348

LOPHOBRANCHI, ii. 456

Lophocitta, ii. 273

Lophogyps, ii. 346

Lophoictinia, ii. 349

Lopholaimus, ii. 362

Lophiomys, ii. 230

Lophophaps, ii. 333

Lophophan.es, ii. 266

LOPHOPHORIN E, ii. 340

Lophophorus, ii. 340

Lophorhina, ii. 274

Lophornis, ii. 107

Loplortix, ii. 339

Lophostrix, ii. 350

LOPHOTID \&, ii. 432

Lophotragus, ii. 220

Lophotriorchis, ii. 348

Lophura, ii. 402

Lord Howe's Island, birds of, i. 453

Loricaria, ii. 444

Loriculus, ii. 326

Loris, ii. 1 6

Lorius, ii. 327

Lota, ii. 439

Loxia, ii. 285

Loxigilla, ii. 285

Loxomylus, Pliocene of Antilles, i. 148

$$
\text { ii. } 237
$$

Loxops, ii. 277

Lucania, ii. 450

LUCANIDÆ, ii. 492

Lucanus, ii. 493

Lucia ii. 477

Lucidella, ii. 522

Lucifinga, ii. 440

LUCINID E, ii. 535

Lucinopsis, ii 536

LUCIOCEPHALIDE, ii. 434

Lucioperca, ii. 425

Luciotrutta, ii. 447

Lucisoma, ii. 452

Lund, Dr., his researches in caves of Brazil, $\mathbf{i}$. 143

Lupus, ii. 197

Lurocalis, ii. 320

Luscinia, ii. 259

Lusciniola, ii. 258

Lutra, European Miocene, i. 118

Indian Miocene, i. 121

ii. 199

Lutronectes, ii. 199

Lyccena, Miocene of Greece, i. 115 ii. 196 
LYCANIDE, ii. 477

Lycalopex. i 197

LYCOUID E, ii. 439

Lycodon, ii. 380

LYCODONTIDE, ii. 380

Lycophidion, ii. 380

Lycorca, ii. 4 To

Lygosoma, ii. 397

Lygosomella, ii. 397

Lymanopoda, ii. 471

Lymnas, ii. 470

Iyncornis, ii. 320

Lyncus, ii. 193

Lytorhynchus, ii. 376 .

Lyre-bird, figure of, i. 441 ii. 298

II.

Mabouya, ii. 397

Macacus, European Pliocene, i. 112

Miocene of Greece, i. 115

Indian Miocene, i. 121

supposed in European Eocene, i. I25

ii. 173

ii. 178

Macaws, ii. 327

Machairodus, i. 110,111

Miocene of Greece, i. 115

European Miocene, i. 118

Indian Miocene, i. 121

N. American Tertiary, i. 134

in Brazilian caves, i. 144

S. American Pliocene, i. 146

ii. 193

Machctornis, ii. 101

Macherhamphus, ii. 349

Machorirhynchus, ii. 271

Machoropterus, ii. 102

Machetes, ii. 353

Macranchenia, S. American Pliocene, i. 146

Macrocalamus, ii. 374

Macroceramus, ii 516

Macrochilus, ii. 491

Macrocyclis, ii. 516

Macrodipteryx, ii. 320

Macrodon, ii. 445

Macrogloss $a$, ii. 482

Macrones, ii. 442

Nacronus, ii. 261

Macronyx, ii. 290

MACROPODIDE, ii. 250

Macropus, ii. 251

Macropygia, ii. 332

Macrorhamphus, ii. 353

MACROSCELIDIDEA, ii. 186

Ifacroscelides, ii. 186

Macrosila, ii. 482

Macrotherium, Miocene of Greece, i. 116

European Hiocene, i. 121 ii. 246

Macrotus californicus, ii. 182

MACROURID E⿰, ii. 440

MACTRID E, ii. 443

Madagascar, extinct birds of, i. 164

description of, i. 272

mammalia of, i. 272

birds of, i. 274

reptiles of, i. 279

amphibia of, i. 280

extinet fauna of, i. 282

general remarks on insert fauna of, $i, 284$

Sladeira, birds of, i. 208

land-shells of, i. 208

beetles of, i. 210
Maleira, wingless insects numerous in, i. 2I I

how stocked with animals, i. 213

NALACANTHID $\mathbb{E}$, ij. 433

Malacca, Sumatra, and Borneo, zoological unity of, i. 353

comparison of manmalia, i. 354

of birds, i. 355

Malacocircus, ii. 261

Malacopteron, ii. 261

Malacoptila, ii. 310

Malacorhynchus, ii. 364

Malacothrix, ii. 230

Malagasy sub-region, description of, i. 272

mammalia of, i. 272

birds of, i. 274

illustration of zoology of, i. 278

reptiles of, i, 279

amplibia of, i. 280

extinct fauna of, i. 282,289

insects of, i. 282

early history of, i. 286

Mclapterurus, ii. 443

Malaya and Indo-Malaya, terms defined, i. 345 (note)

Malaya, meaning of term, ii. 261

Malay Archipelago, distribution of butterfies in ii. 484

distribution of Cicindelidæ in, ii. 487 distribution of Longicorns in, ii. 500

Malayan forms of life reappearing in West Africa, i. 263

fauna, probuble origin of, i. 359

resemblances to that of Madagascar and Ceylon explained, i. 361

Natimbus, ii. $286^{\circ}$

Mallodon, ii. 501

Mallotus, ii. 447

Malta, Post-Pliocene fauna of, i. 114

formerly joined to Africa, i. 201

fossil elephants of, i. 201

birds of, i. 206 (note)

Malurus, ii. 258

Mamnal, the most ancient American, i. 134

Mammalia, means of dispersal of, $i$. 10

as limited by climate, i. 11

as limited by rivers, i. 12

low far limited by the sea, i. 13

dispersed by ice-floes and drift-wond, i. 14

means of dispersal of aquatic, i. 15

of most importance in determining zoo$\operatorname{logical}$ regions, i. 57

classification of, i. 85

birthplace and migrations of some families of, i. 142,153

cosmopolitan gromps of, i. 176

of the Palæarctic region, i. 18 1

of the European sub-region, i. 192

of the Mediterranean sul-region, i. 202

of the Siberian sul)-region, i. 217

characteristic of Western Tartary, i. 218

of the Manchuriau sub-region, i. $2 * 2$

Palæarctic genera of, in the Manchuria: sub-region, i. 222

Oriental genera of, on borders of same sub-region, i. 223

peeuliar to Japan, i. 223

characteristic of N. W. China and Mongolia, i. 226

table of Palæarctic families of, i. 234

range of Palaaretic genera of, i. 239

of the Ethiopian region, i. 253

absence of certain important grouns, i. 253

of the F. African sub-region, i. 260

of W. Afriea, i. 262

of S. Africa, i. 267 
Ma:mmalia, of Madagascar, i. 272

table of Ethiopian fanilies of, i. $29 t$ table of Ethiopian genera of, i. 300 of the Oriental region, i. 315

range of the genera inhabiting the Indian sub-region, i. 322

of Ceylon, i, 327

of the Indo-Chinese sub-region, i. 330 of the Indo-Malayan sub-region, i. 336 illustration of characteristic Malayan, i. 336

of the Philippine Islauds, i. 345

table of Oriental families of, i. 365

table of Oriental genera of, i. 371

of Australian region, i. 390

of the Papuan Islands, i. 410

of the Moluceas, i. 417

of the Timor group, i. 422

of Celebes, i. 427

of Australia, i. 439

illustration of, i. 439

of New Zealand, i. 4.50

table of families of Australian, i. 470

table of genera of Australian, i. 475

destinctive characters of Neotropical, ii. $b$

of S. Temperate Anıerica, ii. 36

of Straits of Magellan, ii. 37

of the Mexiean sub-regsion, ii. 52

of the Antilles, ii. 62

table of Nentropical families of, ii. 85

table of Neotropical genera of, ii. 91

of the Nearctic region, ii. 115

of California, ii. 127

of N. American central plains ii. 129

of E. United States, ii. 132

of Canada, ii. 135

table of Nearctic families of, ii. 140

tahle of Nearctic genera of, ii. 145

Manmalia, extinct, of Old World, i. 107

extinct, of historic jreriod, i. 110

extinct, comparative age of in Europe, i. 127

extinct, of the New World, i. 129

extinct, of N. America and Europe, compared, i. 141

original birthplace of some families and genera, i. 142,153

of the secondary period, i. 160

MANMALIA, summary and ennclusion, ii. 540 lines of migration of, ii. 544

Manakins, ii. 102

IANATIDE, ii. 210

Manatus, N. American Post-Pliocene, i. 130 ii. 210

Manchurian sub-region, description of, i. 220 niamualia of, i. 222

birds of, j. 223

reptiles and amphibia of, i. 227

fresll-water fisl of, i. 227

insects of, $\mathrm{i} 227$

coleoptera of, i. 228

MANIDIDE, ii. 245

Manis, ii. 245

Manorhina, ii. 276

Manticora, ii. 487

Manucollia, ii. 274

Mareca, ii. 363

Margaroperdix, ii. 338

Margxrops, ii. 256

Margarornis, ii. 103

Marginella, ii. 508

Marine Mollusca, general remarks on the distribution of, ii. 557

Marine shells of the Neotropical region, ii. 20

Marmosets, ii. 175

Marquesas Islands, birds of, i. 443
Marsh, Mr., on improvability of Asiatic ans African deserts, i. $20 \mathrm{u}$

oll cameis and goats as destructic to vegetation, i. 200

MARSUPIALIA, ii. 248

general remarks on the distribution of ii. 253

ILarsupials, classification of, i. 91

N. American Post-Pliocene, i. 130

European Miocene, i. 121

first migration to America, i. 155

diversified forms of, i. 391

of America prove no connection with Australia, i. 399

list of Australian genera of, i. 476

MARSUPIALIA and HONO'TREMATA, summury and conclusion, ii. 513

Martes, N. American Tertiary, i. I35 ii. 198

Mascarene Islands, zoology of, i. 280 extinct fauna of, i. 282

gigantic land-tortoises of, i. 259

Masius, ii. 102

MASTACEMBELID , ii. 497

Mastodon, European Pliocene, i. 113

Miocene of Greece, i. 116

European Miocene, i. 120

in Brazilian caves, i. 144

S. American Pliocene, i. 147

Indian Mioceue, i. 123

N. A merican Post-Pliocene, i. 130

N. American Tertiary, i. 135

ii. $227,22 \mathrm{~S}$

Mauritius, zoology of, i. 280

reptiles of, i. 281

McCoy, Professor, on Palæontology of Victoria, i. 460

Mechanitis, ii. 470

Meda, ii. 452

Mediterranean, recent changes in, i. 39

sub-region, description of, i. 199

inanmalia of, i. 202

birds of, i. 203

reptiles and amphibia of, i. 204

fresh-water fish of, i. 205

insects of, i. 205

islands of, i. 206

sea not separating distinct faunas, i. 201

Megabias, ii. 270

Megablubes, ii. 376

Magacephala, ii. 478

ILegacephalon, ii. 342

Megacerops, N. Aunerican Tertiary, i. 137

Megaderma, ii 182

Megarophis, ii. 383

Megalama, ii. 306

MEGAL 2 WIDÆ, ji. 305

MEGALACMIN $E$, ii 300

Megalixalus, ii. 419

Megalocnus, fossil in Cuba, i. 148

Megalomastoma, ii. 521

Megalomeryx, N. Ainerican Tertiary, i. 138

Megalomma, i1. 487

Megalonyx, N. American Post-Pliocene, i. 130

in Brazilian caves, i. 145

S. American Pliocene, i. 147

Megalophrys, ii. 421

Megalostoma, Eocene, i. 169

Megalurus, ii. 258

Megalophonus, ii. 289

Megamys, S. American Eocenc, i. 148

ii. 238

Meganostoma, ii. 478

MEGAPODIID $\approx$, ii. 341

Megapodius, ii. 342

Megaptera, ii. 207 
Megarhynehus, ii. 101

Megaspira, European Tertiary, i. 169 ii. 527

Megatherida, in Brazilian caves, i. 145

Megatherium, N. American Post-Pliocene, i. 130

iu Brazilian caves, i. 145

S. American Pliocene, i. 147

ii. 245

Meiornis, ii. 369

Melampitta. ii. 298

Melampus, ii. 519

Melanerpcs, ii. 303

Mclania, European Secondary, i. 169

MELANIADÆ, ii. 509

Melanitis, ii 471

Melanochlora. ii. 266

Melanocorypha, ii. 289

Melanophidium, ii. 374

Melanoptila, ii. 256

Melanotis, ii. 256

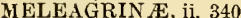

Meleagris, N. American Miocene, i. 163 ii. 340

Meles, ii. 199

Melidectes, ii. 276

Melidora, ii. 316

Melierax, ii. 348

Mclincea, ii. 470

Meliornis, ii. 275

Meliphaga, ii. 275

MELIPHAGID $Æ$, ii. 275

Melipotes, ii. 276

Melirrhophetes, ii. 276

Nelitoea, ii. 474

Melith reptus, ii. 276

Melittophagus, ii. 312

Melizophilus, ii. 259

Mellisuga, ii. 108

Mellivora, Indian Miocene, i. 121

ii. 199

Melolonthidium, Oolitic insect, 1. 167

Melopelia, ii. $\mathbf{3 3 3}$

Melopsittacus, ii. 325

Melopyrrha, ii. 285

Mlelospiza, ii. 284

Melursus, ii. 202

Menetia, ii. 395

Neniccros, ii. 317

Meniscotherium, N. Annerican Tertiary, i. $13 \mathrm{~s}$

Menobranchus, ii. 412

Menopoma, ii. 412

MENOPOMIDE, ii. 412

Menotherium, N. American Tertiary, i. 133

Menura, ii. 298

MENURID王, ii. 298

Mephitis, in Brazilian caves, i. 144 ii. 199

Merganetta, ii. 364

Mergulus, ii. 367

Mergus, ii. 364

Meriones, ii. 232 ii. 230

Meristes, ii. 272

Merluccius, ii. 439

Meroe, ii. 536

MEROPIDE, ii. 312

Meropiscus, ii. 312

Meropogon, ii. 312

Merops, ii. 312

Merulaxis, ii. 297

Merychus, N. American Tertiary, i. 138

Merychippus, N. American Tertiary. i. 135

Merychochcerus, N. American Tertiary, i. 138

Merycodus, N. American Tertiary, i. 138 ii. 220
Merycopotamus, Indian Miocene, i. 122 ii. 214

Merycotherium, of Siberian drift, i. 112 ii. 217

Mesacodon, N. American Tertiary, i. 133

Mesapia, ii. 479

Mesites, ii. 263

Mesohippus, N. American Tertiary, i. 135

Mesomys, ii. 239

Mesonauta, ii, 438

Mesonyx, N. American Tertiary, i. 134

Mesopithecus, Miocene of Greece, i. 115

$$
\text { ii. } 178
$$

Mesoprion, ii. 425

Mesops, ii. 439

Mesosemia, ii. 475

Messalina, ii. 391

Messaras, ii. 474

Metallura, ii. 108

Metapheles, ii. 476

Methonella, ii. 470

Metius, ii. 49:-

Metopia, ii. 102

Metopiana, ii. 364

Metoponia, ii. $2 \mathrm{~S} 3$

Metopothrix, ii. 102

Metriopclia, ii. 333

Mexican sub-region. iii. 51

mammalia of, ii. 52

birds of, ii. 52

reptiles of, ii. 54

amphibia of, ii. 54

fresh-water fish of, ii. 54

insects of, ii. 55

land-shells of, ii. 57

its relations to the $N$. and $S$. American contirients, ii. 57

islands of, ii. 59

Meyer, Dr. A. B., on reptiles and amphibia of New Guinea, i. 415

Mierceca, ii. 270

Micracantha, ii. 501

Micrastur, ii. 347

Mierathene, ii. 3:0

Micrhyla, ii. 414

Nicrobates, ii. 104

Microcebus, ii. 176

Microcerculus. ii. 264

Mierochoera, ii. 107

Microglossus, ii. 325

Microhierax, ii. 349

Microlcstes, oldest European mammal, i. 163

Micromeryx, European Miocene, i. 120 ii. 220

Micropelama, ii. 353

Micropternus, ii. 304

Mieropterus, ii. 364

Microscelis, ii. 267

Microstoma, ii. 448

Microsyops, N. American Tertiary, i. 133

Microtherium, European Mliocene, i. 120

Midas, ii. 176

Middendorf, on extreme northern birds, i. 219

Midea, ii. 478

Miglyptes, ii. 304

Jligrating birds, in which region to be placed. i. 185

Migration of animals, i. 10 general phenomena of, i. 18 of birds, i. 19

of birds in Europe, i. 19

probable origin of, i 22

of birds in India and China, i. 23

of birds in N. America, i. 23

changes in extent of, i. 24 of birds in S. Temperate America, i. 25 
Migration of aniuals, general remarks on, i. 25

Milctus, ii. 477

Milvulus, ii. 102, 291

Nilvus, European Miocene, i. 162 ii. 349

Nimcta, ii. $26 \mathrm{~s}$

Nimetes, ii. 170

Mimocichla, ii. 256

Mimus, ii. 256

Minla, ii. 266

Miocene fauna of the Old World, i. 114 fauna of Geece, i. 115

fauna of Greece, summary of, i. 116

fauna of Central Europe, i. 117

deposits of Siwalik Hills, $i$. 121

faunas of Enrope and Asia, general observations on, i. 123

Miohipmus, N. American Tertiary, i. 135

Mionectes, ii. $\mathbf{i} 01$

Mirafra, ii. 289

Miro, ii. 260

Misgurnus, ii. 453

Mitra, ii. 508

Mitrephorus, ii. 102

Nitua, ii. 343

Mivart, Professor, on classification of primates, i 86

on classification of insectivora, $j .87$

(n classification of amphibia, i. 101 of classification of lemurs, ii. 176

Mixornis, ii. 261

Mniotilta, ii. 279

MNIOTLILTDE, ii. 278

Mochocus, ii. 443

Nocoa, ii 397

Moho, ii. 276

Mole-rat of W. Tartary, i. 218

Mole-rats, ii. 231

Moles, almost wholly Palæarctic, i. 181 ii. 190

Mollienesia, ii. 450

Mollusea, means of dispersal of, i. 30 classification of, $\mathbf{j}$. 104 groups selected for study, i. 104

MOLLUSCA, distribution of, ii. 504 range of families of, in time, ii. 538

Moluceas, zoology of, i. 417

birds of, i. 419

reptiles of, i. 420

insects of, i. 420

peculiarities of fauna of, i. $42 \mathrm{I}$

Molossus, ii. 184

Molothrus, ii. 282

Nolva, ii. 439

MOMOTIDA, ii. 313

Momotus, ii. 313

Mona halcyon, ii. 316

Minarcha, ii. 270

Munasa, ii. 311

Monitor, ii. 389

Monkeys on the higl Himalayas, i. 12 fossil in N. American Miocene, i. 133

in E. Thibet. i. 222

abundance of in the Oriental region, i. 315

Monoceros, ii. 507

Monodon, ii 208

MONODONTID压, ii. 208

Monoplocus, ii. 390

Monopterus, ii. 45

Monotremata, classification of, i. 91

list of Australian genera of, i. 477

MONOTREMATA, ii. 253

remarks on the distribution of, ii. 254

Monotrophis, ii. 289

Montacuta, ii. 535
Nonticola, ii. 256

Montifringilla, ii. 284

Mörch, Dr., on Panama shells, ii. 20

Morelia, ii, 38I

"More-pork" of Australia, figure of, i. 442

Morethria, ii. 395

Mormolyce, ii. 490

IIORMYRID压, ii. 448

Mormyrops, ii. 448

Mormyrus, ii. 488

Morococcyx, ii. 309

Morotherium, N. American Pliocene, i. 140

MORPHID $\nRightarrow$, ii. 472

Morphnus, ii. 348

Morpho, ii. 472

Morunga, ii. 204

Moschus, ii. 219

Motacilla, European Miocene, i. I61 ii. 290

MOTACILLID曆, ii. 290

Motella, ii. 439

Moths, ii. 481

Motmots, ii. 313

Monnd-builders, peculiar Australian birds, i. 393

Moupin, position and zoology of, i. 22I

Mouse-deer, ii. 218

Moxostoma, ii. 451

Mugil, ii. 435

IUGILLID艮, ii, 435

Mulleria, ii. 534

Mulleripicus, ii. 303

MULLID $\&$, ii. 426

Mullus, ii. 426

MIungos, ii. 195

Munia, ii. 287

MURÆNIDÆ, ii. 456

IIurcenopsis, ii. 412

Murex, ii. 507

MURICIDÆ, ji. 507

MIurida, S. American Pliocene, i. 147

MURIDA, ii. 229

Murray, Mr. Andrew, on zoological region. i. 60

MIus, ii. 229

Muscardinus, ii. 232

Muscicapa, ii. 270

MUSCICAPID $\approx$, ii. 270

Muscicapula, ii. 270

Muscigralla, ii. 101

Muscipipra, ii. 101

Muscisaxicola, ii. 101, 291

Muscitodus, ii. 271

Nuscivore, ii. $10 \mathrm{I}$

II usophaga, ii. 307

MUSOPHÁGIDÆ, ii. 307

Mussels, ii. 533

Mustela, Miocene of Greece, i. 115

European Miocene, i. I18

S. American Pliocene, i. 146

ii. 198

Mustclida, in Brazilian caves, i. 144

MUSTELID A, ii. 198

Mustelus, ii. 460

IIYACIDA, ii. 536

IIyadora, ii. 536

Iycalesis, ii. $47 \mathrm{l}$

MIycerobas, ii. 284

$M$ ycetes, ii. 175 ii. 178

Mycetopus, ii 534

MI yd cus, ii. 199

Myiadestes, ii. 260

Miyiagra, ii. 271

Myialestes, ii. 271

Myiarchus, ii. 102, 291 
Myiobius, ii. 101

Myioceyx, ii. 316

Myioch nes, ii. 102

Myiodioctes, ii. 279

Myiodynastes, ii 101

Myiophonus, ii. 263

M yiopithecus, ii. 173

Myiotheretes, ii. 100

Myiozetetes, ii. 101

II ylesinus, ii. 445

Myletes, ii. 445

MYLIOBATIDA, ii. 463

Myliobatis, ii. 463

Mylodon, N. American Post-Pliocene, i. 130 S. American Pliocene, i. 147

Mylopharadon, ii. 452

Mynes, ii. 474

Myochama, ii. 536

Myodes, ii. 250

Myogale, European Miocene, i. 118 ii. 190,191

Myoictis, ii. 249

Myomorphus, fossil in Cuba, i. 148

IIyopotamus, in Brazilian caves, i. 145 ii. 239

Mryospalax, ii. 230

IYOX1DÆ, ii. 232

Myoxus, European Miocene, i. 120

European Eocene, i. 126 ii. 232

Myxomys, ii. 230

Myrina, ii. 477

Myrmeciza, ii. 104

MYRMECOBIID $\approx$, ii. 250

Myrmecobius, ii. 250

Afyrmecophaga, ii. 247

MYRMECOPHAGID\&, ii. 247

Myrmotherula, ii. 104

Myron, ii. 376

Myrtis, ii. 108

Mysarachne, European Miocene, i. 118

IIysops, N. American Eocene, i. 140

$$
\text { ii. } 231
$$

Mystacina tuberculata, ii. 184

MY ystacoleucus, ii. 452

Mystacornis, ii. 258

Mystromys, ii. 230

MYTILID A, ii. 533

Mytilus, ii. 539

MYXINIDÆ, ii. 464

Myxophagus, N. Ameriean Post-Plincene, i. 130

Myxophyes, ii. 420

Myxus, ii. 435

Myzomela, ii. 275

Myzornis, ii. 266

N.

Nenia, ii. 365

Naja, ii. 383

NANDID A, ii. 433

Nandinia, ii. 195

Nandus, ii. 433

Nanina, ii. 513

Nannophryile, ii. 417

Nannophrys, ii. 421

Nanodes, ii. 327

Nanohyus, N. American Tertiary, i. 137

$$
\text { ii. } 215
$$

Nanotragus, ii. 224

Napeogenes, ii. 470

Napothera, ii. 261

Nardoa, ii. 381

Narwhal, ii. 208

Narope, ii. 472
Nasica, ii. 103

Nasiterna, ii. 325

Nasıa, in Brazilian caves, i. 144

$$
\text { ii. } 200
$$

Nathalis, ii. 478

Natica, ii. 539

NATICIDÆ, ii. 508

Nautilus, ii. 539

NATRICINA, ii. 375

Nattereria, ii. 417

Nauclerus, ii. 349

Naucrates, ii. 429

Naultinus ii. 400

NAUTTLID E, ii. 506

Navicella, ii. 510

Nearctic region, defined, i. 79 subdivisions of, i. 80

distinet from Palæaretic, i. 79

ii. 114

zoological eharacteristies of, ii. 115

mammalia of, ii. 115

birds of, ii. 116

reptiles of, ii. 119

amphibia of, ii. 120

fresh-water fishes of, ii. 120

summary of vertebrata of, ii. 120

insects of, ii. 122

land and fresh-water shells of, ii. 124

sub-regions of, ii. 125

conclnding remarks on, ii. 138

tables of distribution of animals of, ii. 139

Nearctic and Neotropical regions, no decided boundary ketween, ii. 117

Nebria, ii. 489

Necrornis, European Miocene, i. 161

NECTARINIIDA, ii. 276

Nectarinia, ii. 276

Nectarophila, ii. 276

Nectogale, ii. 190

Necydalis, ii. 502

Necyria, ii. 476

Nelicurvius, ii. 286

Nemachilus, ii. 453

Nematogenys, ii. 444

NEMEOBIID $\&$, ii. 475

Nemeobius, ii. 475

NENIORHEDIN $\approx$, ii. 224

Nemorhedus, ii. 22.

Nemoricola, ii. 290

Nemosia, ii. 99

Neobatrachus, ii. 420

Neochloe, ii. 280

Neocorys, ii. 290

Neoctantes, ii 104

Neomeris, ii. 209

Neomorphus, ii. 309

Neophasia, ii. 478

Neophron, ii. 346

Neopipo, ii. 102

Neopus, ii. 348

Neorhynchus, ii. 285

Neosorex, ii. 191

Neotoma, ii. 230

Neotomys, ii. 230

Neotragns, ii. 224

Neotropical region, defined, i. 78

subdivisions of, i. 78

relations of $W$. African sub-region with, i. 265

description of, ii. 1

zoological features of, ij, 5

birds of, ii. 6,7

distinctive features of mammalia of, ii. 6

reptiles of ii. 9

amphibia of, ii. 11 
Neotropical region, fresh-water fishes of, ii. 12 summary of vertebrates of, ii. 13

insects of, ii. 13

land-shells of, ii. 19

marine shells of, ii. 20

summary of past history of, ii. 80

tables of distribution of animals of, ii. 84

Neotropical sub-regions, ii. 21

Neoziphius, ii. 208

Nephrecetes, ii. 320

Neptis, ii. 474

NERI IIDE, ii. 510

Neritina, ii. 510

Nerophis, ii. 457

Nesoceleus, ii. 303

Nesocichla, ii. 256

Nesodon, S. American Pliocene, 1. 147

Nesomys, ii. 230

Nesonetta, ii. 364

Nesopsar, ii. 282

Nessia, ii. 399

Nestor, ii. 329

NESTORID E, ii. 329

Nettapus, ii. 363

Neusterophis, ii. 376

Newberry, Dr., on Cretaceous and Tertiary fluras of N. America, ii. 155

Newton, Professor, on position of Menuridoe and Atrichidice, i. 95

ou birds of Iceland, i. 198

on Neotropical sub-regions, ii. 25

on genus Camptolcemus, ii. 39

on peculiar genera of Nearctic and Neo-

tropical birds, ii. 118

on family Panuride, ii. 262

Newtonia, ii. 270

Newts, ii. 413

New Caledonia, birds of, i. 444

New Guinea, zoology of, i. 409

mammalia of, i. 410

birds of, $i .411$

peculiarities of its ornithology, i. 413

illustration of ornithology of, i. 414

reptiles and amphibia of, i. 415 insects of, i. 416

New Zealand, objections to unaking a primary zoological region, i. 62

extinct birds of, i. 164

sub region, description of, i. 449

compared with British Isles, i. 449

maminalia of, i. 4.51

islets of, i. 453

illustration of ornithology of, i. 455

reptiles of, i. 456

amphibia of, i. 457

fresh-water fish of, i. 457

insects of, i. 458

Isongicorns of, i. 458

Myriapoda of, i. 458

land-shells of, i. 459

ancient fauma of, i. 460

origin of fauna of, i. 460

poverty of insects in, i. 462

relations of insect-fauna and flora of, i. 472

Nicator, ii. 272

Nicobar Islands, their zoological relations, i. 332

Nightingale, migration of the, i. 21

Niøht-jars, ii. 319

Nigidius, ii. 498

Niarita, ii. 285

Nilaus, ii 272

Niltava. ii. 270

Ninox, ii. 350

Niscëtus, ii. 348

Nisoides, ii. 348
Nisoniades, ii. 480

NOCTILIONIDE, ii. 184

Nocturnal tree-snakes, ii. 379

Nonnula, ii. 311

Norbea, ii. 397

Norfolk Island, birds of, i. 453

North Africa, zoological relations of, i. 202

North America, remarks on Post-Fliocene, fauna of, $i$. 130

Post-Pliocene fauna of, partly derived from S. America, i. 131

extinct birds of, $i, 163$

Northern Hernisphere, zoological importance of, ii. $\mathbf{1 5 5}$

NOTACANTHI, ii. 437

Notaden, ii. 415

Notharctos, N. American Tertiary, 1. 133

Nothocerus, ii. 344

Nothocrax, ii. 343

Nothoprocta, ii. 344

Nothura, ii. 344

NOTIDANIDÆ, ii. 461

Notiophilus, ii. 489

Notodela, ii. 259

Notoglanis, ii. 443

Notonomus, ii. 490

NOTOPTERID $Æ$, ii. 455

Notopholis, ii. 391

Notornis of New Zealand, 1. 455

Notornis, ii. 352

Nototherium, Australian Post-Tertiary, 1. 157 ii. 251

Nototrema, ii. 418

Noturus, ii. 442

Nucifraga, ii. 273

NUCLE()-BRANCHIATA, ii 531

Nucras, ii. 391

Numenius, ii. 353

NUMIDIN F, ii. 340

Numida, ii. 340

Nuria, ii. 452

Nuthatches, ii. 265

Nutria, ii. 199

Nyctala, ii. 350

Nyctalatinus, ii. 350

Nyctalemon, ii. 482

Nyctalops, ii. 350

Nyctea, ii. 350

Nyctereutes, ii. 197

Nycteris, ii. 182

Nyctibius, ii. 319

Nycticorax, ii. 359

Nyctidromius, ii. 320

Nyctiornis, ii. 312

Nyctipithecus, ii. 175

Nyctiprogne, ii. 320

Nymphalis, ii. 474

NYMPHALID 2 , ii. 473

Nymphicus, ii. 325

Nymphidium, ii. 476

o.

Ochetobius, ii. 452

Ochotherium, in Brazilian caves, i. 145 ii. 245

Ochthaca, ii. 100

Ochthodiceta, ii. 100

Octodontidce, S. American Pliocene, i. 147

OCTODONTID $\&$, ii. 237

Octodon, ii. 238

OCTOPODIDE, ii. 505

Ocyalus, ii. 2S2

Ocydromess, ii. 352

Ocyphaps, ii. 333 
Oäontochila, ii. $4 \subseteq 6$

Odontolabris, ii. 493

Odontophorus, ii. 339

Odontophrynus, ii. 420

Edemit, ii. 364

Edicnemis, ii. 355

Oëdura, ii. 399

Enu, ii. 332

Ogmodon, ii. 383

Ogyris, ii. 477

oligdon, ii. 375

OLIGODONTID $Æ$, i1. 374

Oligosareus, ii. 445

Olisthopus, ii. 489

Olylogon, ii. 418

Olyra, ii. 442

Omaseus, ii. 489

Ommatophoca, ii. 204

Omolepida, ii. 397

Omostenus, ii. 492

Omphalotropis, ii. 521

Omus, ii. 487

ONCIDIAD E, ii. 517

Oncidium, ii. 518

Onychodactylus, ii. 413

Onychogale, ii. 195

Onychogalea, ii. 251

Onychognathus, ii. 288

Onchorhynchus, ii. 447

Oncostoin $\alpha$, ii. 101

Ophidia, classification of, i. 99

OPHIDIA, ii. 372

remarks on the general distribution of, ii. 386

fossil, ii. 387

OPHIDIIDÆ, ii. 440

Ophidium, ii 440

OPHIOCEPHALID E, ii 435

Ophiodes, ii. 397

OPHIOMORID $\mathrm{A}$, ii. 398

Ophiomorus, ii. 398

Ophiophagus, ii. 383

Ophiops, ii 391

Ophioscincus, ii. 397

Ophisaurus, ii. 392

Ophites, ii. 380

Ophonus, ji. 489

Ophryodera, ii. 487

Ophysia, ii. 209

OPISTHO-BRANCHIATA, ii. 529

OPISTHOCOHI, ii. $34 \bar{j}$

Opisthocomus, Brazilian caves, 1. I64 ii. 345

Opisthndelphys, ii. 418

Opisthostoma, ii. 520

Opisthoporus, ii. 520

Oporornis, ii. 279

Opossum, extinct in European Miocene, 1. 121

Opossums, ii. 248

Opsariichthys, ii. 452

Opsiphanes, ii. 472

Orang-utan, ii. 171

Orca, ii. 209

Orcaclla, ii. 209

Orchesticus, ii. 99

Orchilus, ii. 10

Orens, ii. $2: 3$

Orcicola, ii. 260

Orcinus, ii. 452

Oreoccphalus, ii. 401

Oreocincla, ii. 256

Oreodeira, ii. 401

Orcodon, N. American Tertiary, i. I38

Oreodontida, N. American Tertiary, 1. 138

Oreaca, ii. 271

Oreomanes, ii. 278
Oreonectes, ii. 453

Oreonympha, ii. 108

Orcoperdix, ii. 338

OREOPHASINÆ, ii. 343

Oreophasis, ii. 343

Oreophilus, if. 356

Orcopyra, ii. 107

Oreortyx, ii. 339

Oreoscoptes, ii. 256

Oreothraupis, ii. 99

Oreotrochllus, ii. 107

Orestias, ii. 450

Oriental region, defined, i. 75

subdivisions of, i. 75

description of, i. 314

zoologieal features of, i. 315

mammalia of', i. 315

birds of, i. 316

reptiles of, i. 317

amphibia of, i. 317

fresh-water fishes of, i, 318

summary of rerteb.ata of, i. 318

insects of, i. 318

sub-regions of, i. 321

concluding remarks on, i. 362

tables of distribution of animals of, i. 364

Oriental relations of W. African sub-region, $i$. 265

Oriental and Palæarctic faunas once ilentical, i. 362

Oriental and Ethiopian faunas, cause of their resemblances, i. 363

Origma, ii. 260

oriocalotes, ii. 402

Orioles, ii. 268

ORIULIDE, ii. 268

Oriolus, ii. $26 \mathrm{~S}$

Orites, ii. 266

Ornithion, ii. 101

ORNITHORHYNCHIDE, ii. 259

Ornithorhynchus, ii. 253

Oroccetes, ii. 256

Orohippus, N. Anerican Tertiary, i I30

Ortalide $u$ ii. 343

Orthagoriscus, ii. 457

Orthalicus, ii. 516

ORTHIDA, ii. 532

ORTHOCERATID压 ii $500^{\circ}$

Orthodon, ii 452

Orthogonius, ii. 491

Orthogonys, ii. 98

Orthonyx, ii. 260

Orthorhynchus, ii. 108

Orthotomus, ii. 257

Ortygometra, ii. 352

Ortugornis, ii. 338

Ort $y x$, ii. 339

Ortuxelos, ii. 341

ORYCTEROPODIDA，ii. 246

Orycteropus, ii. 246

Orycterus, ii. 231

ORYGINE, ii. 223

Oryx, ii. $2 \approx 3$

Oryzoborus, ii. 285

Oryzorictes, ii. $1 \mathrm{~s}$

Osmerus, ii. 447

Osphranter, ii. 251

Osteobraina, ii. 45 :

Osteochilus, ii $45 \mathrm{I}$

Osteogeniosus, ii. 443

OSTEOGLOSSID \&, ii. 454

Ostcoglossum, ii. 454

Ostinops, ii. 282

OSTREIDA, ii. 533

Ostrich, Miocene of N. India, 1. I62

Ostriches, ii. 368 
Otaria, European Miocene, i. $11 \mathrm{~s}$ ii. 202

OTARIIDE, ii. 202

OTIDIDA, ii. 356

Otidiphaps, ii. 33:

Otilophus, if. 415,428

Otis, ii. 356

Otocorys, ii. 289

Otocryptis, ii. 402

Otogyps, ii. 346

Otomys, ii 230

Otopoma, ii. 521

Ovibos, N. American Post-Plincene, i. 130 ii. 224,225

Owl-parrot, ii. 329

Owls, ii. 350

Oxen, birth-place and migrations of, i. 155

Palæarctic, i. 182 ii. 221

OXUDERCID $\approx$, ii. 431

Oxycena, N. American Tertiary, i. 134

Oxydores, ii. 443

Oxyglossus, ii. 421

Oxygomphus, European Miocene, i. 118 ii. 186

Oxylabes, ii. 262

Oxymycterus, in Brazilian eaves, i. 145

S. American Pliocene, i. 147

ii. 230,231

Oxynotus, ii. 269

Oxypogon, ii. 108

OXYRHAMPHIDE, ii. 292

Oxyrhamphus, ii. 292

Oxyrhopus, ii. 379

Oxyurus, ii. 103

Oysters, ii. 533

P.

Pachyb trachus, ii. 416

Pachycephala, ii. 271

PACHYCEPHALIDE, ii. 271

Pachydactylus, ii. 400

Pachycena, N. American Tertiary, i. 134

Pachygloss $x$, ii. 277

Pachynolophus, European Eocene, i. 126

Pachyrhamphus, ii. $10^{-3}$

Pachyrhynchus, ii. 391

Pachyteles, ii. 490,492

Pachytherium, in Brazilian caves, i. 14.5 ii. 246

Pachyuru, ii. 191

Pceocephalus, ii. 328

Precilus, ji. 489

Pagellus, ii. 427

Pagomys, ii. 204

Pagophila, ii. 364

Pagophilus, ii. 204

Paguma, ii. 195

PAICTIDÆ, ii. 298

Palæarctic region, ancient limits of, ii. 157 defined, i. 171

subdivisions of, i. 7

general features of. i. 180

zoological charcteristies of, i. 181

has few peculiar families, $i .181$

mammalia of, i. 181

birds of, i. 182

high degree of speciality of, i. 184

reptiles and amphibia of, $i$. 186

fresh-water fish of d. 186

summary of vertebrata of, i. 180

insects of, i. 186

coleoptera of, i. 187

number of coleoptera of, i. 189
Palæarctic region, land-shells of, i. 190 sub-regions of, i. 190

general conclusions on the fauna of, i. 231

tables of distribution of animals of, $i .233$

Paleacodon, N. American Tertiary, i. 133

Palactus, European Miocene, i. 162

Palorgithalus, European Eocene, i. 162

Paloelodus, European Miocene, i. 16:

Palcocastor, N. American Tertiary, i. 140 ii. 234

Palcocercus, European Miocene, i. 162

Palococharus, European Miocene, i. 119 ii. 215

Palceocyon, ii. 198

Palcohierax, European Miocene, i. 16:

Palocolagus, N. Amierican Tertiary, i. 140

Palcoolama, S. Anerican Pliocene, i. 147 ii. 217

Palcomephitis, European Miocene, i. 118 ii. 200

Palcomeryx, European Miocene, i. 120 ii. 220

Palcomys, European Miocene, i. 121

ii. 238

Palceontina oolitica, Oolitic insect, i. 167

Palæontology, i. 107

how best studied in its bearing on geographical distribution, i. 168

as an introduction $t o$ the study of geographical distribution, concluding remarks on, i. 169

Palconyctis, European Eocene, i 125

Palceoperlix, European Niocene, i. $16 \mathrm{I}$

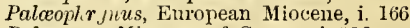

Palceoreas, Miocene of Greece, i. 116

Palceornis, ii. 326

PALAORNITHIDÆ, ii. 326

Palceonyctis, ii. 196, 206

Palceortyx, European Miocene, i. 161

Palcoryx, Niocent of Greece, i. 116

Palcoospalax, i. 111

European Miocene, i. 117

ii. 190

Palcosyops, N. American Tertiary, i. 136

Palceothericle, European Eocene, i. 125

Palceotherium, Enropean Eocene, i. 125 S. American Evcene. i 148

Palceotragus, Miocene of Greece, i. 116

Palcotringa, N. American Cretaceous, i. 164

Pulamedea, ii. 361

PALAMEDEID $\&$, ii. 361

Palapterygidae of New Zealand, i. 164

PALAPTERYGID 2 , ii. 370

Palapteryx, ii. 370

Palestine, birds of, i. 203

Pallasia, ii. 289

Paloplotherium, European Miocene, i. 119

European Eocene, i. 125

Paludicola, ii. 416

Paludina, Eocene, i. 169

European Secondary, i. 169

ii. 510

PALUDINID $\approx$, ii. 510

Pampas, Pliocene deposits of, i. 146

Pamphila, ii. 480

Punda, of Nepaul and E. Thibet, i. 222

Himalayan, figure of, i. 331

ii. 201

Pandion, ii. 349

PANDIONIDÆ, ii. 349

Pangasius, ii. 442

Pangolin, ii. 245

Panolax, N. American Tertiary, i. 140

Panopaca, ii. 536

Panoplites, ii. 107

Panterpe, ii. 109 
Panthalops, ii. 223

PANURIDA, ii. 262

Panurus, ii. 262

Panychlora, ii. 109

Panyptila, ii. 320

Paper-Nautilus, ii. 505

Paphia, ii. 474

Papilio, ii. 479

PAPILTON1D灰, ii. 479

Papuan Islands, zoology of, i. 409

Paracanthobrama, ii. $45 \%$

Paradigalla, ii. 275

Paradiploniystax, ii. 443

Paradisea, ii. 274

Paradise-bird, twelve-wired, figure of, $i$. 414

Paradise-birds, ii. 274

PARADISEID $\approx$, ii. $2 \pi 4$

PARADISEIN $Æ$, ii. 274

Paradoxornis, ii. 262

Paradoxurus, ii. 195

Parahippus, N. American Tertiary, i. 136

Paralabraz, ii. 425

Paramys, N. American Eocene, i. 140 ii. 236

Parandra, ii. 501

Paraphoxinus, ii. 452

Pardalotus, ii. 277

Pareas, ii. 380

Parodon, ii. 445

Pareudiastes, ii. 352

PARIDA, ii. 265

Pariodon, ii. 444

Parisoma, ii 266

Parmacella, ii. 517

Parmarion, ii. 517

Parmophorus, ii. 511

Parnassius, ii. 479

Paroaria, ii. 284

Parotia, ii. 274

Parra, ii. 355

PARRID $\approx$, ii. 354

Parroquet, Papuan, figure of i. 415

Parrots, classification of, i. 96 ii. 324,329

Partridges, ii. 338

Partula, ii. 515

Parula, ii. 279

Pamis, ii. 265

Pasimachus, ii. 490

Passerculus, ii. 284

Passerella, ii. 28

Passeres, arrangement of, i. 94 range of Palæarctic gencra of, i. 24 range of Ethiopian genera of, i. 306 range of Oriental genera of, i. 375 range of Australian genera of, i. 478

PASSERES, ii. 255 general remarks on the distribution of, if. 299

Passerita, ii. 379

Pastor, ii. 287

Patagona, ii. 108

Patella, ii. 539

PATELLIDÆ, ii. 511

Patriofelis, N. American Tertiary, i. 134

Patrobus, ii. 4 S9

Pauxi, ii. 343

Pavo, ii. 340

PAVONIN E, ii. 340

Paxillus, ii. 520

Pearl-oysters, ii. 533

Pease, Mr. Harper, on Polynesian region of Land-shells, ii. 528

Peccaries, ii. 215

Pectinator, ii. 238

VOL, II.
Peculiar groups, geographically, how defined, ii. 184

Pedetes, ii. 232

PEDICULATI, ii, 431

Pedioccetes, ii. 339

Pedionomus, ii. 356

PEGASID A, ii. 456

Pelagius, ii. 204

Pelagornis, European Miocene, i. 162

Pelamis, ii. 384

Pclargopsis, ii. 316

Pelea, ii. 224

PELECANID $Æ$, ii. 365

Pelecanoides, ii. 365

Pelecanus, ii. 365

Pelecium, ii. 490

Pelecus, ii. 453

Pelicans, ii. 365

Peliperdix, ii. 338

Pellorneum, ii. 261

Pelobates, ii: 417

PELODRYAD

Pelodryas, ii. 418

Pelodytes, ii. 421

Pelomedusa, ii. 409

Pelomys, ii. 230

Pelonax, N. American Tertiary, i. 138

Peloperdix, ii. 338

Pelotrophus, ii. 453

Peltaphryne, ii. 415

Peltocephalus, ii. 408

Peltopelor, ii 385

Peltops, ii. 270

Penelope, ii. 34 ?

Penelopides, ii. : 17

Penelopina, ii. 34

PENELOPIN $F$, i. 343

Penetes, ii. 472

Penguins, ii. 366

Pentadactylus, ii. 399

Pentila, ii. 477

Peragalea, ii. 250

Perameles, ii. 250

PERAMELID 2 , ii. 2:0

Peratherium, European Miocene, i. 121 European Eocene, i. 126 ii. 249

Perca, ii. 425

Percarina, i. 425

Perchorus, N. American Tertiary, 1. 137 ii. 215

Percilia, ii 425

Percichthys, ii. 425

PERCID $A$, ii. 425

Percnostola, ii. 104

PERCOPSID AE, ii. 448

Percus, ii. 489

Perdix, 338

Pericallus, ii. 490

Pericrocotus, ii. 268

Peridexia, ii. 487

Perim Island, extinct mammalia of, i. 122 probable southern limit of old Palæarctic land, i. 362 character of fossils of, ii. 157

Periopthalmus, ii. 430

Perisoreus, ii. 273

Perissodactyla, N. American Tertiary, i. 135

Perissoglossa, ii. 279

Peristera, ii. 333

Peristethus, ii. 428

Periwinkle, ii. 510

Pernis, ii. 349

Perodicticus, ii. 176

Perognathus, ii. 235

Peropus, ii. 399 
Persia, hirds of, i. 201

Petasopltora, ii. 108

Petaurista, ii. 252

Peteria, ii. 438

Petrochelidon, ii. 281

Petrodromus, ii. 186

Petrels, ii. 365

Petroca, ii. 260

Petrogale, ii. 251

Petromys, ii. 23?

Petrophussa, ii. 333

Petrorhynchus, ii. 208

Petroscirtes, ii. 431

Peucrea, ii. 28t

Pezophaps, ii. 334

Pezoportus, ii. 325

Pfeifferia, ii. 516

Phacellodomus, ii. 10:

Phacochcerus, ii. 215

Phonicophaës, ii. 309

Phonicophilus, ii. 99

Phonicothraupis, ii. 98

Phrenopepla, ii. 280

Phreochroa, ii. 107

Phoeolema, ii. 107

Phoeoptile, ii. 109

Phaethorn is, ii. 107

Phrieton, ii. 365

Phulacrocorax, ii. 365

Phalangers, ii. 251

Phalangista, ii. 252

Phalangistidæ, ii. 251

Phalaropus, ii. 353

Phapitreron, ii. 333

Phaps, ii. 333

Pharomacrus, ii. 314

Phascogale, ii. 249

Phascolarctos, ii. 252

PHASCOLOMYIDÆ, ii. 252

Phascolomys, Australian Post-Tertiary, i. 157

PH ISI $A N I D E$, ii. 339

PHASIANINE, ii. 340

Phasianus, Miocene of Greece, i. 116

European Post-Pliocene, i. 161 ii. 340

Phasidus, ii. 340

Phatagin ii. 245

Pheasants, in European Miocene, i. 161 golden, of N. China, i. 226

eared, of Mongolia, i. 226 ii. 339

Pheclina, ii. 281

Phelsuma, ii. 400

Phenacodus, N. American Tertiary, i. 138

Pheropsophus, ii. 489

Pherceticus, ii. 285

Phibalura, ii. 102

Philagetes, ii. 502

Philemon, ii. 276

Philentoma, ii. 271

Philepitta, ii. 298

Philetcerus, ii. 286

Philodryas, ii. 376

Philippine IsIands, mammals of, i. 345 birds of, i. 346 origin of peculiar faun 3 of, i. 448

Philohela, ii. 353

Phi'omycus, ii. 517

Philydor, ii. 103

PHILYDORINE, ii. 295

Phloomys, ii. 230

Phlaocryptes, ii. 103

Phlngoenas, ii. 333

Phlogophilus, ii. 108

Phlogopsis, ii. 10

Phlogothraupis, ii. 98, 283
Phoca, ii. 201

Phocena, ii. 209

Phocisle, N. Amerioan Tertiary, i. 140

PHOCIDE, ii. 203

Phodilus, ii 350

Phcenicoccreus, ii. 102, 293

Phon icophceës, ii. 309

PHCENICOP'TERIDE, ii. 361

Phonicopterus, ii. 361

PHOLADIDE, ii. 537

Pholadomya, ii. 536

Pholeoptynx, ii. 350

Pholidotus, ii. 245

Pholidotus, ii. 493

Phonipara, ii. 284

Ploris, ii. 510

Phos, ii. 507

Phractocephalus, ii. 442

Phrygilus, ii. 284

PHRYNISCIDÆ, ii. 414

Phryniscus, ii. 414

Phrynobatrachus, ii 421

Phrynocephalus, ii. 402

Phrynoglossus, ii. 421

Phrynorhombus, ii 441

Phrynosoma, ii. 401

Phycis, ii. 439

Phyllastrephus, ii. 267

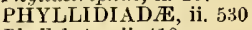

Phyllobates, ii. 419

Phyllodactylus, ii. 399

Phyllomedusa, ii. 418

Phyllomyzas, ii. 101

Phyllomys, in Brazilian caves, i. 145 ii. 239

Phyllornis, ii. 267

PHYLLORNITHIDÆ, ii. 267

Phylloscartes, ii. 101

PHYLLONCOPIN Æ, ii. 257

Phylloscopus, ii. 258

Phyllostomide, in Brazilian caves, i. 144

PHYLLOSTOMID $Æ$, ii. 181

Phyllurus, ii. 400

PHYLLYRHOIDÆ, ii. 530

Phymaturus, ii. 401

Physa, ii. 518

Physalus, ii. 207

Physeter, European Pliocene, i. 112 ii. 208

Physical changes affecting distribntion, i. 7

Physignathus, ii. 402

PHYSOSTOMI, ii. 441

Phytala, ii. 477

Phytotoma, ii. 294

PHYTOTOMIDÆ, ii. 294

Phyton, ii. 502

Piabuca, ii. 445

Piabucina, ii. 445

Piaya, ii. 309

Pica, ii. 273

Picariæ, arrangement of, i. 95 range of Palæarctic genera of, i. 247 range of Ethiopian genera of, i. 309 range of OrientaI genera of, i. 381 range of Australian genera of, i. 482

PICARI $Æ$, ii. 302 general remarks on the distribution of, ii 322

Picathartes, ii. 274

Picicorvus, ii. 273

PICID $\approx$, ii. 302

Picoides, ii. 303

Picolaptes, ii. 103

Picumnus, ii. 303

Picus, Enropean Miocene, i. 161 ii. 303 
PIERIDA, ii. 478

Pieris, ii. 478

Yiezia, ii. 491

Pigeons, classification of, i. 96 remarkable development of, in the Australian region, i. 395

crested, of Australia, figure of, i. 441 ii. 331

abundant in islands, ii. 335

Pigs, power of swimming, i. 13

Pikas, ii. 242

l'ike, ii. 449

Pikermi, liocene fauna of, i 115

Pilchard, ii. 454

Pileoma, ii. 425

Pimelodus, ii. 443

Pinephales, it. 452

Pinacodera, ii. 490

Pinicola, ii. 285

Pinulia, ii. 191

Pionus, ii. 328

Pipa, ii. 422

PIPID $\mathrm{E}$, ii. 421

ripile, i. 343

Yipilo, ii. $2 \mathrm{~S} 4$

l'iping crows, ii. 278

Pipra, ii. 102, 292

Pipreola, ii. 102

PIPRID $Æ$, ii. 103

Pipridea, ii. 95

Piprisoma, ii. 277

Piprites, ii. 102, 292

Pirumutana, ii. 442

Piratinga, ii. 443

Pirinampus, ii. 443

Pitangus, ii. 101

Pithecia, ii. 175

Pithecopsis, ii. 420

Pithys, ii. 104

Pitta, ii. 298

Pittas, ii. 297

Pittasoria, ii. 104

Pittidæe, abundant in Borneo, i. 355

PITTID无, ii. 297

Pituophis, ii. 375

Pit-vipers, ii. 38

Pitylus, ii. 99

Pityriasis, ii. 273

Plagiodontia, ii. 238

Plagiolophus, European Eocene, i. 126

Plagiotelium, ii. 492

PLAGIOSTONATA, ii. 460

Planetes, ii. 490

Planorbis, Europeau Secondary, i. 169

Eocene, i. 169 ii. 518

Plantain-eaters, ii. 307

Plant-cutters, ii. 294

Plants, distribution of, probably the same fundamentally as that of animals, ii. 162

Plataranthomys, ii. 230

Platulea, ii. 360

PLATALEID $\approx$, ii, 360

Platanista, ii. 209

Platemys, ii. 408

Plalurus, ii. 384

Platycercida, gorgeously-coloured Australian parrots, i. 394

PLATYCERCID

Platycercus, ii. 325

Platychile, ii. 487

Platıgonus, N. American Post-Pliocene, i. 130 ii. 215

Platylophus, ii. 273

Platymantis, ii. 419
Platynematichthys, ii. 449

Platynus, ii. 489

Platypocilus, ii. 450

PLATYRHY NCHIN玉, i.. 291

Platyrhynchus, ii. 101

Platysaurus, ii. 392

Platysoma, ii. 489

Platystira, i i. 271

Platystoma, ii. 442

Platystomatichthys, ii. 442

Plecoglessus, ii. 447

Plecostcmus, ii. 444

Plecotus, ii. 183

PLECTOGNATHI, ii. 45 -

PLECTIOMANTID瓜, ii. 417

Plectromantis, ii. 417

Plectrophanes, ii. 286

Plectropterus, ii. 363

Plectrotrema, ii. 519

Plecturus, ii. 374

Plesiarctomys, European Eocene, i. 126 ii. 236

Plesiomeryx, European Eocene, i. 126

Plesiosorex, European Aliocene, i. 118

Plestiodon, ii. 397

Plethodon, ii. 413

PLEUROBRANCHIDÆ, ii. 530

Pleurodeles, ii. 413

Plcurodema, ii. $4-0$

Pleuronectes, ii. 441

PLEURONECT1D $\cong$, ii. 440

Pleurostrichus, ii. 392

Pleurotoma, ii. 508

Pleurotomaria, ii. 539

Pliocene period, old World, mammalia of, i. 112

Pliocene and Post-Pliocene faunas of Europe, general contiusions from, i. 113

of N. America, i. 132

of $\mathrm{S}$. America, i. 140

of Australia, i. 157

Pliohippus, N. American Tertiary, i. 135

Pliolophus, European Eocene, i. 126 ii 216

Pliopithecus, European Miocene, i. 117 ii. $17 \mathrm{~S}$

PLOCEID $Æ$, ii. 286

Plocepasser, ii. 286

Ploceus, ii. 286

Plotosus, ii. 441

Plotus. ii. 365

Plovers, ij. 355

Pluvianellus, ii. 356

Pluvianus, ii. 355

PLYCTOLOPHIDA, ii. 324

Pnoepyga, ii. 263

Podabrus, ii. 249

Podager, ii. 320

PODARGID王, 1i. 318

Podargus, ii. 318

Podica, ii. 352

Podiceps, ii. 367

PODICIPID $\$$, ii. 366

Podilymbus, ii. 367

Podocnemis, ii. 408

Pabrotherium, N. American Tertiary, i. 138 ii 217

Pacilia, ii. 450

Poecilophis, ii. 383

Pocilothraupis, ii. 98

Poephagus, ii. 222

Poephila, ii. 287

Pogonocichla, ii. 271

POGONORHY NCHIN正, ii. 306

Pogonorhynchus, ii. 306

Pogonornis, ii. 275 
Pogonostoma, ii. 487

Pogonotriceus, ii. 101

Pohlia, ii. 418

Poiana, ii. 195

Polemistria, ii 107

Polioaëtus, ii. 349

Poliococcy $x$, ii. 309

Poliohierax, ii. 349

Poliopsitta, ii. 328

Polioptila, ii. 258

Pollanisus, ii. 481

POLYBORIN E, ii. 347

Polyboroides, H1. 347

Polyborus, ii. 347

Polybothris, ii. 497

POLYCENTRIDE, ii. 434

Polycesta, ii. 479

POLYDONTIDE, ii. 459

Polyhirma, ii. 491

POLYNEMID E, ii. 429

Polyommatus, ii. 477

Polynesian sub-region, description of, 1. 442 birds of, i. 443

reptiles of, i. 447

Polypedates, ii. 419

POLYPEDATID A, ii. 419

Polypi, î. 505

Polyplectron, ii. 340

Polyprion, ii. 425

POLYPTERID $\approx$, ii. 458

Polypterus, ii. 458

Polytelis, ii. 325

Pomacanthus, ii. 427

POMACENTRID无, ii. 437

Pomacentrus, ii. 437

Pomatias, ii. 521

Pomatorhinus, ii. 261

Pomotis, ii. 425

Pompholyx, ii. 518

Pontia, ii. 478

Pontoporia, ii. 209

Poccetes, ii. 284

Poodytes, ii. 253

Poospiza, ii. 284

Porcupines, ii. 240

Poritia, ii. 477

Porphyrio, ii. 352

Porpoises, ii. 208

Portax, ii. 223

Porzana, ii. 352

Post-Pliocene, mammalia of Europe, i. 110 remains inply ehanges of physical geography in Europe, i. 111

famna of N. America, i. 129

fauna of N. America, remarks on, i. 130

Potamides, ii. 509

Potamochoerus, ii. 215

Potamodus, ii. 258

Potamogale of W. Africa, figure of, i. 264

Potamogale, ii. 189

POTAMOGALIDE, ii. 189

Potamotherium, European Miocene, i. 118 ii. 200

Potto of W. Africa, figure of, i. 264

ii. 176

Pouched Rats, ii. 233

Praotherium, N. American Post-Pliocene, i. 130

Pratincola, ii. 260

Pratincoles, ii. 355

Presbytes, ii 171

Prepona, ii. 474

Primates, classification of, i. 86 probable birthplace of, i. 153 range of Palæarctic genera of, 1. 239 range of Etliopian genera of, i. 300
Primates, range of Oriental genera of, i. 371 range of Australian genera of, i. 475

Primates, European Pliocene, i. 112

Miocene of Greece, i. 115

European Miocene, i. 117

Indian Miocene, i. 121

European Eocene, i. 124

N. American Tertiary, i. 132

of Brazilian caves, i. 144

PRIMATES, distribution of, ii. 170-180 general remarks on the distribution of, it. 179

summary and conclusion, ii. 540

Prince's Island, birds of, i. 266

Prinia, ii. 257

Prion, ii. 365

Prioneris, ii. 478

PRIONID E, ii. 498

Prionidium, Oolitic insects, i. 167

Prionirhynchus, ii. 313

Prioniturus, ii, 326

Prionochilus, ii. 277

Prionodontes, ii. 246

Prionops, ii. 272

Prionoteles, ii. 314

PRISTID无, ii. 462

Pristimantis, ii. 419

PRISTIOPHORIDÆ, ii. 462

Pristiphoca, in European Pliocene, 1. 112 ii. 204

PRISTIPOMATIDA, ii. 426

Pristiurus, ii. 461

Pristonychus, ii. 489

Proboscidea, classification of, i. 90 range of Ethiopian genus, i. 303 range of Oriental genus, i. 374

Proboscidea, European Pliocene, i. 113 Mincene of Greece, i. 116 European Miocene, i. 120

Indian Miocene, i. 122

N. American Post-Pliocene, i. 130

N. American Tertiary i. 138

of Brazilian caves, i. 144

S. American Pliocene, i. 147

PROBOSCIDEA, ii. 227

summary and conclusion, ii. 542

Procamelus, N. American Post-Pliocene, i. 130 N. American Tertiary, i. 138 ii. 217

Procapra, ii. 223

Procarduelis, ii. 283

Procellaria, ii. 365

PROCELLARIID Æ, ii. 365

Procerus, ii. 488

$$
\text { ii. } 489
$$

Prochilodus, ii. 445

Prochilus, ii. 202

Procnias, ii. 98

Procris, ii. 481

Procrustes. ii. 488

$$
\text { ii. } 489
$$

Proctotretus, ii. 401

Procyon, N. American Post-Pliocene, i. 130 ii. 200

Procyonida, in Brazilian caves, i. 144

PROCYONID $Æ$, ii. 200

PRODUCTIDÆ, ii. 532

Progne, ii. 281

Pronecoderus, ii. 490

Promephitis, Miocene of Greece, i. 115

European Miocene, i. 118 ii. 200

Promerops of East Africa, figure of, i, 261

Promerops, ii 276

Pronophilia, ii, 471

Propalceotherium, European Eocene, i. 126 
Proparus, ii. 266

Propyrrhula, ii. 285

Prorastomus, ii. 211

Proserpina, ii. 527

PROSOBRANCHIATA, ii, 507

Prosthemadera, ii. 275

PROTE1DA, ii. 412

Proteles, ii. 196

PROTELIDA, ii. 196

Protemnodon, Australian Post-Tertiary, i. 157 ii. 251

Proteus, ii. 412

Prothoe, ii. 474

Protohippus, N. American Tertiary, i. 135

Protomeryx, N. American Tertiary, i. 138 ii. 217

Protonopsis, ii. 412

Protonotaria, ii. 279

Protopithecus, in Brazilian caves, i. 144 ii. 178

Protopterus, ii. 458

Protornis, Europe:ın Eocene, i. 162

Prototomus, N. American Tertiary, i. 134

Prolotroctes, ii. 446

Psalidoprogne, ii. 281

Psaltria, ii. 266

Psaltriparus, ii. 266

Psammodromus, ii. 391

Psammodynastes, ii. 377

Psammomys, ii. 230

PSAMMOPHID在, ii. 377

Psammophis, ii. 377

Psammosaurus, ii. 389

Psarisomus, ii. 295

Psephotus, ii. 325

Pseudacris, ii. 418

Pseudcelurus, European Miocene, i. 113 ii. 194

Pseudalopex, ii. 197

Pseudecheneis, ii. 444

Pseudechis, ii. 383

Pseudeutropius, ii. 442

Pseudis, ii. 420

Pseudobagrus, ii. 442

Pseudobias, ii. 270

Pseudobufo, ii. 415

Pseudochalceus, ii. 445

Pseudochelidon, ii. 312

Pseudocolaptes, ii. 103

Pseudocordylus, ii. 392

Pseudocyon, Emropean Miocene, i. 118 ii. 198

Pseudodipsas, ii. 477

Pseudogobio, ii. 452

Pseudogryphis, ii. 346

Pseudogyps, ii. 346

Pserdohage, ii. 383

Pseudolabuca, ii. 453

Pseudoleistes, ii. 282

Pseudomorpha, ii. 490

Pseudomys, ii. 230

Pseudonaje, ii. 383

Pseudoperilampus, ii. 452

PSEUDOPHIDIA, ii. 41I

Pseudophryne, ii. 414

Pseudopontia, ii. 478

Psendopus, ii. 392

Pseudorasbora, ii. 452

Pseudorca, ii. 209

Pseudoscops, ii. 350

Pseudoxiphophorus, ii. 450

Psilopogon, ii. 306

Psiloptera, ii. 497

Psilorhamphus, ii. 104

Psilorhinus, ii. 273

Psilorhynchus, ii. 453
Psittaci, classification of, i. 96

range of Ethiopian genera of, i. 311

range of Oriental genera of, i. 383

range of Australian genera of, i. 484

PSITTACI, ii. 324

general remarks on the distribution of, 11 . 329

PSITTACID $A$, ii. 328

Psittacula, ii. 328

Psittacus, European Miocene, i. 161 ii. 328

Psittinus, ii. 326

Psittirostra, ii. 277

Psittospiza, ii. 99

Psophia, ii. 358

PSOPHIIDÆ, ii. 358

Psophodes, ii. 262

PSYCHROLUTID瓜, ii. 436

Pterocles, European Miocen $\theta$, j. 161 ii. 337

PTEROCLIDÆ, ii. 337

Pterocyclos, ii. 520

Pterodon, European Miocene, i. 125

Ptcroglossus, ii. 307

Pteromys, ii. 235

Pteromyzon, ii. 463

PTEROMYZONTID \#E, ii. 463

Pteronura, ii. 199

Pterophanes, ii. 108

Pterophyllum, ii. 439

PTEROPIDA, ii. 181

PTEROPODA, ii. 531

Pteropodocys, ii. 269

PTE ROPTOCHIDE, ii. 297

Pteroptochus, ii. 297

Pterorhinus, ii. 261

Pterosarion, ii. 452

Pterostichus, ii. 489

Pteruthius, ii. 266

Pterygophlichthys, ii. 444

Ptilocerus, ii. 186

Ptilochloris, ii. 102, 293

Ptilogonys, ii. 280

Ptilonorhynchus, ii. 275

Ptilopachus, ii. 338

Ptilopus, ii. 332

Ptilorhis, ii. 275

Ptilostomus, ii. 273

Ptilotis, ii. 275

Ptosima, ii. 497

Ptyas, ii. 375

Ptychobarbus, ii. 452

Ptyonotus, ii. 428

Pucrasia, ii. 340

Puff-birds, ii. 310

Puffins, ii. 367

Puffinus, ii. 365

PULMONIFERA, ii. 512

Fulsatrix, ii, 350

Puncturella, ii. 511

Pupa, Eocene, i. 169

Pupa vetusta, Palæozoic, 1. 169

Pupa, ii. 514

Pupina, ii. 520

Pupinella, ii. 520

Putorius, ii. 198

PYCNONOTIDÆ, ii. 267

Pycnonotus, ii. 267

Pycnophrys, ii. 270

Pyctorhis, ii. 261

Pygarrhicus, ii. 103

Pyamornis, ii. 107

Pygomeles, ii. 397

PYGOPODID $\mathrm{E}$, ii. 395

Pygoptila, ii. 104

Pygopus, ii. 395 
PYRAMIDELLIDÆ, ii. 509

Pyramezs, ii. 474

Pyranga, ii. 98

Pyrenestes, ii. 286

Pyrgisoma, ii. 284

Pyrgita, ii. 284

Pyriglena. ii. 104

Pyrocephalus, ii. 101, 291

Pyroderus, ii. 103

Pyromelana, ii. 286

Pyrophthalma, ii. 259

Pyrrhocoma, ii. 99

Pyrrhospiza, ii. 285

Pyrrhula, ii. 285

Pyrrhulauda, ii. 289

Pyrrhulina, ii. 445

Pyrrhulopsis, ii. 325

Pyrrhuloxia, ii. 285

Pyrrhura, ii. 528

Pytelia, ii. 287

Python, ii. 381

Pythonida, Enropean Miocene, i. 165

PYTHONID Æ, ii. 381

Pythonodipsas, ii. 379

Pythonopsis, ii. 376

Pythons, ii. 381

Pyxicephalus, ii. 420

Pyxis, ii. 40s

\section{Q.}

Quarirumana, fossil, ii. 178

Quail-snipes, ii. 354

Onerquedula, ii. 363

Querula, ii. 102

Quiscalus, ii. 2S:

\section{R.}

Rachis, ii. 524

Racoon-dog of N. China, i. 226

Racoons, ii. 200

Ruia, ii. 462

RAIIDÆ, ii. 462

Rails, ii. 351

RALLID E. ii. 351

Rallina, ii. 352

Rallus, ii. 352

R.ına, European Miocene, i. 166 ii. 420

Raniceps, ii. 439

RANIDE, ii. 420

Ranodon, ii. 413

Ruppia, ii 419

Rasborc, ii. $45^{\circ}$

Rasborichthys, ii. 453

Rattle-snakes, ii. 384

Rays, ii. 462

Realia, ii 521

Rectes, ii. 272

Recurvirostra, ii. 353

Regalecus, ii. 432

Region, the best term for the primary zoological divisions, i. 68

Aretic, why not adopted, i. 69

Palæarctic, defined, i. 71

Palrearctic, subdivisions of, i. 71

Ethiopian, defined, i. 73

Ethiopian, subdivisions of, i. 73

Oriental, defined, i. 75

Oriental, subdivisions of, i. 75

Australian, defined, i. 77

Australian, subdivisions of, i. 77
Resion, Neotropical, rlefined, i. 78

Neotrolical, subdivisions of, i. 78

Nearctic, defined, i. 79

Nearetic, distinet from Palixaretic, i. 79

Nearctic, subdivisions of, i. 80

Regions, zoological, i. 50

zoological, how they should be formed, i.

zoological, may be defined by negative or positive characters, i. 54

zoological, by what class of animals best deterinined, i. $56^{\circ}$

for each class of animals, not advisable, i. 58

zoolngieal, proposed since 1857 , i. 58

zoolngical, Mr. Sclater's, i. 59

zoological, discussion of those proposed

by various authors, i. 61

zoological, proportionate richness of, i. 61

temperate and tropical, well marked in northern hemisphere, i. 65 and zones, table of, i. 66

comparative richness of, i. 81

and sub-regions, table of, i. 81

order of succession of the, i. 173

Registoma, ii. 521

Reguloides, ii. 258

Regulus, ii. 258

Reinwardtcenas, ii. 333

Reinwardtipicus, ii. 303

Reithrodon, ii. 230

Representative species, i. 4

Reptiles, means of dispersal of, i. 28 classification of, i. 98

Miocene of Greece, i. 116

of Indian Miocene deposits, i. 123

extinct Tertiary, i 165

cosinopolitan groups of, i. 176

peculiar to Palæearctic region, i. 186

of Central Europe, i. 195

of the Mediterranean sub-region, i. 204

of the Siberian sub-region, i. 220

of the Manchurian sub-region, i. 227

table of Palæarctic families of', i. 236

of the Ethiopian region, i. 254

of the $E_{\text {. African sub-region, i. } 260}$

of W. Africa, i. 264

S. African, i. 268

of Madagascar, i. 279

table of Ethiopian families of, i. 297

of the Oriental region, i. 317

of the Indian sub-region, i. 326

of Ceylon, i. 327

of the Indo-Chinese sub-region, i. 331

of the Indo-Malay sub-region, i. 340

table of Oriental families of, i 368

of the Australian region, i. 396

of New Guinea, i. 415

of the Moluccas, i. 4?0

of the Polynesian sub-region, i. 447

of New Zealand, i. 456

table of Anstralian families of, i. 472

Neotropical, ii. 9

of $\mathrm{S}$. Temperate America, ii. 40

of the Mlexican sub-region, ii. 54

of the Antilles, ii. 72

table of Neotropical families of, ii. 88

of the Nearctic region, ii. 119

of Califormia, ii. 128

of Central N. America, ii. 131

of Eastern United States, ii. 133

of Canada, ii. 137

table of Nearctic families of, ii. 142

summary and conclusion, ii. 547

REPTILIA, ii. 372

Retropinna, ii. 447 
Revillagigedo Islands, zoology of, ii. 60 Rhabdornis, ii. 265

Rhabdosoma, ii. 374

RACHIODONTIDE, ii. 377

Rhacophorus, ii. 419

Rhamnophis, ii. 376

RHAMPHASTID $Æ$, ii. $3 \subset 6$

Rhamphastos, ii. 307

Rhamphichthys, ii. 455

Rhamphocanus, ii. 104

Rhamphococcyx, ii. 309

Rhumphocinclus, ii. 256

Rhamphocalus, ii. 98

Rhamphomieron, ii. 108

Rhaphaulus, ii. 520

Rhea, in Brazilian eaves, i. 164 ii. 368

Rhinaster, ii. 213

Rhinatrema, ii. 411

Rhinechis, ii. 376

Rhinelepis, ii. 444

Rhinichthys, ii. 452

RHINID\&, ii. 462

RHINOBATID $\approx$, ii. 462

Rhinoceros, Post-Pliocene, i. 112

European Pliocene, i. 113

Miocene of Greece, i. 116

Indian Miocene. 1. 122

fossil remains of, at $\mathbf{1 6 , 0 0 0}$ feet elevation in Thibet, i. 122

fossil in N. China, i. I23

N. American Tertiary, i. 136

ii. 213

Rhinoceros-hornbill, figure of, i. 339

Rhinocerotida. N. American Tertiary, i. 136

RHINOCEROTID $\approx$, ii. 213

RHINOCHETIDÆ, ii. 359

Rhinochetus, ii. 359

Rhinncoccyx, ii. 309

Rhinocryptc, ii. 297

Rhinoderma, ii 416

RHINODONTIDÆ, ii. 46I

Rhinodoras, ii. 443

Rhinogale, ii. 195

Rhinoglanis, ii. 443

RHINOLOPHID E, ii. 1 \&?

Rhinolophus, ii. 183

Rhinophis, ii. 374

RHINOPHRYNID $\approx$, ii. 414

Rhinoplrynus, ii. 414

Rhinoplax. ii. 317

Rhinopoma, ii. I8s

Rhinortha, ii. 309

Rhipidura, ii. 271

Rhizomys, ii. 231

Rhodeus, ii. 452

Rhodinocincla, ii. 256

Rhodona, ii. 397

Rhodopis, ii. 108

Rhodosttehia, ii. 364

Rhombomys, ii. 230

Rhombus, ii. 441

Rhopodytes, ii. 309

Rhopoterpe, ii. 104

Rhynchoea, ii. 353

RHYNCHOCEPHALID瓜, ii. 405

RHYNCHOCEPHALINA, ii. 405

Rhynchocyon, ii. 186

Rhynchocyclus, ii. 101

Rhynchonella, ii. 539

RHYNCHONELLIDEE, ii. 532

Rhynchops, ii. 365

Rhynchopsitta, ii. 328

Rhynchotus, ii. 344

Rhytina, ii. 210,211

Rhytiodus, ii. 445
Ricinula, ii. 507

Rimator, ii. 263

Rimula, ii. 511

Rissa, ii. 364

Pissoa, ii. 510

Rita, ii. 442

River-hog, of West Africa, figure of, i. 264 of Madagascar, figure of, i. 278

Rivers, limiting the ringe of mantmalia, i. 12 limiting the range of birds, i. 17

River-scene in West Africa, i. 264

River-snails, ii. 510

Rivulus, ii. 450

Rock-snakes, ii. 381

Rucky mountain sub-region, 1i. 129

mammalia of, ii. 129 bircls of, ii. 130 reptiles, amjlibia, and fishes of, ii. 130

Rodentia, classification of, i. .90 range of Palæarctic genera of, 1. 242 range of Ethiopian genera of, i. 304 range of OrientaI genera of, i. 374 range of Australian genera of, i. 476

Rodentia, European Pliocene, i. 113

Miocene of Greece, i. 116

European Miocene, i. 120

European Eocene, i. 126

N. American Post-Pliocene, i. 130

N. American Tertiary, i. 139

of Brazilian caves, i. 144

S. American Pliocene, i. 147

of S. American Eocene, i. 148

RODENTIA, ii. 229

Rodentia, generaI remarks on the distributious of, ii. 243

Rodentia, sunımary and conclusion, ii. 543

Rohteichthys, ii. 452

Rollers, ii. 311

Rollulus, ii. 339

Romaleosoma, ii. 474

Rose-chafers, ii. 494

Rostrhanus, ii 349

Rough-tailed burrowing snakes, ii. 374

Ruff, figure of, i. 195

Rupicapra, ii. 224,225

RUPICAPRIN

Rupicola, ii. 102, 293

RUPICOLIN $Æ$, ii. 293

Ruticilla, ii. 259

RUTICILLIN $Æ$, ii. 257

S.

Saccobranchets, ii, 441

Saccodon, ii. 445

SACCOMYID E, ii. $23: 3$

Saccomys, ii. 233

Saccostomus, ii. 230

Sazda, ii. 516

Sahara, a debatable Iand, i. 25I

Saiga, antelope of W. Tartary, i, 218

Saiga, ii. 223

Saimiris, ii. 175

Sakis, ii. 175

Salamandra, ii. 418

SALA MANDRIDÆ, ii. 413

Salamandrina, ii. 413

Salarix, ii. 448

Salminus, ii. 445

Salmo, ii: 447

SALIONIDE, ii. 447

Salpinctes, ii. 264

Salpornis, ii. 264

Saltator, ii. 99 
Salvin, Mtr., on birds of Galapagos, ii. 30 Sambus, ii. 496

Samoa IsIands, birds of, i. 443

Sand-grouse, Pallas', of Mongolia, i. 226 ii. 337

Sand-Iizarils, ii. 398

Sandpipers, ii. 353

Sandwich IsIands, birds of, i. 445 probable past history of, i. 446 mountain plants of, i. 446 depth of ocean around, i. 447

Sanzinia, ii. 391

Saperda, ii. 501

Sapphironia, ij. 109

Sarcodaces, ii 445

Sarcophilus, ii. 249

SARCORHAMPHINA, ii. 346

Sarcorhamphus, ii. 346

Sargus, ii. 427

Sarkidiornis, ii. 363

Saroglossa, ii. 288

Sarotherodon, ii. 438

Sasia, ii. 303

Satanoperca, ii. 439

SATYRIDA, ii. 471

Satyrites Reynesii, European Cretaceous insect, i. 167

Satyrus, ii. 471

Saucerottia, ii. 109

Saunders, Mr. Edward, on the Buprestidwe of Japan, i. 229

Saurocetes, ii. 210

Saurophis, ii. 392

Saurothera, ii. 309

Saxicola, ii. 260

Saxicolince, ii. 257

Sayornis, ii. 100, 291

Scallops, ii. 533

Scalops, ii. 190

Scapanus, ii. 190

Scaphiopus, ii. 417

Scaphirhynchus, ii. 459

Scaptochirus, ii. 190

Scaptonyx, ii. 190

Scaraphites, ii. 490

Scardafella, ii. 333

Scarites, ii. 489

Scelidotherium, in Brazilian caves, i. 145

S. American Pliocene, i. 147

$$
\text { ii. } 245
$$

Scelodontis, ii. 490

Sceloporus, ii. 401

Scelotes, ii. 398

Schacra, ii. 452

Schasicheila, ii. 522

Schiffornis, ii. 102

Schilbe, ii. 442

Schilbichthys, ii. 442

Schismaderma, ii, 415

Schistes, ii. 108

Schistopleurum, S. American Pliocene, i. 147

Schizodon, ii. 238

Schizogenius, ii. 490

Schizopygopsis, ji. 452

Schizorhina, ii. 494

Schizorhis, ii. 307

Schizothorax, ii. 452

Schoenionta, ii. 502

Schweinfurtl, Dr., on natural history of Central Africa, i. 252

on limits of W. African sub-region, i. 262 (note)

Sciodes, ii. 443

Sciana, ii. 428

SCI ENID E, ji. 428

SCINCLA, ii. 396
Scincus, ii. 397

Seinks, ii. 396

Scissirostrum, ii. 288

Scissor, ii. 445

Sciurcuus, N. American Eocene, i. 140

Sciuravus, ii. 236

SCIURIDE, it. 234

Sciuropterus, ii. 235

Sciurus, European Miocene, i. 120

European Eocene, i. 126

ii. 235,236

Sclater, Mr., on zoological regions, i. 59 why his six regions are adopted, i. 63 on birds of Sandwich Islands, i. 445 on systematic position of Certhidea, ii p. 31

Sclater and Salvin, Messrs., on Neotropical sub-regions, ii. 25

SCLERODERMI, ii. 457

Sclerognathus, ii. 451

SCLERURIN E, ii. 295

Sclerurus, ii. 103

Scolecophagus, ii. 282

SCOLOPACID E, ii. 353

Scolopax, ii. 353

Scomber, ii. 429

SCOMBRESOCID $/$, ii. 449

Scombresox, ii. 449

SCOMBRID $Æ$, ii. 429

SCOPELID $A$, ii. 446

Scops, ii. 350

Scopus, ii. 360

Scortornis, ii. 320

Scotopelia, ii. 350

Scotophilus, ii. 188

Serapteira, ii. 391

Sereamers, ii. 361

Serub-birds, ii. 299

SCYLLID s, if. 461

Scyllium, ii. 461

Scytale, ii. 379

SCYTALIDE, ii. 379

Scytalopus, ii. 297

Scythrops, ii. 310

Sea, as a barrier to mammalia, i. 13

Sea-devils, ii. 463

Seals, fossil in European Miocene, i. 118 of Lake Baikal, i. 218

ii. 203

Sea-pens, ii. 505

Sea-snails, ii. 508

Sea-snakes, ii. 384

Scbastes, ii. 428

Secondary formations, mammalian remains in i. 169

Secretary bird, of Africa, figure of, i. 261 ii. 346

Seemann, Dr., on protective resemblance of sloths, ii. 24

Seisura, ii 270

Selachc, ii. 460

Selasphorus, ii. 108

Selenidera, ii. 307

Selenophorus, ii. 490

Scleucides, ii. 275

Semioptera, ii. 275

Semiplotus, ii. 452

SEMNOPITHECID压, ii. 171

Semnopithecus, European Pliocene, i. 112

Miocene of Greece, i. 115

European Miocene, i. 117

Indian Mliocene, i. 121

ii. 171

ii. 178

Semper, Dr, on Philippine mammalia, i. 345

Senira, ii. 397 
SEPIADE, ii. 505

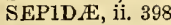

Seps, ii. 398

Sepsina, ii. 398

Sericinus, ii. 479

Sericornis, ii. 258

Sericulus, ii. 275

Serilophus, ii. 295

SERPENTARIIDÆ, ii. 346

Serpentarius, European Miorene, i. 162 ii. 346

Serphophaga, ii. 101

Serranus, ii, 425

Serrasalmo, ii. 445

Sesia, ii. 482

Setophaga, ii. 279

Setornis, ii. 267

Seychelle Islands, zoology of, i. 281 amphibia of, i. 281

Shad, ii. 451

Sharks, ii. 460

Sharp, Dr., on Japan beetles, i. 229

Sharpe, Mr. R. B., his arrangement of Accipitres, i. 97

on birds of Cape Verd Islands, i. 215 on classification of Cuckoos, ii, 309

Sheath-bills, ii. 354

Sheep, Palæarctic, i. 182 ii. 221

Short-tailed burrowing snakes, ii. 373

Shrikes, ii. 272

Sialia, ii. 260

Siamanga, ii. 171

Siaphos, ii. 397

Siberia, climate of, i. 217

Siberian sub-region, description of, i. 216 mammalia of, i. 217

birds of, i. 219 reptiles and amphibia of, i. 220 insects of, i. 220

Sibia, ii. $\Sigma 62$

Siderone, ii. 474

Sieboldia, ii. 412

Sigmodon, ii. 230

Silondia, ii. 442

Silphomorpha, ii. 490

Silubosaurus, ii. 397

Siluranodon, ii. 442

Silurichthys, ii. 441

SILURIDÆ, ii. 441

Silurus, ii. 441

Silybura, ii. 374

Simenia, ii. 197

Simia, ii. 171

SIMIIDE, ii. 170

Simocephalus, ii. 380

Simocyon, Miocene of Greece, i. 115 ii. 198

Simorhynchus, ii. 367

Simotes, ii. 375

Simpulopsis, ii. 516

Sinopa, N. Anerican Tertiary, i. 134

Siphia, ii. $2 \pi 0$

Siphneus, ii. 230

Siphonopsis, ii. 411

Siphonorhis, ii. 320

Siphonostoma, ii. 457

Siren, ii. 411

Sirenia, classification of, i. 89 range of Ethiopian genera of, i. 303 range of Oriental genus, $i .374$ range of Australian genus of, i. 476

Sirenia, European Pliocene, i. 112 European Miocene, i. 119

SIRENIA, ii 210

SIRENIDÆ, ii. 411
SIRENOIDEI, ii 458

Sirystes, ii. 101

Sisor, ii. 444

Sitana, ii. 402

Sitta, ii. 265

Sittasomus, ii. 103

Sittella, ii. 265

SITTID E, ii. 265

Siurus, ii. 279

Siva, ii. 266

Sivatherium, Indian Miocene, i, 122 ii. 226

Siwalik Hills, Miocene deposits of, i. 121

Skenea, ii. 510

Sloths, ii. 244

Slugs, ii. 517

Smaragdochrysis, ii. 109

Smerinthus, ii. 483

Smiliogaster, ii. 453

Sminthus, ii. 230

Smith, Mr. Frederick, on Hymenopters of Japan, i. 230

Smithornis, ii. 270

Smutsia, ii. 245

Snails, ii. 512

Snake, at great elevation in Himalayas, i. 220

Snakes, classification of, i. 99

Eocene, i. 165

large proportion of venomous species in Australia, i. 396

of New Zealand, i. 457

distribution and lines of migration of, ii. 547

Snipes, ii. 353

Society Islands, birds of, 1. 443

Socorro, zoology of, ii. 60

Soft-tortoises, ii. 409

Solarium, ii. 510

Solea, ii. 441

SOLENIDA, ii. 536

Solenodon, ii. 188

SOLENOSTOMIUE, ii. 456

Solitaire, ii. 334

Somateria, ii. 364

Soricictis, European Hiocene, i. 118 i. 196

Soricida, European Mliocene, i. 118

SORICIO $\approx$, ii. 191

Soridia, ii. 397

Sorubim, ii, 442

Sotalia, ii. 209

South African sub-region, description of, 1. 266

mammalia of, i. 267

birds of, i. 267

reptiles of, i. 268

amphibia of, 1.268

fresh-water fish of, 1. 268

butterflies of, 1. 268

coleoptera of, 1. 268

summary of its zoology, 1. 269

South America, fossil fauna of, i. 143

Pliocene deposits of, i. 146

supposed land connection with Australia, i. 398

South America and Africa, parallelism of their past zoological history, ii 83

South Australia, peculiar birds of, 1. 441

SPAL $1 C 1 D Æ$, ii. 231

Spalacomys, ii. 230

Spalacopus, ii. 238

Spalax, ii. 231

Sparganura, ii. 108

SPARID $E$, ii. 426

Spatula, ii. 364

Species, representatire, i. 4 
Spelerpes, ii. 413

Speothos, in Brazilian caves, i. 145

Spermestes, ii. 287

Spermophila, ii. 285

Spermophilus, European Miocene, i. 120

ii. 235,236

Sperniospiza, ii. 286

Sperm Whales, ii. 207

Sphcrocephalus, ii. 209

Sphorodactylus, ii. 400

Sphceroderus, ii. 490

Sphallomorpha, ii. 490

Sphocotheres, ii. 268

Sphenreucus, ii. 258

SPHENISCID E, ii. 366

Spheniscus, ii. 366

Sphenocephalus, ii. 398

Sphenodon, in Brazilian caves, i. 145 ii. 245

Sphenognathus. ii. 493

Sphenoproetus, ii. 107

Sphenops, ii. 398

Sphenostoma, ii. 266

Sphenura, ii. 258

SPHINGIDE, ii. 482

Sphingidea, distribution of, ii. 483

SPHINGINA, ii. 481

Sphingnotus, ii. 501

Sphinx, in European Oulite, i. 167

ii. 482

Sphinx Moths, ii. 482

Sphyrapicus, ii. 303

SPHYRENIDÆ, ii. 429

Spider monkeys, ii. 174

Spilornis, ii. 348

Spilotes, ii. 376

SPINACID E, ii. 461

Spindalis, ii. 98, 284

Spiraxis, ii. 515

PIRIFERIDÆ, ii. 532

SPIRULID $\mathrm{E}$, ii 505

Spizaëtus, ii. 348

Spizella, ii. 284

Spiziapteryx, ii. 349

Spiciastur, ii. 348

Spodiornis, ii. 285

Sponsor, ii. 497

Spoonbills, ii. 360

Sporadinus, ii. 109

Sporopipes, ii. 286

Sprat, ii. 454

Spreo, ii, 288

Squalodon, ii. 210

Squaliobarbus, ii. 452

SQUAMIPENNES, ii. 427

Squatarola, ii. 356

Squirrel monkeys, ii. 175

Squirrels, ii. 234

St. Helena, zoological features of, i. 269 coleoptera of, i. 270

landshells of, i. 271

St. 'Thomas's Island, birds of, i. 266

Staehyris, ii. 261

Stactolcema, ii. 306

Stag-beetles, ii. 492

Stalagmosoma, ii. 495

Starlings, ii. 287

Starnonas, ii. 33

Stations, definition of i. 4

Staurotypus, ii. 408

Steatomys, ii. 230

Steatornis, ii. 319

STEATORNITHIDE, ii. 319

Steganur $x$, ii. 108

Stegnolcema, ii. 343

Stegophiius, ii. 444
Stelgidopteryx, ii. 281

Stellio, ii. 402

Stcllula, ii. 108

Steneofiber, Europe:ın Miocene, i. 120 ii. 284

Steno, ii. 209

Stenodactylus, ii. 400

Stenogyra, ii. 515

Stenopsis, ii. 320

Stencpus, ii. 516

Stenorhina, ii. 375

Stenorhynchus, ii. 204 ii. 421

Stephanophorus, ii. 98

Stercorarius, ii. 361

Sterna, ii. 364

Sternarchus, ii. 455

Sternocera, ii. 496

Sternoclyta, ii. 107

STERNOP TYCHIDÆ, ii. 446

Sternopygus, ii. 455

Sternotheres, ii. 408

Steropus, ii. 489

Stesilea, ii. $50 \mathrm{l}$

Stethodesma, ii. 495

Sthenurus, Australian Post-Tertiary, i. 157 ii. 251

Stichaeus, ii. 431

Sticklebacks, ii. 424

Stigmatura, ii. 101

Stigmodera, ii. 496

S1 OMIIATID E, ii. 447

Storks, ii. 360

Stabomantis, ii. 419

Straits of Magellan, mammalia of, ii. 37 birds of, ii. 39

Strepera, ii 273

Strepsilas, ii. 356

Streptaulus, ii. 520

Streptaxis, ii. 515

Streptocerus, ii. 493

Streptocitta, ii. 274

Streptophorus, ii. 374

STRIGIDÆ, ii. 350

Stringops, ii. 329

STRINGOPID E, if. 329

Strix, European Miocene, i. 162 i. 350

STROMBIDA. ii. 507

Struthio, ii. $36 \mathrm{~s}$

Struthiones, arrangement of, i. 98

range of Ethiopian genera of, i. 313 range of Australian genera of, i. 487

STRUTHIONES, ii. 368 general remarks on the distribution of, ii. 370

STRUTHIONIDA, ii. 368

Struthious birds, probable origin of, i. 287

Sturgeons, ii. 459

Sturnella, ii. 282

Sturnia, ii. 287

STURNID $\nRightarrow$, ii. 287

Sturnopastor, ii. 287

Sturnus, ii. 287

STYGIID 2 , ii. 482

Stygogenes, ii. 444

Stylinodontia, N. American Eocene, i. 139

Stylinodontidee, N. American Eocene, i. 139

Stuporhynchus, ii. 376

Sublegatus, ii. 101

Sub-regions, on what principle formed, i. 180 Palararetic, i. 191

Ethiopian, i. $25 \mathrm{~S}$

Oriental, i. 321

Anstralian, i. 408

Neotropical, ii. 21 
Sub-regions, Nearctic, ii. 125

Succinea, ii. 515

Sngar-birds, ii. 278

Suidce, European Miocene, i. 119

SUID $Æ$, ii. 214

Sula Islands, fauna of, i. 433

Sula, ii. 365

Summary of relations of regions, ii. 155

Sun-birds, ii. 276

Sun-bitterns, ii. 358

Suricata, ii. 195

Surnia, ii. 350

Surniculus, ii. $\mathbf{3 1 0}$

Sus, European Pliocene, i. 113

Miocene of Greece, i. 116

European Miocene, i. 119

Indian Mliocene, i. 122

ii. 215

Suthoro, ii. 262

Suya, ii. 258

Swallows, ii. 281

Swallow-shrikes, ii. 288

Swifts, ii. 320

Swine, ii. 214

Swinhoe, Mr., on zoology of Formosa and Hainan, i. 332

Sycalis, ii. 284

Sylvia, ii. 259

Sylvietta, ii. 264

SYLVIID $Æ$, ii. 256

SYLVIIN સ, ii. 257

Sylviorthorluyncluus, ii. 103

Sylviparus, ii. 266

Syma, ii. 316

Symborodon, N. American Tertiary, i. 137

SYMBRANCHID瓜, ii. 455

Symbranchus, ii. 455

Symmachia, ii. 476

Symmorphus, ii. 269

Symphredra, ii. 474

Symphysodon, ii. 439

Symplectes, ii. 286

SYNALLAXINÆ, ii. 295

Synallaxis, ii. 103

Synaphodus, European Miocene, i. 119

Synaptura, ii. 441

Synehloe, ii. 474

Syridesus, ii 493

Synemon, ii. 481

Syngnathus, ii. 457

SYNGNATHID $Æ$, ii 457

Synodontis, ii. 443

Synoplotherium, N. American Tertiary, i. 134

Syntomis, ii. 481

Syrnium, ii. 350

Syrrhaptes, ii. 337

Sysomygis, ii. 101

T.

Tables of distribution of families and genera explained, i. 177

Taccocoua, ii. 309

Tachydromus, ii. 391

Tachyphonus, ii. 99

Tachyris. ii. 478

Tachytriorchis, ii. 348

Tadorna, ii. 363

Toniogale, ii. 195

Toeinioptera, ii. 100, 291

TENIOPTERIN E, ii. 291

Taniura, ii. 463

Talegallus, ii. 342

Talpa, European Miocene, i. 117 ii. 190

TALPID E, ii. 190
Tamandua, ii. 247

Tamias, ii. 235,236

Tancecia, ii. 474

Tanagers, ii. 283

Tanagra, ii. 98

Tanagrella, ii. 98

TANAGRID无, ii. 283

Tantalus, ii. 361

Tanygnathus, ii. 326

Tanysiptera, ii. 316

Taoniscus, ii. 344

Taphozous, ii. 183

Tapir, fossil in N. China, i. I23

Tapir, Malayan figure of, i. 337

Tapirida, European Eocene, i. 125

TAPIRID $\approx$, ii. 212

Tapirs, birthplace and migrations of, i. 154 ii. 212

Tapirus, European Pliocene $_{4}$ i. 113

Indian Hiocene, i. 122

in Brazilian caves, i. 14

Tarandus, ii. 219

Tarentola, ii 400

Tarsier, Malayan, figure of, i. 337

Tarsiger, ii. 259

TARSIID在, ii. 177

Tarsipes, ii. 252

Tarsizes, ii. 177

Tasmania, comparative zoological poverty of, i. 441

Tutare, ii. 258

Tatusia, ii. 246

Taxidea, ii. 199

Taxila, ii. 475

Taxodon, European Miocene, i. 118 ii. 200

Taygetis, ii. 471

Tchitrea, ii. 271

TECTONARCHINÆ, ii. 275

Teguexius, ii. 390

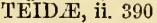

Teinopalpus, ii. 479

Teira, ii. 391

Teires, ii. 390

Teleopis, ii. 375

TELEOSTEI, ii. 424

Telephonus, ii. 2 \%

Tellia, ii. 450

TELLINIDA, ii. 506

Telmatobius, N. Aimerican Cretaceous, i. $16 t$ ii. 417

Telmatolestes, N. American Tertiary, i. 133

Temnotrogon, ii. 314

Temnurus, ii. 273

Tephrocorys, ii. 289

Tephrodornis, ii. 272

Teracolus, ii. $47 \mathrm{~s}$

Terebratula, ii. 539

TEREBRATULID $\approx$, ii. 532

Terekia, ii. 353

Terenura, ii. 104

Teretristis, ii. 279

Terias, ii. 478

Terinos, ii. 474

Terns, ii. 364

Terrapene, ii. 408

T'errestrial MIolluses, ii. 512

Terrestrial Mollusca, summary and conclusion, ii. 551

lines of migration of, ii. 552

Tesia, ii. 263

Testacella, ii. 516 ii. 517

TESTUDINIDÆ, ii. 407

Testudo, Miocene of Greece, i. 116 Indian Miocene, i. 123 
Testudo, great antiquity of the genus, i. 289

Testudo, ii. 408

Tethionea, ii. 501

TETRABRANCHIATA, ii. 506

Tetrach r, ii. 486,487

Tetrachus, European Miocene, i. 117

Tetraceros, ii. 224

Tetracus, ii. 188

Tetradactylus, ii. 397

Tetragonoderus, ii. 490

Tetragonops, ii. 306

Tetragonopterus, ii. 445

Tetragonosoma, ii. 380

Tctranematichthys, ii. 443

Tetrao albus, in Italian caverns, i. $16 \mathrm{~T}$

Tetran, ii. 339

Tetrcogallus, ii. 339

TETRAONIDE, ii. $33 \mathrm{~S}$

Tetraophasis, ii. 340

Tetrodon, ii. 457

TEUTHIDÆ, ii. 505

TEUTHIDID $\mathbb{E}$, ii. 433

Textor, ji. 286

Thais, ii. 479

Thalassarctos, ii. 201

Thalassictis, Miocene of Greece, i. 115

European Miocene, i. 118

ii. 195

ii. 197

Tha'assornis, ii. 361

Thateichthys, ii. 447

Thaluranie, ii. 107

Thamnistes, ii. 104

Thamnobia, ii. 260

Thamnodyastes, ii. 379

Thamnomanes, ii. 104

THAMNOPHILINAE, it. 297

Thamnophilus, ii. 104

Thaumalea, ii. 340

Thaumantis, ii. 472

Thaumastura, ii. 108

Thaumatias, ii. 109

Thecla, ii. 477

Theloderma, ii. 419

Theope, ii. 476

Theorema, ii. 477

Theraps, ii. 438

Therates, ii. 486

Theridomys, European Miocene, 1. 126

European Eocene, i. 126

S. American Eocene, i. 148

ii. 239

Theropithecus, ii. 173

Thestias, ii. 478

Thestor, ii. 477

Thetia, ii. 391

THINOCORID AE, ii. 354

Thinocortes, ii. $35 t$

Thinohyus, ii. N. American Tertiary, i. 137 ii. 215

Thinolestes, N. American Tertiary, i. 133

Thinornis, ii. 356

Thomomys, ii. 233

Thous, ii. 197

Thrasaëtus, ii. 348

Threnetes, ii. 107

Thripadectes, ii. 103

Thripophaga, ii. 103

Thryophilus, ii. 263

Thryothorus, ii. 263

Thrushes, ii. 255

Thyca, ii. 471

Thylacinus, Australian Post-Tertiary, 1. 157 ii. 249

Thylacoleo, Australian Post-Tertiary ${ }_{i}$ j. 157
Thymallus, ii 447

Thynnichthys, 452

Thynnus, ii. 429

Thyreopterus. ii. 491

Thyrus, ii. 398

Tiaris, ii. 284

$$
\text { ii. } 402
$$

Tichodroma, ii. 264

Tiga, ii. 303

Tiger-beetles, ii. 486

Tigrisoma, ii. 359

Tijuca, ii. 102

Tillodontia, N. American Eocene, i. 139

Tillotherida, N. American Eocene, i. 139

Tillotherium, N. American Eocene, i. 130

Tilmatura, ii. 108

Timalia, ii. 261

TIMALIID सE, ii. 260

Timetes, ii. $47 t$

Timor, physical features of, i. 389 group, mammalia of, i. $\$ 22$

birds of, i. 422

origin of fauna of, i. 424

insects of, i. 426

TINAIIDE, ii. 343

TINAMINE, ii. 344

Tinamous, ii. 343

TINAMOTINÆ, ii. 344

Tinamotis, ii. 344

Tinamus, ii. 344

Tinca, ii. $\$ 52$

Tinoceras, N. American Eocene, i. 139

Titanomys, European Miocene, i. 121 ii. 242

Titanotherium, N. American Tertiary, i. 137

Tits, ii. 265

Tityra, ii. 102

TITYRIN Æ, ii. 293

Tmesisternus, ii. 501

Toads, ii. 415

Tockus, ii. 317

TODID $\#$, ii. 313

Todies, ii. 313

Todirhamphus, 310

Todirostrum, ii. 101

Todopsis, ii. 271

Todus, ii. 313

Tolypeutes, ii. 246

Tomarctos, N. American Tertiary, i. 135

Tomistoma, ii. 405

Tonodon, ii. 175

Tonga Islands, birds of, i. 443

Topaza, ii. 107

TORNATELLID $\approx$, ii. 530

TORPEDINID $\AA$, ij. 462

Tortoises, classification of, i. 100

of Mascarene Islands and Galapagos, i. 289 ii. 407

TORTRICIDE, ii. 373

Tortrix, ii. 373

Totanus, ii. 353

Toueans, ii. 306

Touraco of W. Africa, flgure of, j. 264

Toxodon, S. American Pliocene, j. 137

Toxodontida, S. American Pliocene, i. 147

Toxotus, ii. 502

Trachelyopterus, ii. 443

TRACHINIDÆ, ii. 428

Trachinus, ii. 428

Trachurus, ii. 429

Trachycephalus, ii. 401

$$
\text { ii. } 418
$$

Trachydosaurus, ii, 397

Trachyphonus, ii. 306

TRACHYPTERID $Æ$, ii. 432

Trachytherium, European Miocene, i. 119 
TRAGELAPHIN $Æ$, ii. 223

Tragelaphus, ii. 223

Tragocerus, Miocent, of Greece, i. 116

European Miocene, i. 120

Tragopan, Himalayan, figure of, i. 331

Tragops, ii. 379

TRAGULIDÆ, ii. 218

Trigulus, ii. $21 \mathrm{~s}$

Trapelus, ii. 402

Trechus, ii. 489

Tree-crows, ii. 273

Tree-kangaroo, figure of, i. 415

Tree-shrew of Borneo, figure of, i. 337

Tree-snakes, ii. $37 \mathrm{~s}$

Tremarctos, ii. 202

Treron, ii. 332

Tres Marias, zoology of, ii. 59

Tribolonotus, ii. 397

Triboniophorus, ii. 517

Tribonyx, ii. 352

Trichastoma, ii. 261

TRICHECHID $\mathbb{E}$, ii. 203

Trichechus, N. American Post-Pliocene, i. 130 ii. 203

TRICHIURIDÆ, ii. 429

Trichixos, ii. 262

TRICHOGLOSSID $\mathbb{E}$, ii. 327

Trichoglossidæ, birds specially adapted to Australia, i. 393

Trichoglossus, ii. 327

Tricholema, ii. :06

Trichomycterus, ii. 444

Tryeondyla, ii. 486

Trichonis, ii. 477

TRICHONOTIDE, ii. 435

Trichothraupis, ii. 99

Trichotropis, ii. 507

Triclaria, ii 328

TRIDACNID $Æ$, ii. $\varepsilon 3$;

Trigla, ii. 428

TRIGLID \&, ii. 427

Trigona, ii. 536

TRIGONIAD E, ii. 534

Trigonoptera, ii. 501

Trimeresurus, ii. 385

Tringa, ii. 353

Tringoides, ii. 353

TRIONYCHID \pm , ii. 409

Trionyx, Indian Miocene, i. 128

Miocene and Eocene, i. 165 ii. 409

Triprion, ii. 418

Triptorhinus, ii. 297

Tristan d'Acunha, znology of, i. 271

Tristram, Canon, sumunary of the birds of Palestine, i 203

on the arrangement of the Sylviidie, ii. 257 Triton, ii. 413

TRITONIAD 2 , ii. 530

Trochalopteron, ii. 261

Trochatella, ii. 522

TROCHILID $E$, ii. 321

Trochilus. ii. 108

Trochus, ii. 510

Troglodytes, ii 170

$$
\text { ii, } 263
$$

TROGLODYTID E. ii. 263

Trogon, European Hiocene, i. 161 ii. 314

Troyen, ii. 314

TROGONID $\mathrm{E}$, ii. 314

TROGONOPHID $\approx$, ii. 388

Trogonophis, ii. 38s

Trogontherium, Post-Pliocene of Europe, i 111 ii. 234

Tropidechis, ii. 383
Tropidococcyx, ii. 379

Tropinlodipsas, ii. 379

Tropidolepis, ii. 401

Tropidolepisma, ii. 397

Tropidonotus, ii. 375

Tropidophorus, ii. 397

Tropidopterus, ii. 490

Tropidorhynchus, ii. 276

Trucifelis, N. American Post-Pliocene, 1, 129

Trugon, ii. 333

Trumpeters, ii. 358

Truncatella, ii. 519

Trgyon, ii. 463

TRYGONID在, ii. 463

Tuatara, ii. 405

Tulora, ii. 521

Tundras of Siberia, greatest extent of, 1. 216

Tupaia, ii. 186

TUPAIIDÆ, ii. 186

Tupaiddo, European Miocene, i. 118

Turaccena, ii. 333

Turacos, ii. 307

Turacus, ii. 307

TURBINID $\mathrm{E}$, ii. 510

TURDIDÆ, ii. 255

Turdinus, ii. 262

Turdus, ii. 256

Turnagra, ii. 262

Turner, Mr., on classification of Edentata, $i$. 90

TURNICID $\mathbb{E}$, ii. 341

Turnix, ii. 341

TURRITELLID $E$, ii. 509

Tursio, ii. 209

Turtles, ii. 409

Turtur, ii. 333

Tylas, ii. 267

Tylodon, European Eocene, 1. 125 ii. 196

Tylognathus, ii. 451

Tylotviton, ii. 413

Typhlina, ii. 372

Typhline, ii. 372

Typhlocalamus, ii. 374

TYPHLOPID $Æ$, ii. 372

Typhlops, ii. 372

Typhloscincus, ii. 399

Typotherium, S. American Pliocene, 1. 147

TYRANNID $E$, ii. 290

TYRANNIN $巴$, ii 291

Tyranniscus, ii. 101

Tyrannulus, ii. 101

Tyrannus, ii. 102, 291

Tyrant-Shrikes, ii. 290

U.

Uaru, ii. 439

Uintacyon, N. American Tertiary, 1. 134

Uintatherium, N. American Eocene, i. 139

Uintornis, N. American Eocene, i. 163

Uma, ii. 401

UMBRIDÆ, ii. 449

Umbrina, ii. 428

Ungalia, ii. 381

Ungulata, elassification of, i. 89

antiquity of, i. 154

of the Palæarctic region, i. 182

range of Palæarctic genera of, i. 241

range of Ethiopian genera of, i. 303

range of Oriental genera of, i. 374

range of Australian genera of, i. 476

Ungulata, European Pliocene, i. 112

Miocene of Greece, i. 115

European Miocene, i. 119 
Lngulata, Indian Miocene, i, 121

European Eocene, i. 125

N. American Post-Pliocene, i. 133

N. American Tertiary, i. 135

of Brazilian eaves, i. 144

S. American Pliocene, i. 146

UNGULAT $A$, ii. 211

general remarks on the distribution of ii 226

sumnary and conclusion, ii. 542

Unio, European Secondary, i. 169

$$
\text { ii. } 534
$$

UNIONIDÆ, ii. 534

Upucerthia, ii. 103

UPUPID $\approx$, ii. 317

Uragus, ii. 285

Urania of Madagascar, i. 282

Urania, ii. 482

URANIID无, ii. 482

Uria, ii. 367

Uroaëtus, ii. 348

Urocissa, ii. 273

Urochroa, ii. 107

Urochroma, ii. 328

Urocyon, ii. 197

URODELA, ii. 411

Urogalba, ii. 311

Urolestes, ii. 272

Uromastix, ii. 402

UROPELTID $\&$, ii. 373

Uuropeltis, ii. 374

Uropsila, ii 264

Uropsilus, ii. 190

Uropsophorus, ii. 355

Urospatha, ii. 313

Urospizias, ii. $34 \mathrm{~s}$

Urosticte, ii. 108

Urotrichus, ii. 190

Urotriorchis, ii 347

Ursida, N. American Tertiary, i. 135 in Brazilian caves, i. 144

CRSIDE, ii. 201

Ursitaxus, Indian Mliocene, i. 121 ii. 200

Ursus, Post-Pliocene, i. 112

Indian Mliocene, 121

ii. 201

Urubutinga, ii. 348

Crva, ii. 195

Uta, ii. 401

Utica, ii. 477

V.

Vaginulus, ii. 518

Valgus, ii. 49.

Valvata, ii. 510

Vanga of Madagascar, figure of, i. 278

Vanga, ii. 272

Vandellia, ii. 444

Vanellus, ii. 356

Vanessa, ii. 474

VARANID疋, ii. 389

Varanus, Miocene of Greece, i. 116 Indian Miocene, i. 123

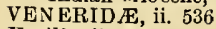

Venilia, ii. 303

Vermicella, ii. 383

Verreauxia, ii. 303

Vertebrata, summary of Palæaretic, i. 186

summary of Ethiopian, i. 255

summary of Oriental, i. 318

summary of Australian, i. 397

summary of Neotropical, ii. 13

summary of Nenretic, ii. 120
Vespertilio, European Eocene, i. 125 ii. 183

VESPERTILIONID EE, ii. 183

Vidua, ii. 286

Vipera, ii. 385

VIPERID E, ii. 385

Viperus, European Miocene, i. 165

Vipers, ii. 385

Vireo, ii. 280

VIREONID E, ii. 279

Vireolanius, ii. 280

Vireosylvia, ii. 280

Viscacha, ii. 237

Vitrina, ii. 516

Viverra, European Pliocene, i. 112

European Miocene, i. 118

ii. 195

Viverricula, ii. 195

Viverrida, European Miocene, i. 118

European Eucene, i. 125

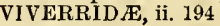

Vivia, ii. 303

Volatinia, ii. 284

Voluta, ii. 508

Volutes, ii. 508

VOLUTID $\approx$, ii. $50 \mathrm{~S}$

Volvocivora, ii. 269

Vulpes, ii. 197

Vultur, ii. 346

VULTURID $A$, ii. 345

VULTURINE, ii. 340

W.

Wagtails, ii. 290

Walden, Viscount, on birds of Philippine islands, i. 346

on birds of Celebes, i. 428

on arransement of the Timaliidr, ii. 261

IVallego, ii. 441

Wall-lizards, ii. 399

Walrus, ii. 203

Wart-snakes, ii. 382

Washakius, N. American Tertiary i. 134

Waterhouse, Mr. G. R., on classification of rodentia, i. 90

on classification of marsupials, i. 91

Water-lizards, ii. 389

Weaver-finches, ii. 286

West African sub-region, description of, i. 262 mammalia of, i. 262

birds of, i. 262

Oriental or AIalayan element in. i. 263

river scene with characteristic animals, i. 264

reptiles of, i. 264

amphibia of, i. 264

Oriental and Neotropical relations of, i. 265

insects of, i. 265

land-shells of, i. 265

islands of, i. 265

West Australia, peculiar birds of, i. 441

Whelks, ii. 507

Whip-snakes, ii. 379

Whydah finch of W. Africa, figure of, i. 264

Wing-shells, ii. 507 ii. 533

Wollaston, Mr. T. V., on the Coleoptera of the Atlantic Islands, i. 209

on the wings of the Madeiran beetles, i. 211

on the origin of the insect fauna of the Atlantic Islands, i. 214

on the Coleoptera of the Cape Verd Islauds,

i. 215 
Wollaston, Mr. T. V., on the beetles of St. Helena, i. 270

Wombats, ii. 253

Woodpeckers, ii. 302

Wood-warblers, ii. 278

Woolly monkeys, ii. 174

Wrens, ii. 263

Wrynecks, ii. 304

\section{$\mathrm{x}$.}

Xanthocephalus, ii. 282

Xantholoema, ii. 306

Xanthomelus, ii. 275

Xanthopygia, ii. 270

Xanthosomus, ii. 282

Xanthotis, ii. 275

Xema, ii. 364

Xenelaphis, ii. 370

Xenica, ii. 471

Xenicus, ii. 265

Xenochrophys, ii. 375

Xenocypris, ii. 452

Xenodermus, ii. 376

Xenodon, ii. 375

XENOPELTIDE, ii. 373

Xenopeltis, ii. 373

Xenophrys, ii. 421

Xenopipo, ii. 102

Xeriops, ii. 103

Xenorhina, ii. 415

XENORHINIDÆ, ii. 415

Xenospingus, ii. 284

Xenurelaps, ii 383

Xenurus, in Brazilian eaves, i. 145 ii. 246

Xiphias, ii. 430

Xiphidiopicus, ii. 303

XIPHIID正, ii. 430

Xiphius, ii. 208

Xiphocolaptes, ii. 103

Xiphodontid $\propto$, Enropean Miocene, i. 119

Xipholena, ii. 102

Xiphorhampus, ii. 445

Xiphorhynchus, 103

Xiphostoma, ii. 445

Xystrocera ii. 501
Y.

Ypthima, ii. 471

Yuhina, ii. 266

YUNGID必, ii. 304

Yungipicus, ii. 303

Yunx, ii. 304

Z.

Zabrus, ii. 489

Zalophus, ii. 203

Zamenis, ii. 375

Zanclostomus, ii. 309

Zaocys, ii. 375

Zebras, ii. 211

Zegris, ii. 478

Zemeros, ii. 475

Zenaida, ii. 333

Zenaidura, ii. 332

Zephyrus, ii. 477

Zeuglodon, ii. 210

Zeuglodontidce, N. American Tertiary, i. 140 ii. 210

Zeus, ii. 429

Zeuxidia, ii. 472

Zoarces, ii. 431

Zonites, ii. 516

Zonites priscus, Palæozoic, i. 169

Zonotrichia, ii. 284

ZONURID $Æ$, ii. 391

Zonurus, ii. 392

Zoological characteristies of Palæearctic region, i. 181

Ethiopian region, i. 252

Oriental region, i. 315

Australian region, i. 390

of Neotropical region, ii. 5

of Nearetic region, ii. 115

Zoological regions, discussion on, i. 50

their origin and relations, ii. 155-161

Zoothera, ii. 256

Zootoca, ii. 391

Zosterops, ii. 277

Zygona, ii. 481

ZYGANIDE, ii. 481

Zygnopsis, ii. 398

THE END. 


- D Date Dqu

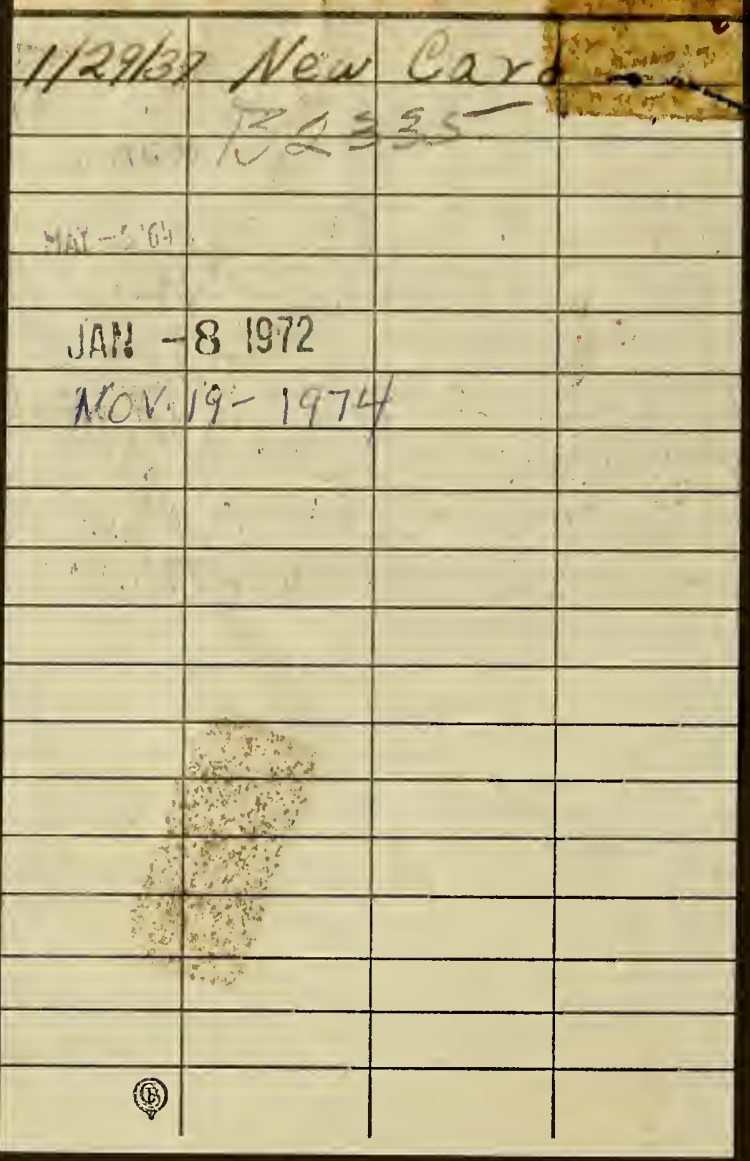




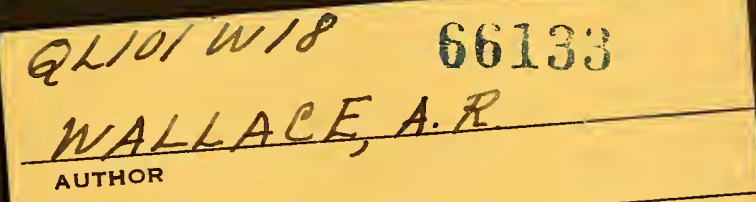

TITLE

$$
\text { WAllACE, A. }
$$

\section{BOSTON COLLEGE LIBRARY}

\section{UNIVERSITY HEIGHTS}

CHESTNUT HILL, MASS.

Books may be kept for two weeks and may be renewed for the same period, unless reserved.

Two cents a day is charged for each book kept overtime.

If you cannot find what you want, ask the Librarian who will be glad to help you.

The borrower is responsible for books drawn onphis card and for all fines accruing on the same. 
